\author{
UNIVERSIDADE DE SÃO PAULO \\ ESCOLA DE COMUNICAÇÕES E ARTES \\ PROGRAMA EM PÓS-GRADUAÇÃO EM MÚSICA
}

IURY CARDOSO

A adaptação para violão das 12 Danzas Españolas

$O p .37$ de Enrique Granados através de novas

propostas de scordature

São Paulo 


\title{
IURY CARDOSO
}

\section{A adaptação para violão das 12 Danzas Españolas}

\section{Op.37 de Enrique Granados através de novas propostas de scordature}

\begin{abstract}
Versão Corrigida
(A versão original se encontra disponível tanto na Biblioteca da unidade que aloja o Programa de Pós-graduação quanto na Biblioteca Digital de Teses e Dissertações da USP)
\end{abstract}

Dissertação apresentada à Escola de Comunicações e Artes da Universidade de São Paulo para obtenção do título de Mestre em Música.

Área de Concentração: Processos de Criação Musical

Linha de Pesquisa: Performance.

Orientador: Prof. Dr. Edelton Gloeden

São Paulo 
Autorizo a reprodução e divulgação total ou parcial deste trabalho, por qualquer meio convencional ou eletrônico, para fins de estudo e pesquisa, desde que citada a fonte.

Catalogação na Publicação

Serviço de Biblioteca e Documentação

Escola de Comunicações e Artes da Universidade de São Paulo Dados fornecidos pelo(a) autor(a)

Cardoso, Iury

A adaptação para violão das 12 danzas españolas op.37 de Enrique Granados através de novas propostas de scordature / Iury Cardoso. -. São Paulo: I. Cardoso, 2017.

230 p.: il.

Dissertação (Mestrado) - Programa de Pós-Graduação em Música - Escola de Comunicações e Artes / Universidade de São Paulo.

Orientador: Edelton Gloeden

Bibliografia

1. Violão 2. Transcrição 3. Scordatura 4. Granados 5. Danzas Españolas Op.37 I. Gloeden, Edelton II. Título.

CDD 21.ed. - 780 


\section{FOLHA DE AVALIAÇÃO}

Nome: CARDOSO, Iury

Título: A adaptação para violão das 12 danzas españolas $O p .37$ de Enrique Granados através de novas propostas de scordature

Dissertação apresentada à Escola de Comunicações e Artes da

Universidade de São Paulo para obtenção do título de Mestre em Música.

Aprovado em:

Banca Examinadora

Prof. Dr.

Instituição:

Julgamento:

Prof. Dr.

Instituição:

Julgamento:

Prof. Dr.

Instituição:

Julgamento: 
À Tamara Alvarenga Caetano 


\section{AGRADECIMENTOS}

Aos meus amados pais, Glória de Almeida e Gentil Cardoso, pelo amor incondicional com que me presenteiam todo o tempo.

À minha avó Isaura de Almeida, por tanta dedicação e carinho.

Aos queridos João Caetano e Edinéia Alvarenga, por me acolherem na família e serem constantemente especiais e cuidadosos.

Ao mestre Edelton Gloeden, que me presenteou com ensinamentos valiosos, sábios conselhos e com sua amizade ao longo desses anos. Serei eternamente grato.

À Giselle Reis pelo companherismo sincero e único, por tanto carinho e suporte em tempos difíceis.

Ao querido Luiz Cancello, por seu auxílio a esse trabalho e amizade.

Ao amigo Dario Gayoso, pelo constante suporte, incentivo e companheirismo.

Ao Francisco Pupo, pela preciosa amizade e bondade desprendida com a qual sempre me auxilia.

Aos companheiros de estrada Leandro Quintério e Carolina Andrade, por desde o início fazermos juntos todo esse processo.

Ao César Bueno e Aline Costa por me mostrarem lados encantadores da vida que estavam passando desapercebidos.

Ao meu irmão Thiago Ramos, por todas nossas histórias partilhadas.

As minhas irmãs, Tahiana Passos, Luciana Miguel e Stephanie Braz. Pessoas com quem eu amo partilhar a vida. Estaremos sempre juntos! 


\section{RESUMO}

CARDOSO, Iury. A adaptação para violão das 12 danzas españolas Op.37 de Enrique Granados através de novas propostas de scordature. 2017. 233 p. Dissertação (Mestrado em Música) - Escola de Comunicações e Artes, Universidade de São Paulo. São Paulo, 2017.

Este trabalho trata do processo de transcrição para violão solo das 12 Danzas Españolas $O p$. 37 de Enrique Granados, escritas originalmente para piano. Tal processo desenvolveu-se através da observação de versões para violão de outras obras originais para piano, comparações entre os recursos instrumentais específicos desses dois instrumentos e de um levantamento histórico, onde foram analisadas as principais problemáticas de adaptação dos elementos musicais e estéticos da obra original em um novo meio. A fim de contextualizar esse trabalho no panorama da transcrição, visitamos a história de Granados, analisando os aspectos gerais de suas Danzas Españolas, bem como discutimos a conceituação da scordatura para, a partir daí, empregar o método de pesquisa de diferentes possibilidades de afinação na busca de viabilizar a transcrição da obra em questão, sem perder de vista, durante esse processo, a ideia original do compositor. Através dos resultados alcançados, da maneira como compreendemos os métodos empregados, constatamos um amplo campo de possibilidades a serem pesquisadas e novas soluções de adaptação e scordature a serem empregadas, estabelecendo a prática da transcrição como um procedimento válido artisticamente, desde que devidamente contextualizado.

Palavras-chave: Violão. Transcrição. Scordatura. Granados. Danzas Españolas Op.37. 


\begin{abstract}
CARDOSO, Iury. The adaptation for guitar of the 12 danzas españolas Op.37 of Enrique Granados through new proposals of scordature. 2017. 233 p. Dissertação (Mestrado em Música) - Escola de Comunicações e Artes, Universidade de São Paulo. São Paulo, 2017.

This work deals with the process of transcription for guitar solo of the 12 Danzas Españolas Op. 37 of Enrique Granados, written originally for piano. This process was developed through the observation of guitar versions of other original works for piano, comparisons between the specific instrumental resources of these two instruments and a historical survey, where the main problems of adaptation of the musical and aesthetic elements of the original work were analyzed in a new medium. In order to contextualize this work in the transcription panorama, we visit the history of Granados, analyzing the general aspects of its Danzas Españolas, as well as discussing the conception of the scordatura to, from there, to use the research method of different tuning possibilities in the seeking to make feasible the satisfactory assimilation of the work in question, without losing sight of, during this process, the original idea of the composer. Through the results obtained, as understood by the methods employed, we find a wide field of possibilities to be researched and new solutions of adaptation and scordature to be used, establishing the practice of transcription as an artfully valid procedure, provided that it is properly contextualized.
\end{abstract}

Keywords: Guitar. Transcription. Scordatura. Granados. Spanish Dances Op.37. 


\section{LISTA DE SIGLAS}

orig. - partitura original para piano (Granados, 1987)

tIC - transcrição de Iury Cardoso

tML - transcrição de Miguel Llobet

gG. - gravação de Granados (GRANADOS, 2005) 


\section{SUMÁRIO}

INTRODUÇÃO $\quad$ p. 12

1 BIOGRAFIA RESUMIDA DE ENRIQUE GRANADOS (1867 - 1916) p. 18

2 ASPECTOS GERAIS DAS 12 DANZAS ESPAÑOLAS OP.37 p. 23

$2.1 \mathrm{~N}^{\mathrm{o}} 1$ Minuetto $\quad$ p. 25

$2.2 \mathrm{~N}^{\mathrm{o}} 2$ Oriental p. 26

$2.3 \mathrm{~N}^{\mathrm{o}} 3$ Zarabanda $\quad$ p. 27

$2.4 \mathrm{~N}^{\mathrm{o}} 4$ Villanesca $\quad$ p. 28

$2.5 \mathrm{~N}^{\mathrm{0}} 5$ Andaluza $\quad$ p. 30

$2.6 \mathrm{~N}^{\circ} 6$ Rondalla Aragonesa p. 32

$2.7 \mathrm{~N}^{\mathrm{0}} 7$ Valenciana $\quad$ p. 32

$2.8 \mathrm{~N}^{\circ} 8$ Asturiana p. 36

$2.9 \mathrm{~N}^{\circ} 9$ Mazurca $\quad$ p. 36

$2.10 \mathrm{~N}^{\circ} 10$ Danza Triste $\quad$ p. 37

$2.11 \mathrm{~N}^{\circ} 11$ Zambra p. 38

$2.12 \mathrm{~N}^{\mathrm{o}} 12$ Arabesca p. 39

3 CONCEITUAÇÃO DA SCORDATURA p. 41

3.1 A scordatura no violão $\quad$ p. 41

$\begin{array}{ll}3.2 \text { A scordatura estendida } & \text { p. } 43\end{array}$

4 O PROCESSO DE TRANSCRIÇÃO PARA VIOLÃO DAS 12 DANZAS

$\begin{array}{ll}\text { ESPANOLAS OP. } 37 & \text { p. } 46\end{array}$

4.1 Aplicação dos procedimentos tradicionais de adaptação e aspectos gerais

$\begin{array}{ll}\text { das transcrições } & \text { p. } 46\end{array}$

$\begin{array}{ll}4.1 .1 \text { Tessitura } & \text { p. } 47\end{array}$

$\begin{array}{ll}\text { 4.1.2 Escolha de tonalidades } & \text { p. } 52\end{array}$

4.1.3 Disposição das notas nos acordes p. 53

4.1.4 Omissões p. 55

$\begin{array}{ll}4.1 .5 \text { Acréscimos } & \text { p. } 57\end{array}$

$\begin{array}{ll}\text { 4.1.6 Simulação do pedal do piano } & \text { p. } 59\end{array}$

$\begin{array}{ll}\text { 4.1.6.1 Campanela p. } 59 & \text { p }\end{array}$

4.1.6.2 Ressonâncias p. 61 
4.1.7 Reelaboração do material musical

p. 62

4.2. Nossas propostas de scordature para as transcrições

p. 64

5 TRANSCRIÇÕES DAS 12 DANZAS ESPAÑOLAS OP. 37

p. 68

5.1 Danza $n^{\circ} 1$

p. 68

5.1.1 Partitura da transcrição

p. 71

5.2 Danza $n^{\circ} 2$

p. 74

5.2.1 Partitura da transcrição

p. 77

5.3 Danza $n^{\circ} 3$

p. 81

5.3.1 Partitura da transcrição

p. 83

5.4 Danza $n^{\circ} 4$

p. 88

5.4.1 Partitura da transcrição

p. 89

5.5 Danza $n^{\circ} 5$

p. 95

5.5.1 Partitura da transcrição

p. 98

5.6 Danza $n^{\circ} 6$

p.102

5.6.1 Partitura da transcrição

p.106

5.7 Danza $n^{\circ} 7$

p.112

5.7.1 Partitura da transcrição

p.116

5.8 Danza $n^{\circ} 8$

p. 123

5.8.1 Partitura da transcrição p. 125

5.9 Danza $n^{\circ} 9$

p. 130

5.9.1 Partitura da transcrição

p.132

5.10 Danza $n^{\circ} 10$

p.139

5.10.1 Partitura da transcrição

p.141

5.11 Danza $n^{\circ} 11$

p. 146

5.11.1 Partitura da transcrição

p. 148

5.12 Danza $n^{\circ} 12$

p. 154

p.158

5.12.1 Partitura da transcrição

p.163

6 CONSIDERAÇÕES FINAIS

p.166

REFERÊNCIAS BIBLIOGRÁFICAS

p.170 


\section{INTRODUÇÃO}

Inúmeros foram os procedimentos da prática de transcrição musical na história da música ocidental, desde a formação do repertório instrumental na era renascentista - cujo foco era voltado basicamente a novas roupagens, partindo de obras vocais - até a função doméstica da música no romantismo, com reduções de aberturas de óperas e sinfonias, produzidas pelas editoras com finalidades comerciais (BARBEITAS, 2000).

Podemos observar, na história do violão, que grandes intérpretes sempre se valeram da prática da transcrição como forma de ampliação do repertório, sobretudo de obras dos períodos renascentista, barroco e romântico. De certa forma, havia uma preocupação, que durou do final do século XVIII até meados do século XX, em trazer para o violão obras de compositores referenciais (J. S. Bach, W. A. Mozart, G. Rossini, F. Chopin, F. Mendelssohn, etc.), de forma a chamar a atenção para as possibilidades do violão como instrumento de concerto.

A transcrição na história do violão tornou-se uma tradição a partir do século XIX. Nesse período, sua finalidade era proporcionar uma expansão do repertório ao mesmo tempo que demonstrava a capacidade do instrumento em executar música séria ou de entretenimento, possibilitando a este certa ascendência cultural, seja do ponto de vista da difusão, seja da qualidade composicional. Pertencem a esse período, por exemplo, as seis Rossiniane, op. 119124 (variações e pot-pourris de árias famosas de Rossini) de Mauro Giuliani (1781 - 1829) e as Six airs choisis de l'opéra de Mozart la Flûte Magique, op. 19 de Fernando Sor (1778 1839).

Fernando Sor revela nessa transcrição, ao nosso ver, um compromisso entre o
idiomatismo do violão e a escrita original de Mozart. Tal postura diante da partitura
original se mantém basicamente em todas suas transcrições do Op. 19. Sua concepção
parece [...] não transgredir a obra-fonte, preservando sua sintaxe e contribuindo para
que a transcrição pudesse legar ao repertório instrumental o ideal dos compositores
clássicos (REGO, 2012, p. 205).

O segundo quartel do século XIX, até as duas primeiras décadas do século XX, constituiu um período em que a transcrição ganhou destaque através da figura de Francisco Tárrega (1852 - 1909) e de seus discípulos Miguel Llobet (1878 - 1938) e Emilio Pujol (1886 - 1980), que representam a continuidade da contribuição iniciada por seu mestre na história do violão, cada qual com suas abordagens da chamada "Escola de Tárrega" (DUDEQUE, 1994). Essas adaptações para violão, basicamente dos alemães Schumann, Beethoven e Bach, 
além de Mozart e dos operistas Wagner, Rossini e Verdi, constituíram um ponto de partida para a tendência, já mencionada, de demonstrar através de transcrições, que o violão era capaz de gerar música séria e somavam-se a uma outra vertente de repertório, o das peças de caráter de apelo popular, que eram ancoradas na demanda do nacionalismo já em estado avançado na Europa e Espanha.

\begin{abstract}
A característica mais marcante desse período é a atenção voltada para o repertório pianístico. Tárrega também transcreveu trechos de música de câmara, música orquestral, óperas italianas, alemãs e francesas, diversificando as influências na arte da transcrição num período em que o violão tinha pouca presença nos grandes circuitos de concertos (GLOEDEN; MORAIS, 2008, p. 73).
\end{abstract}

A referência a Tárrega, em transcrições de obras originalmente escritas para piano, é singular. Sua experiência como pianista e familiaridade com o repertório possibilitavam um contato profundo com obras que estavam em vias de passarem para o chamado "cânone" da música de concerto. Sua habilidade em executar as peças originais ao piano proporcionava fidelidade e exequibilidade a suas transcrições violonísticas; era, portanto, um músico apto a realizar esse tipo de trabalho. Chama a atenção o enfoque por ele dado à música de Enrique Granados e Isaac Albéniz (1860-1909), que elogiou a transcrição que Tárrega fez de sua Serenata, afirmando: "Esto és lo que yo habia concebido!" (MESTRES', 1927 apud GLOEDEN, 1996, p. 47)

Tais princípios da arte caracterizada por Tárrega foram levados adiante por seus discípulos diretos e a cultura da transcrição perdura até os dias de hoje, porém de forma extremamente diversificada, abrangendo desde a releitura de obras contemporâneas até procedimentos de música popular. Sobre esse aspecto chamamos a atenção para a observação abaixo:

Uma transcrição, por mais idiomática que seja, apresenta um dilema de interpretação
ao constituir-se em uma forte intervenção do intérprete em uma obra musical, muitas
vezes de maneiras não imaginadas pelo seu autor. Acreditamos que a tensão
estabelecida por esse dilema seja a própria fonte da riqueza do procedimento, que
explicaria a longevidade da transcrição (GLOEDEN; MORAIS, 2008, p. 84).

A transcrição engloba diversas abordagens que estão muito além do que simplesmente transferir as notas da obra do instrumento original para o novo meio receptor. Há constantemente problemas na adaptação de textura e de disposições de acordes. No caso do violão, ao se lidar com as diferentes tessituras, há decisões que precisam ser assumidas pelo transcritor, sobretudo quando se trata de transcrições de obras originalmente escritas para

\footnotetext{
${ }^{1}$ MESTRES, Apeles. Volves Musicals. Barcelona: Salvador Bonavía, 1927.
} 
instrumentos de teclado. Tais decisões exigem soluções engenhosas e muitas vezes criativas e pressupõem um conhecimento profundo da estrutura da obra, bem como do resultado causado por qualquer alteração (MORAIS, 2007). Segundo Morais (2007, p. 24) "Não seria um trabalho de precisão da transposição literal do texto, mas um trabalho que envolve algum nível de criação. Em certos casos, trata-se de uma reelaboração do material”. Citamos também um texto de Rudolph Stephan que embasa nossa posição:

A validade duma transcrição não pode avaliar-se pela maneira como o original é retomado e mantido, tanto quanto possível, intacto, mas na medida em que se sente que foi usado um tratamento adequado. Noutros termos, pode dizer-se que uma transcrição é bem conseguida quando nos dá a impressão de ser uma composição original, conquanto, modificando embora o fenômeno acústico, a realidade musical obtida seja análoga ao original (STEPHAN, 1968, p. 156).

Dentre as categorias que podem se dividir os processos de reelaboração musical e a discussão sobre suas diferenças terminológicas (arranjo, adaptação, transcrição, orquestração etc), esclarecemos que o termo transcrição, utilizado no decorrer desse trabalho, representa o conceito apresentado por Pereira, citado a seguir:

Assim, apoiados na questão etimológica do termo transcrição, percebe-se que além de
ser uma prática que possui maior grau de fidelidade com o original, traz também um
procedimento no qual há sempre uma mudança de meio instrumental, ou seja,
"transporta-se" de um instrumento a outro, ou de um meio a outro. A transcrição não
é tão livre, pois o intuito é guardar ao máximo a ideia original, além de que o meio
para o qual se destina é fundamental, pois as variações que surgem, vêm a partir da
necessidade de adequação às especificidades de cada instrumento (PEREIRA, 2011,
p.52).

Através da pesquisa do patrimônio de transcrições, os objetivos desse trabalho foram: 1. Observar as versões para violão de outras obras originais para piano, comparando os recursos instrumentais específicos desses dois instrumentos, em busca de melhores soluções de adaptação para a transcrição das 12 Danzas Españolas de Enrique Granados; 2. Investigar as transcrições realizadas por violonistas referenciais, objetivando um levantamento das técnicas de adaptação empregadas por esses compositores e intérpretes em suas transcrições, para aplicálas na adaptação da obra em questão à linguagem violonística; 3. Buscar, através da experimentação, novas possibilidades de scordature que possam auxiliar na solução dos problemas de adaptação, principalmente das Danzas com escassas transcrições satisfatórias para violão solo, a saber, Danzas $n^{\circ} 1,6,7,8,9$ e 11, e; 4. Realizar uma versão própria como forma de aplicação dos conceitos observados durante o levantamento técnico dos procedimentos de adaptação.

Em relação à pesquisa sobre os aspectos biográficos de Granados e a contextualização de suas Danzas Españolas, a maior parte das informações históricas vieram do livro de Clark 
(2011), umas das publicações mais representativas sobre a vida e obra do compositor. A publicação digital da Fundación Juan March (1991), assim como o texto de Bergadà (2011) foram esclarecedores nesse aspecto também. Além disso, utilizamos um texto sobre as origens dos diferentes tipos de danças espanholas (DANZAS ESPAÑOLAS, 2016) e dois programas de rádio da BBC sobre o assunto: Enrique Granados (2016) e Granados e Albéniz (2014). Ainda nos aspectos históricos, o livro de Dudeque (1994) foi de grande auxilio no que se refere à história do violão.

É possível perceber que uma análise em pormenores da riqueza dos materiais musicais utilizados nas 12 Danzas Españolas Op. 37 provavelmente renderiam uma dissertação exclusiva dedicada a esse tema. Não é nossa intenção entrar nos mais diversos detalhes da composição, mas apenas fornecer subsídios para uma compreensão geral da obra, dando enfoque ao processo de adaptação para o violão.

Há vários tópicos abordados pela pesquisa sobre os procedimentos de transcrição musical recorrentes no repertório violonístico e há uma diversidade de trabalhos sobre o assunto. O ressurgimento do violão no século XX: Miguel Llobet, Emilio Pujol e Andrés Segovia (GLOEDEN, 1996) é uma importante referência presente em grande parte das dissertações que envolvem o instrumento em questão. Os trabalhos de Morais (2007) e Pereira (2011) apresentam reflexões críticas acerca das terminologias e oferecem caminhos de investigação, enquanto Gloeden e Morais (2008) fazem um levantamento dos aspectos históricos da transcrição. Várias outras pesquisas, abrangendo esse aspecto, foram utilizadas (por exemplo: Stephan, 1968; Bota, 2008; Barbeitas, 2000; Rego, 2012 e Souto, 2010).

$\mathrm{Na}$ investigação sobre a conceituação da scordatura, sua origem e aplicação no repertório violonístico, são importantes os trabalhos de Campbell, Greated e Myers (2004), Borges (2007), Stefan (2012), Tyler (1998) e Vasconcelos (2002).

Nossa pesquisa foi qualitativa, aprofundando-se no processo de transcrição para violão solo das 12 Danzas Españolas Op. 37 de Enrique Granados, onde foram analisadas as principais problemáticas de adaptação da obra original em um novo meio. Por conta da investigação das possibilidades de adaptação através da pesquisa de diferentes opções de scordature, nosso trabalho foi também, de certo modo, uma pesquisa experimental, onde cada uma das peças passou, muitas vezes, por transcrições em diferentes tonalidades e scordature, em busca daquela que julgamos a melhor opção. 
As primeiras análises tiveram como foco as transcrições históricas de uma tradição iniciada por Francisco Tárrega e levada adiante por Miguel Llobet e Emílio Pujol. Suas transcrições foram comparadas com as partituras originais, com a finalidade de observar suas características de adaptação e as escolhas adotadas para tornar a obra exequível e fluente no violão. Das partituras analisadas, podemos salientar as adaptações de Tárrega e Llobet (2006) das peças de Albéniz (1987a, 1987b e 1987c) e Granados (1987), assim como as diversas transcrições de Segovia (1960). Foram importantes também as gravações de violonistas referencias interpretando obras transcritas para violão (por exemplo: Segovia, 1988 e 1997; Bream, 1982 e Barrueco, 1997).

Para a proposta da realização de versões próprias, foram investigadas as transcrições da geração atual de violonistas referenciais ${ }^{2}$. Além disso foi possível encontrar trabalhos recentes de pós-graduação voltados a prática da transcrição, é possível citar: Carvalho (2012), Costa (2006, 2012) e Betancourt (1999). A finalidade dessa análise foi observar as novas atitudes de adaptação frente ao próprio instrumento.

Como o presente trabalho é inserido na área de pós-graduação em performance, a parte prática é também produto da investigação teórica e deve estar relacionada a tal. Para isso, as abordagens levantadas no trabalho foram aplicadas em nossas transcrições e foram determinantes no processo de adaptação das 12 Danzas Españolas para violão solo.

Para a realização de nossas transcrições, foram consultadas as seguintes fontes: a primeira edição das 12 Danzas Españolas para piano solo publicada pela editora Casa Dotesio (GRANADOS, 1890), atualmente conhecida como Unión Musical Española, e sua reimpressão pela Dover Publications (GRANADOS, 1987). Desta foram retirados os exemplos contidos nesse trabalho. Todas as indicações de agógica foram preservadas tais como apresentadas nas partituras originais. As principais referências sonoras vieram da gravação das Danzas, executadas por Alicia de Larrocha (LARROCHA, 1995), assim como das gravações realizadas entre 1908 e 1916 das Danzas $\mathrm{n}^{\circ} 1,2,5,7$ e 10, interpretadas pelo próprio compositor (GRANADOS, 2005).

Sendo assim, construímos nosso trabalho com a seguinte estrutura: No capítulo 1 comentamos brevemente sobre a formação do movimento do nacionalismo musical espanhol e biografamos Enrique Granados, com a finalidade de situar o leitor na contextualização de sua obra, assim como pontuar algumas das principais conquistas do mestre espanhol; O capítulo 2 se refere exclusivamente as 12 Danzas Españolas, objeto principal de nossa pesquisa.

\footnotetext{
2 David Russel, Manuel Barrueco, Paul Galbraith, Sergio Abreu, Sergio Assad, Nícolas de Souza Barros, são alguns exemplos de importantes transcritores.
} 
Apontamos aspectos musicais essenciais em cada uma delas, assim como tratamos de sua importância e contextualização histórica, frente a sua influência na música espanhola e na obra de Granados; no capítulo 3 discutimos a conceituação da scordatura, incluindo alguns exemplos de sua manifestação no repertório violonístico e considerações sobre a scordatura por um viés de técnica estendida; no capítulo 4 relatamos a aplicação das técnicas tradicionais de adaptação - absorvidas através da investigação do patrimônio de transcrições referenciais nas Danzas Españolas; e por fim, no capítulo 5, apontamos as particularidades de adaptação do ciclo em questão, assim como o processo de pesquisa e as decisões acerca de nossas configurações de scordature. Nos subcapítulos referentes a cada uma das doze peças, estão presentes também as partituras das respectivas transcrições, produto final de nossa pesquisa. 


\section{BIOGRAFIA RESUMIDA DE ENRIQUE GRANADOS (1867-} 1916)

Esse pequeno resumo biográfico tem a finalidade de situar o leitor na contextualização da obra, assim como pontuar algumas das principais conquistas do mestre espanhol.

Em Lleida ${ }^{3}$, no dia 27 de julho de 1867, nasce Panteleón Enrique Joaquín Granados, filho de Enriqueta Elvira Campiña e do militar Calixto Granados y Armenteros. É interessante notar que Granados era catalão apenas por nascimento e não por etnia. Seu pai era cubano por segunda geração e sua mãe era de Santander, em Cantabria, e também possuia alguns ancestrais mexicanos (BERGADÀ, 2011).

Quando sua família mudou para Barcelona, Granados teve suas primeiras instruções musicais, ainda rudimentares com um soldado catalão idoso chamado José Junqueda. Seu primeiro professor significante, no entanto, foi Francisco Xavier Jurnet, com quem Granados teve aulas de piano de 1878 até 1882 . Acerca de sua educação formal, comenta Clark:

Notamos que, além de seus estudos de piano, o jovem Granados tinha uma quase total
falta de educação formal. E, no entanto, ele se tornou um homem muito refinado e
educado, fluente em três idiomas - castelhano, catalão e francês - e inteirado com os
mais recentes desenvolvimentos literários. Aqueles que mais tarde frequentaram sua
casa comentaram sobre sua grande coleção de livros, que incluía prosa e poesia de
autores estrangeiros e nativos. Ele especialmente valorizava os clássicos espanhóis
(CLARK, 2011, p.16, tradução nossa). ${ }^{4}$

Posteriormente sua mãe o levou para ter aulas com Joan Baptista Pujol (1835-1898), que inicialmente não aceitou Granados como estudante por já ter muitos alunos sob seus cuidados. Contudo, devido a insistência de Enriqueta por uma audição, Pujol mudou de ideia ao escutar o jovem ao piano. Granados cresceu tocando a música de Schumman, Schubert, Chopin, Lizst e outros compositores da Europa Central que foram, para ele, grande fonte de inspiração; e determinantes na formação de sua personalidade musical. Após um curto período de tempo, Granados venceu um concurso na academia Pujol interpretando a Sonata em Sol menor, Op. 22 de Schumann. A banca, na ocasião, contava com Martínez Imbert (1845-1915),

\footnotetext{
${ }^{3}$ Embora conhecida como Lérida na Espanha, Lleida é o nome oficial catalão.

${ }^{4}$ We notice that, aside from piano study, young Granados had a near-total lack of formal education. And yet, he eventually became a very refined and educated man, fluent in three languages - Castilian, Catalan, and French and current with the latest literary developments. Those who later frequented his home commented on his large collection of books, including prose and poetry, by authors foreign and natives. He especially prized the Spanish classics.
} 
Isaac Albéniz e Felipe Pedrell (1841-1922), com quem, no ano seguinte, começou a estudar harmonia e composição. Pedrell, uma figura importante, exerceu grande influência em diversos compositores espanhois referenciais, como: Isaac Albéniz, Manuel de Falla (1876 - 1946), Cristòfor Taltabull (1888 - 1964), Joaquín Turina (1882 - 1949), Pedro Blanco (1883 - 1919), entre outros. Através da etnomusicologia, Pedrell estimulava a utitilização de temas, ritmos e escalas próprias nas composições de seus discípulos, gerando o que foi conhecido como nacionalismo musical espanhol (CLARK, 2011).

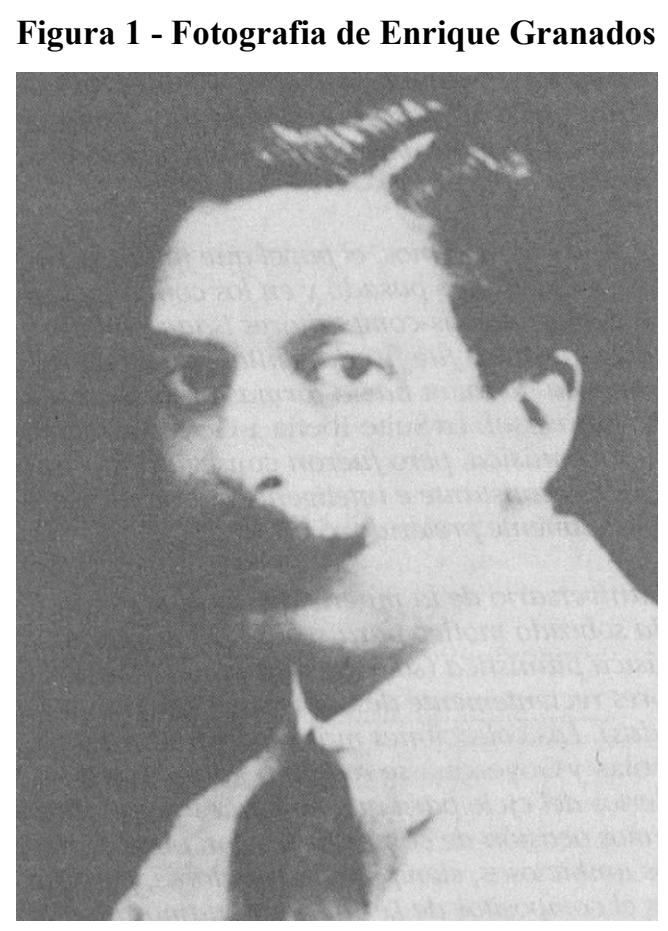

Fonte: (FUNDACIÓN JUAN MARCH, 1991)

Devido a morte de seu pai, em 1882, o jovem Granados passou a tocar piano em cafés para contribuir com o orçamento da família e, em abril de 1886, com dezoito anos de idade, deu seu primeiro concerto formal no Ateleu Barcelonés, ao lado de alguns alunos de Pujol. O programa contava com a Tarantelle de Gottschalk e a Fantasia de José Garcia Robles.

Assim como muitos estudantes espanhóis antes e depois dele, Granados percebeu que deveria deixar o país para fazer estudos mais avançados e ganhar mais legitimidade perante os olhos do público e da crítica. Partiu então para França e desembarcou em sua capital no verão de 1887 com o intuito de estudar com Charles de Beriot (1833 - 1916), mas foi impedido de se apresentar nas audições do conservatório por um caso repentino de tifo. Devido ao longo período de recuperação, a data dos exames havia passado, mas isso não impediu Granados de ter aulas particulares com Beriot, com quem pode se desenvolver principalmente nos campos 
da improvisação, canto, estilo lírico-musical e na forma particular com que fazia uso dos pedais do piano (FUNDACIÓN JUAN MARCH, 1991).

Foi durante seus dois anos de estadia em Paris que Granados conviveu com os mais diversos pintores, escritores e músicos, destacando as figuras de Erik Satie (1866 - 1925) e Claude Debussy (1862 - 1918). Foi também companheiro de moradia do pianista Ricard Viñes (1875 - 1943), que futuramente se tornaria conhecido por sua interpretação do repertório moderno francês e espanhol.

Ao retornar para Barcelona em 14 de julho de 1889, o interesse pela música popular espanhola não demorou a se manifestar em suas obras, seguindo com isso a inclinação nele estimulada por Pedrell. É nesse período que Granados publica suas célebres 12 Danzas Españolas e começa a obter fama como pianista virtuoso e compositor, sendo sua atividade como concertista muito intensa, dando recitais em Paris, Nova York e em diversas cidades da Espanha. Atuava ao lado de figuras como: Joaquín Malats (1872 - 1912), Eugène Ysaye (1858 - 1931), Camille Saint Saëns (1835 - 1921), Pau Casals (1876 - 1973) e Isaac Albéniz, entre outros (GRANADOS AND ALBENIZ, 2014).

Em 1892 casou-se com Maria de los Desamparados Gal y Lloveras, conhecida simplesmente por Amparo Gal. Com ela, o compositor teve seis filhos.

Figura 2 - Retrato de Enrique Granados

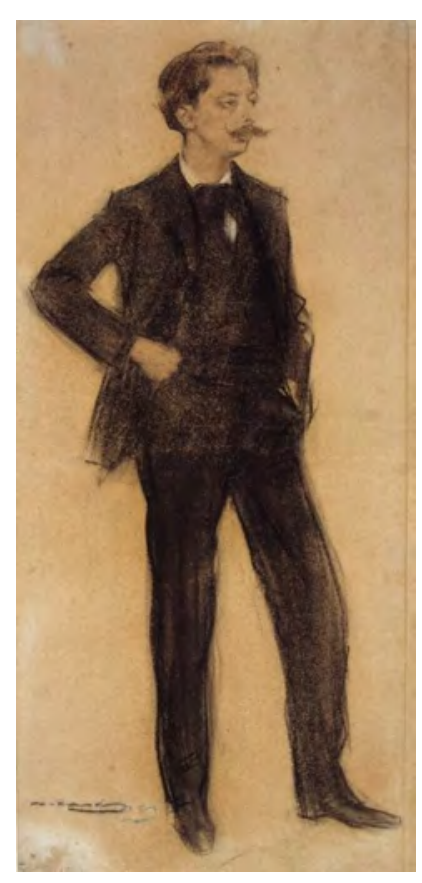

Fonte: Casas [entre 1897 e 1899] 
Foi em 1898 que Granados obteve seu primeiro grande sucesso, com a ópera Maria del Carmen e, nos dois anos que se seguiram, em Barcelona, criou a "Sociedade de Concertos Clássicos". Nessa mesma época, ao lado de Pedrell, fundou a "Academia Granados", uma instuição direcionada ao ensino da arte pianística, a qual foi diretor até sua morte. Em 1907 dá início a composição do poema sinfónico Dante, inspirado na "Divina Comédia" do poeta florentino, cuja versão inacabada teve sua estréia em uma sessão privada em Barcelona (GRANADOS AND ALBENIZ, 2014).

Embora atuante nas mais diversas áreas da composição, na sua produção pianística que o compositor demonstrou seus melhores dotes. Neste sentido, o ponto culminante de sua carreira artística foi alcançado na obra Goyescas, em sua forma original para piano, e nas Tonadillas en estilo antiguo, para soprano e piano.

Entre 1908 e 1916 Granados realizou algumas gravações em rolo tocando piano, que são registros preciosos para constatar o trabalho do compositor catalão como pianista (GRANADOS, 2005).

Goyescas, obra organizada em dois livros de partituras, representam um marco na carreira de Granados. O primeiro livro foi estreado pelo próprio compositor em 1911 no Palau de la música Catalana, em Barcelona e a estréia parisiense da obra completa ocorreu em abril de 1914 na Salle Pleyel, em um concerto organizado pela Societé Musicale Indépendente. Devido ao sucesso da apresentação, o diretor da Opéra National de Paris pediu a Granados que transformasse a suíte em uma ópera em troca de conceder sua éstreia na mesma cidade. Granados dedicou-se a essa missão e também intitulou sua ópera como Goyescas, utilizando o libreto do espanhol Fernando Periquet y Zuaznaba (1873 - 1940). A prometida estréia da ópera não se concretizou por causa da Primeira Guerra Mundial. O compositor, então, aceitou o convite do Metropolitan Opera House em Nova York para que sua obra tivesse sua estréia ali em 1916. Trata-se de uma ópera de um ato, de estrutura complexa que tenta refletir o ambiente das classes populares de Madrid no fim de século XVIII; o mundo artístico de Goya e de Ramón da Cruz, o mesmo universo de majos e majas que foram estilizados em suas Tonadillas. Intimamente ligada com as Goyescas, justamente por recolher alguns de seus temas melódicos, está a obra de maior maturidade de Granados, as Tonadillas al estilo antiguo, que também foram inauguradas na Salle Pleyel em 1914 (ENRIQUE GRANADOS, 2016).

Depois do triunfal estréia da versão operística de Goyescas em 28 de janeiro de 1916 no Metropolitan de Nova York, Granados foi convidado pelo presidente Woodron Wilson a dar um concerto na Casa Branca. Lamentávelmente, durante seu regresso a Europa, estava a bordo 
do barco a vapor inglês Sussex, que foi torpedeado por um submarino alemão no canal da Mancha, entre Folkestone e Dieppe. Granados faleceu, no auge de sua maturidade artística, junto com sua esposa Amparo na tarde do dia 24 de março de 1916 (FUNDACIÓN JUAN MARCH, 1991).

Granados foi um inovador na criação de um estilo de composição e grande parte de sua música para piano emana a tradição romântica do início do século XIX. Sobre sua morte manisfestou-se Debussy: "Este fim lamentável priva a música de uma de suas criaturas mais amáveis 5"(CLARK, 2011). Outro traço da personalidade de Granados é que o compositor nunca se comprometeu totalmente com nenhum estilo, ideologia, identidade ou movimento em particular. Em um processo de afirmação contínua de sua individualidade, ele admirava o belo, onde quer que ele encontrasse: em uma mazurka de Chopin, uma pintura de Goya, uma malagueña murciana, uma poesia moderna catalã ou mesmo na ópera de Wagner (ENRIQUE GRANADOS, 2016).

Talvez o maior investimento de Granados como artista foi ter habitado três reinos diferentes: Catalunha, Espanha e Europa. A habilidade em se comunicar nessas diversas vertentes culturais foi o principal ingrediente em sua vida criativa. Sua versatilidade era memorável e o destacou da maioria de seus contemporâneos em Barcelona. Granados tinha uma relação próxima com pintores, dramaturgos e poetas e ele mesmo gostava de desenhar esboços e escrever alguns versos. Talvez por conta dessa influencia incorporava no título de suas obras elementos de outros campos artísticos, como as valses poéticas, escenas poéticas e goyescas, por exemplo (ENRIQUE GRANADOS, 2016).

\footnotetext{
${ }^{5}$ Este fin lamentable priva la música de una de sus criaturas mas amables.
} 


\section{ASPECTOS GERAIS DAS 12 DANZAS ESPAÑOLAS OP.37}

Granados é universalmente reconhecido como um dos compositores mais importantes da Espanha. Sua música é multifacetada, embora seja essencialmente romântica com algumas características nacionalistas. Era descrito em sua época como o "Chopin espanhol", "o último romântico" e por seus compatriotas como "o nosso Schubert". Embora não exista uma única definição que descreva adequadamente sua personalidade, Granados tinha um estilo musical inconfundível (FUNDACIÓN JUAN MARCH, 1991).

Granados foi influenciado pelo romantismo europeu, principalmente pela música de meados do século XIX, em especial por Schumann, Chopin, Schubert e Wagner. A forma que trata a harmonia, sua rica paleta de cores pianísticas, estruturas formais soltas e sua imaginação vívida, sempre tingida com certa dose evocativa, colocam-no firmemente dentro da escola romântica. As grandes formas, tais como sonatas e concertos pareciam não atrair Granados. Sua personalidade artística foi mais adequada para formas rapsódicas mais curtas, especialmente aquelas com base nas variações (BERGADÀ. 2011).

A primeira das obras-primas do compositor, e talvez a mais célebre de todas elas, foi a coleção de doze peças para piano solo intituladas de Danzas Españolas, divididas em quatro livros de três Danzas cada. Ao contrário de Grieg em sua Slatter, Op.72 (Norwegian Peasant Dances), Granados não utiliza quaisquer temas folclóricos em suas Danzas Españolas. Em vez disso, ele sublimou características típicas espanholas em seu próprio estilo musical pessoal.

Houve consideráveis confusões sobre a data de composição do ciclo. Segundo o compositor Henri Collet (1885 - 1951), “[...]Granados estava trabalhando nas danças em Paris durante 1888" (CLARK, 2011, p. 30). Apesar de uma carta escrita por Granados parecer datálas de 1883, é provável que o número final foi confundido com um "3" ao invés de um "8". Dada a idade de dezesseis anos do compositor em 1883, é pouco provável que tais obras apresentassem tal maturidade composicional em uma idade tão precoce (FUNDACIÓN JUAN MARCH, 1991). A data de término também não é clara, mas Granados estreou suas Danzas em 20 de abril de 1890 no Teatro Lírico de Barcelona e publicou-as pela editora Casa Dotesio no mesmo ano. Obteve então as mais elogiosas considerações, segundo nos aponta Clark:

Depois que as danzas foram publicadas, Granados enviou cópias para vários dos principais músicos da Europa, incluindo Saint-Saëns, Jules Massenet, Edvard Grieg, e César Cui. Cui achou-as "encantadoras em melodia e harmonização" e excepcionais em sua "originalidade individual". Massenet o saudou como "o Grieg espanhol", 
enquanto Saint-Saëns e Bériot adicionaram suas vozes ao coro de louvor. Os espanhóis, também, encontraram muita inspiração nelas. O regente e compositor de Barcelona Joan Lamote de Grignon as orquestrou, assim como Rafael Ferrer muitos anos depois. Afonso Albéniz, filho do compositor, alegou que Isaac sempre guardou uma cópia das danzas españolas em seu piano. Talvez a organização da Iberia de Albéniz, que consiste em quatro livros de três peças cada, foi inspirada pelas danzas españolas de Granados e destinada ainda como um gesto de admiração. Pedrell muito considerava as danzas também ${ }^{6}$ (CLARK, 2011, p. 30, tradução nossa).

As Danzas de Granados são ricas em expressão melódica e variedade rítmica. Com exceção das Danzas de número 3, 7 e 9, todas são em forma ternária com seções contrastantes em andamento e caráter, onde as codas e retransições são curtas e descomplicadas. Em relação à métrica musical, as de número 4 e 8 possuem compasso $\frac{2}{4}$ enquanto na $\mathrm{n}^{\mathrm{o}} 5$ temos um $\frac{6}{8}$. Todas as outras nove Danzas são escritas em $\frac{3}{4}$ (O compasso ternário é uma característica da música popular espanhola).

A linguagem harmônica é estritamente diatônica e o cromatismo aparece como um colorido para a textura. Embora muitos dos primeiros trabalhos de Granados possuam a cadência final na dominante, apenas uma das Danzas, a de $\mathrm{n}^{\circ} 11$, apresenta essa característica. Outro ponto importante a se considerar é que Granados apenas deu título à Danza $n^{\circ} 4$ Villanesca. Os outros foram adicionados posteriormente por editores.

De qualquer forma, a primeira coisa que alguém que se aproxima dessa música deve entender é que os títulos podem ser enganosos. Tentar analisar a música em si como algum tipo de manifestação dos títulos colocados lá, não por Granados, mas por seus editores, pode levar a uma má interpretação do seu caráter. Na verdade essas danças são representações altamente estilizadas, filtradas através da própria personalidade e origens de Granados. Elas não citam melodias populares por si só e não foram, de forma alguma, qualquer tipo de pesquisa de campo ou transcrição ${ }^{7}$ (CLARK, 2011, p. 31 , tradução nossa).

\footnotetext{
${ }^{6}$ After the danzas were published, Granados sent copies to several of the leading musicians in Europe, including Camille Saint-Saëns, Jules Massenet, Edvard Grieg, and César Cui. Cui found them " charming both in melody and harmonization" and outstanding in their "individual originality". Massenet hailed him as "the Spanish Grieg”, while Saint-Saëns and Bériot added their voices to the chorus of praise. Spaniards, too, found much inspiration in them. The Barcelona conductor and composer Joan Lamote de Grignon orchestrated them, as did Rafael Ferrer many years later. Afonso Albéniz, son of the composer, claimed that Isaac always kept a copy of the danzas españolason his piano. Perhaps the organization of Albéniz's Iberia, consisting as it does of four books of three pieces each, was inspired by Granados's danzas españolas and was even intended as a gesture of admiration. Pedrell thought highly of the danzas as well.

${ }^{7}$ In any case, the first thing someone approaching this music must understand in that the subtitles can be misleading. To try to analyse the music itself as some manifestation of the subtitles placed there, not by Granados but by his publishers, may lead to a misinterpretation of its character. In truth, these dances are highly stylized renditions, filtered through Granados's own personality and backgrounds. They do not quote folk melodies per se and were in no way to product of anything like fieldwork or transcription.
} 
Em meio a tantas diferenças de títulos empregados em edições e gravações, este trabalho levará em consideração, os títulos que, segundo nossa pesquisa dos aspectos musicais essenciais das Danzas, estiveram de acordo com os reconhecidos na gravação de Alicia de Larrocha (LARROCHA, 1995). Larrocha é uma das mais importantes intérpretes do repertório pianístico espanhol em geral. Estudou com Frank Marshall (1883 - 1959), aluno e associado de Granados, na academia fundada pelo próprio compositor (FUNDACIÓN JUAN MARCH, 1991).

\subsection{No 1 Minuetto}

Para introduzir o ciclo, Granados "alonga" um ritmo característico das seguidillas e fandangos para criar a atmosfera de uma espécie de fanfarra nos primeiros compassos. Algumas edições sugerem o título Galante para enfatizar essa atmosfera. A Danza $n^{\circ} l$ foi dedicada à sua esposa Amparo Gal. A peça possui o contraste de uma seção “A” mais dançável com uma seção "B" mais lírica em caráter (Figura 3).

Figura 3 - Início das seções A e B - Danza n ${ }^{\circ} 1$
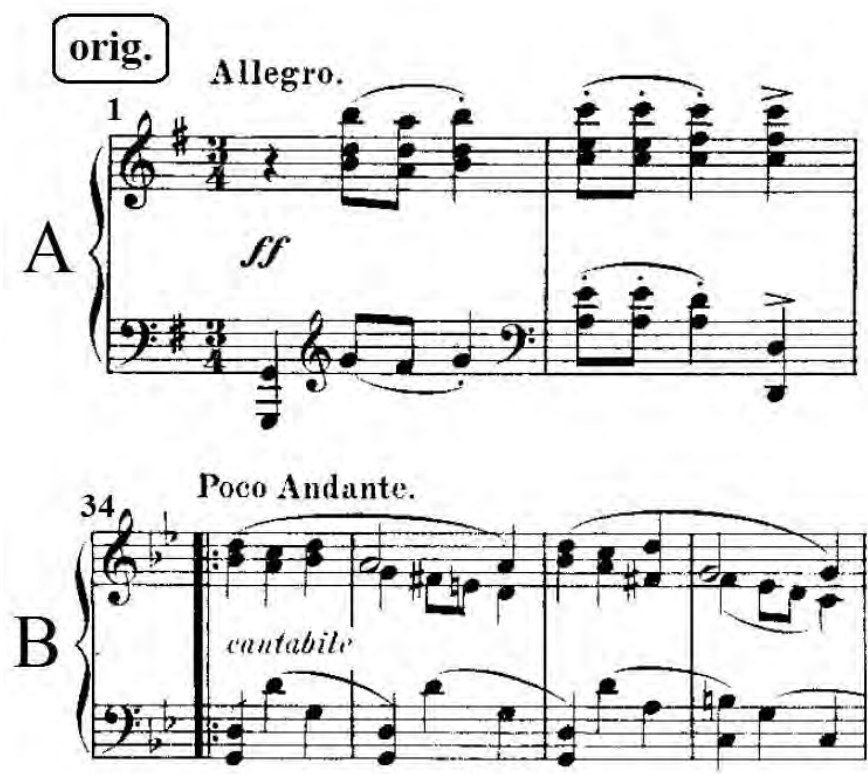

Fonte: Granados (1987) 


\section{$2.2 \mathrm{~N}^{\circ} 2$ Oriental}

Dedicada a Julián Martí, é uma das Danzas mais conhecidas do ciclo. O fascínio pelo oriente é algo frequentemente manifestado na arte do século XIX. Podemos encontrar, principalmente em compositores espanhóis, uma grande sucessão de serenatas mouriscas, caprichos árabes e marchas orientais. Ostinatos rítmicos, melismas, escalas com inflexões cromáticas e o tão utilizado intervalo de segunda aumentada são alguns artifícios utilizados para climatizar a cultura oriental na música.

Tais peças são reminiscências da poesia de românticos espanhóis como José de Zorrilla (1817 - 1893), cujos versos, como o poema épico Granada, estão cheios de "sultões e princesas mouras lunáticas, de turbantes e alcázares perolados, de gerânios e cravos e paixão andaluz". No entanto, a "Oriental" de Granados se eleva acima dos clichês banais e exprime charme e sinceridade convincentes ${ }^{8}$ (CLARK, 2011, p. 32, tradução nossa).

O tema "A" apresenta no acompanhamento o movimento pendular de uma escala que vai de tônica à dominante e a omissão da quarta atribui um contorno arabesco a linha. Uma singela linha melódica se apresenta em terças, intervalo que é característico na música hispânica quando cantada a duas vozes ou mesmo executada ao violão. A peça assemelha-se em conceito a um noturno de Chopin, onde temos uma melodia expressiva com um acompanhamento murmurante (CLARK, 2011). Existe nos dois temas principais da Danza um aspecto de hemíola, onde Granados justapõe o ritmo ternário inerente do acompanhamento com o binário das linhas melódicas (Figura 4).

\footnotetext{
${ }^{8}$ Such pieces are reminiscent of the poetry of spanish romantics like José de Zorrilla (1817 - 1893), whose verses, such as the epic poem Granada, are full of "sultans and moonstruck morish princesses, of turbans and pearly alcazars, of geraniums and carnations and andalusian "passion". However, Granados's "Oriental" rises above the level of hack-neyed clichés and exihibits compelling charm and sincerity.
} 
Figura 4 - Hemíola nos principais temas melódicos
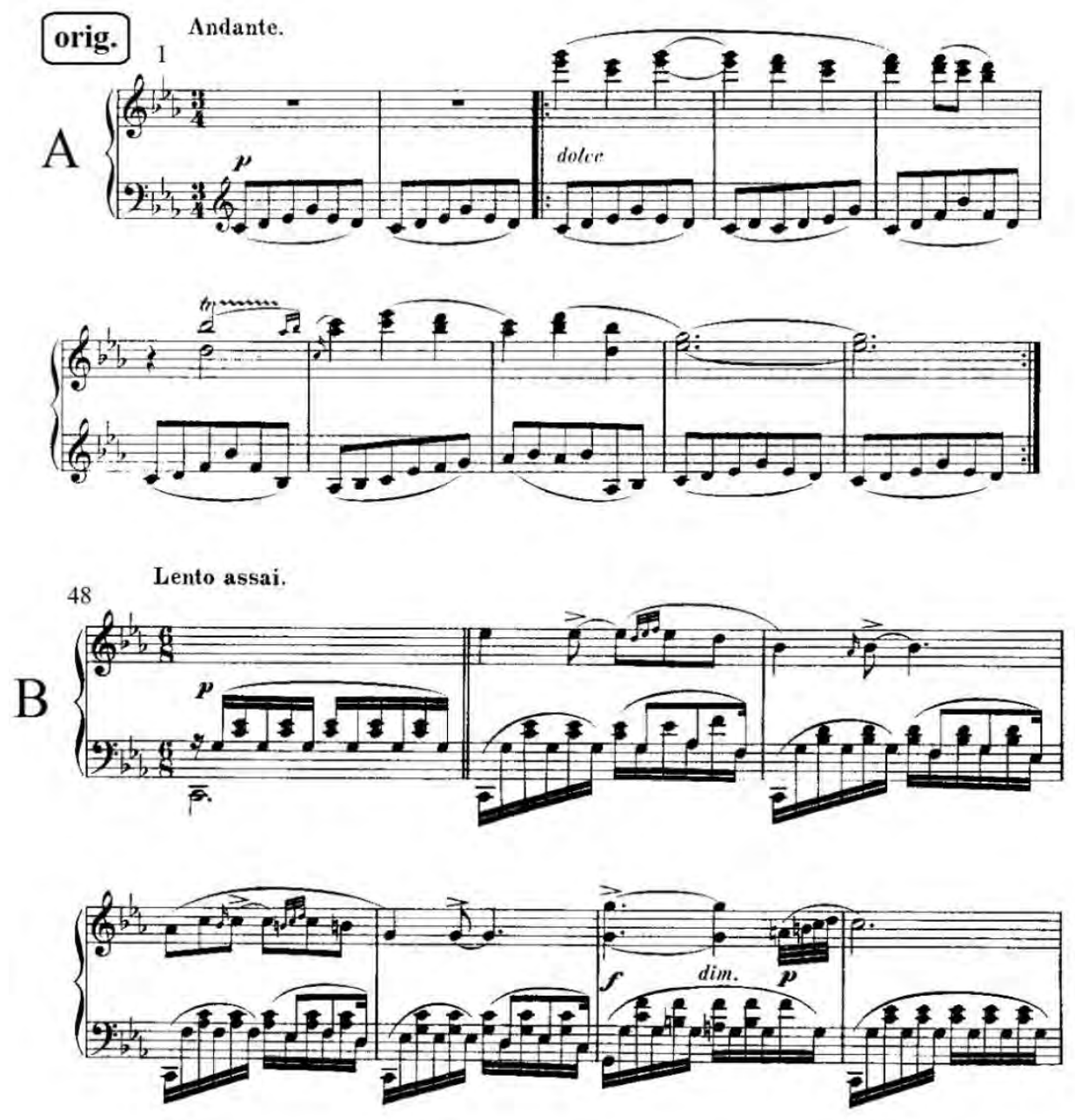

Fonte: Granados (1987)

A linha melódica da seção "B" possui algumas características do canto flamenco, como os acentos fora dos tempos fortes e o contorno melódico de alcance limitado que enfatiza uma determinada nota (DANZAS ESPAÑOLAS, 1999).

\subsection{No3 Zarabanda}

Dedicada a Joaquin Vancells e escrita em Ré Maior, essa Danza de caráter vivo e enérgico contrasta com um certo lirismo de uma curta seção em Si menor. O motivo do tema principal oitavado apresentado por Granados possui certa semelhança com outra de suas composições: a tonadilla “El tra la la y punteado" (Figura 5). 
Figura 5 - Tema principal da seção A

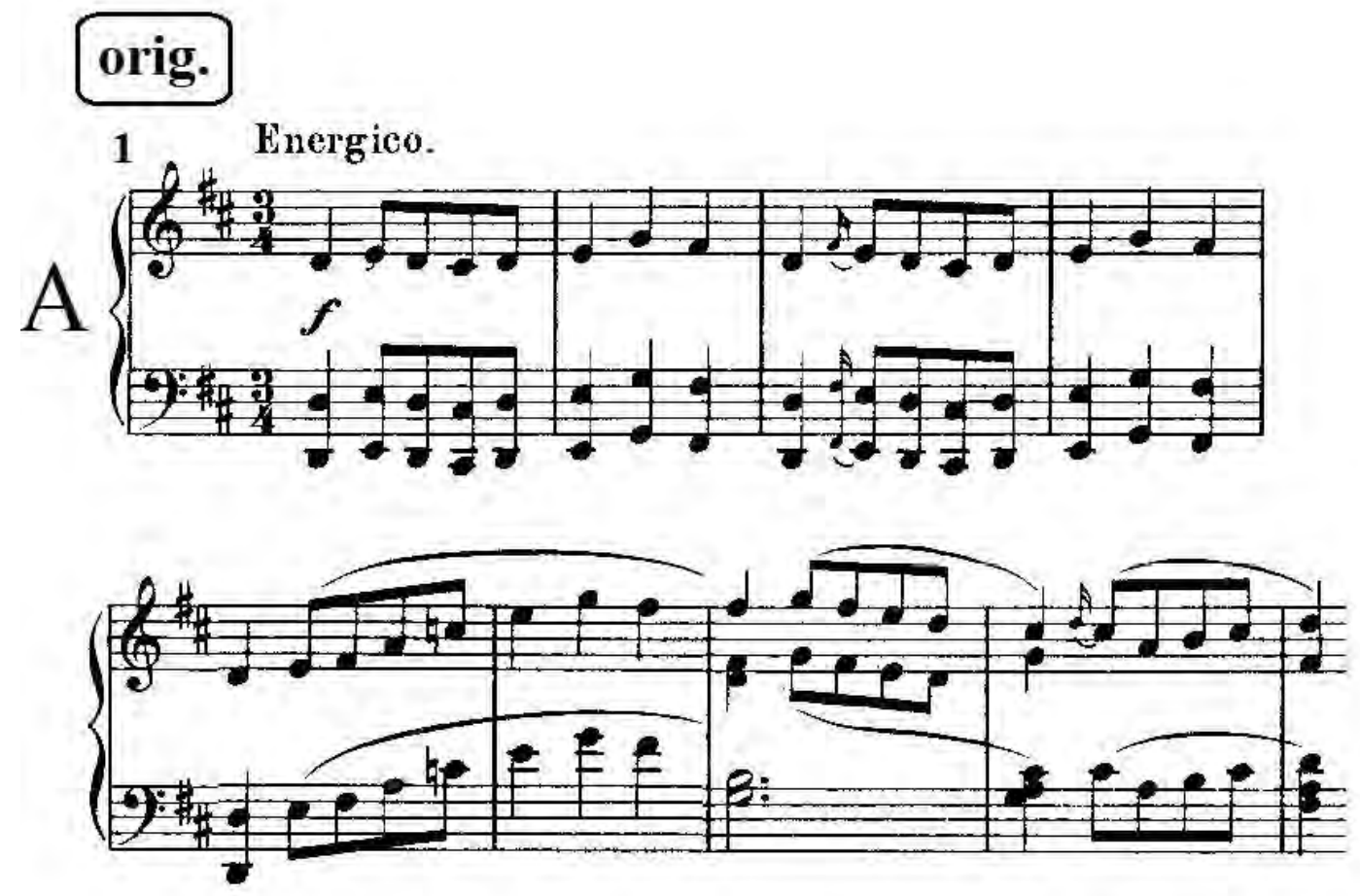

Fonte: Granados (1987)

Algumas edições e compact discs também apresentam o título Fandango.

\section{$2.4 \mathrm{~N}^{\circ} 4$ Villanesca}

Durante a seção "A”, o motivo do tema principal é largamente utilizado e acompanhado de um baixo pedal em Sol. Aqui, através do crescendo poco a poco, a repetição trabalha a favor do efeito emotivo e não da monotonia (Figura 6). 
Figura 6 - repetição do motivo musical com crescendo

orig. Allegretto, alla pastorale.
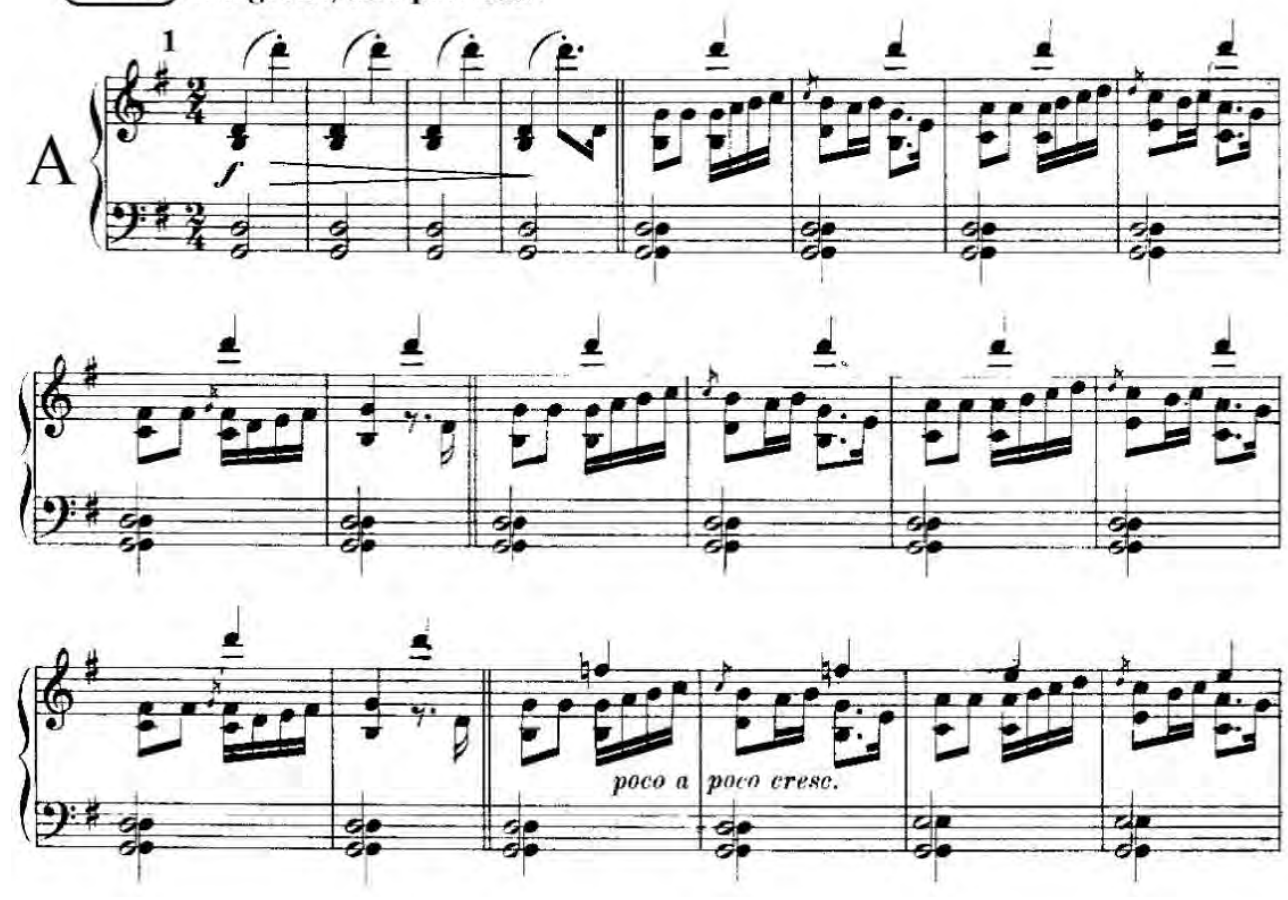

Fonte: Granados (1987)

Sendo o único título dado por Granados, reconhecemos sua inclinação de inspirar-se na poesia para nomear suas obras. Villanesca refere-se à rusticidade, tanto na música quanto na poesia, a qual apresenta diversas estrofes fechadas com um estribillo (refrão); Granados respeita esse costume em sua Danza. A indicação canción y estribillo presente na seção "B" evoca o arcaísmo da poesia (Figura 7).

Figura 7 - Canción y estribillo na seção B

orig.

Cancion y estribillo.
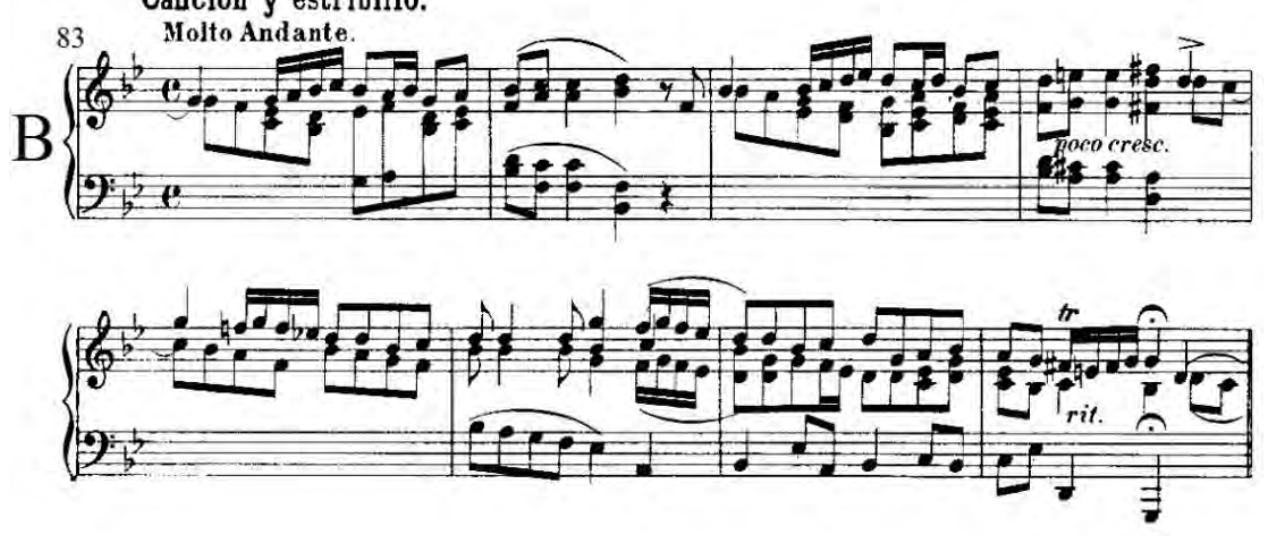

Fonte: Granados (1987) 
A peça é dedicada a Torquato Tasso, não o escritor italiano, mas sim o pai de uma de suas alunas.

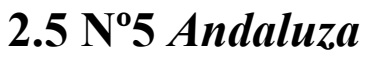

Esta Danza foi dedicada a Alfredo García Faria e é, indubitavelmente, a mais conhecida do ciclo e talvez a peça mais famosa de Granados. O título editorial playera popularizado como referência a essa Danza é bastante equivocado. Em nada ela se assemelha ao canto popular andaluz que faz alusão, o qual possui um parentesco com as seguidillas. Faz jus, no entanto, ao folclore do Sul e daí vem seu acertado título "Andaluza" (DANZAS ESPAÑOLAS, 1999). Granados viveu alguns dissabores após a popularização dessa peça, pois chegou a receber algumas cartas anônimas de compatriotas catalães extremistas com ofensas e acusações indignadas, acusando-o escrevendo agora danças andaluzas (CLARK, 2011).

Grande parte da popularidade dessa Danza deve-se ao fato de ter sido transcrita por diversos violonistas ao longo das gerações que se seguiram. Mesmo Granados, em sua época, teve conhecimento desse processo através da transcrição histórica do virtuose e compositor catalão Miguel Llobet. A textura e a rítmica da Danza, principalmente do acompanhamento, são idiomáticas para o violão. Devido a posição central do instrumento na música popular espanhola, era comum haver evocações e transcrições de outras peças de Granados.

Nessa Danza, em especial, Granados realmente cria a atmosfera onde um violonista acompanha um cantor e dançarino andaluz (CLARK, 2011).

Os temas principais das seções " $A$ " e "B" $\mathrm{B}$ "apresentam uma unidade. Durante a segunda seção, o compositor utiliza-se de uma sequência do mesmo motivo ascendente que constitui o tema principal da seção “A”, só que dessa vez, em seu tom homônimo, acrescentando o lirismo que lhe é peculiar nas seções contrastantes (Figura 8). 
Figura 8 - Motivo ascendente na seção A e seu homônimo na seção B

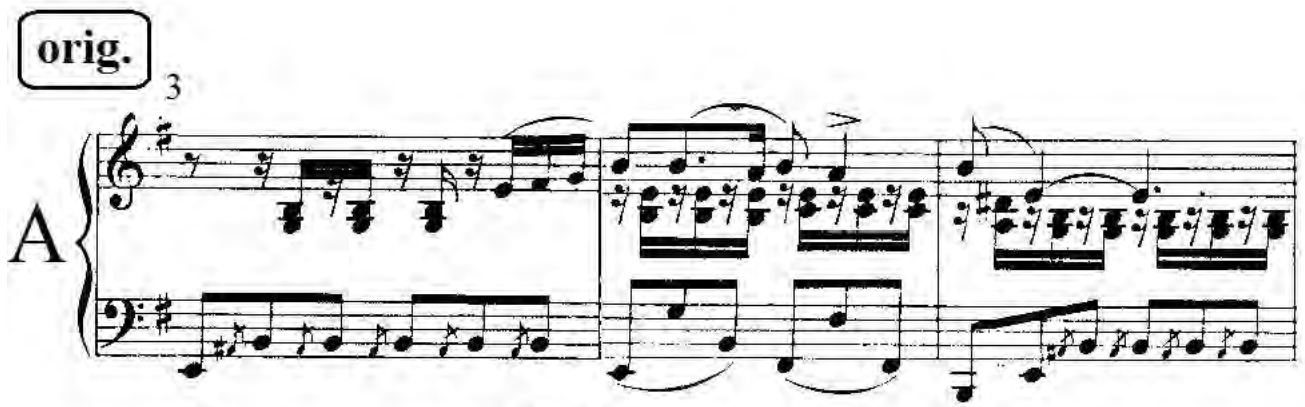

Andante.

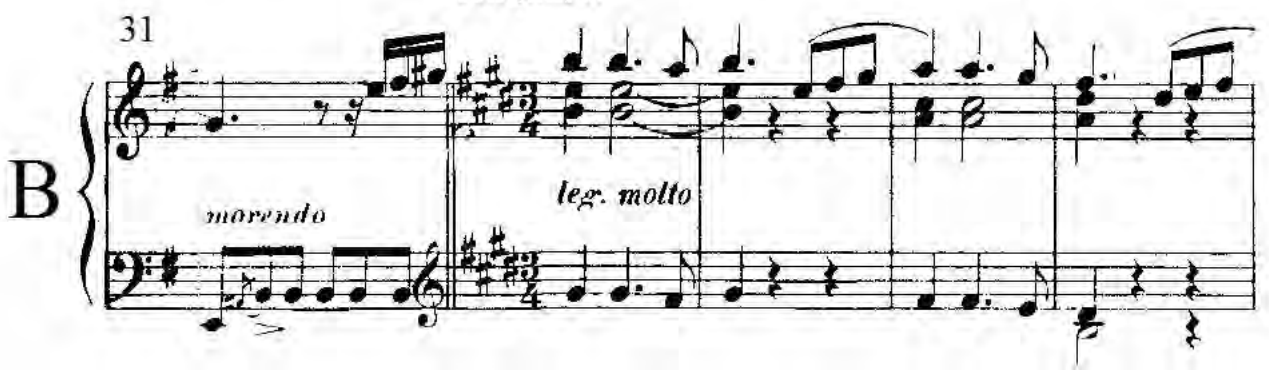

Fonte: Granados (1987)

Essa mesma sequência possui um consequente que se move na direção melódica oposta (Figura 9).

Figura 9 - Consequente do tema principal da seção B

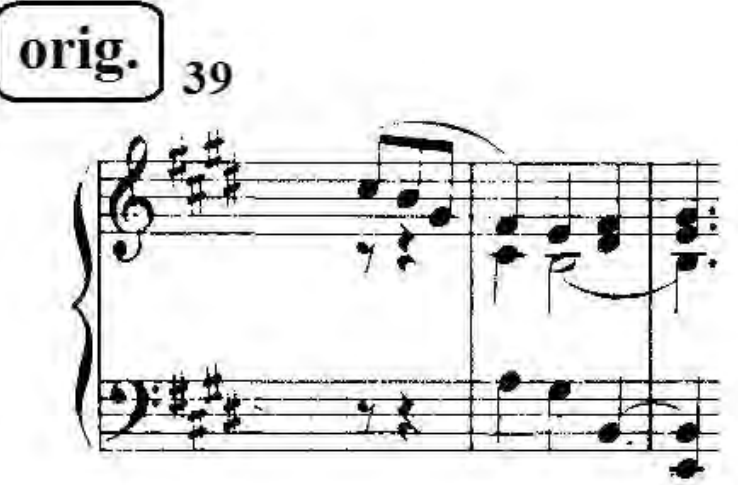

Fonte: Granados (1987) 


\subsection{No6 Rondalla Aragonesa}

A Rondalla teve sua origem na Espanha medieval; o nome diz respeito a um conjunto musical formado normalmente por instrumentos de cordas pulsadas, que eram muito comuns, especialmente na Catalunha, Múrcia, Valência e Aragão. A esta última região se atribui a origem da Jota, uma representação cênica de compasso ternário que é dançada e cantada, acompanhada principalmente por castanholas. É muito popular por toda a Espanha e possui muitas variações regionais (DANZAS ESPAÑOLAS, 1999).

Característico da jota tradicional é a alternância de estribillo e copla (refrão e verso) entre as seções onde dança ou canção predominam. Os momentos de dança possuem ritmo estrito e se revezam com as coplas, que tendem a ser mais livres. Granados usa o termo para evocar esse caráter no início da seção "B” da peça (Figura 10). A peça foi dedicada a D. Murillo.

Figura 10 - Início das seções A e B - Danza nº

orig.
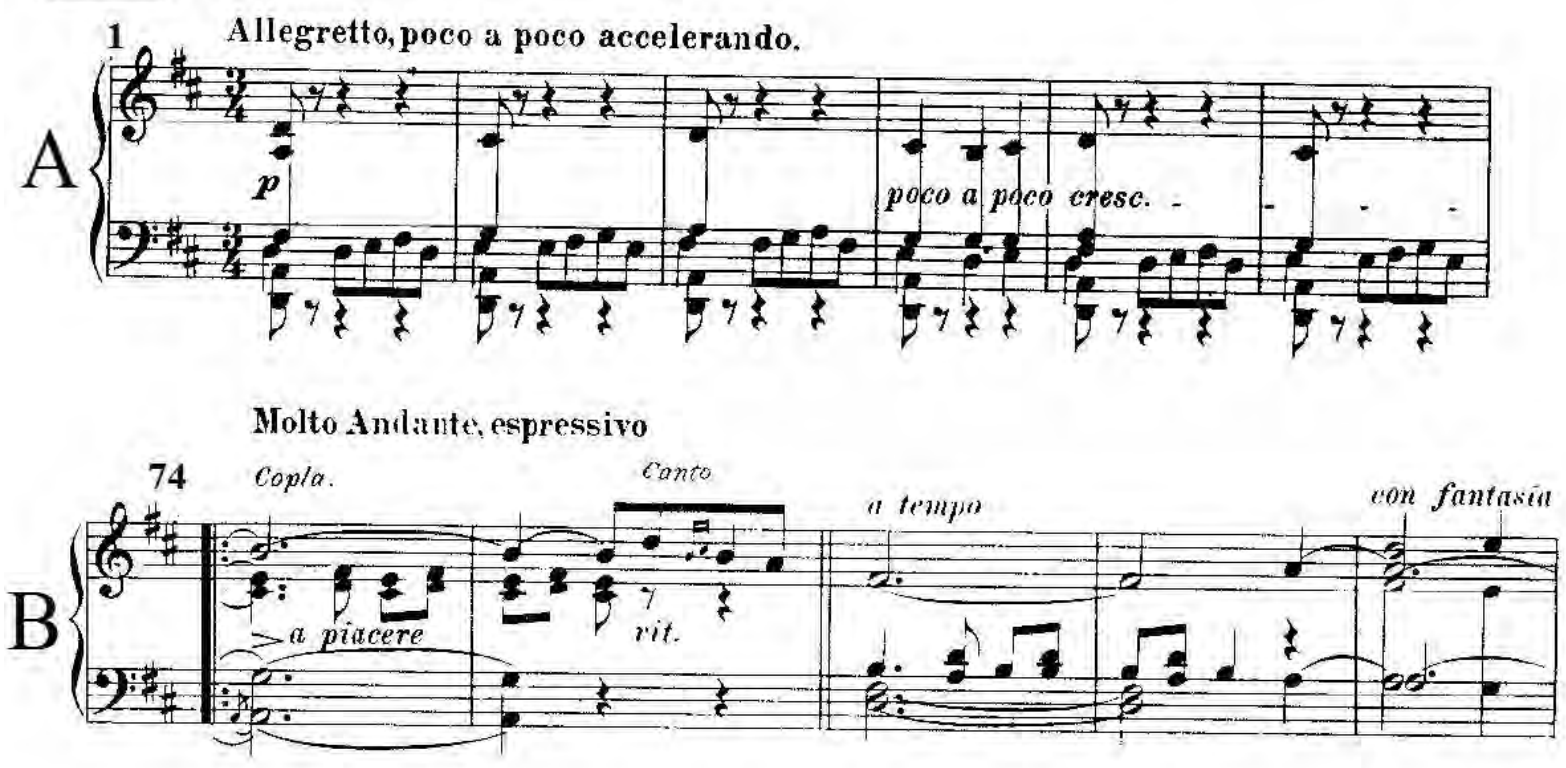

Fonte: Granados (1987)

\section{7 $\mathrm{N}^{0} 7$ Valenciana}

Granados dedicou essa peça ao compositor César Cui. Trata-se de uma jota valenciana onde novamente observamos uma evocação ao acompanhamento de um violão e castanholas na escrita e no caráter da peça. Estas seções são interrompidas por curtas frases melódicas, tocadas em oitavas, que simulam interjeições vocais (CLARK, 2011). Esse tipo de alternância 
entre instrumentos e vozes e o contraste entre dança e canto, são comuns na música popular espanhola em geral (Figura 11).

Figura 11 - Melodias oitavadas interrompem o caráter dançável durante a seção A

\section{orig.}
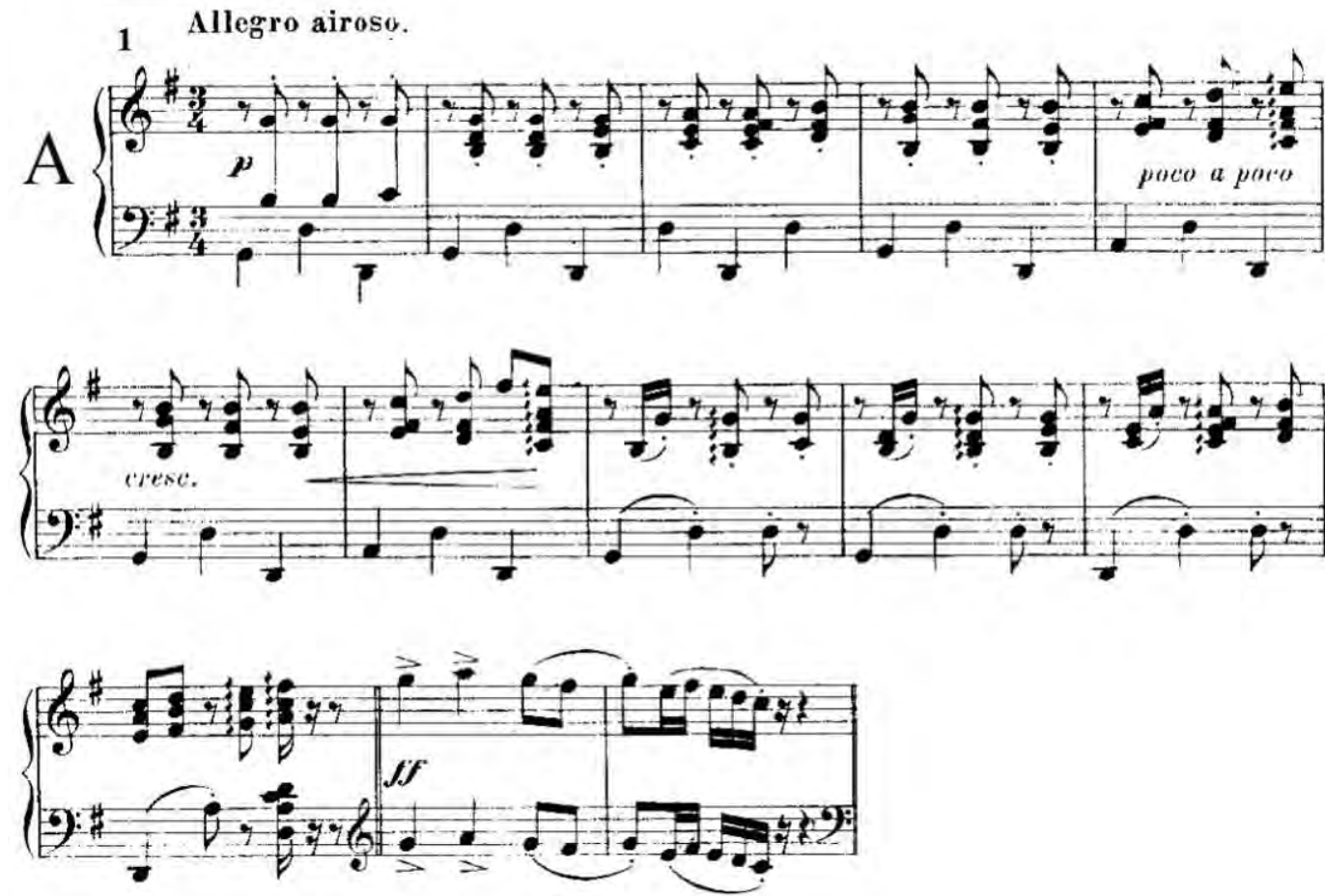

Fonte: Granados (1987)

Alguns fatores de grande importância a serem considerados nessa peça foram as alterações feitas por Granados ao longo dos anos. Sobre isso, nos elucida Clark:

Granados esteve muitas vezes sobre pressão financeira e apressou-se em entregar a peça para o editor antes dela amadurecer. Mais tarde ele pode fazer mudanças significativas na versão publicada, as quais ele iria incorporar em sua performance e transmitir para seus alunos ${ }^{9}$ (CLARK, 2011, p. 36, tradução nossa).

Ao que tudo indica, Granados nunca ficou satisfeito com a versão original e realizou diversas correções, que felizmente foram executadas em uma de suas performances gravadas entre 1908 e 1916 (GRANADOS, 2015). Através da tradição oral pudemos transportar as modificações do compositor para nossa transcrição. Alicia de Larrocha também teria realizado o mesmo processo, “[...] a edição crítica feita por ela e Douglas Riva finalmente colocou no

\footnotetext{
${ }^{9}$ Granados was often under financial pressure and would rush a piece to the publisher before it had matured. Later he might make significant changes to the published version, which he would them incorporate into his performance and convey to his students.
} 
papel as mudanças que Granados teria realizado se tivesse vivido o suficiente para fazê-lo 10 ", (CLARK, 2011, p. 36, tradução nossa). Entretanto, não tivemos acesso a essa edição, apenas a sua gravação (LARROCHA, 1995), na qual Larrocha executa as mesmas alterações presentes na versão de Granados.

Nos exemplos a seguir, demonstramos uma comparação entre a versão original e a gravação de Granados, com uma edição nossa das alterações. Embora o material temático e a estrutura da peça permaneçam o mesmo - e a maioria das modificações dizem respeito ao campo da articulação e pequenos ajustes de textura - existem mudanças significativas, como por exemplo, o destaque de determinadas notas do acompanhamento, agregando-lhes um sentido melódico (Figura 12).

Figura 12 - Acréscimo de motivo melódico
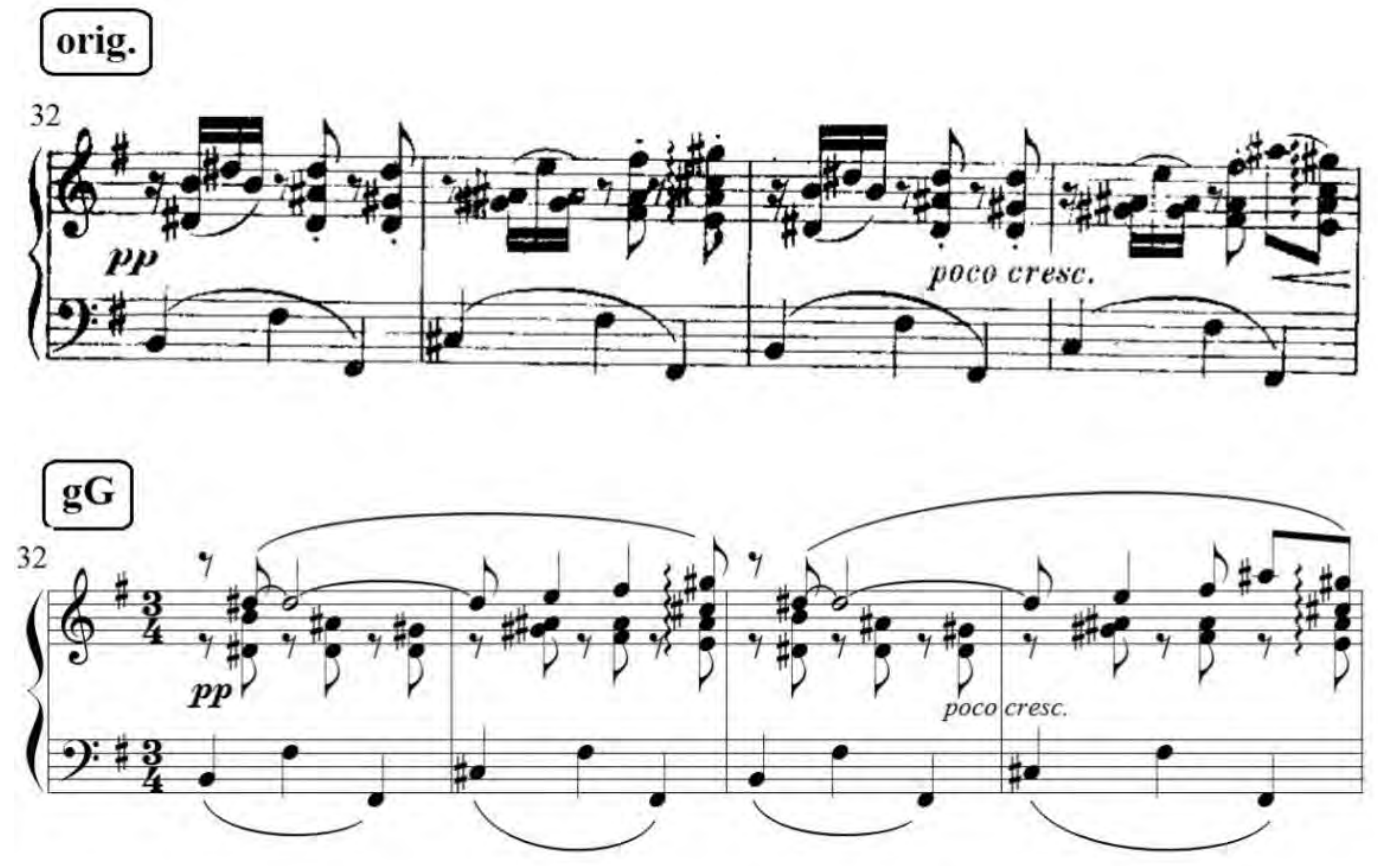

Fonte: elaborada pelo autor

A revisão da coda apresenta uma reelaboração do material musical utilizado e um compasso a menos, comparando-se com a partitura original (Figura 13).

\footnotetext{
${ }^{10}[\ldots]$ the recent critical edition by her and Douglas Riva finally puts into print the changes Granados would himself have made had he lived long enough to do so.
} 
Figura 13 - Revisão da coda
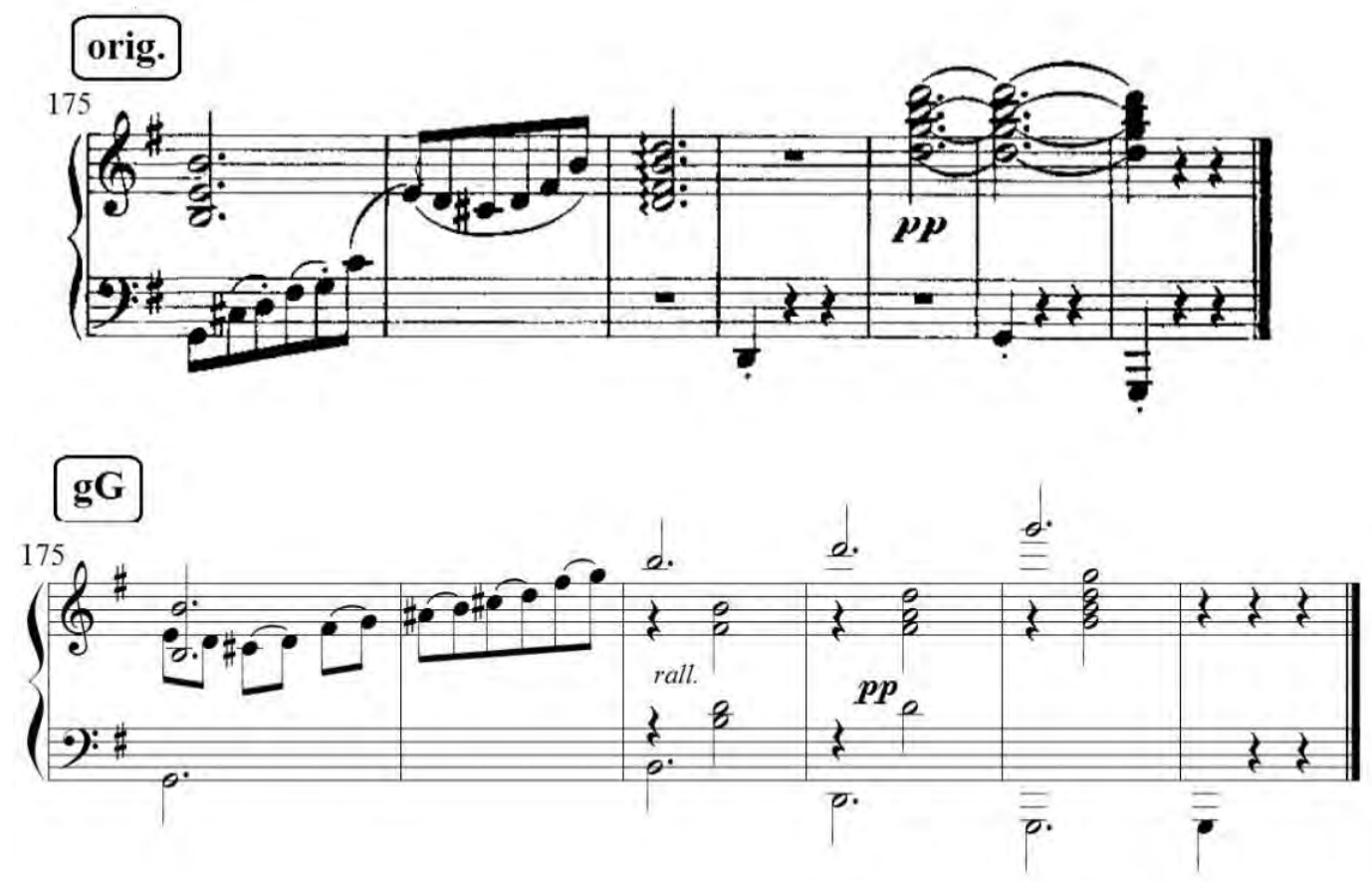

Fonte: Granados (1987)

Todos os outros ajustes não exemplificados nesse subcapítulo serão considerados em nossa transcrição. A seguir, mais um dos exemplos de revisão (Figura 14).

Figura 14 - Exemplo de revisão

orig.
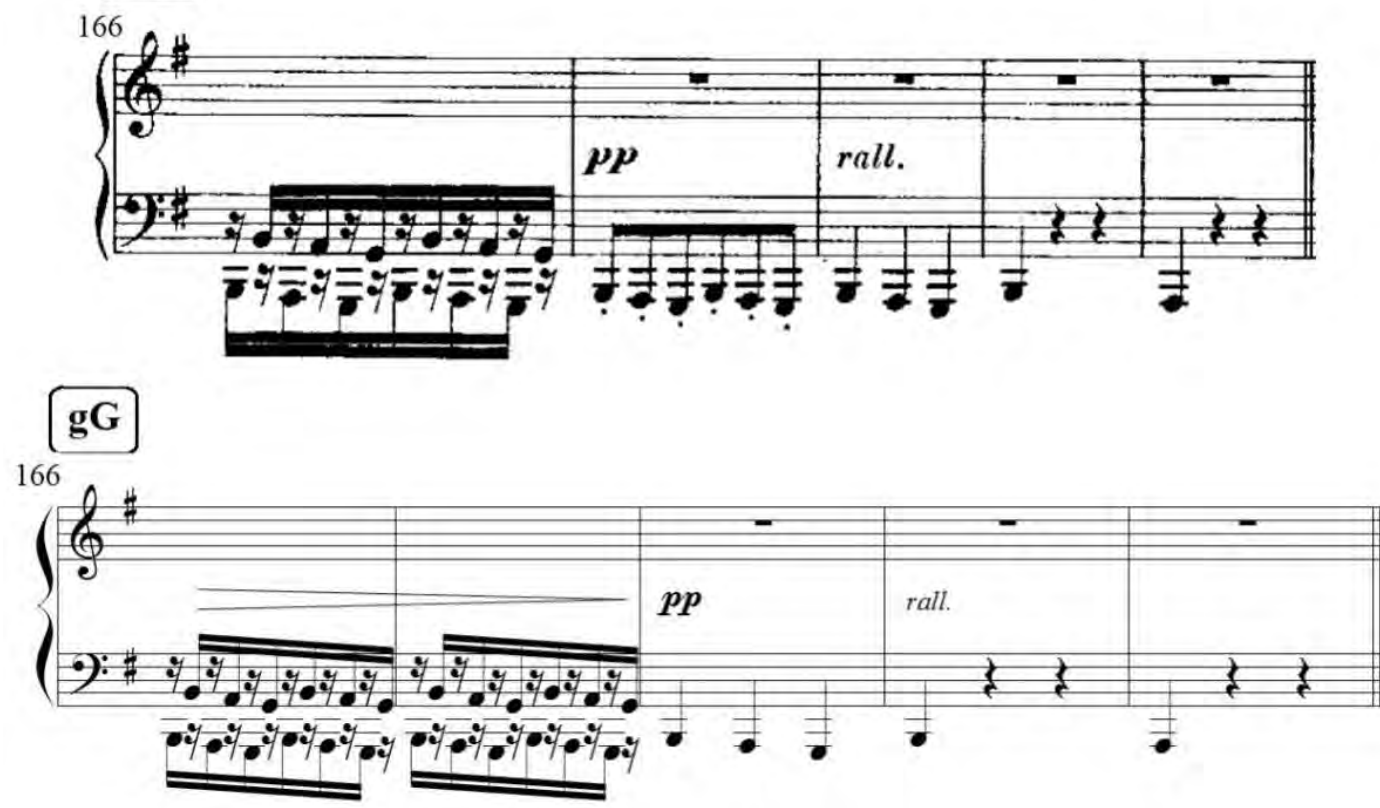

Fonte: Granados (1987) 


\section{$2.8 \mathrm{~N}^{\circ} 8$ Asturiana}

Algumas edições atribuem a Danza o título de Sardana, dança de roda oriunda da região da Catalunha, realizada em círculo por um número indeterminado de pessoas e acompanhadas de uma cobla (banda de instrumentos), no entanto, a gravação referencial de Larrocha (1995) apresenta o título Asturiana. É provável a influência das danças populares da região, tais como el corri-corri e el pericote (DANZAS ESPAÑOLAS, 1999). Os contrastes de registros, os acordes sustentados e o baixo pedal são características da seção “A” (Figura 15).

Figura 15 - Início da seção A - Danza nog

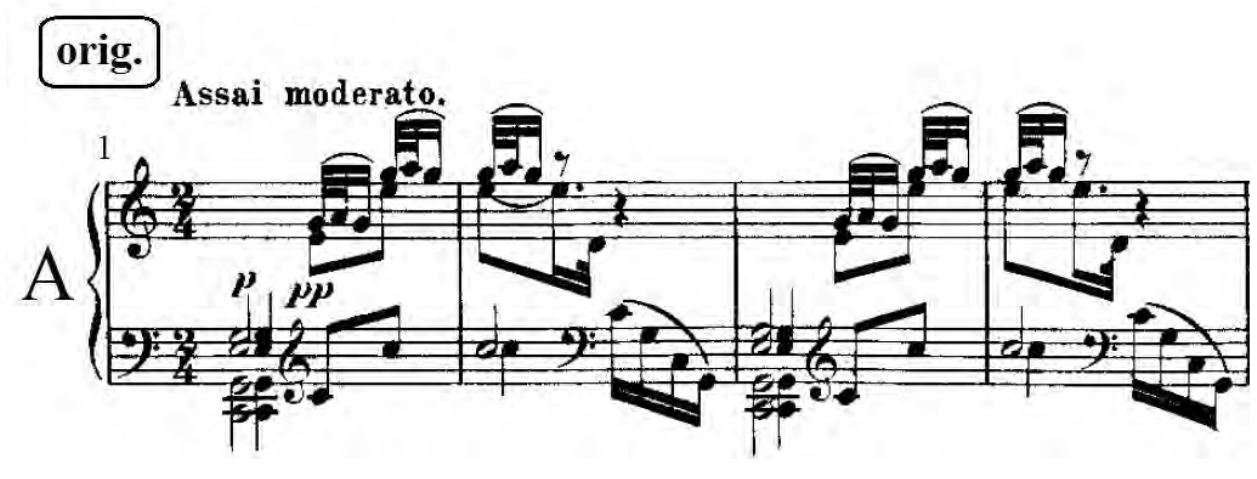

Fonte: Granados (1987)

A seção "B” é contrastante e faz alusão ao ritmo de uma dança moura (Figura 16).

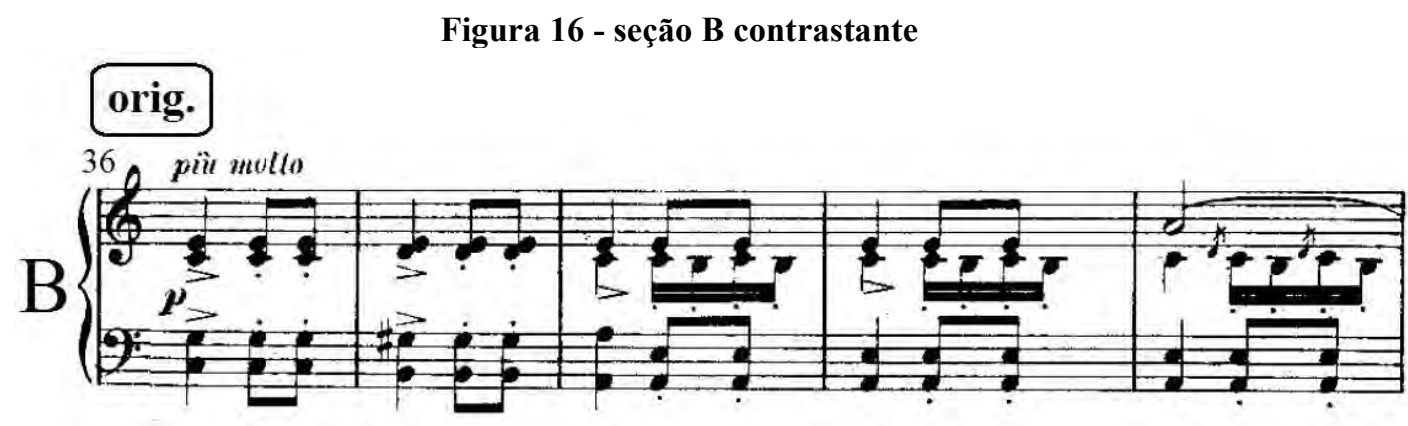

Fonte: Granados (1987)

\subsection{No9 Mazurka}

É interessante perceber o desenho melódico binário que se sobrepõe ao compasso ternário da abertura (Figura 17). 
Figura 17 - Hemíola na seção A

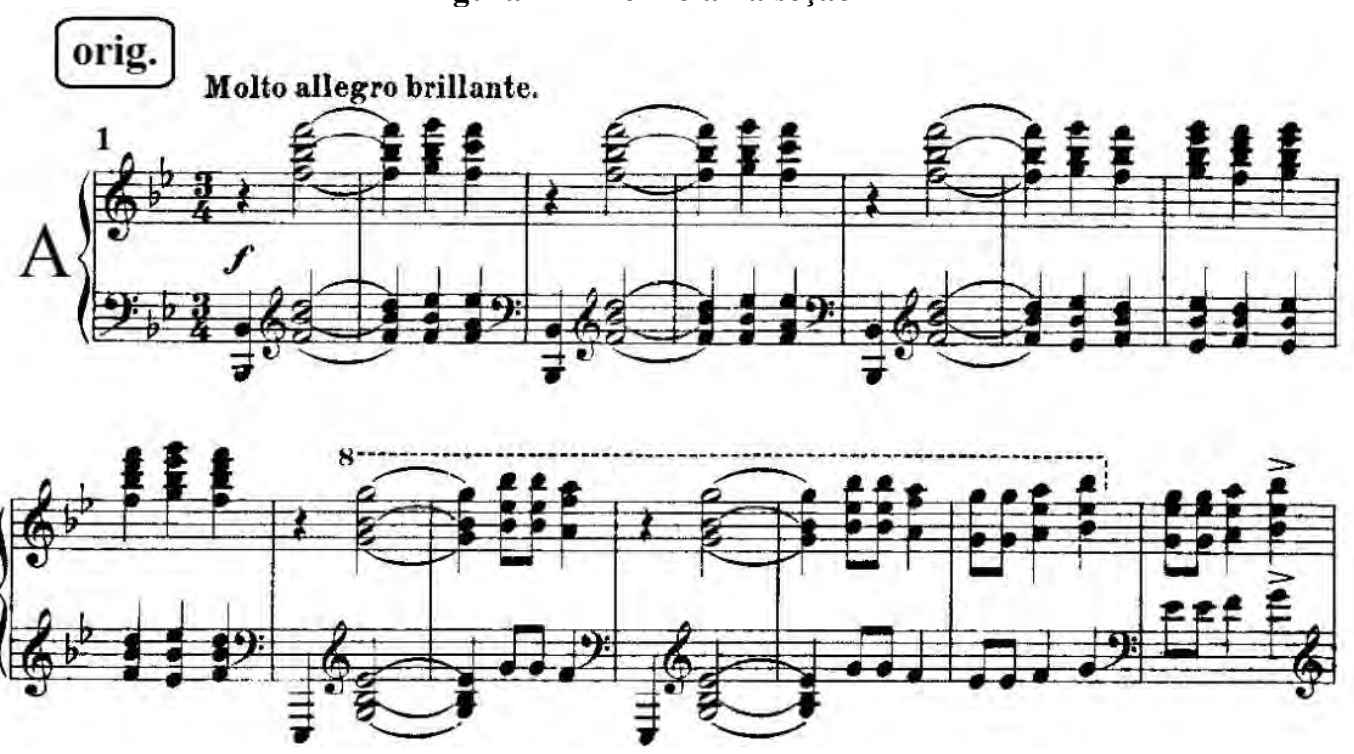

Fonte: Granados (1987)

Há um certo clima tonadillero no grupo de temas que surge a seguir (Figura 18). Algumas edições atribuem o subtítulo "Romántica" a peça.

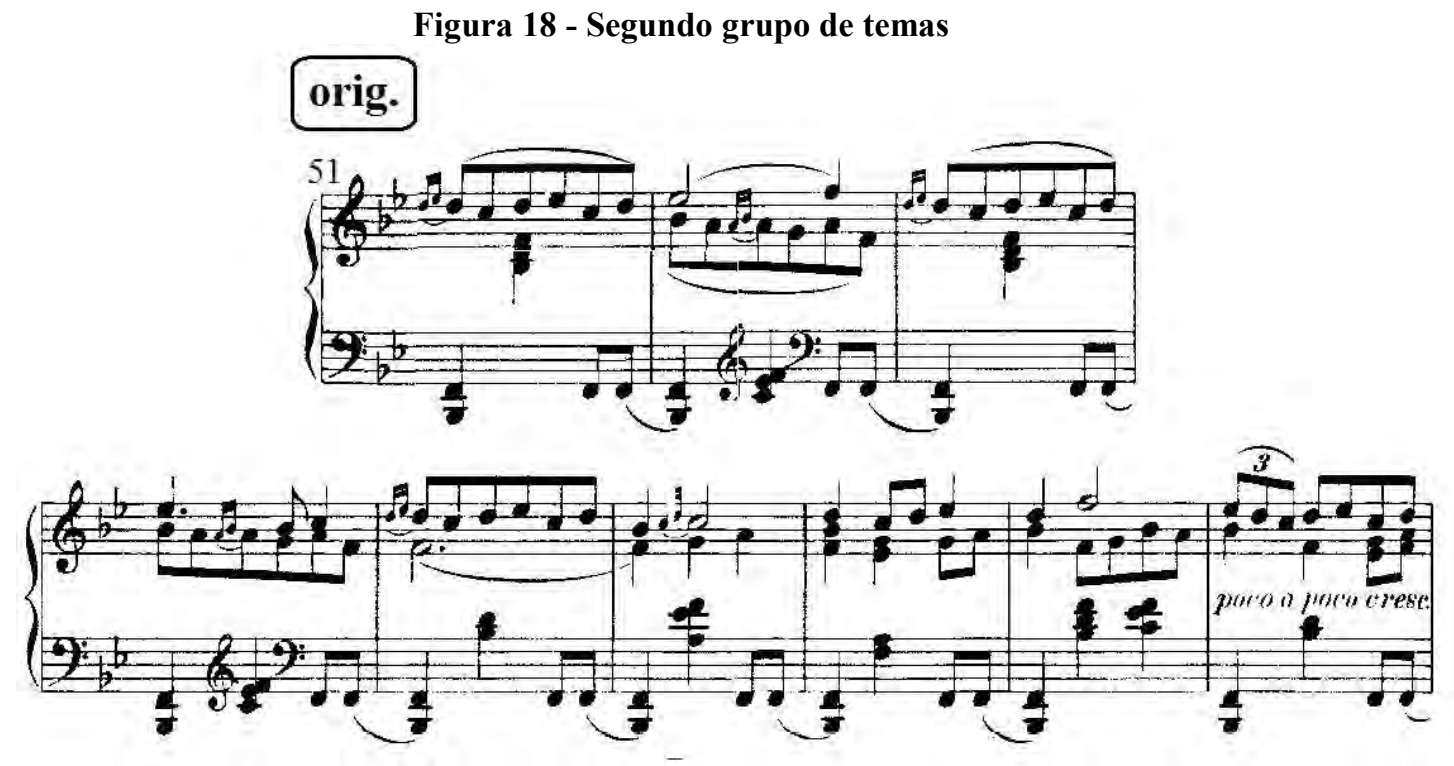

Fonte: Granados (1987)

\subsection{N¹0 Danza Triste}

Dedicada a Doña Isabel de Borbón e escrita na tonalidade de Sol Maior, a seção "A" da Danza apresenta um grupo de temas que modula para dois outros centros tonais (Si bemol Maior e Ré Maior) antes de entrar em contraste com o caráter cantabile e rubato da seção 
central em Ré (Figura 19). O estilo de acompanhamento é semelhante ao da Danza $n^{\circ} 7$, que faz referência ao violão da música popular espanhola.

Figura 19 - Contraste entre as seções

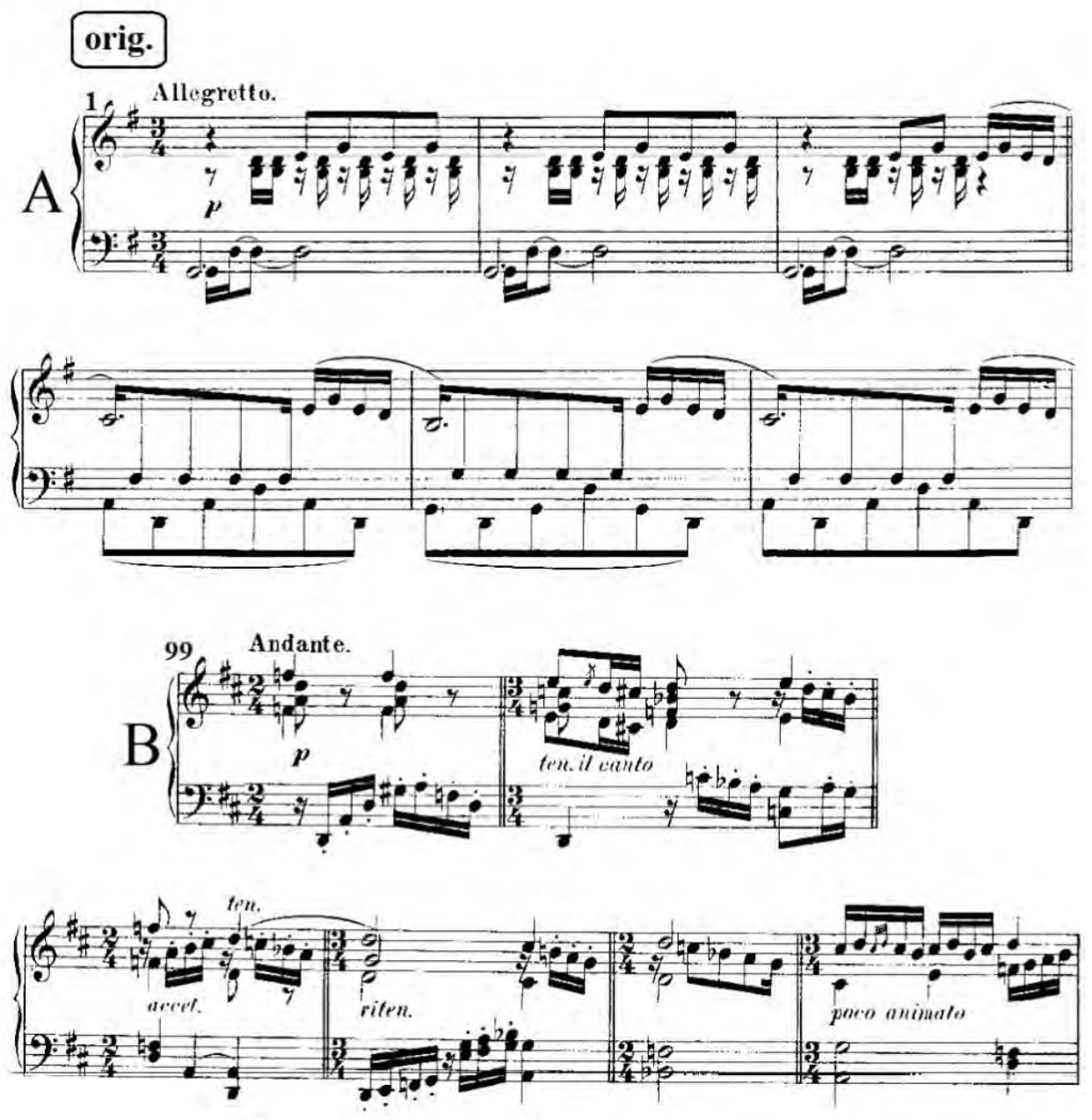

Fonte: Granados (1987)

\subsection{No11 Zambra}

O motivo principal da peça é apresentado em forma de introdução, e desenvolvido em seguida para uma melodia hipnótica e pouco angulosa, insistente na nota Ré, lembrando o lamento de um cantor flamenco. Este pode ter sido o motivo do acréscimo do título editorial "Zambra"; que se relaciona com a dança flamenca natural dos ciganos de Granada (FUNDACIÓN JUAN MARCH, 1991). Granados utiliza os motivos da primeira seção da Danza para desenvolver a seção “B”, com um caráter recitativo (Figura 20). 
Figura 20 - Melodias com centro em Ré

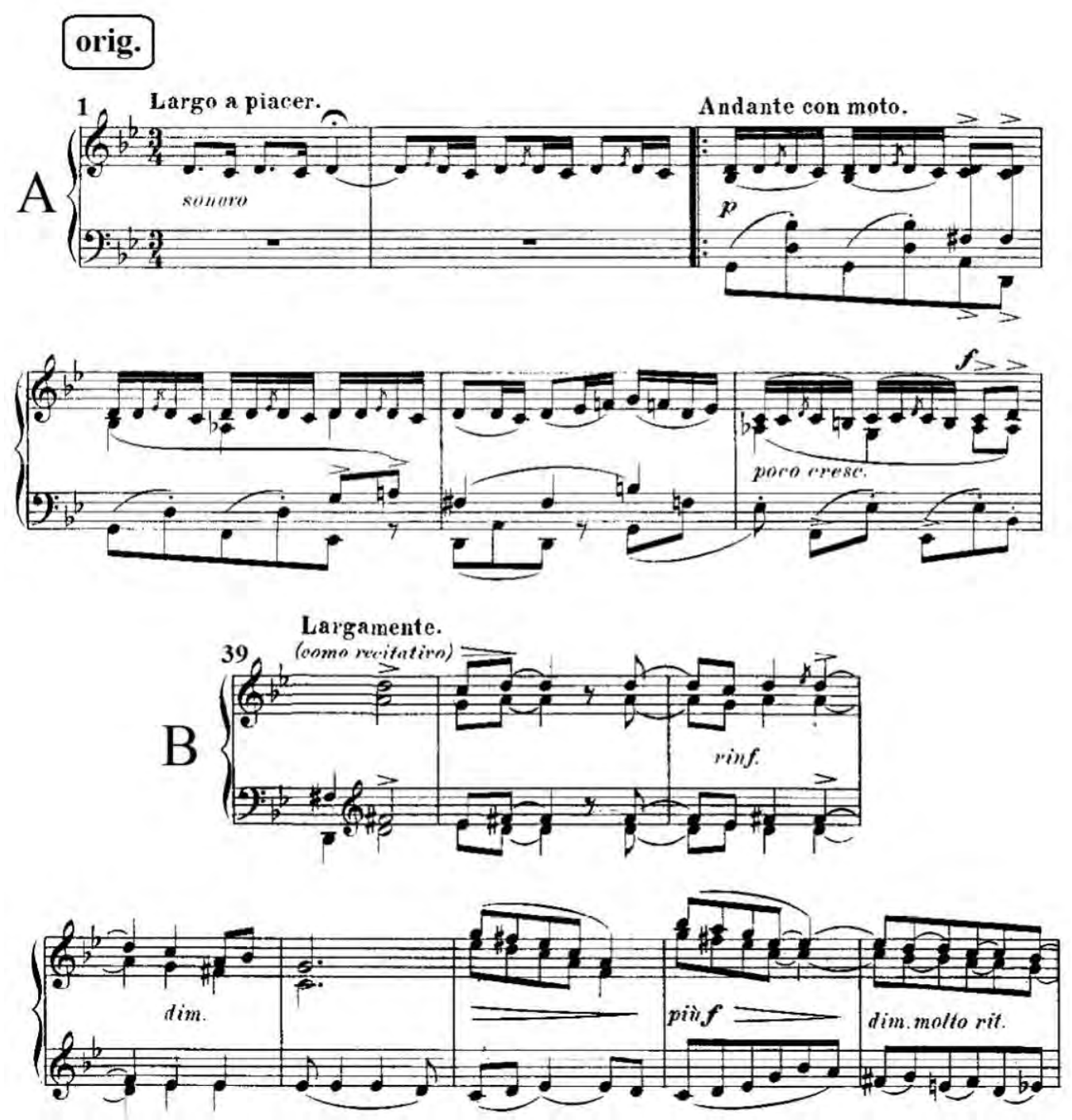

Fonte: Granados (1987)

\section{$2.12 \mathrm{~N}^{0} 12$ Arabesca}

Temos aqui uma forma rondó onde o tema principal é intercalado com trechos de caráter mais cantabile durante a seção “A” (Figura 21). 
Figura $21-1^{\circ}$ grupo de temas

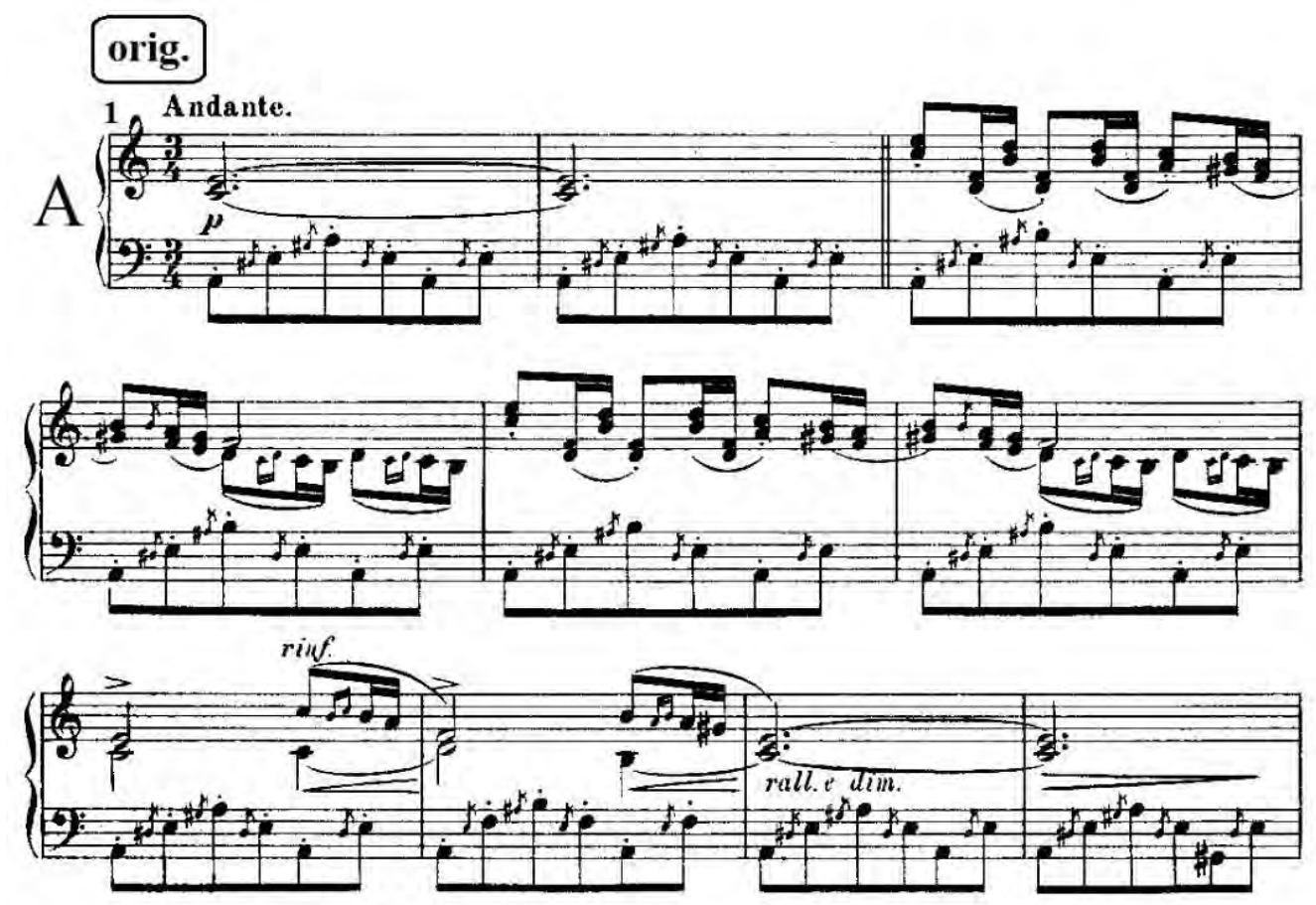

Fonte: Granados (1987)

A seção "B" apresenta fragmentos de uma curta melodia que abrange o âmbito de uma terça e destaca sua primeira nota. Novamente o caráter insistente e enfático de melodias flamencas é aplicado (Figura 22).

Figura 22 - Seção B

orig.
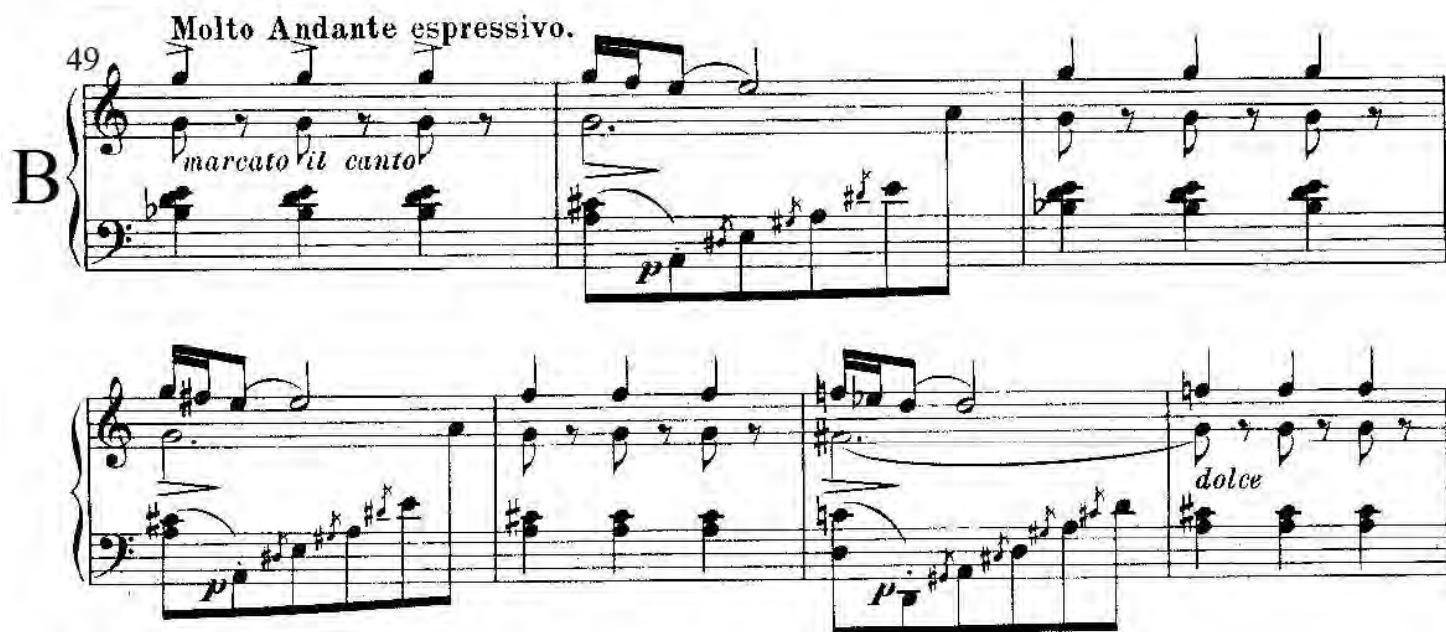

Fonte: Granados (1987) 


\section{CONCEITUAÇAO DA SCORDATURA}

O termo italiano scordatura diz respeito a descrição de um processo de reconfiguração da afinação tradicional, particularmente "[...] de instrumentos de corda, especialmente alaúdes e violinos" (SADIE, 1994, p. 848) por parte de um intérprete. Esse processo de afinação alternativa remete a uma configuração diferenciada das cordas soltas do instrumento em relação a um padrão pré-estabelecido. Campbell, Greated e Myers (2004, p. 277) afirmam que: "scordatura é um termo utilizado para designar uma afinação que se utiliza de um conjunto de alturas diferente daquelas consideradas as convencionais de determinado instrumento de corda".

A scordatura esteve em voga entre 1600 e 1750, mas suas referências mais antigas se encontram nos livros franceses de guitarra de quatro ordens, dentre eles Tiers livre de guiterne de Adrien Le Roy, publicado em 1552. Naquele período, o procedimento mais comum consistia em abaixar a afinação da corda mais grave para aumentar a tessitura do instrumento e ampliar as possibilidades de uso das cordas soltas (TYLER, 1980, p.14).

A scordatura foi usada para ampliar em direção aos graves a extensão de um instrumento, através da afinação da corda mais grave um tom abaixo, para facilitar a execução de certas passagens, criar efeitos especiais, aumentar o brilho, ou ainda produzir sonoridades combinadas (SADIE, 1994, p. 848).

Dentre seus mais diversos usos, a scordatura pode auxiliar na emulação de outros instrumentos, facilitar a execução de composições inteiras, ou mesmo explorar novas cores, timbres, sonoridades e possibilidades harmônicas alternativas.

\subsection{A scordatura no violão}

Instrumentos de cordas dedilhadas, dos mais diversos, foram sempre usados na construção do fazer musical, quer seja para simples acompanhamento monódico em canções seculares da Idade Média, quer seja como agente ativo e independente a partir do repertório renascentista. Esse caráter polivalente, de acompanhador ou solista, possivelmente despertou o interesse cada vez maior, por parte de compositores, em escrever e explorar recursos idiomáticos desses instrumentos. Aliado a um desenvolvimento paulatino de diferentes sistemas de afinação, durante a história da música ocidental, estabelecidos em regiões geográficas e períodos diferentes, um desses recursos, a scordatura, fora explorado com afinco. Acerca dessa 
pluralidade de afinações, encontra-se um comentário no Dicionário Grove de Música sobre as scordature de alaúdes:

Das muitas afinações, dois tipos são os mais importantes. O conhecido como “afinação renascentista" consistia tipicamente de Sol-dó-fá-lá-ré'-sol', ou Lá-ré-solsi-mi'-lá' (a altura não era absoluta). Essa sequência de intervalos continuou a ser aplicada em certos tipos de alaúde durante o séc. XVII e início do XVIII. A outra, que surgiu de experiências com a afinação renascentista feitas pelos alaudistas franceses no início do séc. XVII, consistia tipicamente de Lá-ré-fá-lá-ré'-fá, hoje conhecida como "afinação barroca"; existiram muitas variantes (SADIE, 1994, p. 16).

Podemos constatar, que "[...] é a partir da padronização do sistema musical (temperado) que os instrumentos se estabeleceram, tanto em sua concepção de construção quanto de técnica" (STEFAN, 2012, p. 46). A afinação tradicional do violão moderno, após várias experimentações, fixou-se somente nas três últimas décadas do séc. XVIII, durante o período romântico (Figura 23).

Figura 23 - Afinação tradicional do violão

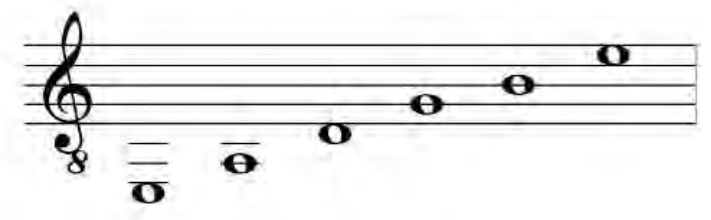

Fonte: elaborada pelo autor.

É de praxe, então, que para modificar a tessitura, o compositor ou intérprete pode afinar uma ou mais cordas em alturas diversas, alterando as possibilidades harmônicas e expressivas, não necessitando de nenhuma intervenção mecânica que não seja a usual. Também uma prática com relação a pequenos ajustes na afinação tradicional já fora consolidada. Afinações diversas como a sexta corda em Ré (um tom abaixo da afinação tradicional), a quinta em Sol (um tom abaixo) ou a terceira corda em Fá sustenido (meio tom abaixo) são exemplos de procedimentos incorporados ao manuseio da técnica no intuito de possibilitar que o violão simule e/ou abarque a tessitura de outros instrumentos (como o alaúde, vihuela, violino, etc.), ou ainda, seja capaz de executar determinadas harmonias, contrapontos e articulações de forma mais natural. "No classicismo encontramos ainda a utilização da sexta corda em Fá em algumas obras de Fernando Sor (1778 - 1839), como a Fantasia op.10" (BORGES, 2007, p. 28). A seguir, ilustramos as três configurações de ajustes da afinação tradicional já consolidadas e suas manifestações no repertório violonístico (Figura 24) 
Figura 24 - Ajustes consolidados da afinação tradicional

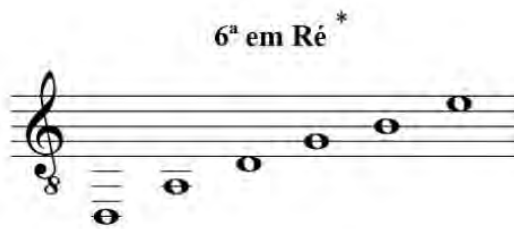

${ }^{*}$ Repertório violonístico em geral

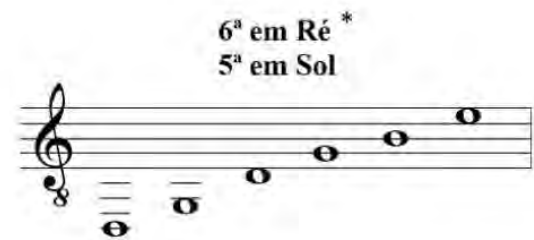

* Repertório violonístico em geral

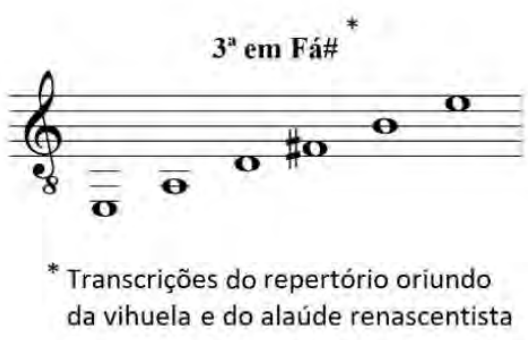

Fonte: elaborada pelo autor.

Além dessas configurações, existiram outras mais incomuns utilizadas em determinadas ocasiões por compositores tradicionais (Figura 25).

Figura 25 - Outros ajustes de afinação
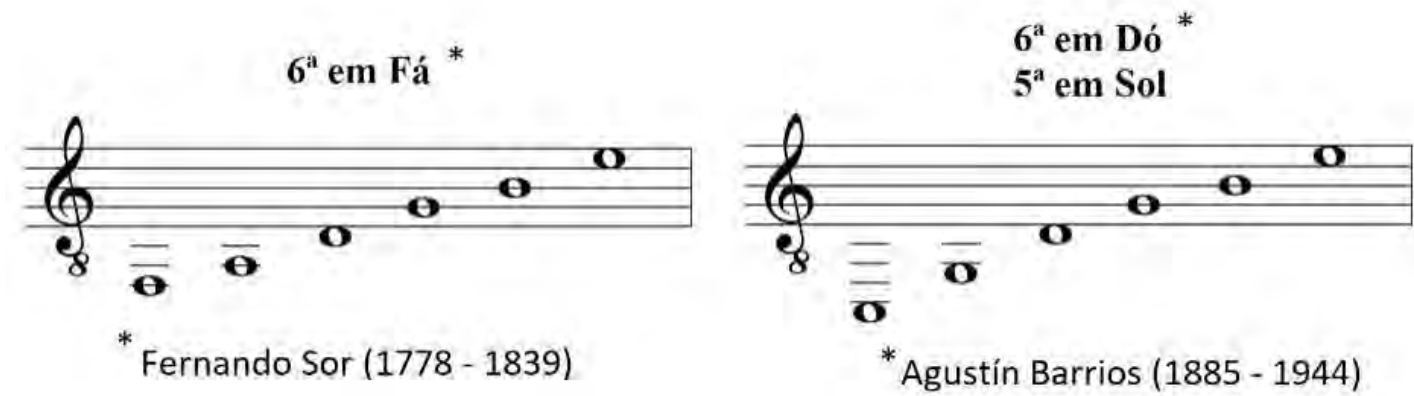

Fonte: elaborada pelo autor

No contexto da música erudita, a scordatura é resultado das experimentações e da mudança de orientação por que vem passando a música contemporânea, em relação ao papel do timbre e à busca por novas linguagens, sonoridades e técnicas estendidas. Na música popular, o desenvolvimento de novas scordature “[...] tem raízes na música havaiana, no blues, que influenciou várias gerações, e na mais recente onda da new age e suas ramificações". (VASCONCELOS, 2002, p. 61).

\subsection{A scordatura estendida}

Entende-se pelas definições apresentadas no item anterior, que o conceito tradicional de scordatura pode ser confundido com o conceito sobre "técnicas estendidas" Apesar de ambos referirem-se a procedimentos que visam ampliar as possibilidades técnicomusicais ao longo da história, o pensamento sobre scordatura por um viés estendido pode implicar em outras prerrogativas. 
No que diz respeito à produção de novos efeitos, a scordatura pode ser utilizada, por exemplo, para alterar a afinação deliberadamente no meio de uma peça. No exemplo abaixo, Leo Brouwer, em sua peça Paisaje Cubano com Campanas utiliza o recurso por um viés estendido, propondo, um afrouxamento da tarraxa para a execução de um glissando descendente (Figura 26).

Figura 26 - Uso da scordatura sob uma perspectiva de expressão musical

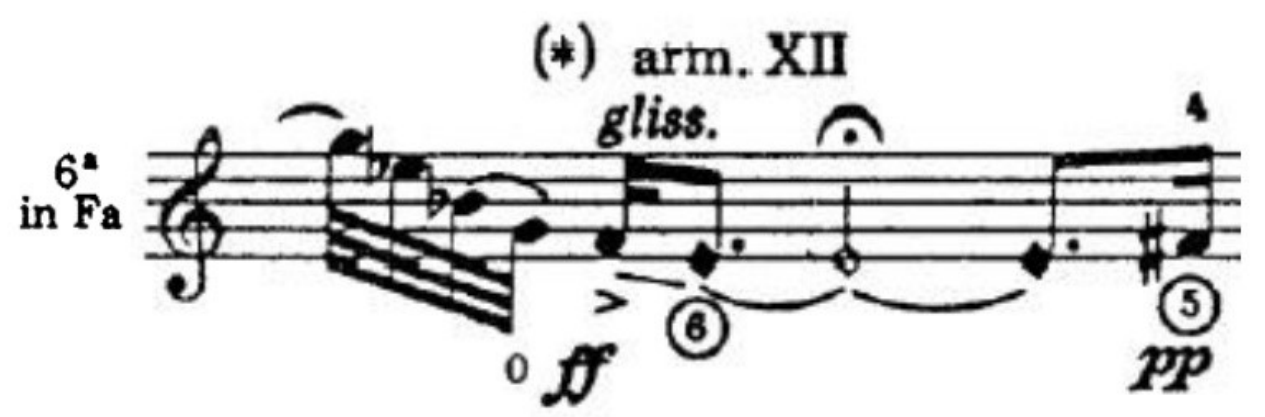

(*) Accordare la $6^{*}$ in $\mathrm{Mi}$

Fonte: Brouwer (1986)

Desse modo, um pensamento sobre técnicas estendidas na scordatura poderia ser desenvolvido a partir de duas premissas: procedimentos diferenciados da manipulação do recurso em questão; ou configurações distintas da afinação tradicional e de seus ajustes. A seguir, ilustramos alguns exemplos de scordature diferenciadas e sua utilização no violão por alguns compositores e transcritores (Figura 27). 
Figura 27 - Scordature estendidas
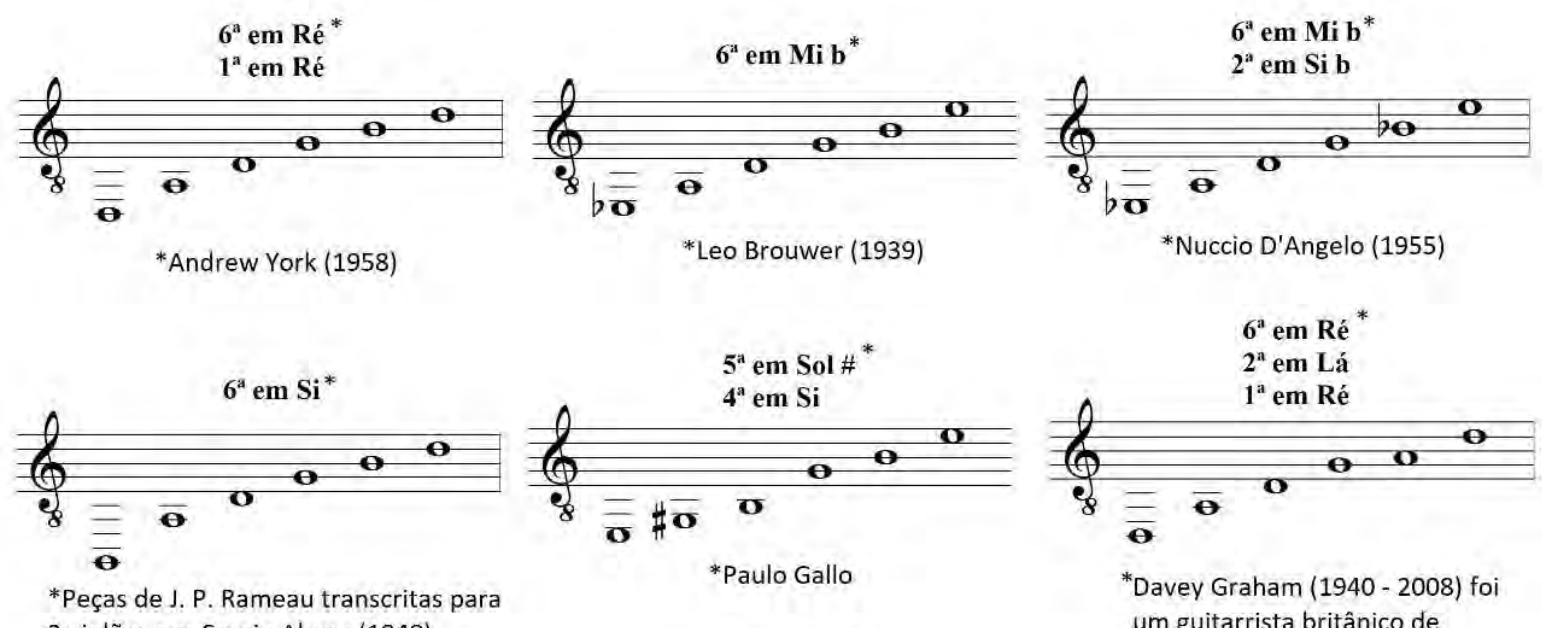

* Peças de J. P. Rameau transcritas para 2 violões por Sergio Abreu (1948)

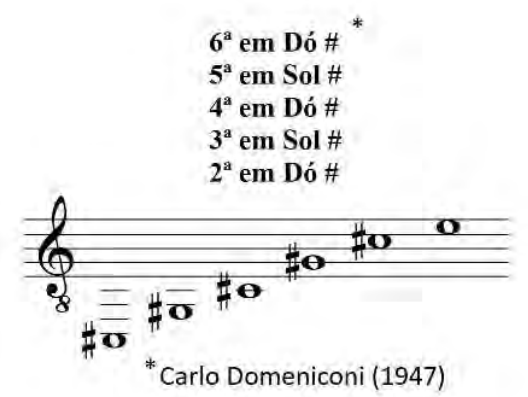

*Davey Graham (1940 - 2008) fo um guitarrista britânico de Folk, Jazz e Blues. Scordatura popularmente conhecida como "DAD GAD"

Fonte: elaborada pelo autor 


\section{O PROCESSO DE TRANSCRIÇÃO PARA VIOLÃO DAS 12 DANZAS ESPAÑOLAS OP.37}

Podemos observar que transcrições históricas foram realizadas por intérpretes referencias como: Francisco Tárrega, Miguel Llobet, Andrés Segovia (1893 - 1987), Narciso Yepes (1927 - 1997), John Williams (1941), Julian Bream (1933) e a partir deles Manuel Barrueco (1952), David Russell (1953) e tanto outros que dedicaram-se em algum momento a ampliar o repertório violonístico através de transcrições. Eles se utilizaram basicamente da afinação padronizada do violão e também de seus ajustes tradicionais (sexta corda em Ré e quinta corda em Sol por exemplo) de acordo com a necessidade. Por um viés tonal, notamos que a afinação tradicional do violão e seus ajustes consolidados abarcam tonalidades relacionadas às cordas soltas do instrumento.

Funcionam muito bem no violão peças estruturadas nos tons de Dó Maior, Ré Maior ou Ré menor (com a utilização da sexta corda em Ré ou não), Mi Maior ou Mi menor, Fá Maior (com menor frequência), Sol Maior ou Sol menor (com a utilização da sexta corda em Ré e quinta corda em Sol ou não), Lá Maior ou Lá menor e Si menor. No momento em que obras escritas para outros instrumentos em tonalidades que não sejam essas tentam ser adaptadas para violão, a primeira opção é normalmente transpor para um dos tons supracitados. Embora isso resolva uma grande parte dos casos, muitas obras permanecem sem soluções de adaptação, se a afinação tradicional for mantida.

\subsection{Aplicação dos procedimentos tradicionais de adaptação e aspectos gerais das transcrições}

Durante o estudo das peças, o processo de adaptação para o violão compreendeu diversas etapas onde decisões foram tomadas através de um constante exercício de reflexão. Algumas danzas passaram por mais de uma versão até a finalização do trabalho. Não estamos lidando com instrumentos como o violino, por exemplo, que possui obras que são casos convenientes para transcrições, por sua maior adaptabilidade às possibilidades do violão. Ambos os instrumentos são de cordas pressionadas com quatro dedos da mão esquerda e o violino não produz tantas notas simultâneas que o violão não possa reproduzir, guardada as 
devidas proporções (BOTA, 2008). O mesmo não se dá com a adaptação de peças originalmente escritas para piano à linguagem violonística.

A seguir serão comentados alguns dos procedimentos de aspectos tradicionais de adaptação aplicados em nossa transcrição.

\subsubsection{Tessitura}

Nesse quesito, tivemos o grande desafio deste trabalho. Foram realizadas em nossa transcrição adequações consideráveis devido a grande diferença de tessitura entre os dois instrumentos, o piano moderno de oitenta e oito teclas e o violão de seis cordas. Este, embora seja um instrumento de afinação não-fixa, tem um limite de quanto podemos alterar sua afinação, para que se obtenha um resultado satisfatório.

O violão, embora possua inúmeros recursos técnicos e de efeitos sonoros, possui uma extensão limitada em relação ao piano. Dessa forma, as obras escritas originalmente para piano ao serem transportadas para violão terão que ser ajustadas em relação à tessitura. É exatamente aí que surge a dificuldade de transcrever uma obra de piano para violão, pois é necessário buscar caminhos para que se obtenha, mesmo dentro das diferenças instrumentais, uma transcrição que possa manter ao máximo as ideias originais e ao mesmo tempo consiga adquirir sua própria autenticidade (PEREIRA, 2011, p. 61).

$\mathrm{Na}$ sequência, ilustramos a diferença de tessitura entre os dois instrumentos, considerando a afinação tradicional do violão e a extensão máxima utilizada nas Danzas Españolas (Figura 28). 
Figura 28 - Diferença de tessituras

Tessitura do piano

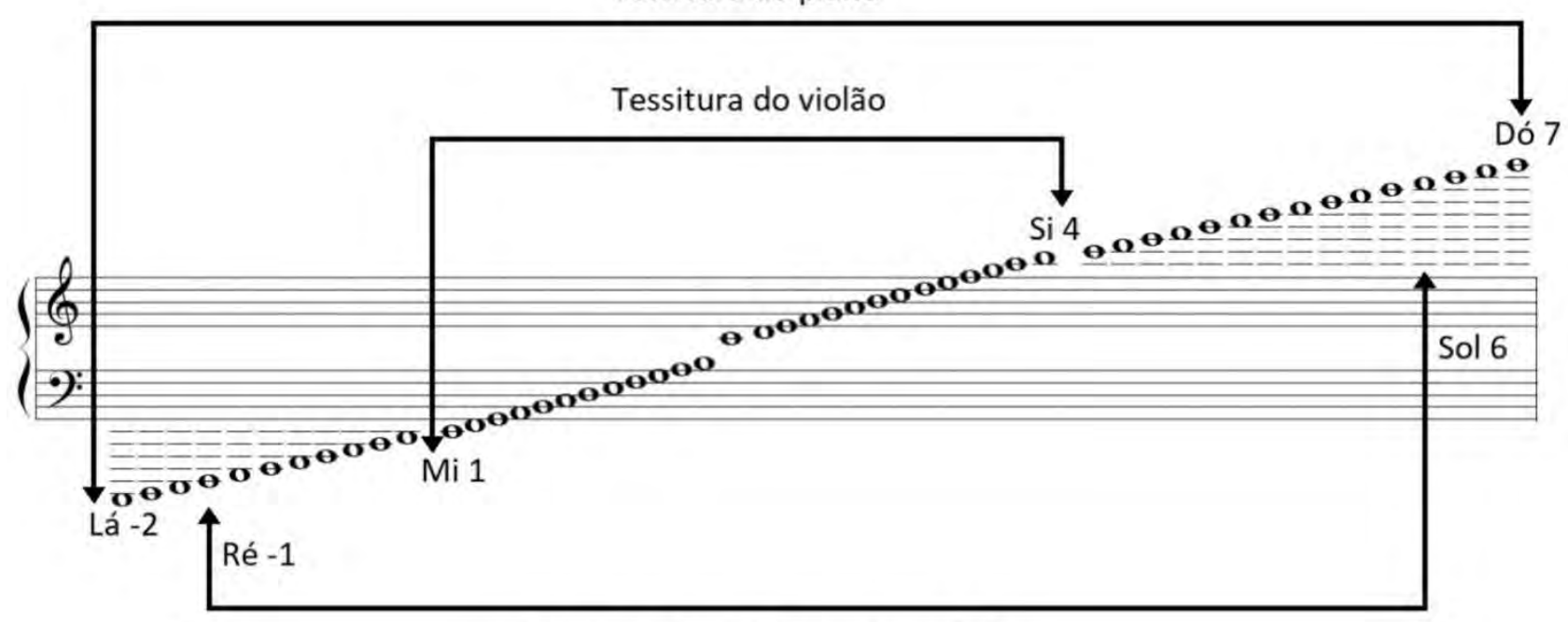

Tessitura das 12 danzas españolas

Fonte: elaborada pelo autor

Embora exista no violão a possibilidade de se obter notas mais graves (alterando a afinação da sexta corda) e mais agudas (através de harmônicos oitavados), nessas extremidades é imposta certa limitação para um desenvolvimento harmônico e contrapontístico, devido as características físicas do instrumento.

As diferentes scordature apresentadas nesse trabalho, cada qual com suas configurações específicas, não possibilitam um aumento da tessitura violonística tradicional, sendo a nota mais grave utilizada em nosso ciclo de transcrições um Ré (ajuste da sexta corda um tom abaixo). Para lidar com essa diferença entre os instrumentos, resolvemos dividir a tessitura em partes; considerando, por exemplo, a tessitura de uma seção, de um grupo de temas, ou até mesmo, de uma única uma frase. Nota-se no exemplo a seguir, a realocação em outra oitava da frase que começa no compasso 32, após a finalização de uma ideia musical adaptada na altura original (Figura 29). 
Figura 29 - Mudança de registro da frase musical - Danza nº 7 (scordatura utilizada: Ré1, Lá, Ré, Fá\#, Si, Mi3)

orig.
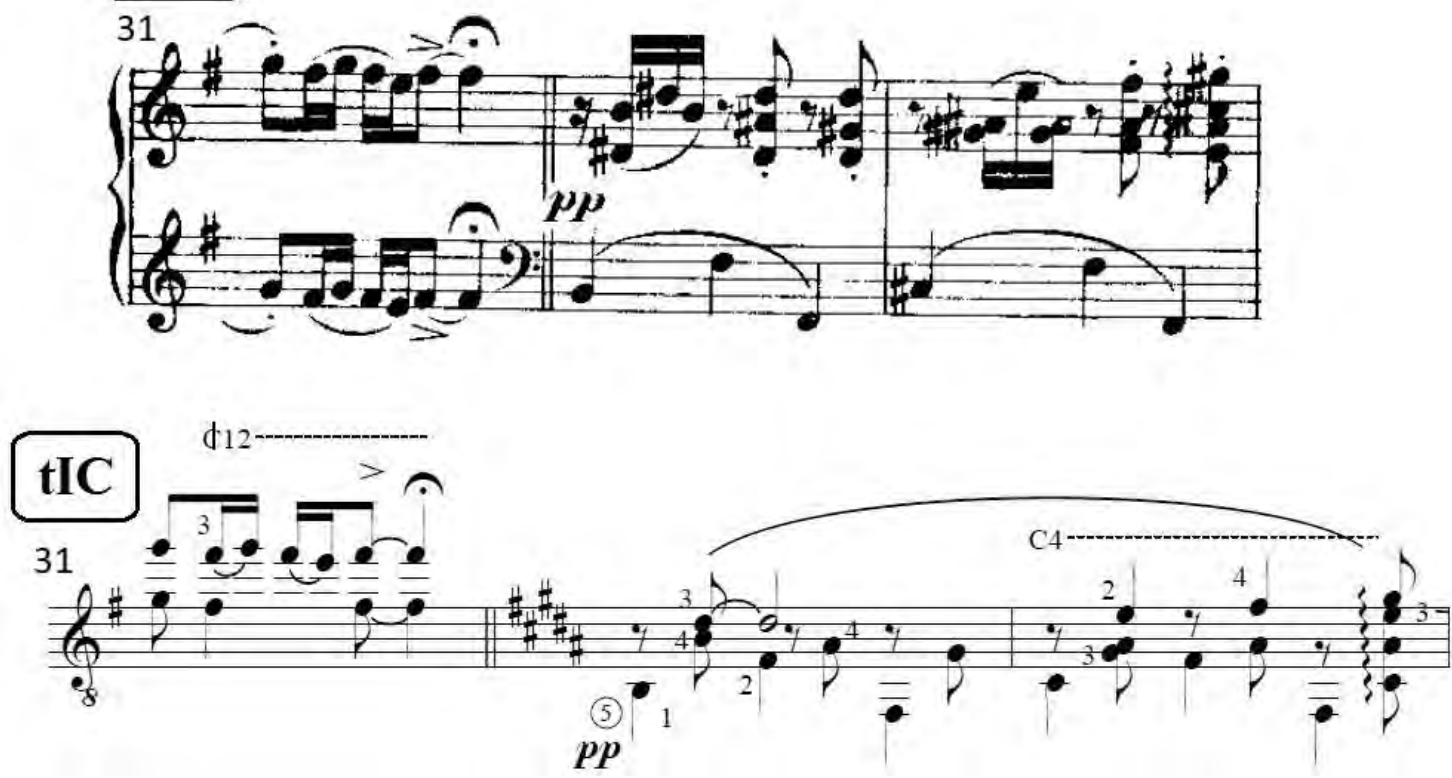

Fonte: elaborada pelo autor

Mais um exemplo de mudança de registro após o fechamento de uma frase (Figura 30).

Figura 30 - Mudança de registro da frase musical - Danza $n^{\circ} 11$ (scordatura: Ré1, Sol, Ré. Sol, Sib, Mib3)

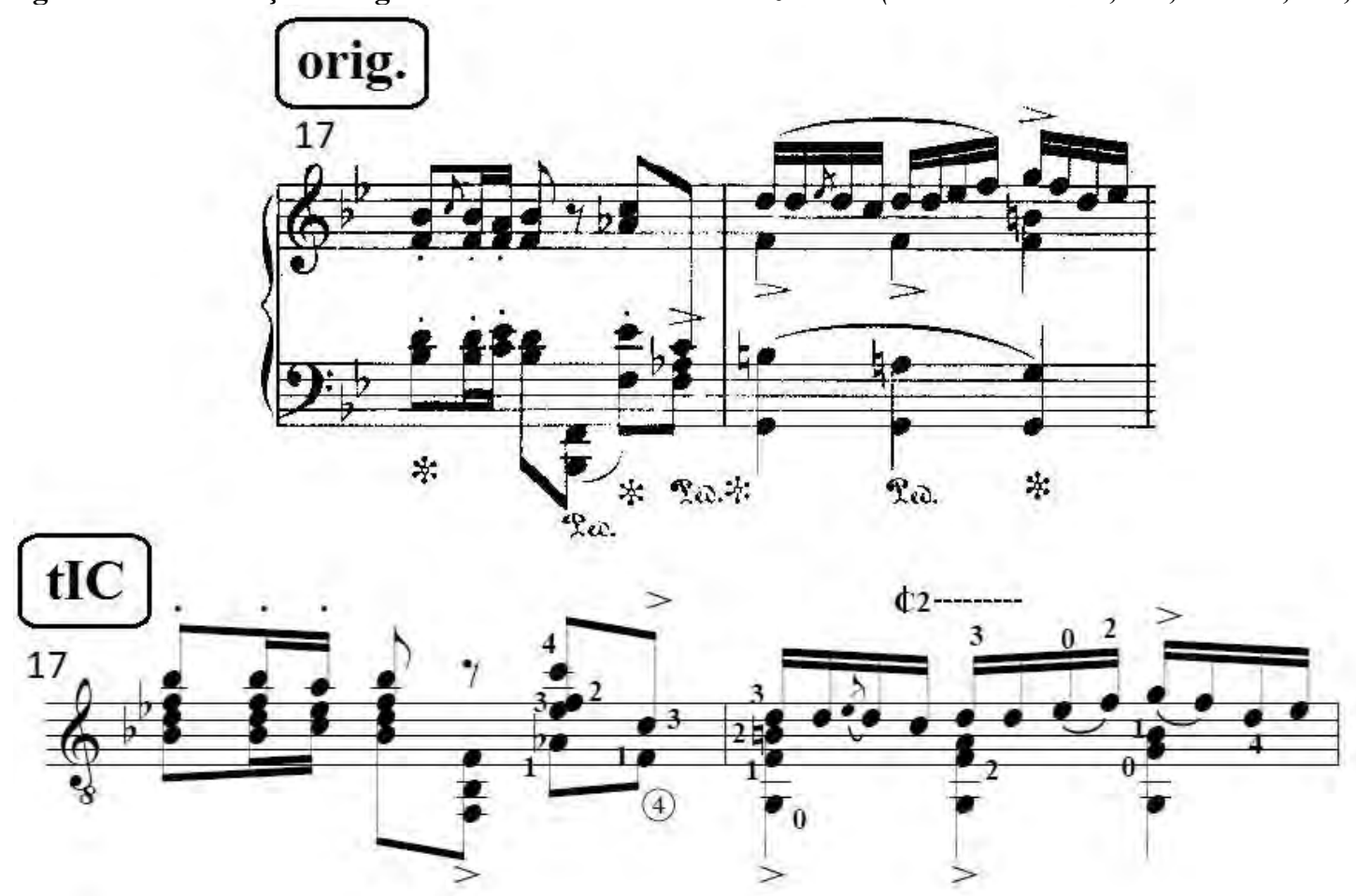

Fonte: elaborada pelo autor 
Algumas poucas situações exigiram a alteração do registro de uma única linha individual, mantendo as outras na mesma região (Figura 31).

Figura 31 - Mudança de oitava das terças que acompanhavam a melodia - Danza n¹2 (afinação tradicional).
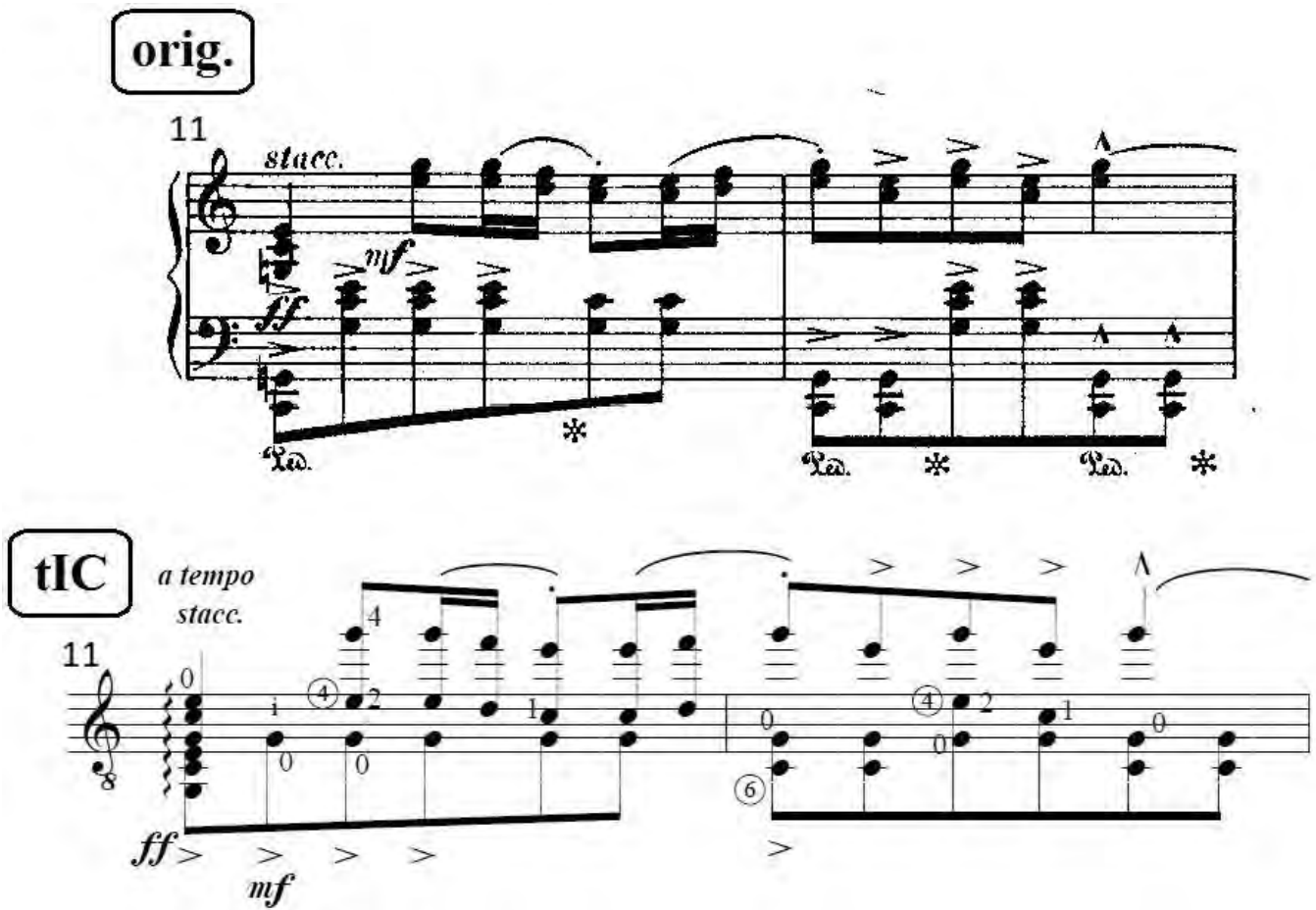

Fonte: elaborada pelo autor

Harmônicos oitavados foram utilizados para estender a tessitura violonística e lidar com o registro agudo de algumas frases da partitura original (Figura 32). 
Figura 32 - Harmônicos oitavados na adaptação do registro agudo pianístico - Danza no7 (scordatura: Ré1, Lá, Ré, Fá\#, Si, Mi3)

\section{orig.}
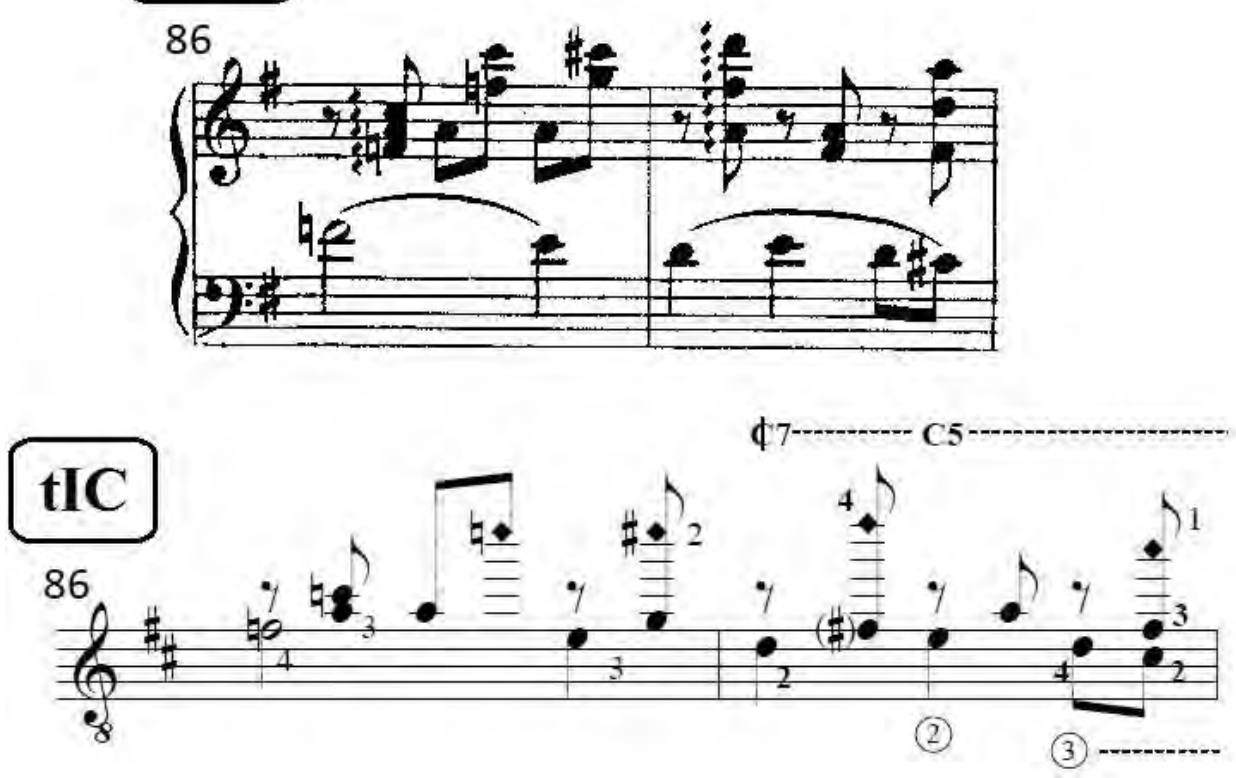

Fonte: elaborada pelo autor

Devido a scordatura aplicada na adaptação da Danza nog (transposta de Dó Maior para Ré Maior em nossa transcrição), foi possível explorar o registro superagudo do violão na execução do acorde do compasso 118, através do emprego dos harmônicos presentes na casa cinco (Figura 33). 
Figura 33 - emprego dos harmônicos para extensão da tessitura - Danza nº (scordatura: Ré1, Lá, Ré, Fá\#, Lá, Ré3)

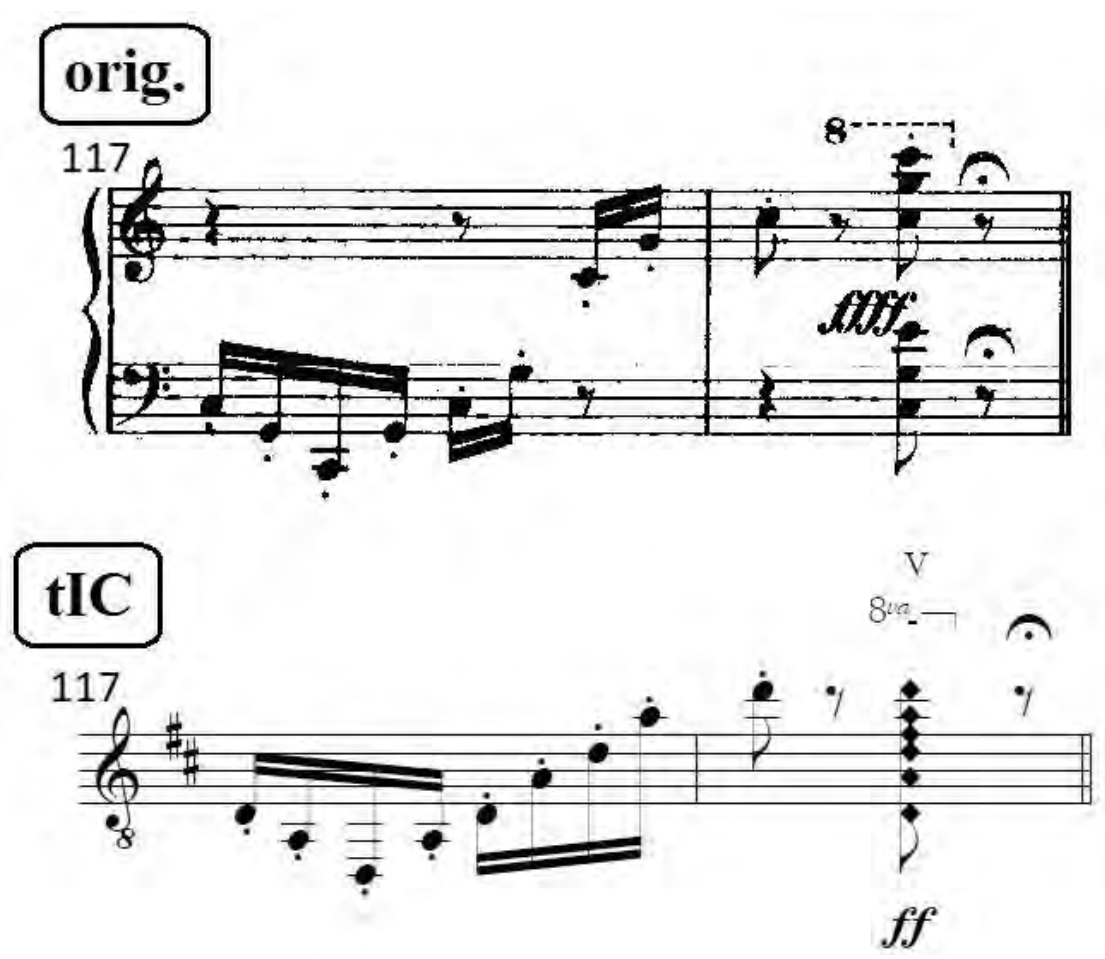

Fonte: elaborada pelo autor

Em suma, podemos dizer que as maiores ocorrências de ajustes giraram em torno das mudanças de oitava. Buscamos sempre manter as linhas melódicas dos temas principais nas alturas originais. Foi necessário, porém, transcrever certos trechos uma oitava abaixo e dentro disso, transpor algumas linhas para uma oitava superior ou inferior para se adaptarem melhor às possibilidades do violão.

\subsubsection{Escolha das tonalidades das transcrições}

Com exceção das três Danzas em que tivemos que alterar a tonalidade original para realizar a transcrição, a saber, Danzas $n^{\circ} .2,8$ e 9 , todas as transcrições foram feitas tendo em vista técnicas de adaptação que permitissem a conservação do tom original do ciclo em questão. Tal feito foi possível em nove das doze Danzas Españolas. Nas três Danzas supracitadas em que a tonalidade original foi alterada, existe a possibilidade, em duas delas ( $\mathrm{n}^{\circ} 2$ e 9), de se atingir o tom original com a utilização de um capo tasto ${ }^{11}$, caso o intérprete julgue pertinente. Entretanto,

\footnotetext{
11 'Expressão para um dispositivo em forma de barra, uma 'pestana móvel', que reduz a extensão sonora das cordas e facilita a transposição para uma tonalidade mais alta, sem alterar a configuração dos dedos” (SADIE, 1994, p. 168).
} 
manifestamos nossa inquietação em relação a Danza $n^{\circ} 8$, escrita originalmente em Dó Maior. Neste caso, a melhor opção de transcrição encontrada por nós transpõe a peça para Ré Maior.

\subsubsection{Disposição das notas nos acordes}

Uma configuração específica de acorde pode ser exequível num determinado registro do violão e não ser funcional em outro. É comum o violonista constantemente alterar a abertura dos mesmos de acordo com região em que deseja tocá-los; diferentemente, no piano, a execução de um grupo de notas é igualmente fácil ou difícil, independente da oitava em que aparece. Devido a tal característica, foi constante nosso trabalho de reorganizar acordes e linhas de contraponto durante o processo de transcrição. Na grande maioria dos casos, prezamos por não alterar o estado dos acordes (posição fundamental, primeira inversão, etc.), mas após posicionar suas extremidades (soprano e baixo), a escolha de posição das notas intermediárias deveria ser idiomática ao instrumento, de acordo com o que facilitasse a execução (Figura 34).

Figura 34 - Exemplos de reconfiguração de acordes em nossas transcrições

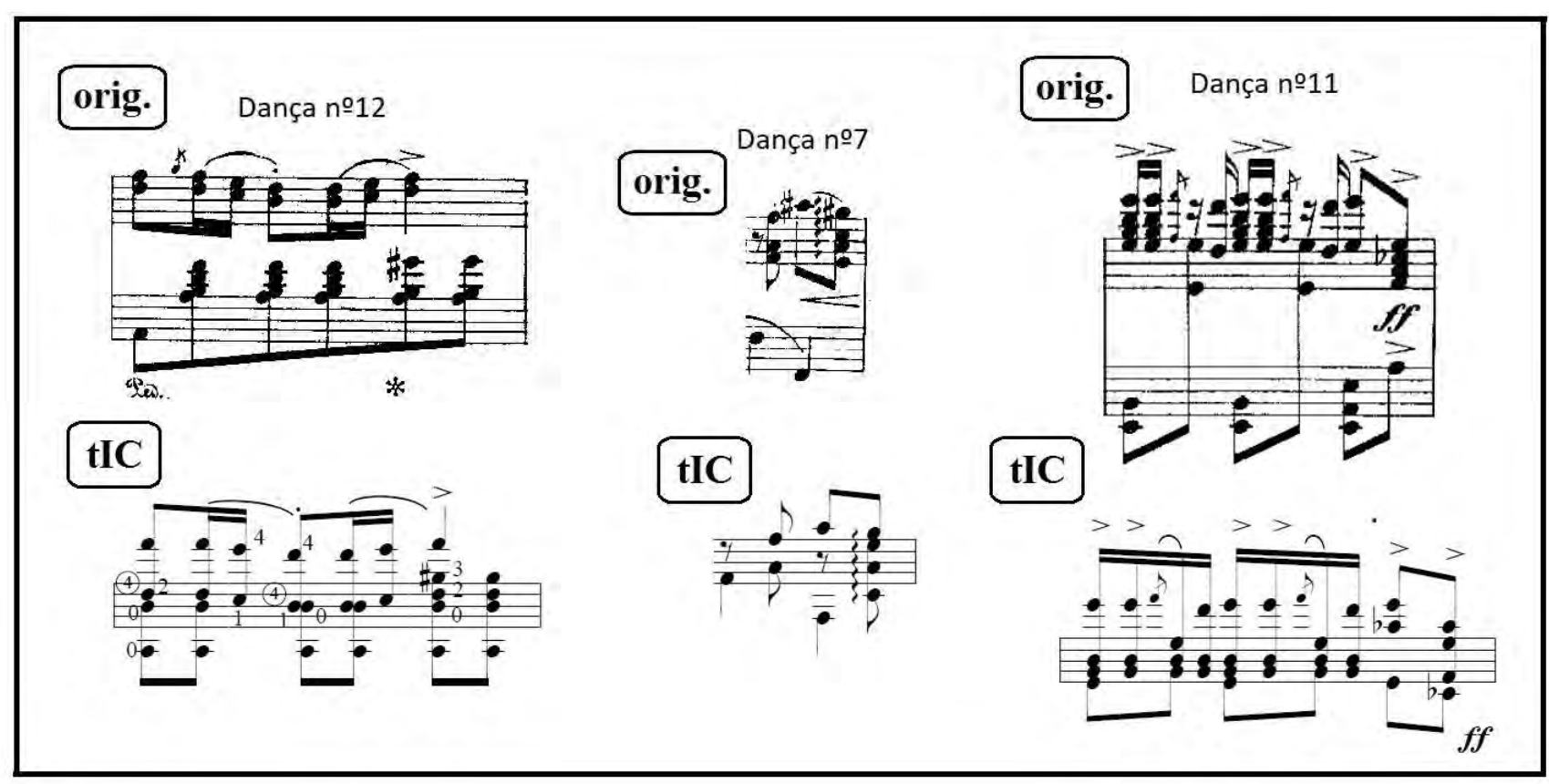

Fonte: elaborada pelo autor

Em poucos casos, houve a necessidade de alterar notas dos baixos, criando inversões. No caso a seguir, o acorde de cinco notas foi invertido para não omitirmos nenhuma de suas alturas (Figura 35). 
Figura 35 - Inversão do acorde de 5 notas no último tempo do compasso

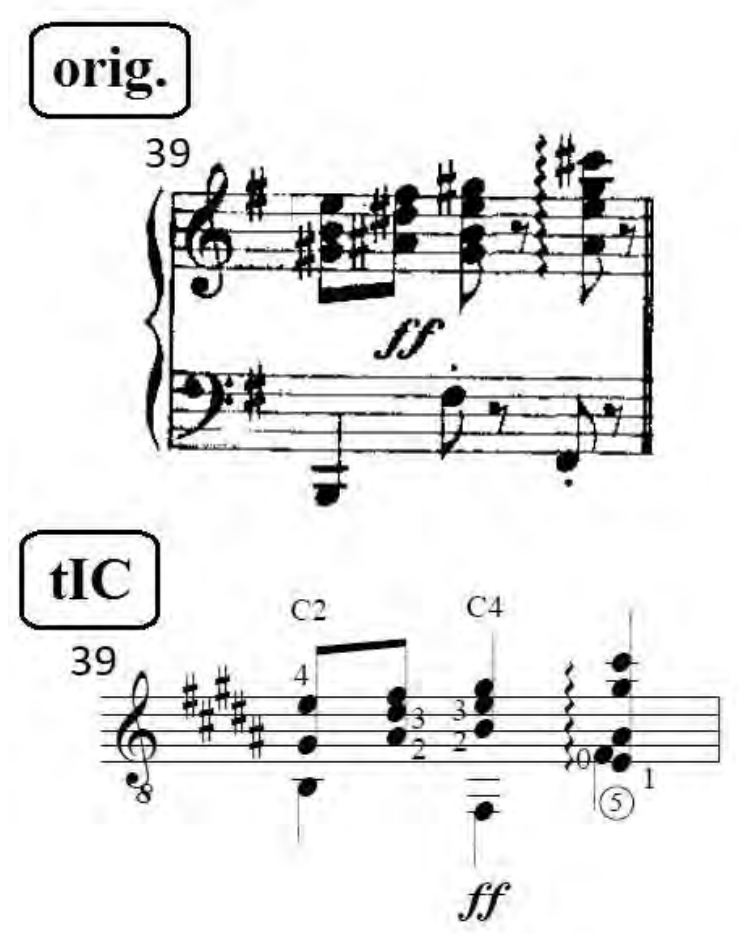

Fonte: elaborada pelo autor

Aqui, por uma necessidade sonora, o primeiro acorde de Sol Maior na posição fundamental foi alterado para a segunda inversão, com a finalidade de manter o fortíssimo e gerar um acorde mais aberto, visto que o registro agudo do violão não proporcionaria uma dinâmica sonora correspondente a necessidade da ideia musical. Foi necessário suprimir a terça do acorde e adicionar uma nona devido às características da scordatura da peça (Figura 36).

Figura 36 - Inversão de acorde - Danza no8 (scordatura: Ré1, Lá, Ré, Fá\#, Lá, Ré3)

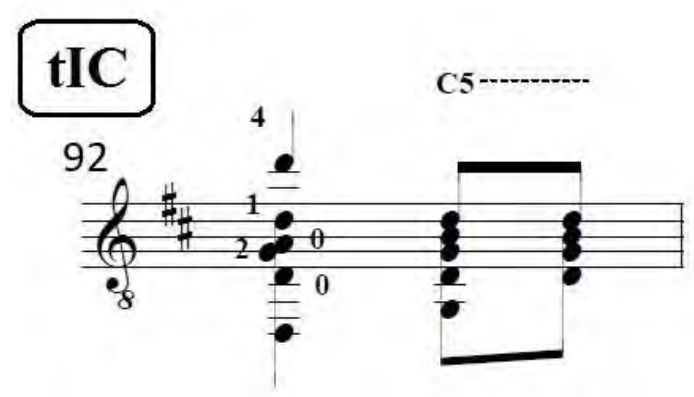

Fonte: elaborada pelo autor 


\subsubsection{Omissões}

Podemos afirmar que as mudanças mais significativas se deram nesse âmbito, dada a grande possibilidade de densidade textural permitida por instrumentos de teclado, como o piano, e a diferença de tessituras. Inicialmente os dobramentos de notas dos acordes foram retirados buscando transformá-los essencialmente em tríades ou tétrades nos momentos onde uma execução fluída de determinadas harmonias, contrapontos e articulações se tornava indispensável (Figura 37).

Figura 37 - Redução da textura dos acordes - Danza $n^{0} 3$ (6 ${ }^{\mathrm{a}} \mathrm{em}$ Ré)

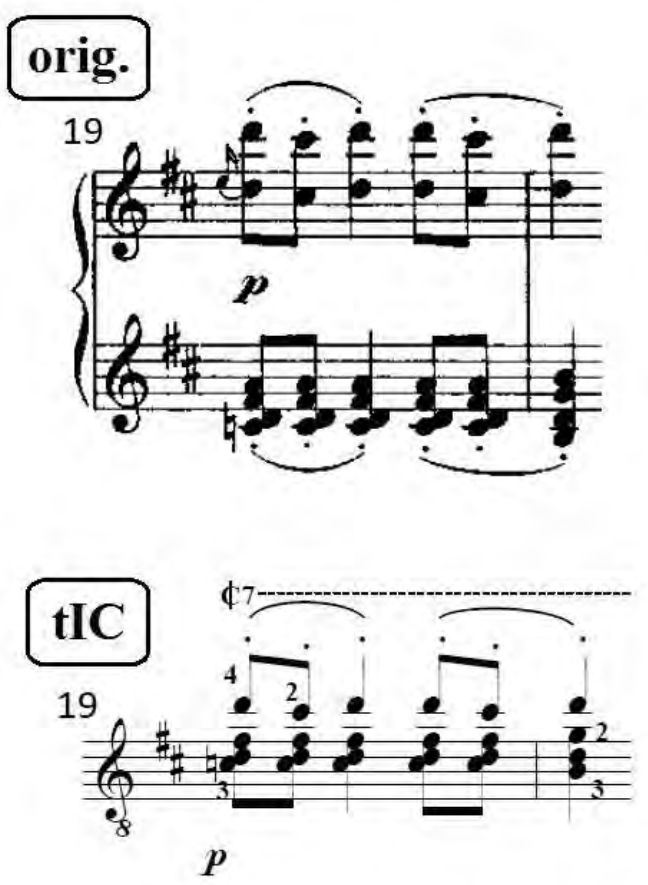

Fonte: elaborada pelo autor

Foram simplificadas algumas linhas melódicas oitavadas, geralmente na seguinte proporção: três oitavas foram reduzidas para duas e em outros casos duas oitavas reduzidas para uma (Figura 38). 
Figura 38 - Redução de oitavas - Danza n 3 (6 em Ré)

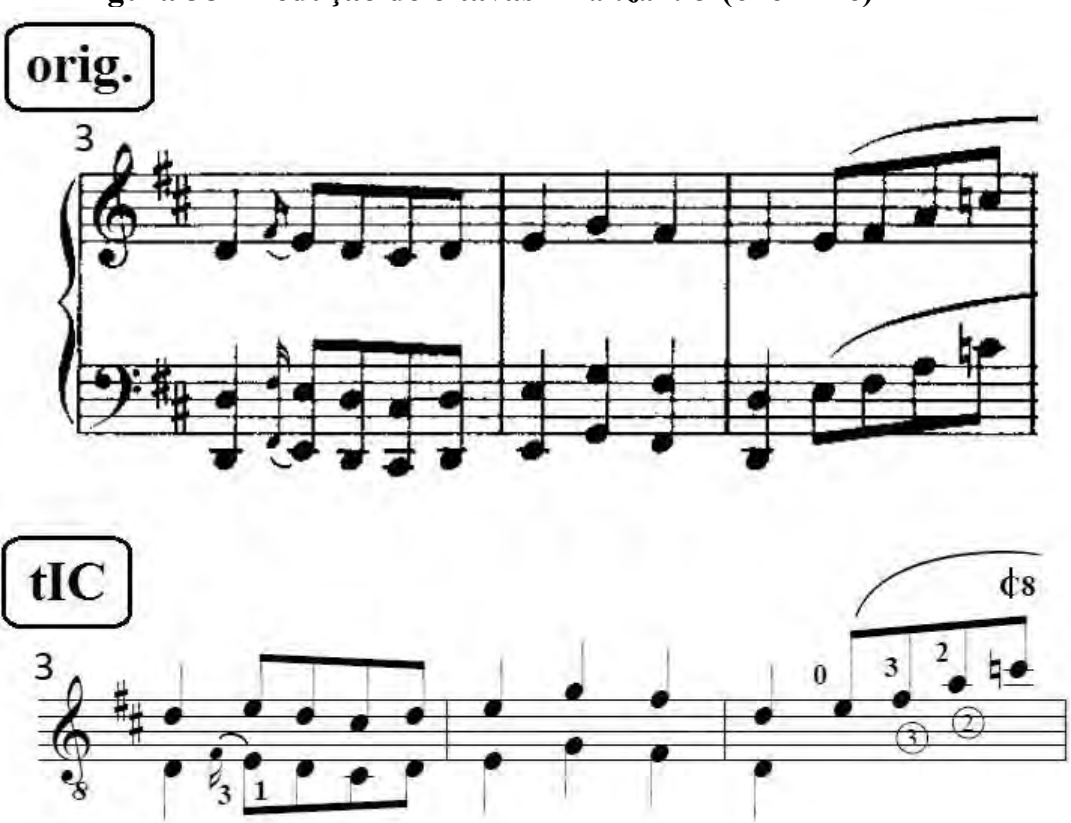

Fonte: elaborada pelo autor

Tais omissões foram realizadas em momentos em que a textura dialogava com dinâmicas mais intensas, salvo em algumas situações, como a ocorrência de extremidades que possuíam necessariamente a mesma nota. Na sequência, a ocorrência de três oitavas em uníssono orquestral em nossa transcrição (Figura 39).

Figura 39 - Uníssono orquestral - Danza nº (scordatura: Ré1, Lá, Ré, Fá\#, Lá, Ré3)

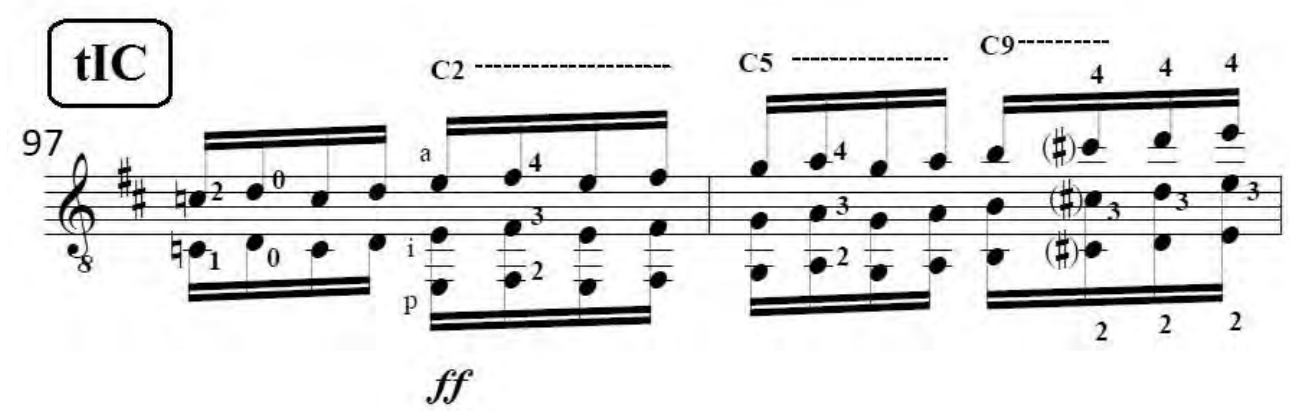

Fonte: elaborada pelo autor

As omissões ocorreram também no campo das ornamentações, em situações onde a manutenção na transcrição de uma appoggiatura presente no original, por exemplo, acarretaria uma simplificação exagerada do material musical (Figura 40). 
Figura 40 - Omissão de ornamentos - Danza nº 12 (afinação tradicional)

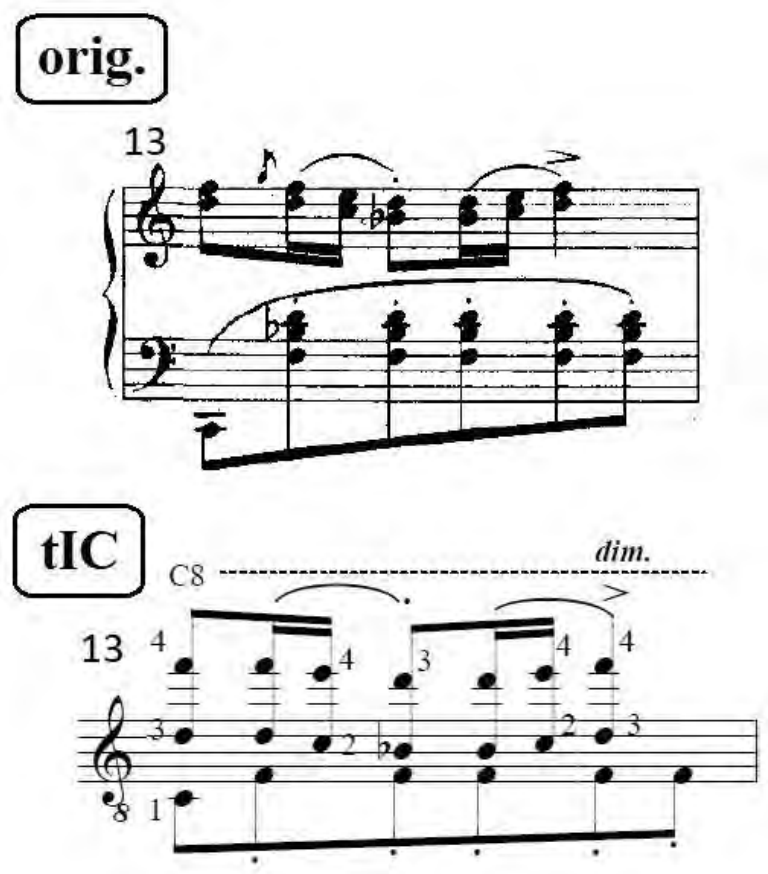

Fonte: elaborada pelo autor

\subsubsection{Acréscimos}

Muitas das notas acrescentadas foram conseqüências das próprias omissões. A impossibilidade de executar determinada nota ou linha presente no original, em muitas ocasiões abria uma lacuna que poderia ser preenchida; com o dobramento de alguma das notas do acorde, por exemplo, ou com o acréscimo de um arpejo para ocupar o lugar de um mordente, simulando a mesma rítmica (Figura 41). 
Figura 41 - Substituição de ornamentações - Danza n9 (scordatura: Ré1, Lá, Ré, Fá\#, Si, Mi3)

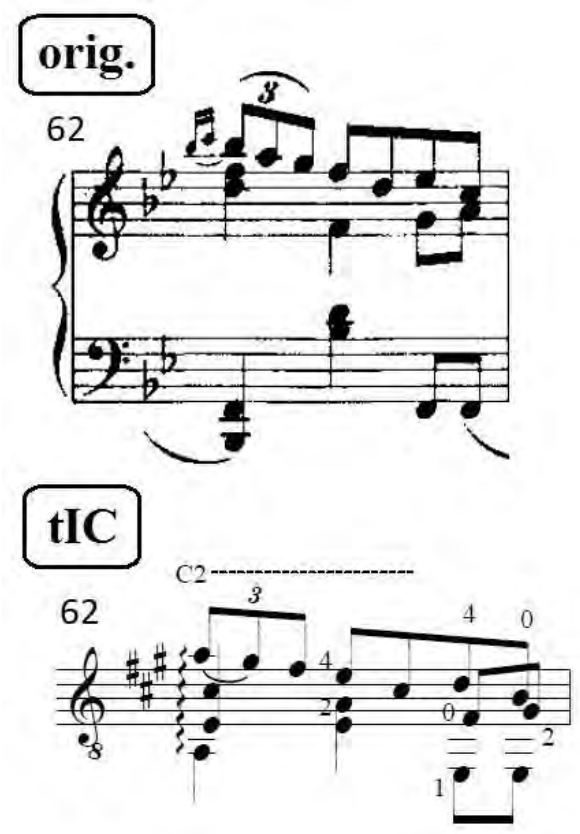

Fonte: elaborada pelo autor

Em outras situações, o acréscimo foi útil para completar acordes e auxiliar na execução de fortíssimos e de gradações equivalentes de dinâmicas (Figura 42).

Figura 42 - Acréscimo de nota no acorde - Danza n$^{\circ} 7$ (scordatura: Ré1, Lá, Ré, Fá\#, Si, Mi3)

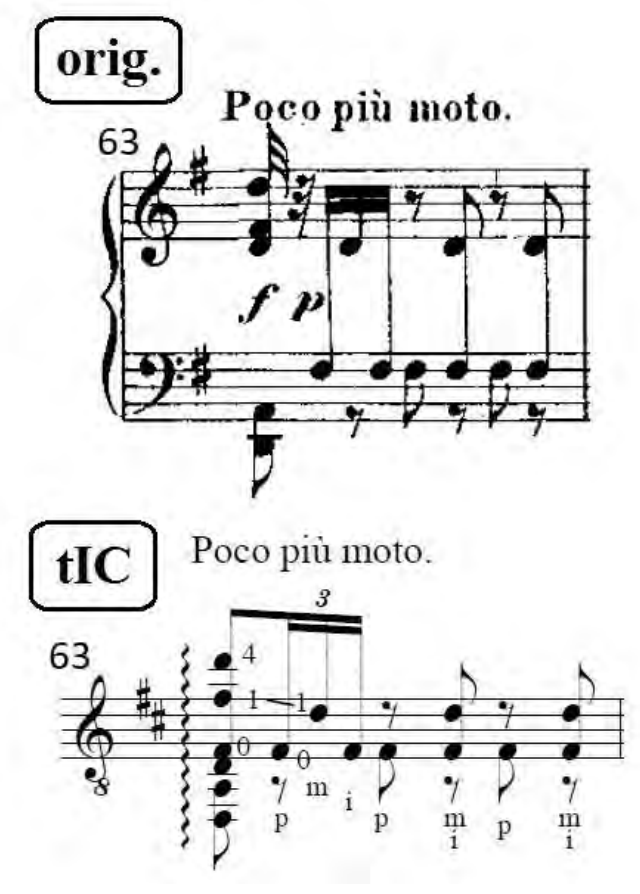

Fonte: elaborada pelo autor

Considerando que as notas do registro superagudo do violão possuem menor corpo sonoro, adicionamos, na Danza $n^{\circ} 3$, a oitava nas notas ocorrentes nessa região (Figura 43). 
Figura 43 - Reforço da ressonância de notas superagudas com oitavas - Danza ${ }^{0} 3$ (6 ${ }^{\mathrm{a}} \mathrm{em}$ Ré).

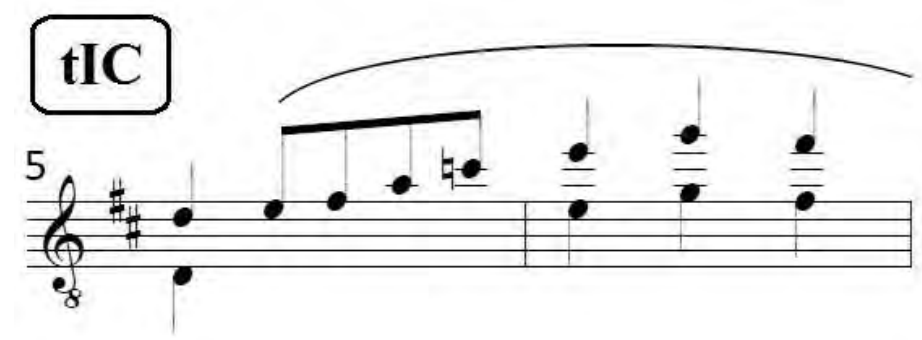

Fonte: elaborada pelo autor

Um elemento idiomático característico do violão é o rasgueado, caracterizado por golpes de mão direita sobre as cordas em sentido vertical para baixo ou para cima, criando, de certa forma, um efeito percussivo. A adição dessa técnica na transcrição veio a favor da dinâmica (Figura 44).

Figura 44 - Aplicação de rasgueado na transcrição - Danza nº 11 (scordatura: Ré1, Sol, Ré, Sol, Sib, Mib3)

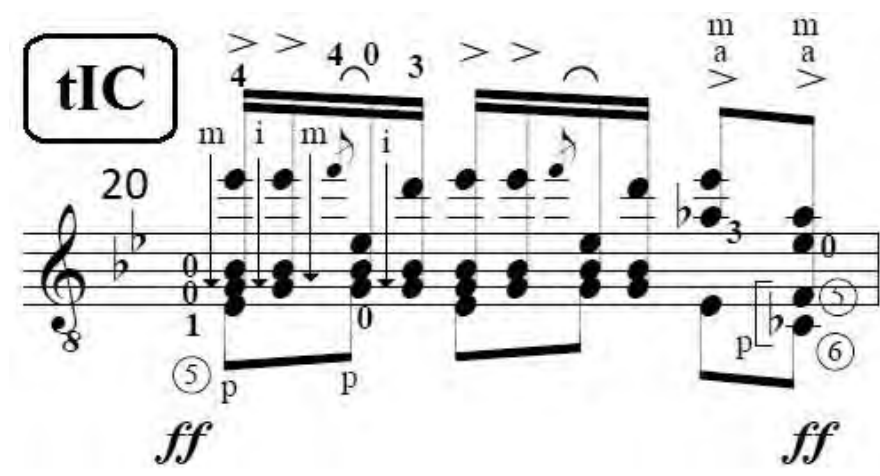

Fonte: elaborada pelo autor

\subsubsection{Simulação do pedal do piano}

Na tentativa de reproduzir o pedal de sustentação, algumas abordagens foram aplicadas nas transcrições. As principais delas foram:

\subsubsection{Campanela}

O termo diz respeito ao efeito resultante da ressonância de notas sustentadas, utilizando ordens diferentes de cordas em sentido transversal, contrapondo-se a abordagem melódica usual que utiliza uma digitação que dispõe as notas uma após a outra em sentido longitudinal às cordas do violão (SOUTO, 2010). Sobre esse conceito elucida-nos Nogueira: 
O recurso idiomático denominado Campanela, [...] foi muito utilizado no séc. XVII por diversos autores e seu efeito é causado pela ressonância de notas sustentadas em passagens melódicas, pisadas ou tocadas em ordens diferentes de cordas. (NOGUEIRA, 2008, p. 111).

Sua aplicação em nossas transcrições foi vantajosa, como, por exemplo, no motivo do acompanhamento do tema principal da Danza $n^{\circ} 2$ (Figura 45).

Figura 45 - Aplicação da campanela no motivo do acompanhamento - Danza $n^{\circ 2}$ (afinação tradicional)
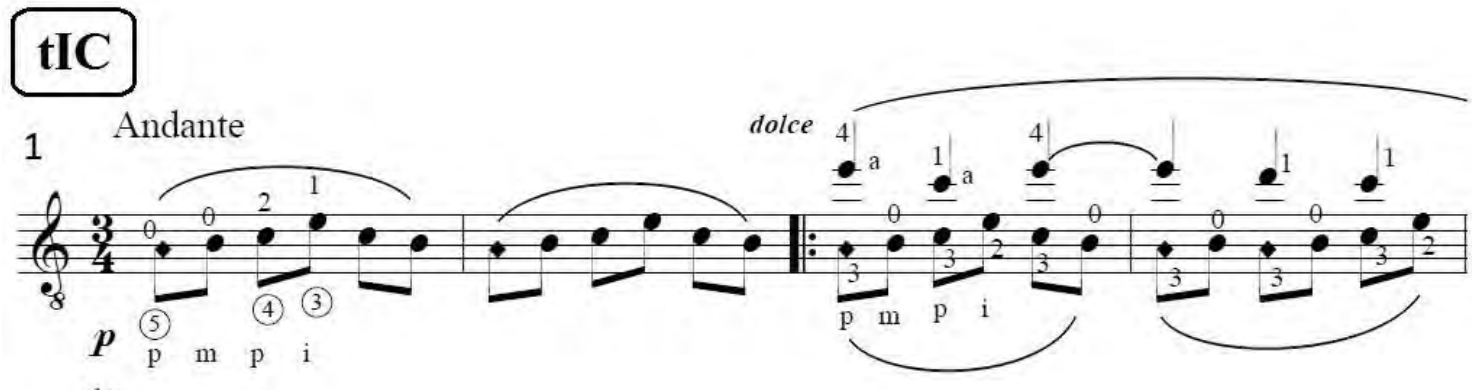

Fonte: elaborada pelo autor

Aqui segue um trecho da Danza $n^{\circ} 10$ onde a campanela atua na linha melódica da retransição para a seção “A” (Figura 46).

Figura 46 - Campanela aplicada na Danza $n^{\circ} 10$ (6 $6^{\mathrm{a}} \mathrm{em}$ Ré e $5^{\mathrm{a}} \mathrm{em}$ Sol)

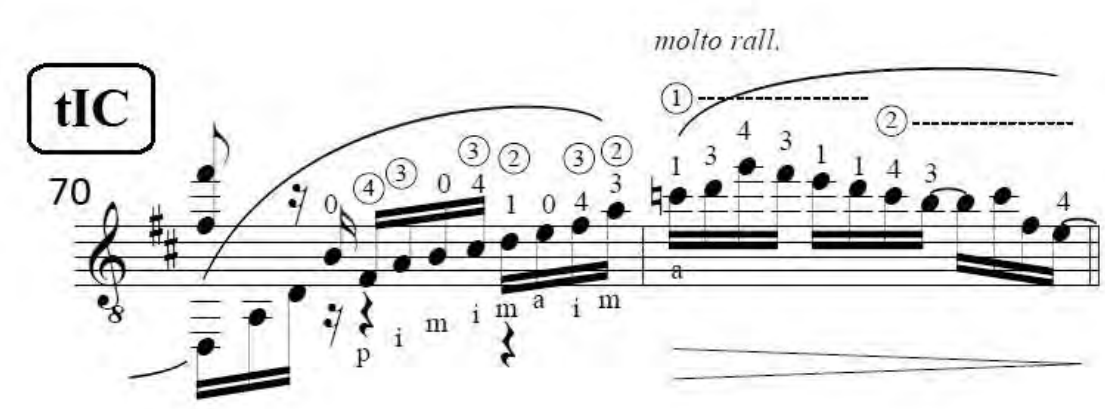

Fonte: elaborada pelo autor

A dificuldade de execução em allegro molto, dos graus conjuntos presentes na coda da Danza $n^{\circ} 8$, foi contornada com a mudança de registro e uso da campanela. Este recurso atribui, através de sua ressonância característica, uma sensação harmônica ao trecho, compensando a omissão dos acordes de acompanhamento presentes no original. Além disso, permite que linhas melódicas sejam abordadas como arpejos, uma técnica muito natural para o violão (Figura 47). 
Figura 47 - Campanela na coda da Danza n8 (scordatura: Ré1, Lá, Ré, Fá\#, Lá, Ré3)

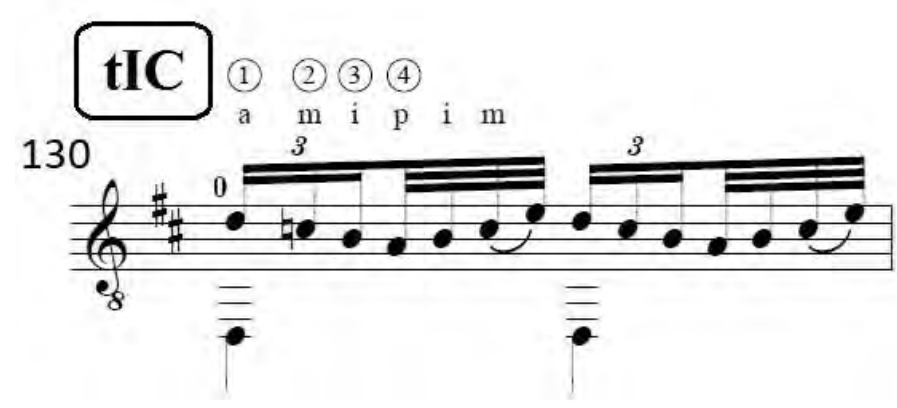

Fonte: elaborada pelo autor

\subsubsection{Ressonâncias}

Notas acrescentadas puderam auxiliar na ressonância de outras notas ou mesmo em passagens. Temos um caso interessante no final da Danza $n^{\circ} 12$, onde a peça se encerra com um Lá 4. No entanto, o registro superagudo do violão não possui tanta ressonância quanto as outras regiões, o que causa uma sonoridade deficiente na finalização da obra em questão. Optamos por reforçar a ressonância da nota Lá com o acréscimo de um harmônico, oitava abaixo (Figura 48).

Figura 48 - Reforço de ressonância com harmônico - Danza n ${ }^{\circ} 12$ (afinação tradicional)

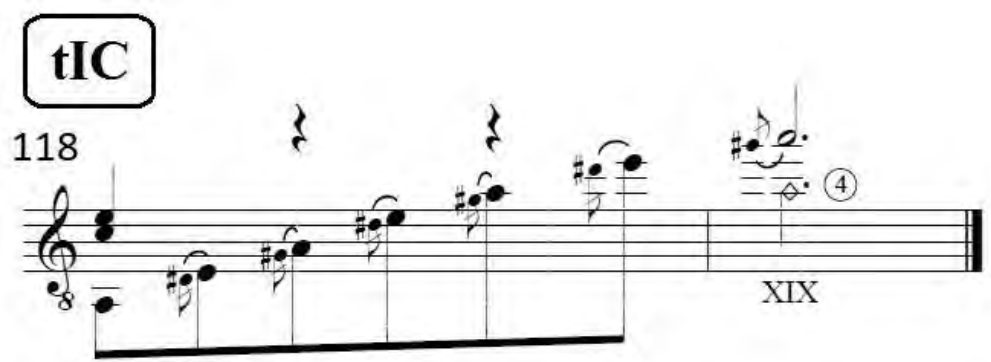

Fonte: elaborada pelo autor

Em nossa transcrição da Danza $n^{\circ} 8$, para evitar as prováveis interrupções sonoras ocasionadas pelas mudanças de posição da mão esquerda do violonista, acrescentamos em diversos momentos, dobramentos de notas pertencentes aos acordes, posicionando-os em cordas soltas. O foco dessa abordagem é auxiliar a ressonância, simulando o ambiente sonoro gerado pelo uso do pedal de sustentação durante a execução da peça no piano (Figura 49). 
Figura 49 - Reforço de ressonância com auxílio de cordas soltas - Danza n n $^{\circ}$ (scordatura: Ré1, Lá, Ré, Fá\#, Lá, Ré3)

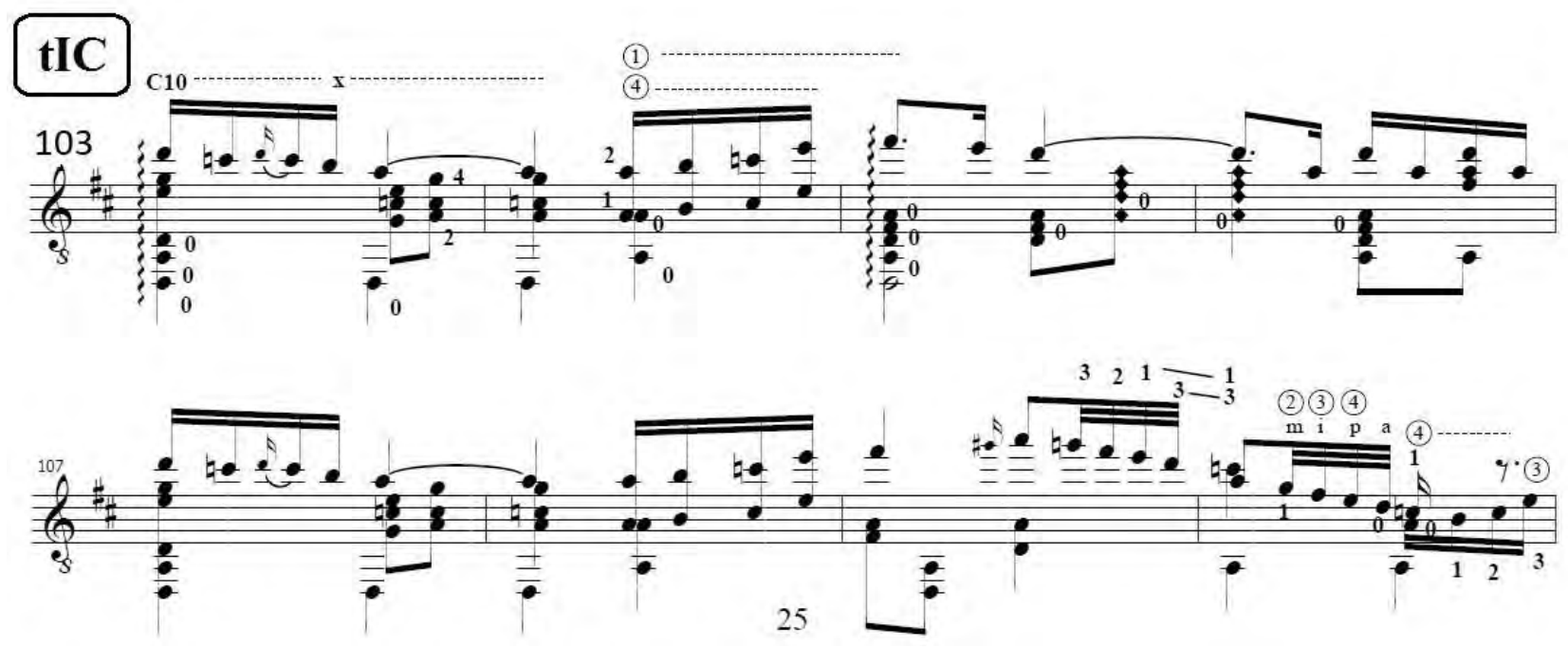

Fonte: elaborada pelo autor

\subsubsection{Reelaboração do material musical}

Nos momentos em que a tradução mais literal possível do texto original não se tornou exequível ao violão, buscamos, baseados no estudo e na pesquisa do legado de transcrições, reelaborar o material musical conservando sua essência quando adaptado à linguagem violonística. Esta é uma tentativa de conceber a frase musical caso tivesse sido composta originalmente para violão, e não como um processo de adaptação. Vemos aqui um tipo de postura adotada por Francisco Tárrega e Miguel Llobet em suas transcrições.

O primeiro exemplo trata dos compassos de textura mais densa apresentados na Danza $n^{\circ}$. Ali não é possível obter fluência na execução ao violão do modo em que o trecho se apresenta, contudo, considerando a harmonia para reconfigurar a sequência de notas do acorde e realocando a melodia em outro registro, conseguimos obter um resultado que julgamos satisfatório (Figura 50). 
Figura 50 - Reelaboração do material musical - Danza n7 (scordatura: Ré1, Lá, Ré, Fá\#, Si, Mi3)
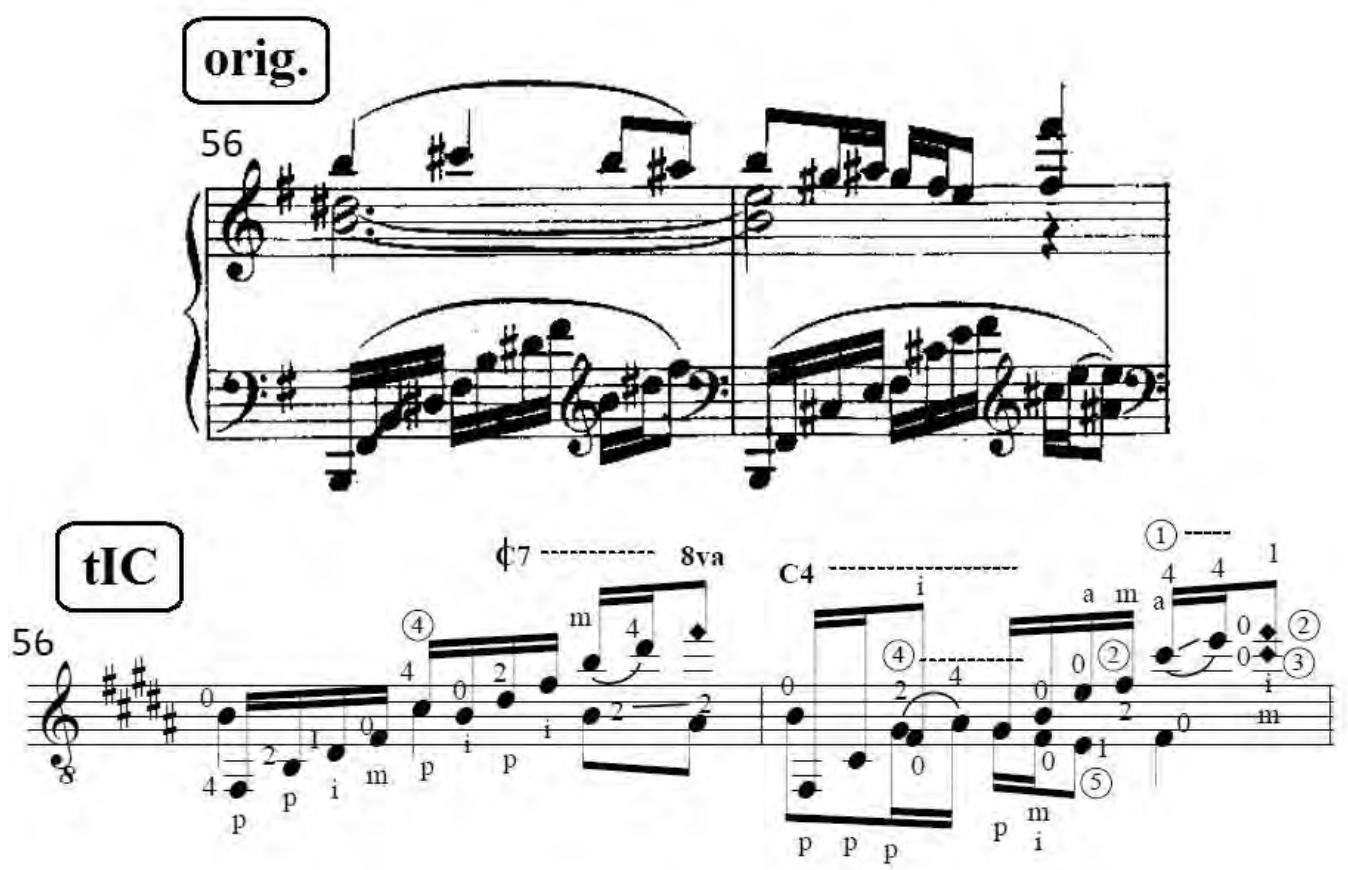

Fonte: elaborada pelo autor

Durante o primeiro grupo de temas da seção "A" da Danza $n^{\circ}$. 9, seria um tanto impraticável executar integralmente a textura e os saltos de oitava do motivo apresentados na figura seguinte (Figura 51).

Figura 51 - Saltos de oitava e textura densa

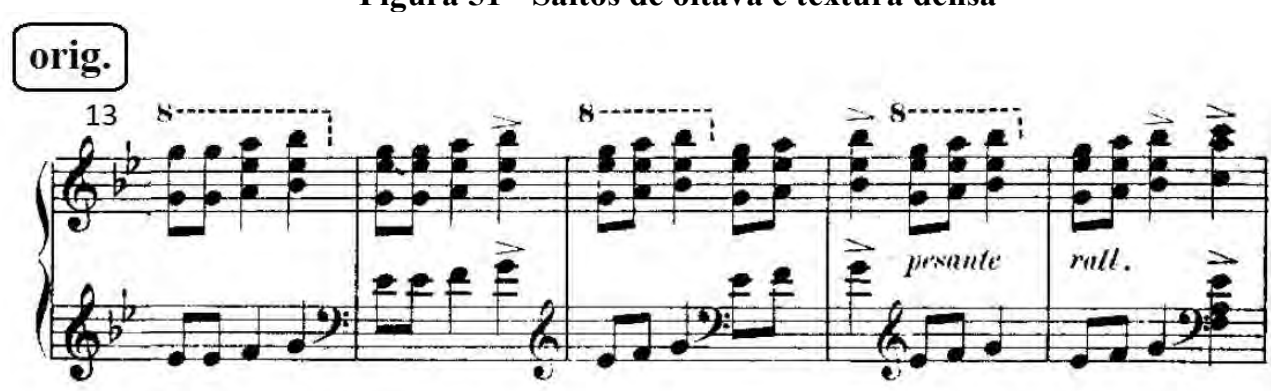

Fonte: elaborada pelo autor

$\mathrm{Na}$ tentativa de manter o aspecto mais denso da textura, aplicamos o rasgueado como solução de adaptação, suprimindo a linha do baixo e substituindo-a por um acorde pedal de Ré Maior. Tal modificação também amparou as mudanças de oitava do motivo, possibilitando a utilização de um dedo guia (Figura 52). 
Figura 52 - Uso de rasgueados na reelaboração musical - Danza nº (scordatura: Ré1, Lá, Ré, Fá\#, Si, Mi3)

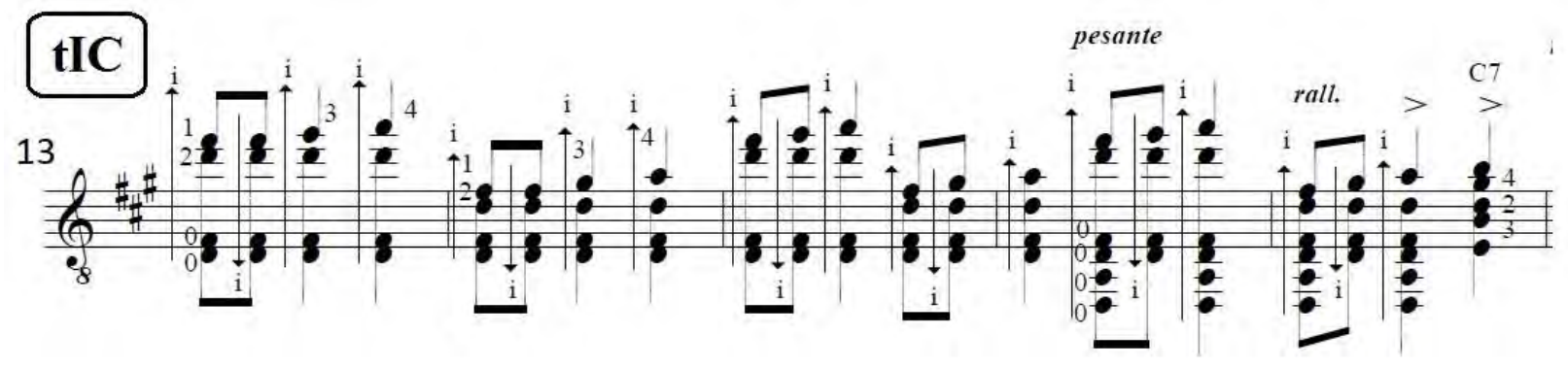

Fonte: elaborada pelo autor

O final da Danza $n^{o} .9$ também foi alvo de uma reelaboração do material musical (Figura $53)$.

Figura 53 - Reelaboração do final - Danza nº9 (scordatura: Ré1, Lá, Ré, Fá\#, Si, Mi3)

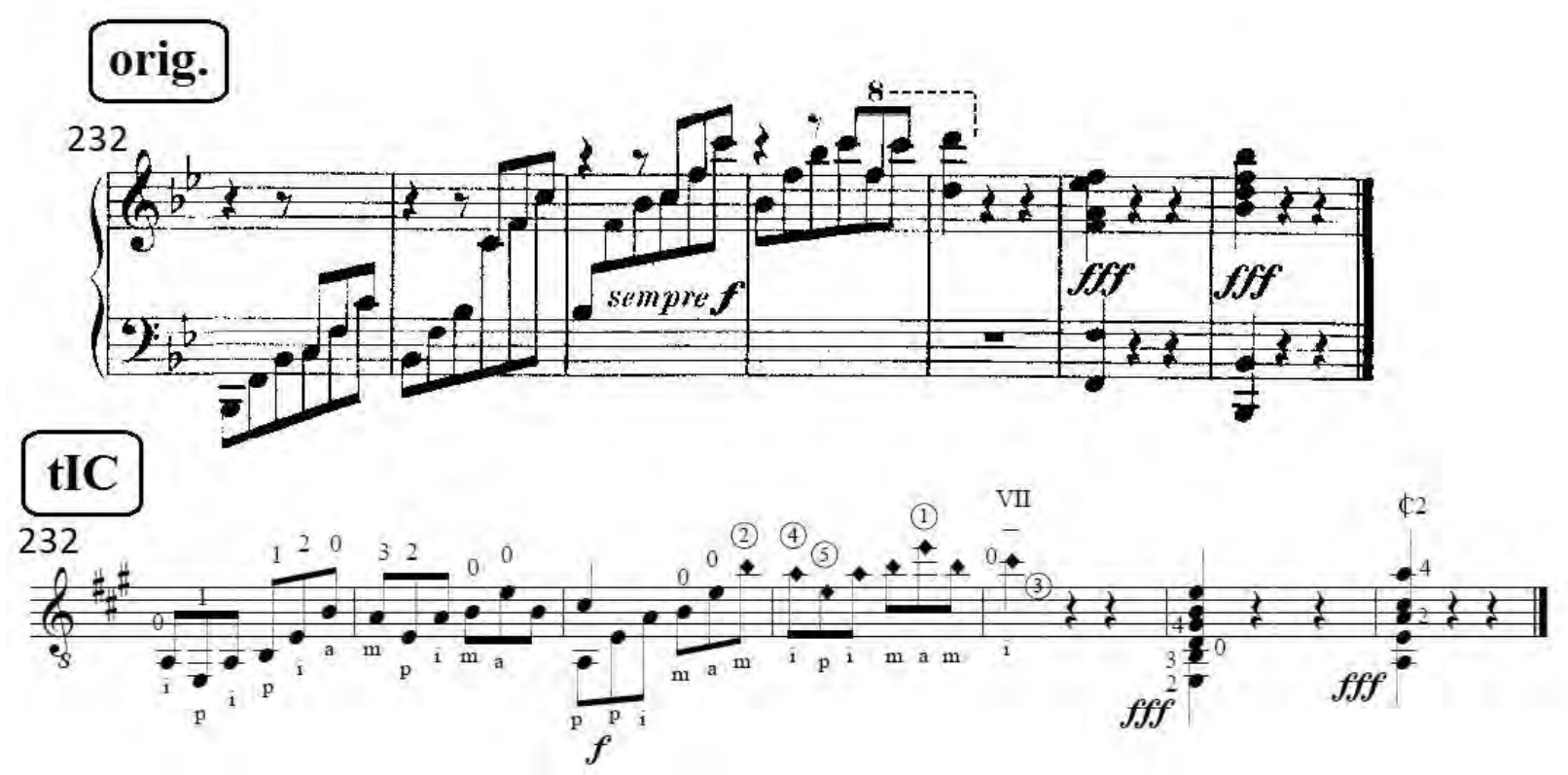

Fonte: elaborada pelo autor

\subsection{Novas propostas de scordature para as transcrições}

Um ajuste tradicionalmente utilizado para simular a afinação da vihuela, na execução ao violão do repertório do Renascimento, é a alteração da terceira corda (Sol) para Fá sustenido. Embora o manuseio dessa técnica pareça restritamente relacionada a esse repertório, sua utilização em nosso processo de adaptação das Danzas Españolas foi de amplo auxílio na resolução das Danzas $n^{\circ} 1,7,8$ e 9 . A afinação tradicional do violão consiste na relação de um intervalo de terça maior entre a segunda e terceira cordas ( $\mathrm{Sol}$ e $\mathrm{Si}$ ) e em intervalos de quartas justas entre as demais. A alteração da terceira corda para Fá sustenido posiciona agora o intervalo de terça maior entre a 
terceira e quarta cordas, ao mesmo tempo em que mantém a relação de quarta justa entre todas as outras. A figura a seguir demonstra algumas situações em nossas transcrições das Danzas Españolas, onde este pequeno ajuste de um semitom auxiliou na resolução de certos empecilhos. O leitor violonista poderá executar o trecho com a scordatura tradicional do violão, seguida da leitura com a terceira corda em Fá\# e notar a fluidez resultante da alteração (Figura 54).
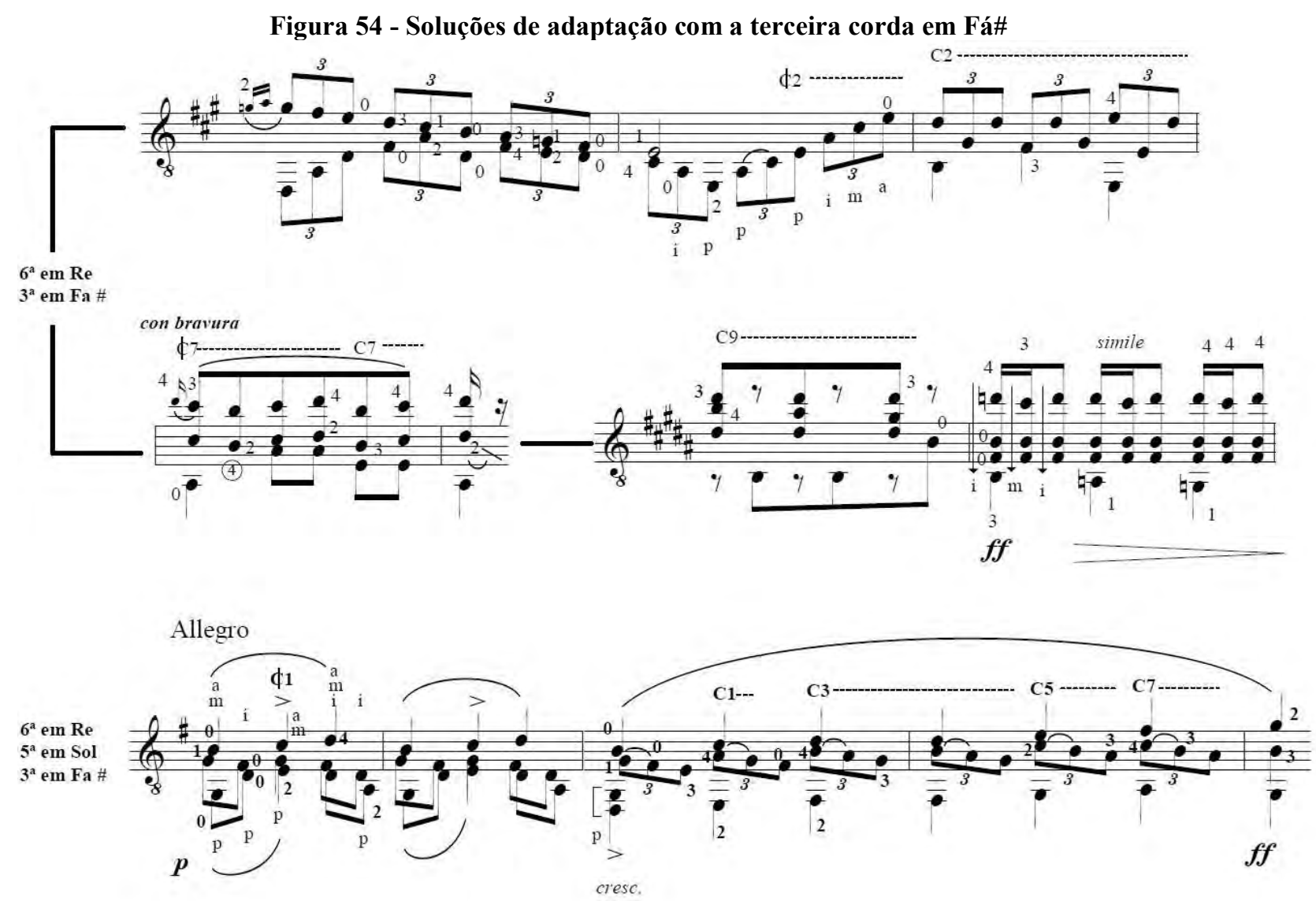

Fonte: elaborada pelo autor

Nos momentos em que os procedimentos tradicionais de adaptação para violão solo não foram suficientes para possibilitar a tradução mais literal possível do texto original, buscamos a solução de tais problemas na experimentação de novas possibilidades de scordature que abarcassem algumas das Danzas, especialmente as de número 6, 8 e 11. Essas novas propostas de afinação surgiram do seguinte objetivo: a busca de adequação, através de novas scordature, preferencialmente de partes das Danzas onde as características dos aspectos musicais não permitiam uma adaptação exequível ao violão. Salientamos que seções de menor complexidade musical e densidade de textura podem ser ajustadas em diferentes opções de afinação.

É curioso perceber que em muitos casos, ao examinarmos uma determinada obra, a sensação de inviabilidade de uma transcrição é gerada não pela observação de toda a extensão da 
peça, e sim através da constatação de uma seção ou seções específicas de maior densidade. É neste momento, que determinamos a inviabilidade de um resultado satisfatório com a transcrição. Ao compreender isso, nos concentramos em resolver as problemáticas de adaptação nas seções que causavam, aparentemente, a impressão de impossibilidade de transcrição da obra, ao mesmo tempo em que buscamos adaptar os trechos de menor densidade à nova scordatura. Nos subcapítulos subsequentes, detalharemos o processo, em cada uma das 12 Danzas Españolas, das escolhas decisivas de adaptação feitas nas seções crucias.

A tabela a seguir demonstra o quadro de transposições e de novas propostas de scordature de nossa transcrição (Tabela 1).

Tabela 1 - Scordature utilizadas nas 12 Danzas Españolas

\begin{tabular}{|c|c|c|c|c|c|c|c|c|c|c|c|c|}
\hline Danza & $\mathbf{N}^{0} 1$ & $\mathrm{~N}^{0} 2$ & $N^{0} 3$ & $N^{0} 4$ & $N^{0} 5$ & $N^{0} 6$ & $\mathbf{N}^{0} 7$ & $\mathrm{~N}^{0} 8$ & $\mathrm{~N}^{09}$ & $N^{0} 10$ & $N^{0} 11$ & $N^{0} 12$ \\
\hline $\begin{array}{l}\text { Tonalidade } \\
\text { Original }\end{array}$ & G & $\mathrm{Cm}$ & $\mathrm{D}$ & G & Em & $\mathrm{D}$ & G & $\mathrm{C}$ & $\mathrm{Bb}$ & G & $\mathrm{Gm}$ & $\mathrm{Am}$ \\
\hline $\begin{array}{l}\text { Tonalidade } \\
\text { da transcrição }\end{array}$ & G & Am & $\mathrm{D}$ & G & Em & $\mathrm{D}$ & G & D & $\mathbf{A}$ & G & $\mathrm{Gm}$ & $\mathrm{Am}$ \\
\hline$\sigma^{a} \operatorname{corda}(\mathrm{Mil})$ & Ré & - & Ré & Ré & - & Ré & Ré & Ré & Ré & Ré & Ré & - \\
\hline $5^{a} \operatorname{corda}($ Lál) & Sol & 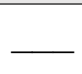 & - & Sol & 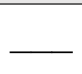 & - & - & - & - & - & Sol & 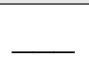 \\
\hline $4^{a}$ corda (Ré2) & - & - & 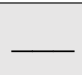 & - & - & $\longrightarrow$ & - & - & - & $\longrightarrow$ & - & 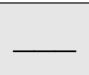 \\
\hline $3^{a} \operatorname{corda}(\operatorname{Sol} 2)$ & Fá\# & 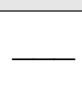 & - & $\longrightarrow$ & 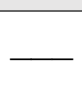 & Sol\# & Fá\# & Fá\# & Fá\# & 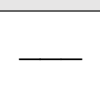 & 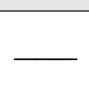 & - \\
\hline $2^{a} \operatorname{corda}(\mathrm{Si} 2)$ & - & 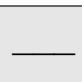 & $\longrightarrow$ & $\longrightarrow$ & 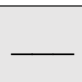 & Lá & 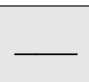 & Lá & 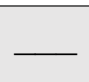 & $\longrightarrow$ & $\mathrm{Sib}$ & - \\
\hline $1^{a} \operatorname{corda}(\mathrm{Mi} 3)$ & 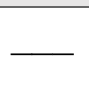 & 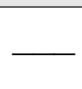 & 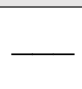 & 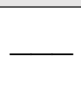 & 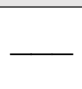 & Ré & $\bar{\tau}$ & Ré & 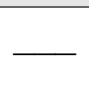 & $\longrightarrow$ & Mib & \\
\hline
\end{tabular}

Fonte: elaborada pelo autor

Embora essas novas propostas de scordature possam possibilitar a execução ao violão das Danzas de Granados, consequentemente, um problema gerado a se lidar é com a instabilidade da afinação recorrente das constantes modificações de alturas nas cordas do violão, no caso de uma apresentação integral do ciclo em concerto. Caso o intérprete preze pela execução da sequência numérica da obra, o tempo para estabilizar a afinação entre uma Danza e outra pode ser grande, o que poderia ser resolvido utilizando mais de um instrumento, reservando cada um deles para as peças com scordature próximas. Pensando em uma solução mais simples, essa situação pode ser parcialmente contornada considerando uma ordem de proximidade de 
scordature na execução das Danzas. Na tabela a seguir sugerimos uma proposta de execução (Tabela 2).

Tabela 2 - Sugestão de ordem de execução das Danzas Españolas

\begin{tabular}{|c|c|c|}
\hline Danzas (Granados) & Scordatura & Ajustes a serem realizados \\
\hline $\mathrm{N}^{\mathrm{o}} 2 / \mathrm{N}^{\mathrm{o}} 5 / \mathrm{N}^{\mathrm{o}} 12$ & TRADICONAL & \\
\hline $\mathrm{N}^{\circ} 3 / \mathrm{N}^{\circ} 10$ & $6^{\mathrm{a}}$ em Ré & $6^{a}$ corda desce para Ré \\
\hline $\mathrm{N}^{0} 7 / \mathrm{N}^{\circ} 9$ & $\begin{array}{c}6^{\mathrm{a}} \text { em Ré } \\
3^{\mathrm{a}} \text { em Fá\# }\end{array}$ & $3^{a}$ corda desce para Fá\# \\
\hline $\mathrm{N}^{0} 1$ & $\begin{array}{l}6^{\mathrm{a}} \text { em Ré } \\
5^{\mathrm{a}} \mathrm{em} \text { Sol } \\
3^{\mathrm{a}} \mathrm{em} \text { Fá\# }\end{array}$ & $5^{\mathrm{a}}$ corda desce para Sol \\
\hline $\mathrm{N}^{\circ} 4$ & $\begin{array}{l}6^{\mathrm{a}} \text { em Ré } \\
5^{\mathrm{a}} \mathrm{em} \mathrm{Sol}\end{array}$ & $3^{\text {a }}$ corda sobe para Sol \\
\hline $\mathrm{N}^{\mathrm{o}} 11$ & $\begin{array}{c}6^{\mathrm{a}} \text { em Ré } \\
5^{\mathrm{a}} \mathrm{em} \mathrm{Sol} \\
2^{\mathrm{a}} \mathrm{em} \mathrm{Si} \mathrm{b} \\
1^{\mathrm{a}} \mathrm{em} \mathrm{Mi} \mathrm{b}\end{array}$ & $\begin{array}{l}2^{\mathrm{a}} \text { corda desce para Si b } \\
1^{\mathrm{a}} \text { corda desce para Mi b }\end{array}$ \\
\hline $\mathrm{N}^{\circ} 8$ & $\begin{array}{l}6^{\mathrm{a}} \text { em Ré } \\
3^{\mathrm{a}} \text { em Fá\# } \\
2^{\mathrm{a}} \text { em Lá } \\
1^{\mathrm{a}} \mathrm{em} \text { Ré }\end{array}$ & $\begin{array}{l}5^{\mathrm{a}} \text { corda sobe para Lá } \\
3^{\mathrm{a}} \text { corda desce para Fá\# } \\
2^{\mathrm{a}} \text { corda desce para Lá } \\
1^{\mathrm{a}} \text { corda desce para Ré }\end{array}$ \\
\hline $\mathrm{N}^{\mathrm{o}} 6$ & $\begin{array}{c}6^{\mathrm{a}} \text { em Ré } \\
3^{\mathrm{a}} \text { em Sol\# } \\
2^{\mathrm{a}} \text { em Lá } \\
1^{\mathrm{a}} \text { em Ré }\end{array}$ & $3^{a}$ corda sobe para Sol\# \\
\hline
\end{tabular}

Fonte: elaborada pelo autor 


\section{TRANSCRIÇÕES DAS 12 DANZAS ESPAÑOLAS OP. 37}

Após as considerações gerais anteriores acerca das técnicas de adaptação, apresentaremos nos subcapítulos posteriores nossa transcrição do ciclo das 12 Danzas Españolas e apontaremos os pontos cruciais de adaptação em cada uma delas. Tais pontos impulsionaram-nos a buscar uma configuração especifica de scordatura que - unida às técnicas de transcrição empregadas e discutidas no capítulo anterior - apresentasse um resultado satisfatório e abarcasse todo o restante da peça.

\subsection{Danza no1}

Tonalidade original e da transcrição: Sol Maior

Scordatura utilizada:

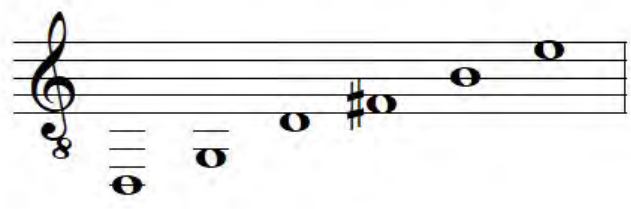

Nosso foco principal de resolução nessa transcrição foi abarcar satisfatoriamente a frase presente nos compassos 11 -12 e sua variação (compassos 23 -25). A frase se constitui de uma progressão de graus conjuntos em todas as vozes (Figura 55)

Figura 55 - Progressão de graus conjuntos

$$
\text { orig. }
$$

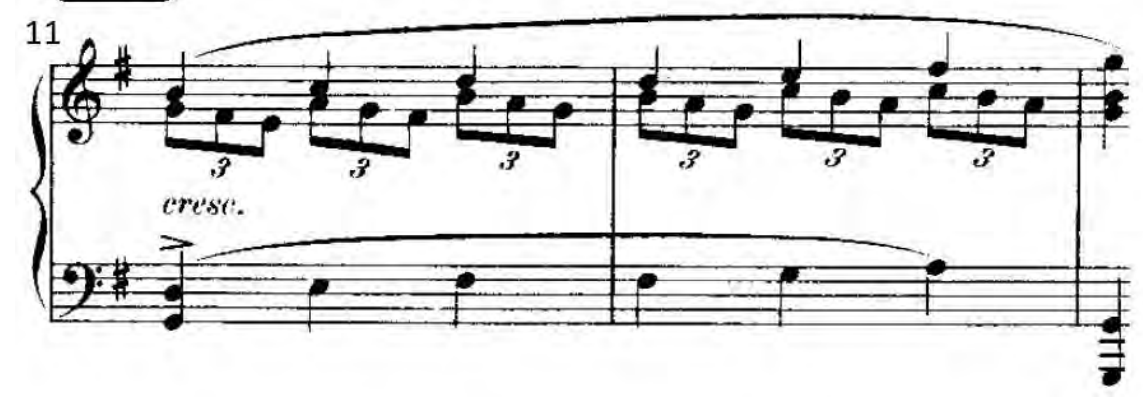

Fonte: elaborada pelo autor 
Nossa meta era uma adaptação que não omitisse nenhuma das vozes do material musical, ao mesmo tempo que possibilitasse uma execução fluida levando em consideração o andamento allegro indicado. Consideramos que as notas de cada tempo dessa progressão deveriam ser executadas numa mesma posição sem utilização de corda soltas, gerando então um padrão que poderia se repetir em outras posições, com pequenas diferenças. Através do ajuste da sexta corda para Ré e da terceira corda para Fá\# tornou-se possível tal feito e com uma sequência de mudanças de posições com pestana, a proposta foi realizada (Figura 56)

Figura 56 - Comparativo entre original e transcrição

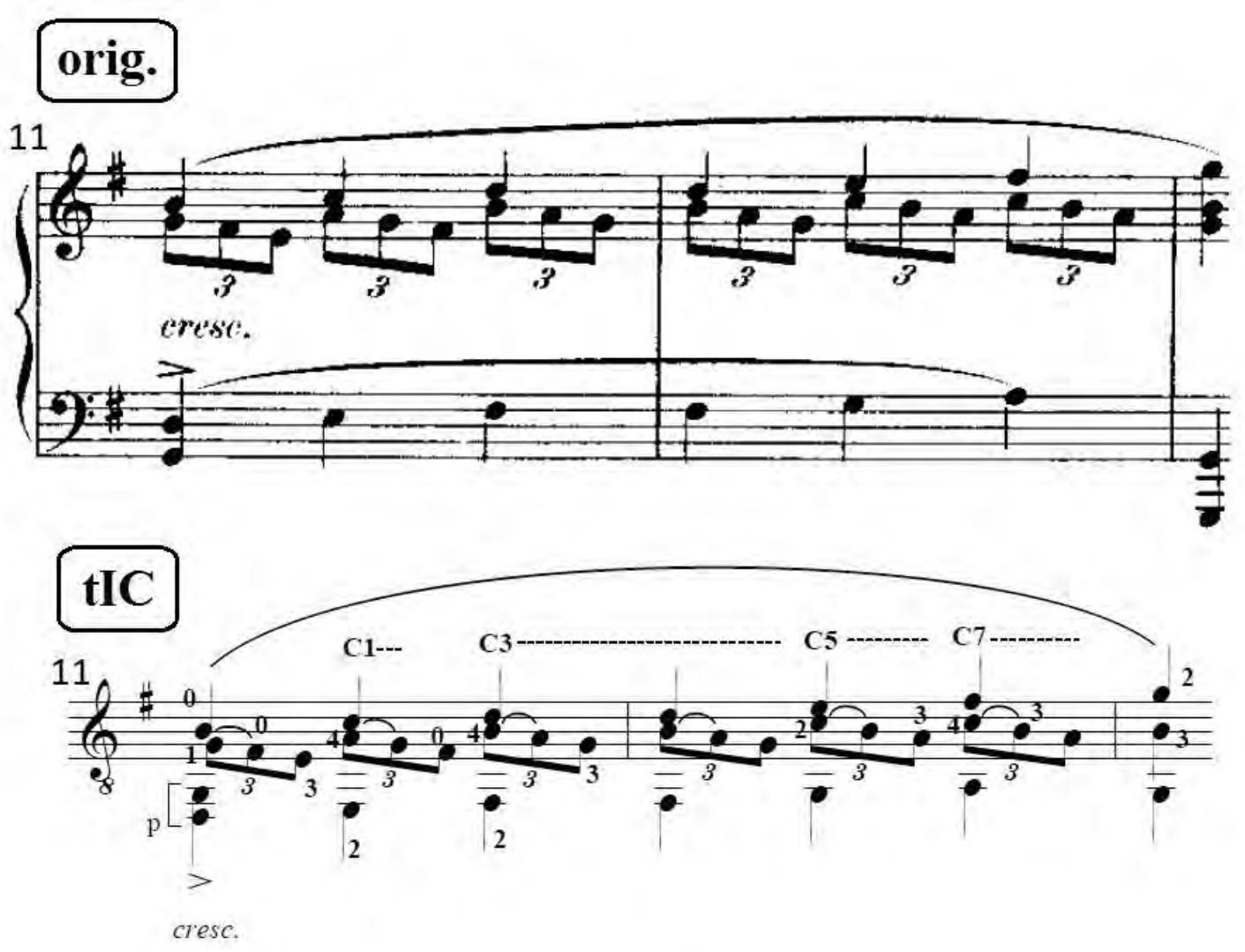

Fonte: elaborada pelo autor

Importante notar que não é necessário utilizar a quinta corda nesta passagem, o que permitiu o ajuste da mesma para Sol (a tônica da peça). A finalidade deste ajuste é clara, pois a ocorrência da tônica é constante, principalmente na seção central (poco andante) que possui no antecedente do seu tema um baixo pedal em Sol (Figura 57). 
orig.
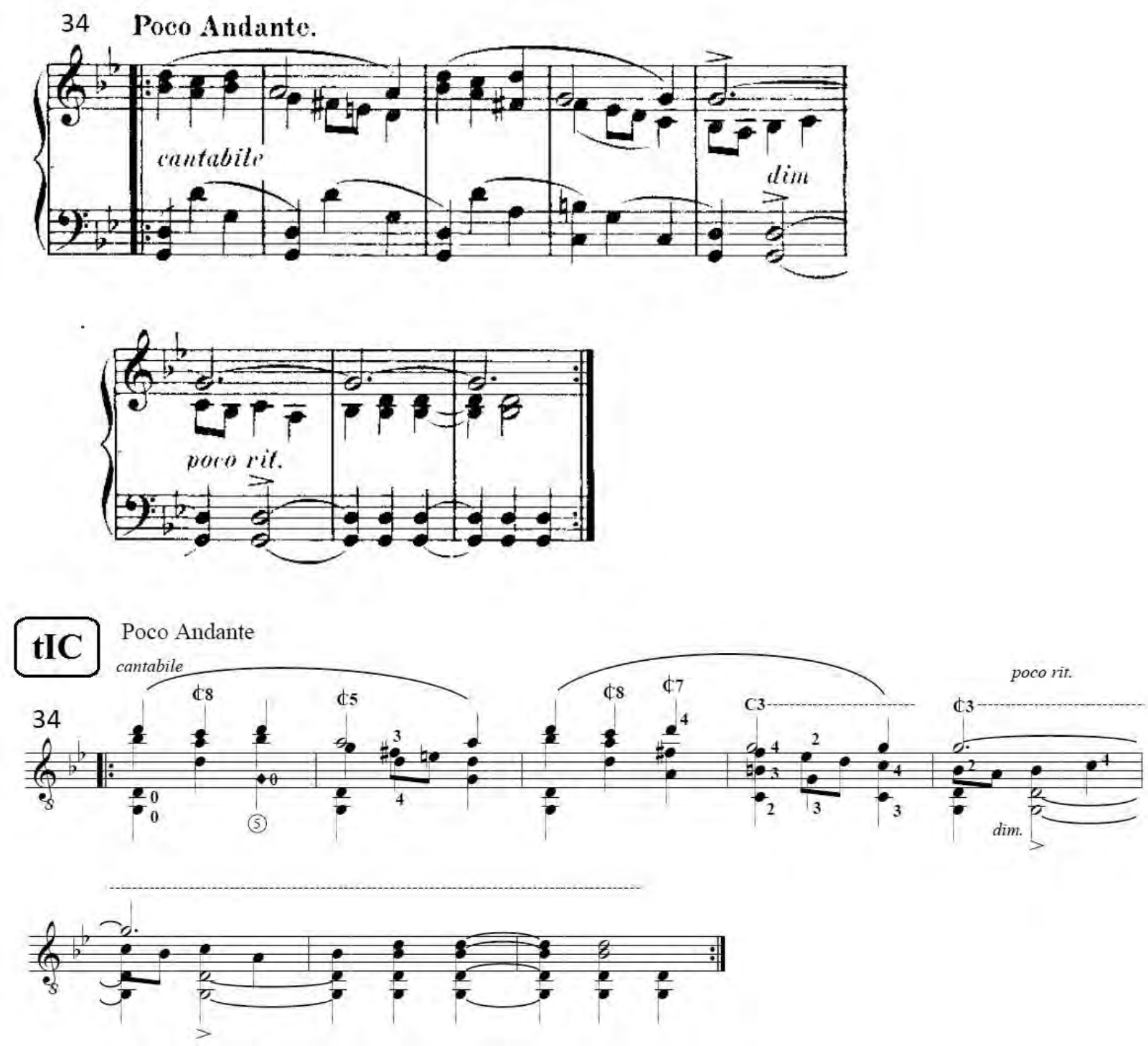

Fonte: elaborada pelo autor 
Transcrição para violão de Iury Cardoso

Enrique Granados
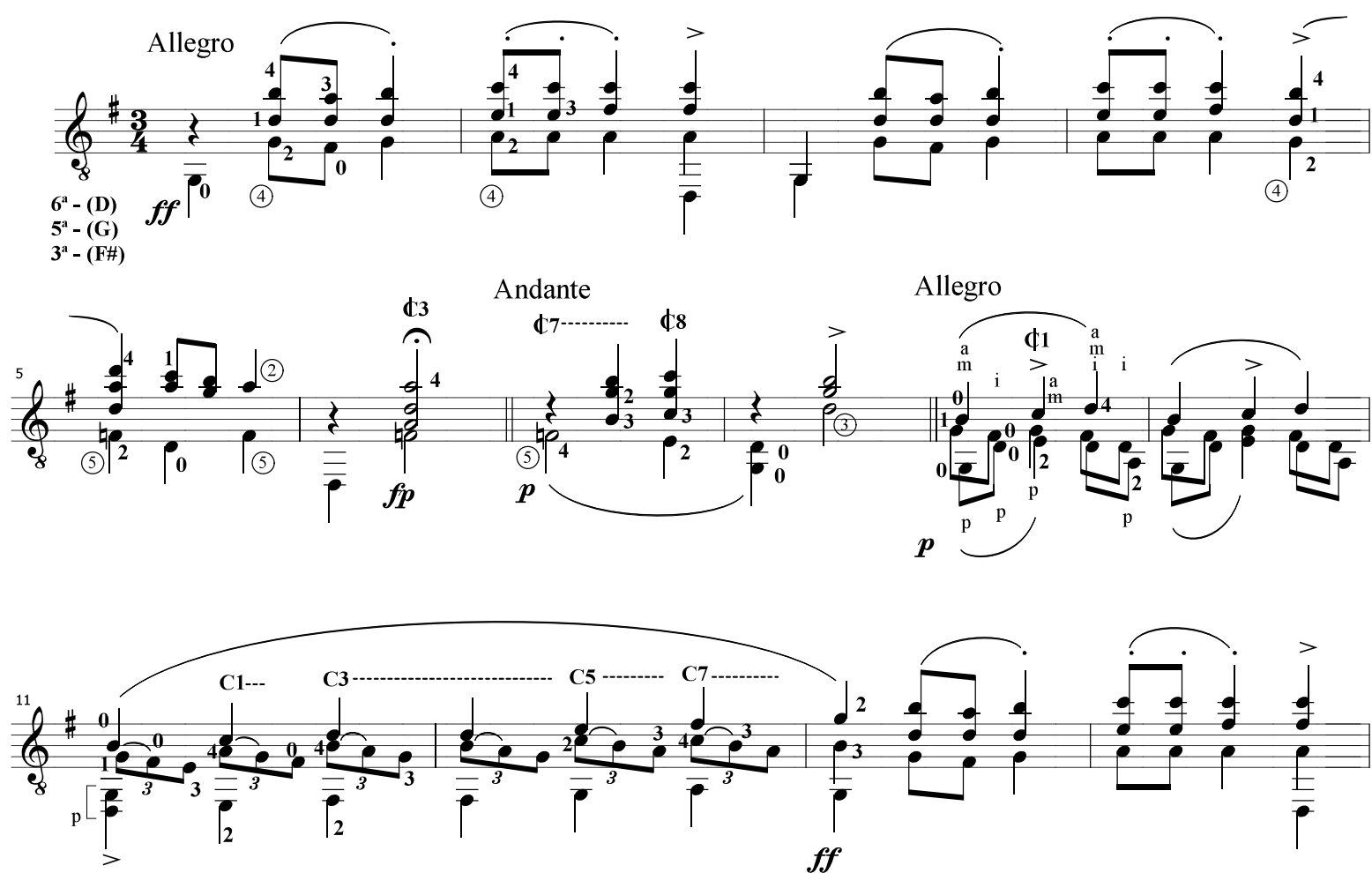

cresc.
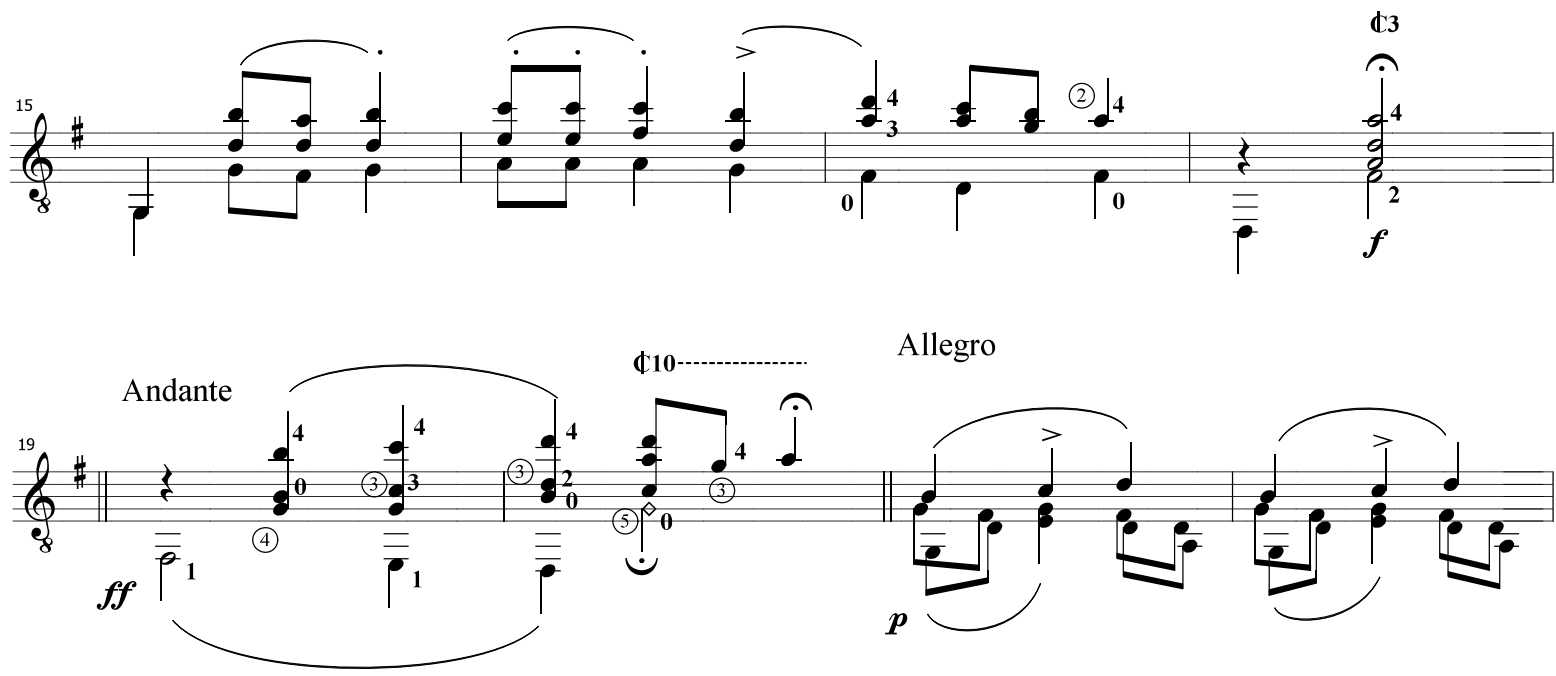


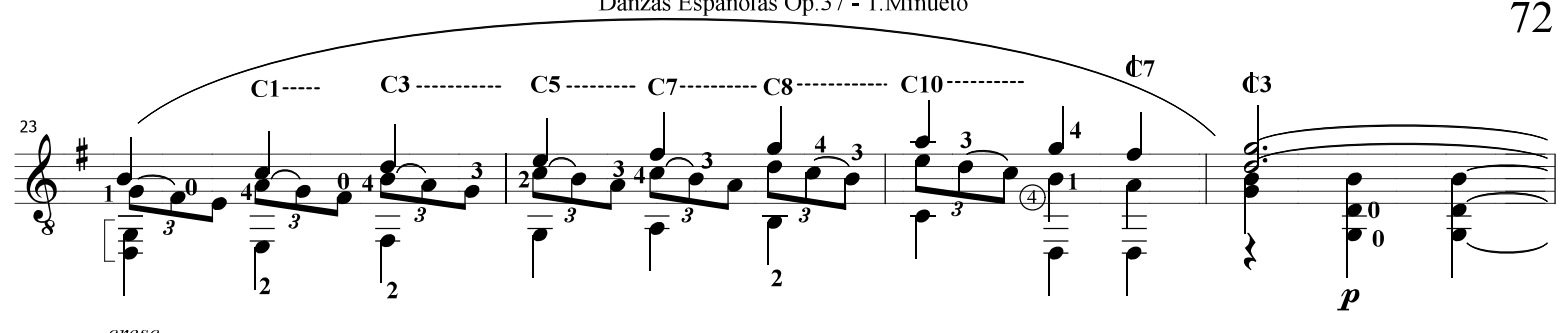

cresc.
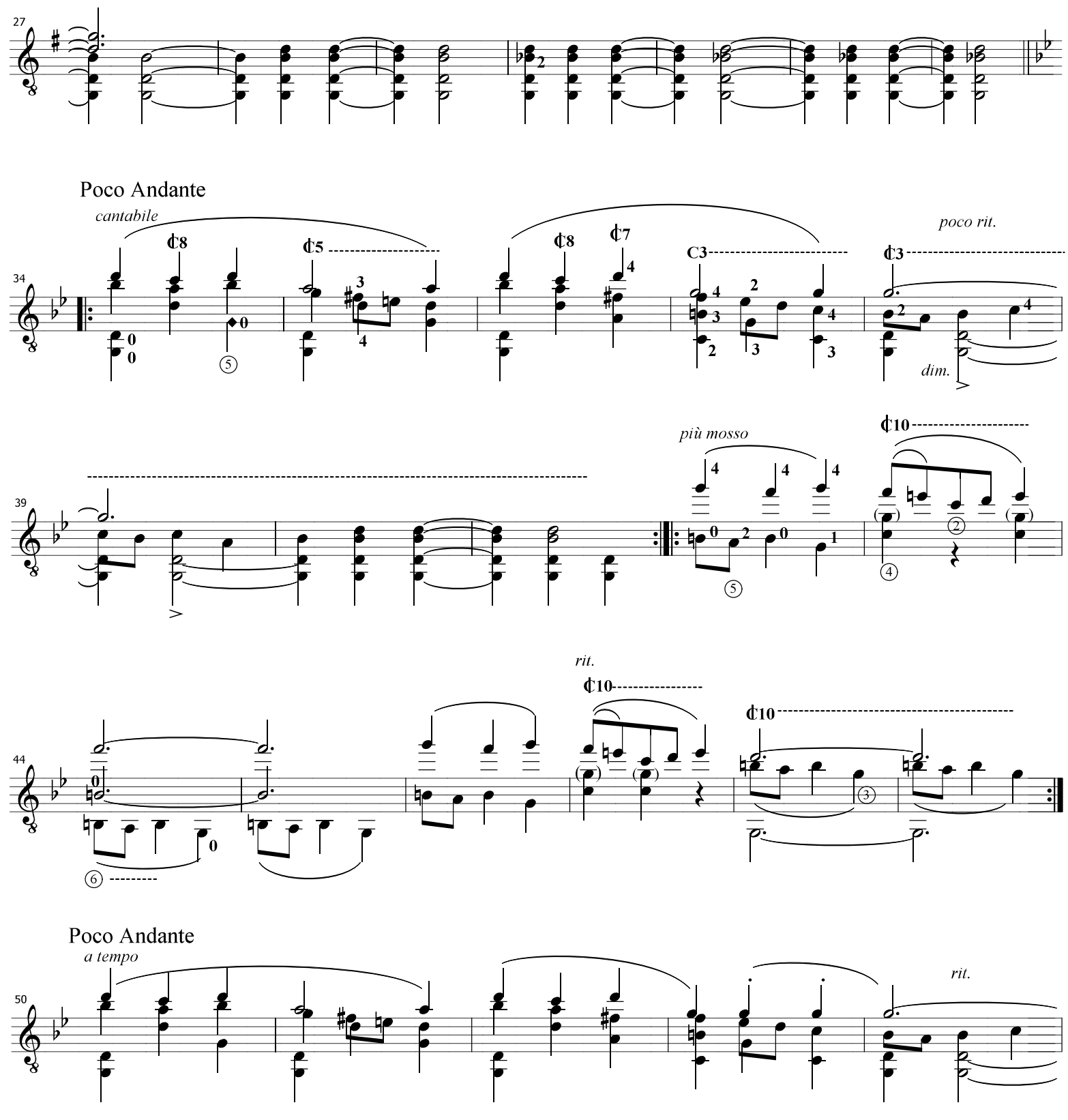

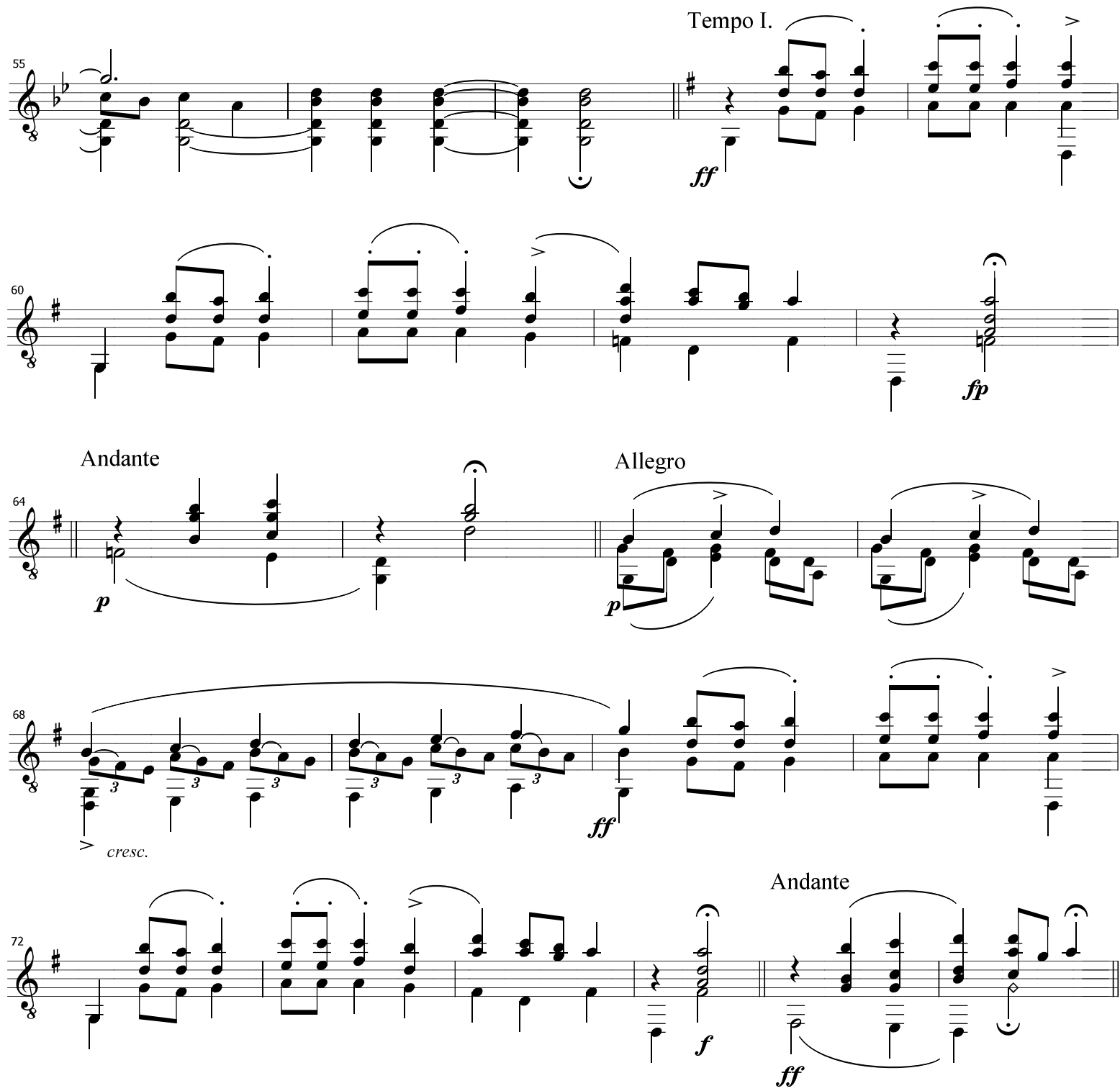

Allegro
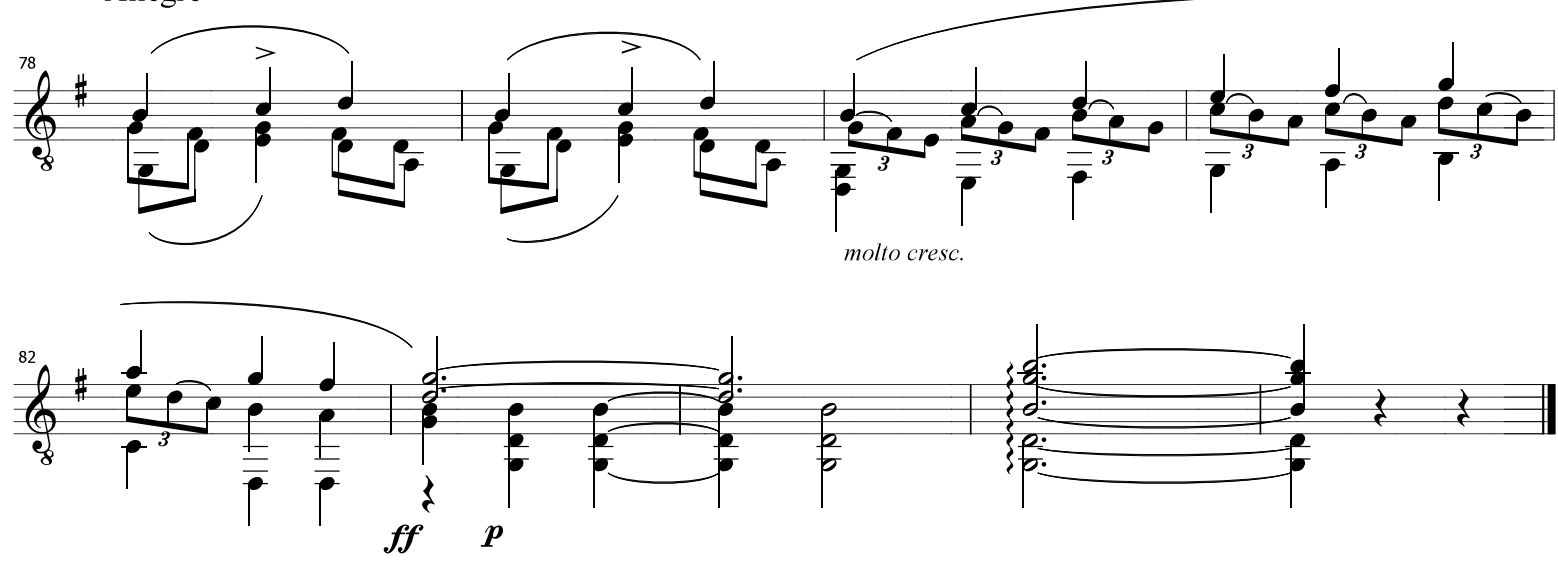


\section{$5.2 \operatorname{Danza~}^{\circ} 2$}

Tonalidade original: Dó menor

Tonalidade da transcrição: Lá menor

Afinação tradicional.

Opcional: uso do capo tasto na casa 3 para atingir a tonalidade original.

A principal preocupação ao transcrever a Danza $n^{0} 2$ para violão solo foi preservar o legato e a atmosfera evocativa e dolce da peça (Figura 58).

Figura 58 - Início da seção A
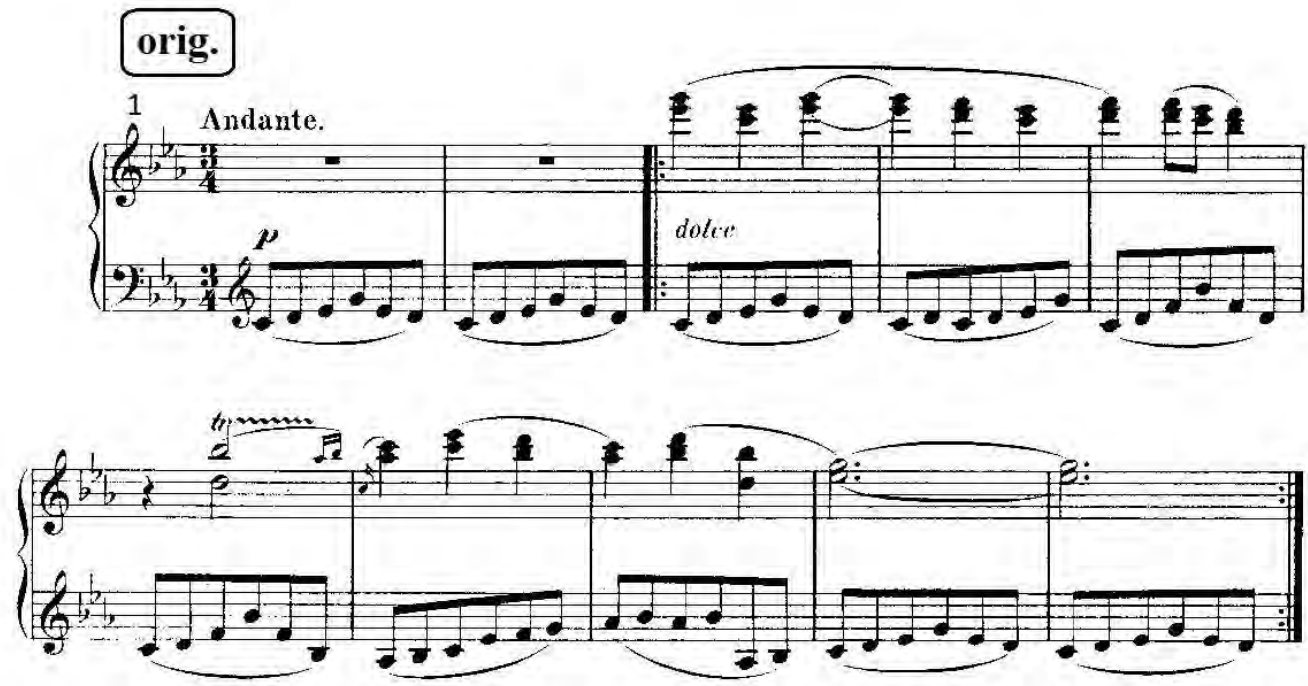

Fonte: elaborada pelo autor

O legato é algo particularmente desafiador de se realizar ao violão; não temos no instrumento o auxílio de um pedal de sustentação como no piano, por exemplo. Como efeito análogo optamos pela utilização, sempre que possível, da campanela; tanto como auxílio na execução do legato, quanto para se aproveitar de sua ressonância característica, principalmente na linha presente na clave de Fá da partitura original (Figura 59). 
Figura 59 - Uso da campanela na Danza $n^{\circ} 2$

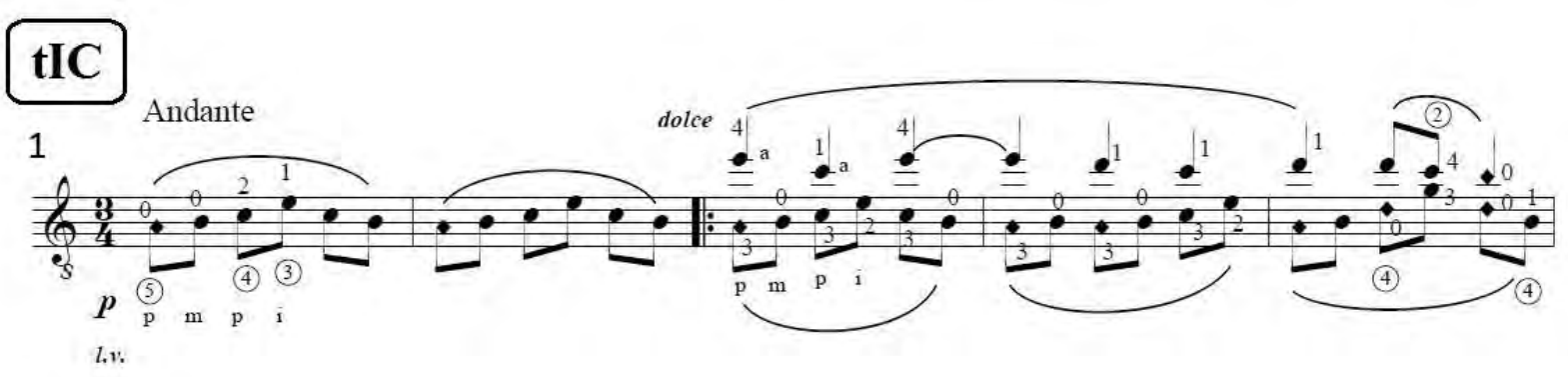

Fonte: elaborada pelo autor

A ideia era aplicar a campanela nesse motivo do acompanhamento, posicionando cada uma das suas quatro notas em diferentes cordas do violão. Para tal feito, foi necessário retirar as terças da linha melódica, de modo a não causar a interrupção das ressonâncias do acompanhamento. Outro aspecto diz respeito a tonalidade de Lá menor, a qual foi escolhida para a transcrição por, além de ser funcional com a afinação tradicional do violão, posicionar o tema principal na região da casa doze do instrumento, contando que os harmônicos naturais presentes nessa região colaborassem com a sustentação das notas do motivo do acompanhamento, sem a necessidade de se manter as cordas presas.

O uso da campanela possibilitou também a execução do trinado presente no consequente do tema principal. Ao se familiarizar com o dedilhado sugerido de mão direita, o qual foi inspirado no tremolo ${ }^{12}$, é possível atingir a velocidade necessária no trinado sem omitir nenhuma das notas na linha do acompanhamento (Figura 60).

Figura 60 - Campanela aplicada ao trinado

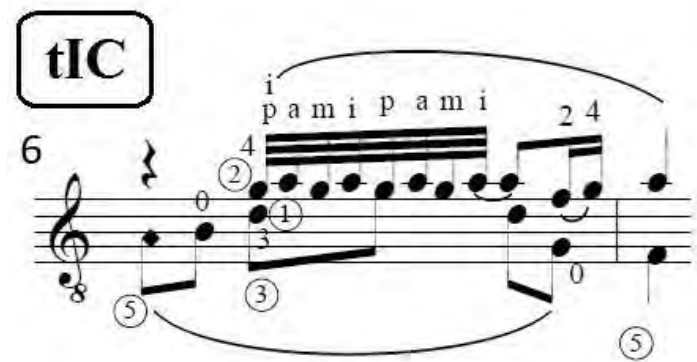

Fonte: elaborada pelo autor

\footnotetext{
12 Técnica onde a nota de uma melodia é repetida várias vezes rapidamente, criando parcialmente a ilusão de notas longas sustentadas por um espaço de tempo maior. No violão, a repetição das notas é normalmente feita com os dedos anelar, médio e indicador em sequência, antecedidos pelo polegar no baixo. Daí a analogia à execução do trinado em questão.
} 
O restante da peça foi adaptado através das técnicas de transcrição citadas no capítulo anterior, tais como: omissões, transposições de oitavas, reconfiguração de acordes, etc. 

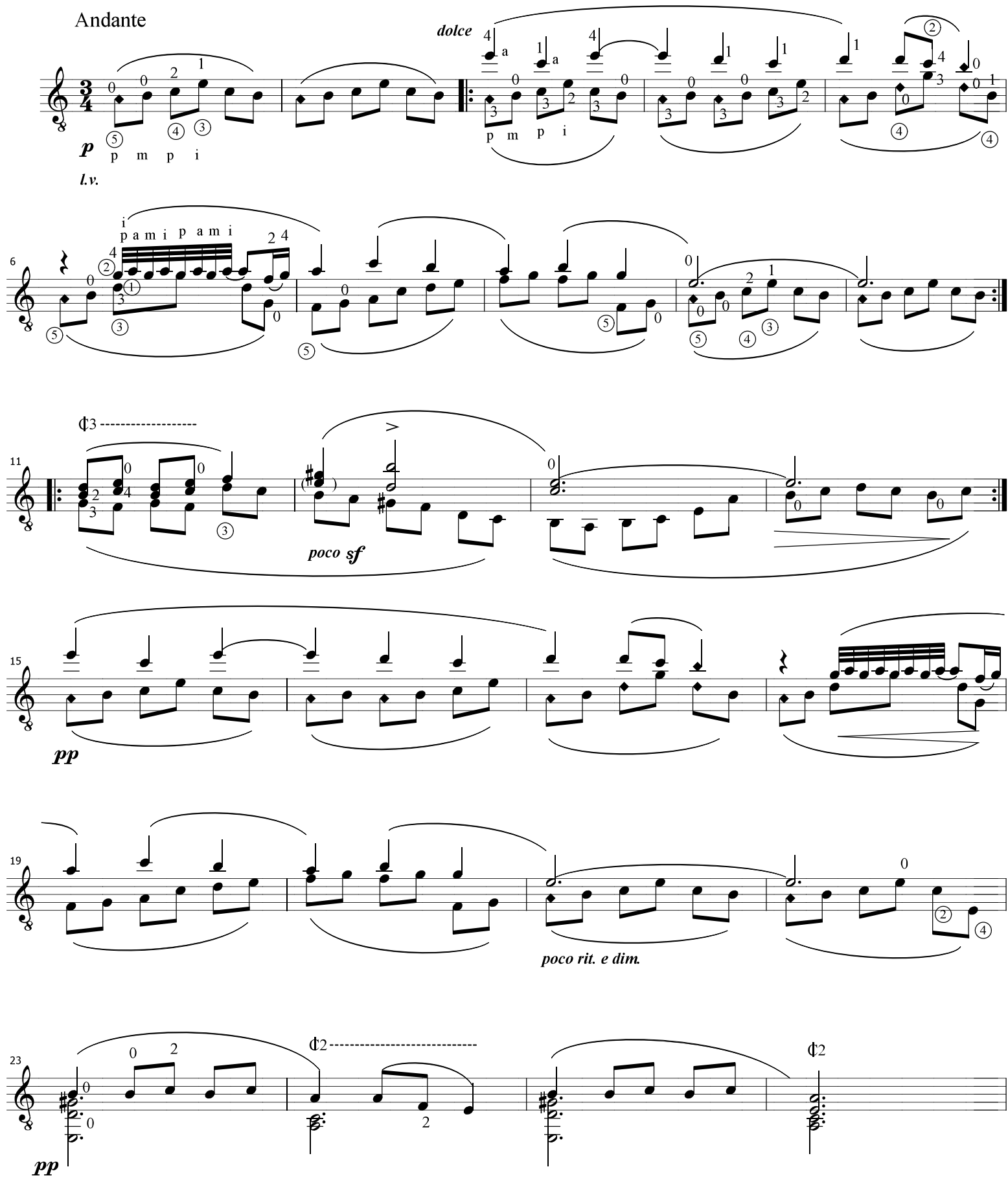

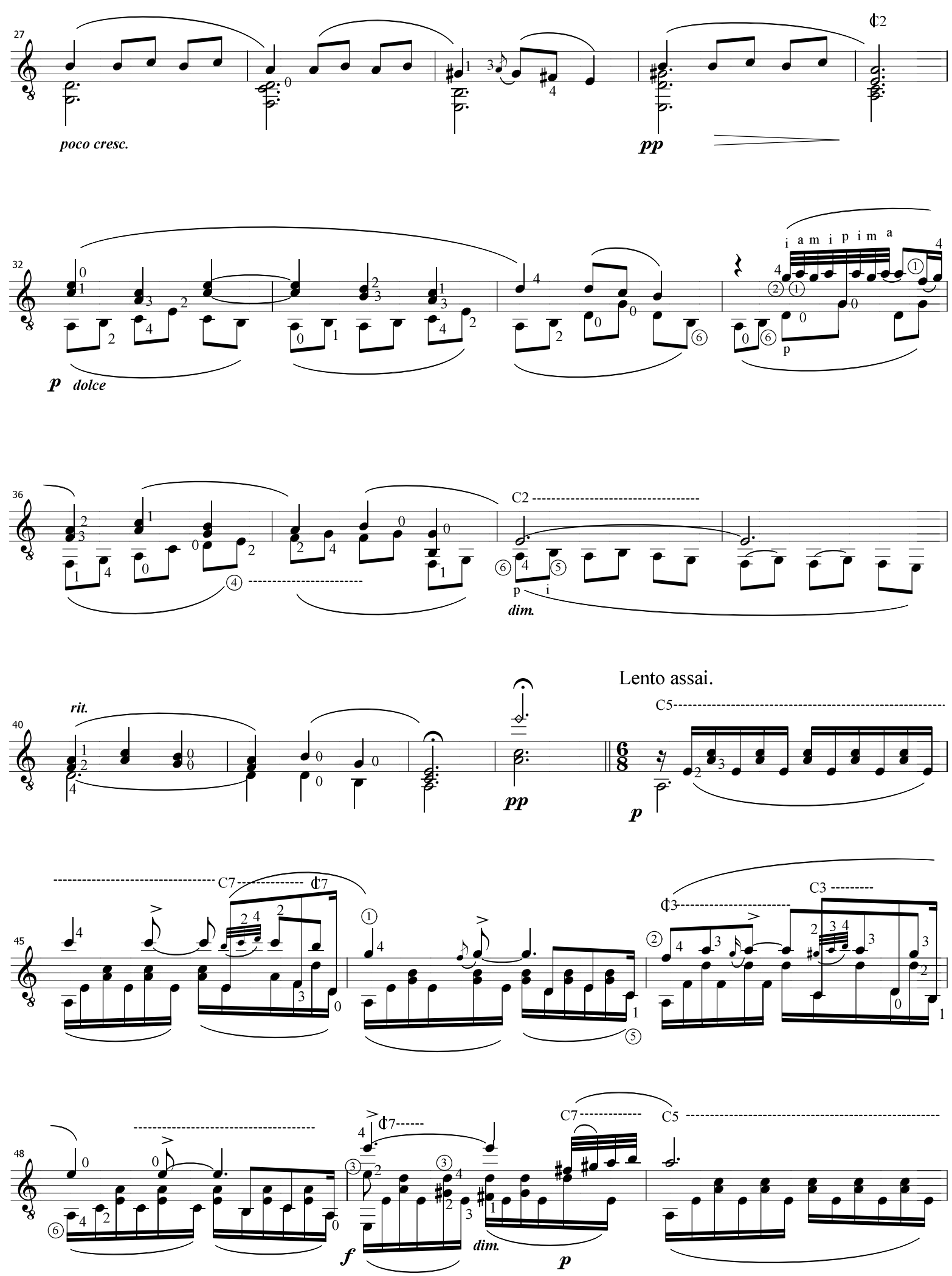

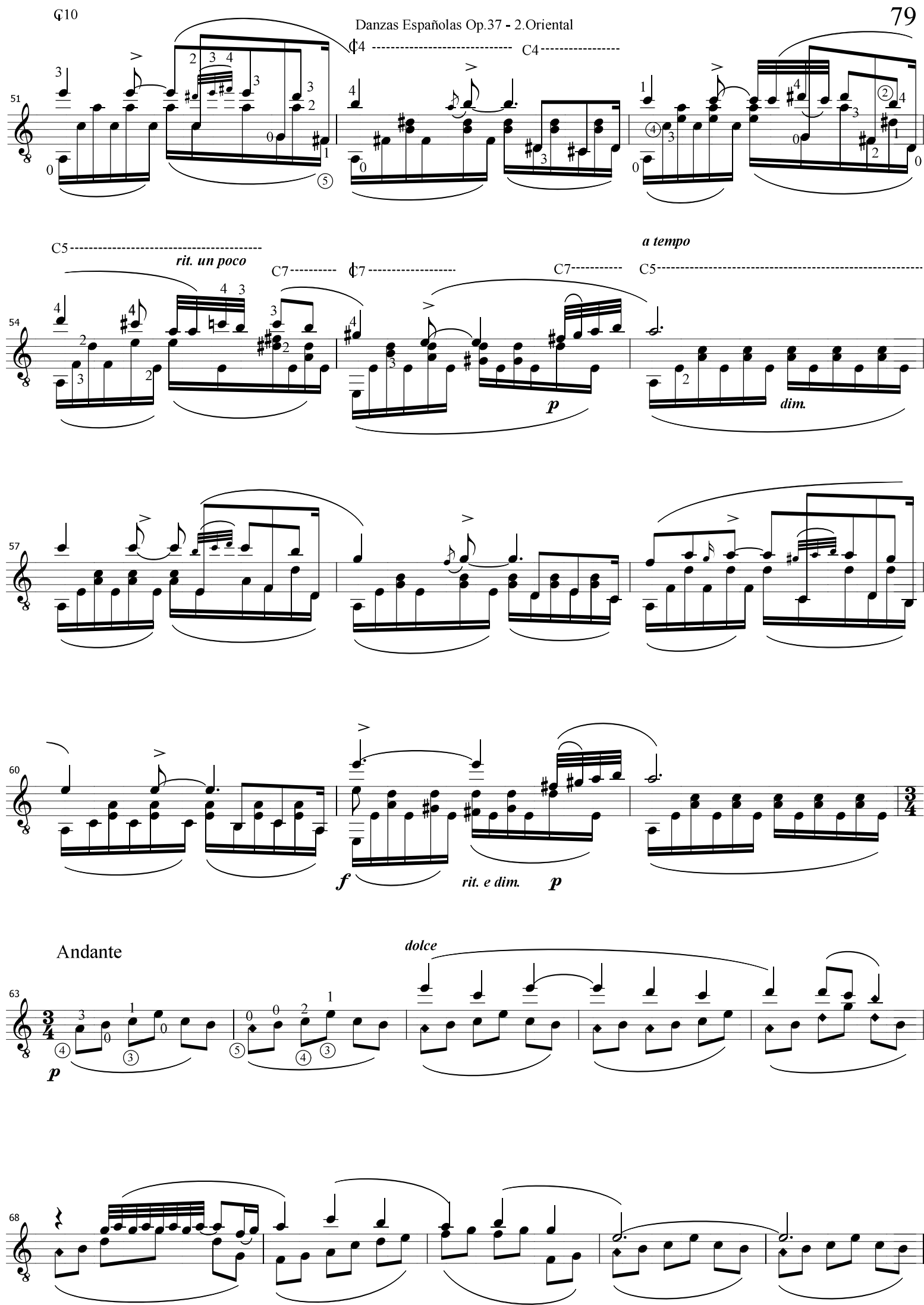

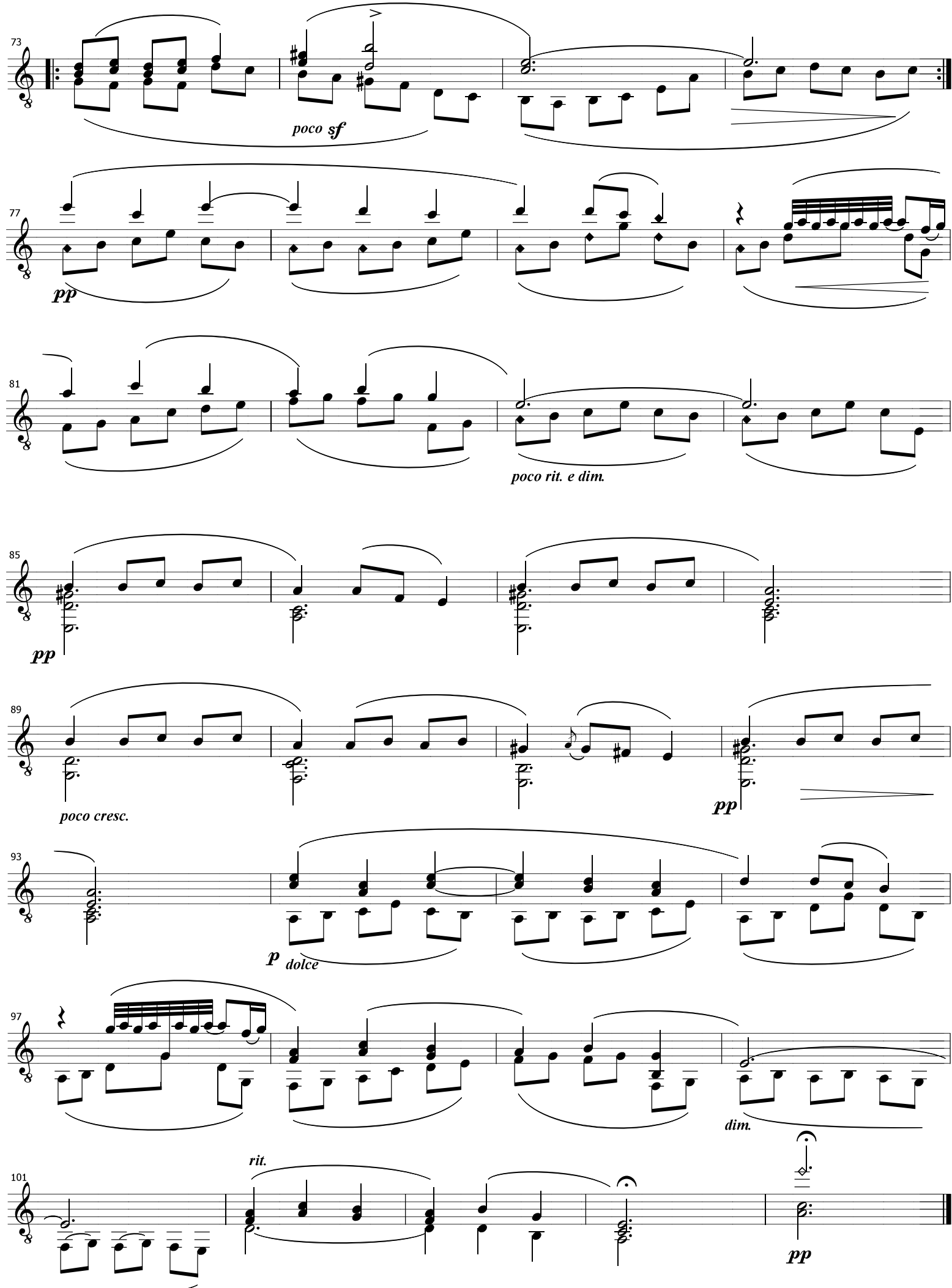


\subsection{Danza no 3}

Tonalidade original e da transcrição: Ré Maior

Afinação tradicional com o ajuste da sexta corda em Ré.

A maioria das modificações realizadas estão ligadas à omissões e transposições de oitavas. A regra foi basicamente, nos momentos de melodias oitavadas, reduzir três oitavas para duas e duas oitavas para uma, permitindo uma reprodução mais natural ao violão (Figura 61). 
Figura 61 - Comparativo - Danza $n^{\circ} 3$
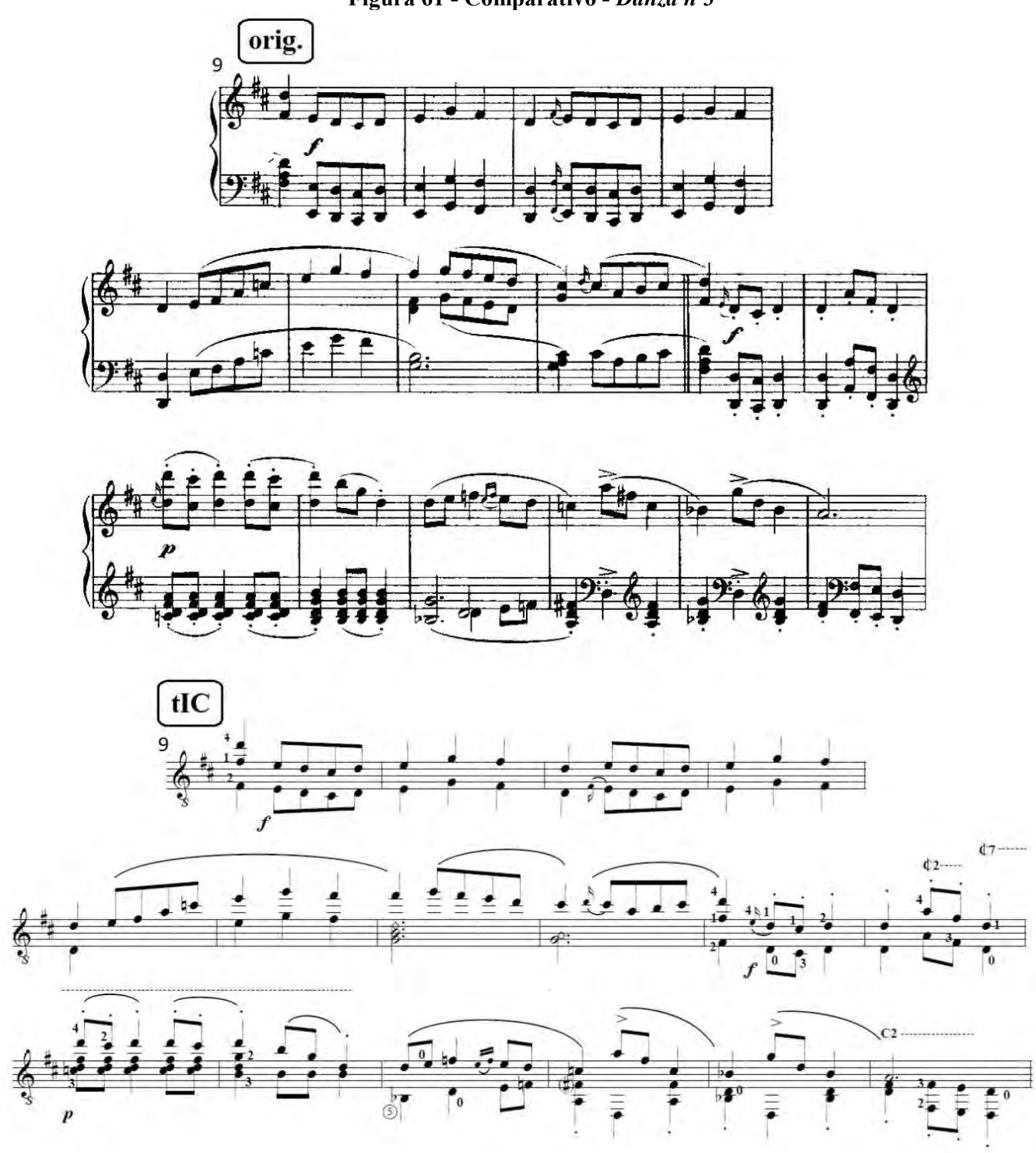

Fonte: elaborada pelo autor 

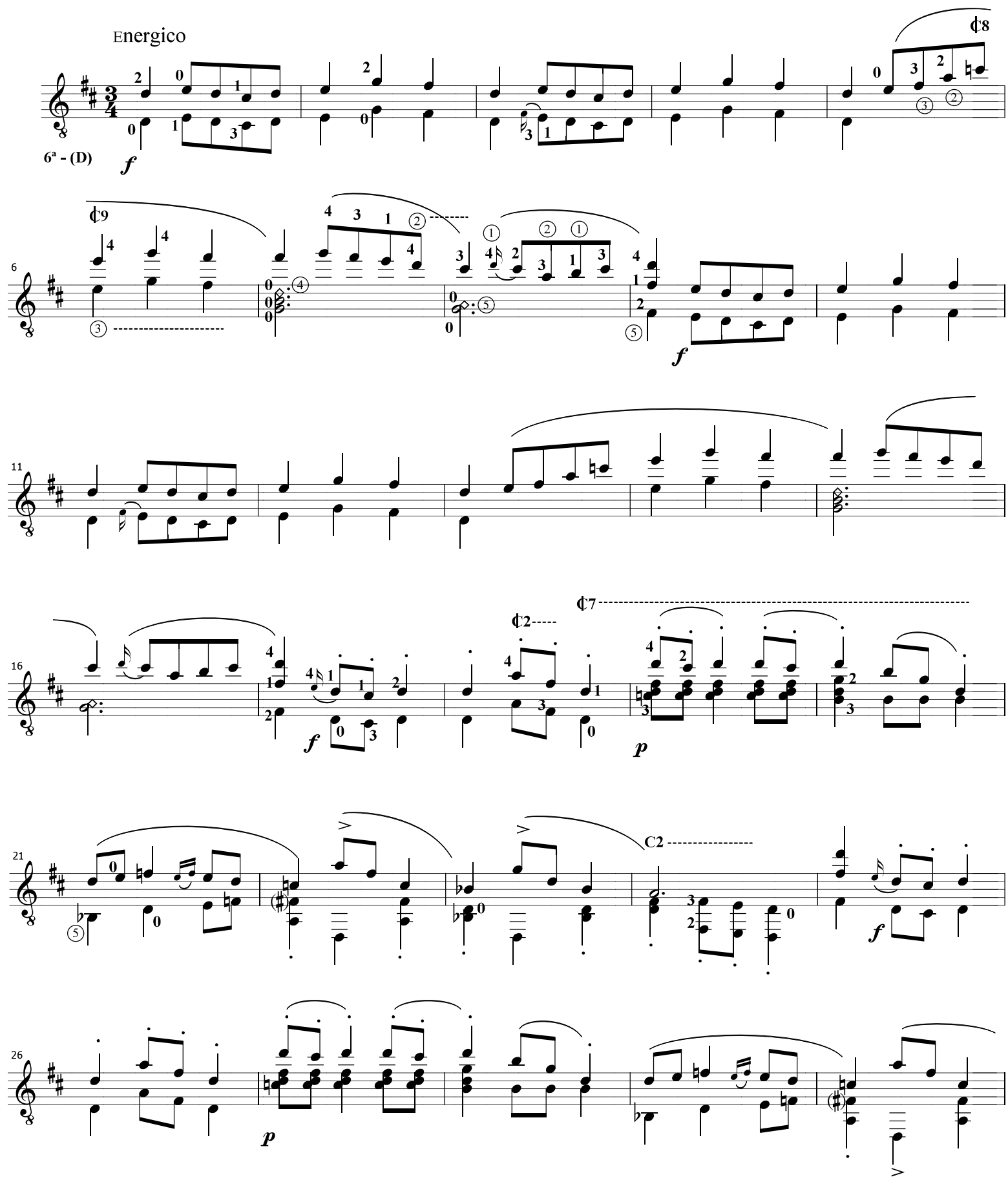


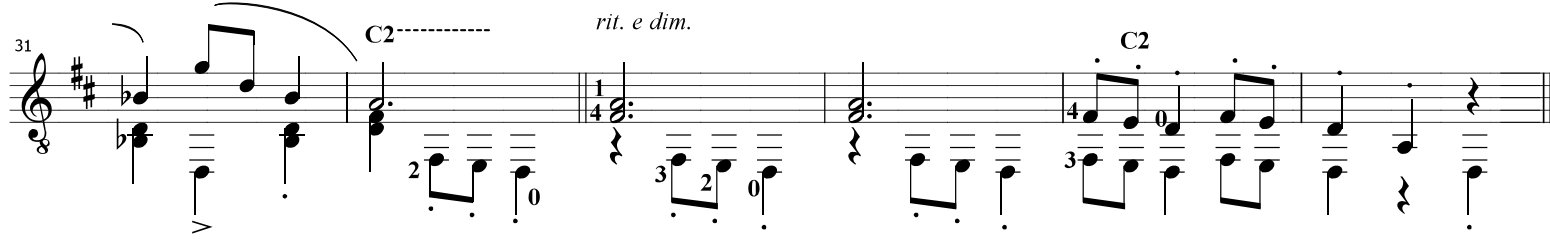

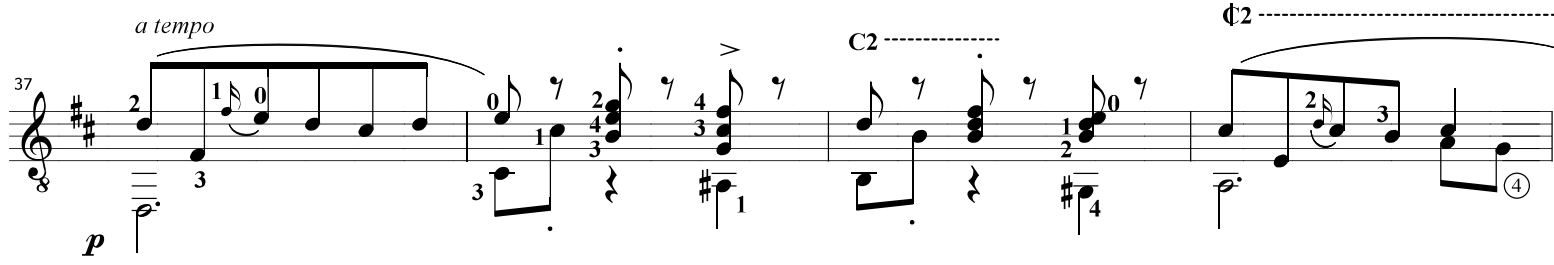
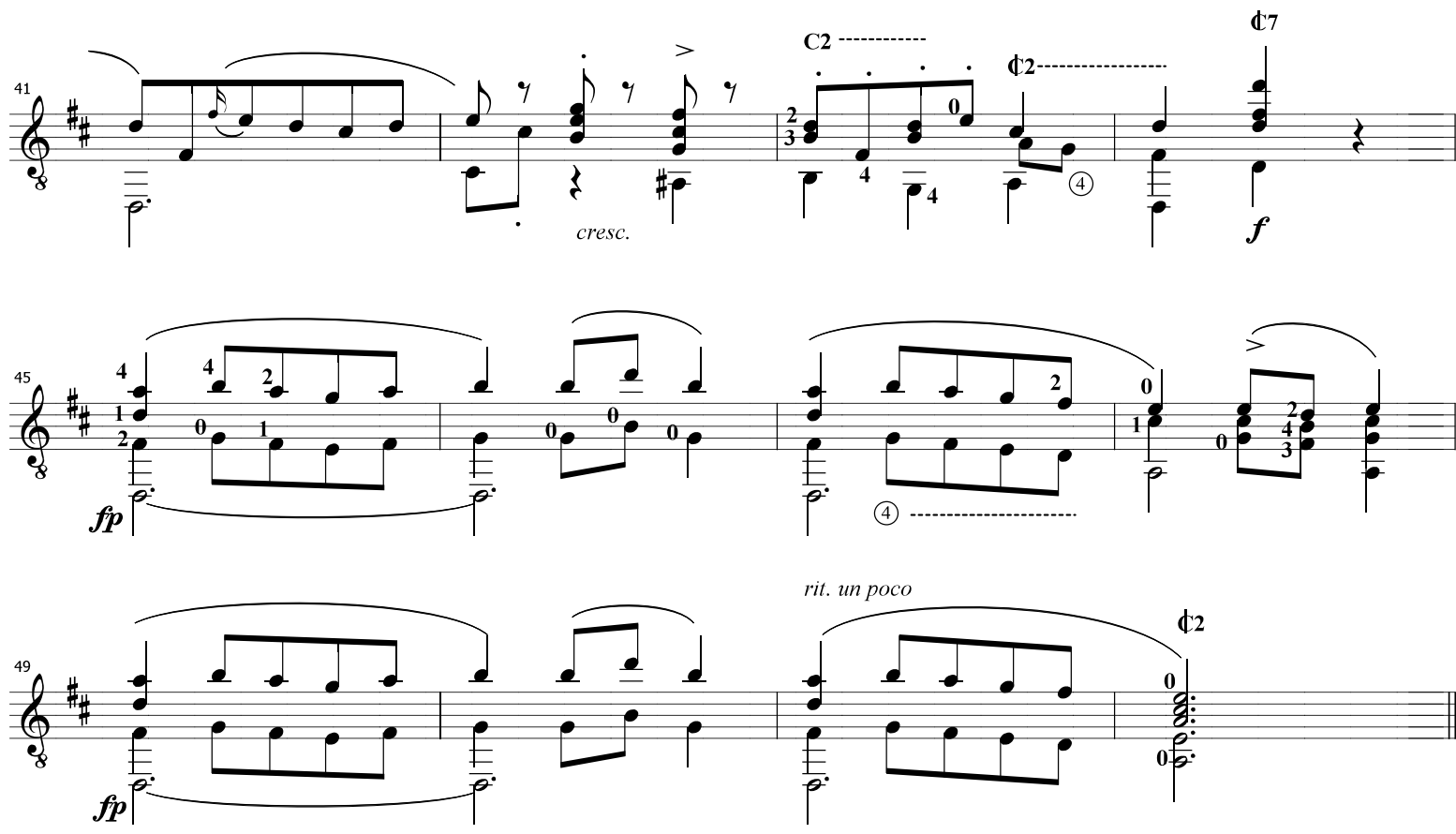

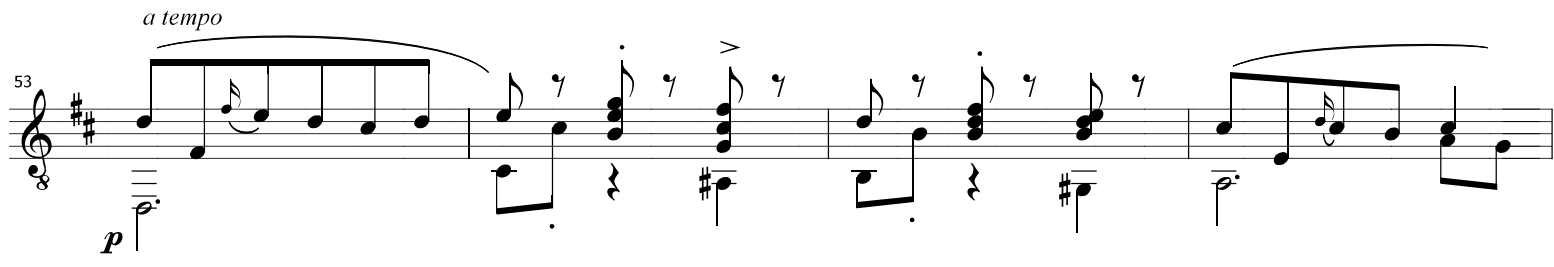

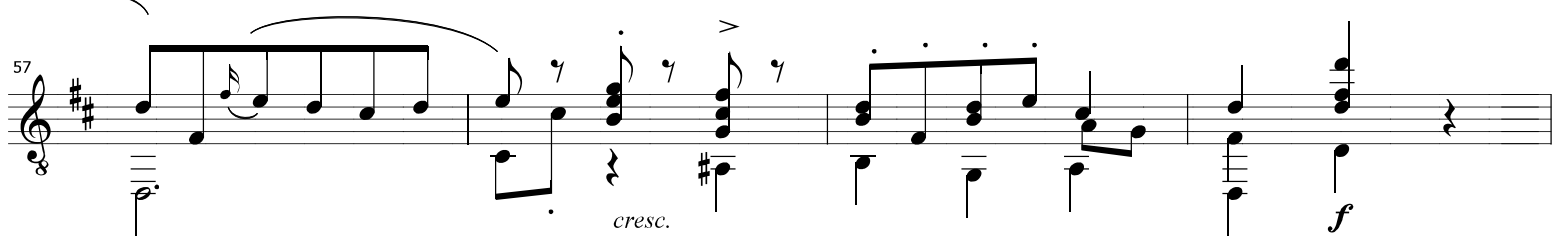


$\overbrace{8}$

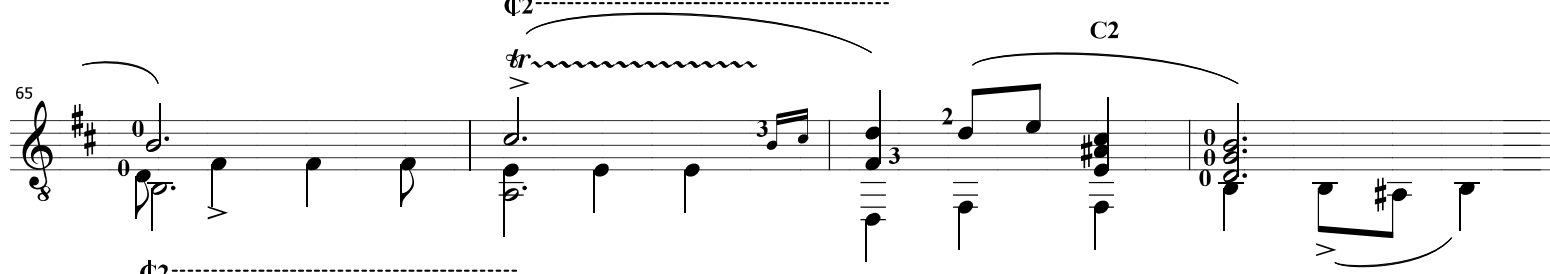

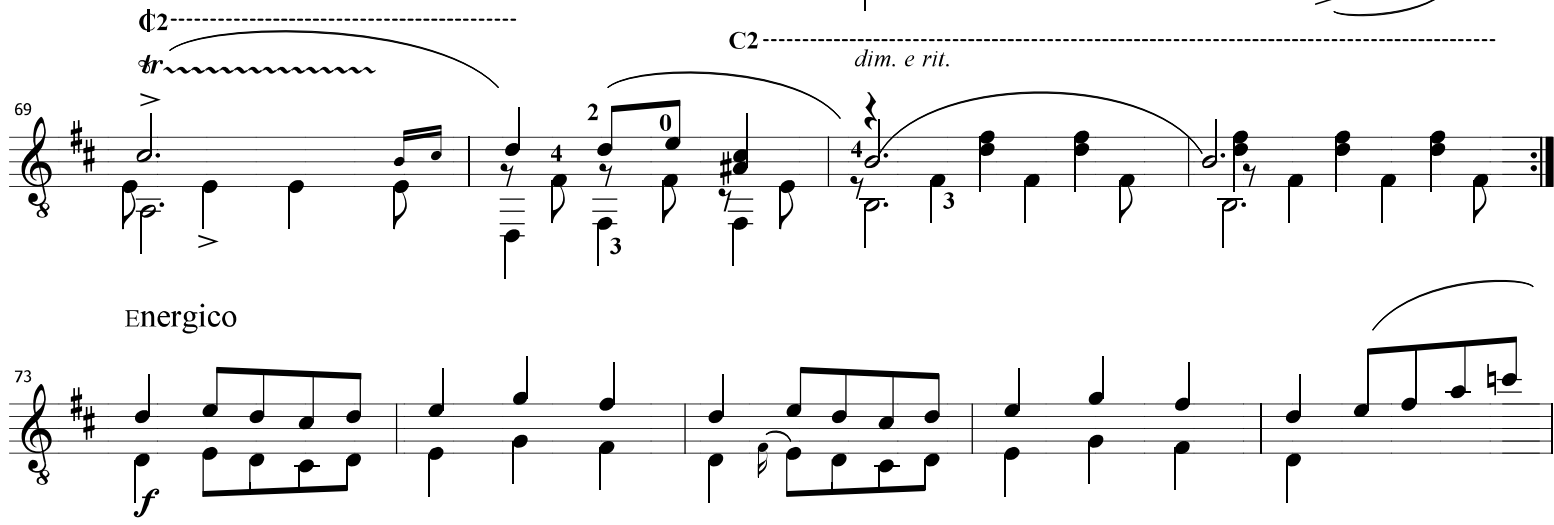

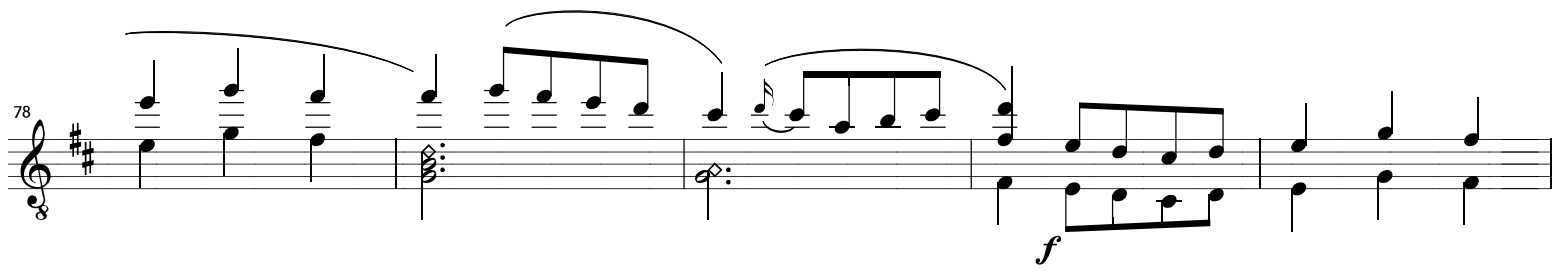

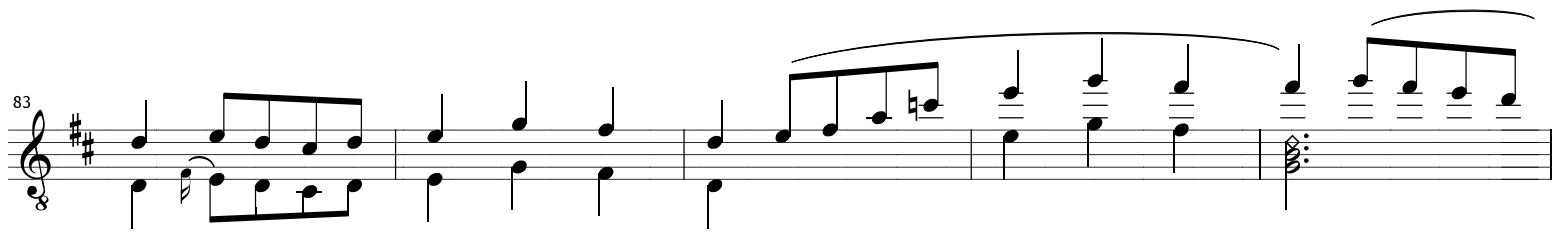

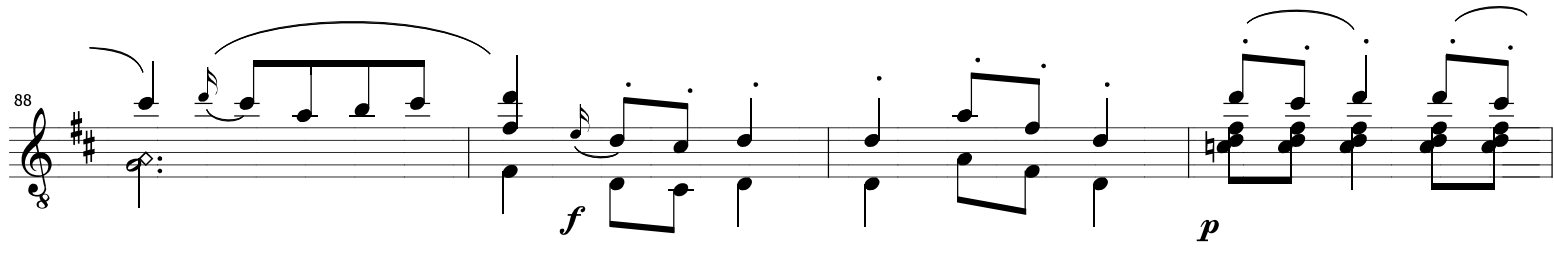

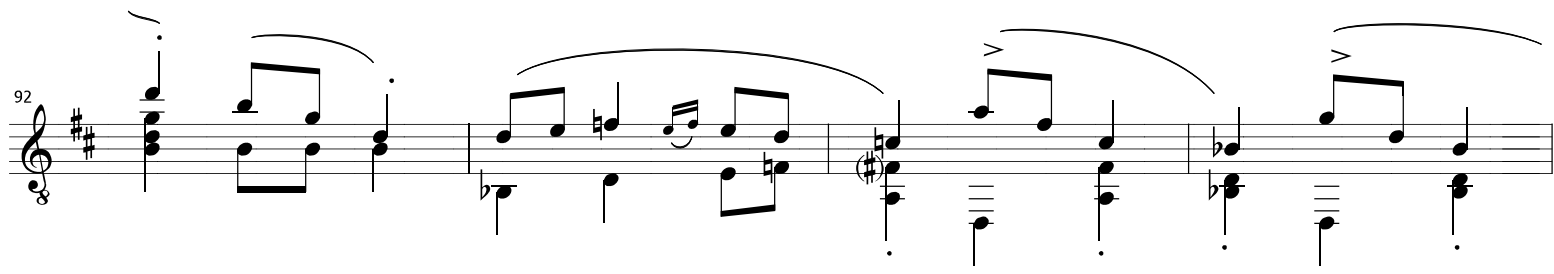




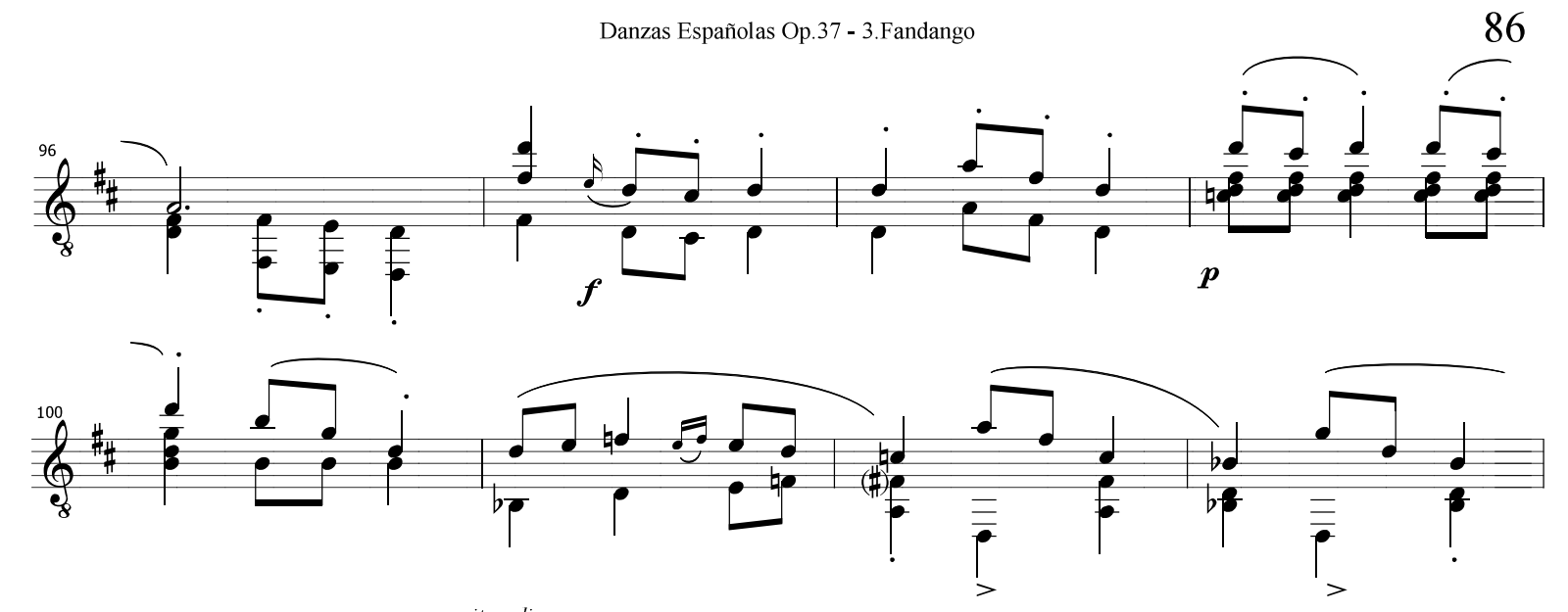

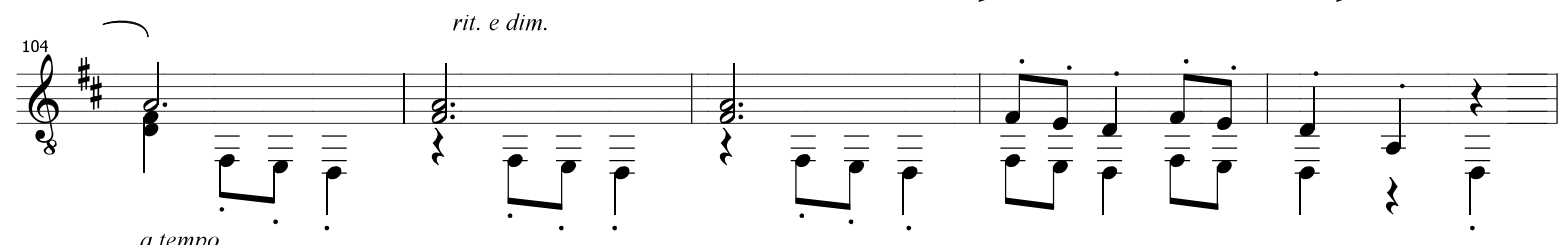

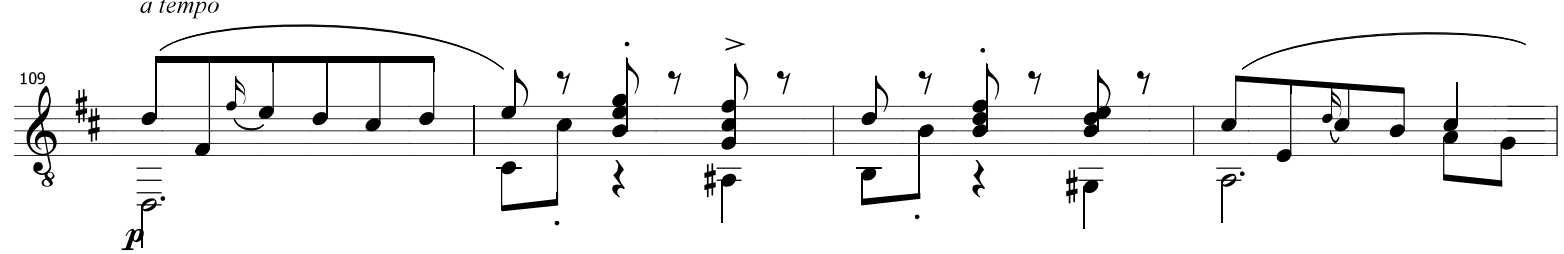

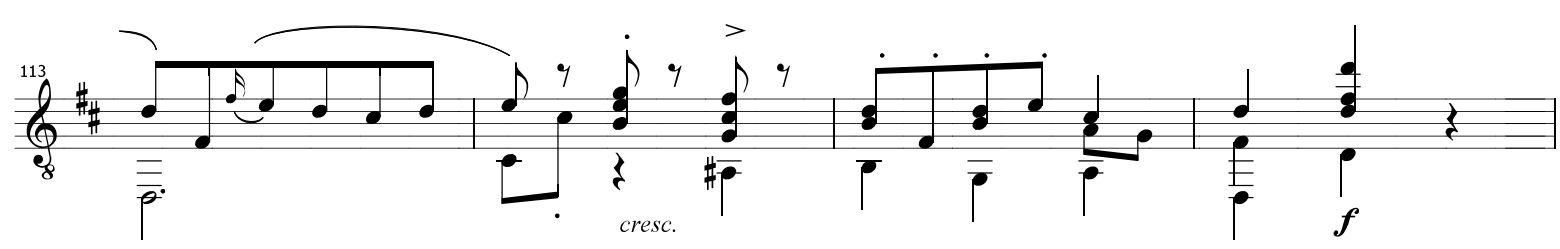

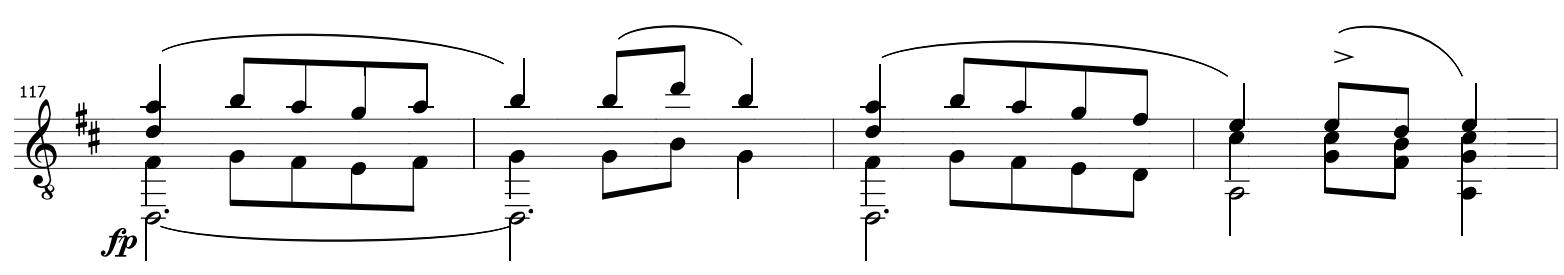

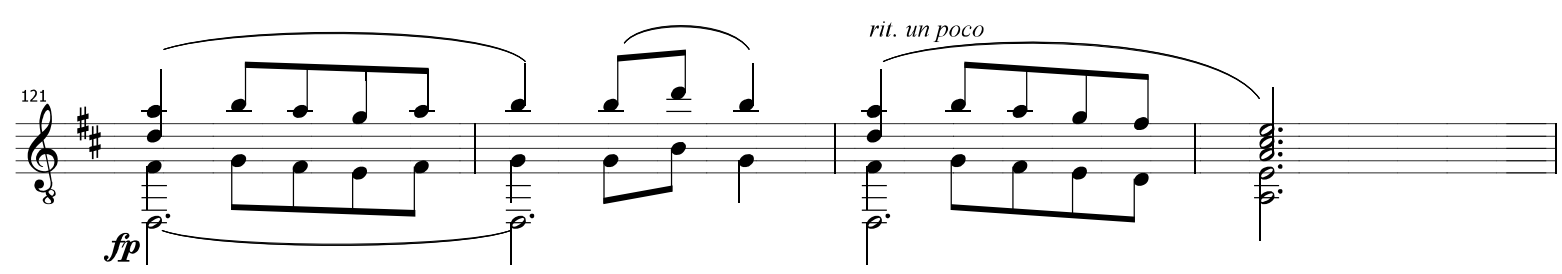

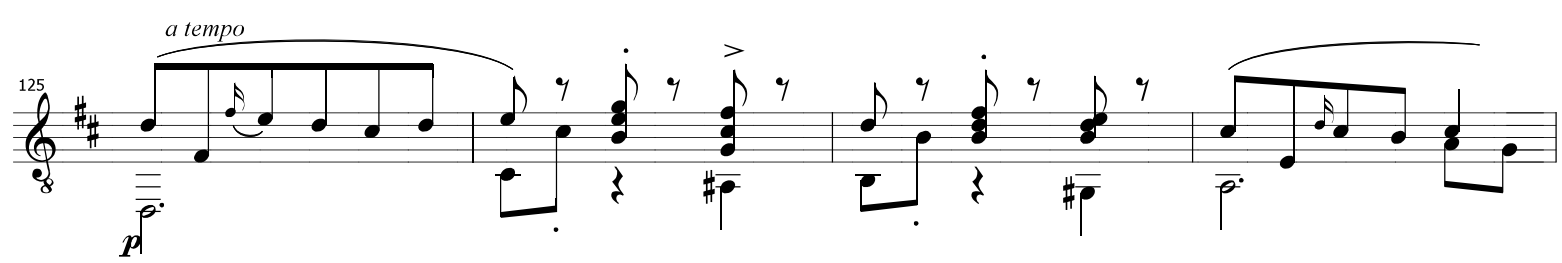



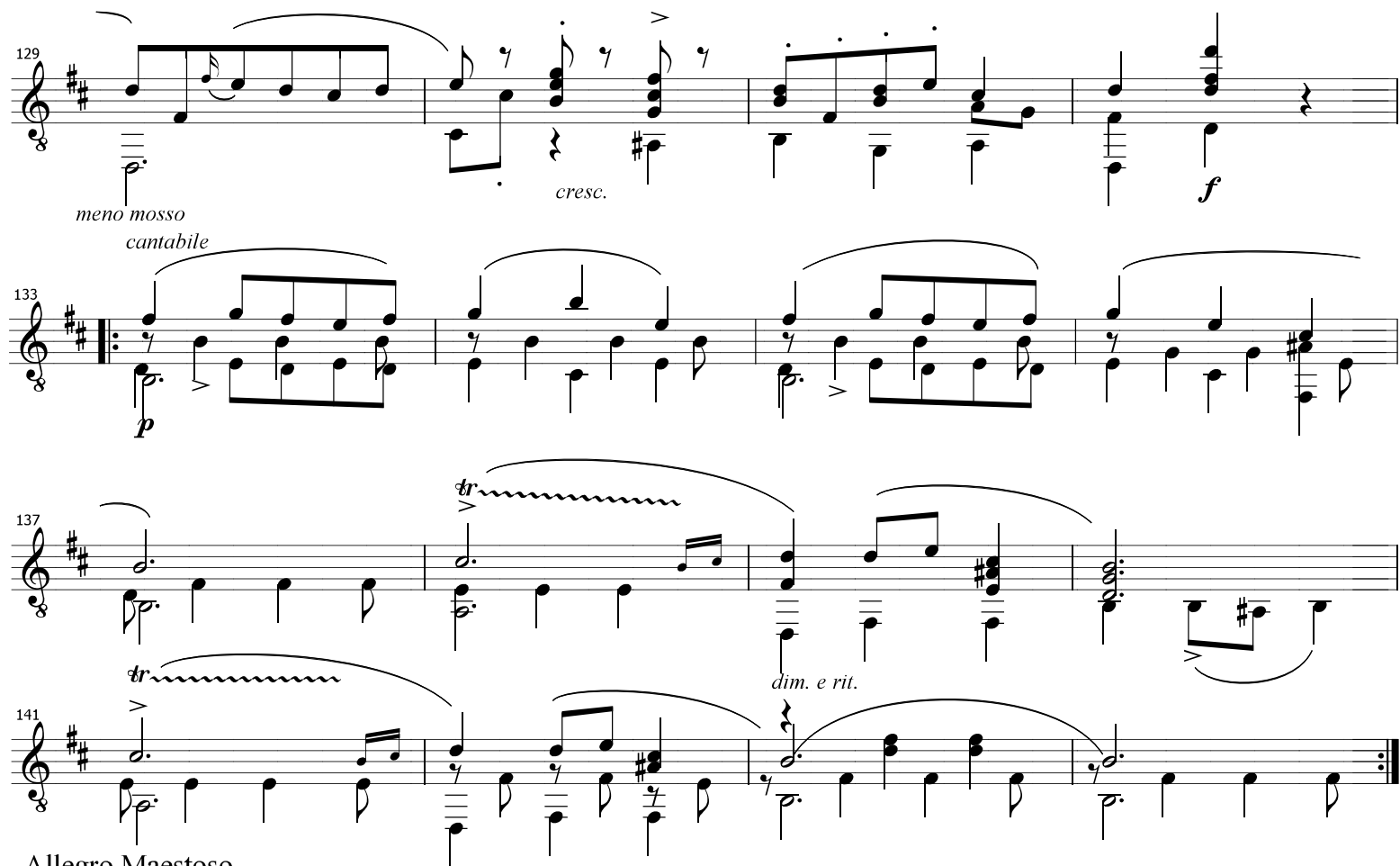

Allegro Maestoso
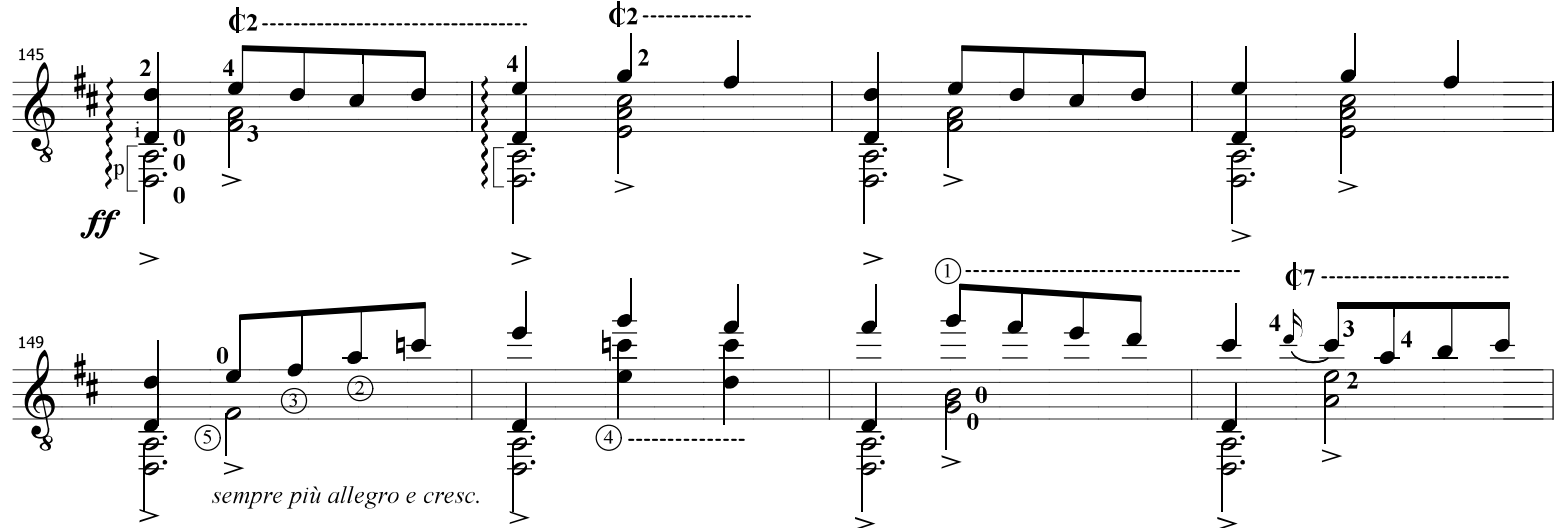

stacc. sempre e animando e più

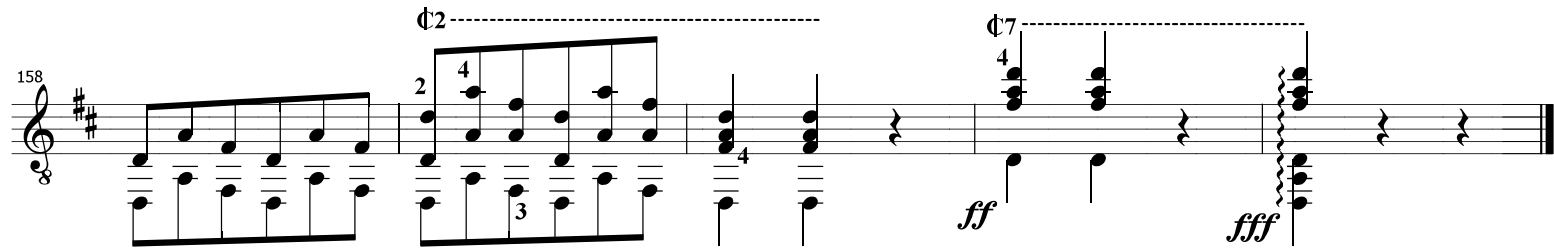




\subsection{Danza n'4}

Tonalidade original e da transcrição: Sol Maior

Afinação tradicional com o ajuste da sexta corda em Ré e da quinta corda em Sol.

Assim como as Danzas $n^{\circ} 5$ e 10, a Danza $n^{\circ} 4$ "Villanesca" possui uma adaptabilidade natural para violão. As gravações de Manuel Barrueco e Julian Bream são referenciais e apontamos esta última como principal parâmetro para nossa transcrição. Apenas pequenas omissões foram realizadas, que em nada prejudicaram a exposição do material musical. Limitamo-nos então, a acrescentar ligados de execução e sugestões de dedilhados para auxiliar na performance (Figura 62).

Figura 62 - Início da seção A
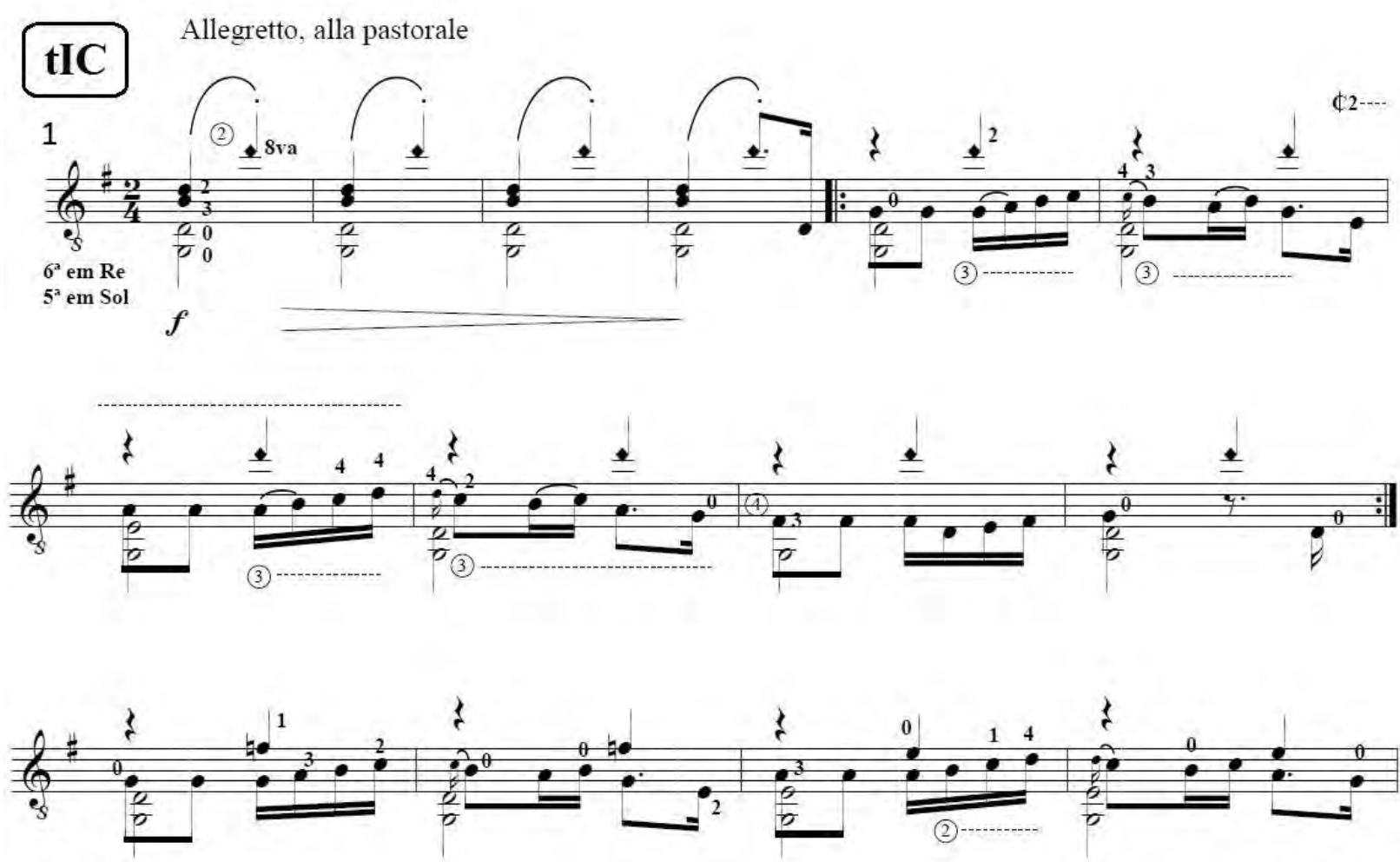

poco a poco cresc.

Fonte: elaborada pelo autor 
Transcrição para violão de \\ 4.Villanesca}

Allegretto, alla pastorale

Enrique Granados
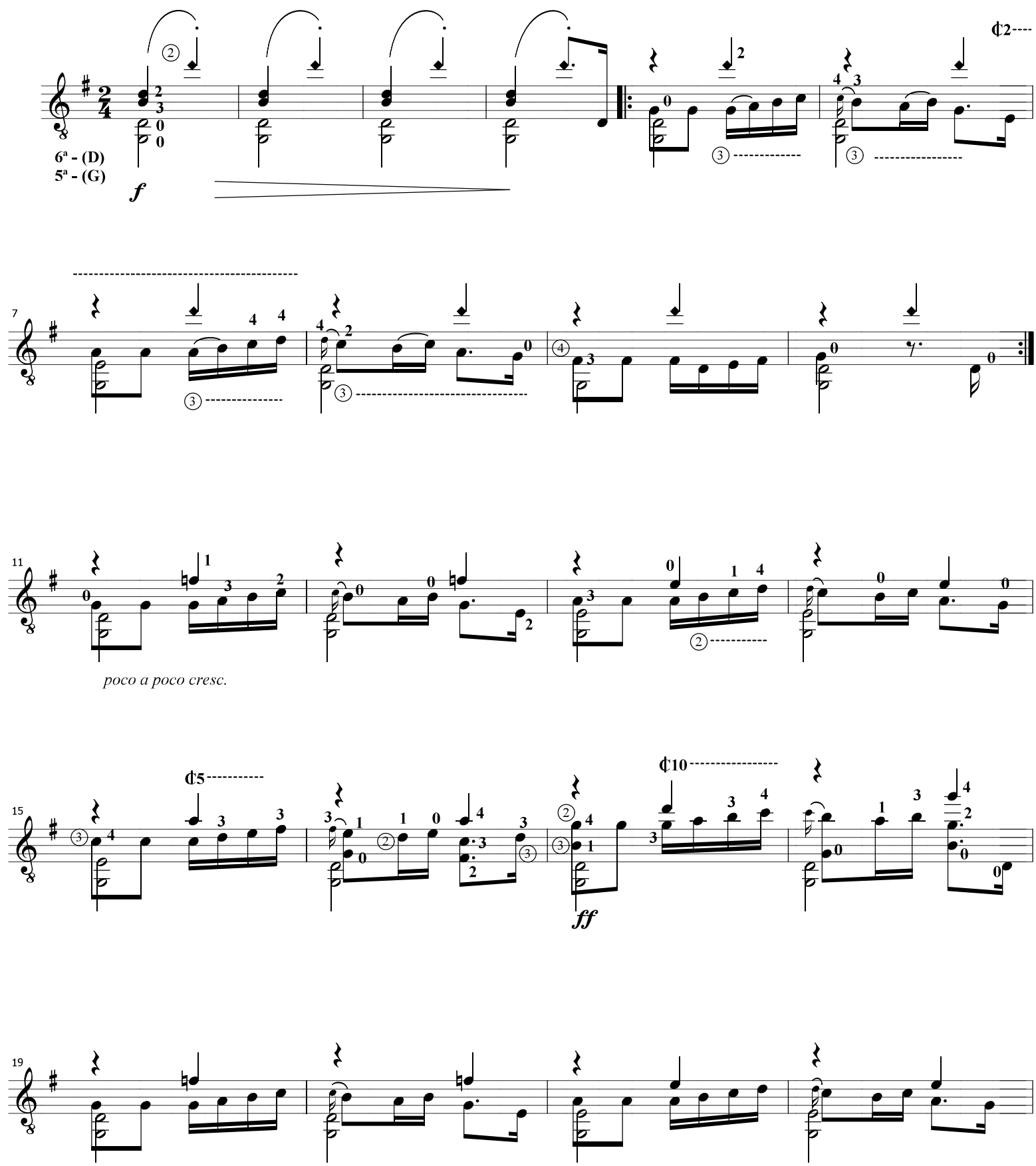

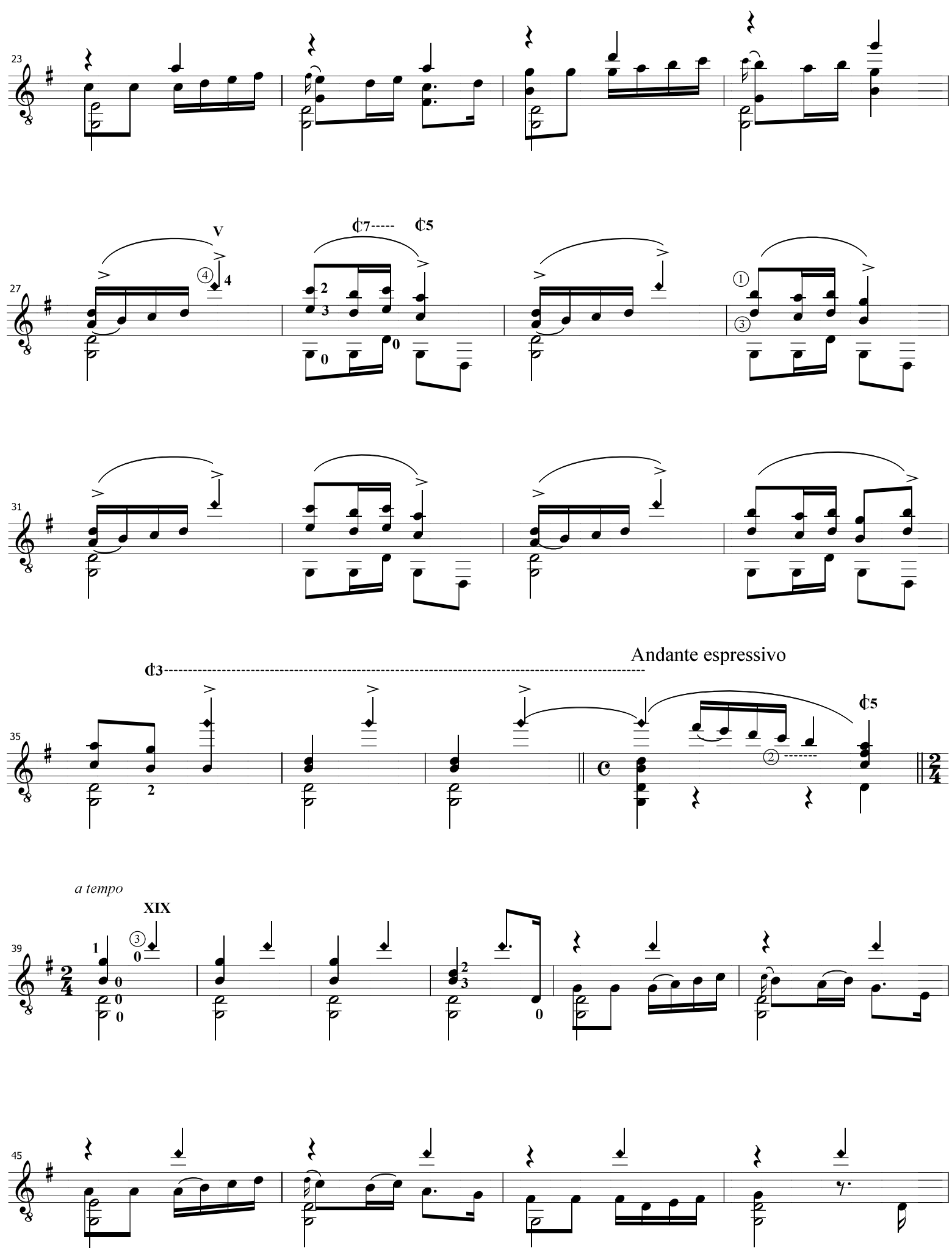

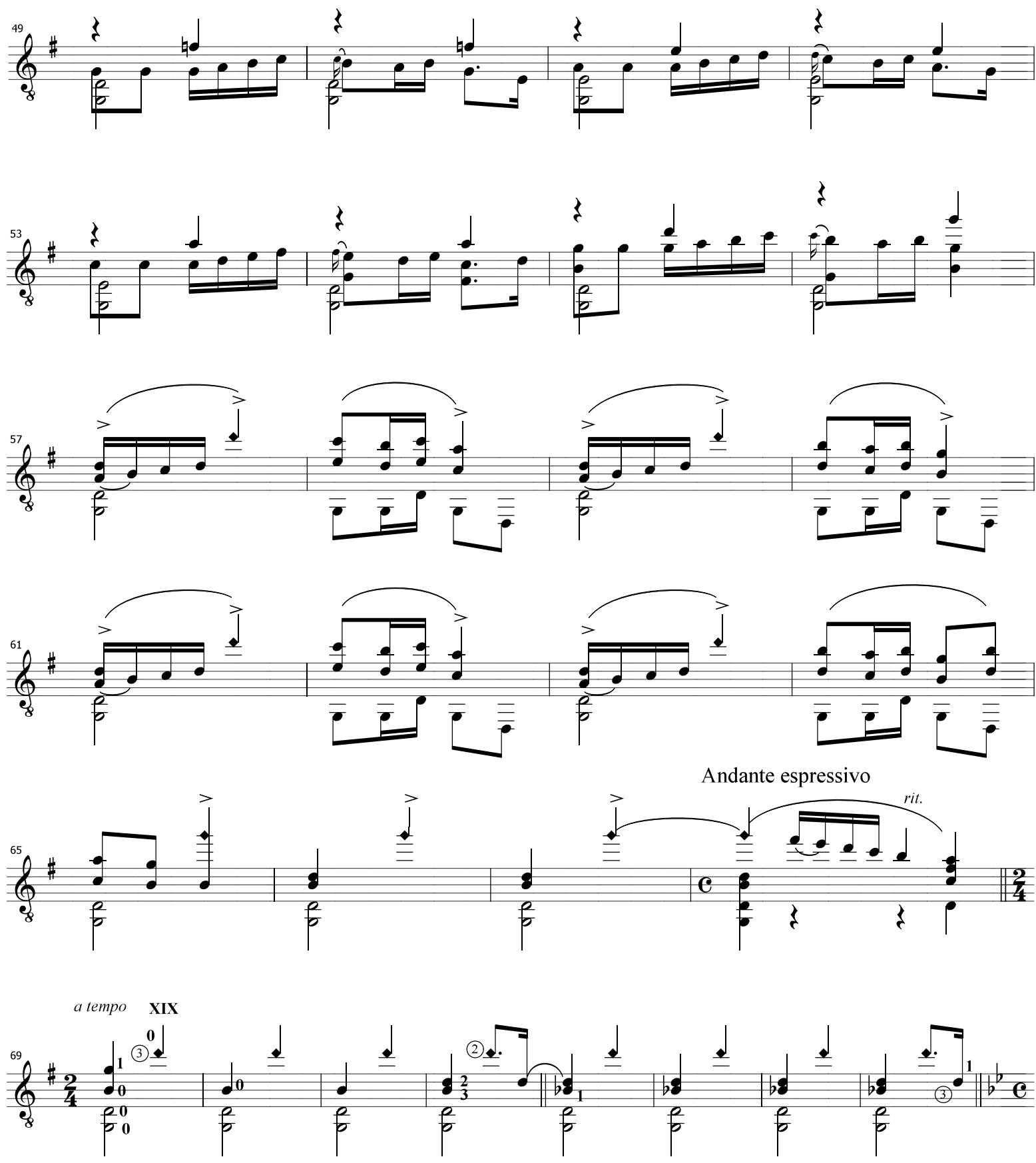

Cancion y estribillo

Molto Andante

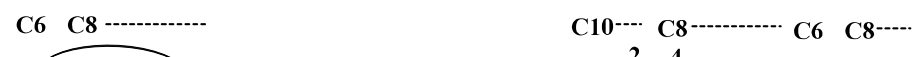

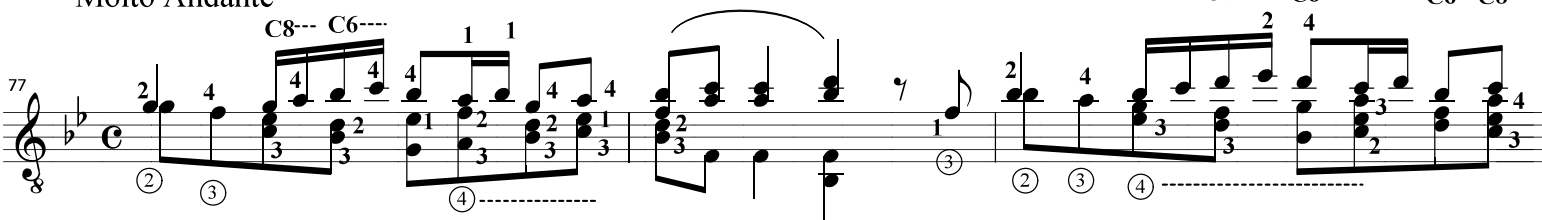



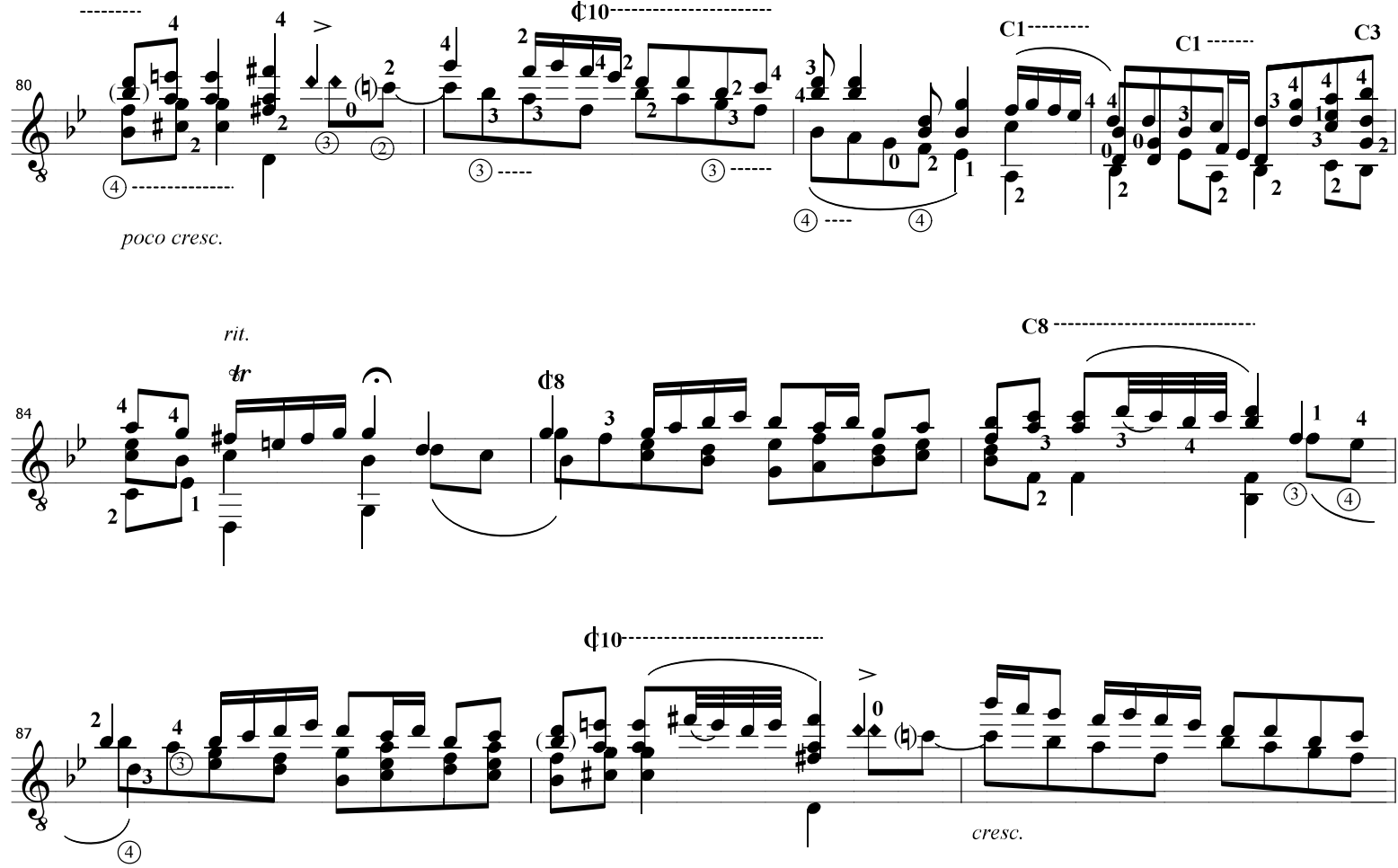

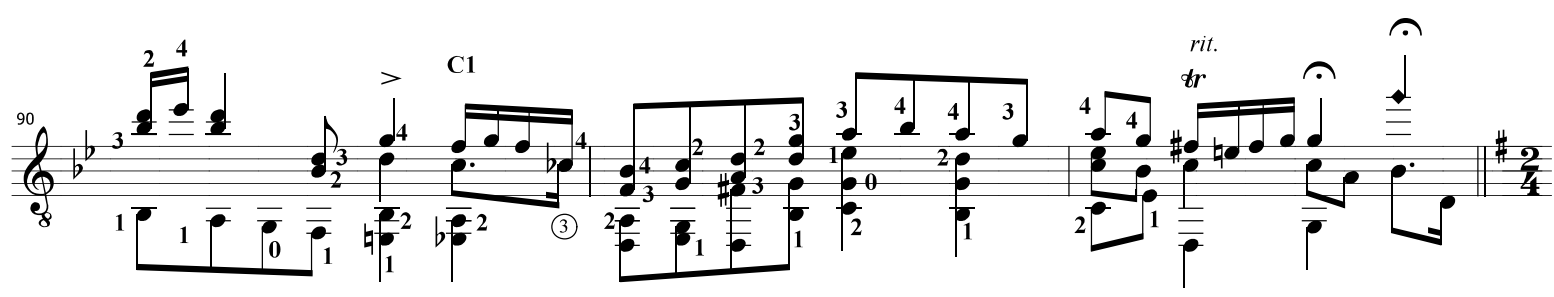
poco dim.

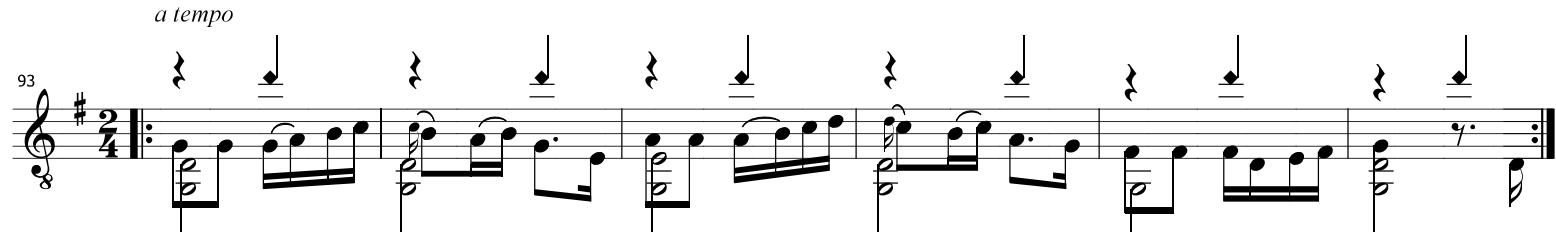

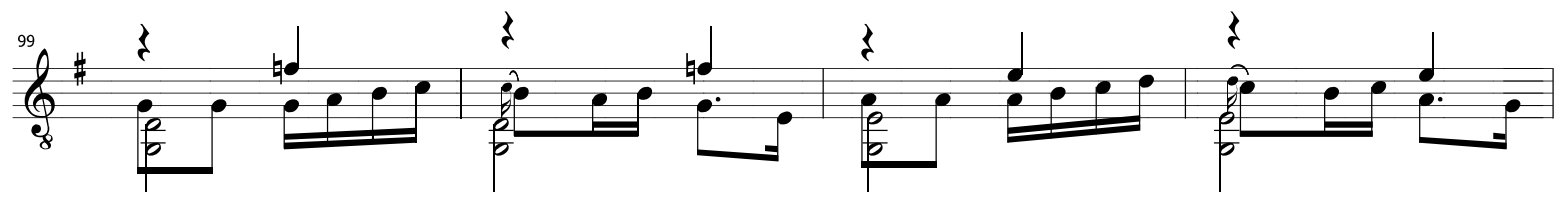



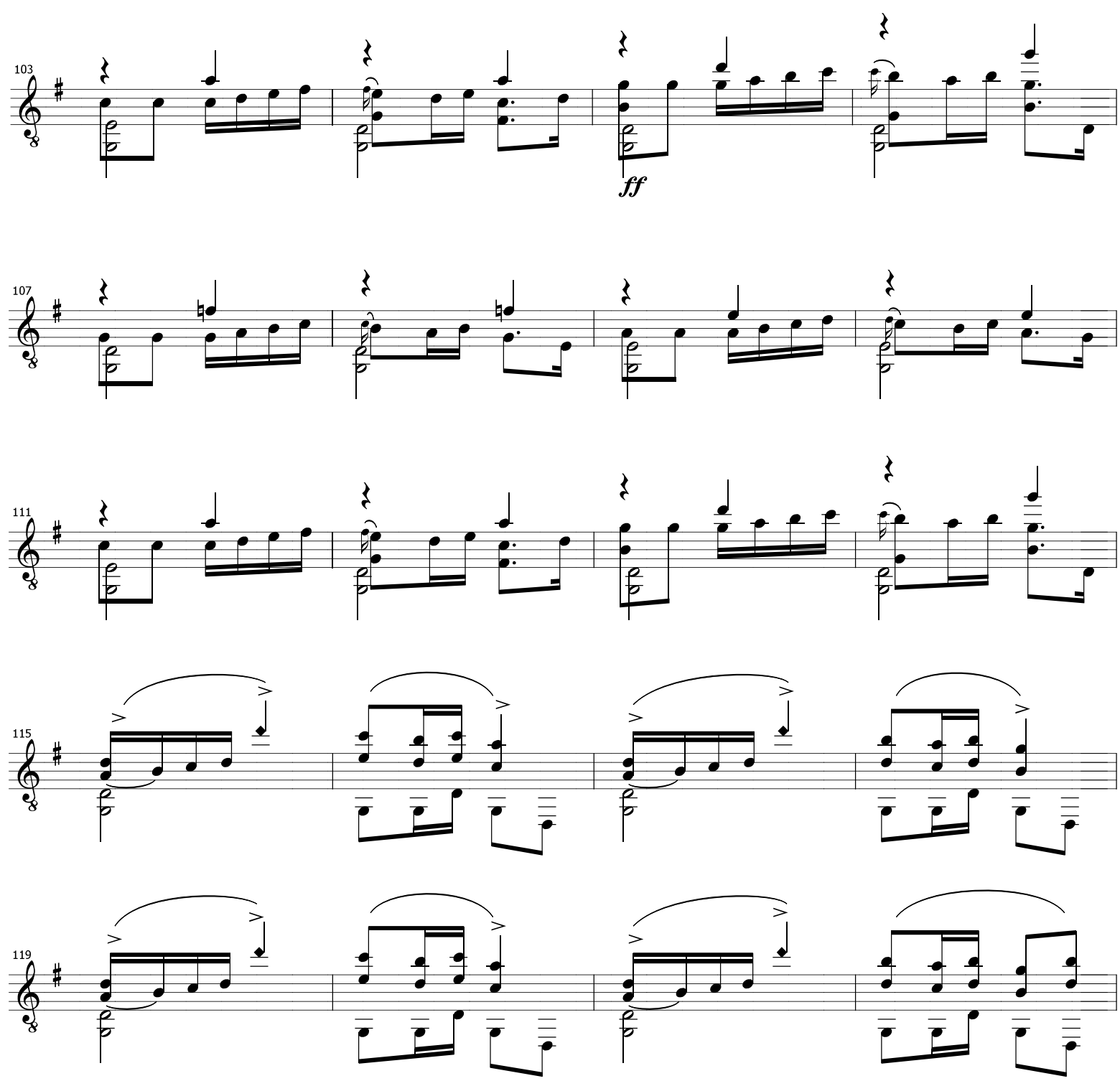

Andante espressivo
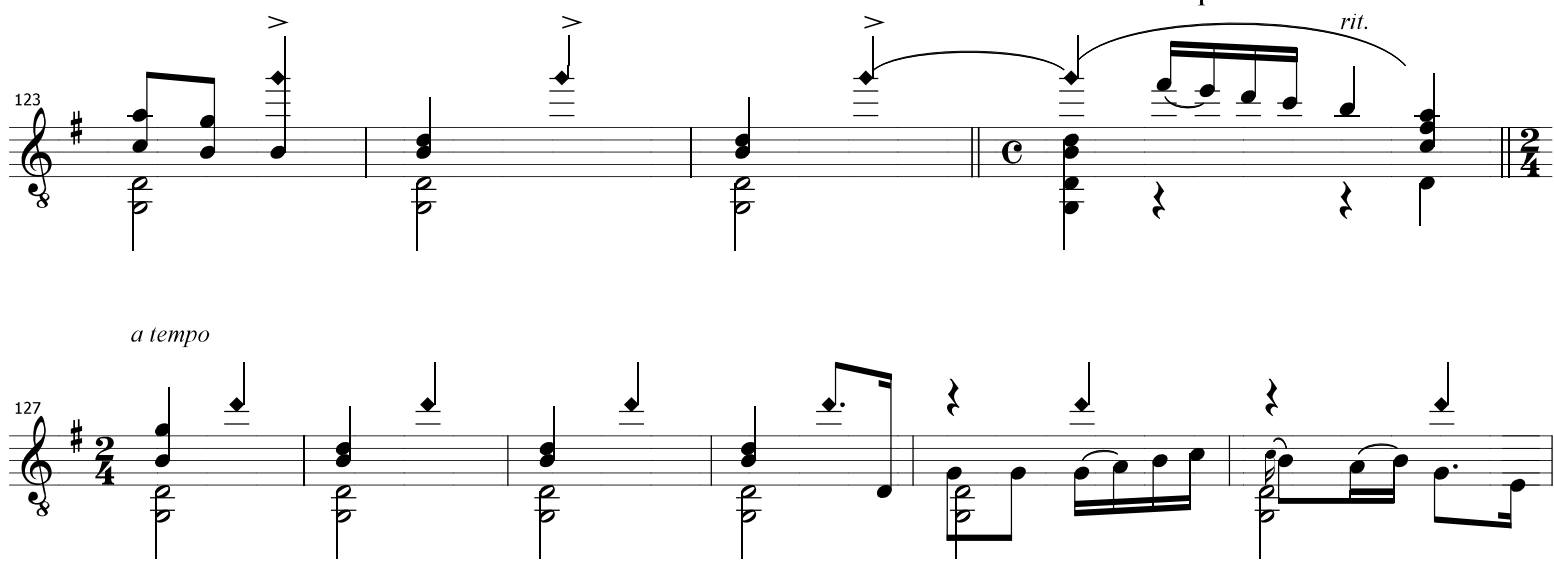


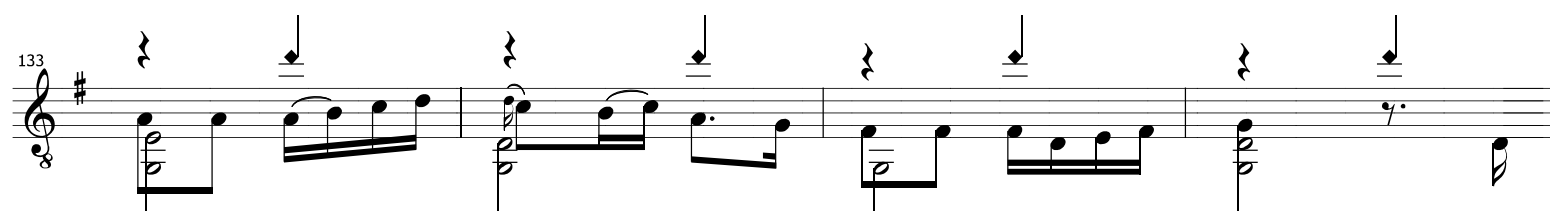
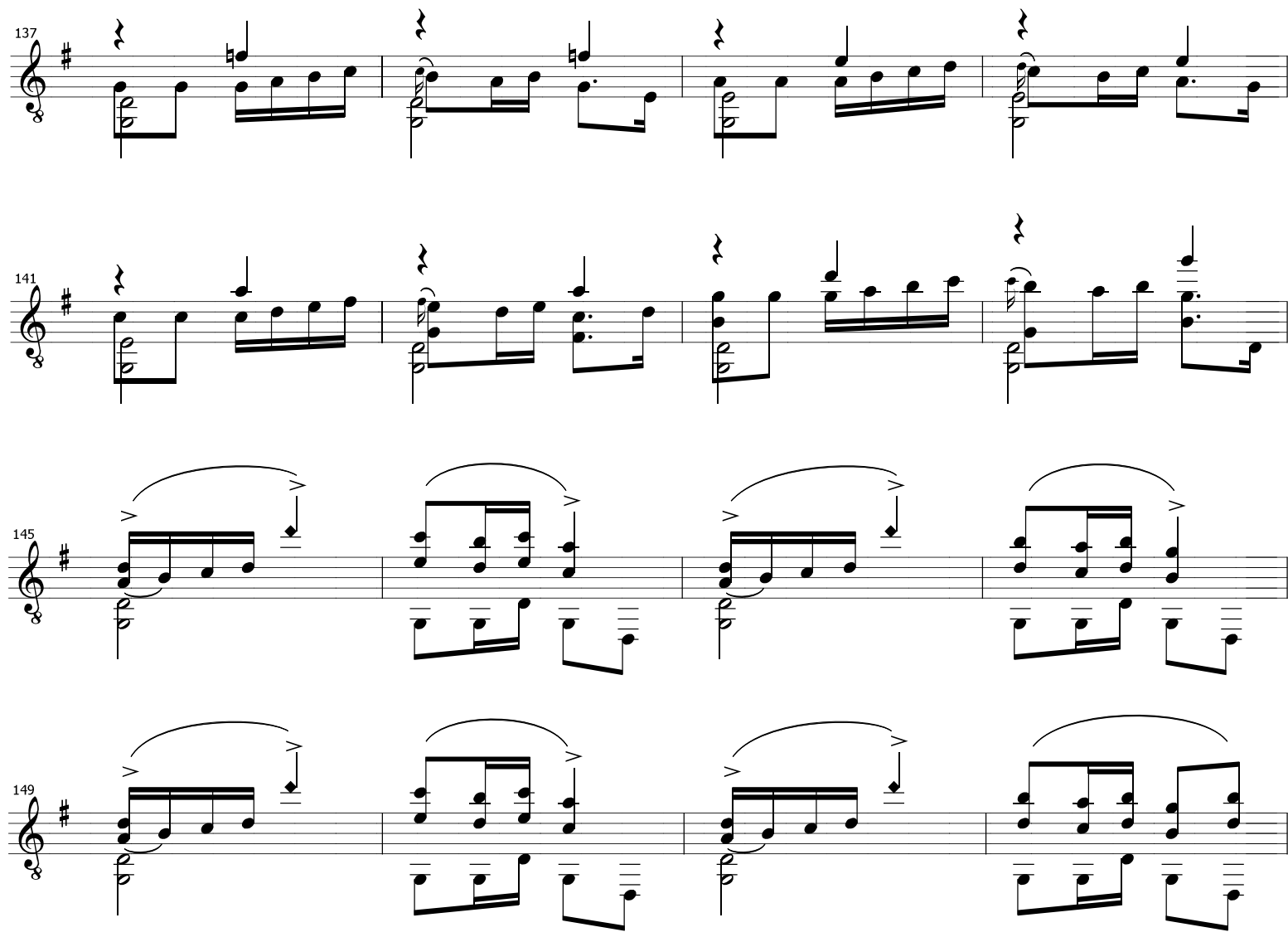

Andante espressivo
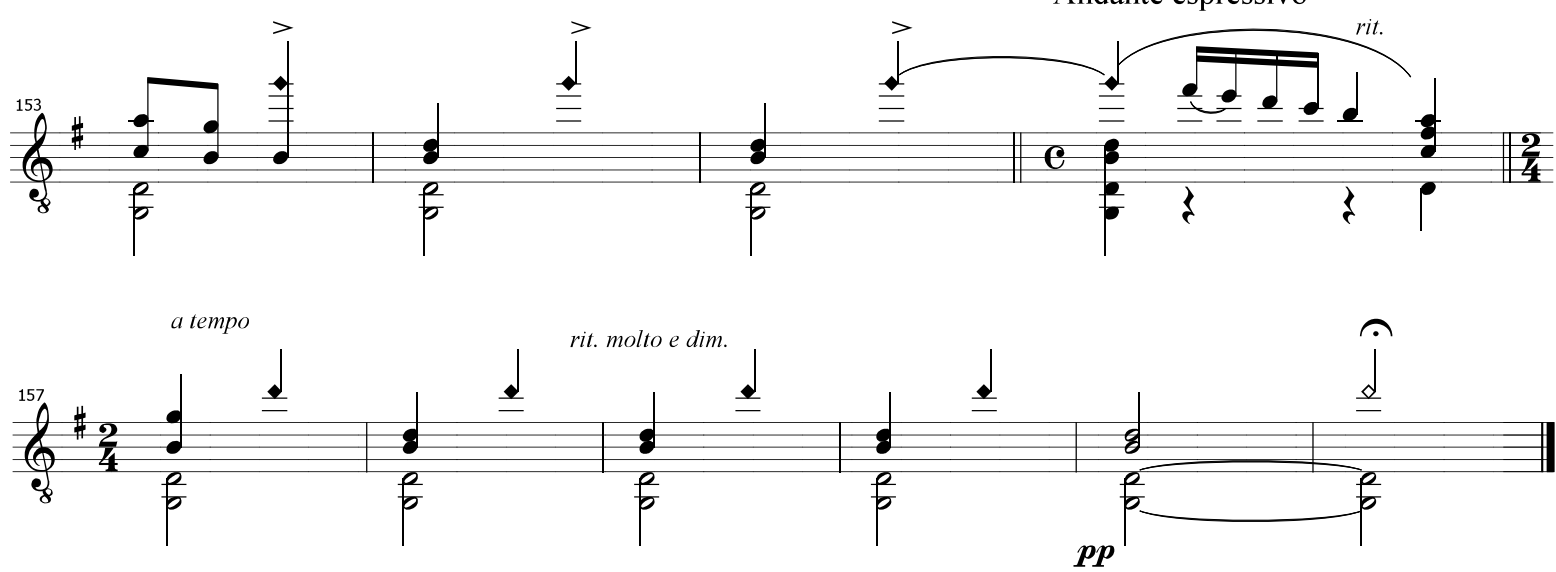


\subsection{Danza n'5}

Tonalidade original e da transcrição: Mi menor

Afinação tradicional.

A peça de Granados mais transcrita e tocada no violão é, indubitavelmente, $a$ Danza $n^{\circ} 5$ Andaluza. Devido a suas características de adaptabilidade é possível, utilizando a afinação tradicional do violão, fazer praticamente uma leitura direta na partitura original, realizando apenas alguns ajustes.

Tomando a transcrição histórica de Miguel Llobet (LLOBET, 1987) como referência, ilustraremos a seguir algumas das modificações que fizemos em prol de uma fidelidade maior à partitura original. Tais ajustes podem ser opções interessantes para a performance da peça. A primeira delas diz respeito à anacruse da linha melódica do tema (compasso 3). Vale notar que, nas transcrições e gravações já consolidadas da peça, ocorre a omissão justificável do baixo e sua appoggiatura. Com uma proposta de dedilhado funcional, buscamos um resultado mais fiel ao original (Figura 63). 
Figura 63 - comparativo com a transcrição de Miguel Llobet

\section{orig.}
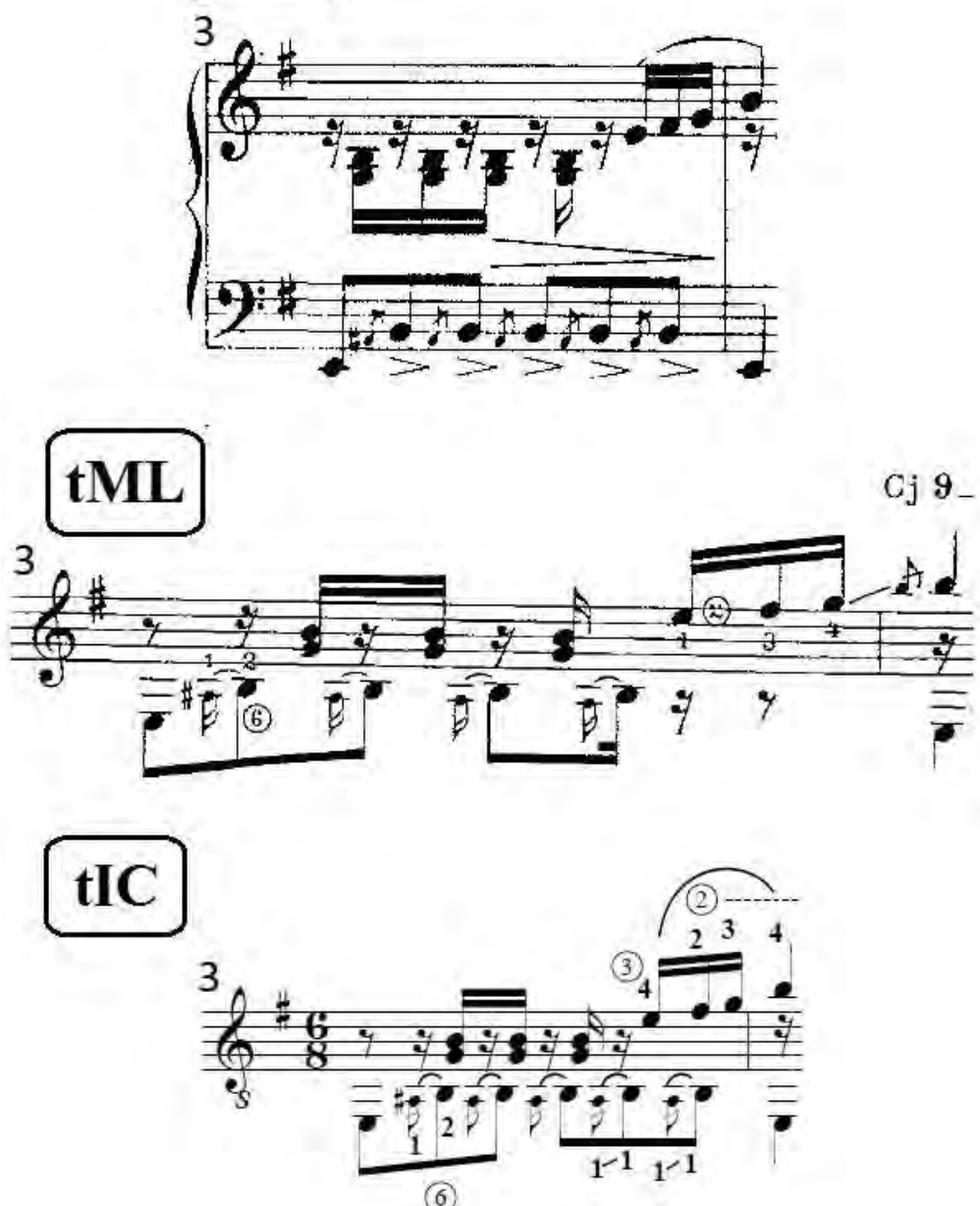

Fonte: elaborada pelo autor

Na primeira aparição do tema na seção central da peça, Andante, optamos por manter a proporção de alturas original entre o primeiro e segundo tema (Figura 64). 
Figura 64 - Comparativo entre transcrições

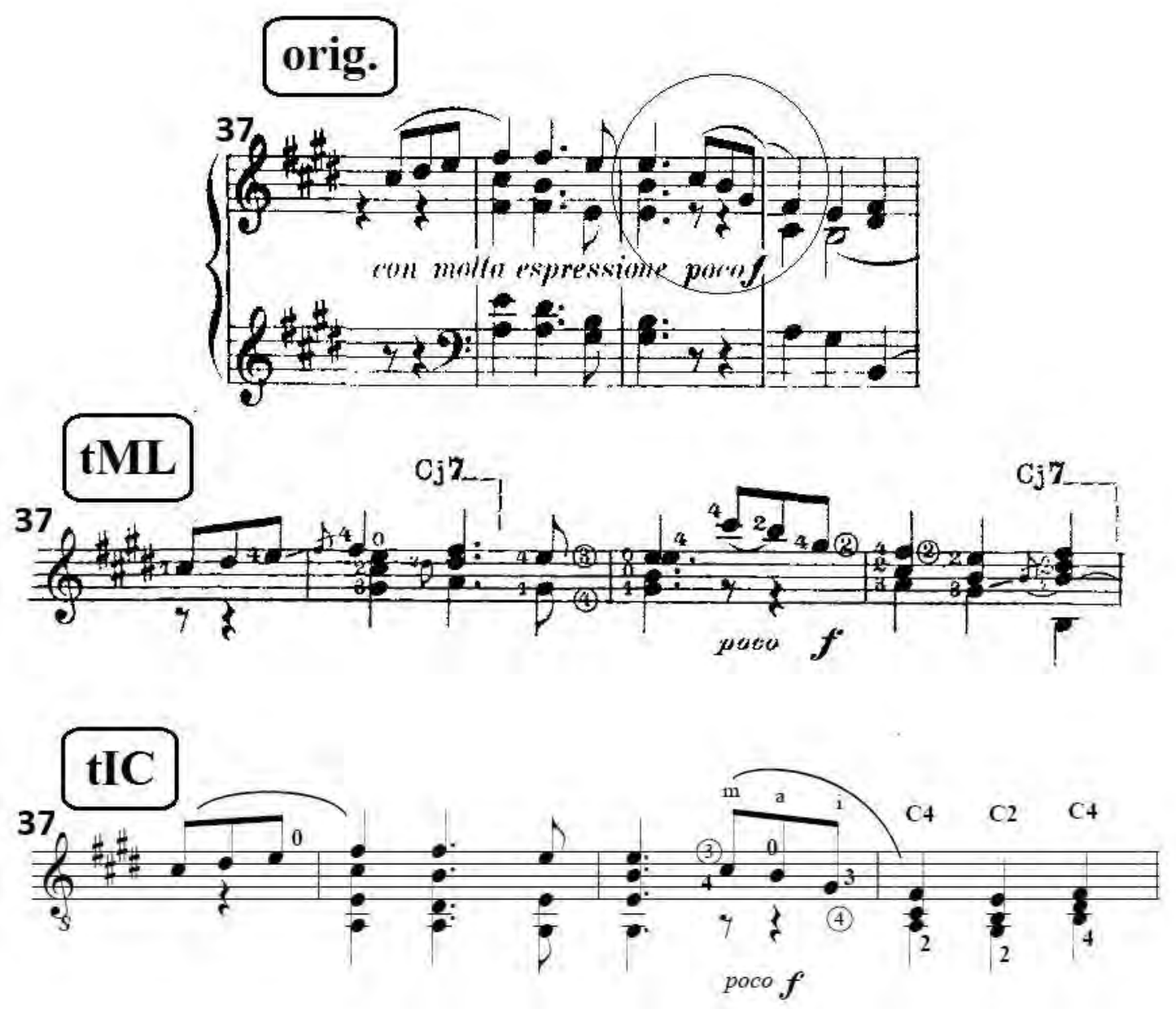

Fonte: elaborada pelo autor 

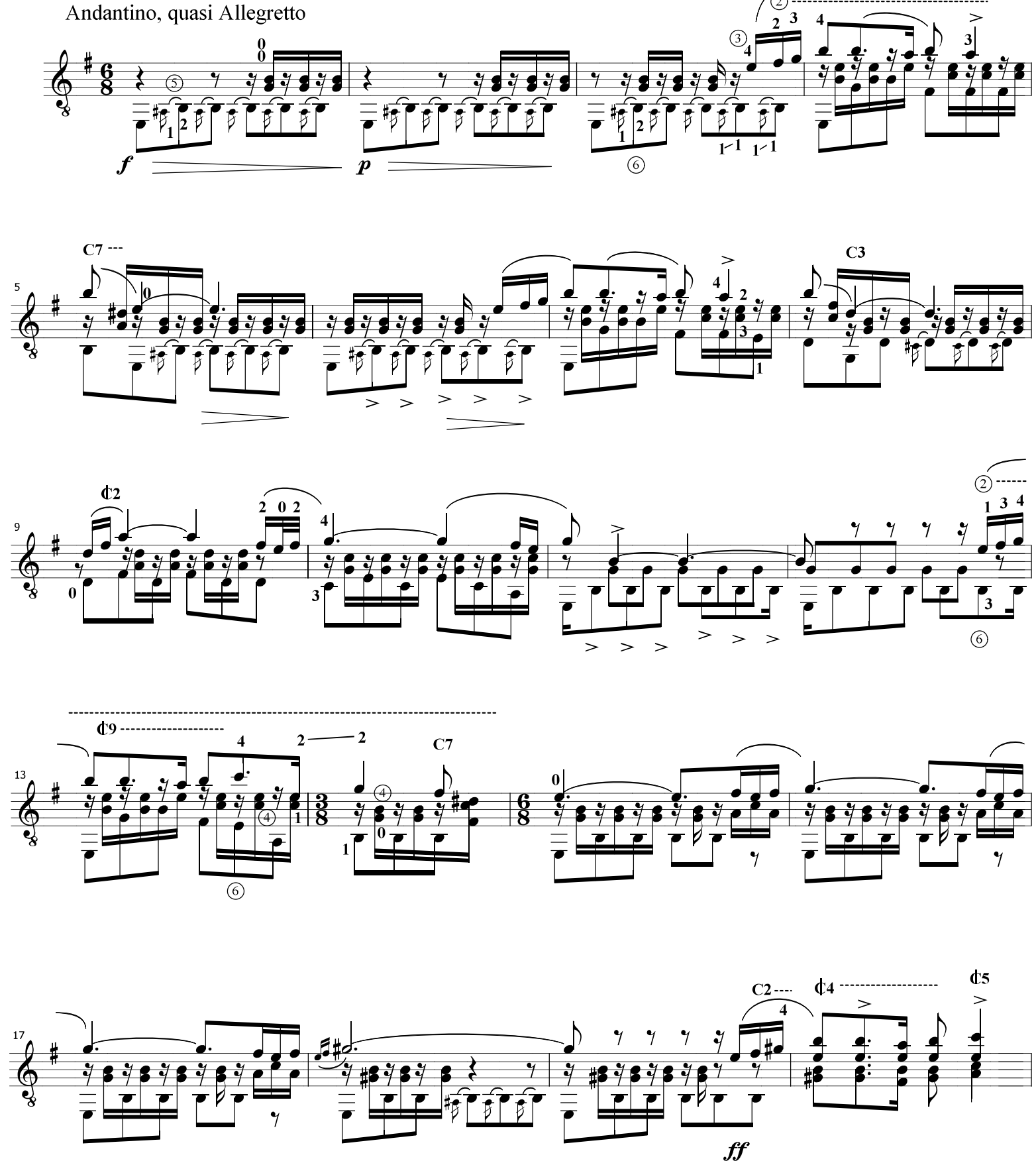
(5)
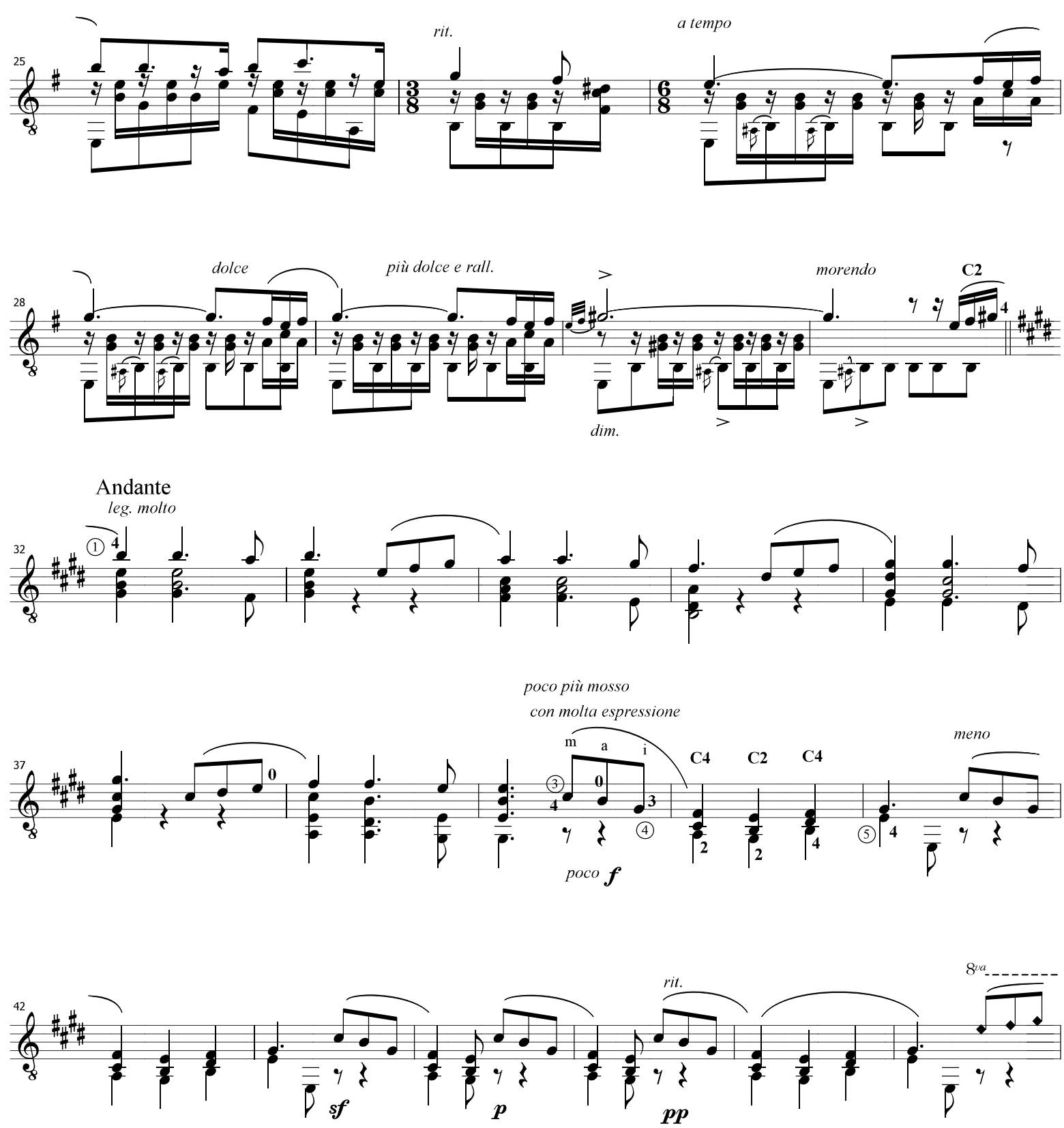

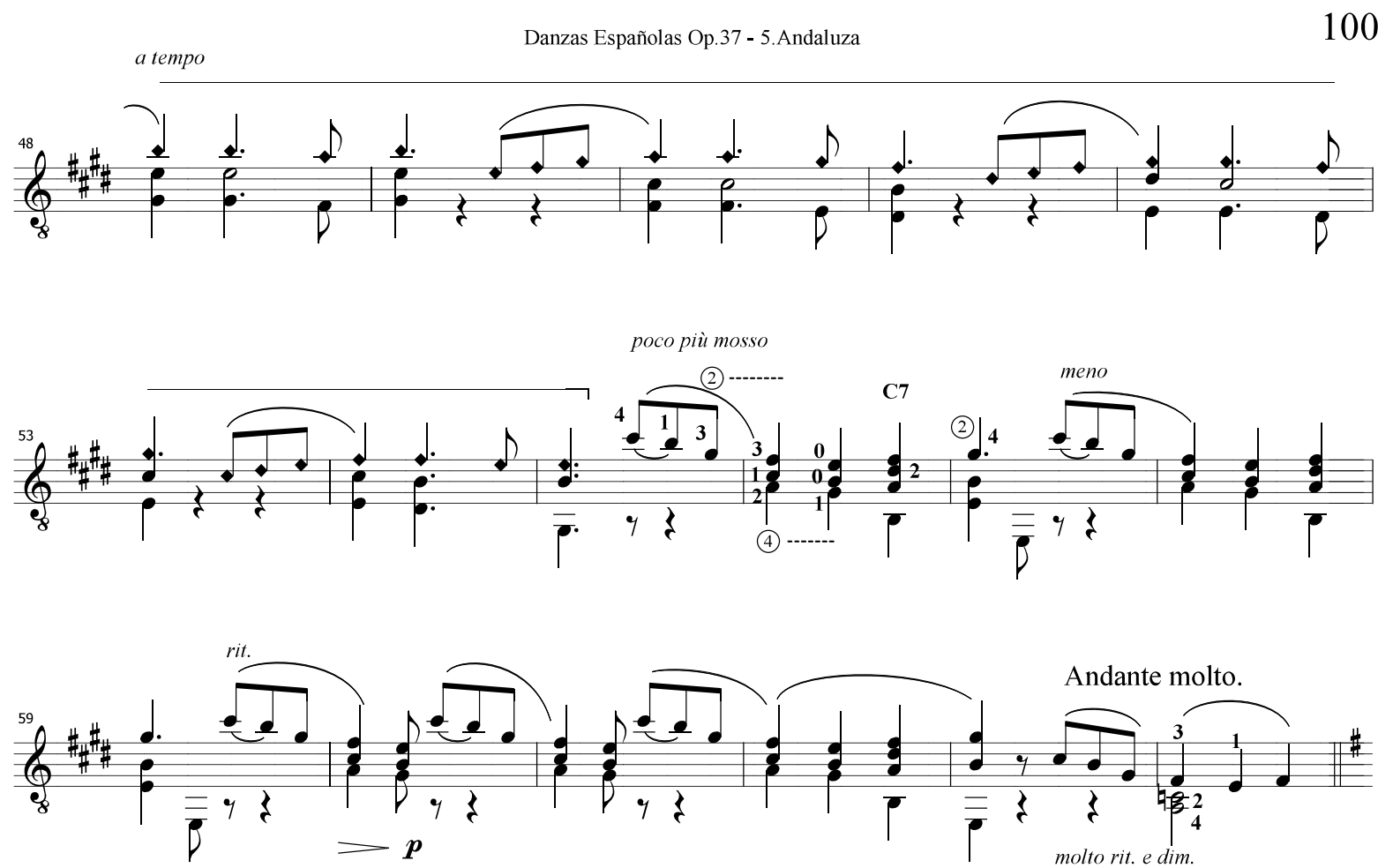

Tempo I.

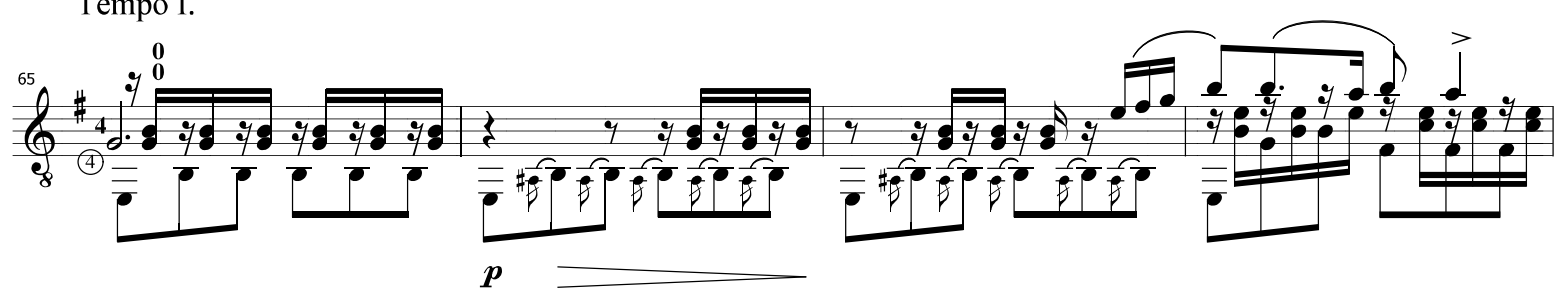
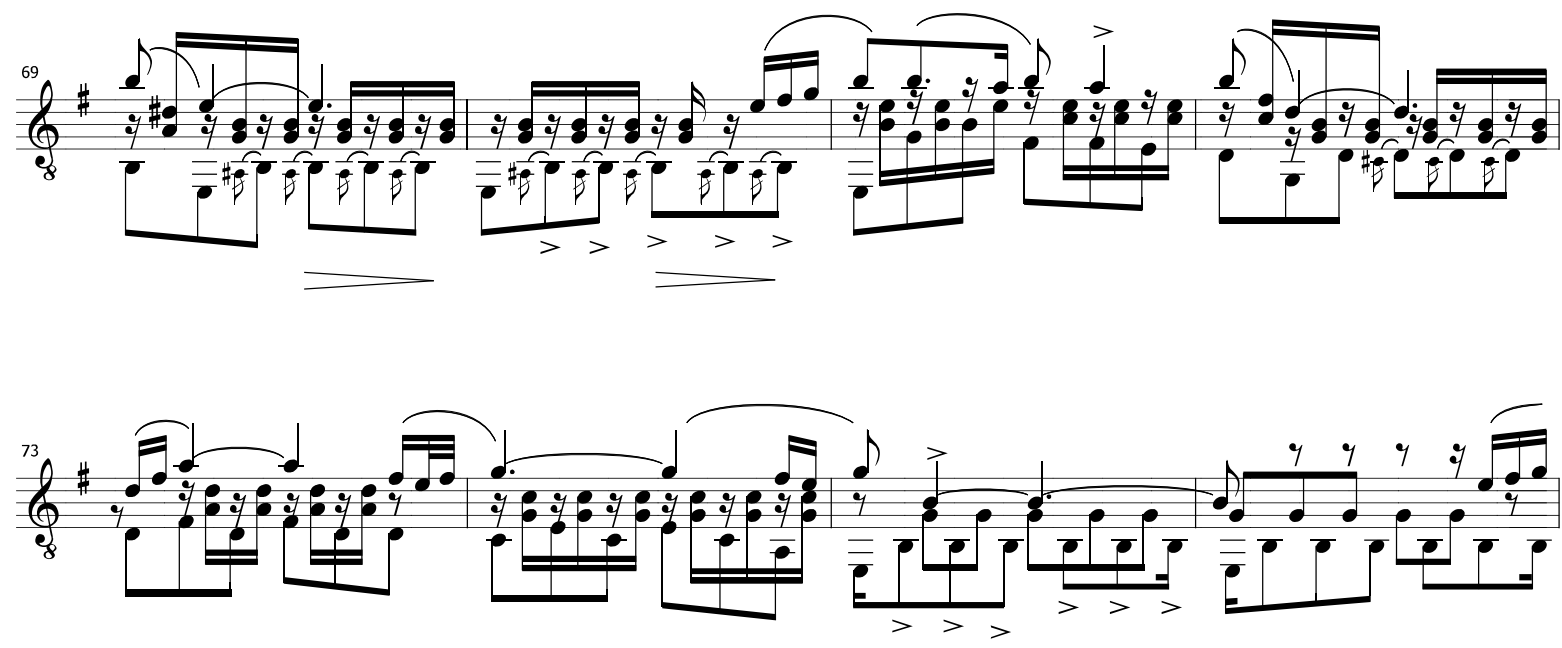

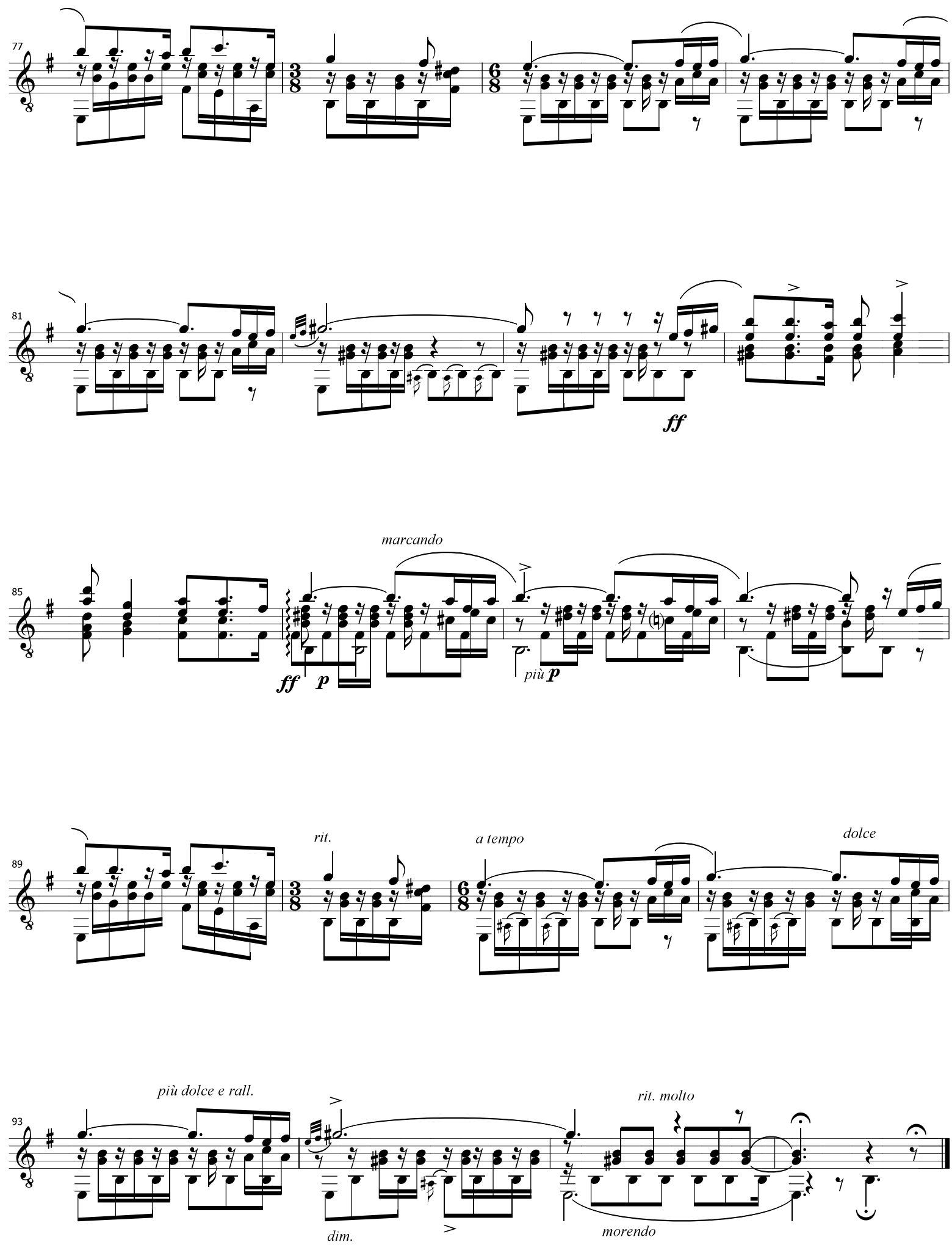


\subsection{Danza n\%6}

Tonalidade original e da transcrição: Ré Maior

Scordatura utilizada:

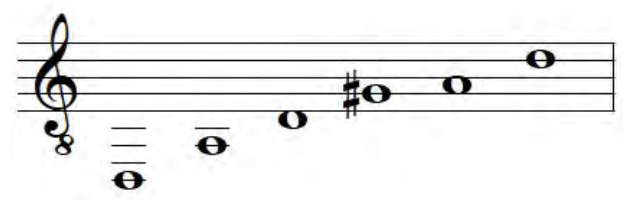

Aqui tivemos um dos grandes desafios de adaptação. A ausência de qualquer transcrição satisfatória para violão solo é justificada por algumas características da peça, presentes principalmente na seção "A". Apontamos duas delas: 1. O crescendo e accelerando poco a poco que conduz o primeiro grupo de temas da seção até seu ápice no compasso 37 e; 2. A presença constante das appoggiaturas (Sol sustenido) que antecedem as notas "Lá" no motivo do acompanhamento ocorrente nos compassos 33 a 40 (Figura 65). 
Figura 65 - O cresc. e accel. conduzem a seção A ao seu ápice no compasso 37

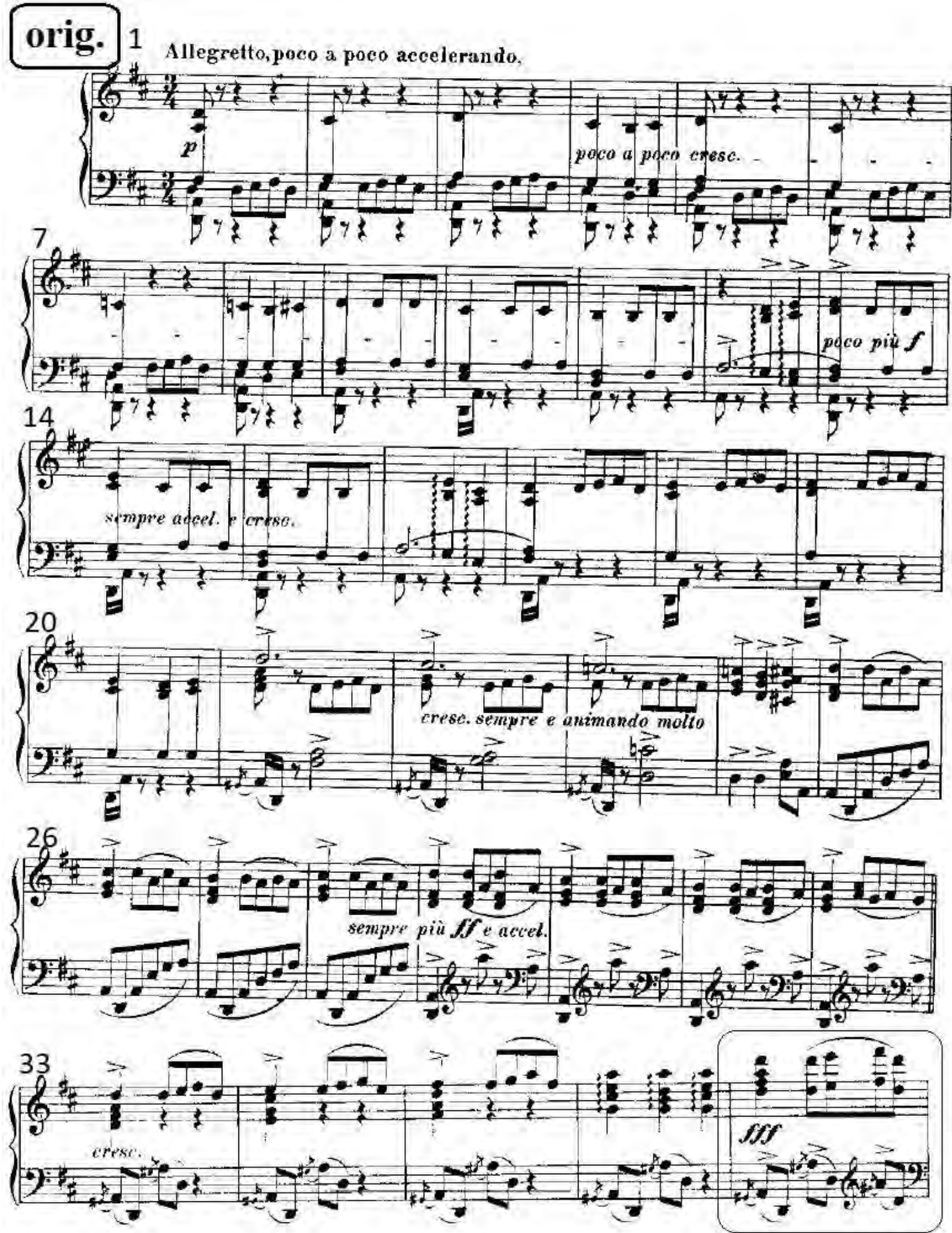

Fonte: Granados (1987)

A primeira seção da peça possui dois temas, cada qual com seu antecedente e consequente, que são repetidos com alterações de alturas e texturas até o fechamento da seção, 
que possui uma coda. A estrutura harmônica dos temas gira em torno das funções principais da tonalidade de Ré Maior com a presença de um intervalo pedal de quinta no registro grave (Ré e Lá). Julgamos que tal simplicidade harmônica foi proposital para criar a sensação de um crescendo de um único acorde por toda a seção, tendo em vista o pedal constante de Ré. Baseados nesse conceito e considerando a grande diferença de possibilidades sonoras entre o piano e o violão, percebemos que só conseguiríamos uma execução natural nas diferentes gradações de dinâmicas exigidas com uma scordatura que formasse o acorde de Ré Maior através de cordas soltas. Antes da solução final, a scordatura utilizada foi essa (Figura 66):

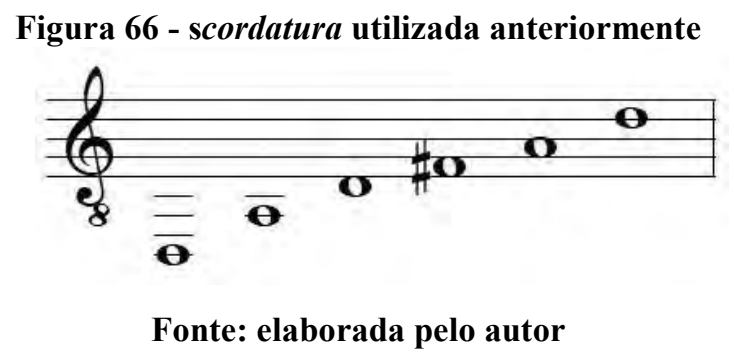

No entanto essa configuração de afinação não possibilitou no violão a execução das appoggiaturas supracitadas. A presença desse ornamento na seção atribui certa personalidade característica à sua sonoridade; julgávamos necessária então, sua adaptação. A solução veio através da constatação de que, na prática, devido à aceleração constante do andamento na peça, a appoggiatura em questão soa como um intervalo harmônico da sua nota real. Considerando a scordatura proposta anteriormente, foi feito um último ajuste, agora, da terceira corda para Sol sustenido. A nova scordatura permite que quando a terceira corda é tocada junto com a segunda, seja gerado esse mesmo intervalo de segunda menor (Sol sustenido e Lá). Essa configuração de afinação proporcionou a possibilidade de adaptação da seção "A" e com os devidos ajustes, todo o restante da peça pôde ser abarcado (Figura 67). 
Figura 67 - Solução de adaptação na Danza n6

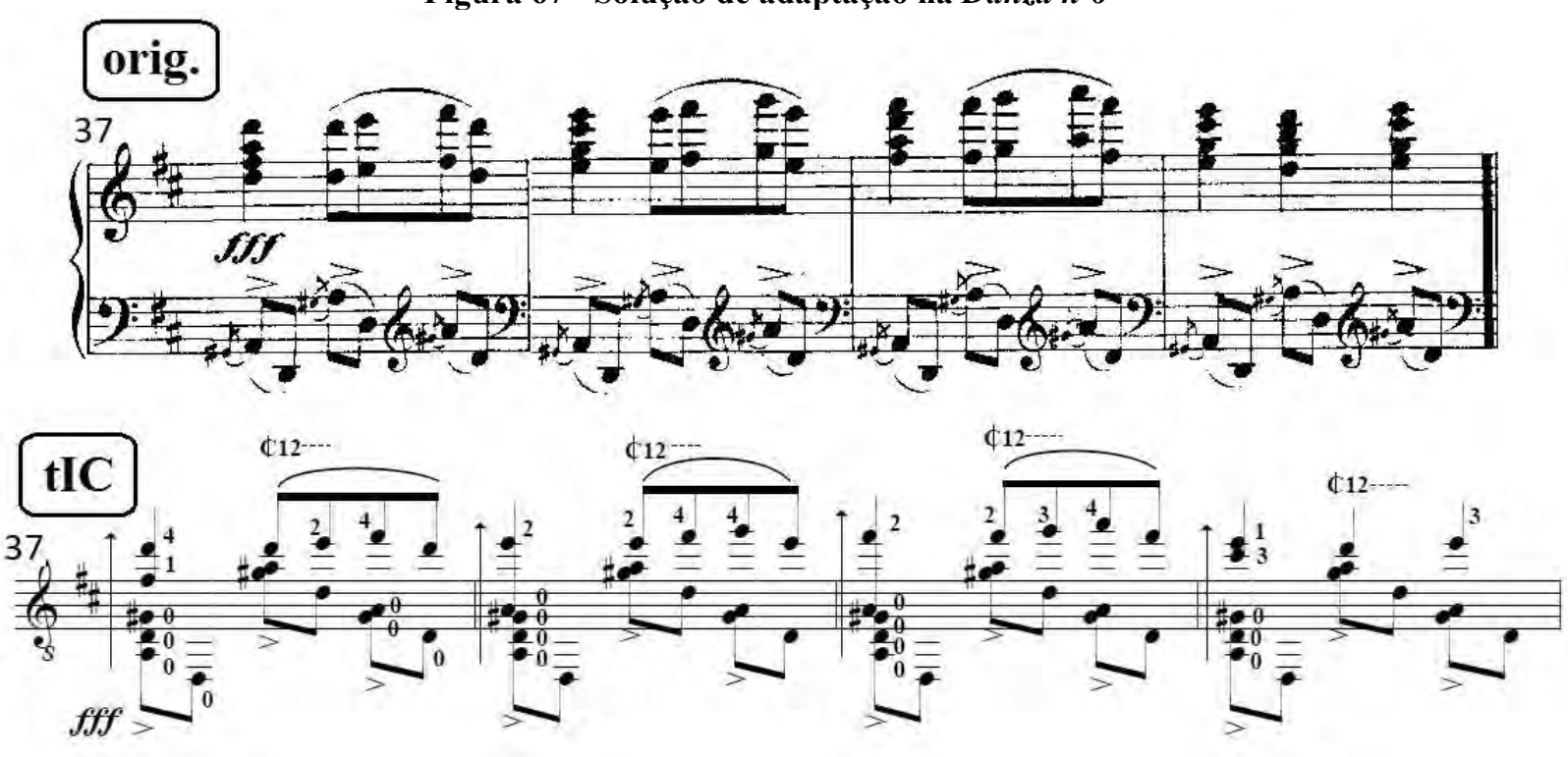

Fonte: elaborada pelo autor

Alguns outros trechos foram beneficiados em nossa transcrição com esta scordatura, devido a outras ocorrências do motivo Sol\# - Lá (Figura 68).

Figura 68 - Motivo (Sol\# - Lá) na seção central da peça
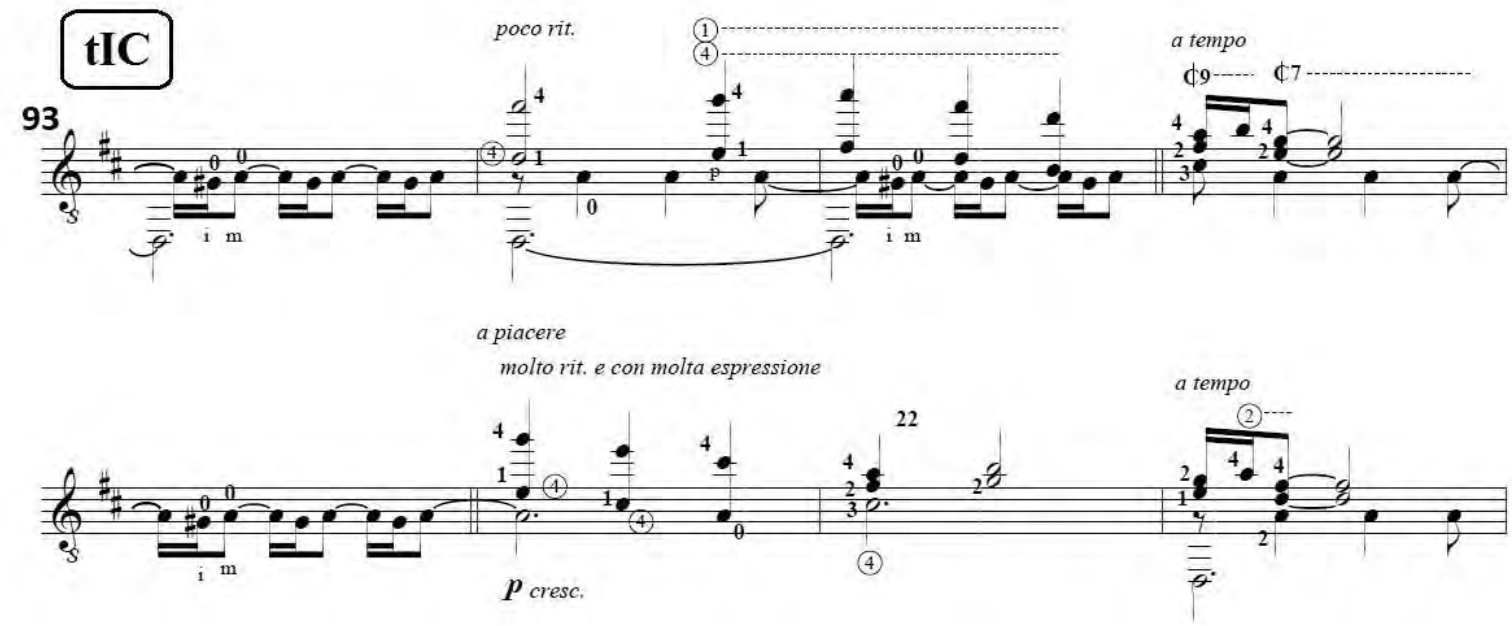

Fonte: elaborada pelo autor 
5.6.1 Partitura da transcrição

Danzas Españolas

Op.37

\section{Rondalla Aragonesa}

Transcrição para violão de

(Jota)

Iury Cardoso

Enrique Granados

Allegretto, poco a poco accelerando
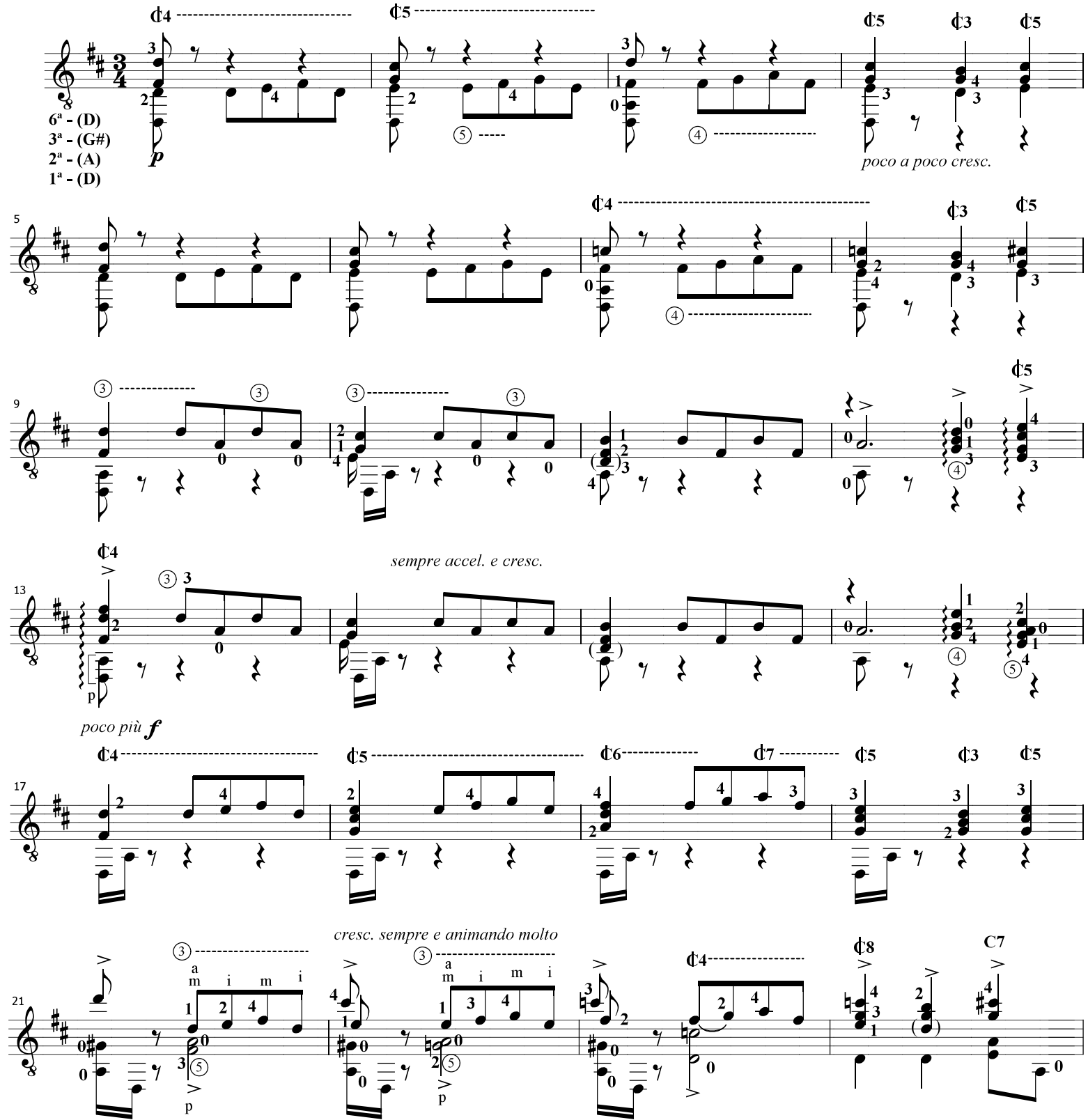


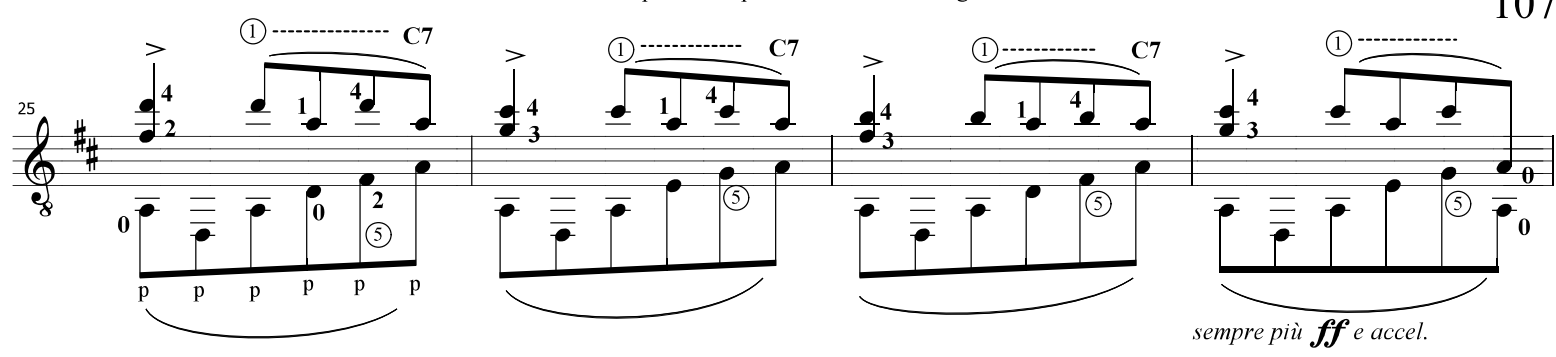

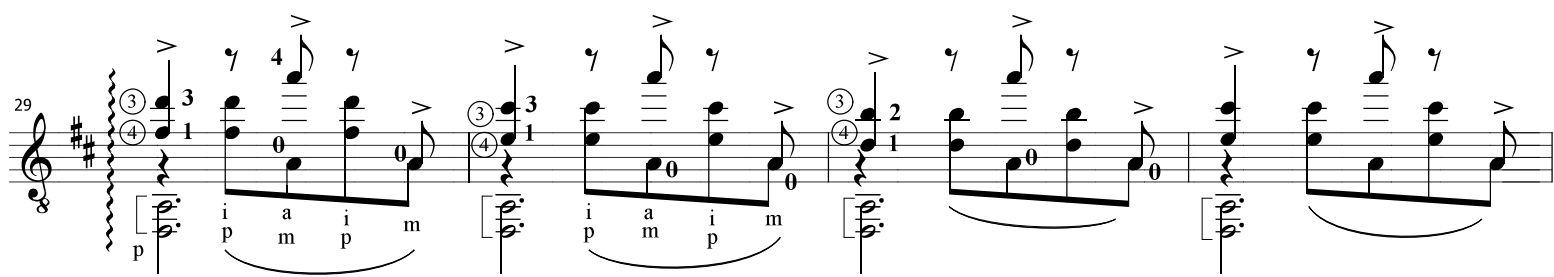
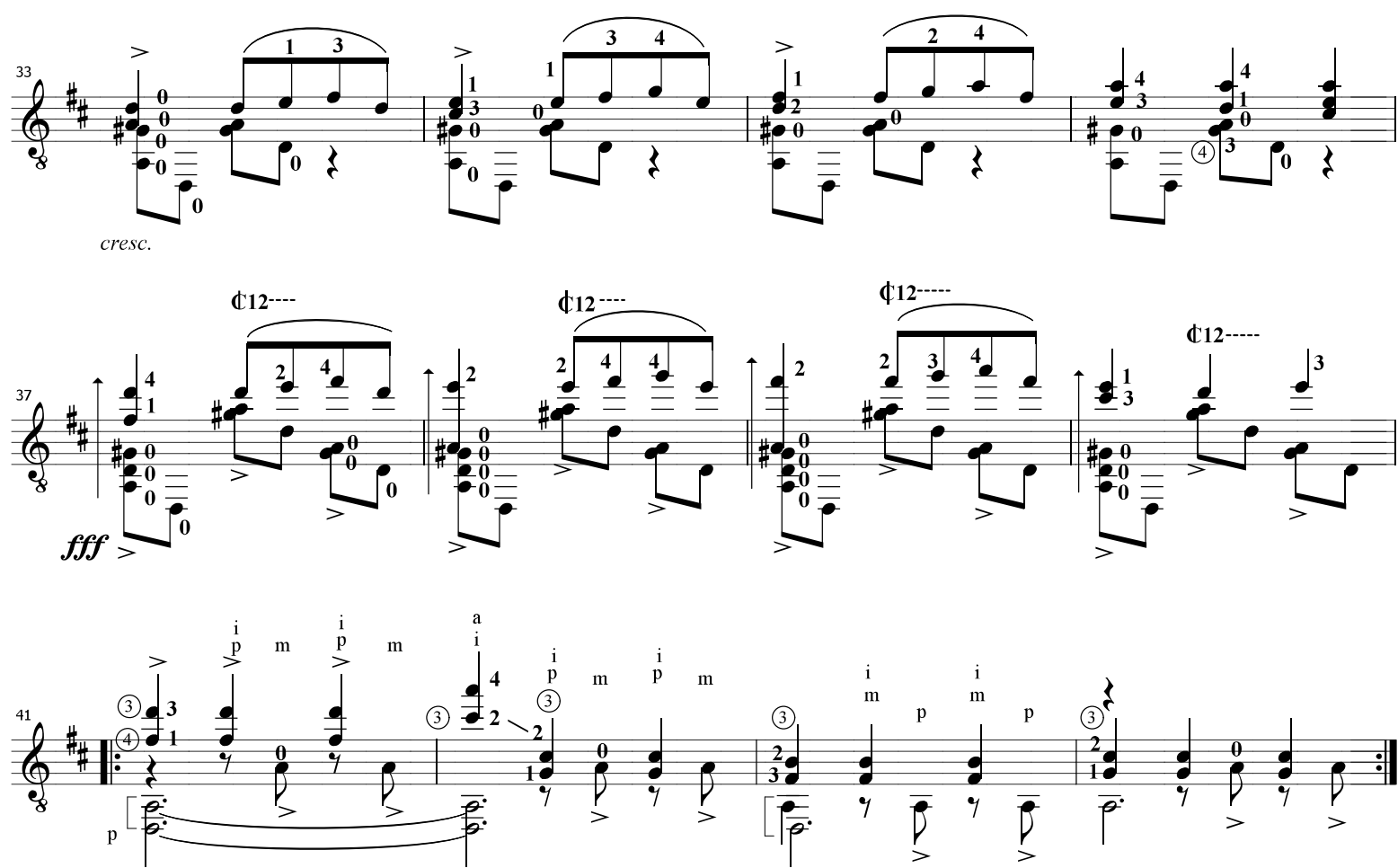

Vivace.

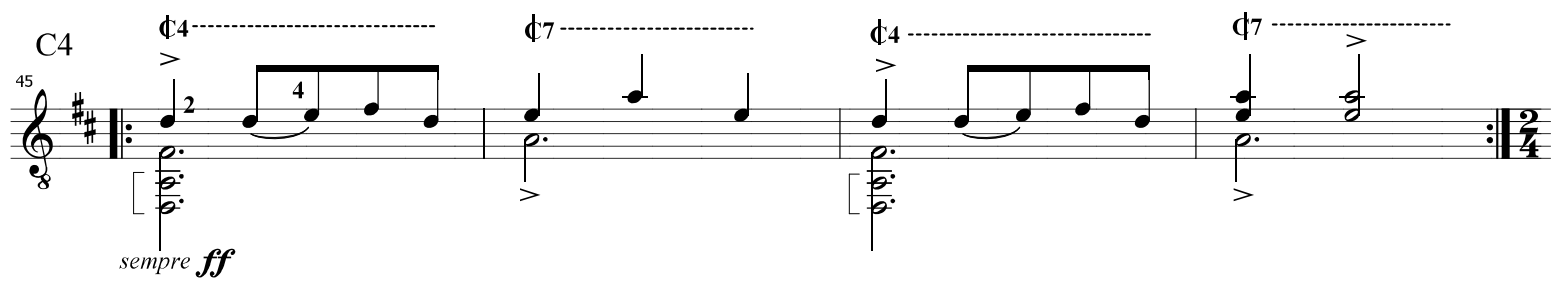


Danzas Españolas Op.37 - 6.Rondalla Aragonesa

108
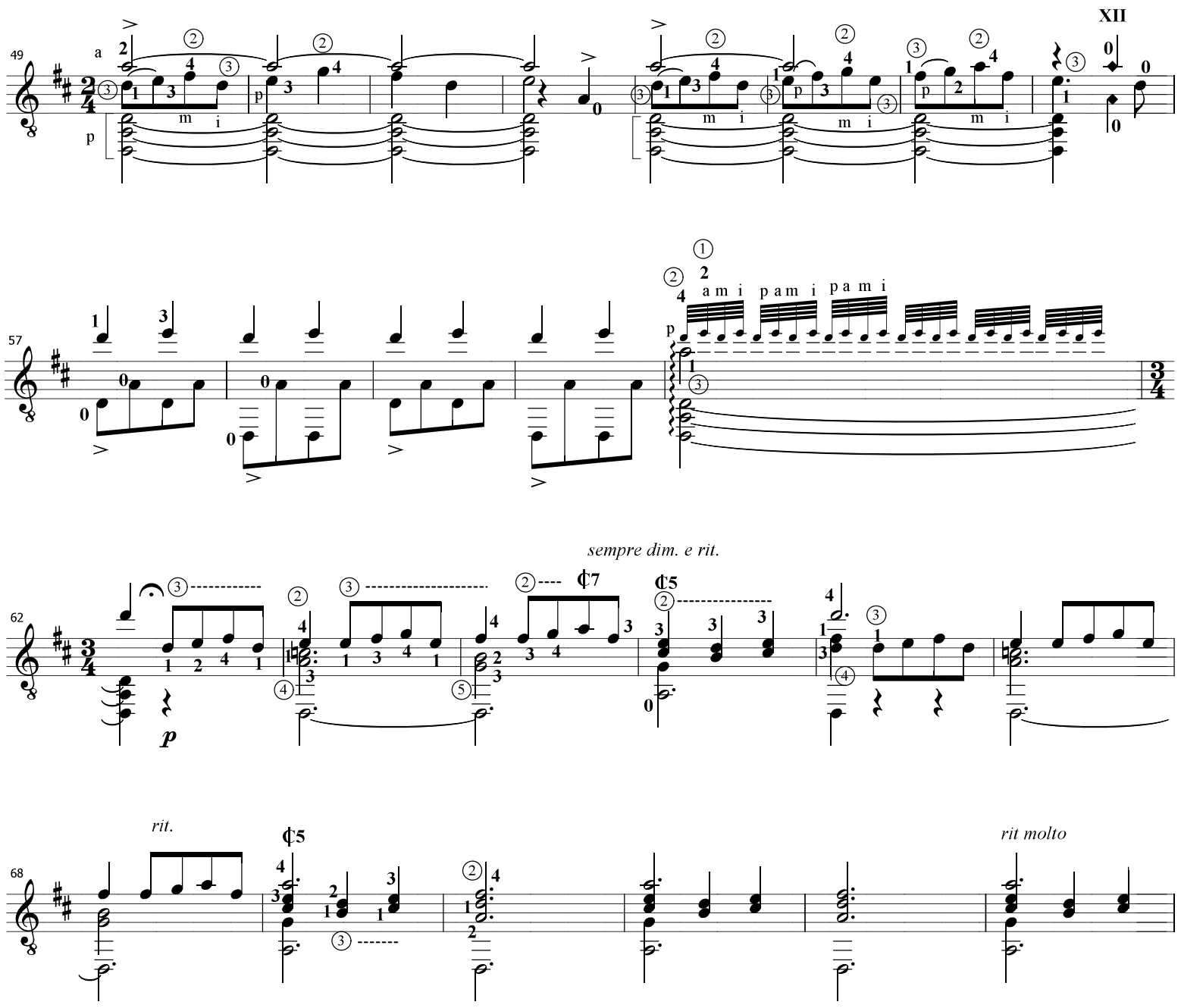

Molto Andante, espressivo
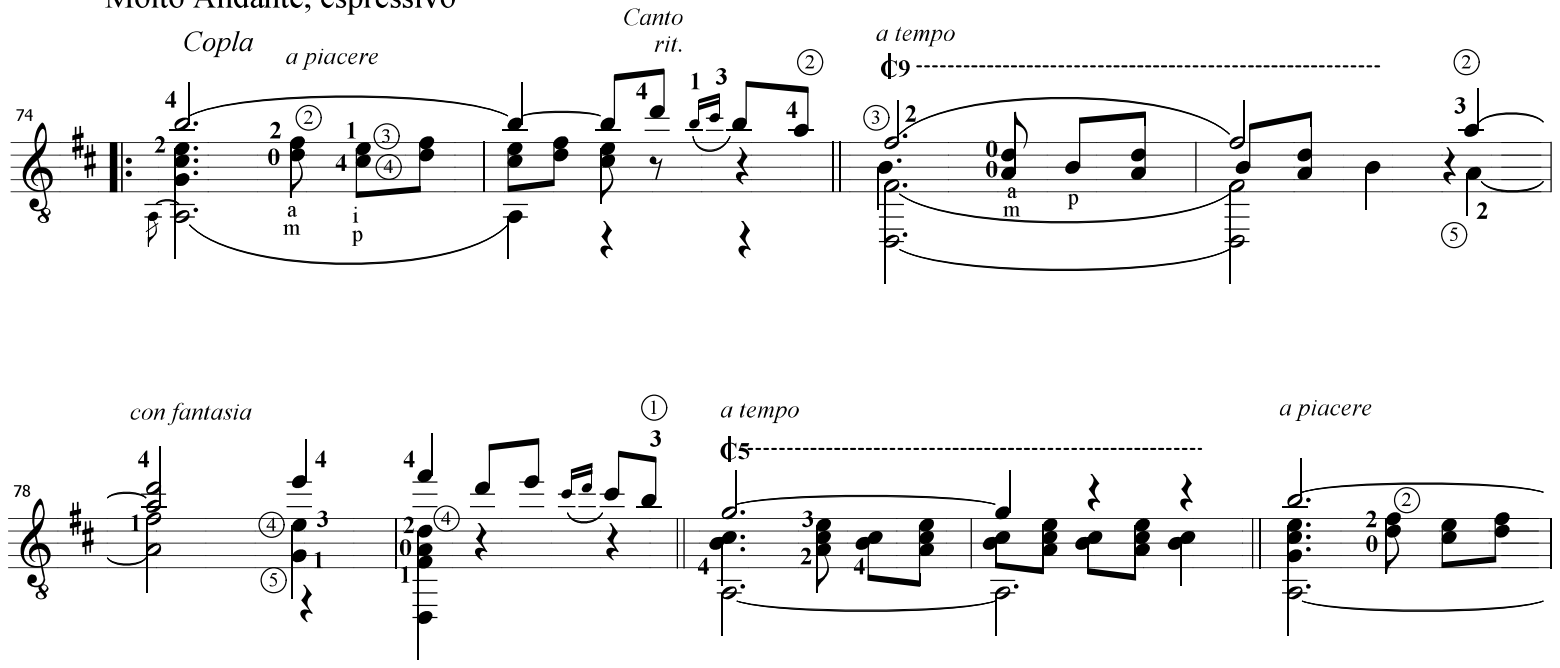

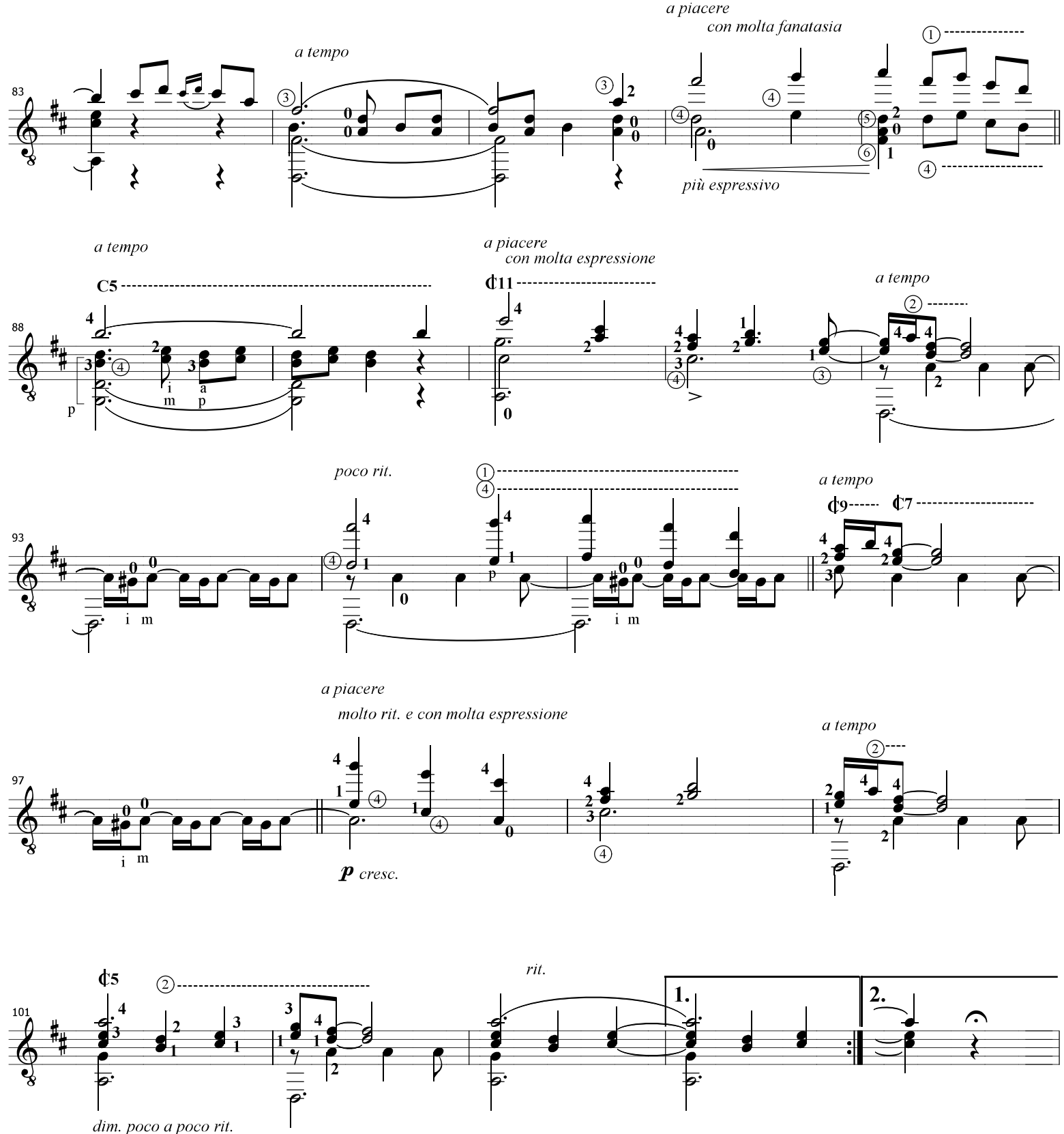

Tempo I.

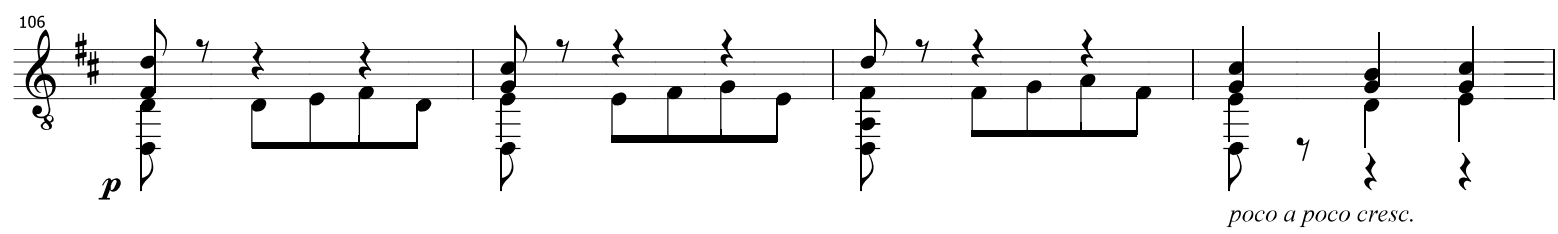


fit?

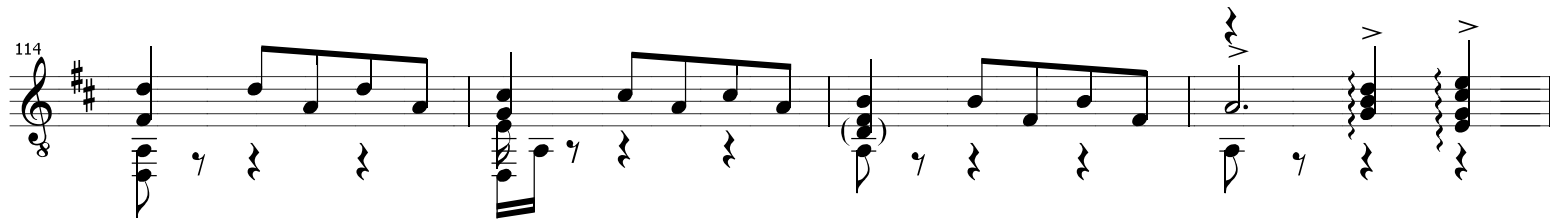

sempreaccel. e cresc. pocopiù $\boldsymbol{f}$

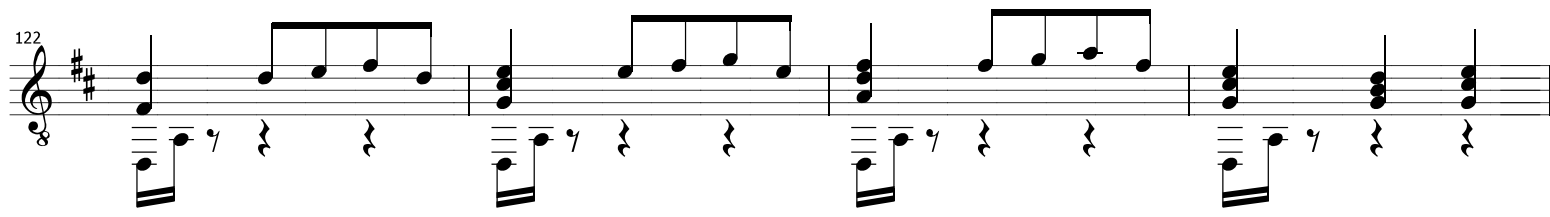

(6)
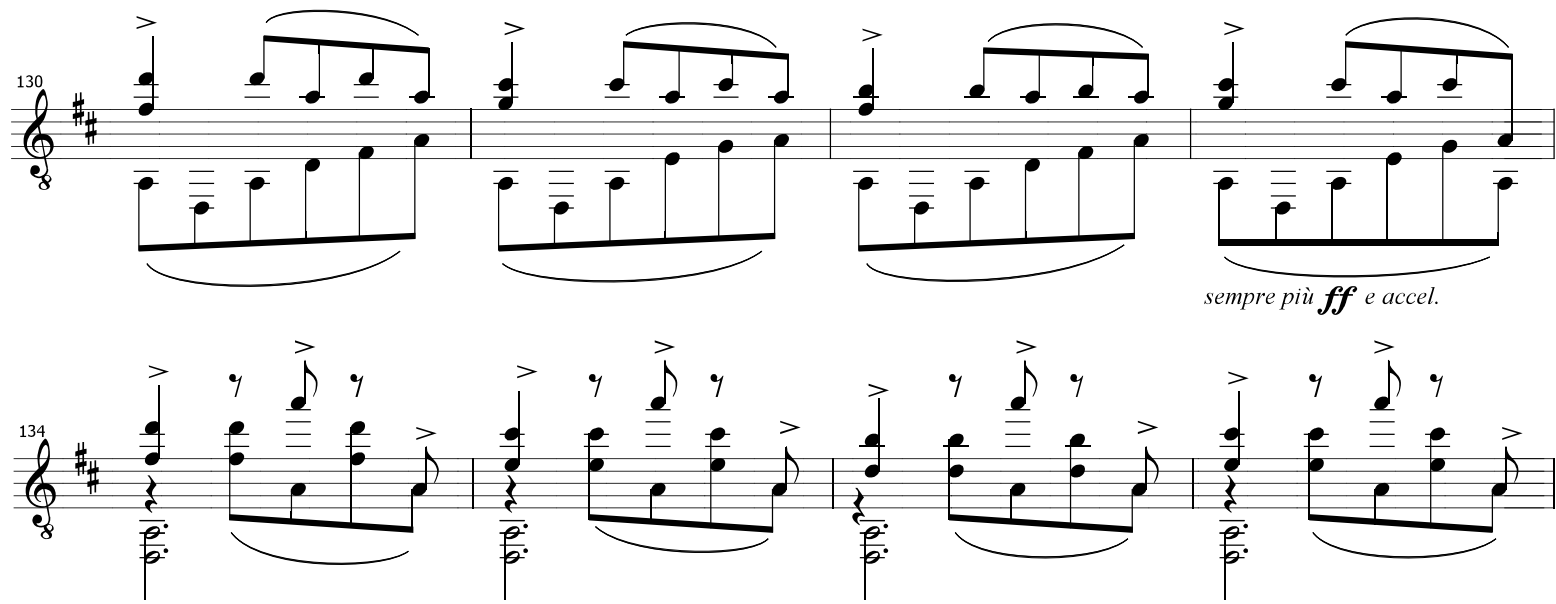


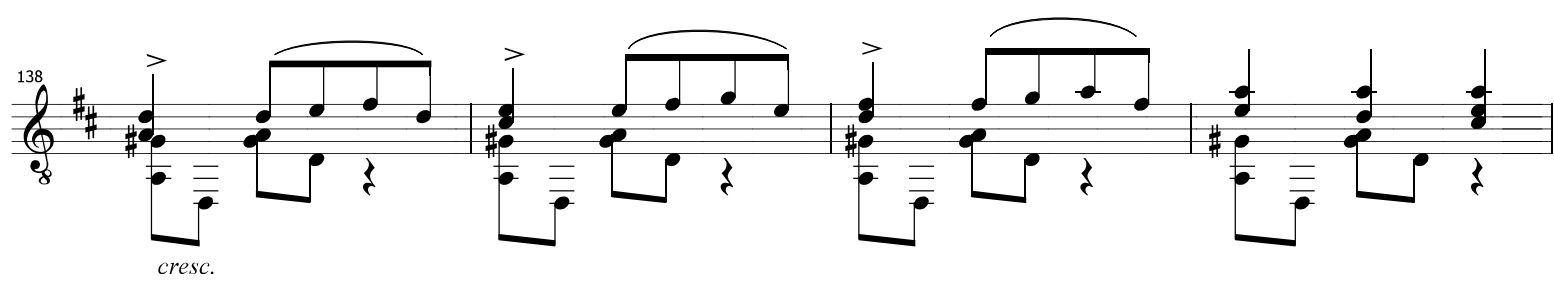

fff $>$ (6)

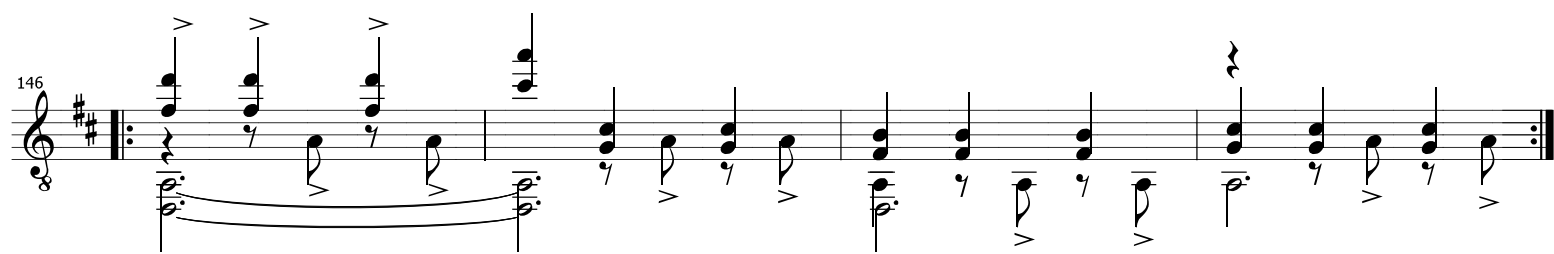
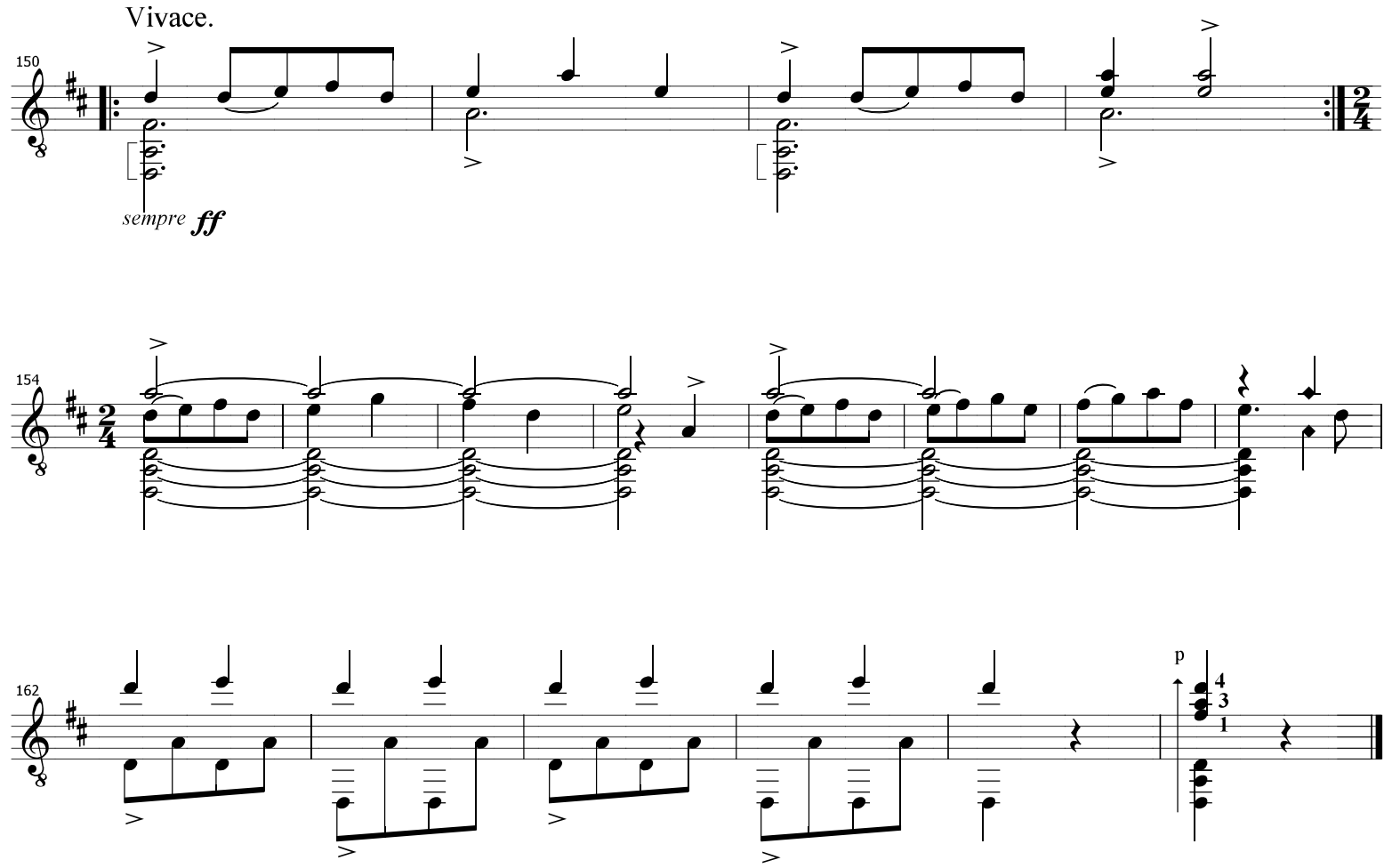


\subsection{Danza $n^{07}$}

Tonalidade original e da transcrição: Sol Maior

Scordatura utilizada:

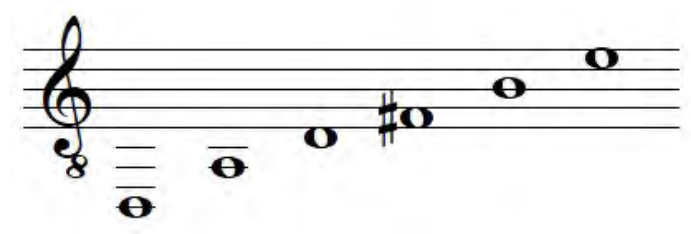

Consideramos em nossa transcrição da Danza $n^{\circ 7}$ as alterações não publicadas de Granados, apontadas no capítulo 2.7.

O grande desafio na transcrição desta peça foi encontrar uma scordatura que possibilitasse uma adaptação eficiente de suas três sessões. As armaduras de clave das sessões "A" e "C" (Sol Maior e Ré Maior, respectivamente) são próximas, enquanto a seção "B", em Si Maior, possui maior diferença de material intervalar. Era necessária uma configuração de afinação equilibrada entre as três tonalidades; essa scordatura proposta, agora com a terceira corda em Fá sustenido e a sexta corda em Ré, foi de grande auxílio, principalmente durante a seção em Si Maior e Ré Maior. Na sequência, ilustramos alguns trechos de nossa adaptação (Figura 69, 70 e 71). 
Figura 69 - compassos 48 - 55 da Danza $n^{\circ 7}$
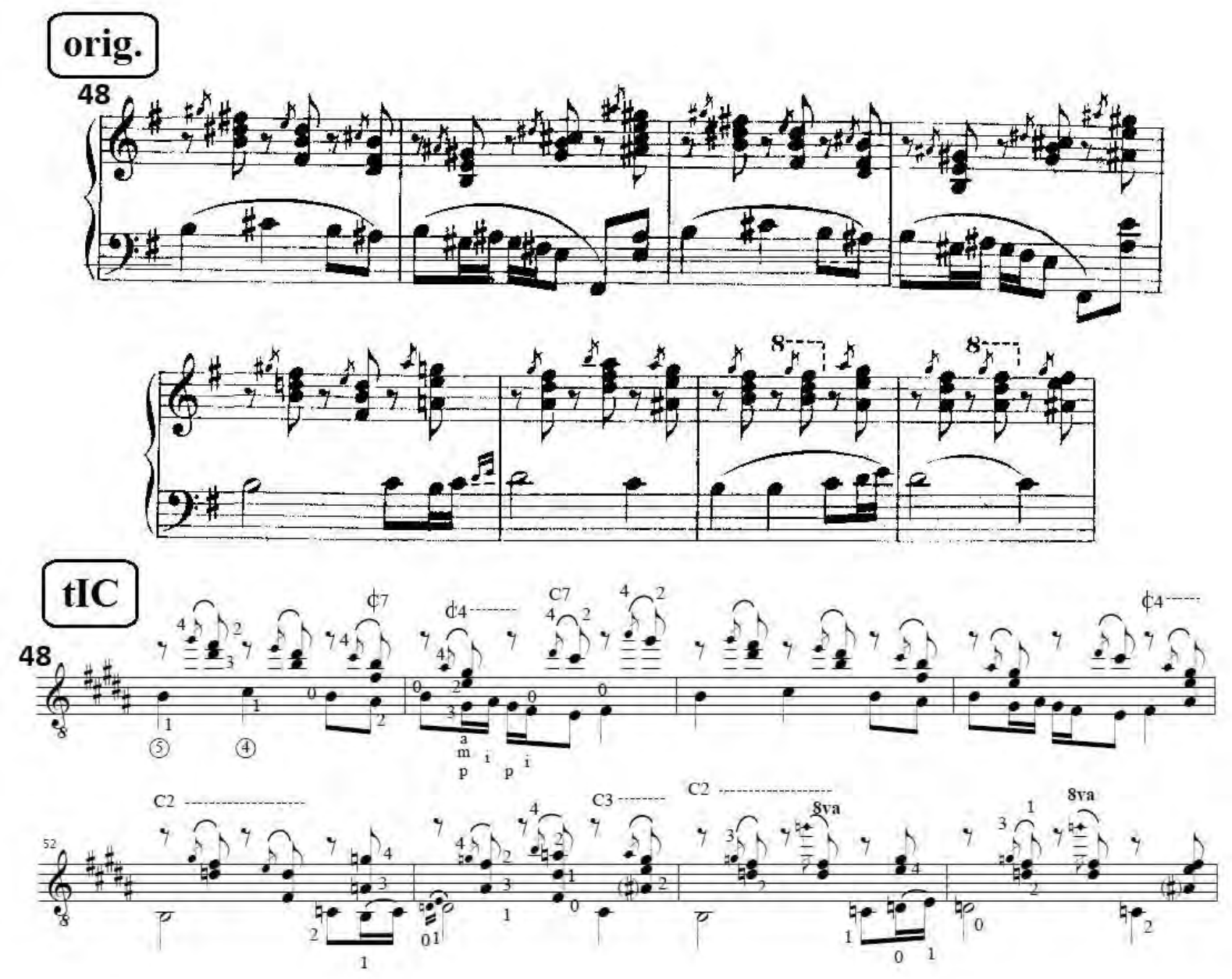

Fonte: elaborada pelo autor 


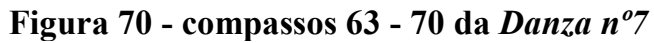

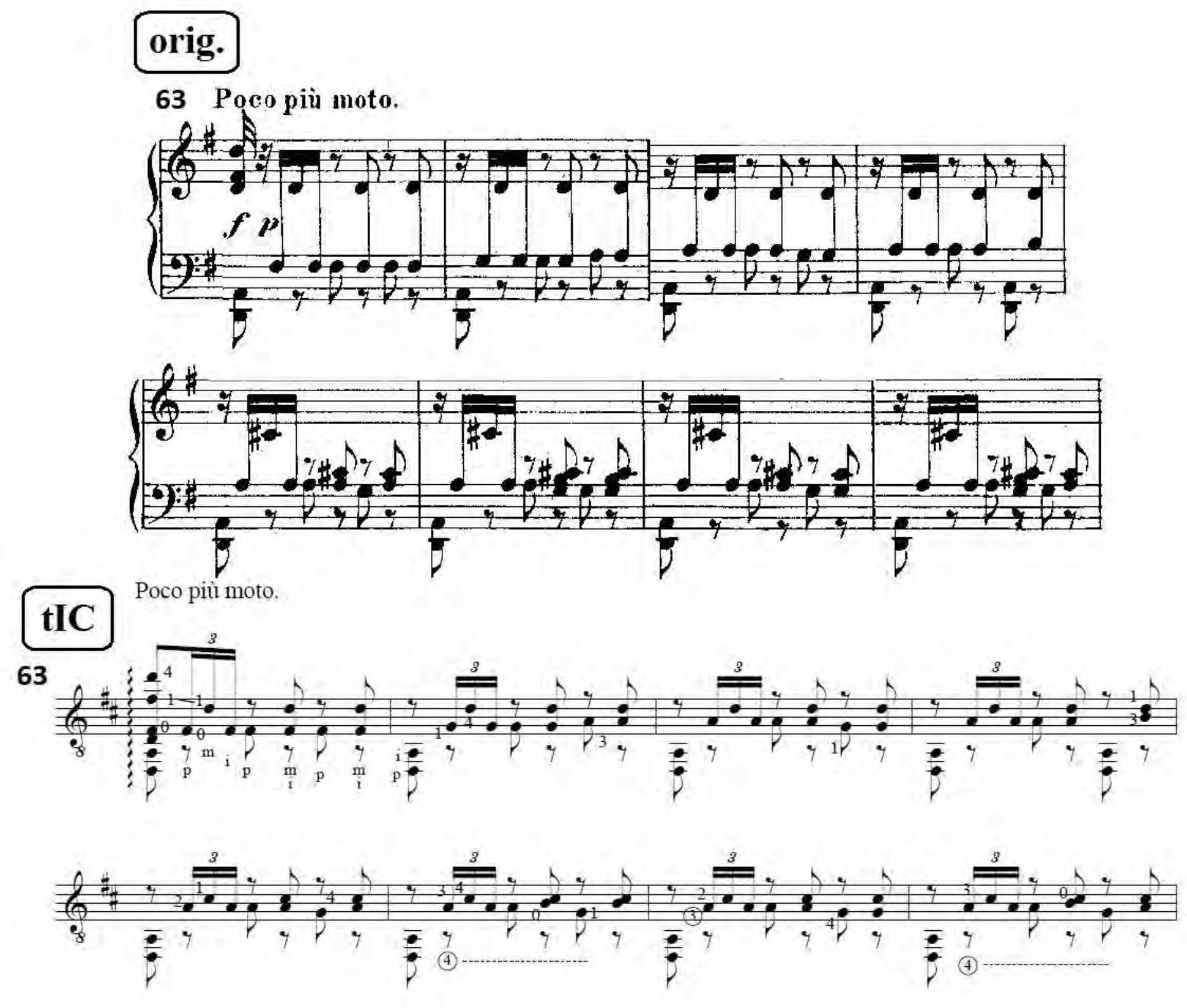

Fonte: elaborada pelo autor 

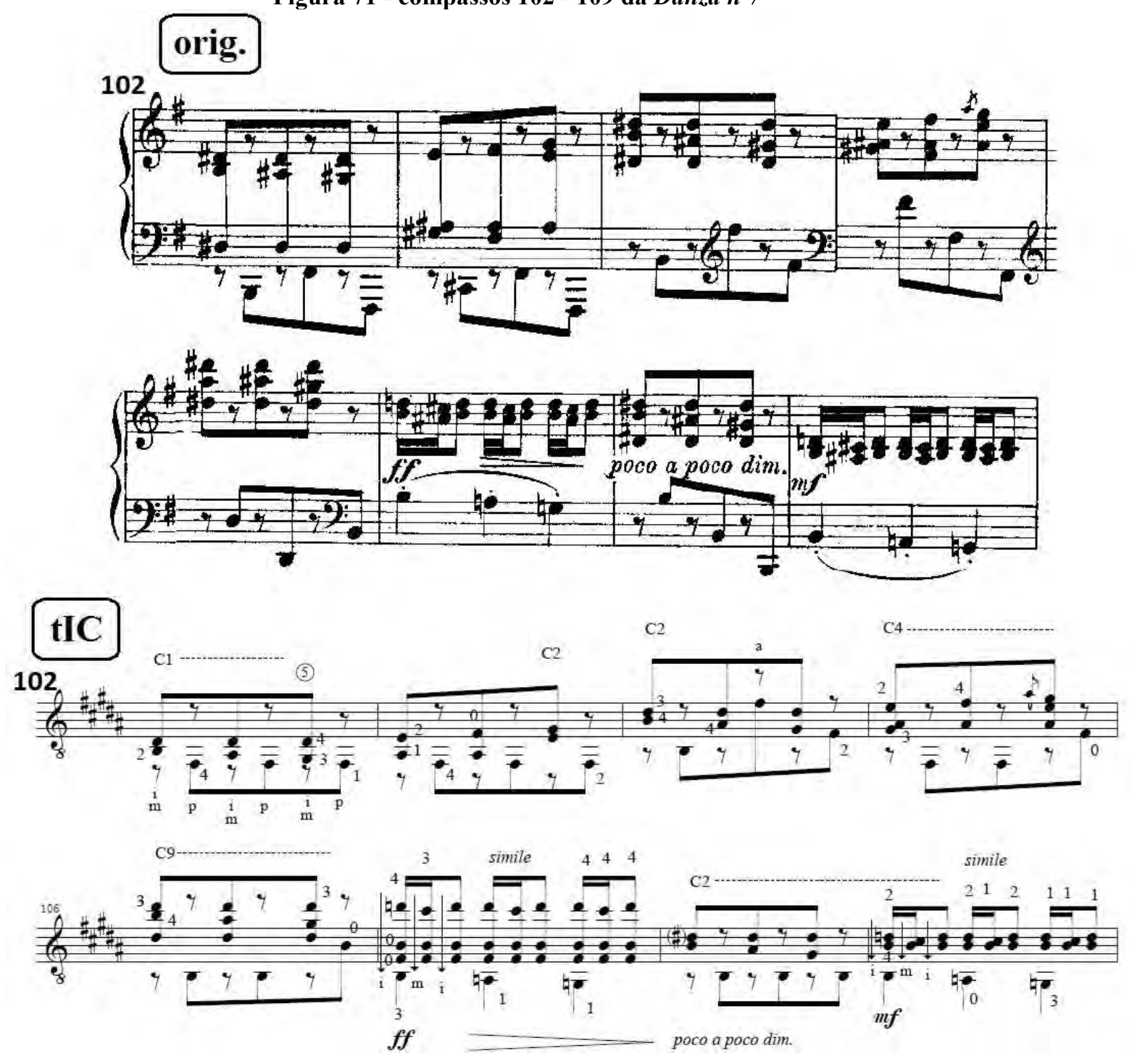

Fonte: elaborada pelo autor

Embora essa nova proposta de scordatura tenha resolvido algumas dificuldades, foi necessário reimaginar como algumas ideias musicais seriam realizadas caso tivessem sido concebidas ao violão, e em acréscimo, com essa nova proposta de scordatura. 


\section{Op.37 \\ 7.Valenciana}

Transcrição para violão de Iury Cardoso

Enrique Granados

Allegro airoso
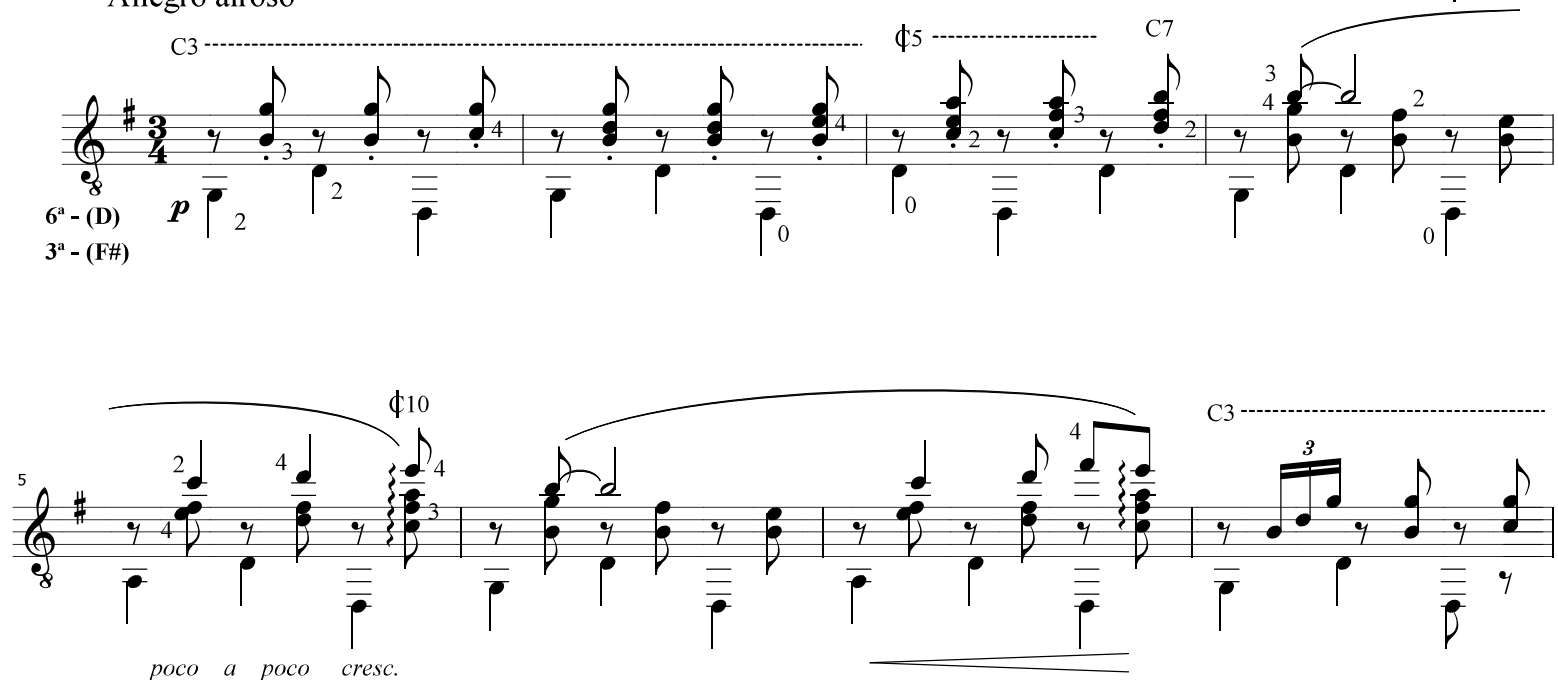

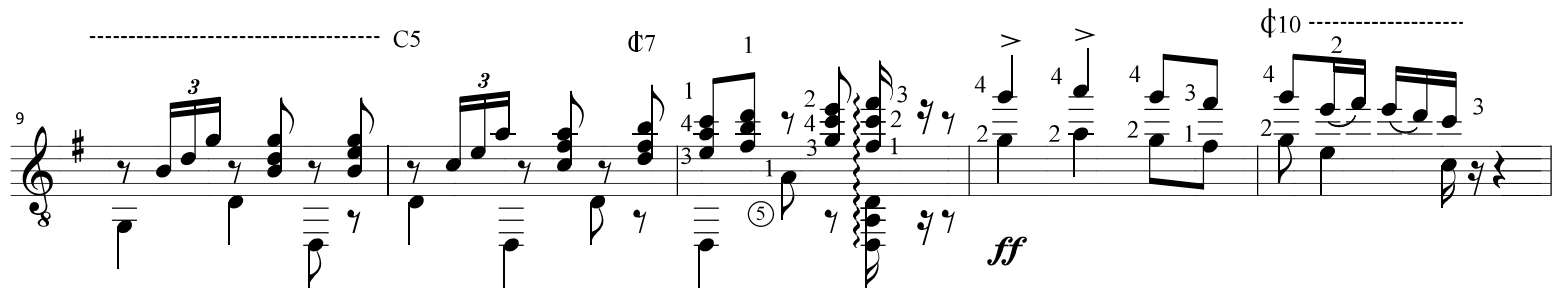
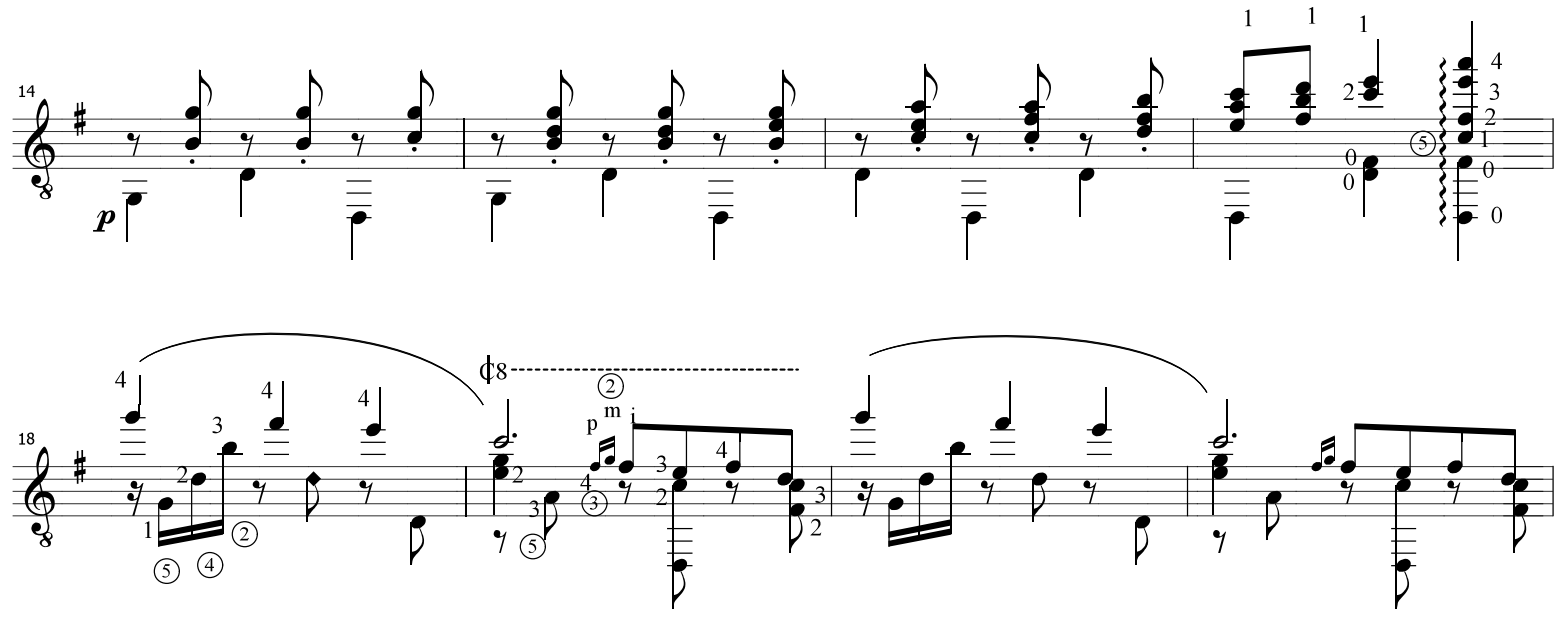
cresc.

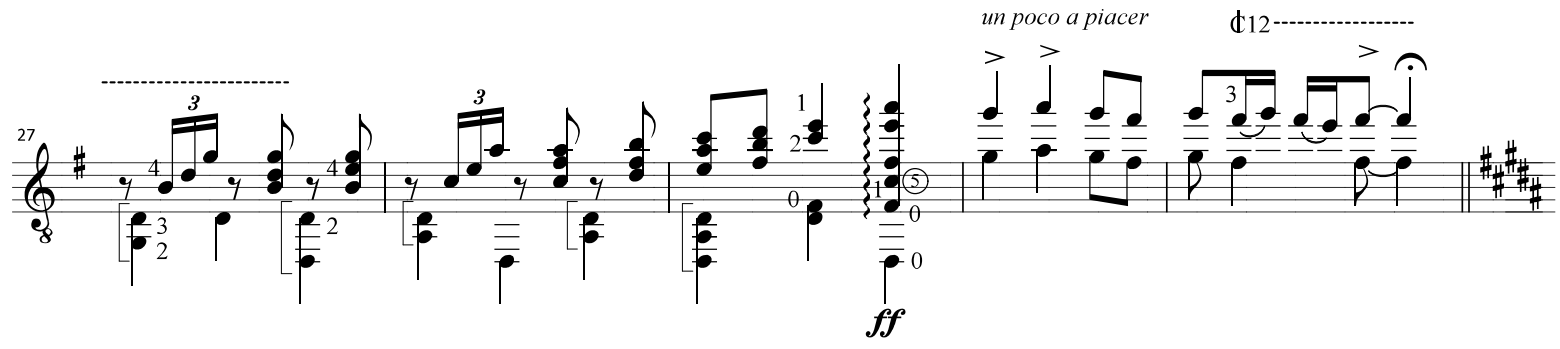
要 poco cresc.
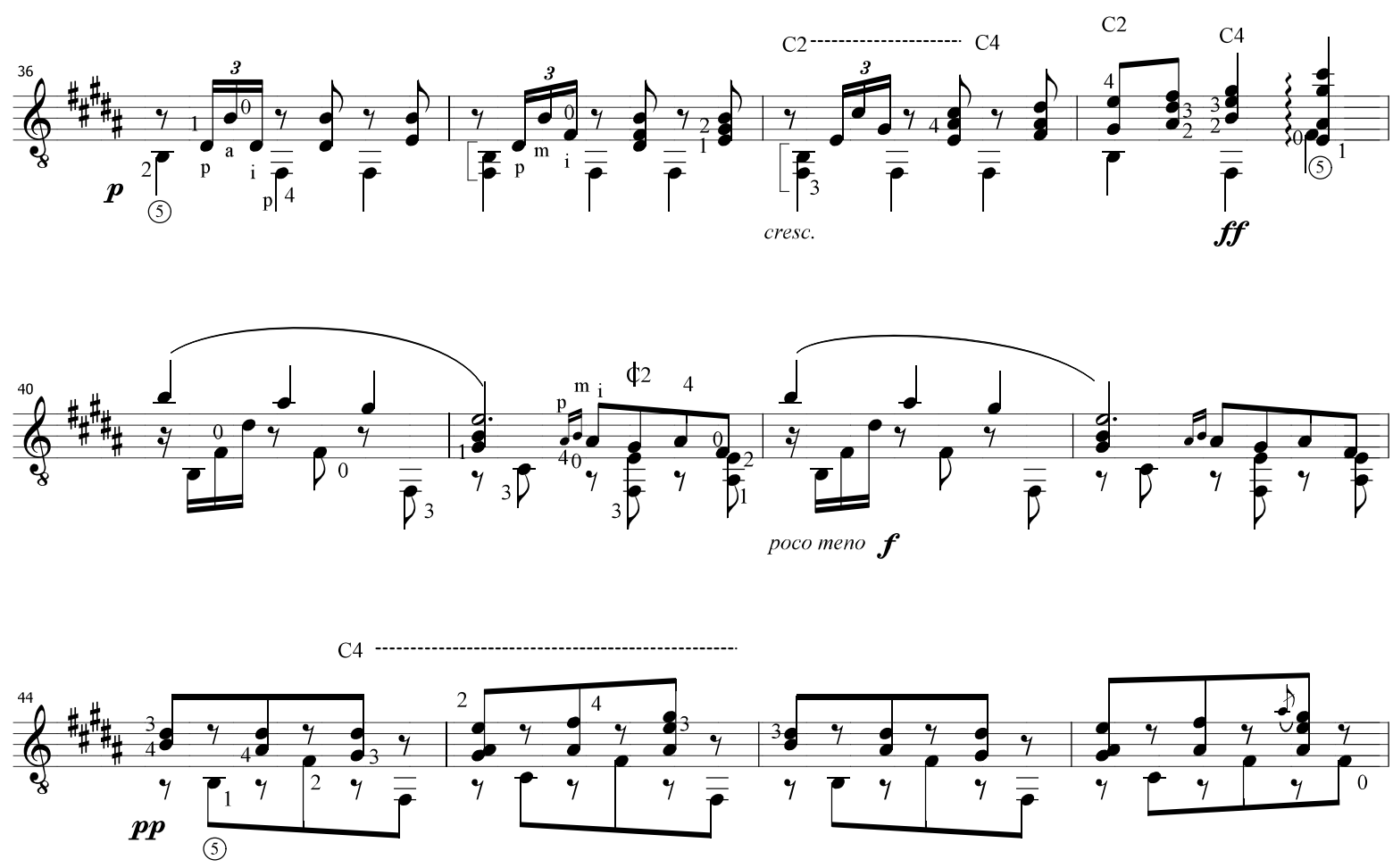
每

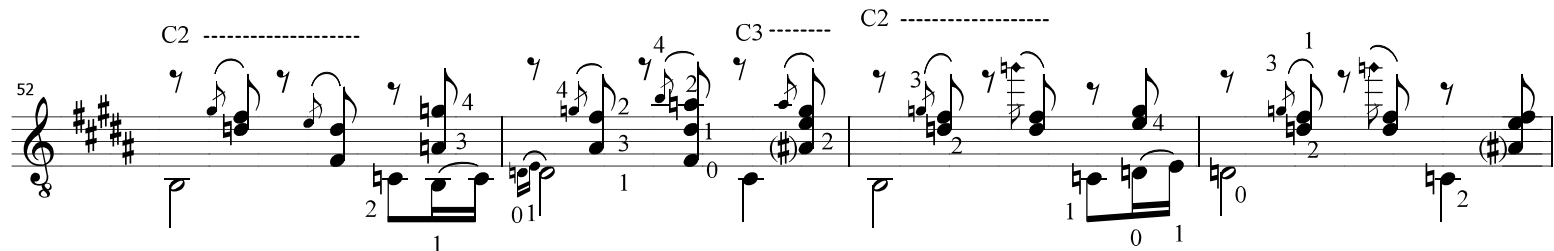
$\frac{b_{8}}{b_{0}}$ $b_{0}$ Poco più moto.

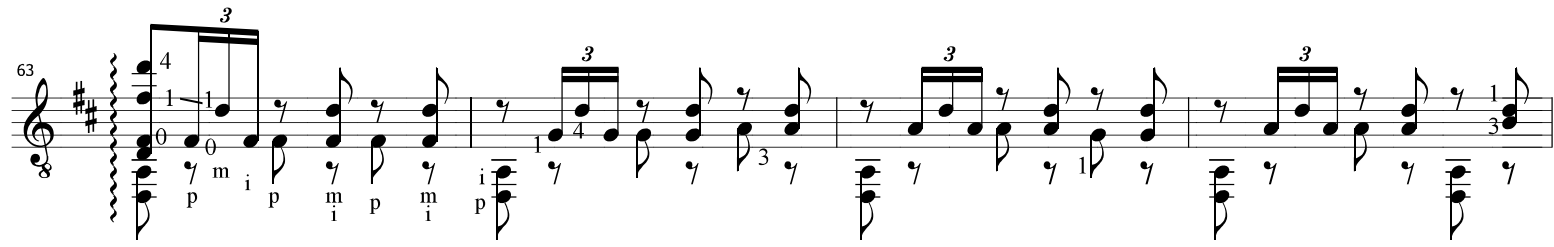

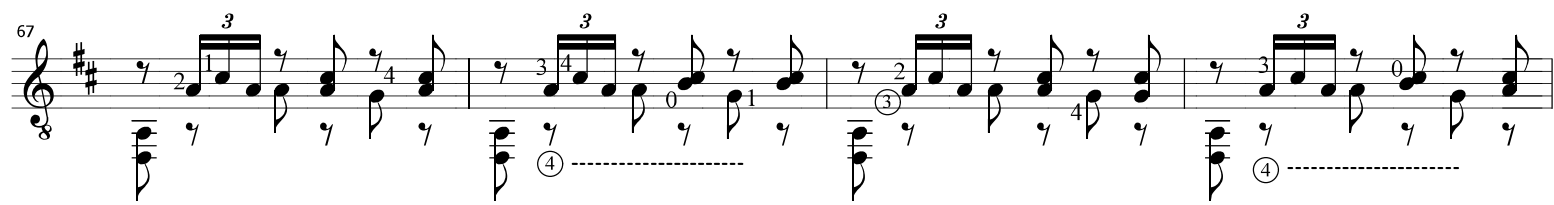


急
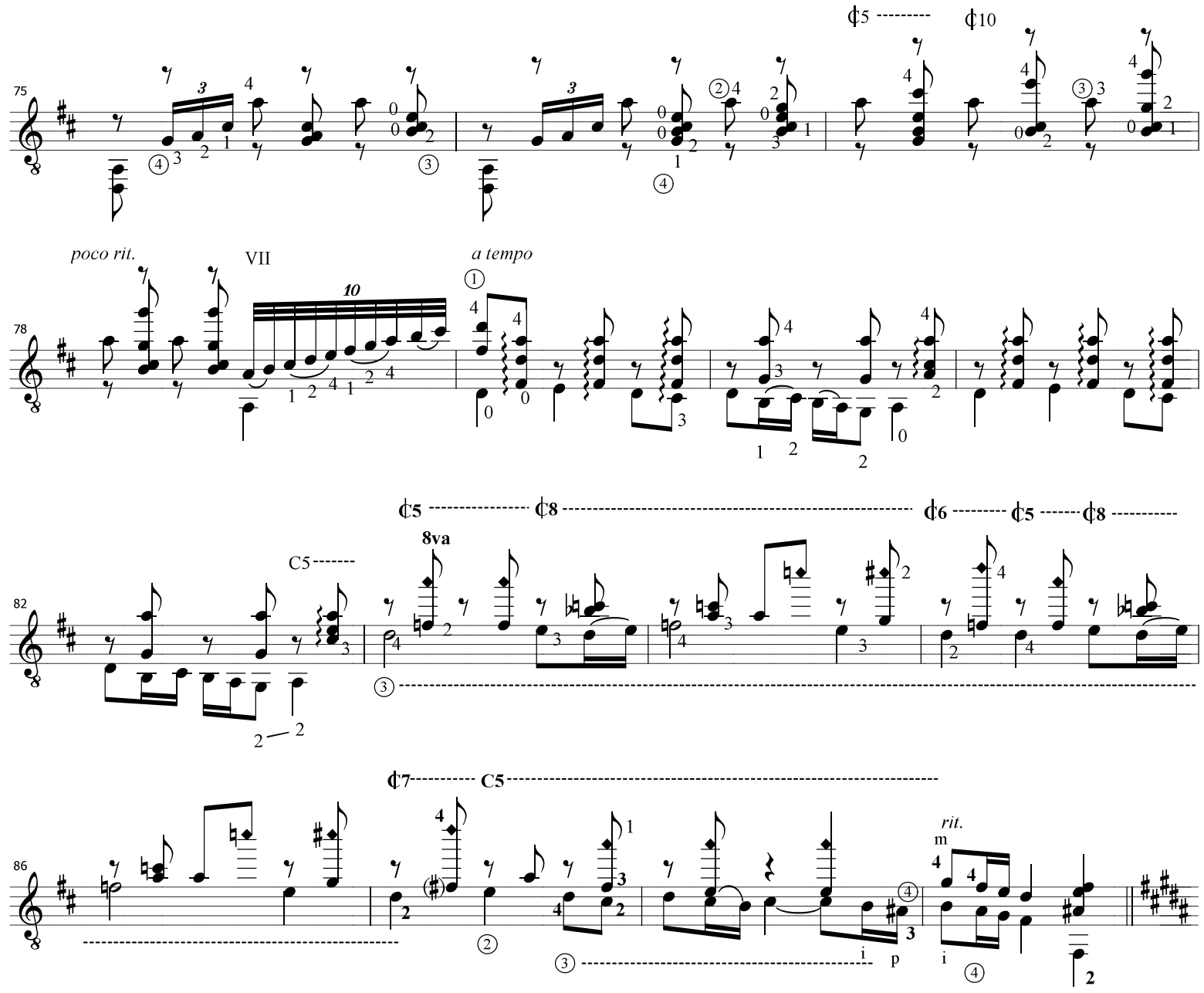

Tempo I.

$\oint_{8}^{b_{1}}$ 


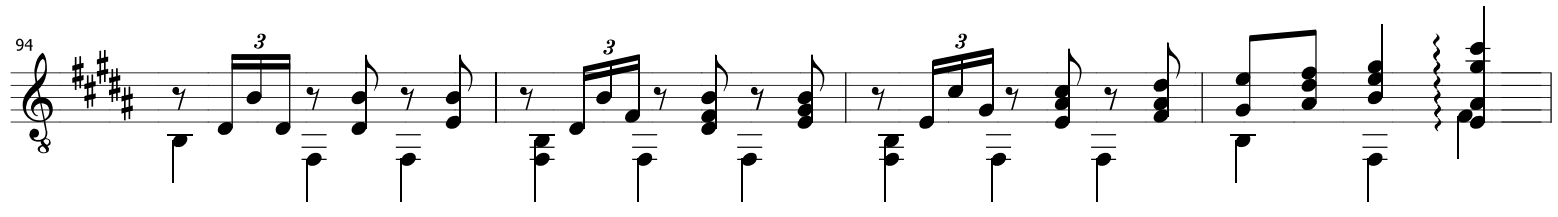
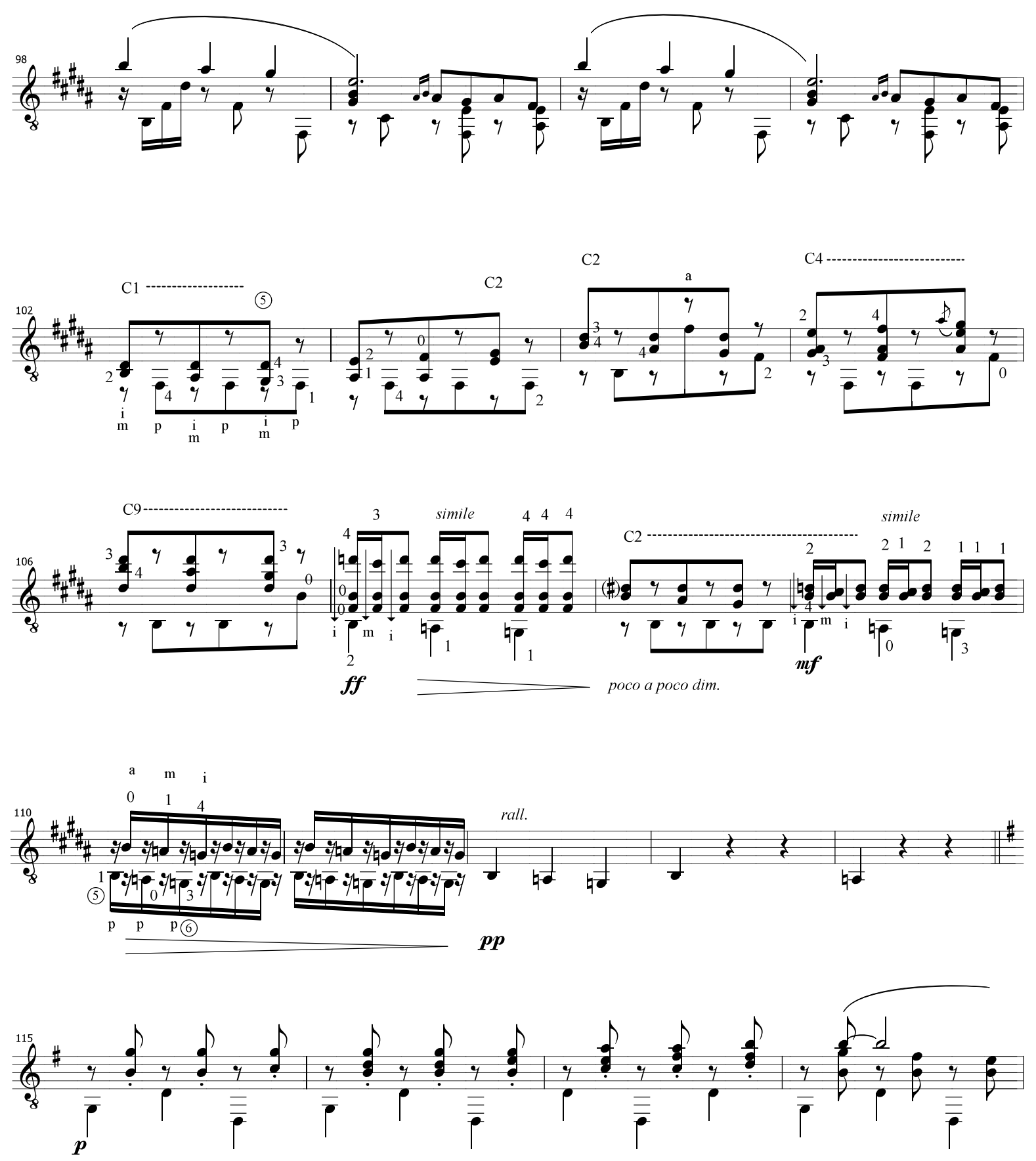


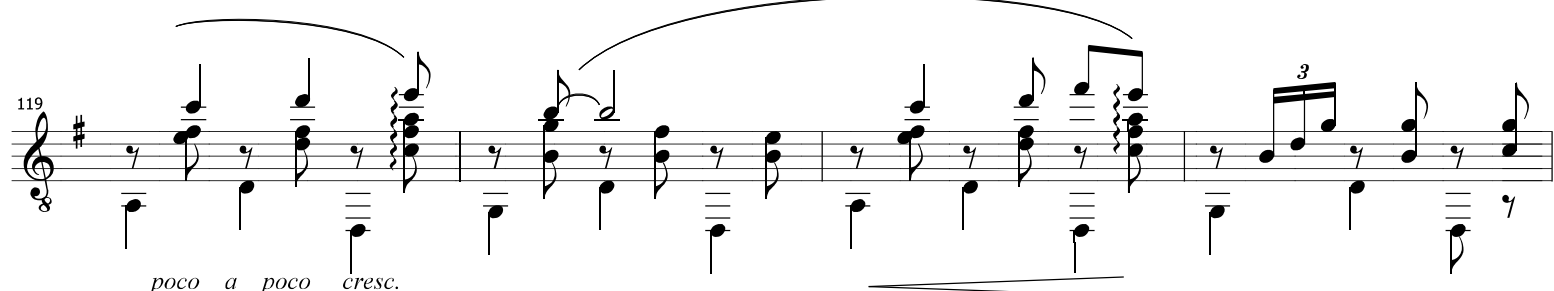

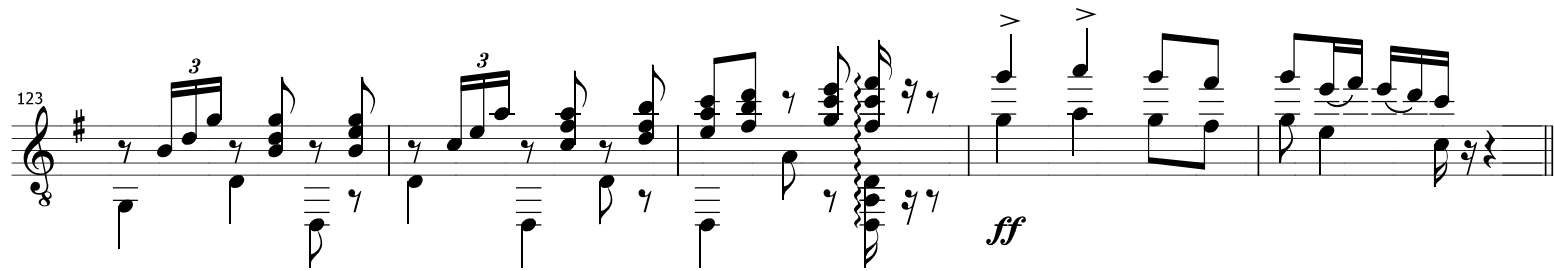

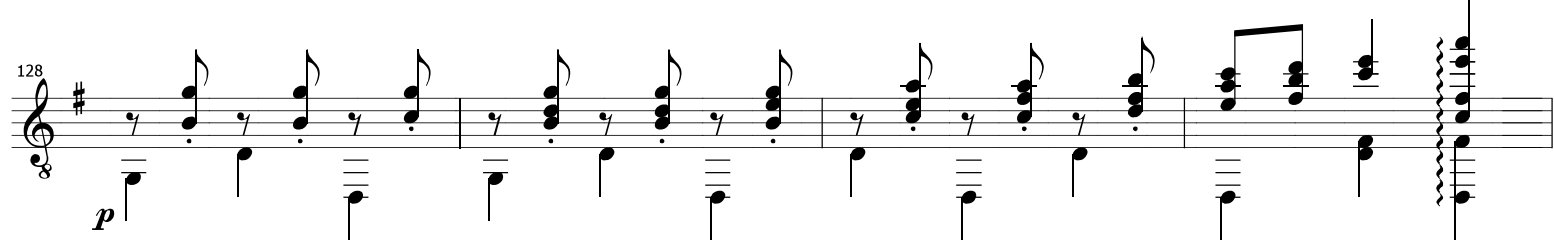

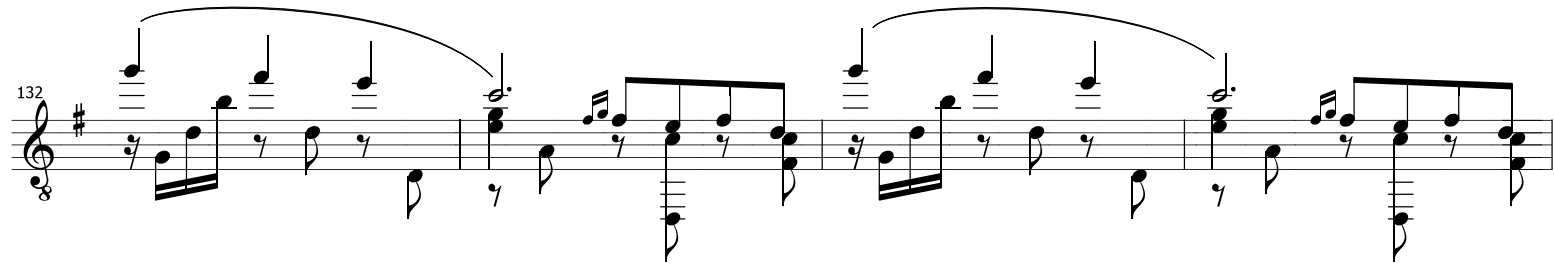

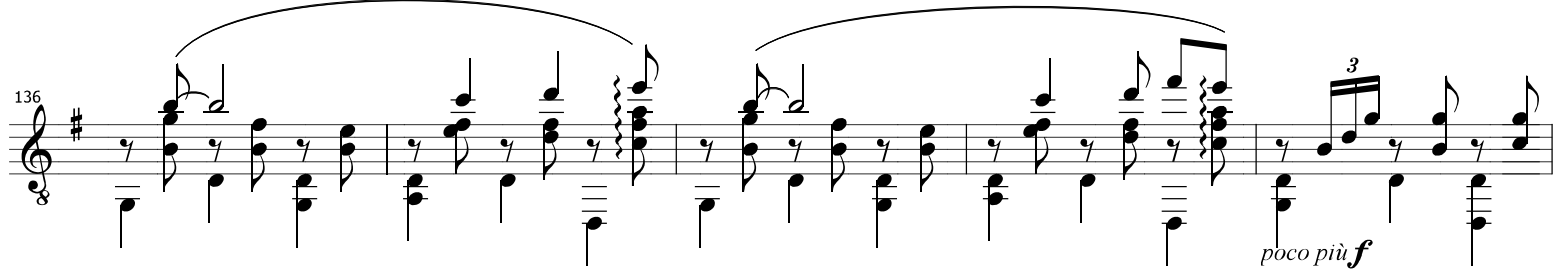

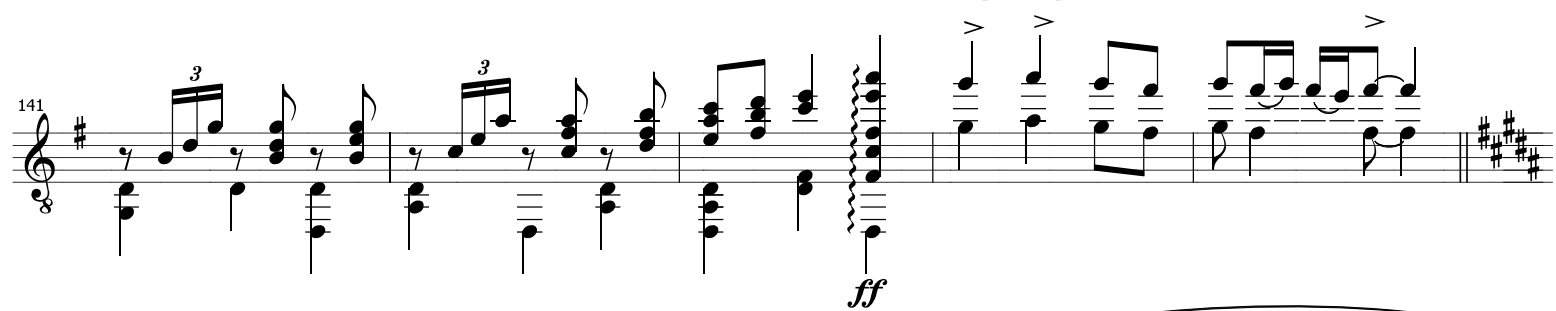
$\oint_{8}^{146}$ 


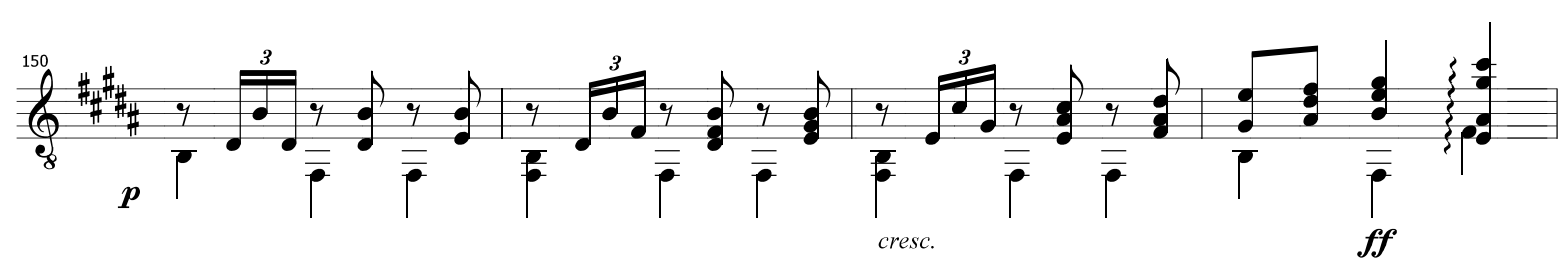

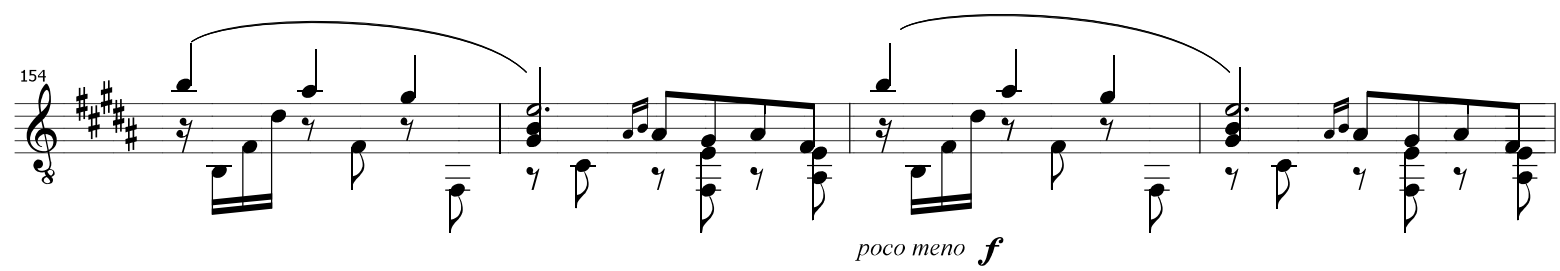

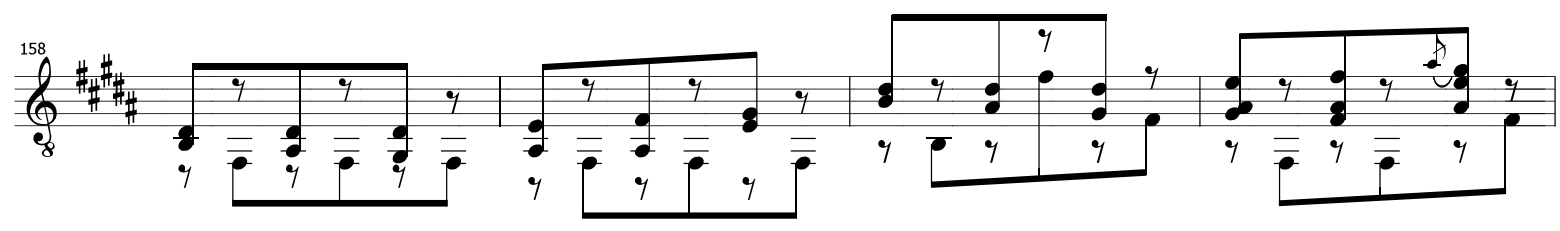

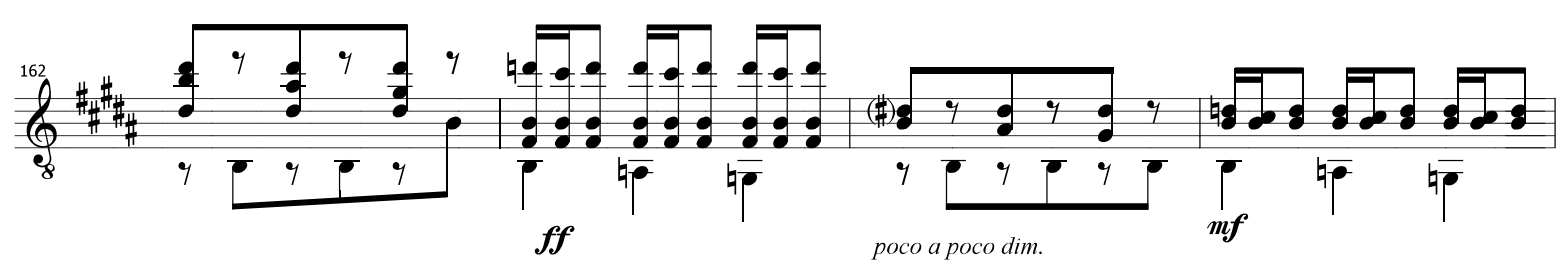

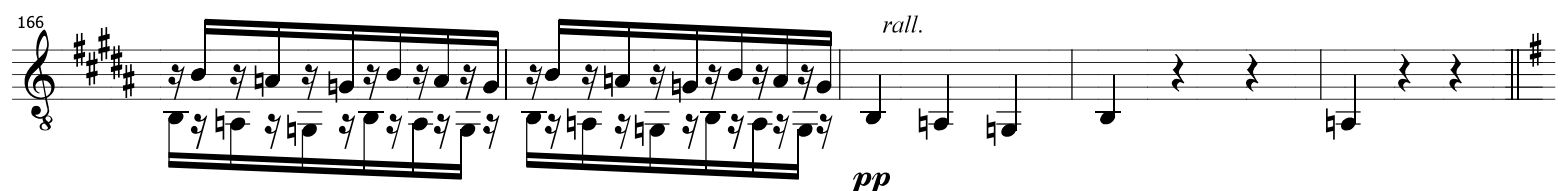

Andante.

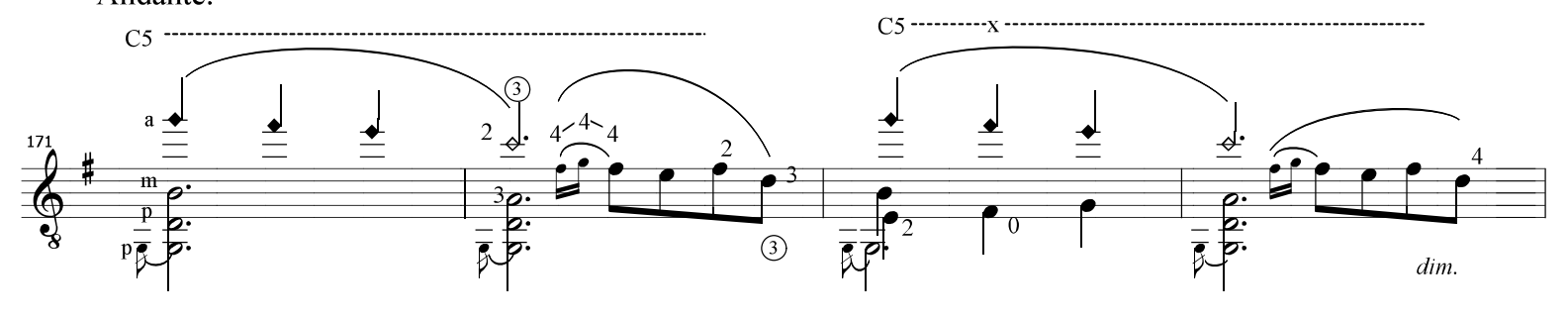

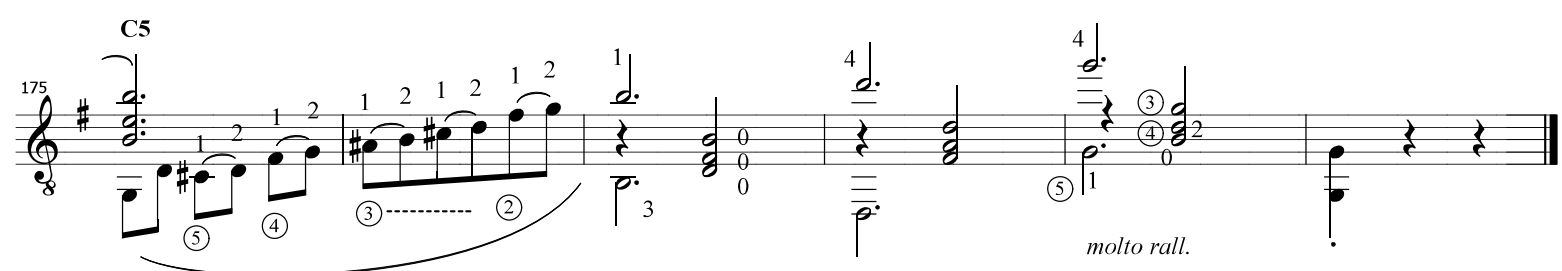




\section{$5.8 \operatorname{Danza}^{\circ} 8$}

Tonalidade original: Dó Maior

Tonalidade da transcrição: Ré Maior

Scordatura utilizada:

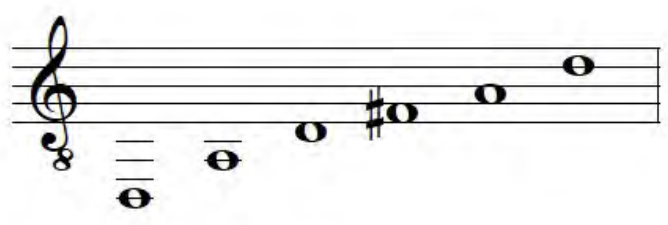

Nossa preocupação inicial ao transcrever $a$ Danza $n^{\circ} 8$ era reproduzir algumas características do ambiente sonoro gerado pelo pedal de sustentação do piano. Justamente, por não termos essa possibilidade acústica no violão, a importância de uma scordatura que propiciasse uma ressonância adequada na maioria dos trechos da peça era essencial. Deveria também, garantir a exequibilidade do material musical proposto e suas variações de texturas.

Podemos observar durante toda a seção "A" a repetição de um movimento harmônico pendular constante entre os acordes de Dó Maior e Sol menor com sétima, dentro de um pedal de Dó (Figura 72). 
Figura 72 - Movimento harmônico pendular na Danza $n^{\circ} 8$

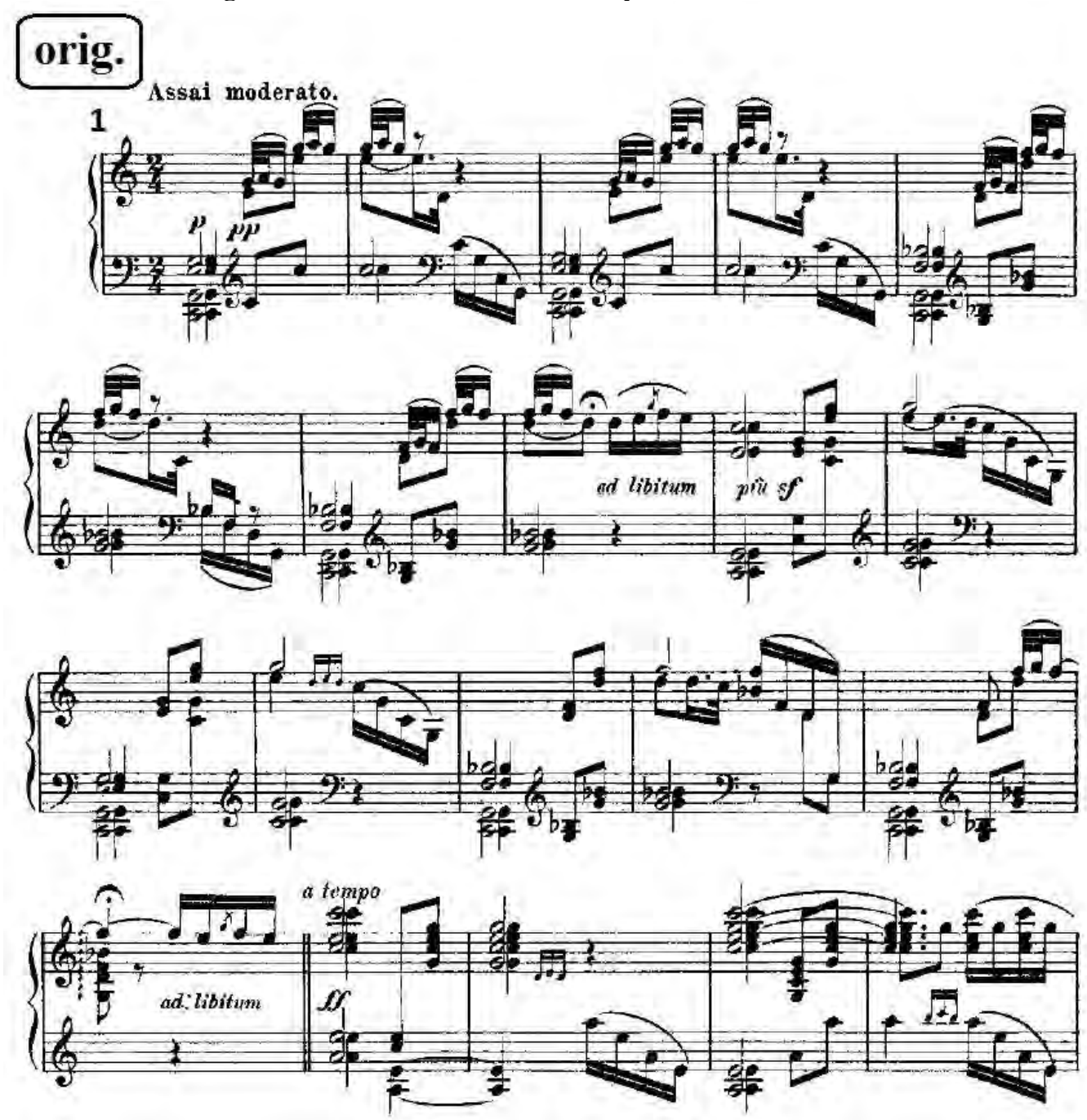

Fonte: elaborada pelo autor

Considerando esse aspecto harmônico, inicialmente foram testadas algumas opções de scordature que formassem um acorde de Dó Maior com as cordas soltas, partindo de uma sexta corda afinada em sua tônica. Entretanto o resultado para a maioria das sessões foi bastante deficiente. Depois de diversas configurações testadas, a melhor opção encontrada por nós foi transpor a peça para Ré Maior e utilizar a scordatura indicada.

A partir daí a preocupação era proporcionar a ocorrência constante de ressonâncias, evitando qualquer tipo de interrupção das mesmas. Através da alteração da disposição das notas de alguns acordes, possibilitamos a presença constante de cordas soltas para apoiar a manutenção desse ambiente sonoro. Com isto, houve uma menor preocupação, principalmente em relação as mudanças de posição da mão esquerda, que provavelmente seriam responsáveis por cortes na ressonância. Tais aspectos poderão ser observados na transcrição a seguir. 


\section{Asturiana}

Transcrição para violão de Iury Cardoso
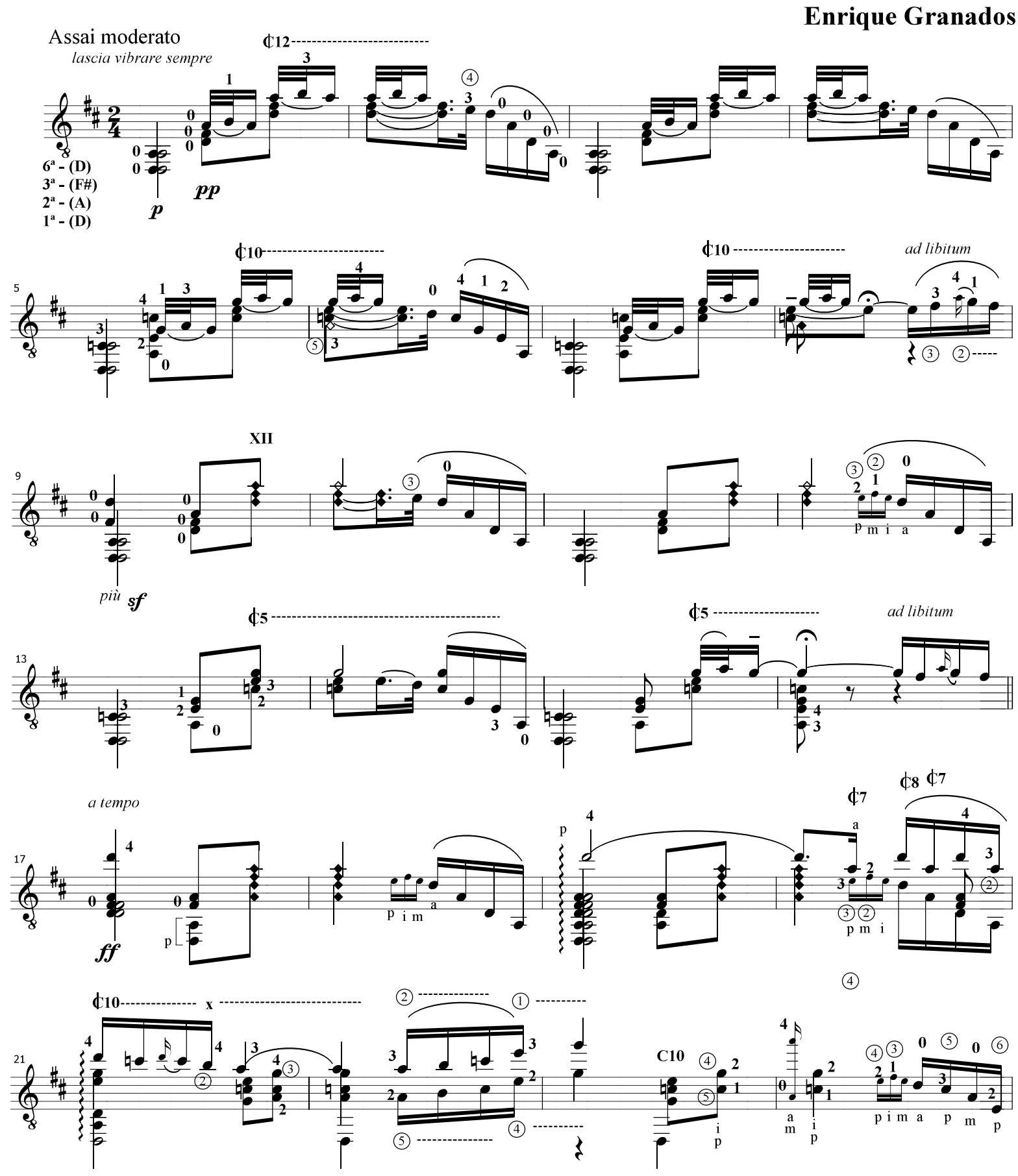


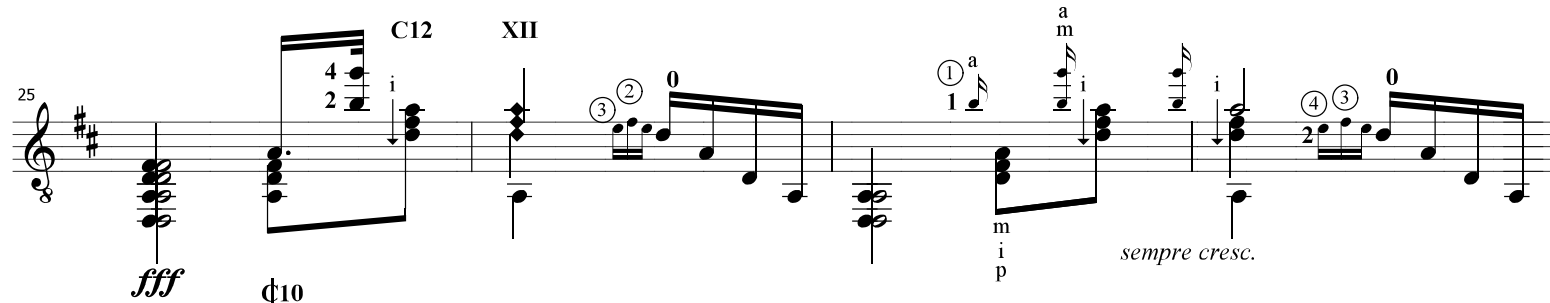

$e_{8}$
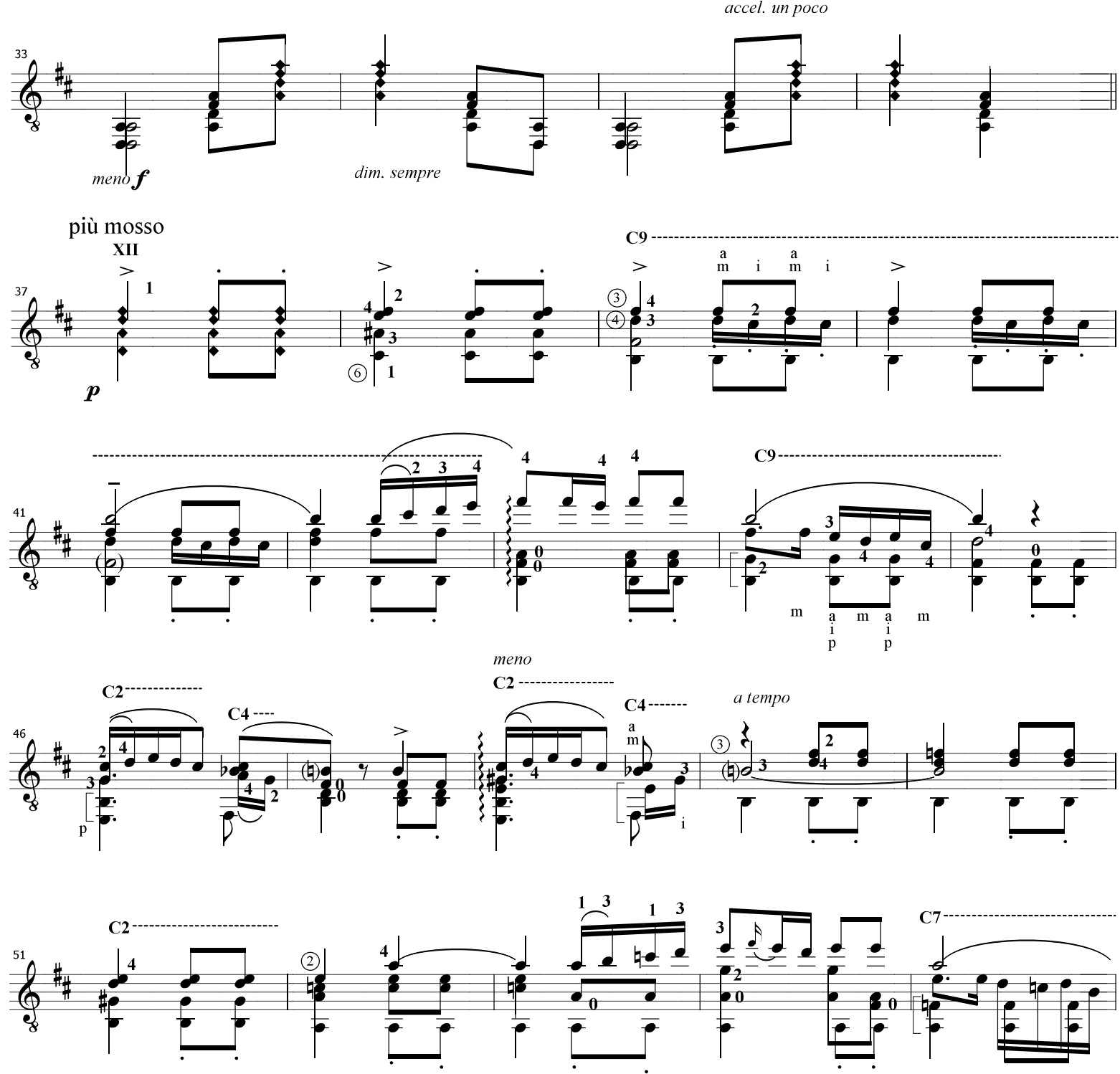

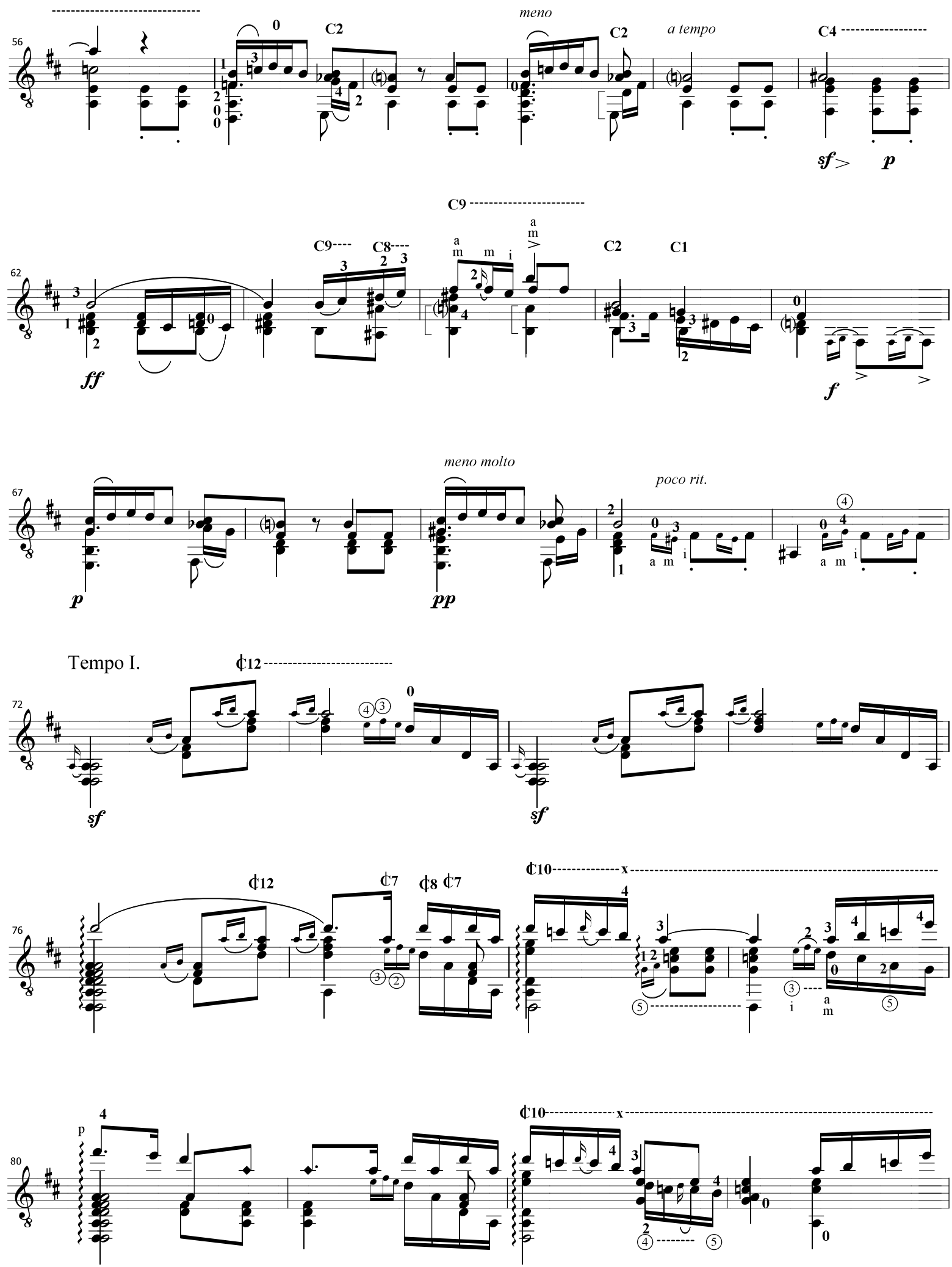


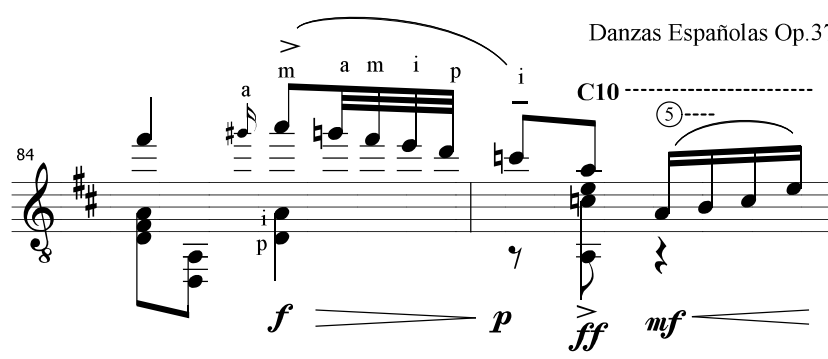

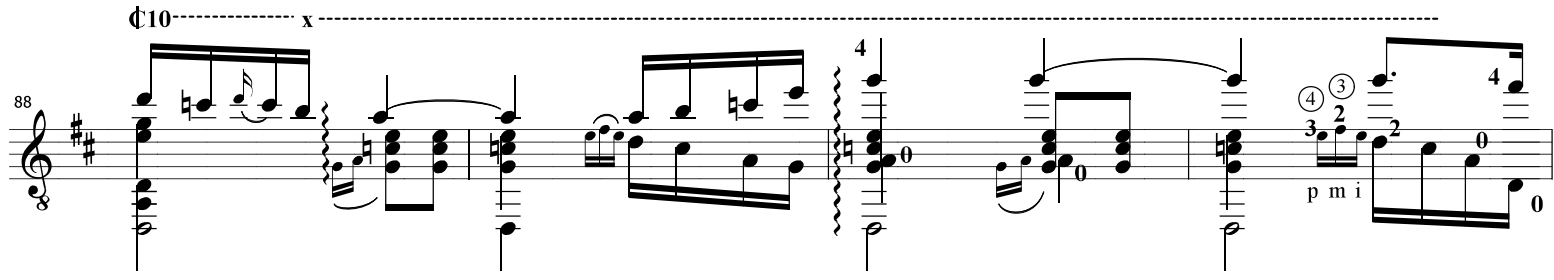
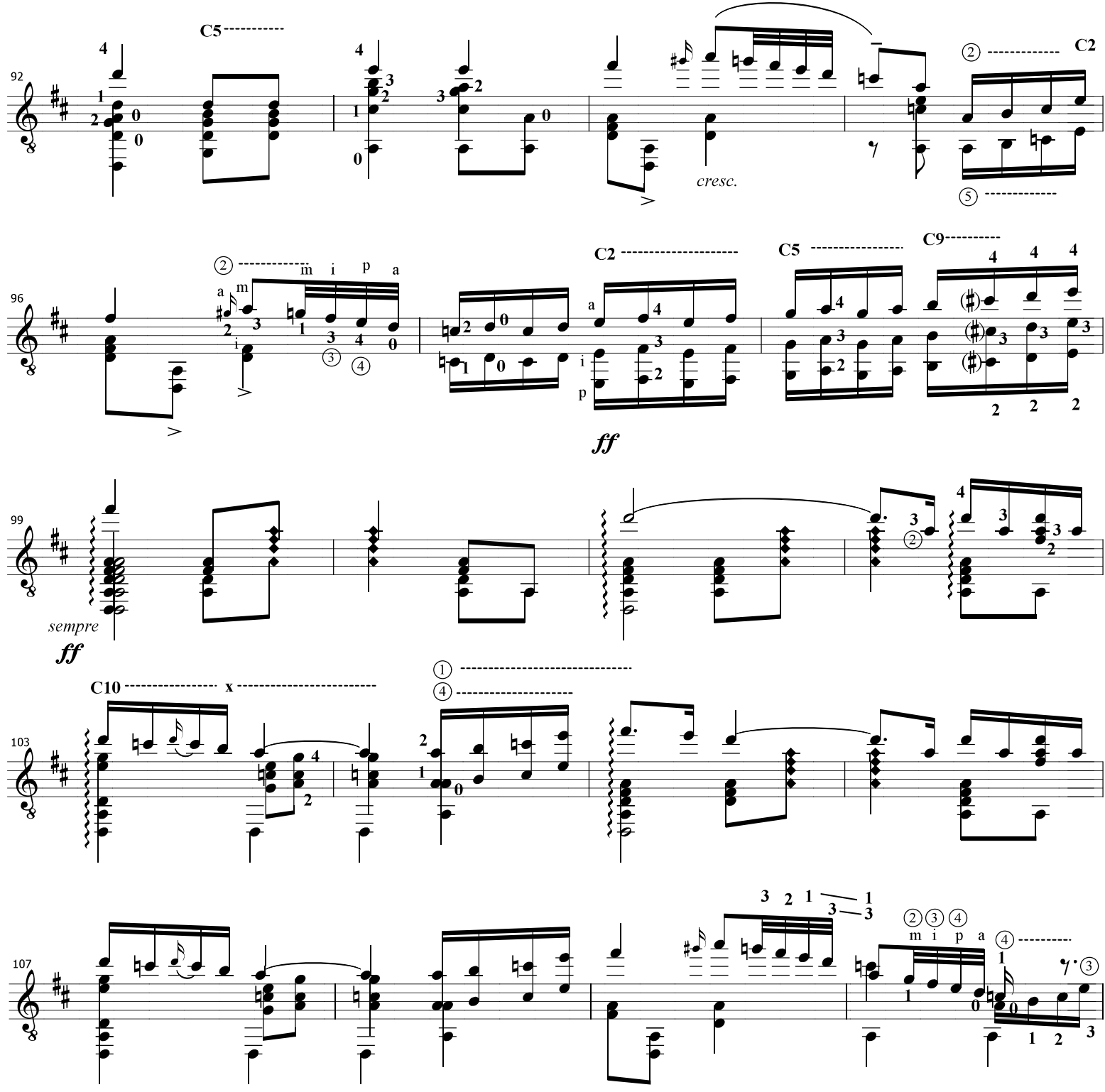

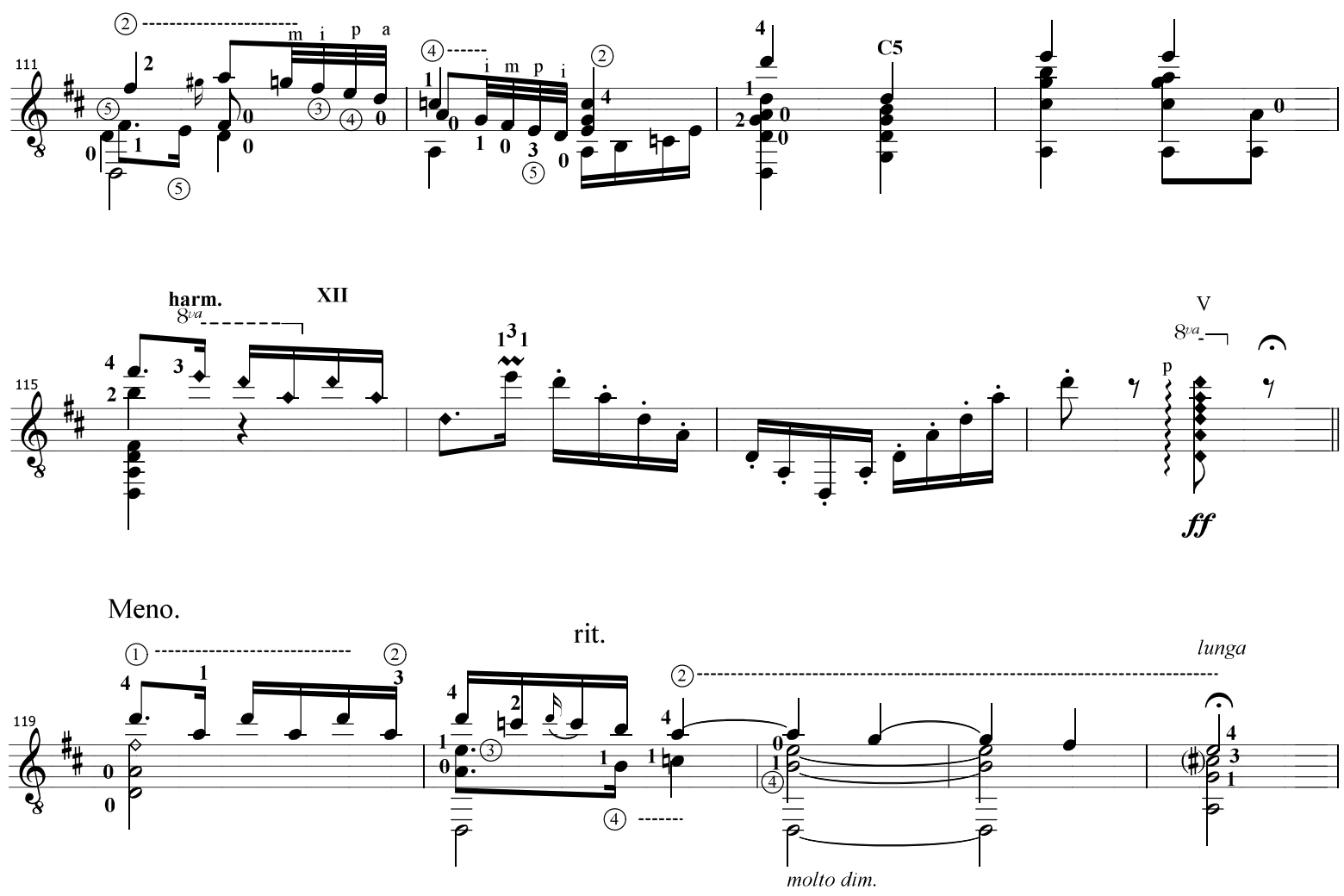

Allegro molto.
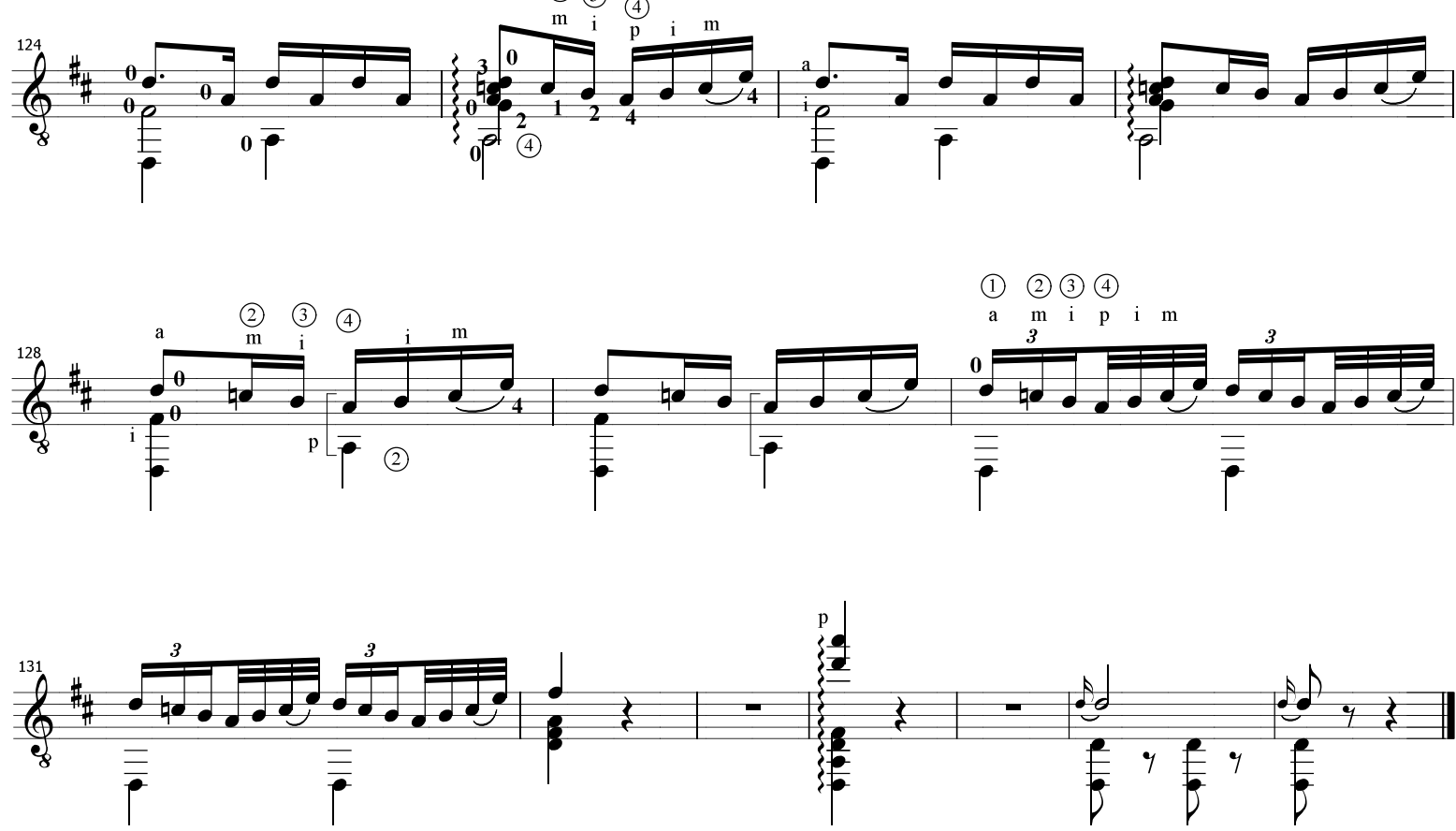


\subsection{Danza no9}

Tonalidade original: Si bemol Maior

Tonalidade da transcrição: Lá Maior

Scordatura utilizada:

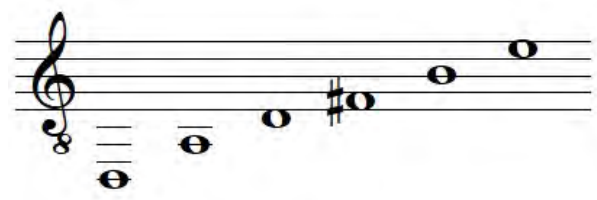

Opcional: Uso do capo tasto na casa 1 para atingir a tonalidade original.

O ajuste da terceira corda em Fá sustenido novamente se mostrou eficiente em possibilitar diferentes opções de dedilhados nos registros médio e agudo do violão.

Considerando as cordas soltas do instrumento, a nota Sol (terceira corda solta na afinação tradicional), não faz parte de nenhuma das sete tríades das funções harmônicas principais da tonalidade de La Maior. O Fá sustenido está presente em três delas. Obviamente, não só das funções principais se constitui a peça, mas a predominância delas é beneficiada com a disponibilidade de uma corda solta afinada em uma nota constituinte de sua formação.

Além das soluções de adaptação exemplificadas no capítulo 4, a scordatura em questão amenizou a dificuldade de uma importante passagem constituída de escalas e arpejos (Figura 73), assim como tornou mais exequível o contraponto da melodia com uma escala cromática (Figura 74). 
Figura 73 - Escalas e arpejos na Danza ${ }^{\circ} 9$
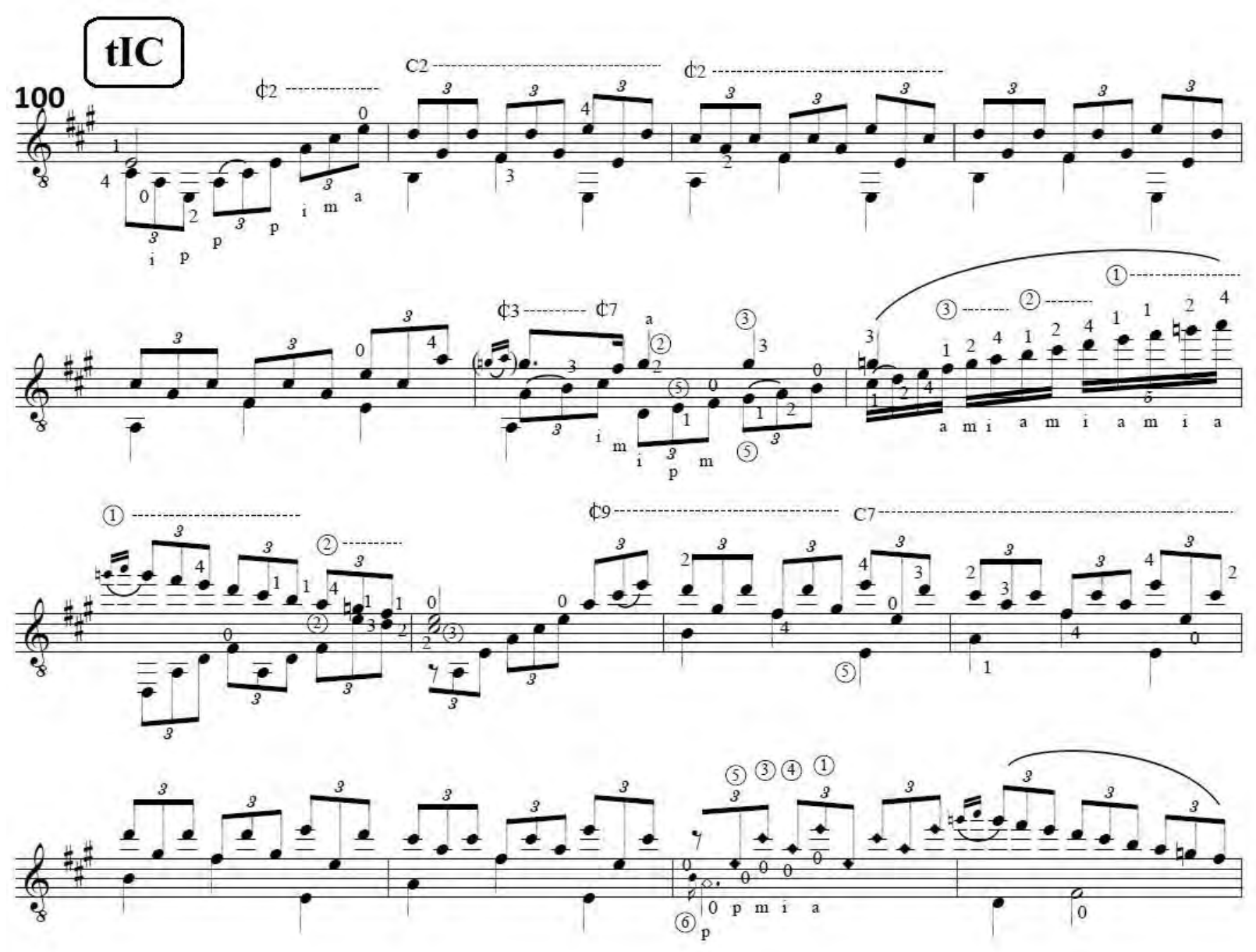

Fonte: elaborada pelo autor

Figura 74 - Contraponto cromático na Danza n $n^{\circ 9}$

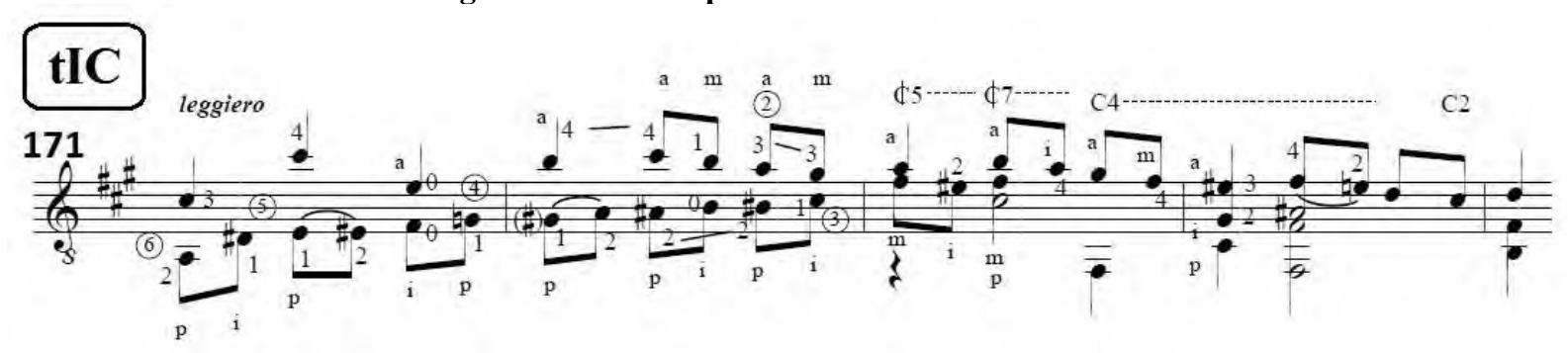

Fonte: elaborada pelo autor 


\section{Op.37 \\ 9.Mazurka}

Transcrição para violão de Iury Cardoso

Molto allegro brillante.

Enrique Granados
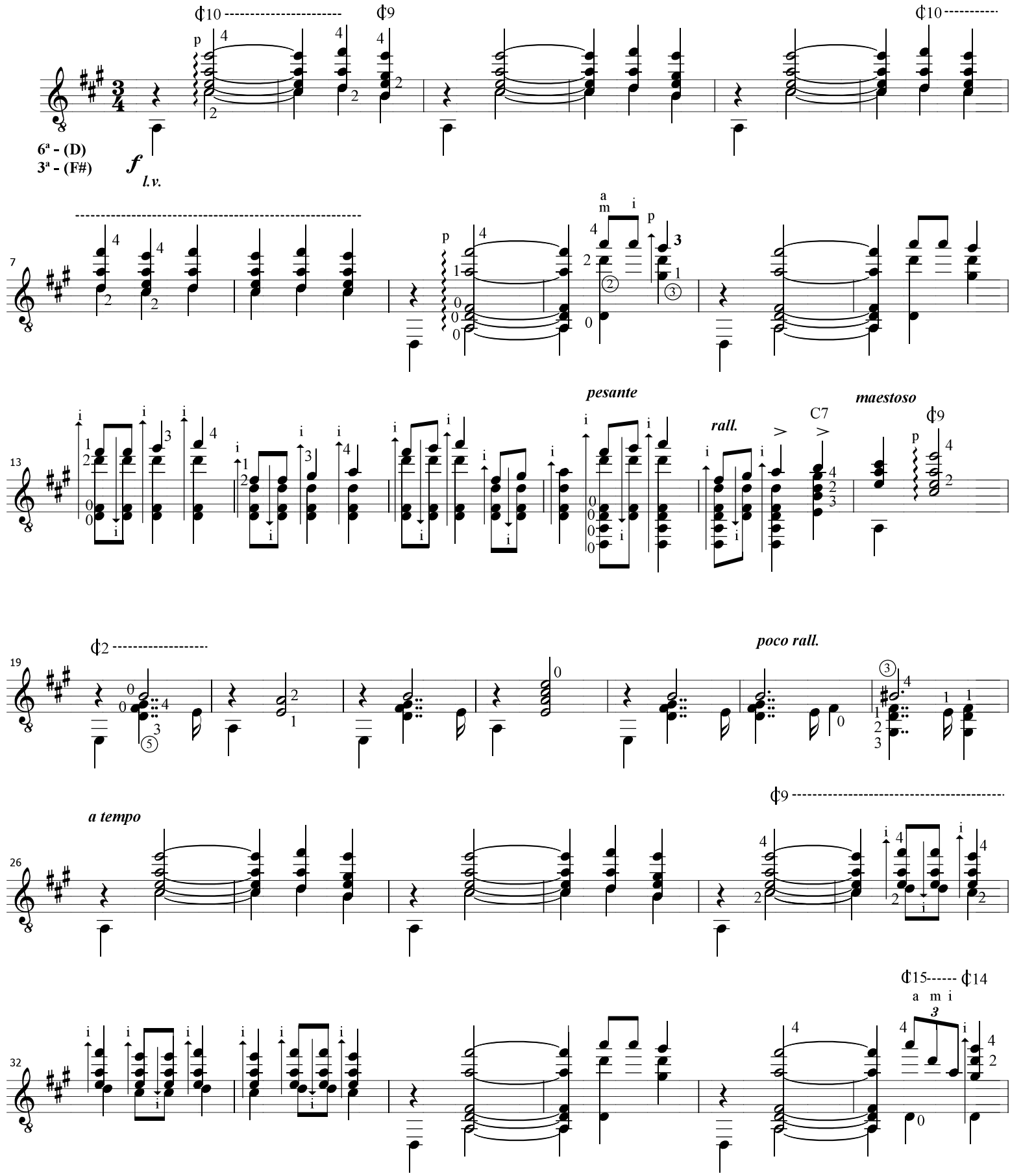


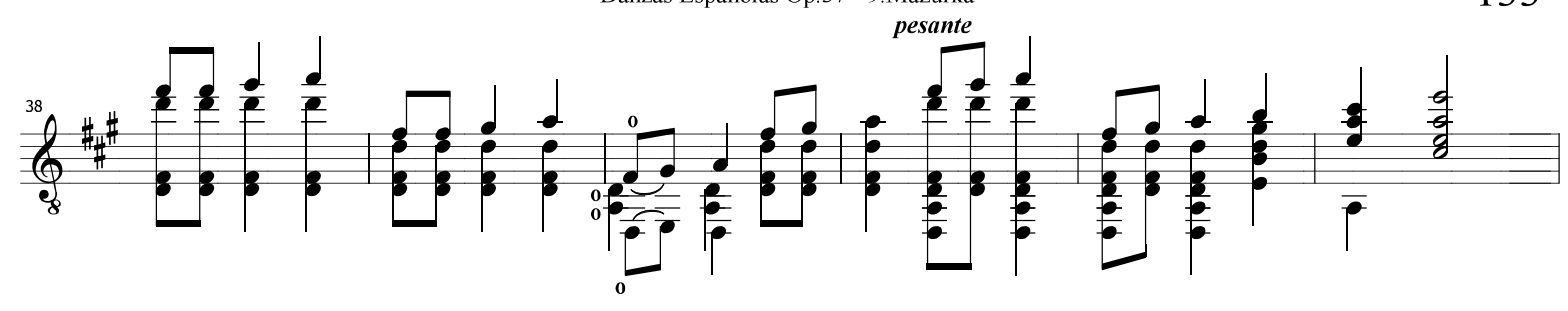

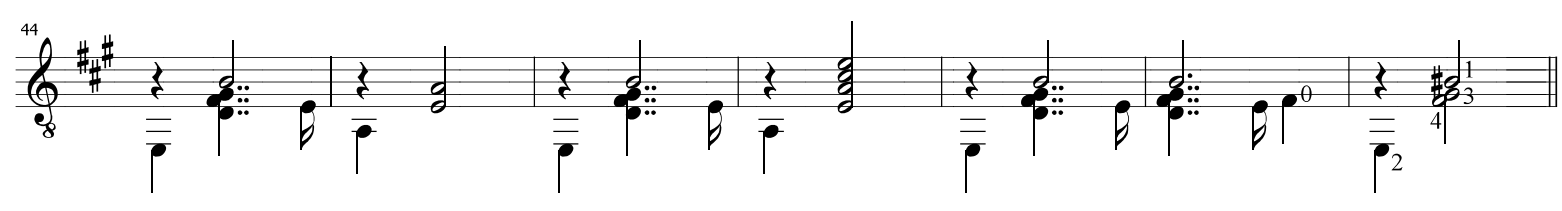

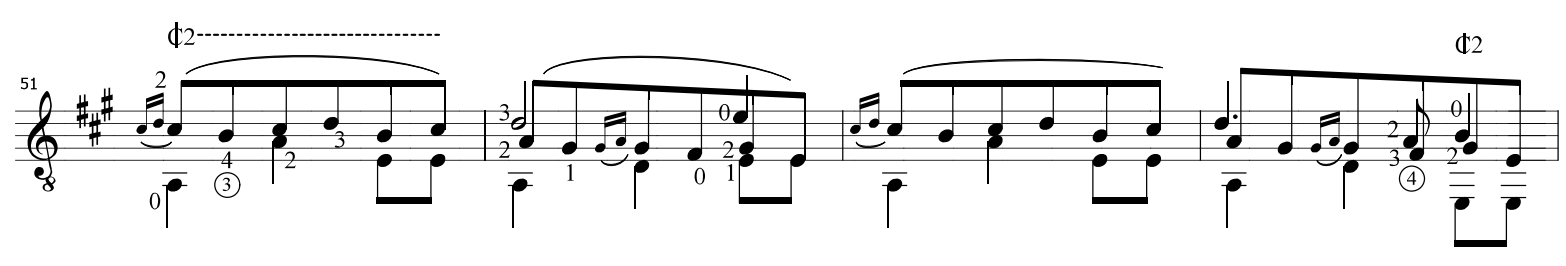

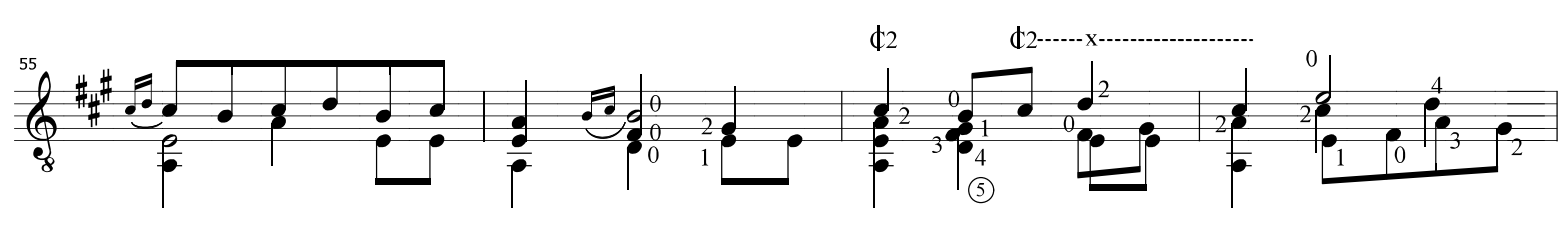

poco a poco cresc.

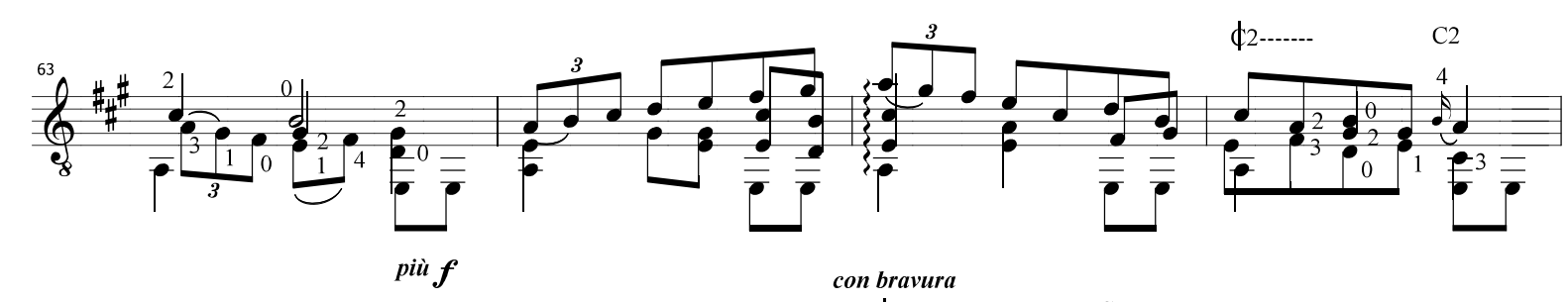

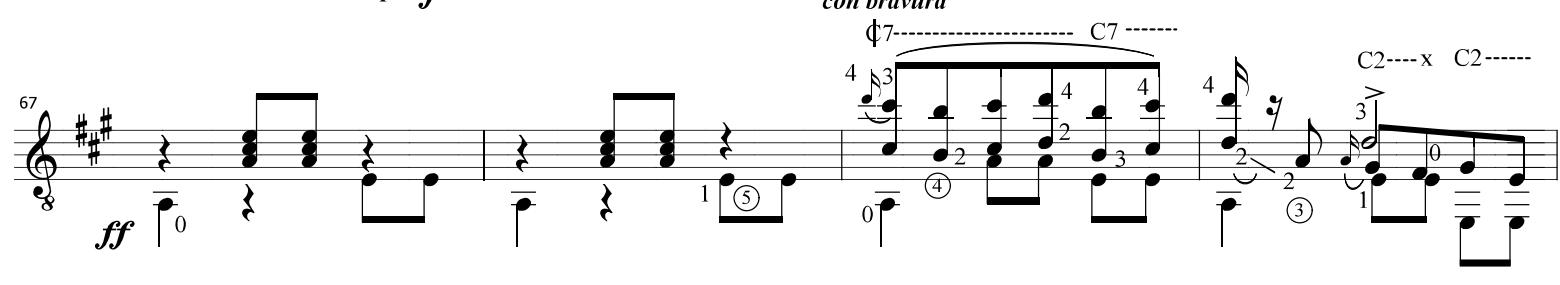




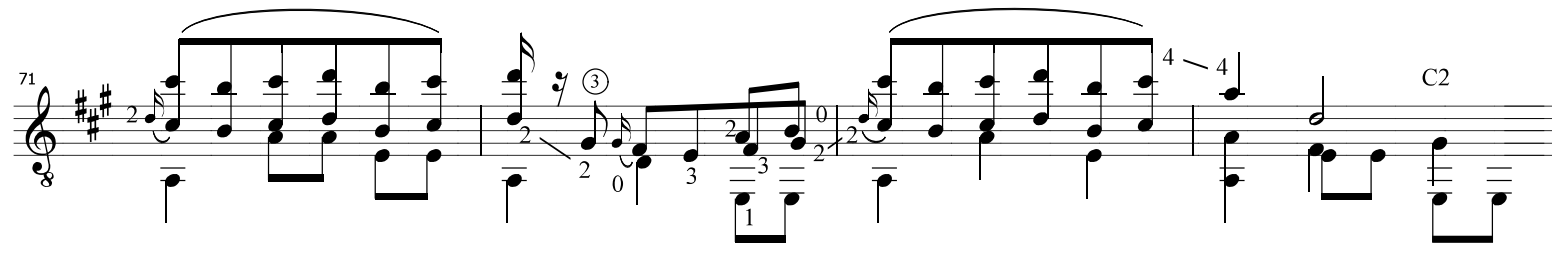
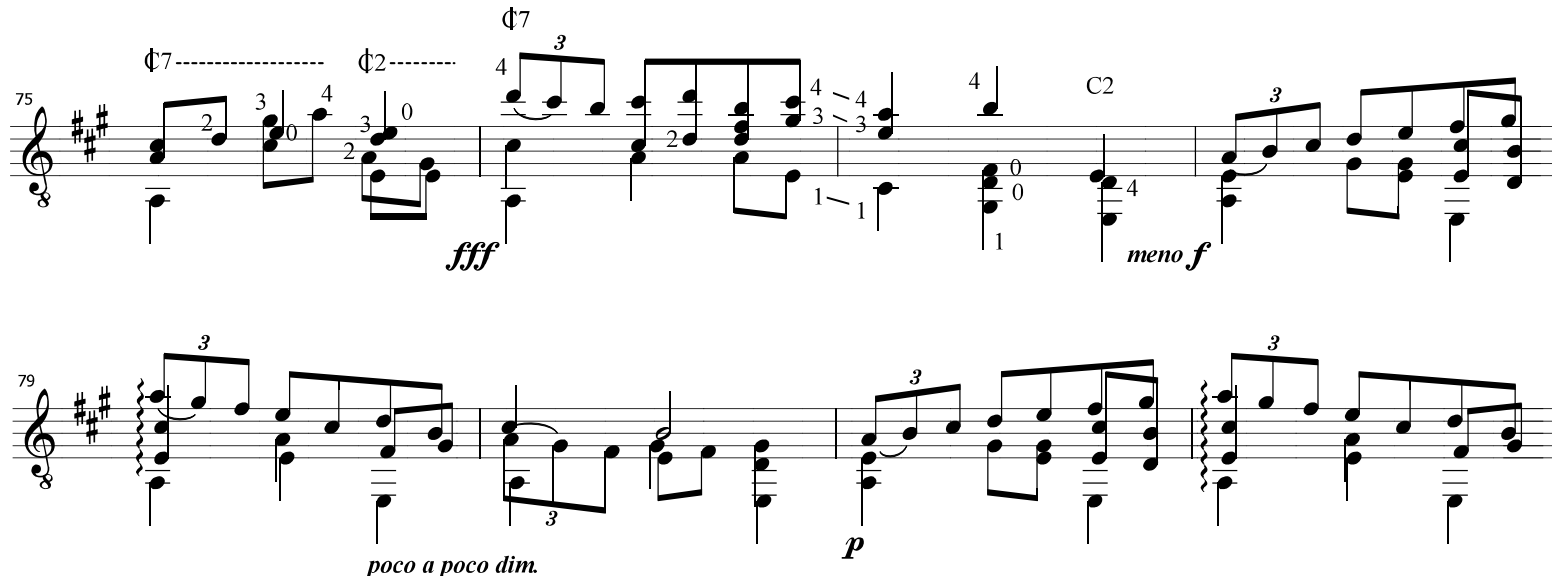

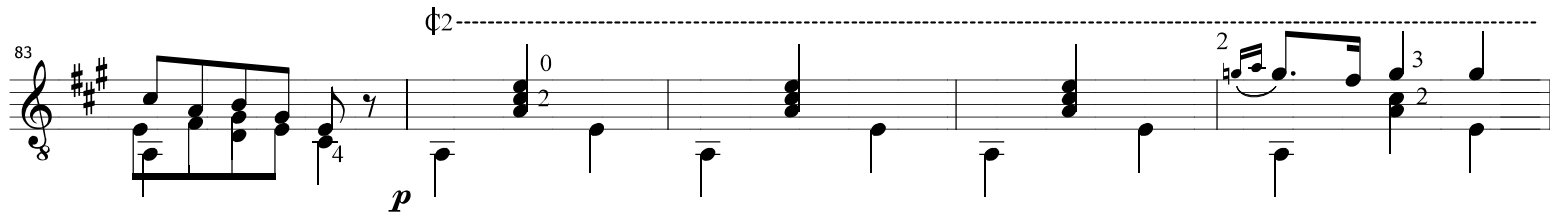

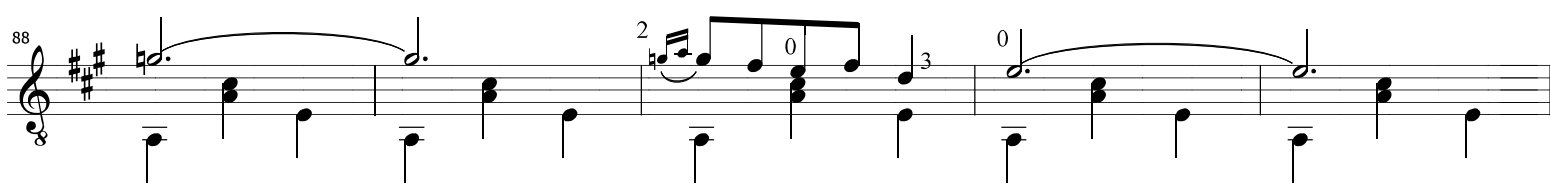

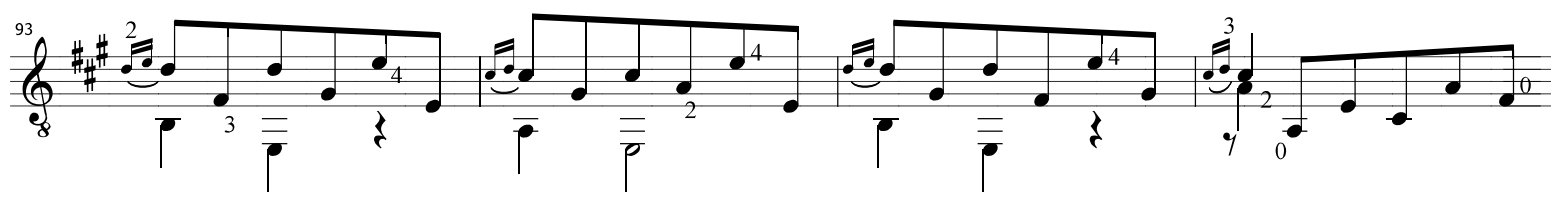
$\oint_{8}$ 


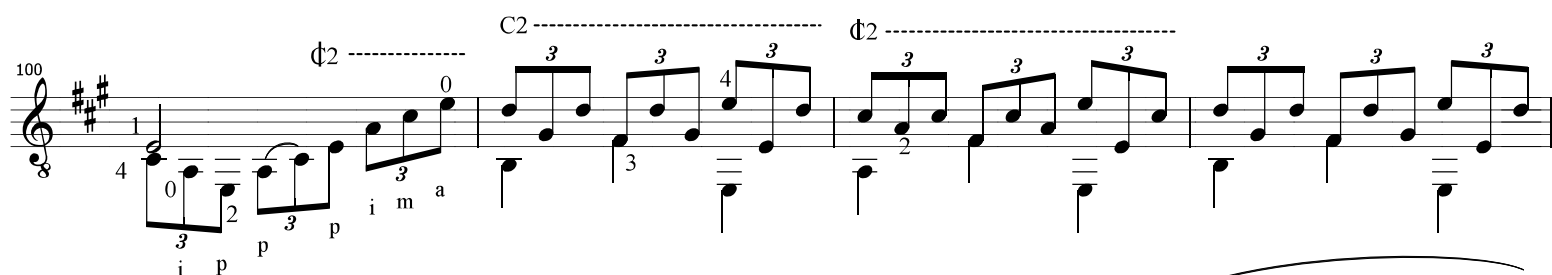

(3)

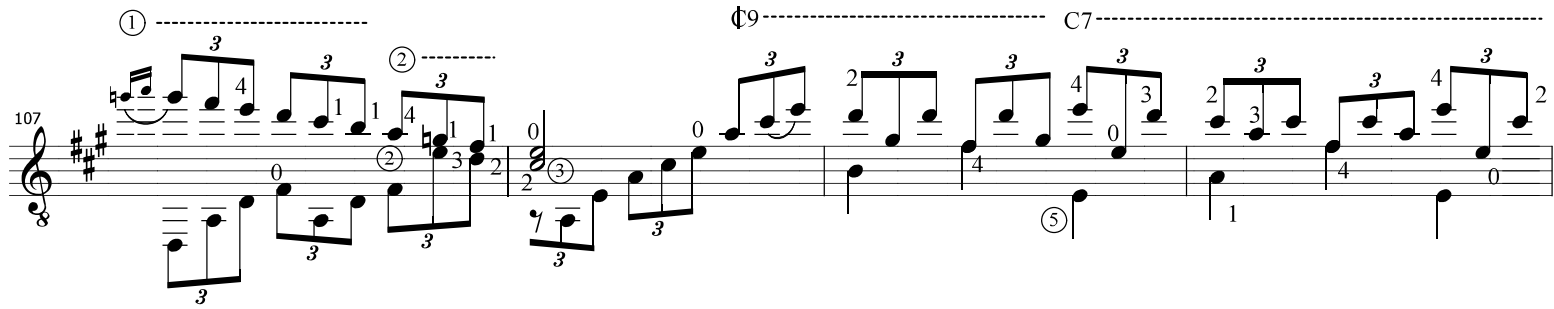
$e_{8}^{6}$

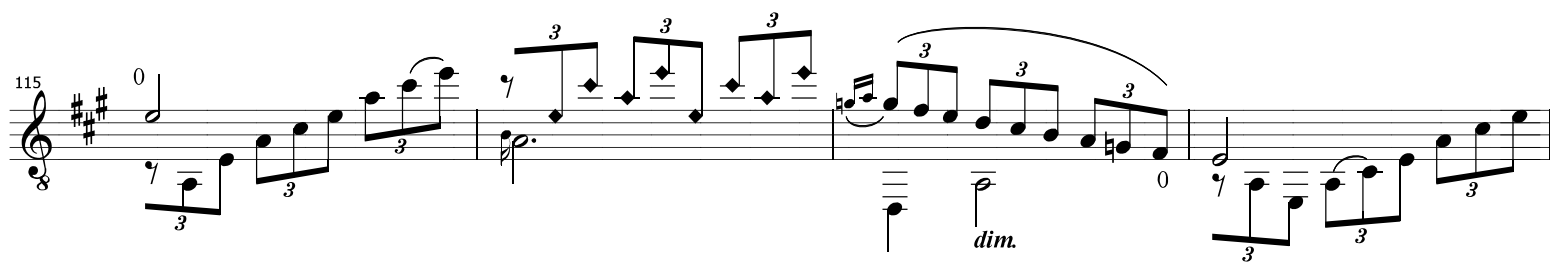

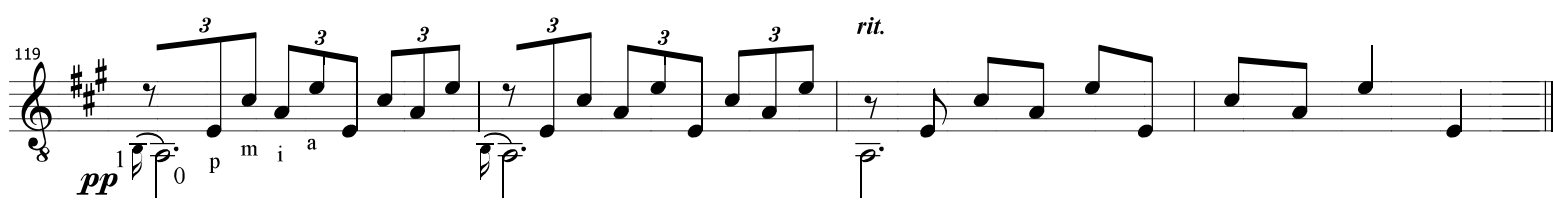
Tempo I.

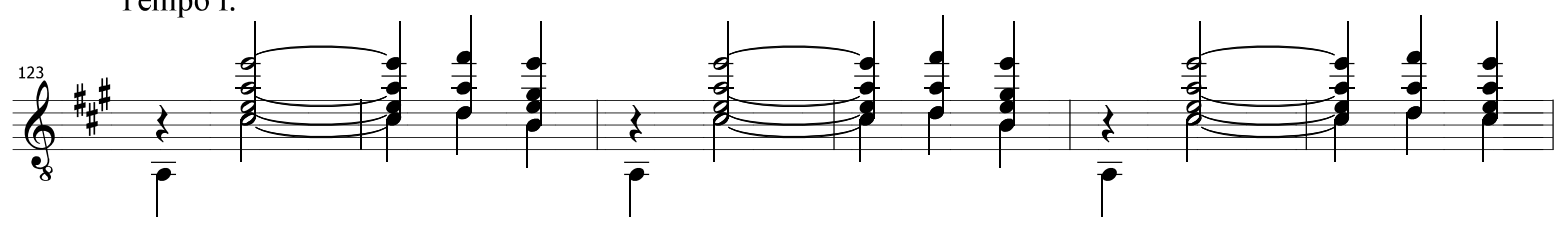


Danzas Españolas Op. 37 - 9.Mazurka

(a)

(6) maestoso

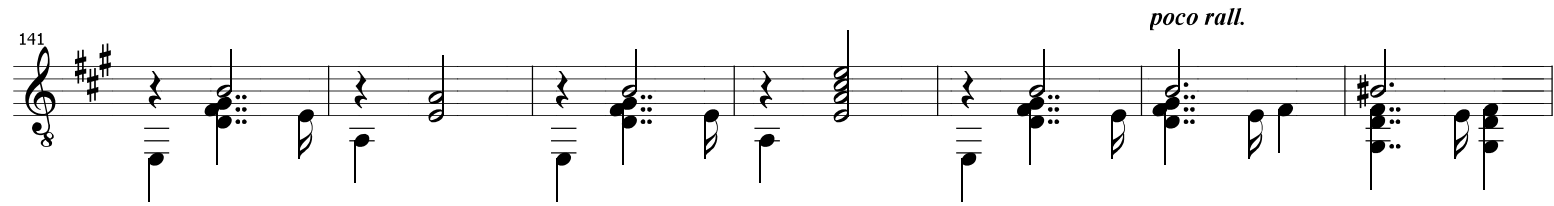

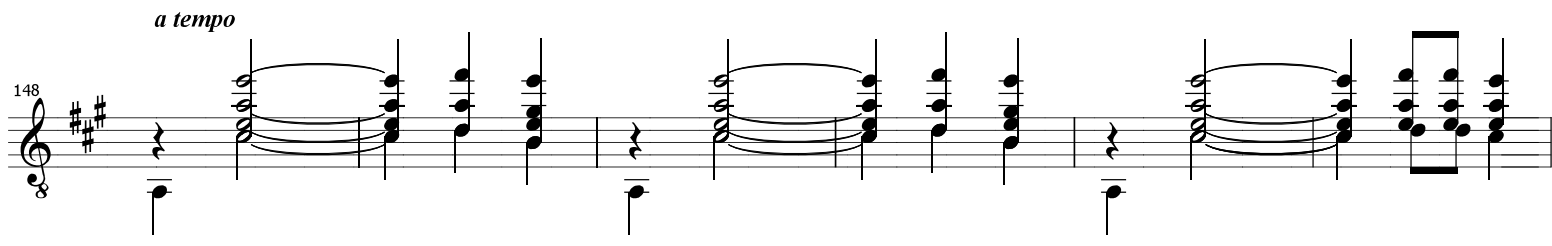

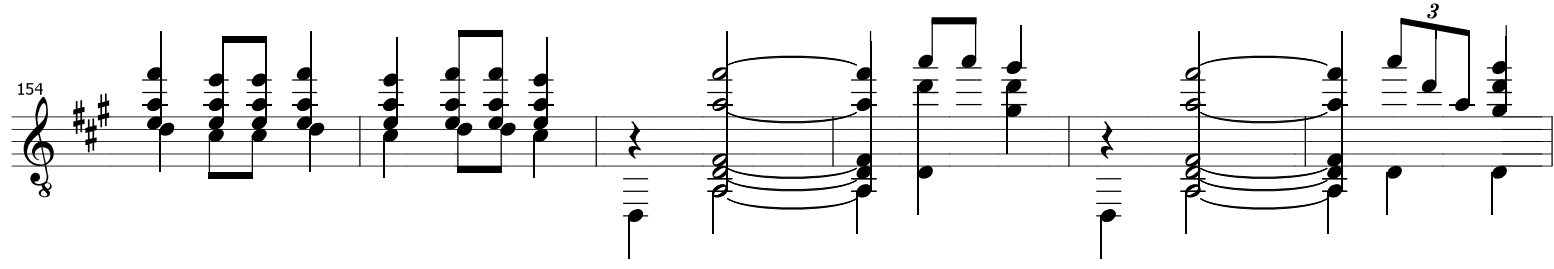

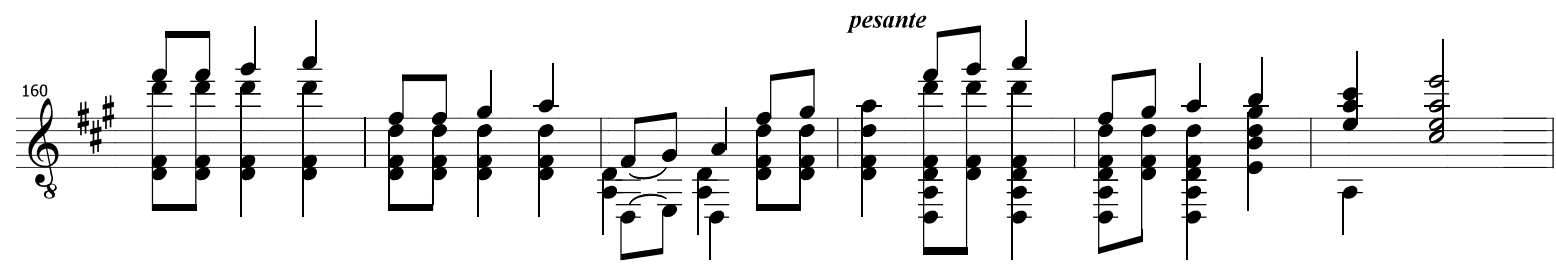

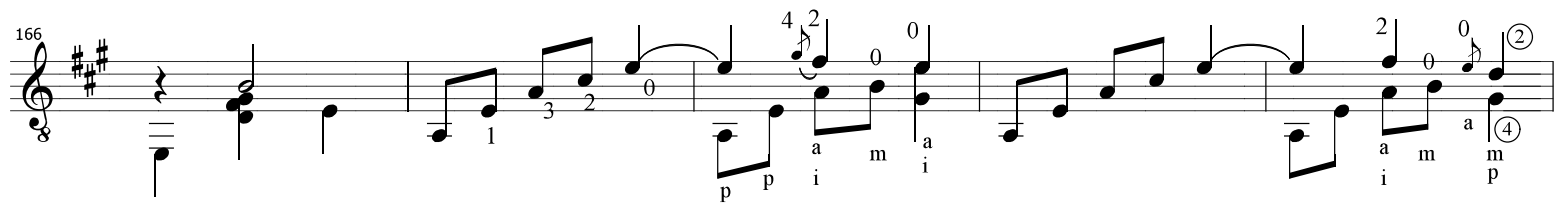


leggiero

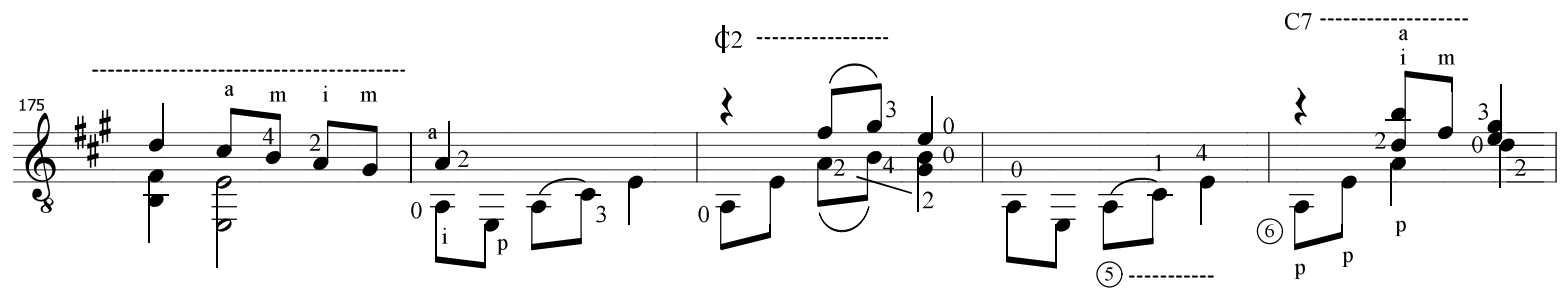

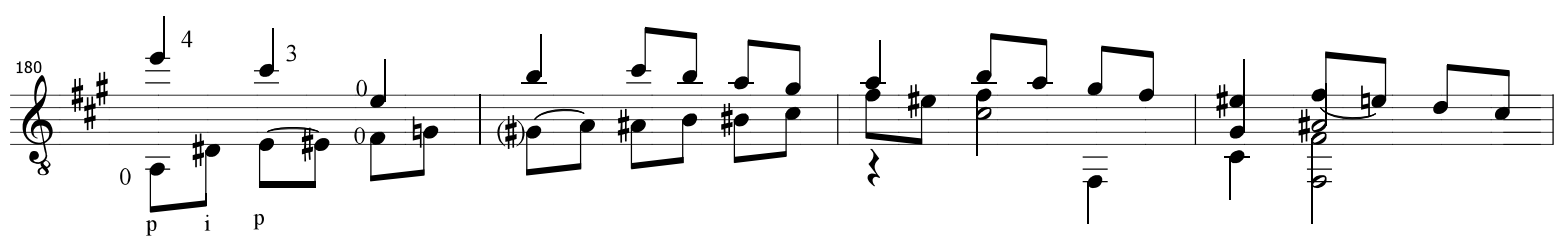

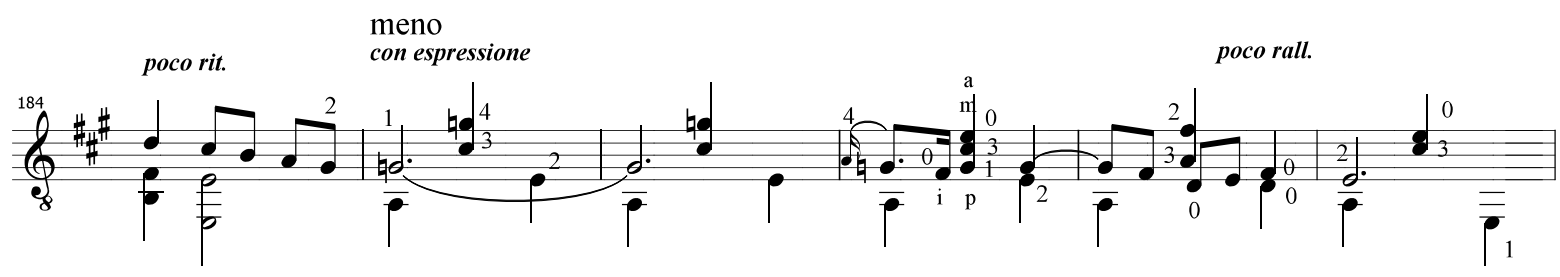

a tempo

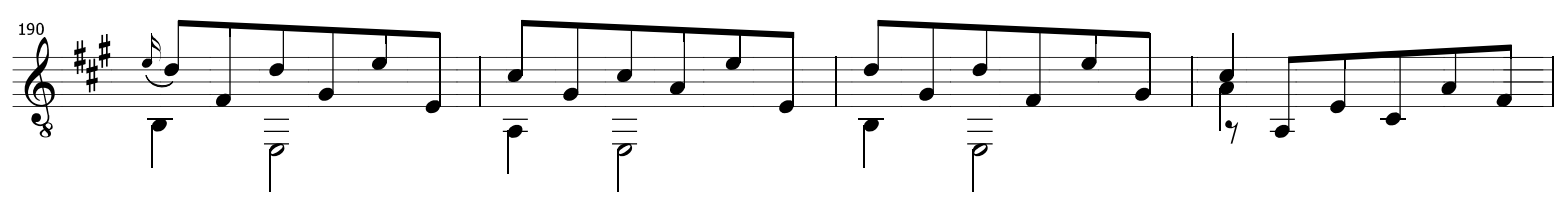

$e_{3}^{(0)}$

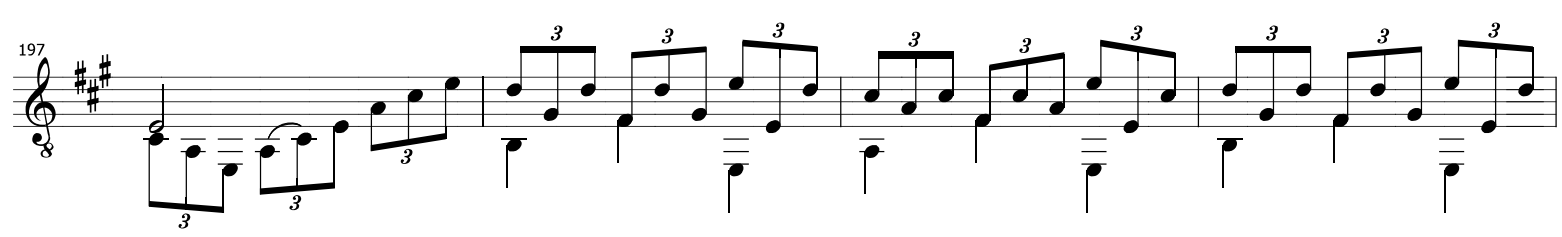


$e_{8}^{6}$

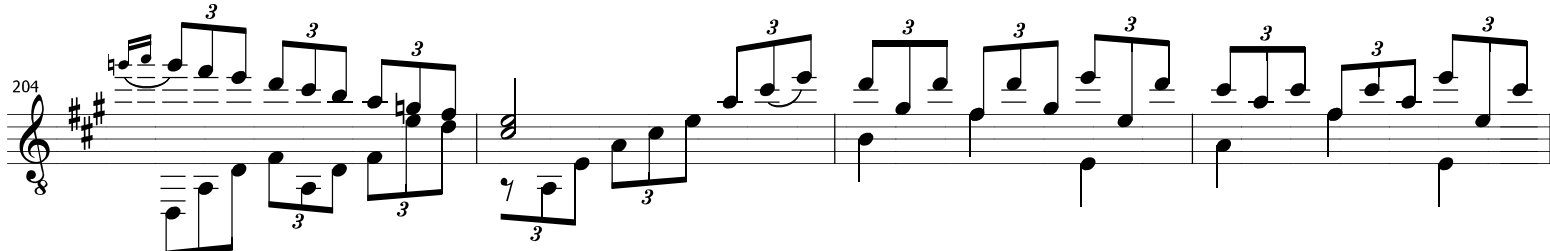

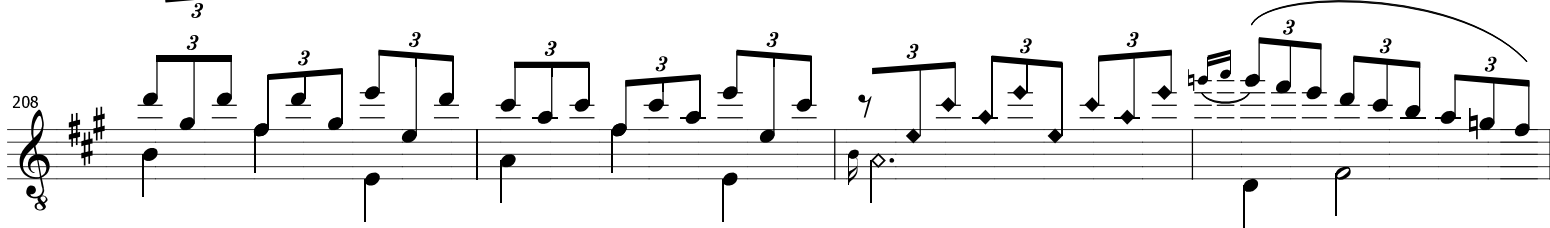
$\int_{8}^{(12)}$

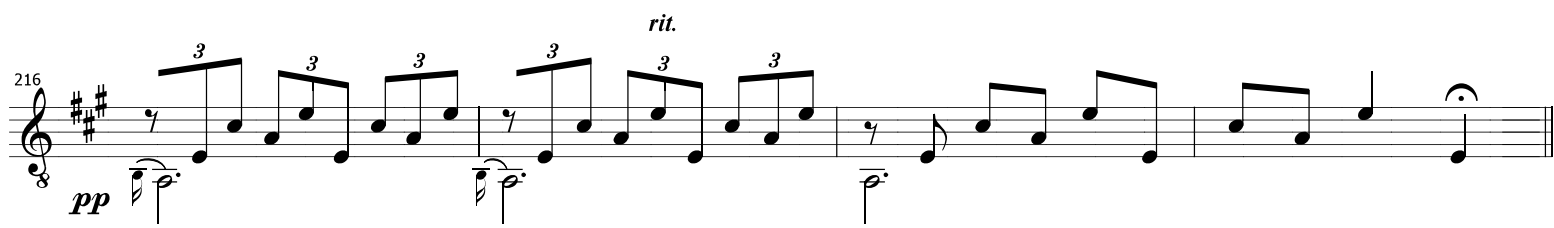
Vivo. $f$ (a) lunga $e_{8}$ 


\subsection{Danza n'10}

Tonalidade original e da transcrição: Sol Maior

Afinação tradicional com o ajuste da sexta corda em Ré.

Esta é outra das Danzas consagradas de Granados no que diz respeito a transcrições. Apontamos a gravação de Andrés Segovia como uma das primeiras referências fonográficas da peça.

Ocorre também nessa Danza uma adaptabilidade natural para o violão. Escrita no tom de Sol Maior, em uma primeira impressão, uma scordatura com a sexta corda em Ré e a quinta corda em Sol aparentaria ser uma boa opção, no entanto, vinte e quatro compassos da peça possuem o centro tonal em Ré, o qual abrange uma modulação do tema e a seção central (compassos 48 a 61). Levando em consideração tal fato, manter a quinta corda em sua afinação tradicional é uma boa opção para disponibilizar o baixo Lá, fundamental da dominante de Ré. Felizmente a seção em Sol Maior funciona muito bem ao violão contando apenas com o ajuste tradicional da sexta corda em Ré.

Em muito pouco nossa transcrição difere das tradicionais dessa peça. Gostaríamos de pontuar apenas algumas reconfigurações de acordes que tiveram como intuito facilitar algumas passagens; por exemplo, essa adaptação aplicada ao trecho em Si bemol Maior, nos compassos 16 a 18 (Figura 75).

Figura 75 - Adaptação alternativa do trecho em Si bemol Maior.

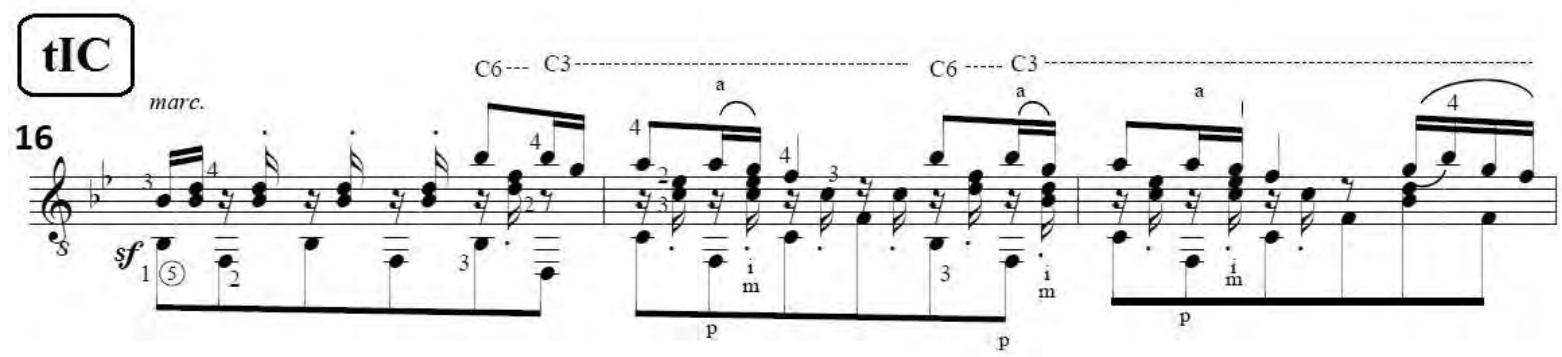

Fonte: elaborada pelo autor

Através da inversão de alguns baixos, esse trecho se tornou mais exequível ao violão (Figura 76): 
Figura 76 - Inversão de baixos
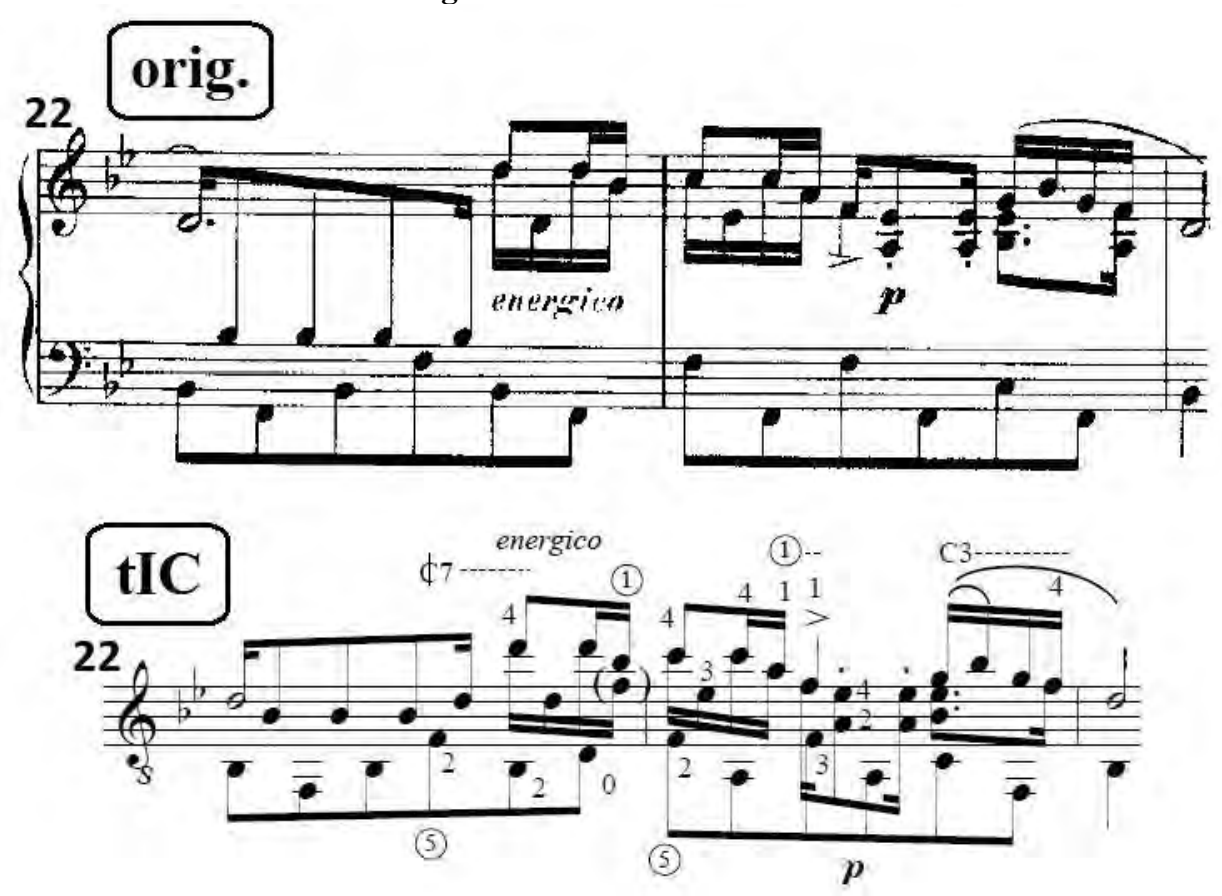

Fonte: elaborada pelo autor 


\section{Danza triste}

Transcrição para violão de Iury Cardoso

Allegretto
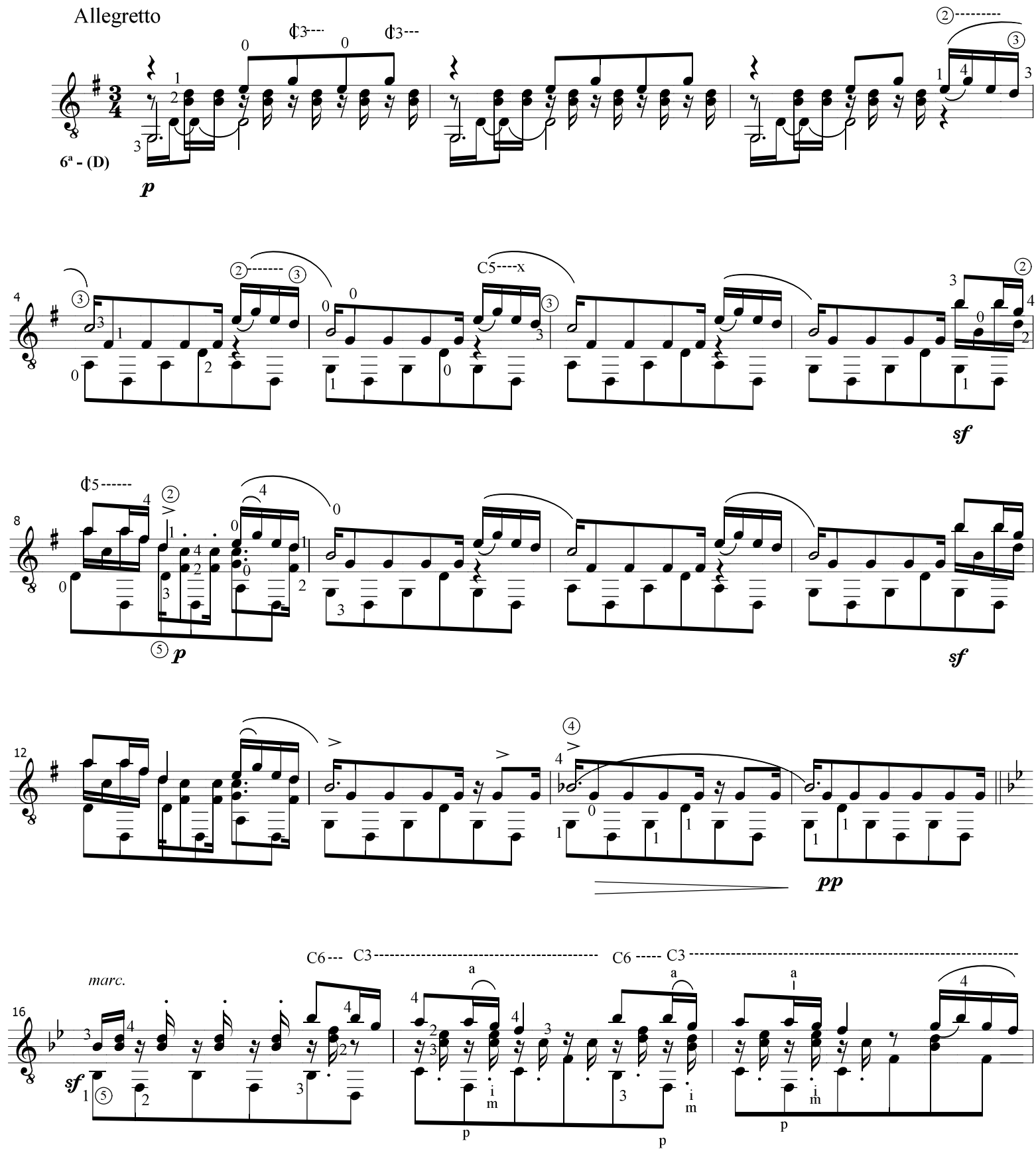

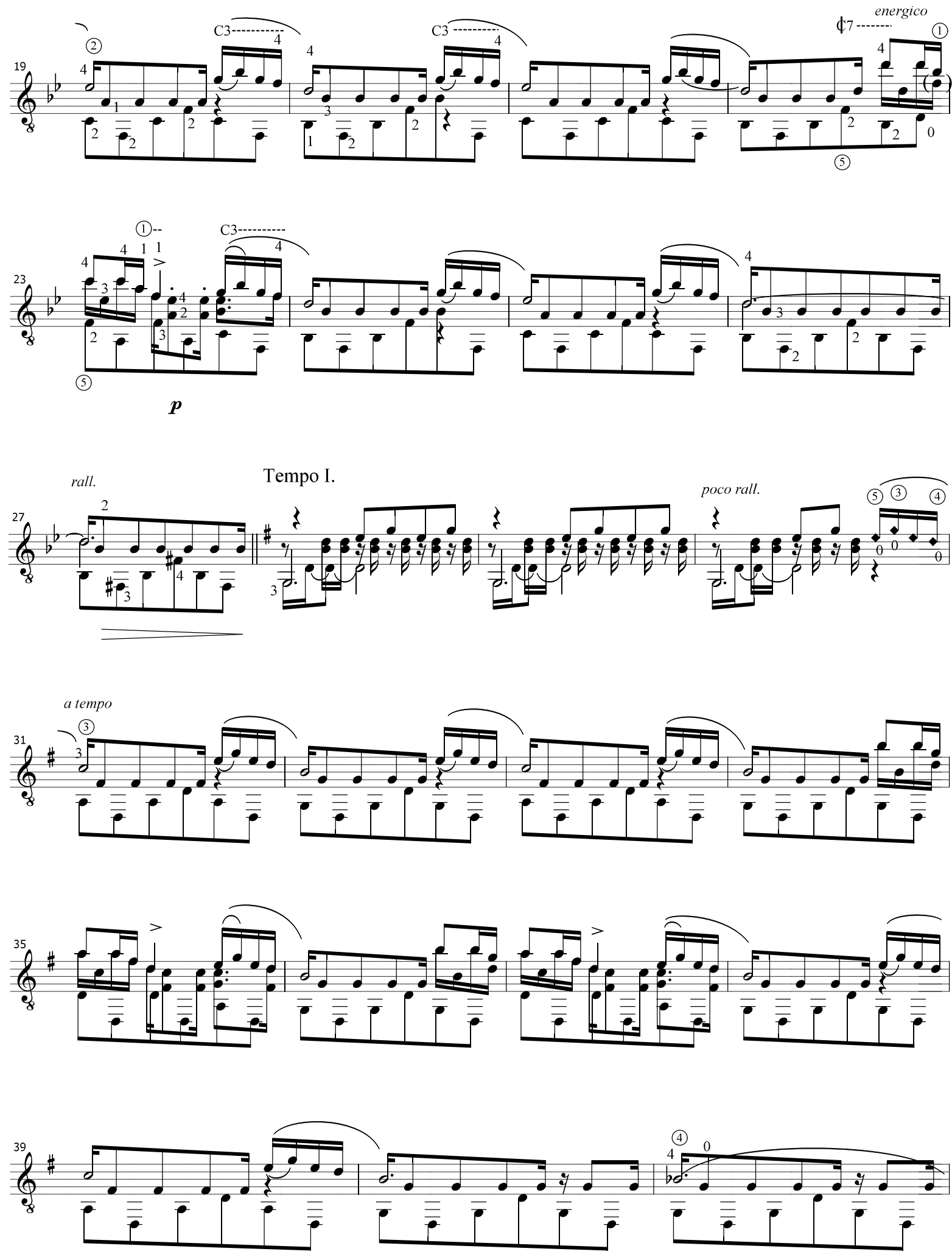

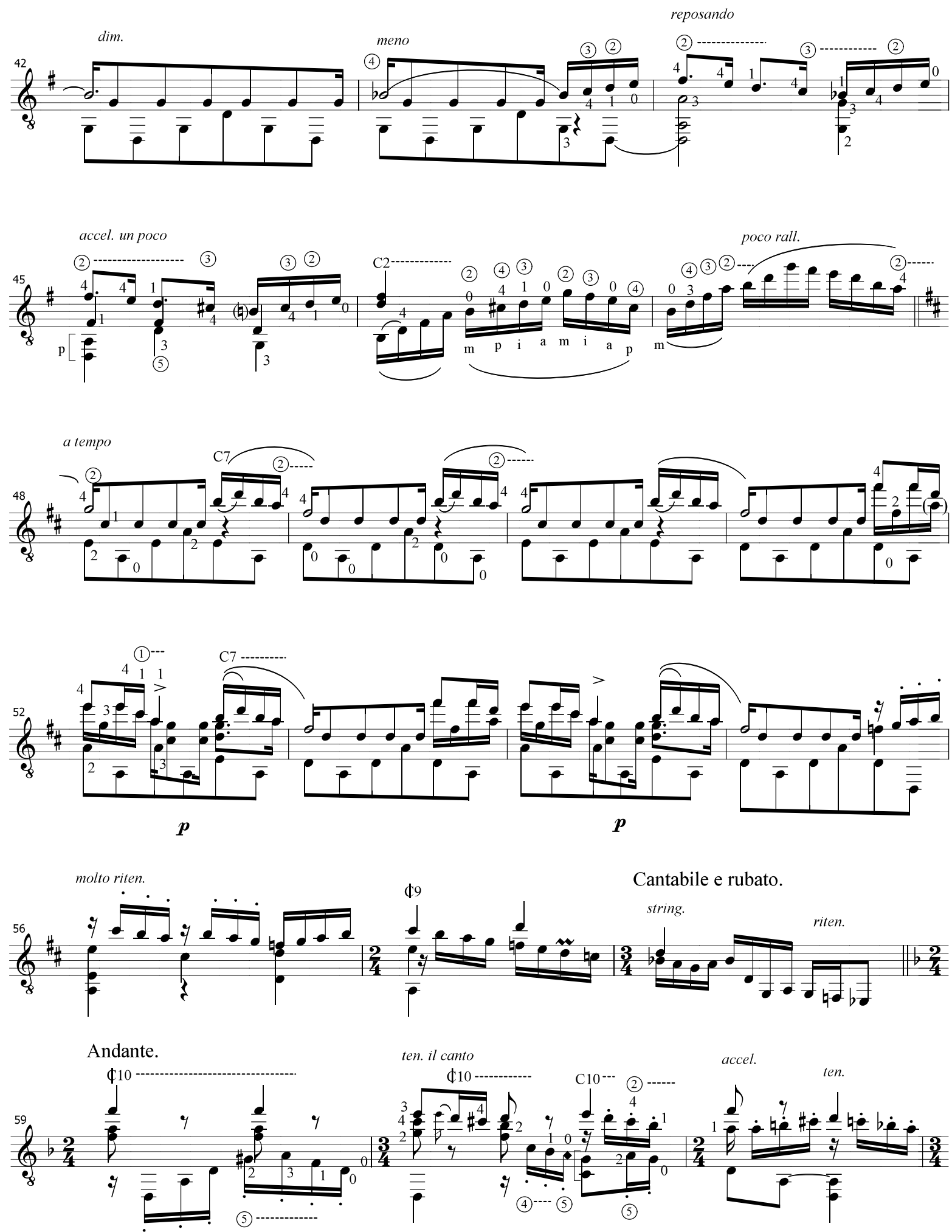


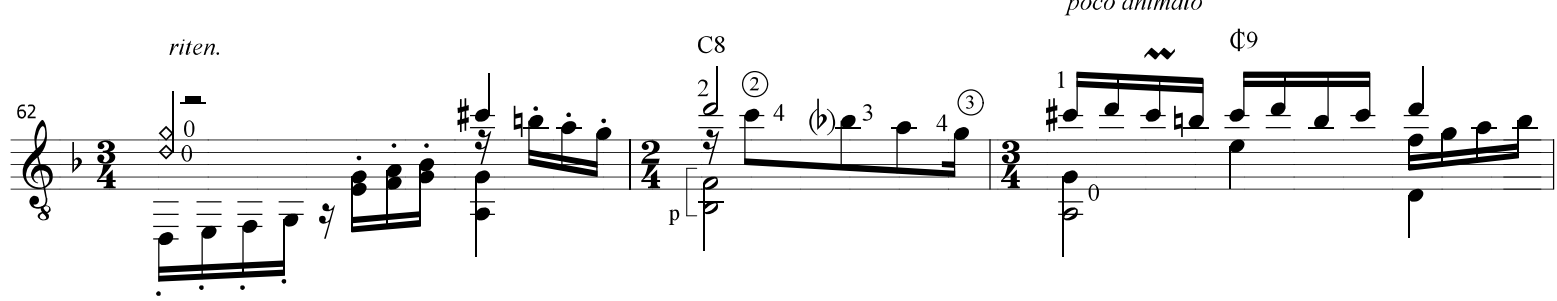
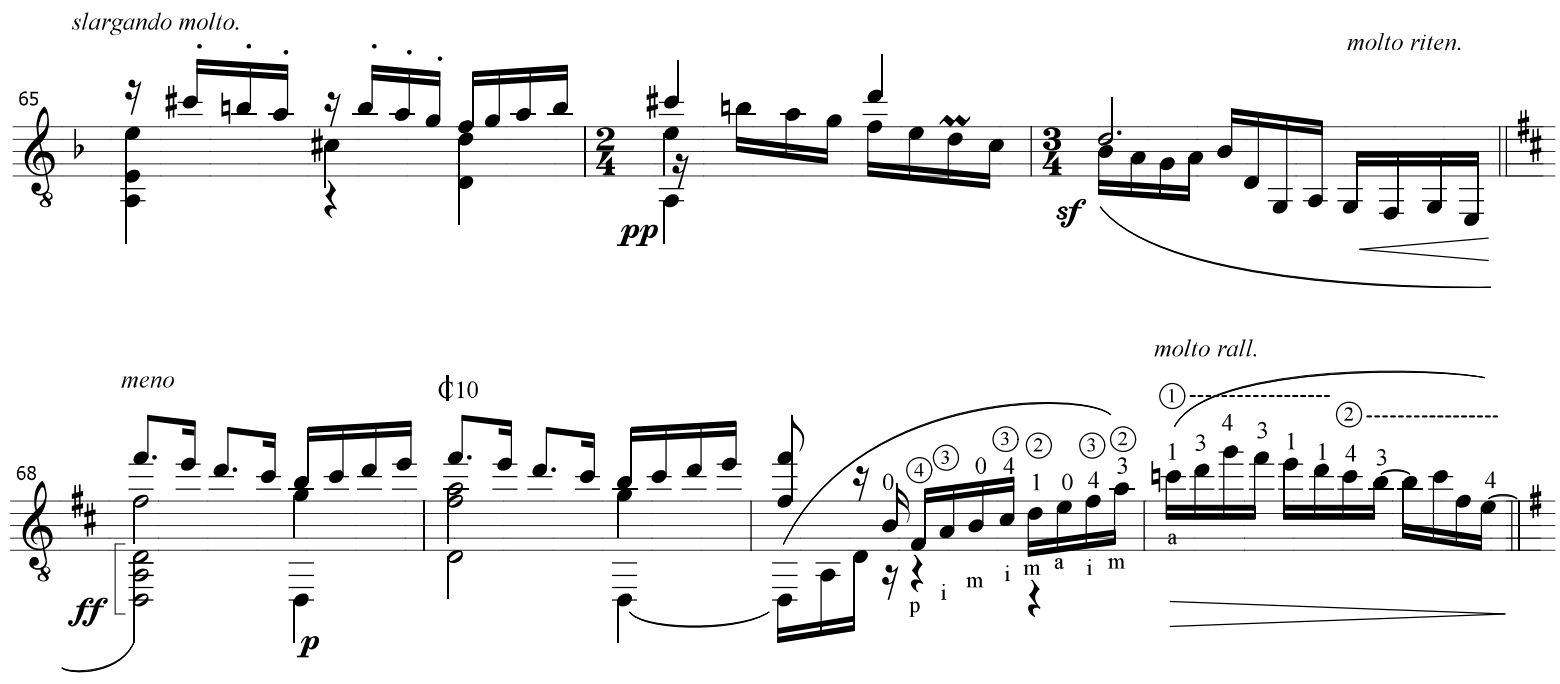

Tempo I.

军
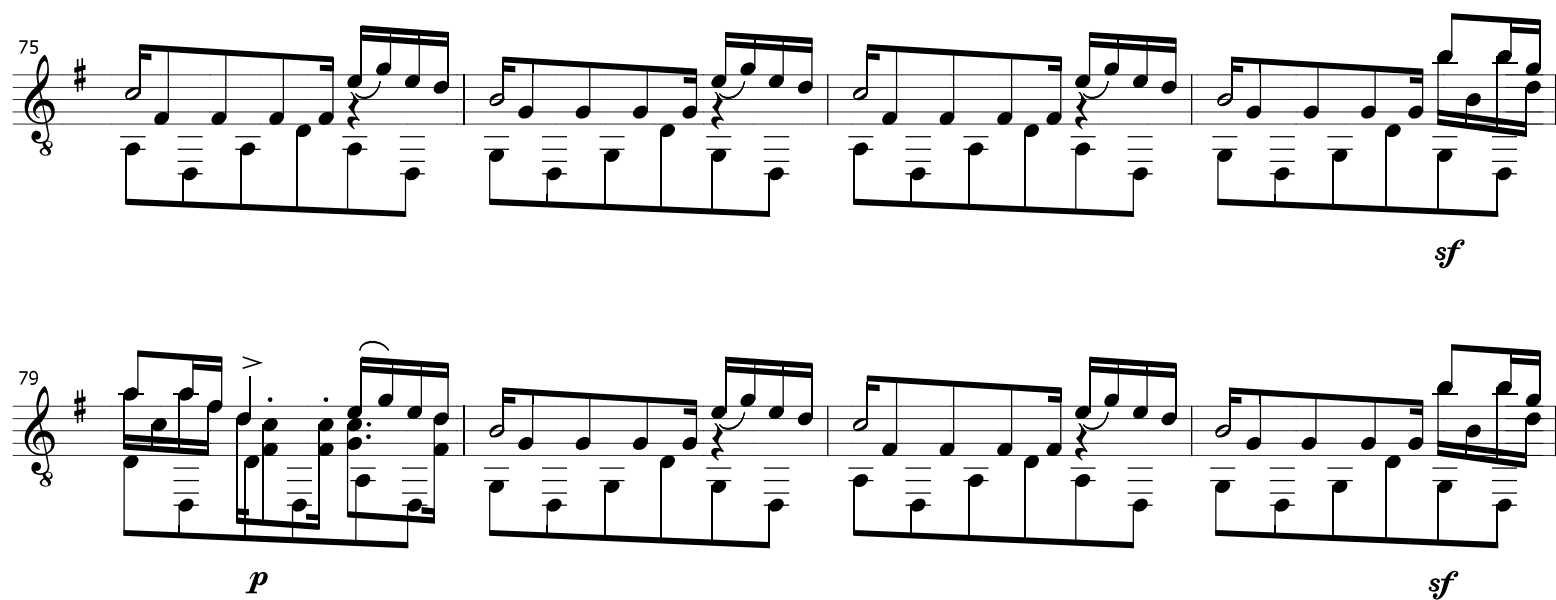

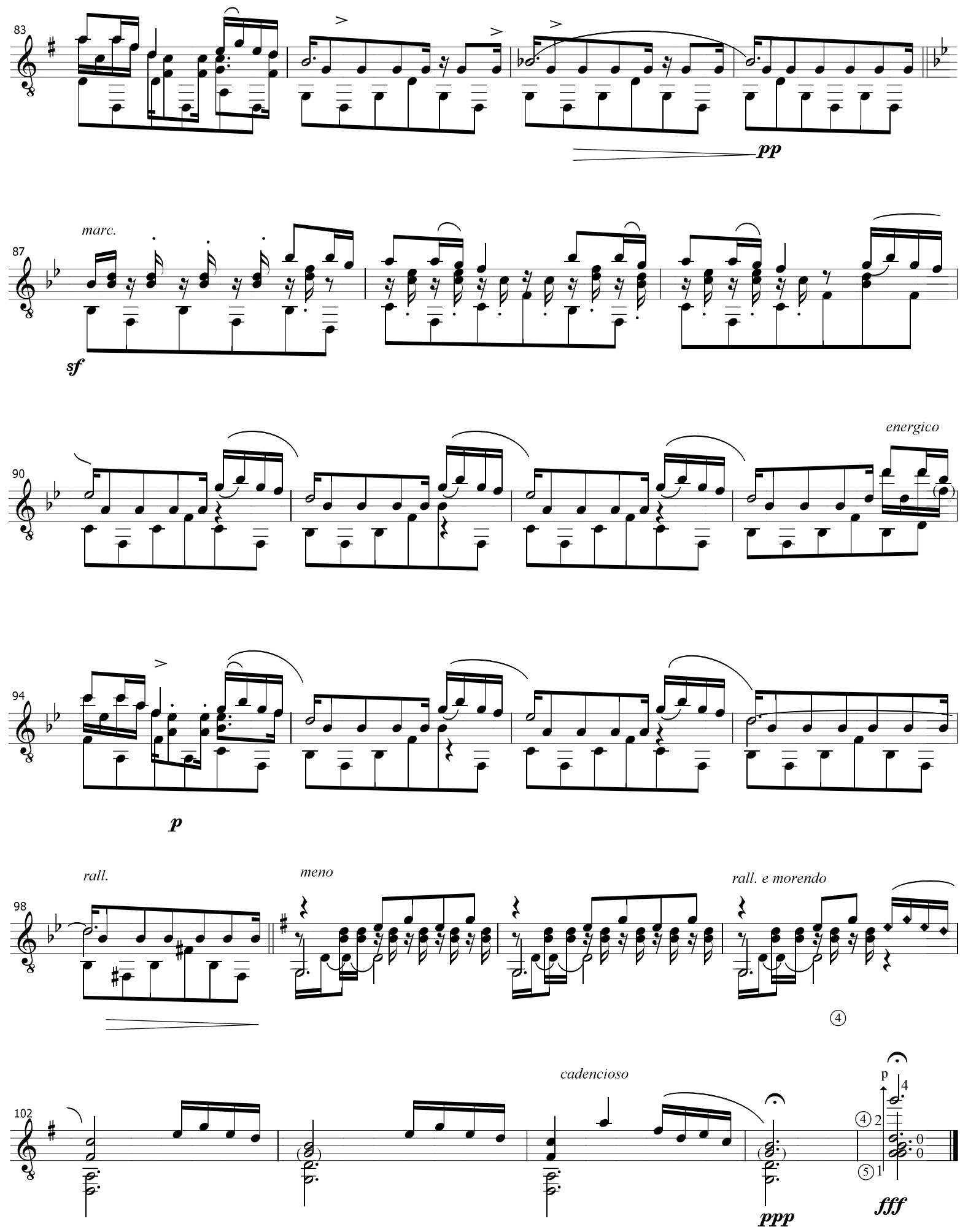


\subsection{Danza $n^{0} 11$}

Tonalidade original e da transcrição: Sol menor

Scordatura utilizada:

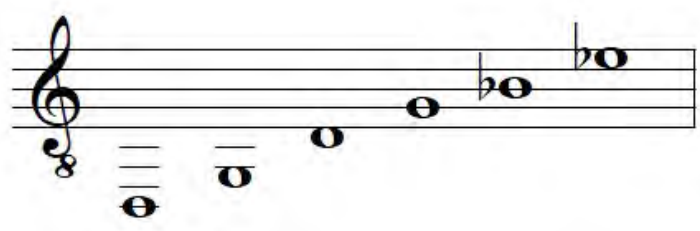

Outra das Danzas que apresentou obstáculos à nossa adaptação. Nossa primeira opção foi realizar uma transcrição que transpunha a peça para Lá menor, todavia a afinação tradicional do violão, constituída predominantemente com intervalos de quarta justa, não proporcionou uma estrutura propícia para receber a peça.

A solução considerada adequada por nós, veio através da modificação de uma scordatura tradicionalmente usada em peças escritas em Sol Maior para violão solo, a saber: a afinação tradicional com ajuste da sexta corda para Ré e da quinta corda para Sol (Utilizada na transcrição da Danza $n^{\circ} 4$ ). Considerando a tonalidade homônima de Sol Maior, alteramos as duas únicas cordas cujas notas não pertenciam à escala de Sol menor (Figura 77).

Figura 77 - Modificação da afinação para a tonalidade de Sol menor

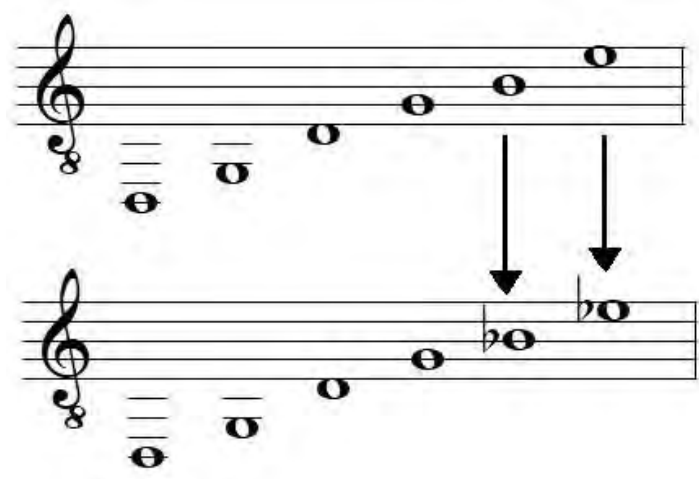

Fonte: elaborada pelo autor

Tal ajuste foi essencial para permitir a adaptação de diversas passagens, incluindo o que era nossa maior preocupação inicialmente: o ápice da seção “A” que ocorre a partir do compasso 20 (Figura 78). 
Figura 78 - Ápice da seção A.

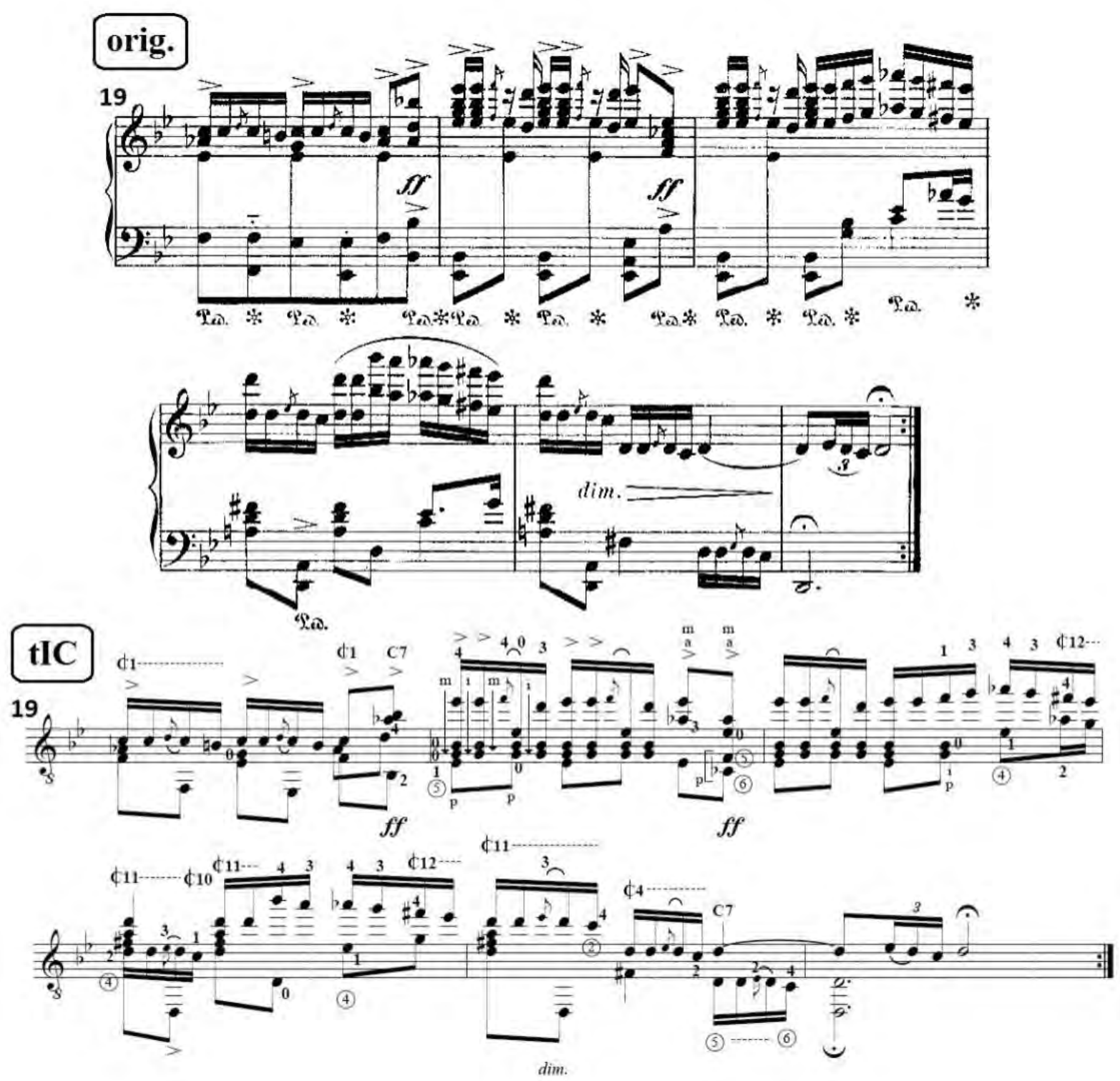

Fonte: elaborada pelo autor 
5.11.1 Partitura da transcrição

Danzas Españolas

Op.37

11.Zambra

Transcrição para violão de Iury Cardoso
Enrique Granados

Andante con moto
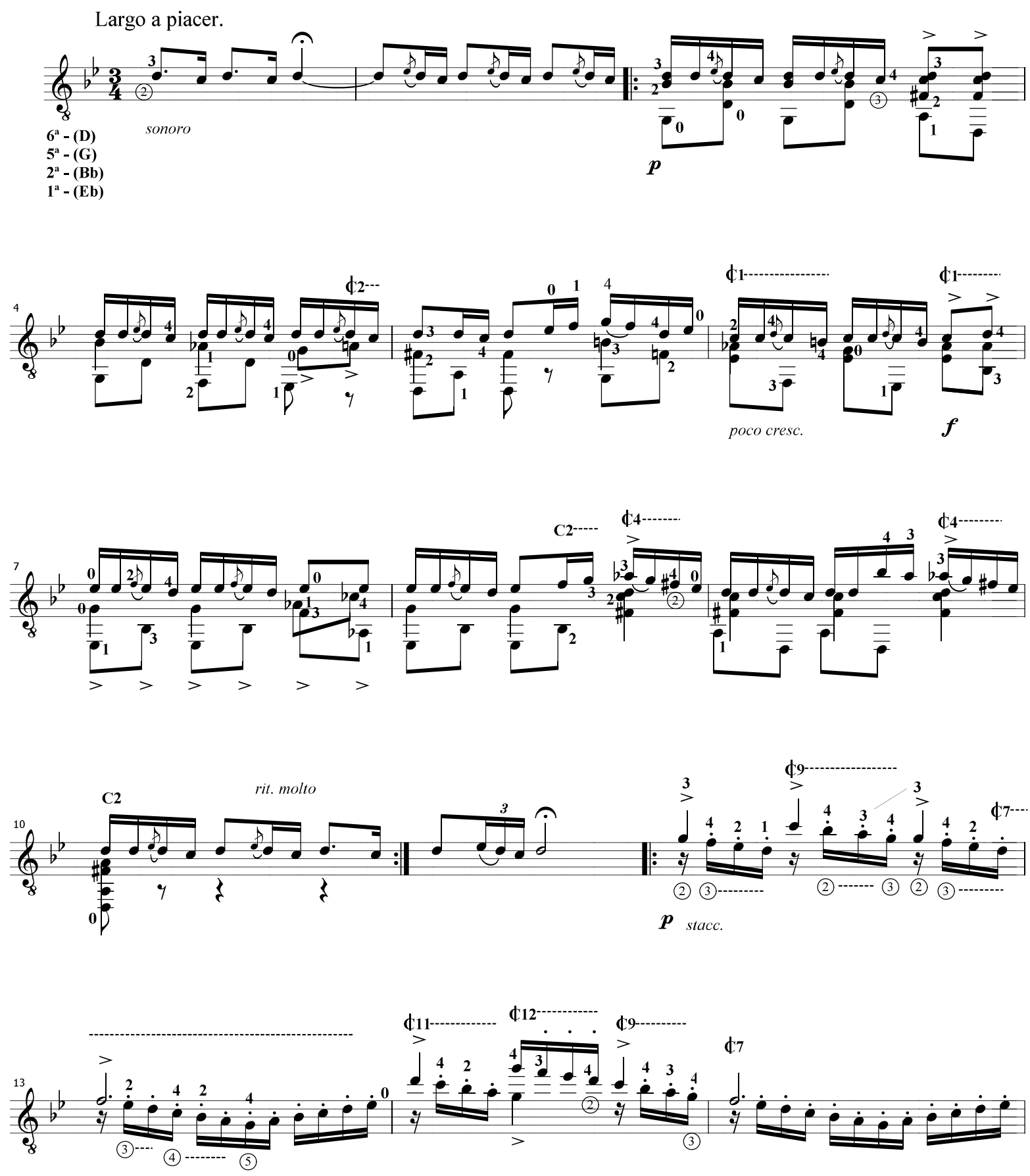

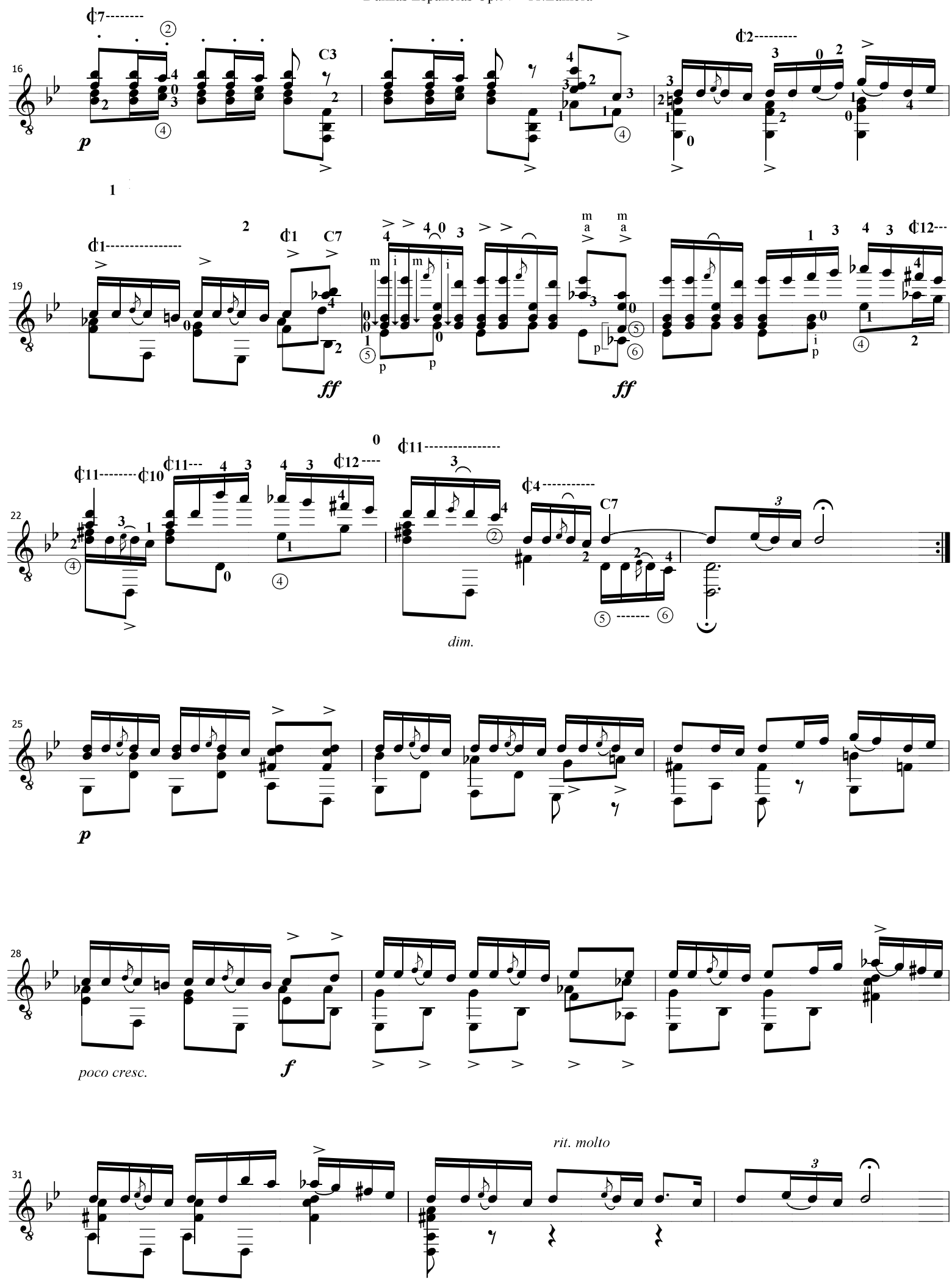


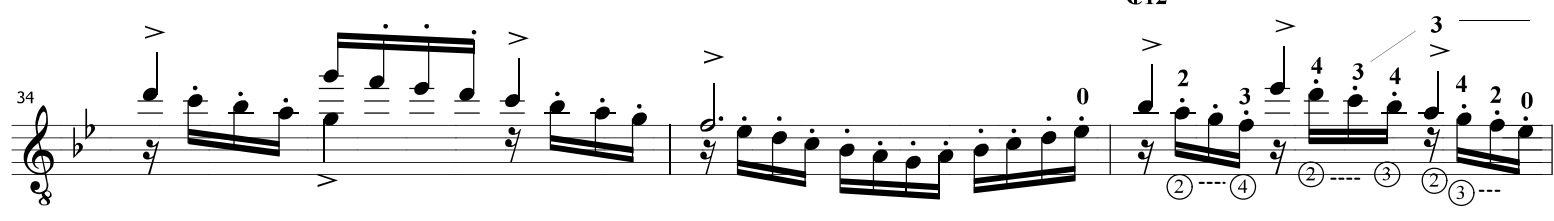

dim. poco a poco
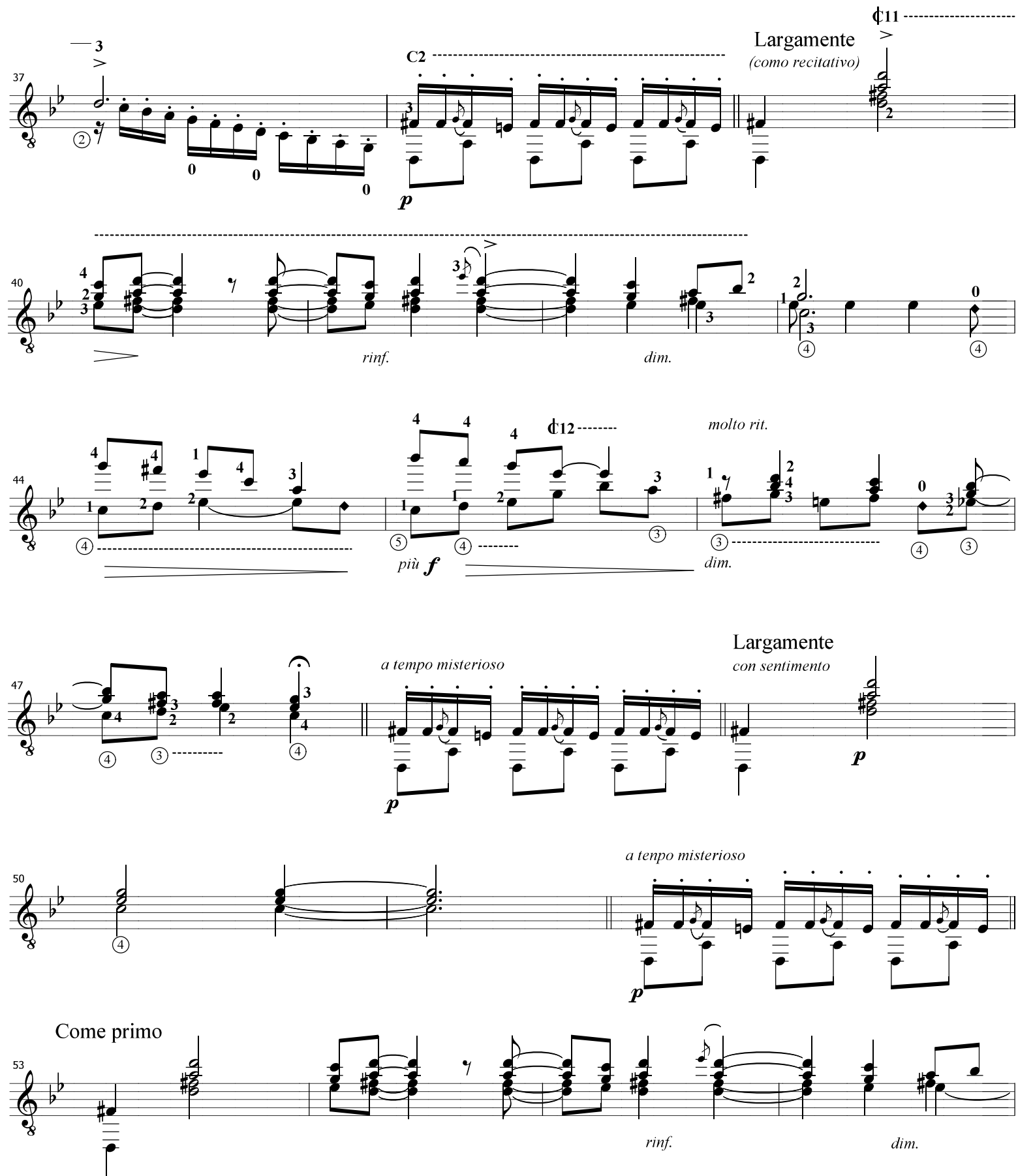
Danzas Españolas Op.37 - 11.Zambra

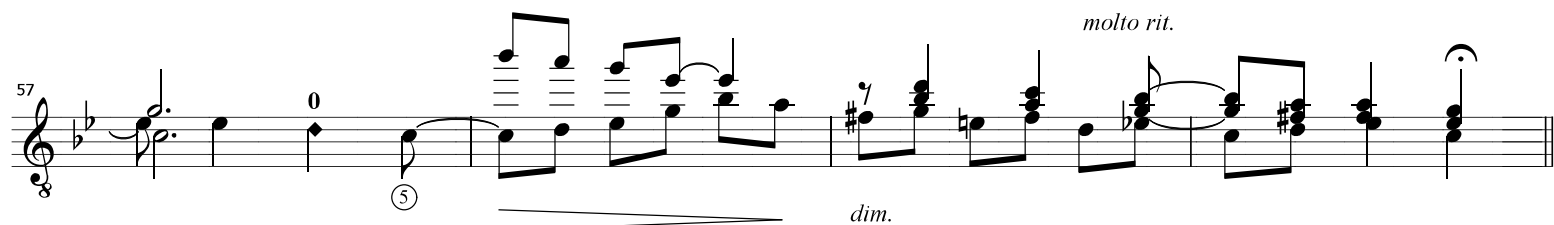

con anima
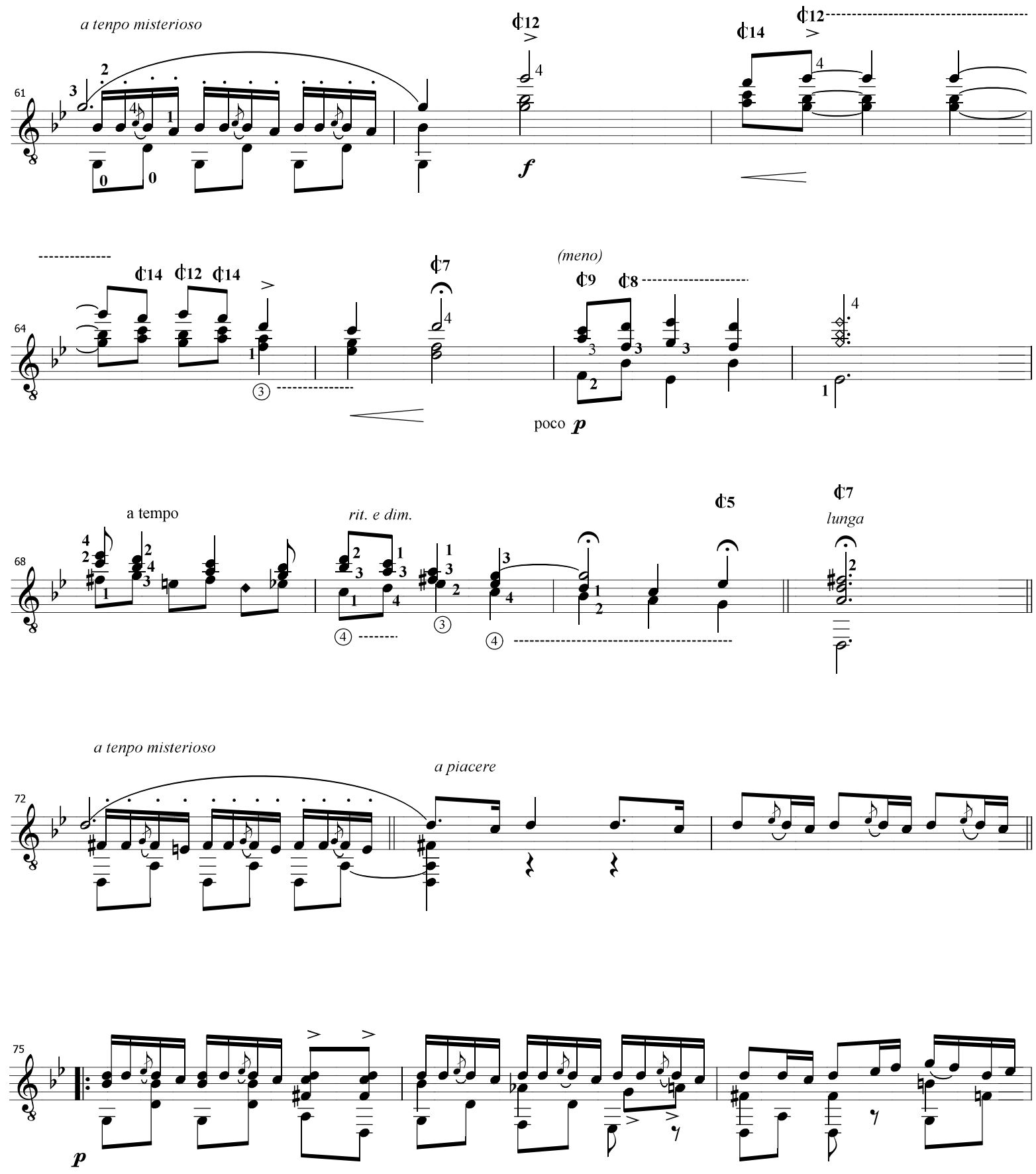


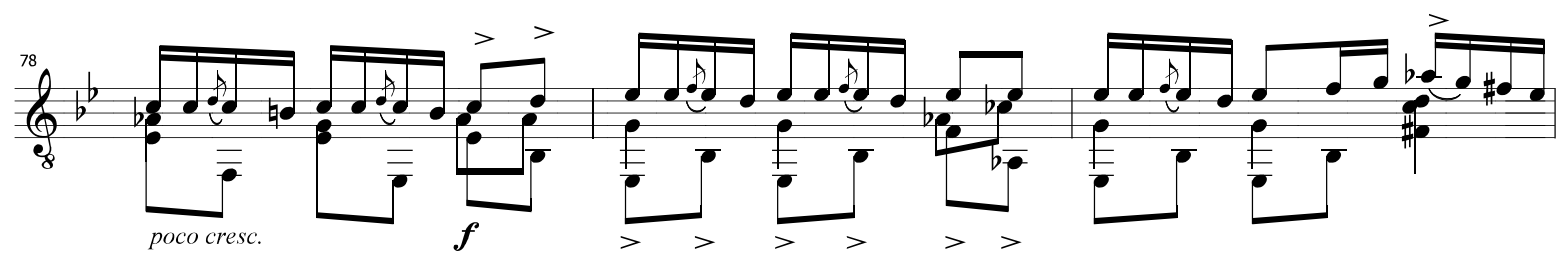

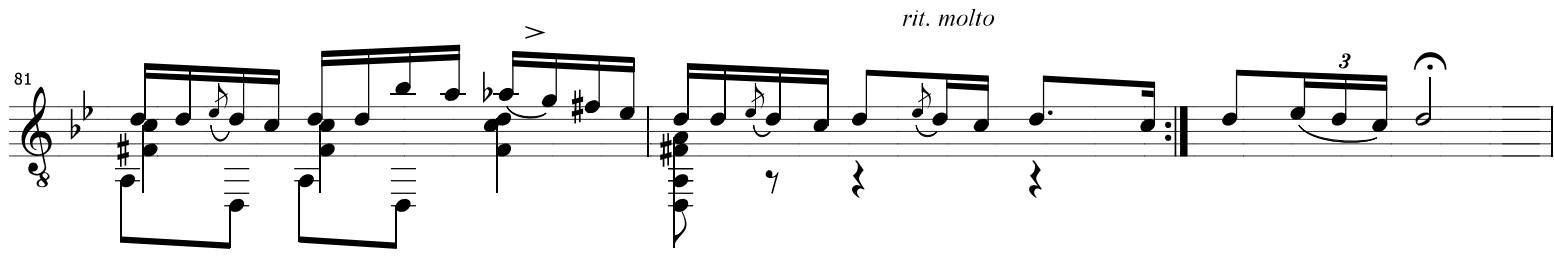

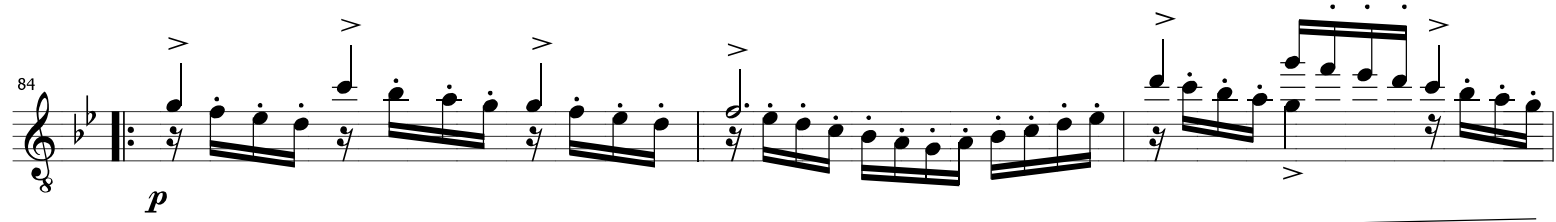
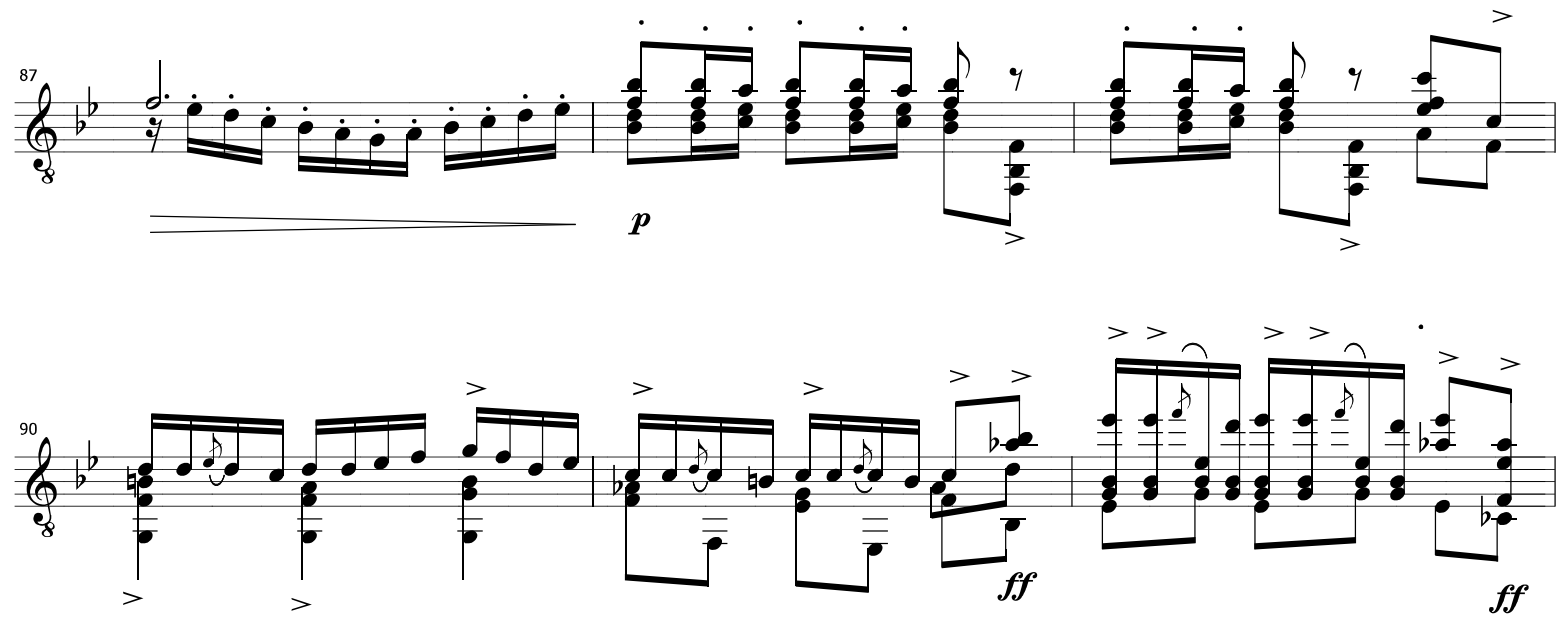

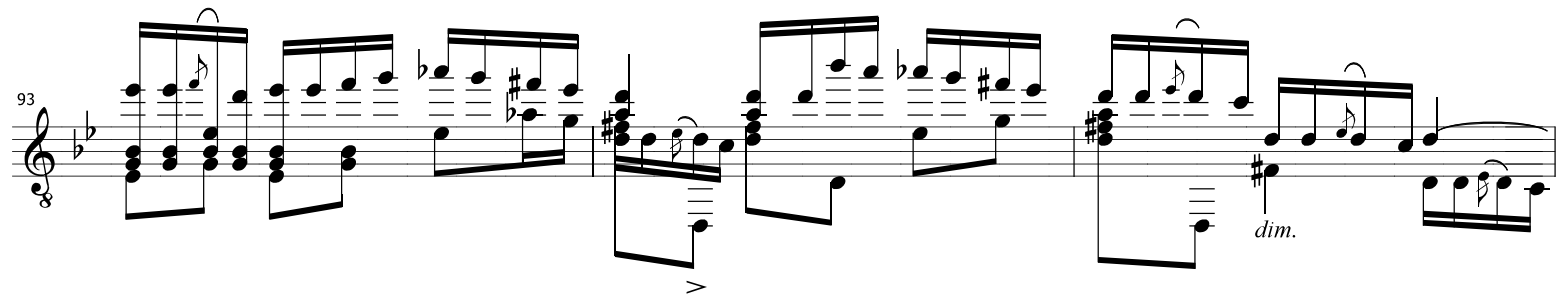



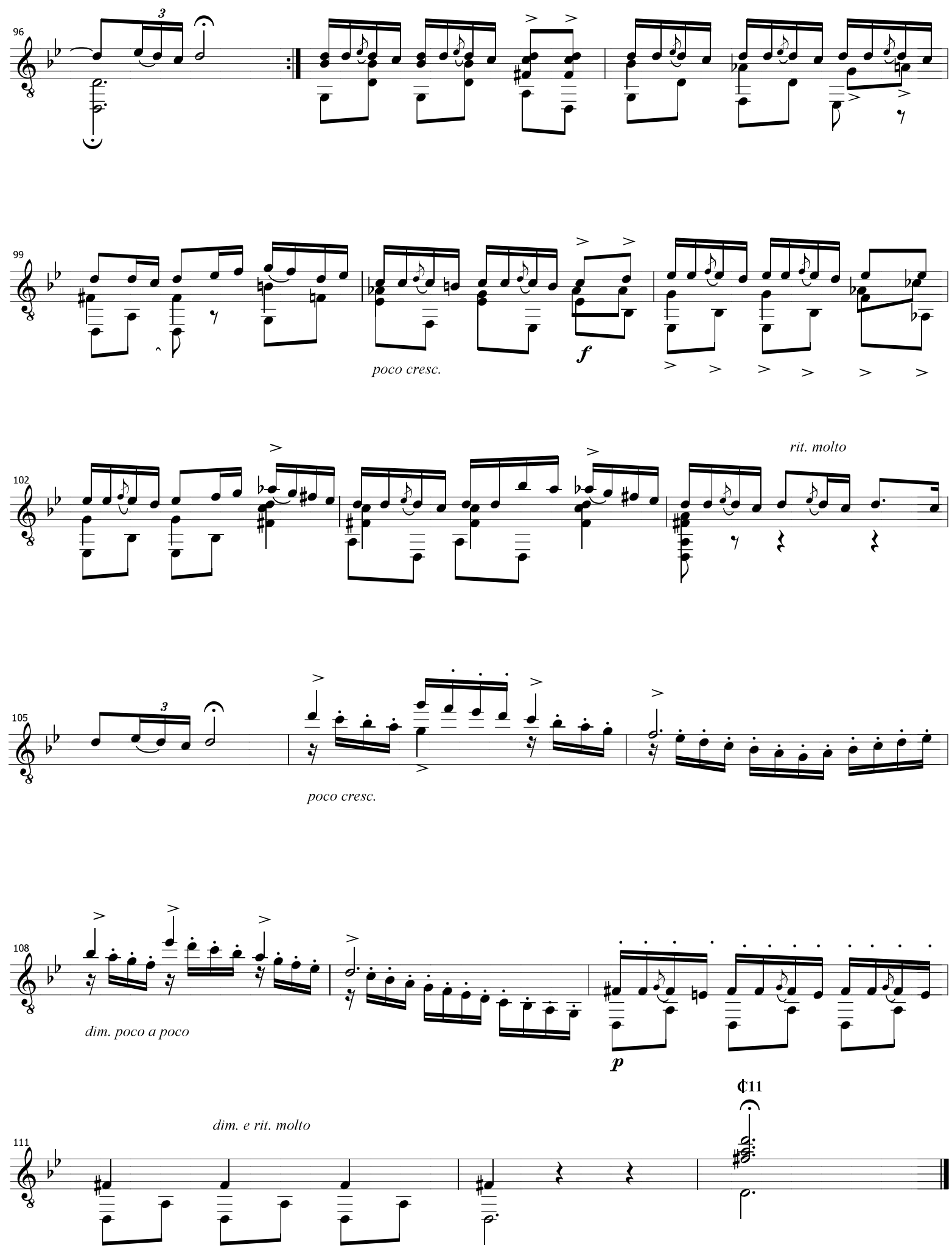


\subsection{Danza $n^{\circ} 12$}

Tonalidade original e da transcrição: Lá menor

Afinação tradicional.

Devido à sua tonalidade e material musical utilizado, foi possível abarcar a última Danza do ciclo com a afinação tradicional do violão. Destacamos a transcrição de Manuel Barrueco como referência para a nossa. Na sequência exemplificamos como abordamos o tema principal, onde algumas escolhas de transposições de oitavas e omissões proporcionaram, ao nosso ver, naturalidade a execução (Figura 79).

Figura 79 - Tema principal - Danza $n^{\circ} 12$

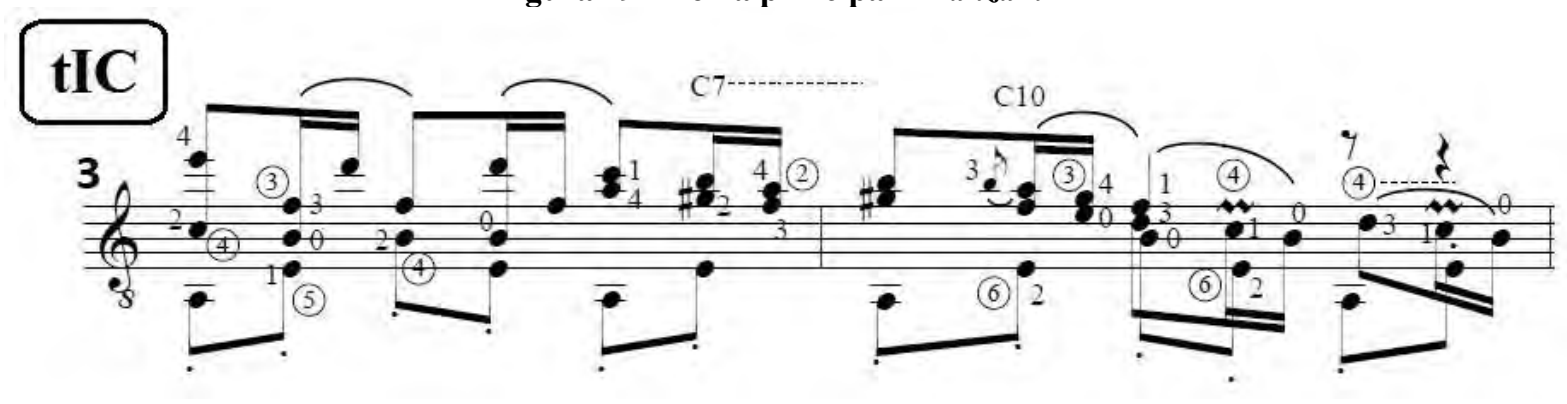

Fonte: elaborada pelo autor

Para possibilitar a adaptação do segundo grupo de temas mantendo a mesma proporção de alturas do primeiro, foi necessário realocar algumas frases e omitir os ornamentos (Figura $80)$. 
Figura 80 - Adaptação do segundo grupo de temas (primeiros compassos)

orig.
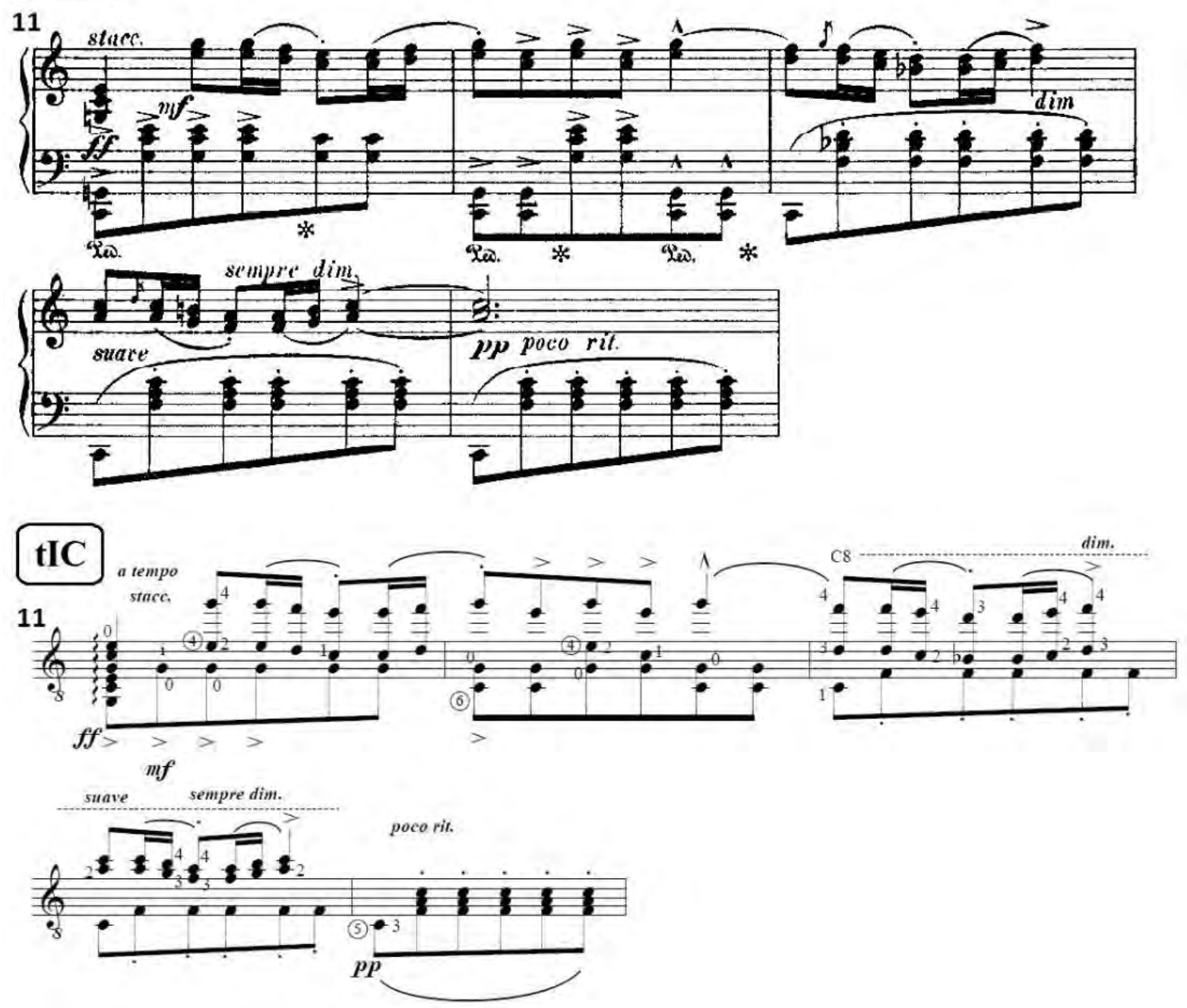

Fonte: elaborada pelo autor

No trecho a seguir, as cordas soltas Sol e La foram escolhidas para assumir a posição do acorde pedal, enquanto a linha melódica em terças, presente no original, teve seu paralelismo alterado para décimas, com a finalidade de evitar uma distância intervalar muito grande entre a melodia e o acompanhamento (Figura 81). 
Figura 81 - Transposição das terças

\section{orig.}
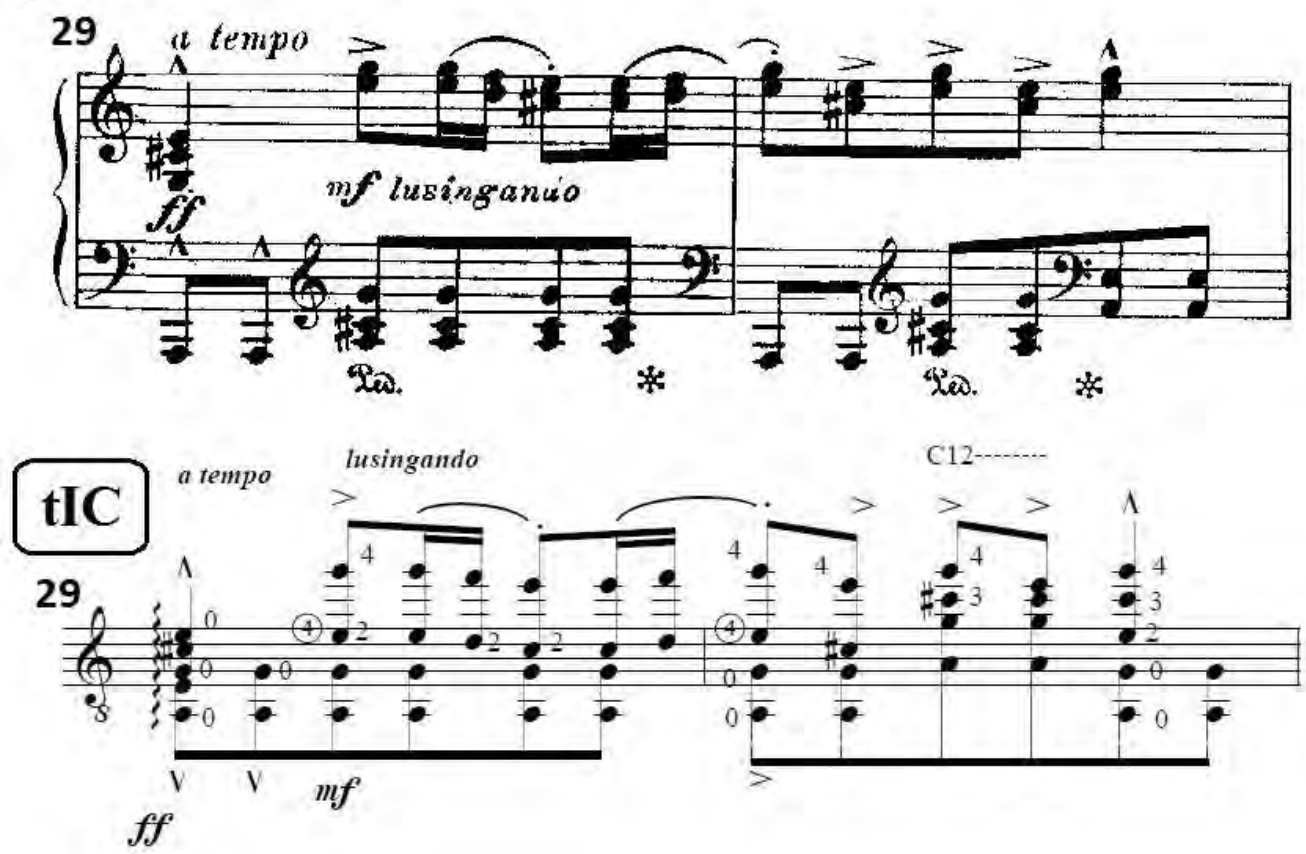

Fonte: elaborada pelo autor

Com uma proposta de dedilhado de mão direita, foi possível manter o trinado ocorrente no final da segunda seção (Figura 82). 
Figura 82 - Manutenção do trinado na transcrição orig.
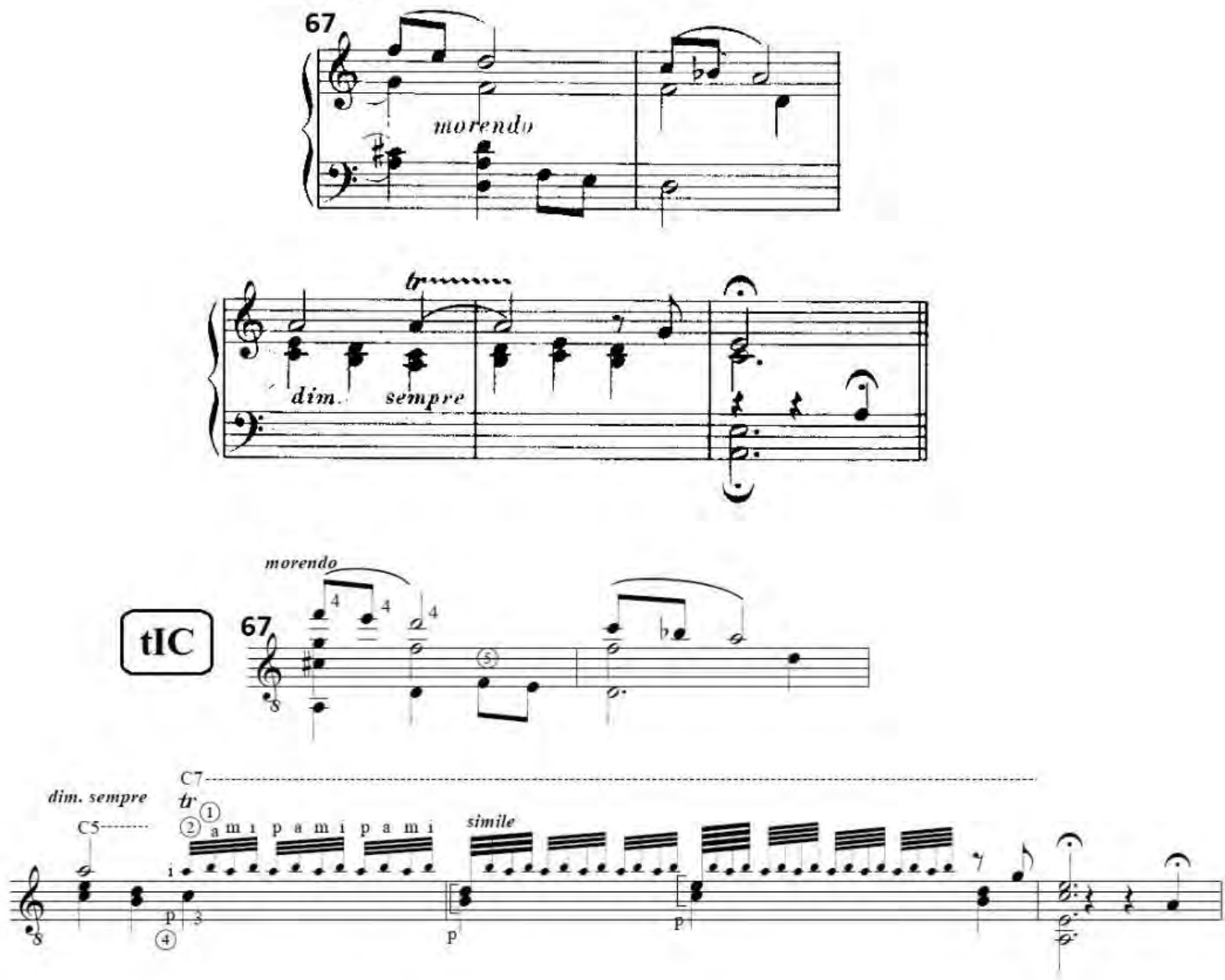

Fonte: elaborada pelo autor 
Transcrição para violão de Iury Cardoso
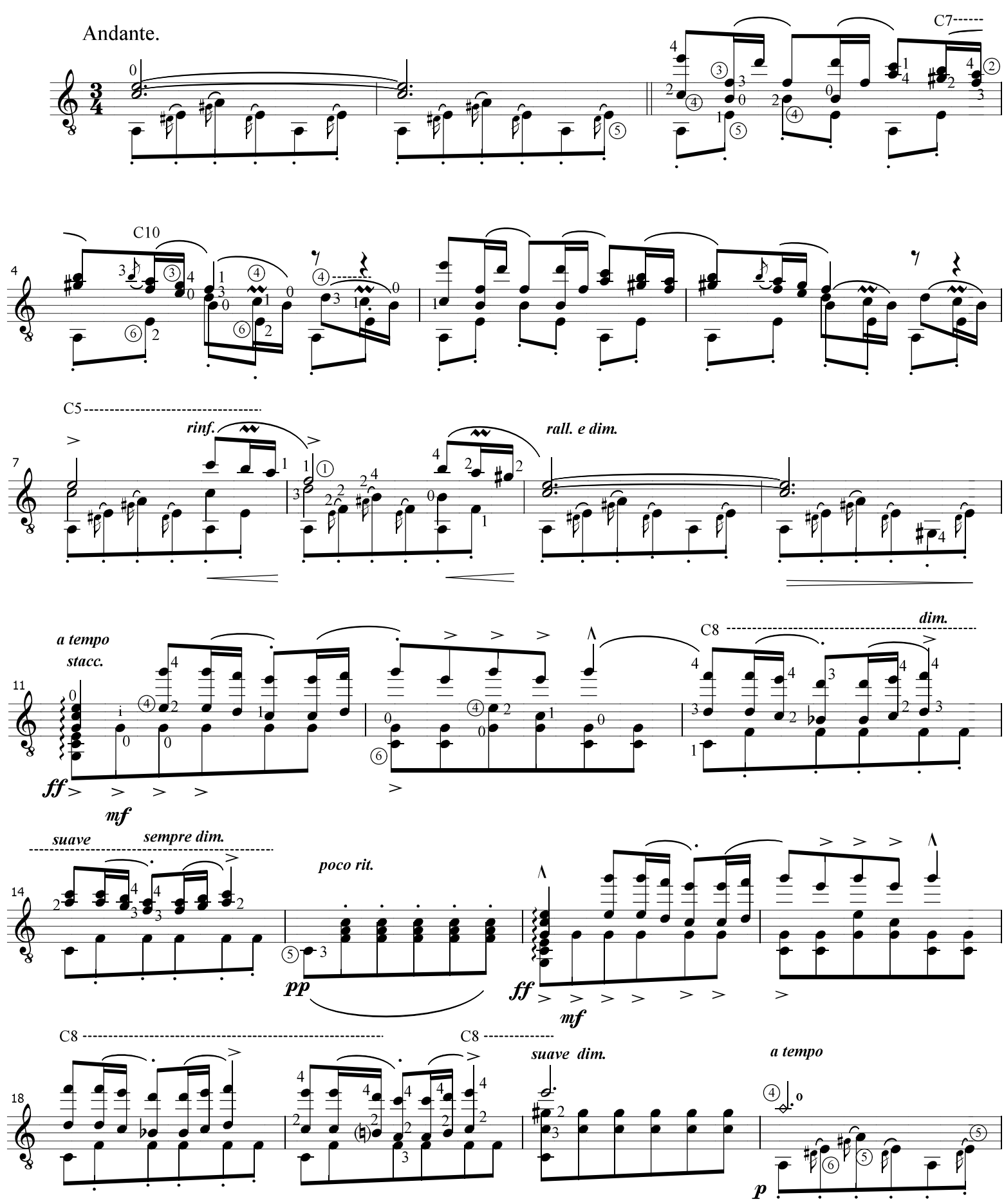
3.
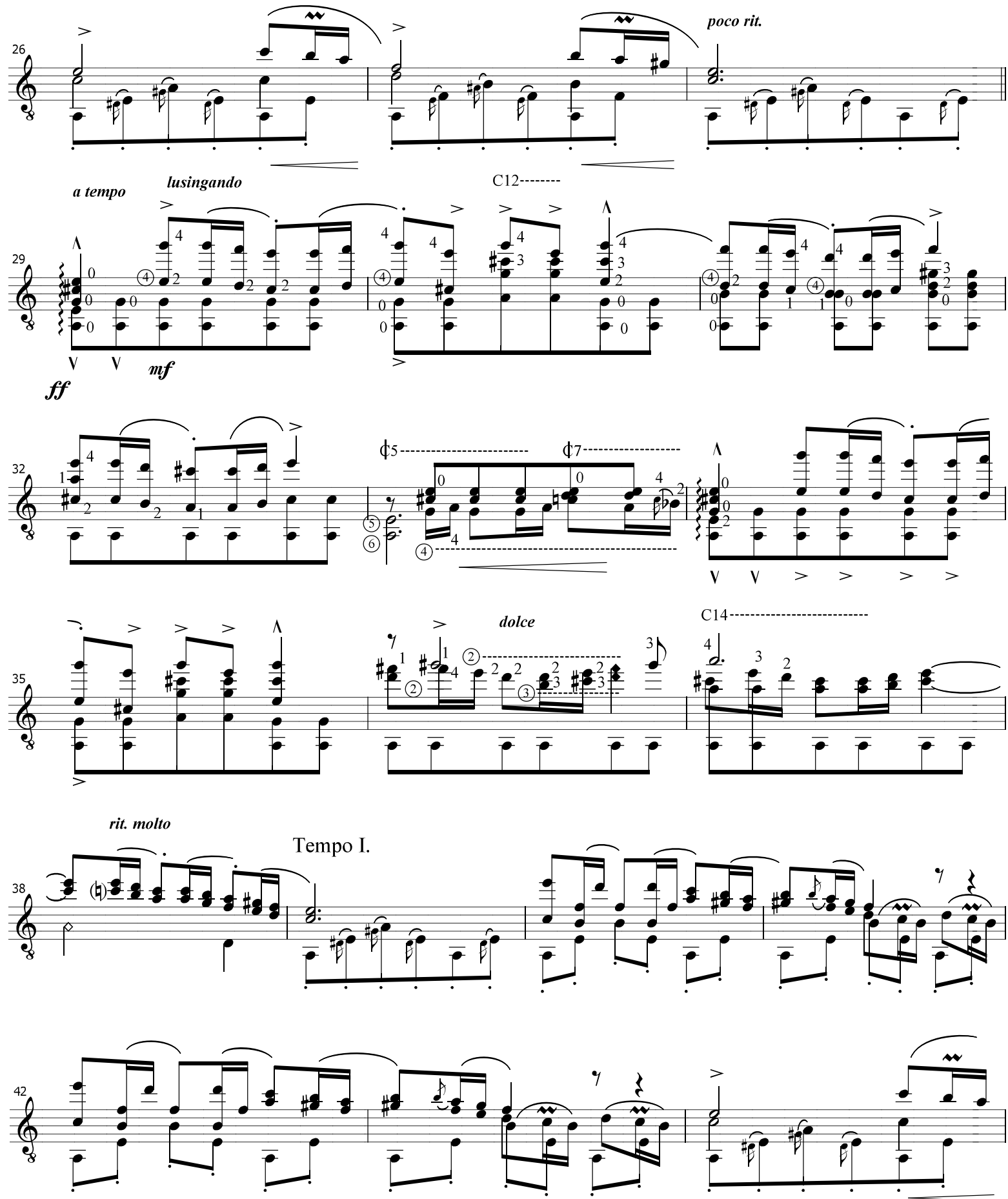


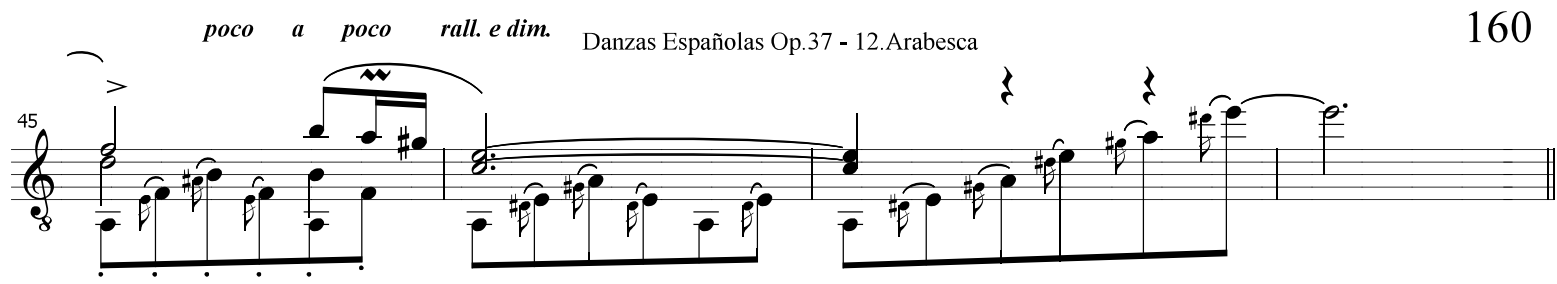

Molto Andante espressivo.
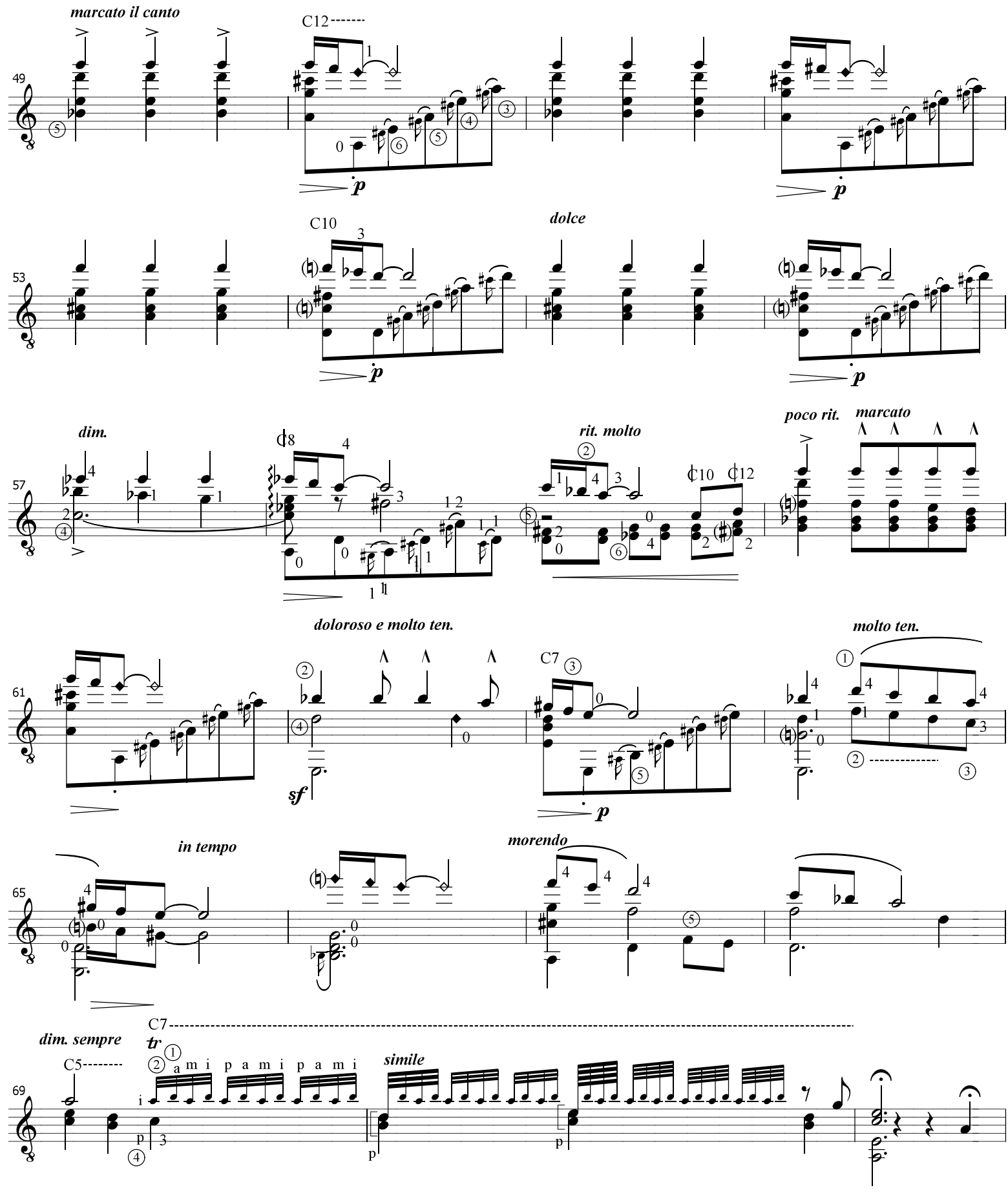
Andante.
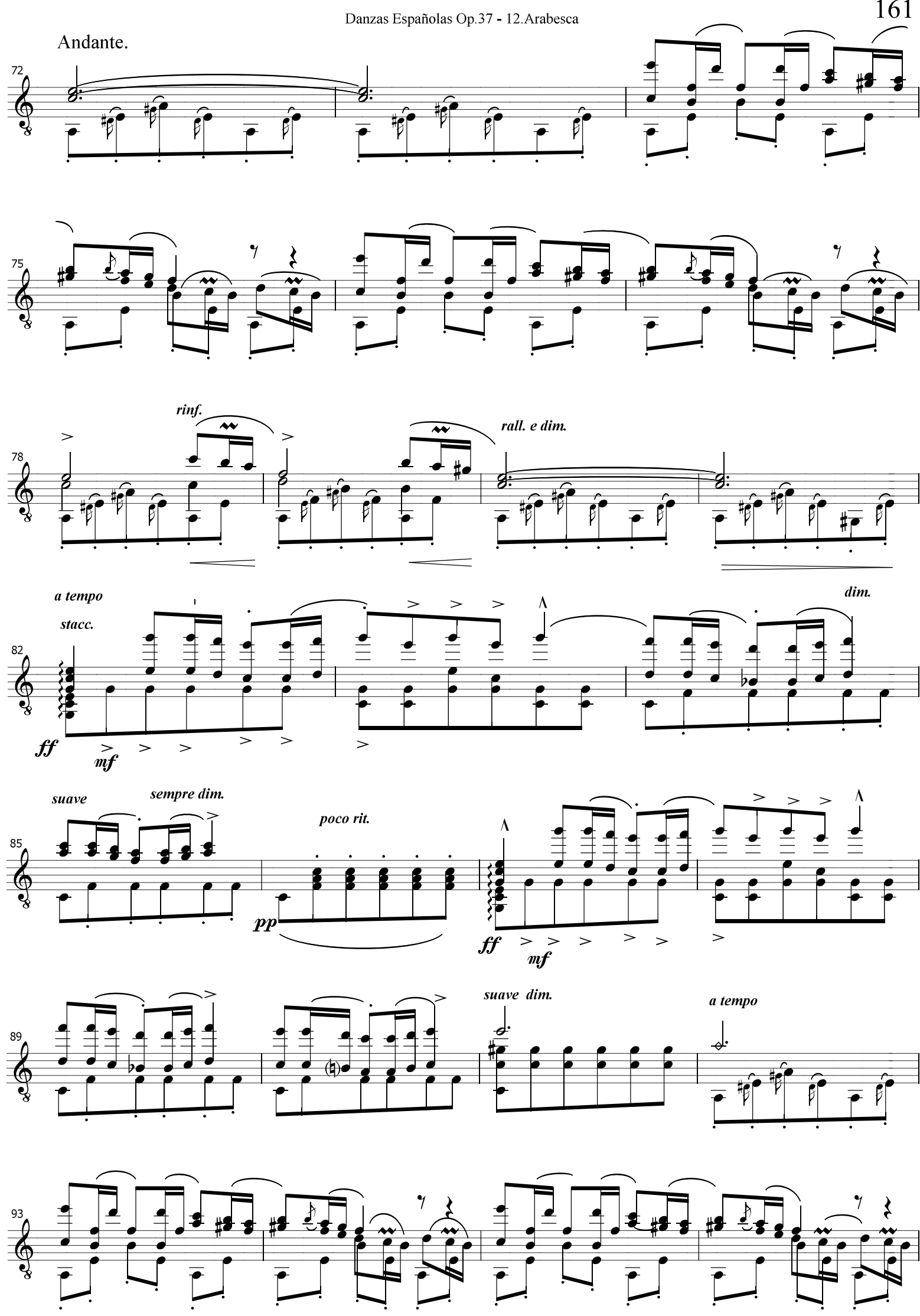

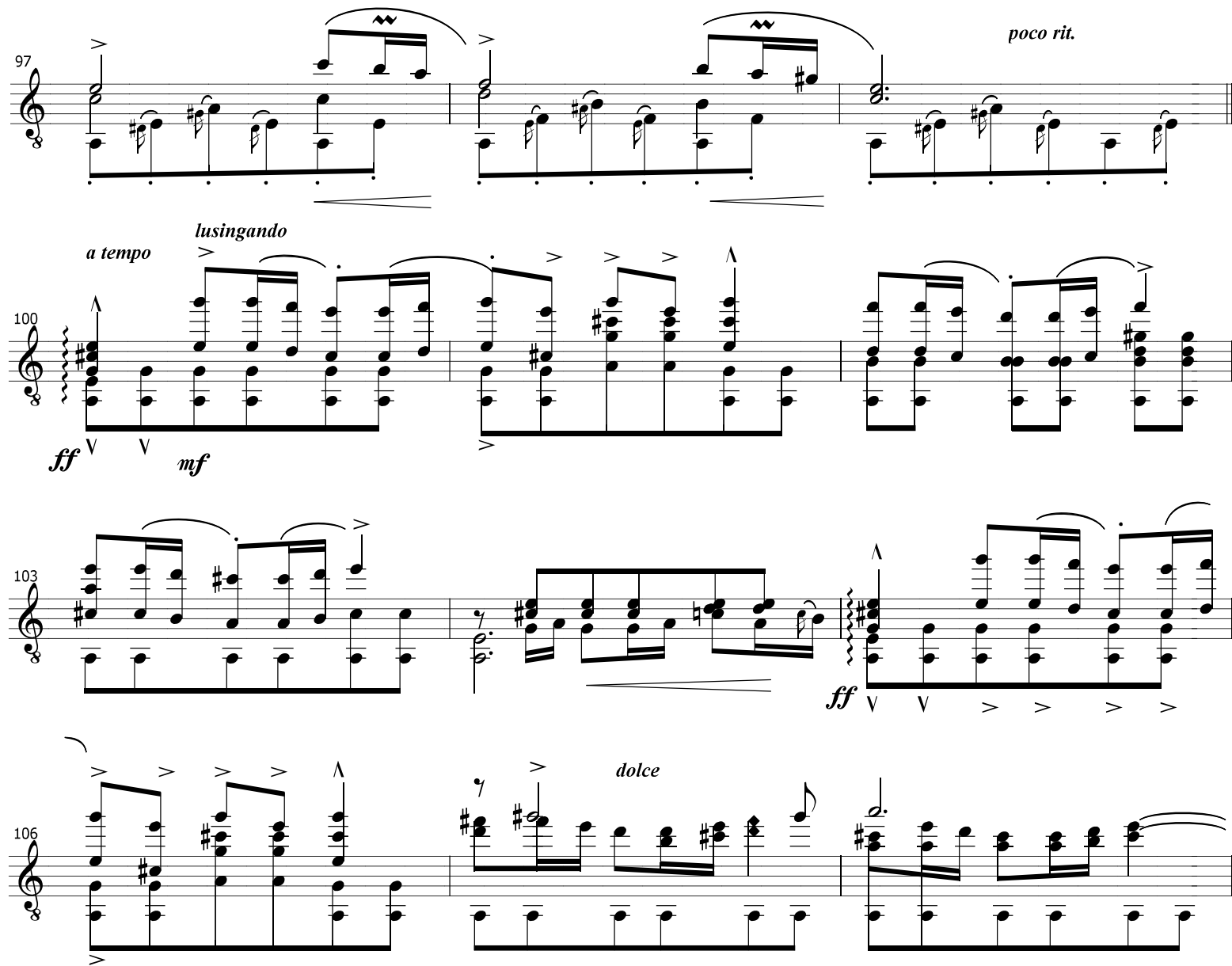

$\int_{0}^{0}$
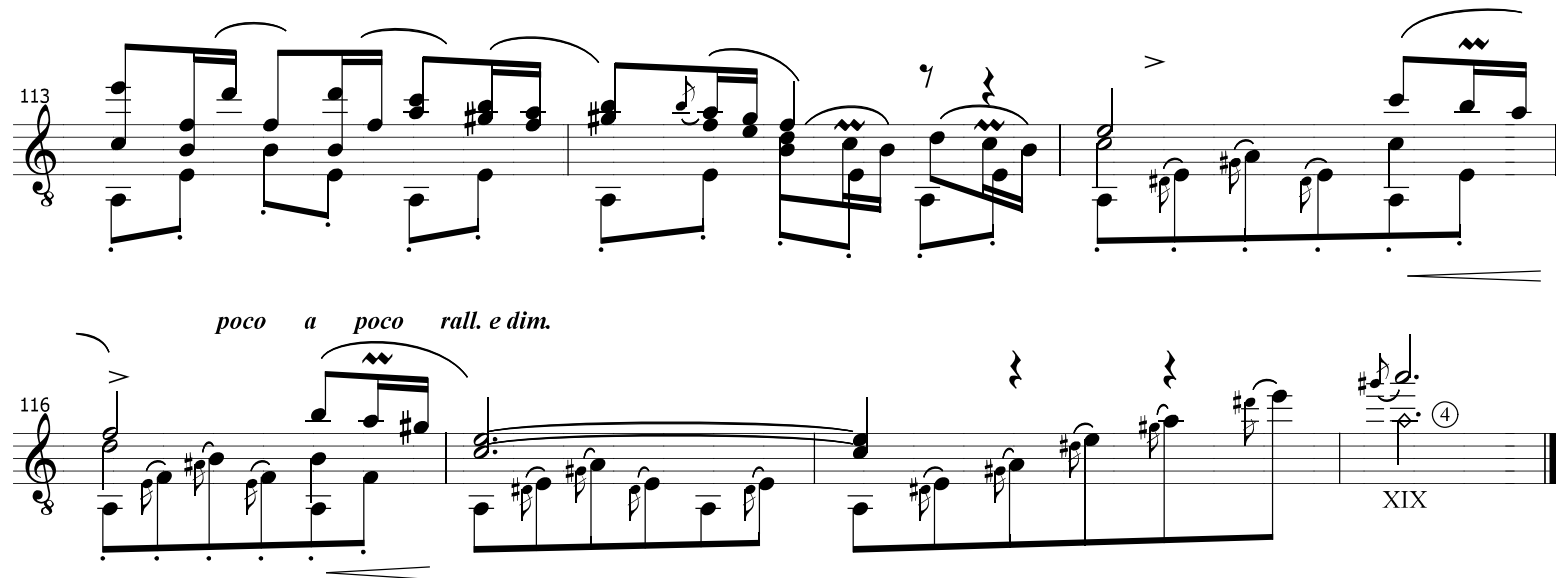


\section{CONSIDERAÇÕES FINAIS}

Iniciamos nosso trabalho através de um breve histórico bibliográfico de Enrique Granados e verificamos os aspectos musicais e estilísticos de suas 12 Danzas no contexto da música espanhola.

Posteriormente, discutimos a conceituação da scordatura e sua aplicação ao violão como uma ferramenta de transcrição. Analisamos as características oriundas da maleabilidade do instrumento para modificar sua afinação e consequentemente, sua estrutura musical, de acordo com a necessidade.

Através da pesquisa das diferentes configurações de afinação utilizadas, acreditamos que as scordature apresentadas nesse trabalho, se apresentam como uma extensão daquelas utilizadas até então no repertório violonístico. Embora o conceito que envolve o termo técnicas estendidas se encontre em aberto - devido ao curto distanciamento histórico em que os pesquisadores atuais se encontram desse objeto, aliado à diversidade das interações que podem caracterizar uma extensão técnica - é justificável entender a expressão como um conceito que se refira a reformulação das técnicas já há muito incorporadas ao aparato técnico, que denominamos por "tradicional” (STEFAN, 2012).

Ao consultar tratados e livros sobre interpretação de música antiga, nota-se que a prática da transcrição é tão longínqua quanto a história dos instrumentos musicais. É comum, desde o Renascimento, que encontremos versões de uma mesma obra para instrumentos diversos. Visitamos então, o legado das transcrições históricas e verificamos seus procedimentos, com a finalidade de absorvê-los e aplicá-los em nossa abordagem de adaptação.

O processo de transcrição das 12 Danzas Españolas envolveu diversas etapas, onde decisões foram tomadas através de um constante exercício de reflexão. A busca do equilíbrio entre a ideia original do compositor e as possibilidades de adequação aos recursos do violão impôs desafios que foram desde a interpretação da partitura e das sonoridades características do piano até o estudo envolvendo as técnicas de adaptação empregadas nas transcrições para violão de obras originais de outros instrumentos. A ampla observação das concepções criativas do compositor da obra original, incluindo-se sua correspondente poética musical, são fatores necessários à realização de uma transcrição de um instrumento para outro. É Imprescindível também, o amplo conhecimento das possibilidades violonísticas, pois frequentemente o 
transcritor se depara com passagens onde o compositor faz uso de recursos que não são totalmente compatíveis ao violão, mas podem ser traduzidos de forma criativa. Este tratamento foi adotado por Tárrega e seus principais discípulos (Llobet e Pujol) em suas transcrições, quando frequentemente reelaboravam o material musical como se tivesse sido concebido originalmente para o violão.

O instrumento para o qual se destina a transcrição também funciona como um filtro que seleciona aspectos do evento sonoro compatíveis com suas características idiomáticas e exclui aqueles que não lhes são próprios (MORAIS, 2007). Portanto, uma transcrição feita através de uma abordagem restrita ao texto musical resultará superficial. O contato com a resultante sonora, quer seja pessoalmente ou por gravações, se faz necessário para uma busca mais consistente, que visa encontrar o elemento correspondente do meio que recebe a obra transcrita. Contudo, em se tratando de elementos de linguagem instrumental, toda transcrição musical implica, de fato, em perdas e ganhos. No entanto é intrigante observar como um meio de características timbrísticas distintas, “[...] é capaz de assumir um material que não foi a princípio pensado pra ele, mostrando que a essência da música não se limita a sonoridades particulares que se pode obter sobre determinados instrumentos" (PEREIRA, 2011, p. 68).

Em relação a correspondência de elementos das 12 Danzas Españolas, acreditamos que, nesse caso, a transcrição atua como uma viagem de retorno às fontes inspiradoras da composição, que frequentemente contemplam elementos folclóricos estreitamente ligados à tradição popular do violão na Espanha (COSTA, 2006).

Nos momentos onde a tradução literal do texto não foi possível, abordamos a transcrição dentro da mesma perspectiva adotada por Tárrega, Llobet e Pujol, no que diz respeito à reelaboração do material musical, incitando o exercício imaginativo de supor como a seção, passagem ou frase musical seriam, caso concebidas ao violão. Para completar o cerco, o auxílio das novas scordature propostas foi determinante.

Através da análise das scordature apresentadas nesse trabalho, constatamos que alguns ajustes na afinação podem apresentar opções promissoras de abarcamento de obras escritas originalmente para outros instrumentos, peças que anteriormente tenham apresentado um número muito grande de dificuldades de adaptação através da afinação e ajustes tradicionais.

Como violonistas, talvez agora possamos voltar atrás na história da música e completar, considerando diferentes propostas de scordature, alguns ciclos inacabados, realizados por 
transcritores do passado; assim como se familiarizar com as diferentes possibilidades musicais geradas no violão através da alteração de sua afinação e ajustes tradicionais. 


\section{REFERÊNCIAS BIBLIOGRÁFICAS}

ALBÉNIZ, Isaac. Granada. Transcrição de Francisco Tárrega. Union Musical Española. Ediciones S. L. Madrid, 1987. 1 Partitura [5 p.]. Violão.

. Sevilla. Transcrição de Miguel Llobet. Union Musical Española. Ediciones S. L. Madrid, 1987. 1 Partitura [7 p.]. Violão.

Cádiz. Transcrição de Miguel Llobet. Union Musical Española. Ediciones S. L. Madrid, 1987. 1 Partitura [7 p.]. Violão.

BARBEITAS, Flavio Terrigno. Reflexões sobre a prática da transcrição: as suas relações com a interpretação na música e na poesia. Per Musi, Belo Horizonte, v.1, n. 1, p. 89-97, $2000 . \quad$ Disponível em: $<$ http://www.musica.ufmg.br/permusi/port/numeros/01/num01_cap_09.pdf $>$ Acesso em: 11 fev. 2017.

BERGADÀ, Montserrat. Enrique Granados. In. FUNDACIÓN JUAN MARCH. Semblanzas de compositores españoles. Madrid, 2011. p. 164-169. Disponível em: $<$ https://recursos.march.es/web/musica/publicaciones/semblanzas/ebook/semblanzas-decompositores-fundacion-juan-march.pdf >. Acesso em: 20 jun. 2017.

BETANCOURT, Rodolfo J. The process of transcription for guitar of J.S.Bach Chaconne from partita II for violin without accompaniment, BWV 1004. 1999. 67 p. Dissertação (Mestrado em música) The Lamont School of Music, Denver, 1999.

BOTA, João Victor. A Transcrição Musical como processo criativo. 2008. 99 p. Dissertação (Mestrado em Música) Instituto de Artes da Universidade Estadual de Campinas, Campinas, 2008.

BORGES, Rafael Garcia. O uso da scordatura para a execução no violão de obras compostas para alaúde barroco: transcrição e exemplos extraídos da obra de Silvius Leopold Weiss. 2007. 122 p. Tese (Doutorado em Música) Universidade federal do Rio Grande do Sul, Porto Alegre, 2007.

BROUWER, Leo. Paisaje cubano com campanas. Paris: Max Eschig. 1986, Partitura [4.p]. Violão.

CAMPBELL, D. M.; GREATED, C.; MYERS, A. Musical Instruments: History, Technology and Performance of Instruments of Western Music. Oxford University Press, 2004. $495 \mathrm{p}$

CARVALHO, Diogo Salmeron. Transcrições para violão: soluções técnico-musicais para interpretação de obras selecionadas de Claude Debussy e Maurice Ravel. 2012. 200 p. Dissertação (Mestrado em música) Universidade de São Paulo, São Paulo, 2012. 
CASAS, Ramon. Enrique Granados. [entre 1897 e 1899]. 1 pintura. Disponível em: $<$ http://www.museunacional.cat/en/colleccio/portrait-enric-granados/ramon-casas/027628-d $>$. Acesso em: 14 mar. 2016.

CLARK, Walter Aaron. Enrique Granados: poet of the piano. Reprint edition. Londres: Oxford University Press, 2011. 304 p.

COSTA, Gustavo Silveira. O processo de transcrição para violão de tempo di ciaccona e fuga de Béla Bartók. 2006. 86 p. Dissertação (Mestrado em música) Universidade de São Paulo, São Paulo, 2006.

. Seis sonatas e partitas para violino solo de J. S. Bach ao violão: fundamentos para a adaptação do ciclo. 2012. 108 p. Tese (Doutorado em música) Universidade de São Paulo, Ribeirão Preto, 2012.

DANZAS ESPAÑOLAS. Texto publicado em Monografias.com. 1999. Disponível em: $<$ http://www.monografias.com/trabajos/danzasesp/danzasesp.shtml $>$. Acesso em: $21 \mathrm{mar}$. 2016.

DUDEQUE, Norton Eloy. História do Violão. Curitiba: Editora UFPR, 1994. 113 p.

ENRIQUE GRANADOS. Diretor: Donald Macleod. BBC MUSIC. 2016. 1 aúdio (61min). Disponível em: $\quad<$ https://www.bbc.co.uk/music/artists/e378c6b3-7d74-48b5-ab049aac0df7562c $>$. Acesso em: 15 jan. 2017.

FUNDACIÓN JUAN MARCH. EI piano de Enrique Granados. Madrid, 1991.

GRANADOS AND ALBENIZ (1867-1916 AND 1860-1909). Diretor: Donald Macleod. BBC MUSIC. 2014.21 aúdio (62min). Disponível em: $<$ http://www.bbc.co.uk/programmes/p021bhpy>. Acesso em: 18 out. 2016.

GRANADOS, Enrique. Danzas Españolas. Barcelona: Casa Dotesio, 1890. Partitura [67 p.] Piano.

. Goyescas, Spanish Dances and other works for solo piano. Mineola: Dover Publications, 1987. Partitura [176 p.] Piano.

Granados Danza Española n5 Andaluza. Transcrição de Miguel Llobet. Madrid: Union Musical Española. Ediciones S. L, 1987. Partitura [p.8]. Violão.

. Masters of the piano roll - Granados plays Granados. Londres: Dal Segno Records, 2005. 1 CD (74 min). Remasterizado em digital.

GLOEDEN, Edelton. O ressurgimento do violão no século XX: Miguel Llobet, Emilio Pujol e Andrés Segovia. 1996. Dissertação (Mestrado em música) Universidade de São Paulo, São Paulo, 1996.

GLOEDEN, Edelton; MORAIS, Luciano César. Intertextualidade e transcrição musical: novas possibilidades a partir de antigas propostas. Opus, Goiânia, v. 14, n. 2, p. 72-86, dez. 2008. 
BREAM, Julian. Julian Bream plays Granados \& Albéniz. New York: RCA records, 1982. 1 CD (62 min). Digital estéreo.

LARROCHA, Alicia de. Granados, Spanish Dances, Works for piano. New York: RCA Victor, 1995. 1 CD (67 min). Digital estéreo.

LLOBET, Miguel. Guitar Works. Fenton: Mel bay publications, 2006. Partitura [206 p.]. Violão.

BARRUECO, Manuel. Manuel Barrueco plays Albéniz \& Turinia. Londres: EMI classics, 1997. 1 CD (64 min). Digital estéreo.

MORAIS, Luciano César. Sérgio Abreu: poética e herança histórica através de suas transcrições para violão. 2007. 204 p. Dissertação (Mestrado em música) Universidade de São Paulo São Paulo, São Paulo, 2007.

NOGUEIRA, Gisela Gomes Pupo. A viola com anima: uma construção simbólica. 2008. 203 p. Tese (Doutorado em música) Universidade de São Paulo, São Paulo, 2008.

PEREIRA, Flávia Vieira. As práticas de reelaboração musical. 2011. 302 p. Tese (Doutorado em música) Universidade de São Paulo, São Paulo, 2011.

REGO, Eusiel Silva do. Fernando Sor e as transcrições Opus 19 para violão de Seis árias escolhidas de A flauta mágica de Mozart: uma abordagem estético-analítica. 2012. 287 p. Dissertação (Mestrado em Música) Universidade de São Paulo, São Paulo, 2012.

SADIE, Stanley. Dicionário Grove de música. Rio de Janeiro: Jorge Zahar Ed., 1994.

SEGOVIA, Andrés. Transcriptions. Ancona: Bèrben Edizioni Musicali, 1960. Partitura [160 p.]. Violão.

SEGOVIA, Andrés. The Complete Early Recordings (1927-1939). Erba: Fono Enterprise, 1997. 2 CD (121 min). Digital estéreo.

SOUTO, Luciano Hercílio Alves. Transcrição Musical: Um estudo crítico do repertório para instrumentos de cordas dedilhadas. 2010. 113 p. Dissertação (Mestrado em música) Universidade Estadual Paulista "Júlio de Mesquita Filho” (Unesp). São Paulo, 2010.

STEFAN, Gilberto de Souza. O ensino do trêmolo e da scordatura na contemporaneidade. 2012. 76 p. Dissertação (Mestrado em música) Universidade Federal de Goiás. Goiânia, 2012.

STEPHAN, Rudolf. Enciclopédia Meridiano Fischer: Volume 7 - Música. Tradução de Carlos Alberto Siqueira e Isabel Varela Sanches. Lisboa: Ed. Meridiano. 1968. 567 p.

SEGOVIA, Andrés. The legendary Andrés Segovia: My favorite works. Chicago: MCA Classics, 1988. 1 CD (69 min). Digital estéreo.

TYLER, James. The early guitar: a history and handbook. Coleção: Early music series, vol. 4. Londres: Oxford University Press, 1980. 176 p. 
VASCONCELOS, Marcus A. Varela. Recursos idiomáticos em scordatura na criação de repertório para violão. 2002. 161 p. Dissertação (Mestrado em Artes) Universidade Estadual de Campinas. Campinas, 2002. 


\section{Anexos}

ANEXO A (Único) - Partitura original das 12 Danzas Españolas Op. 37, publicada pela Dover Publications em 1987. Foi a principal referência para a realização do processo de nossas transcrições. 


\section{SPANISH DANCES \\ (Danzas Españolas)}

1
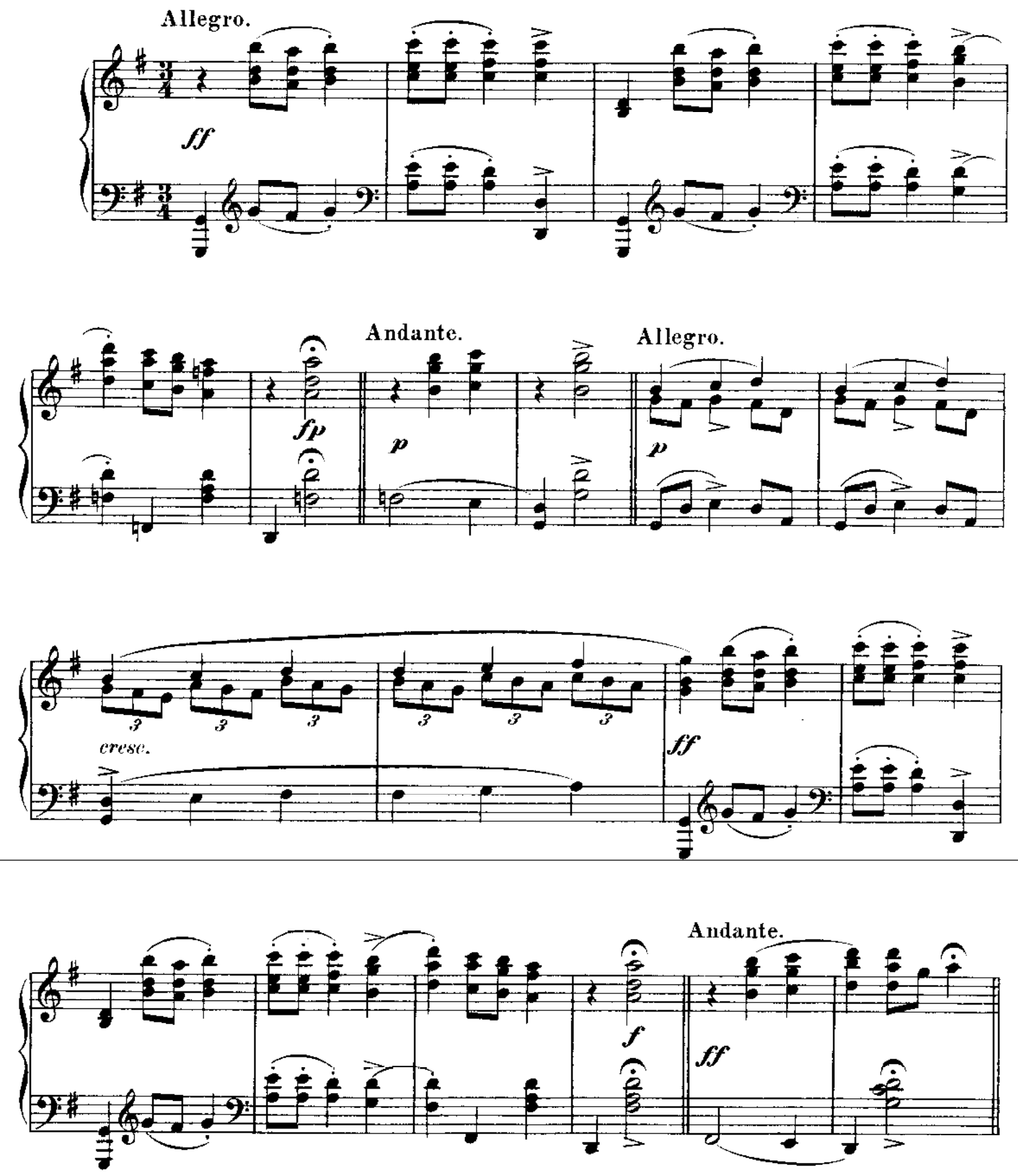
Allegro.
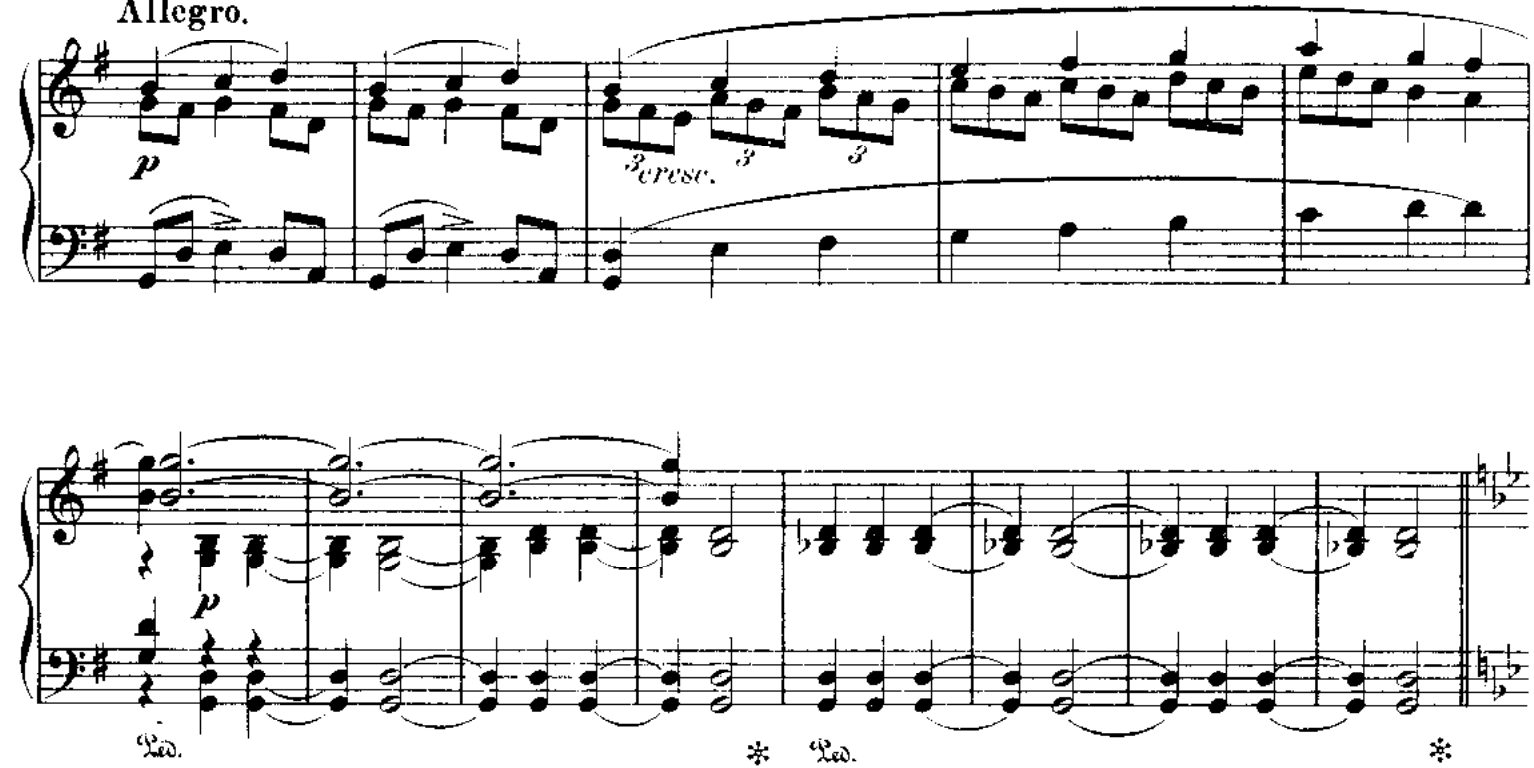

Poco Andante.
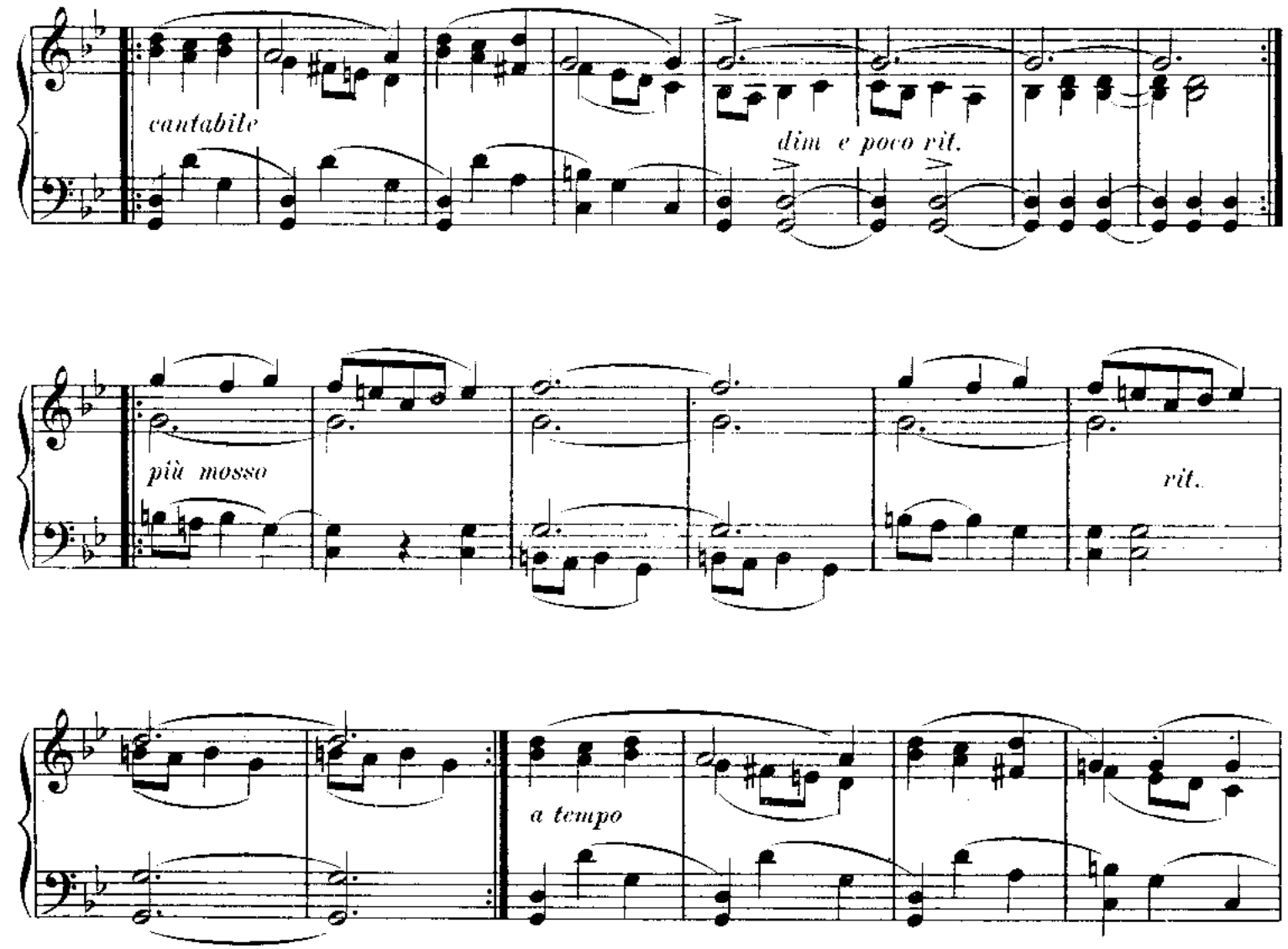
Tempo 1.
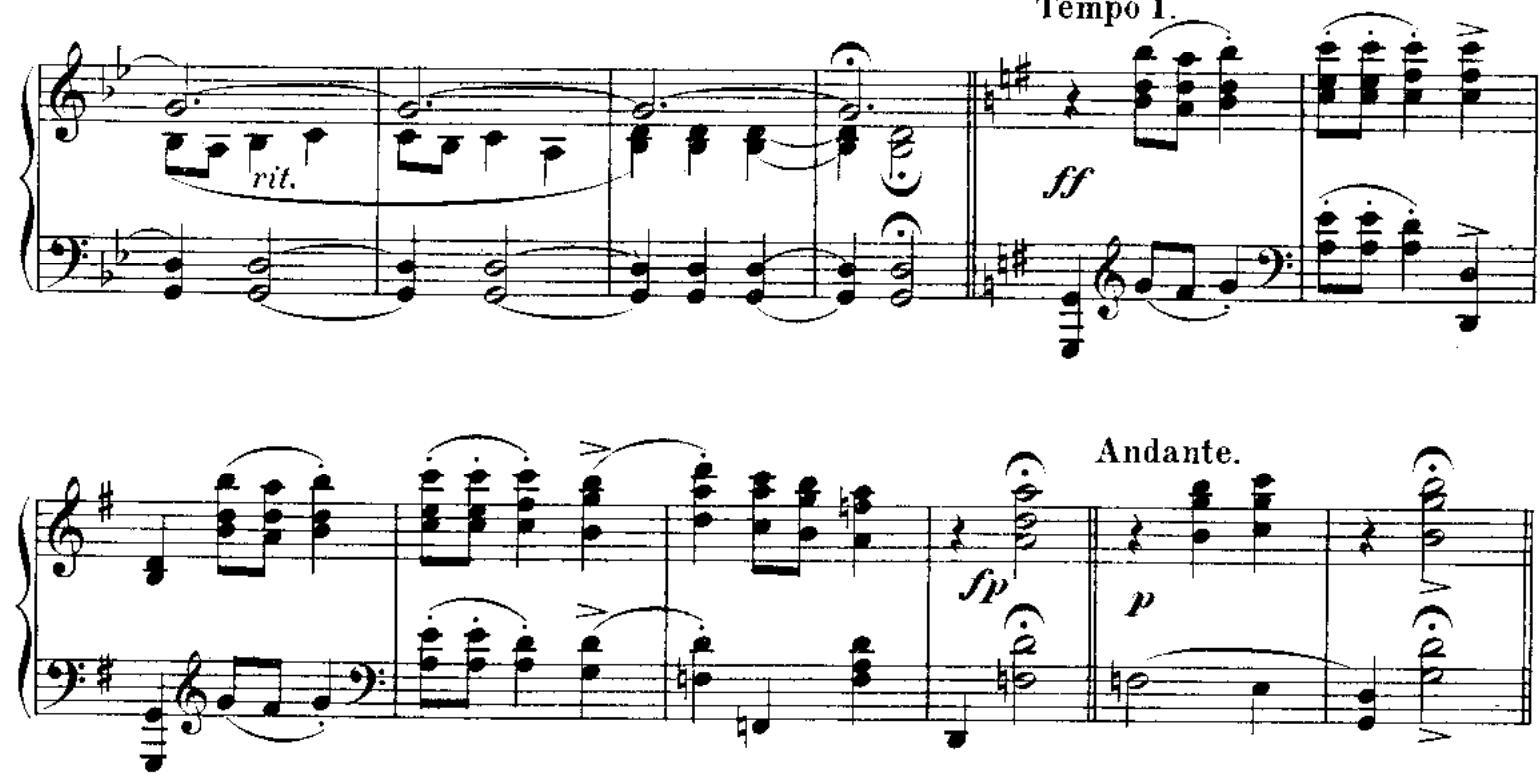

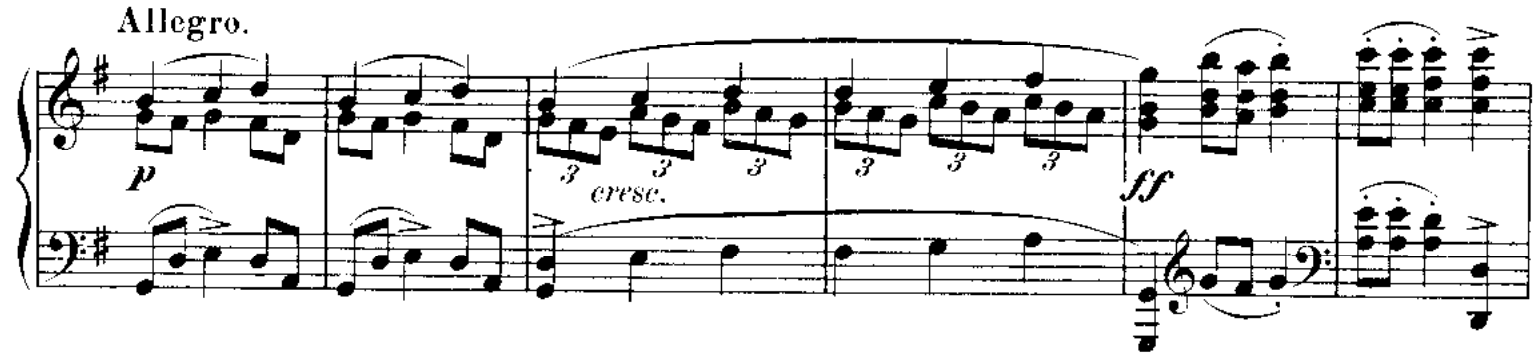
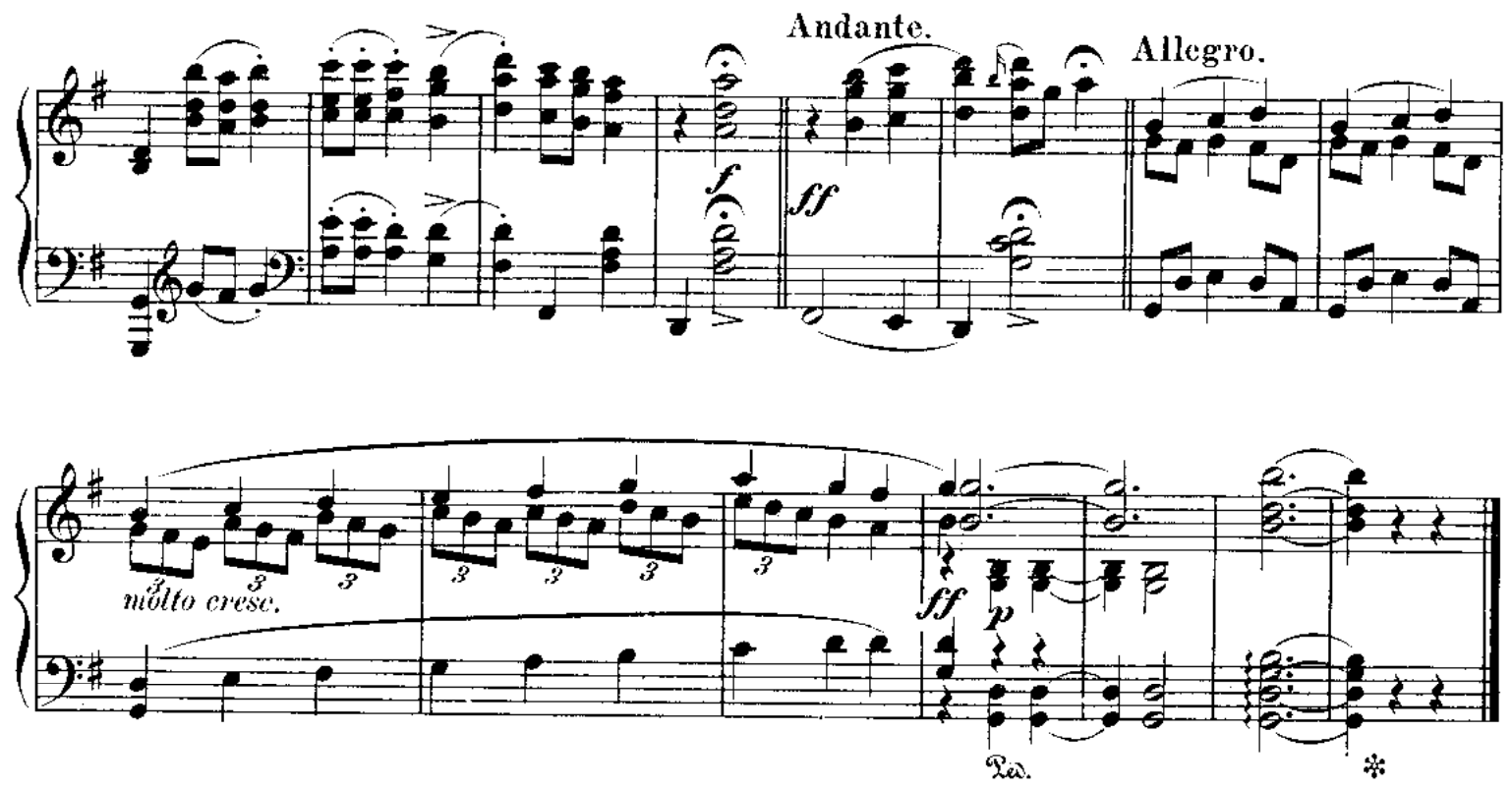

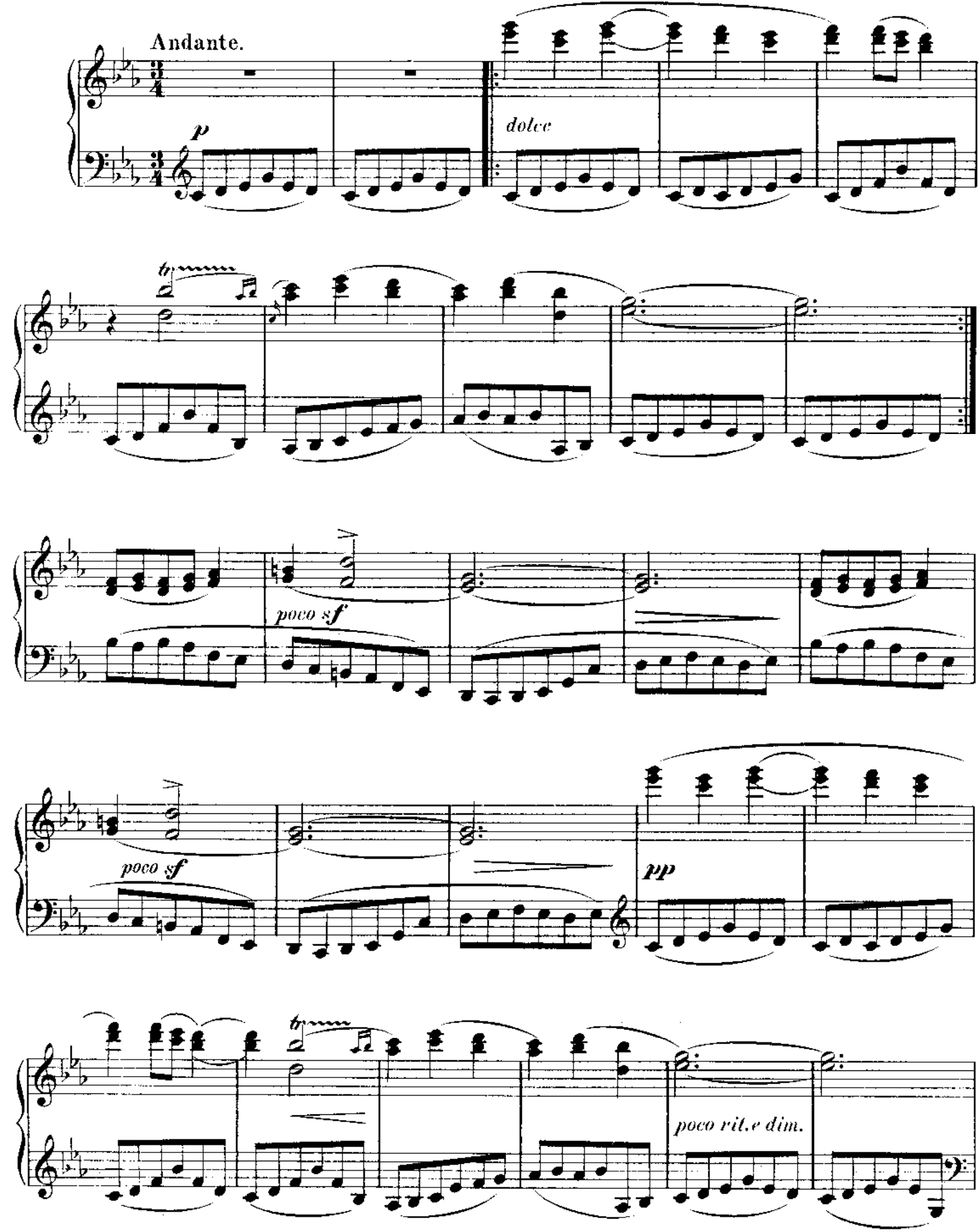

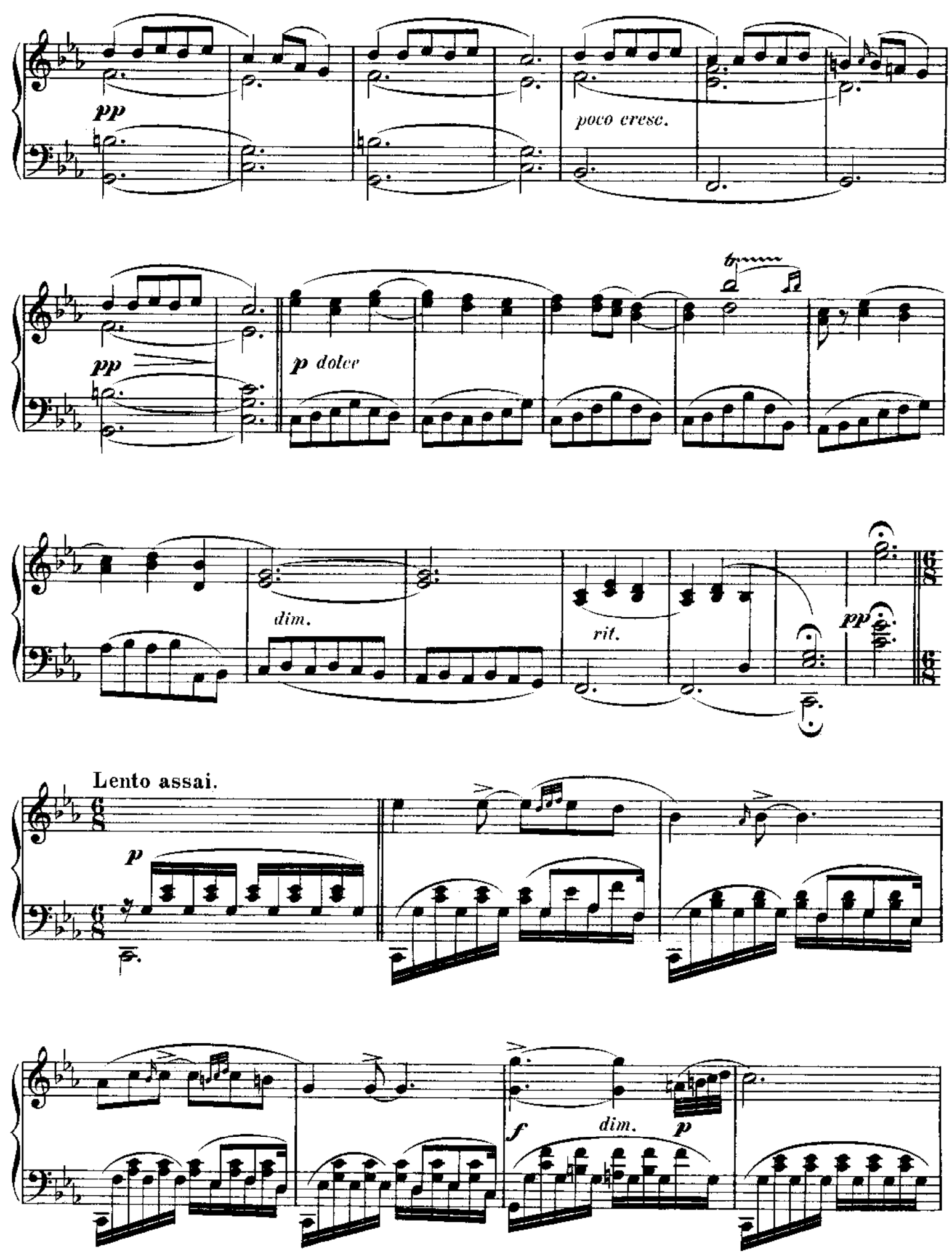

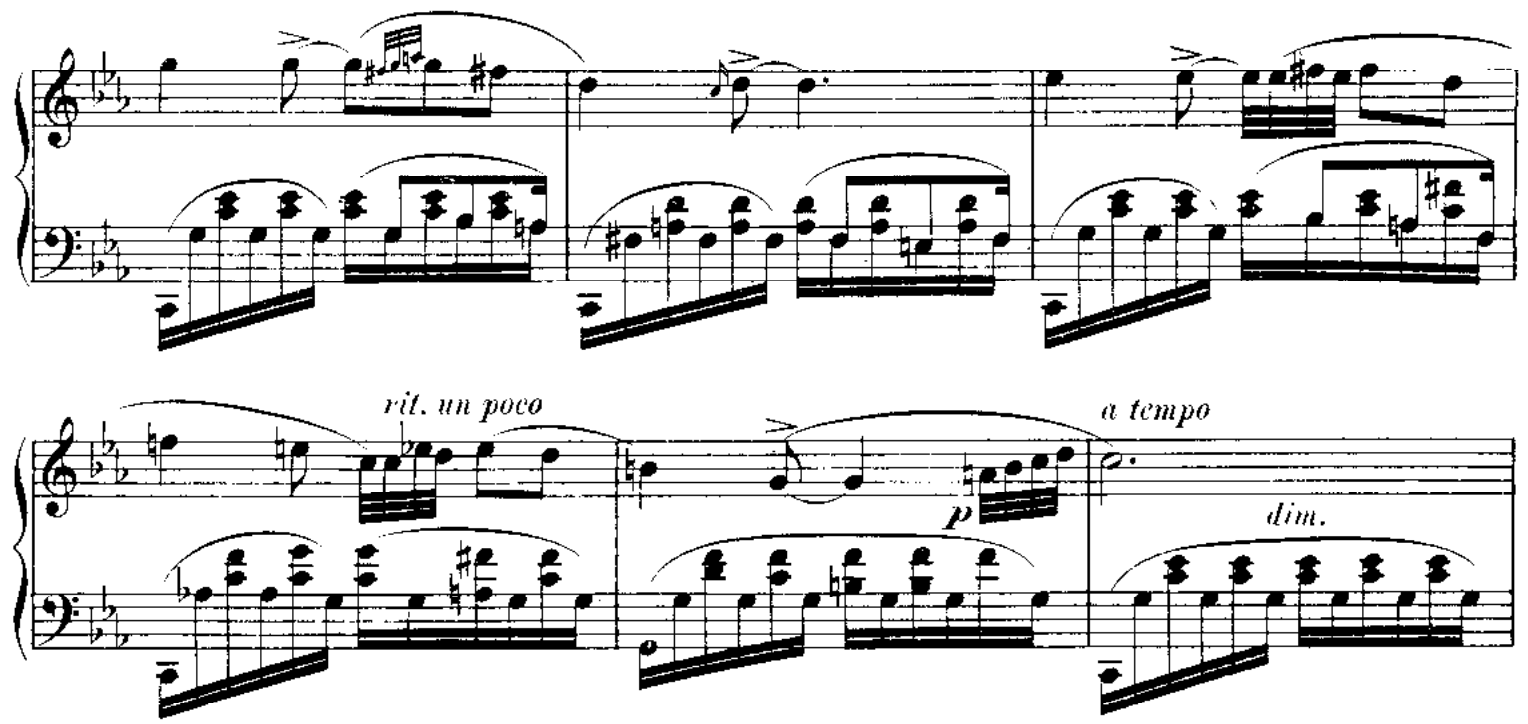

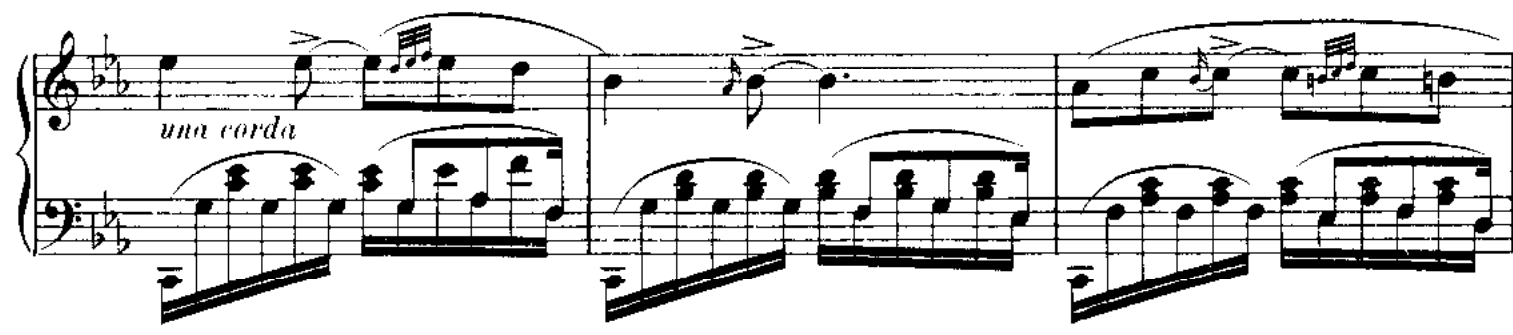
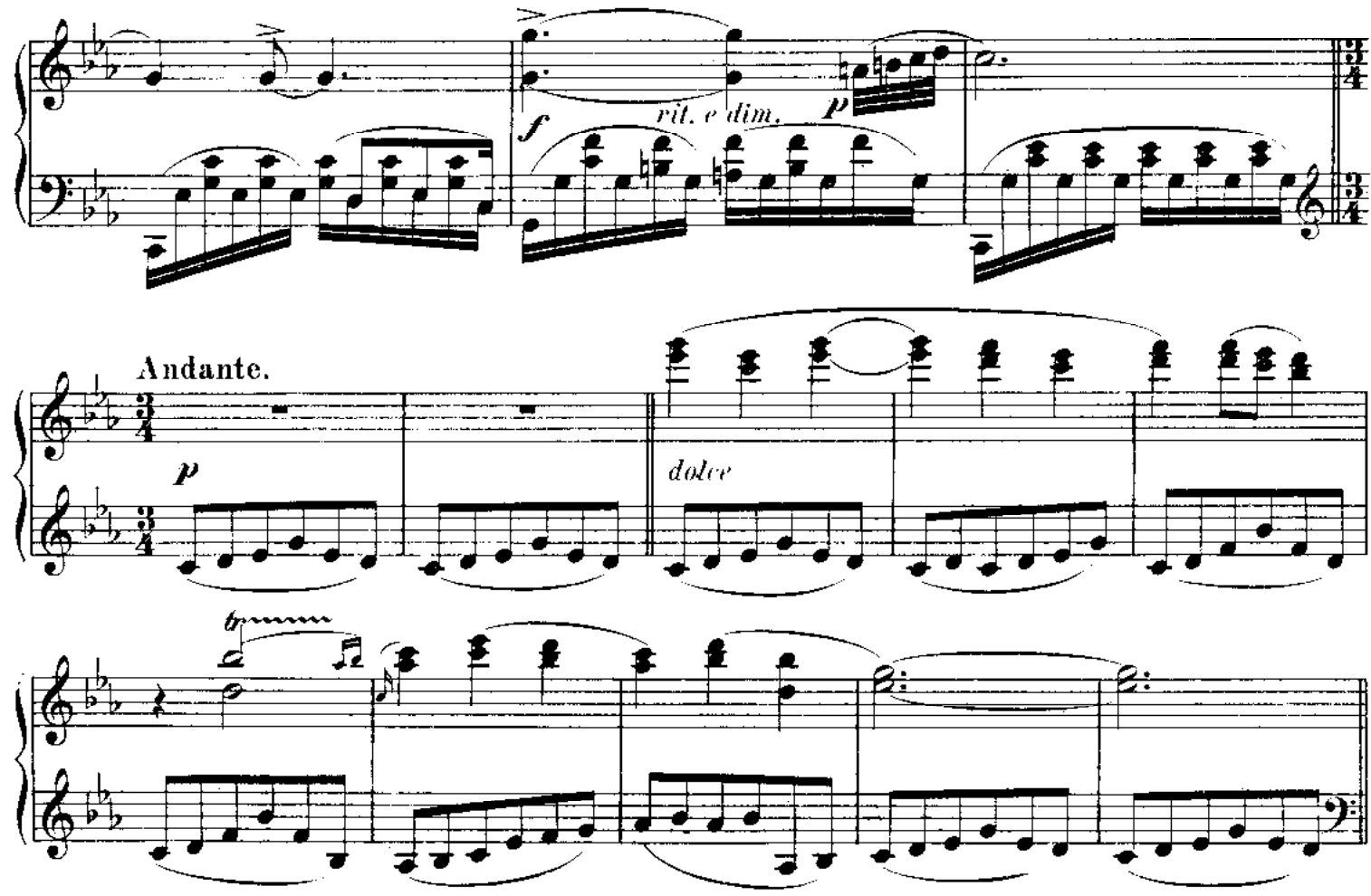

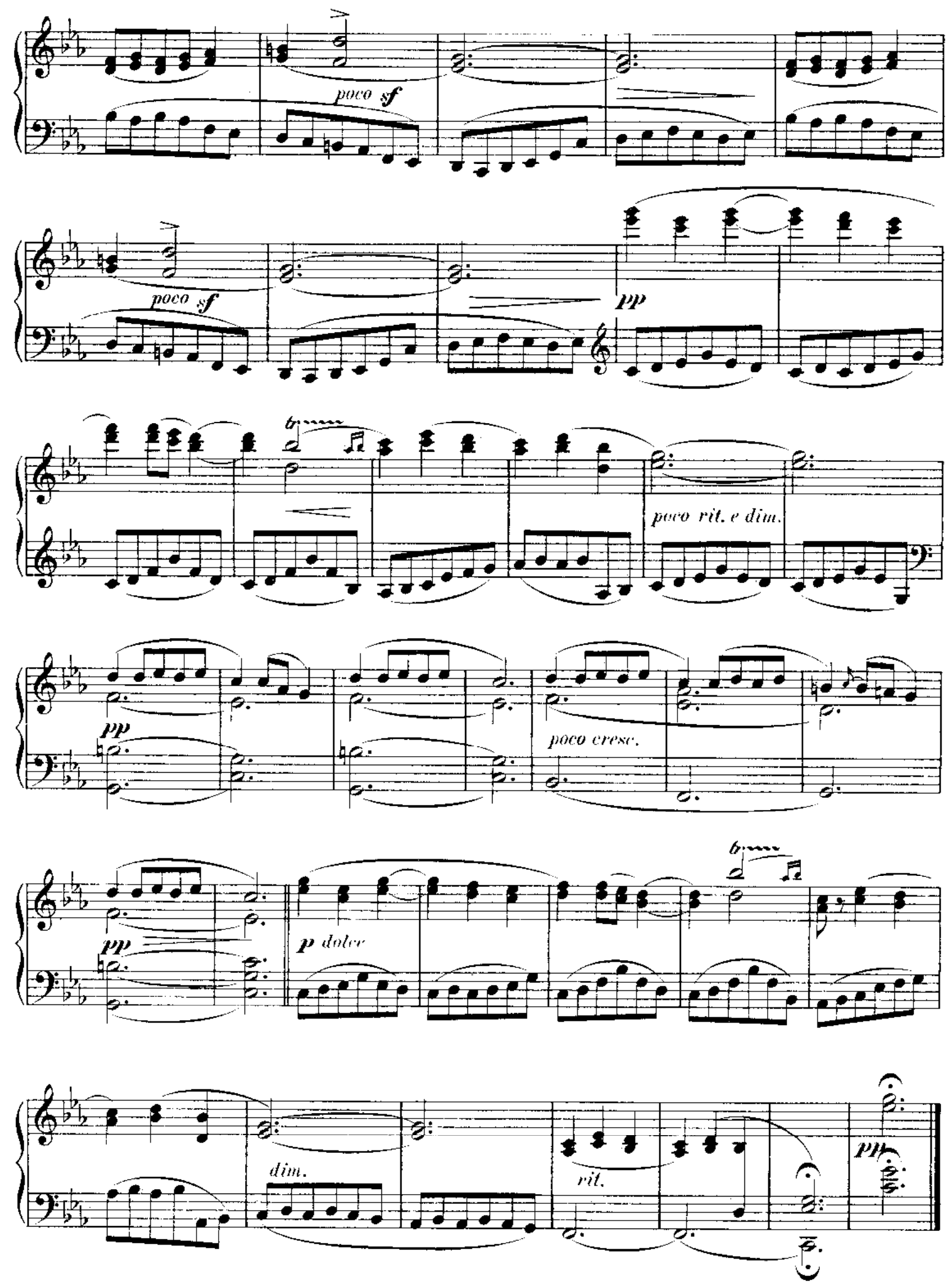

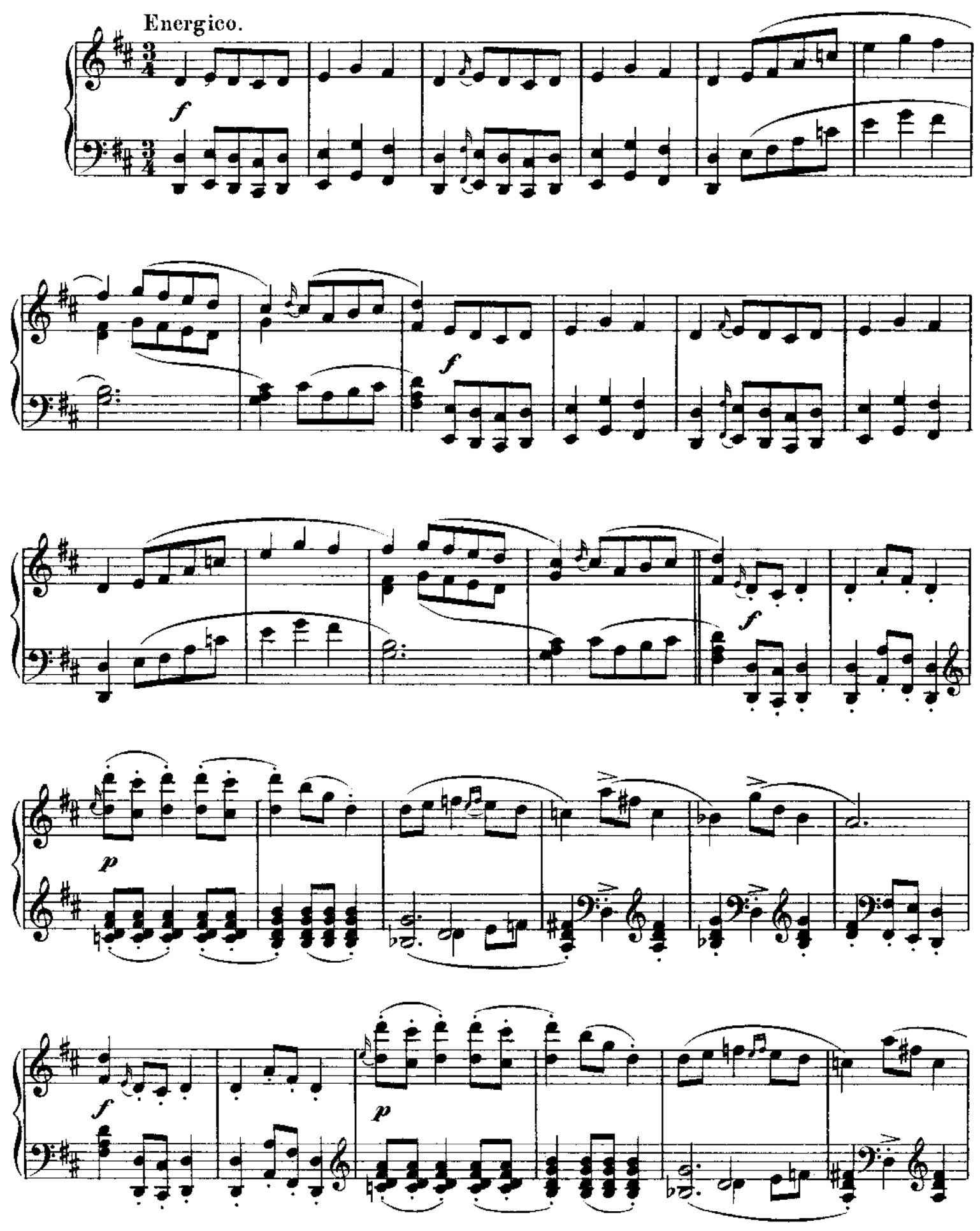

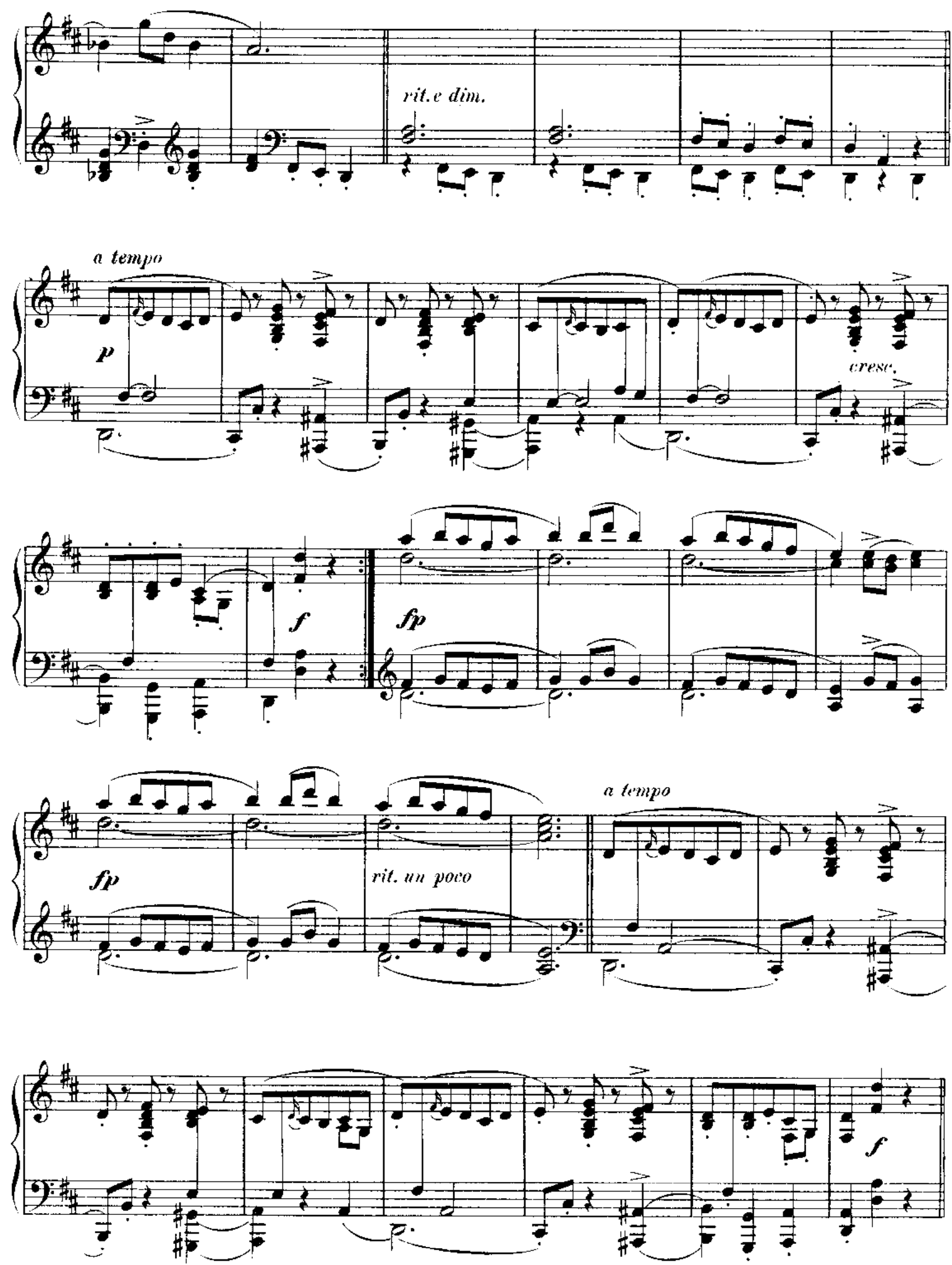

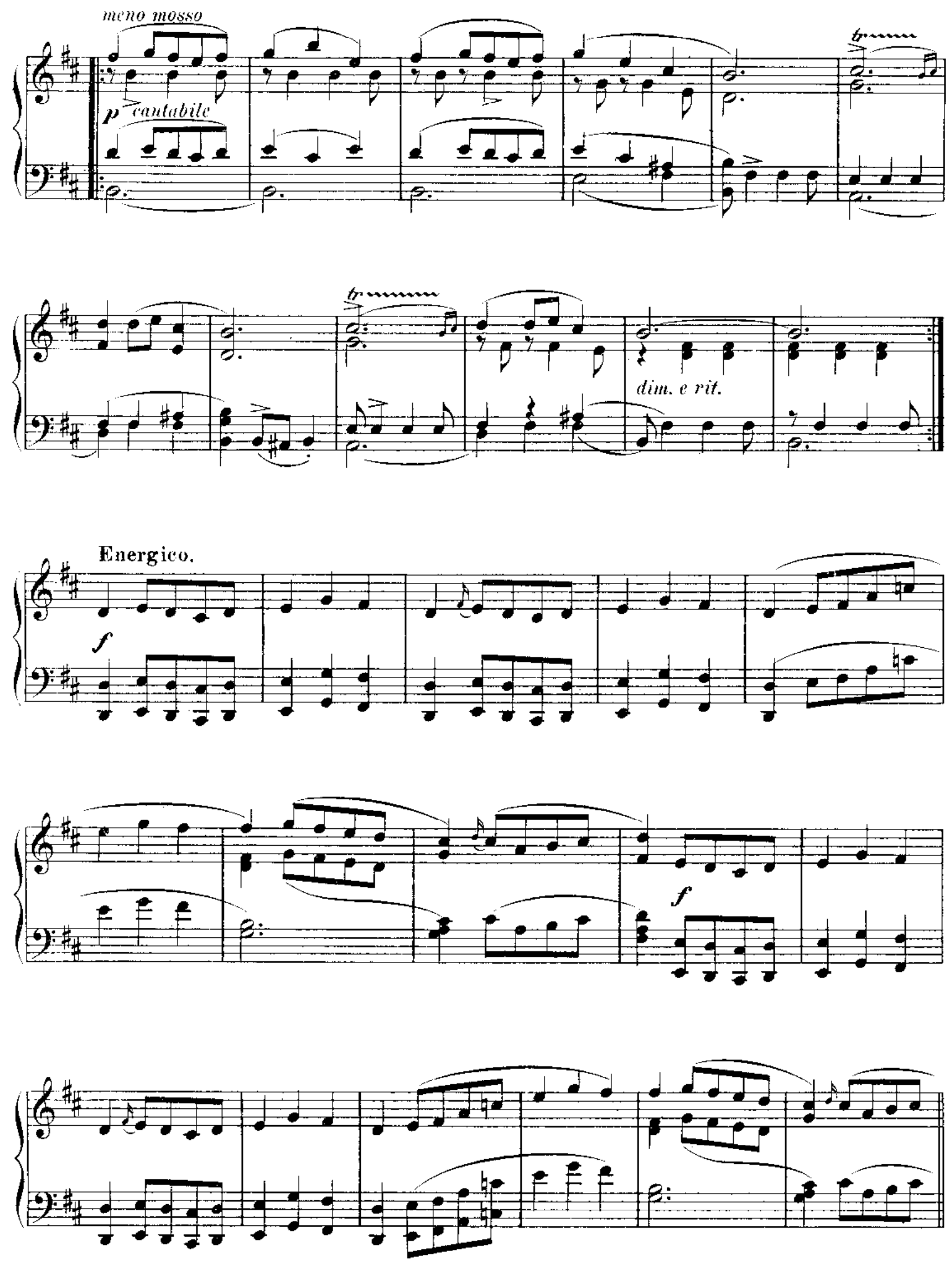

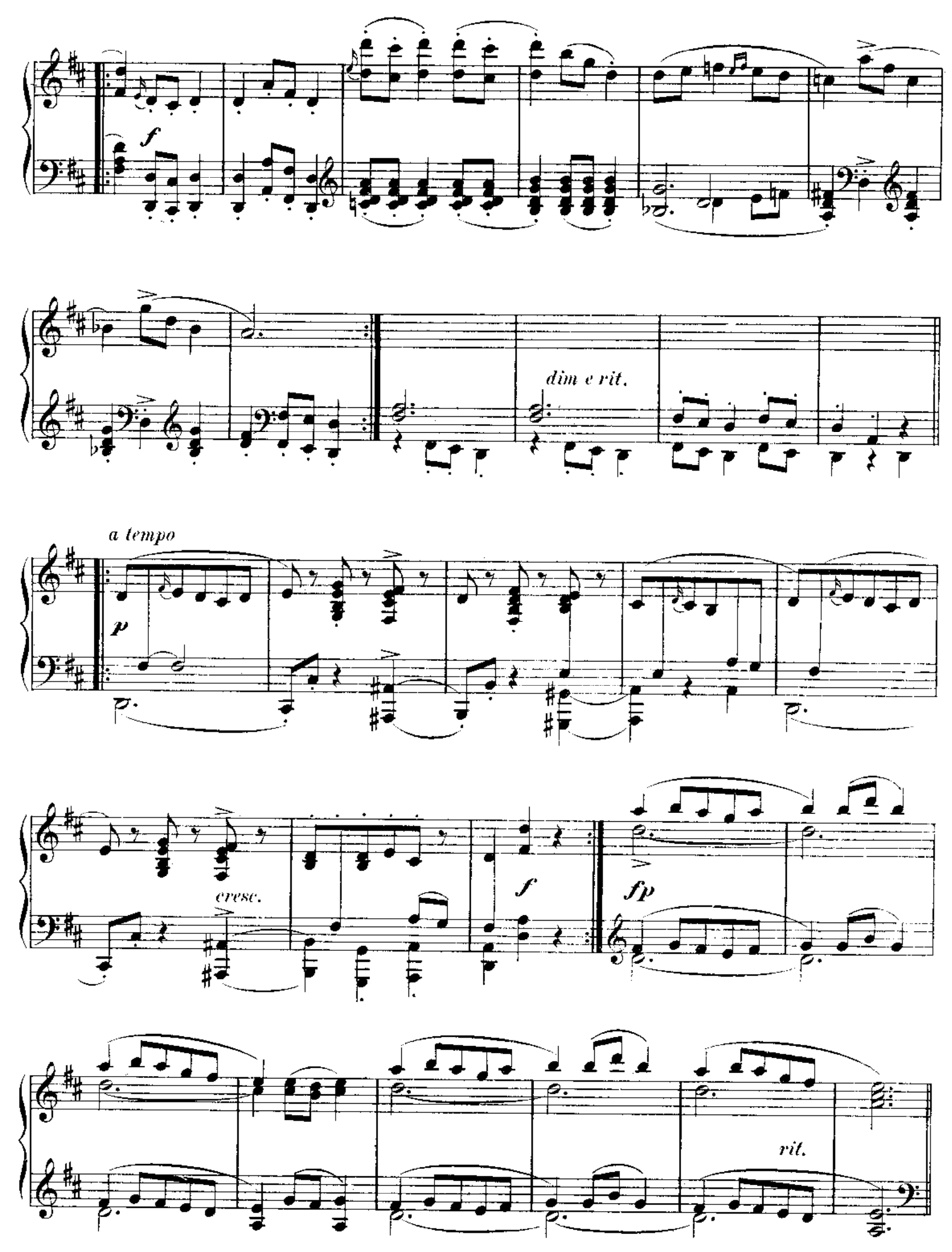

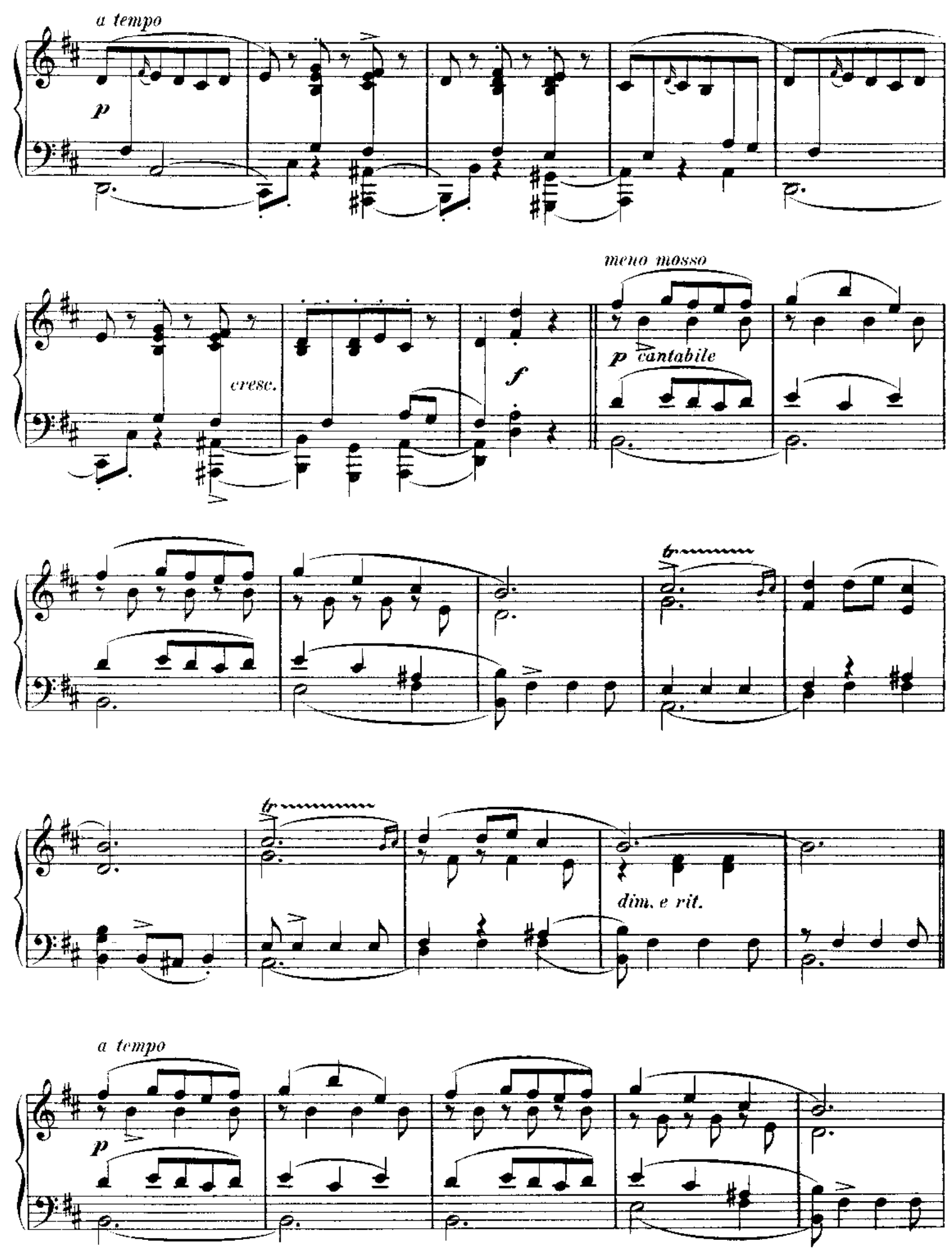

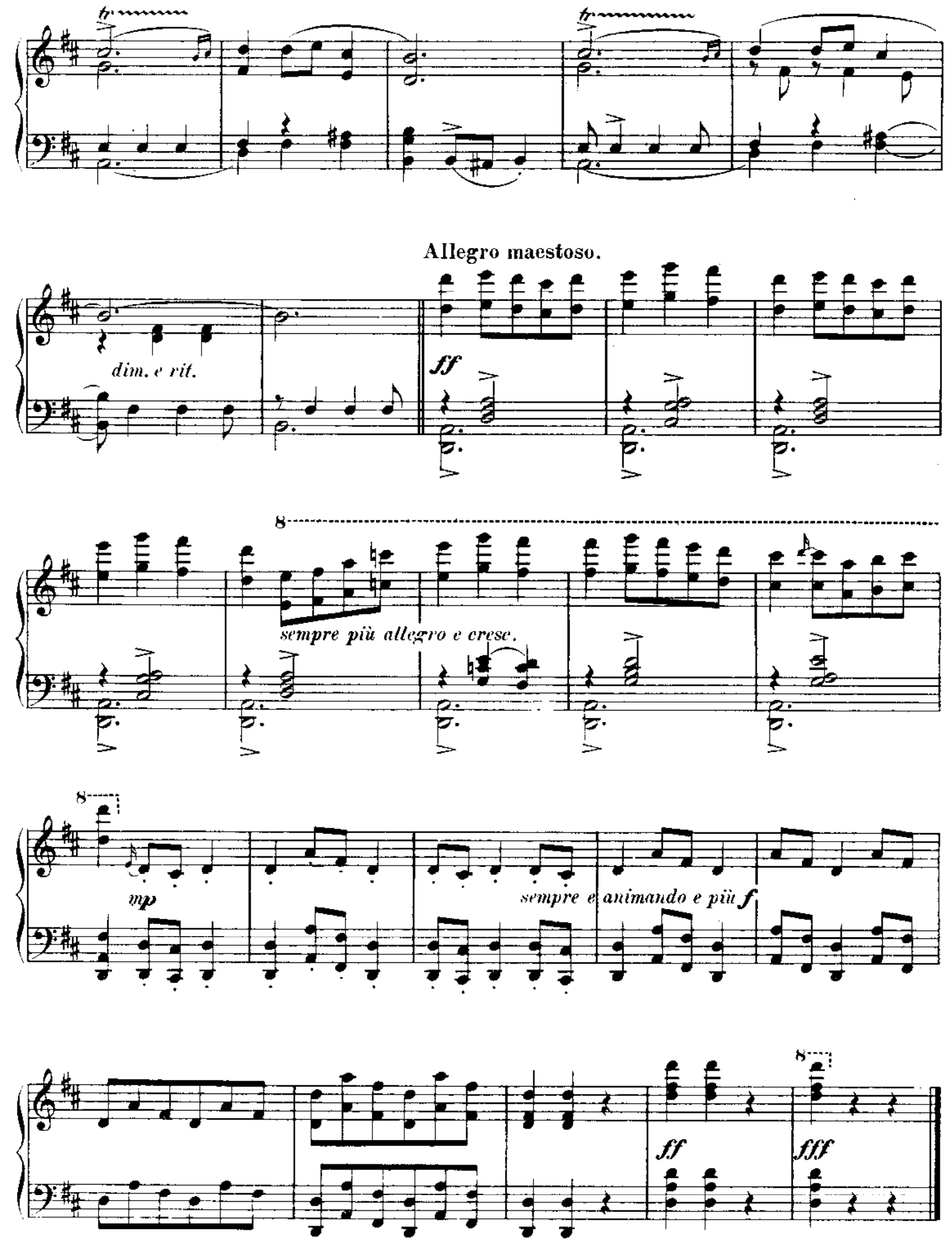
4 Villanesca

Allegretto, alla pastorale.
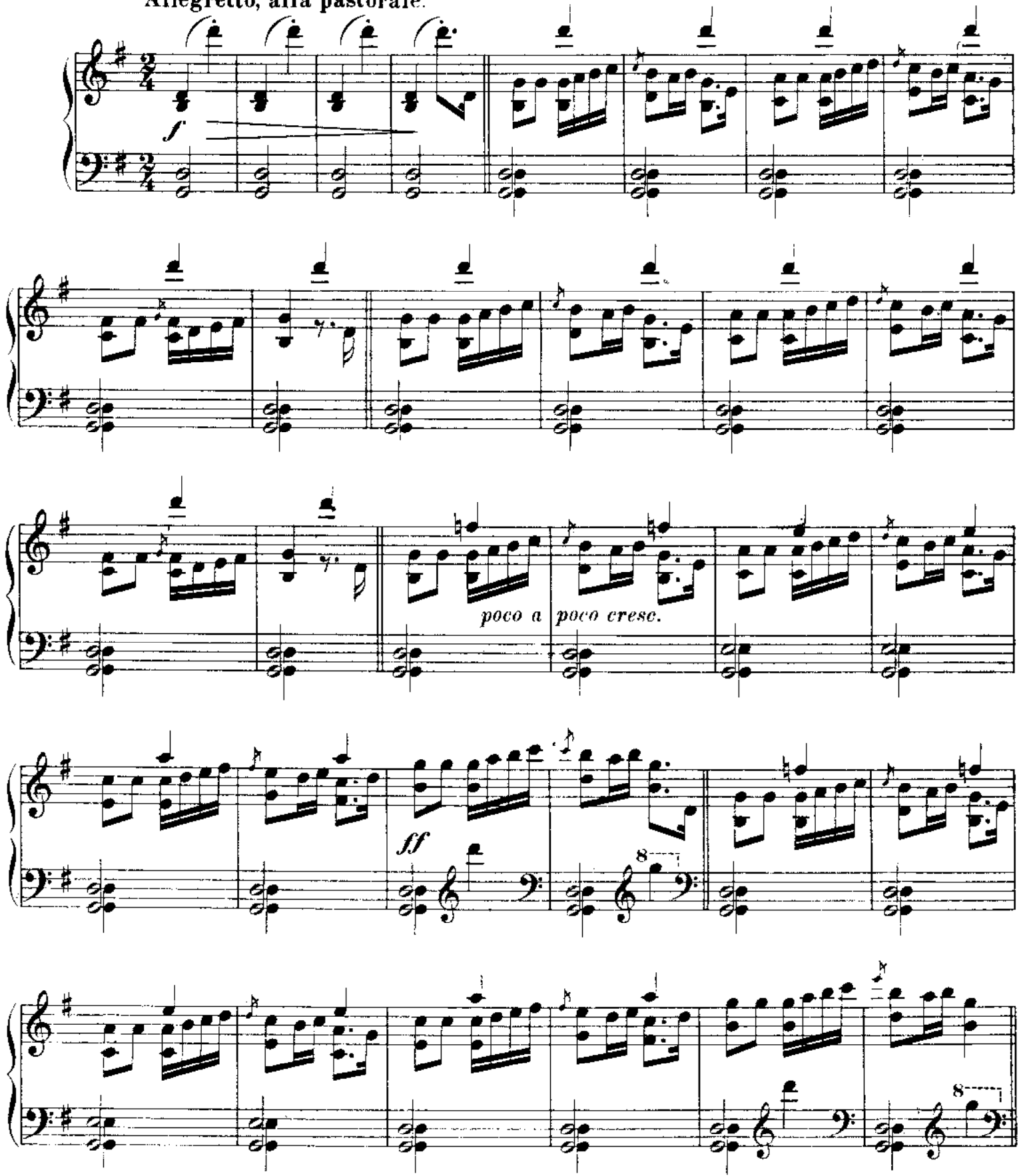

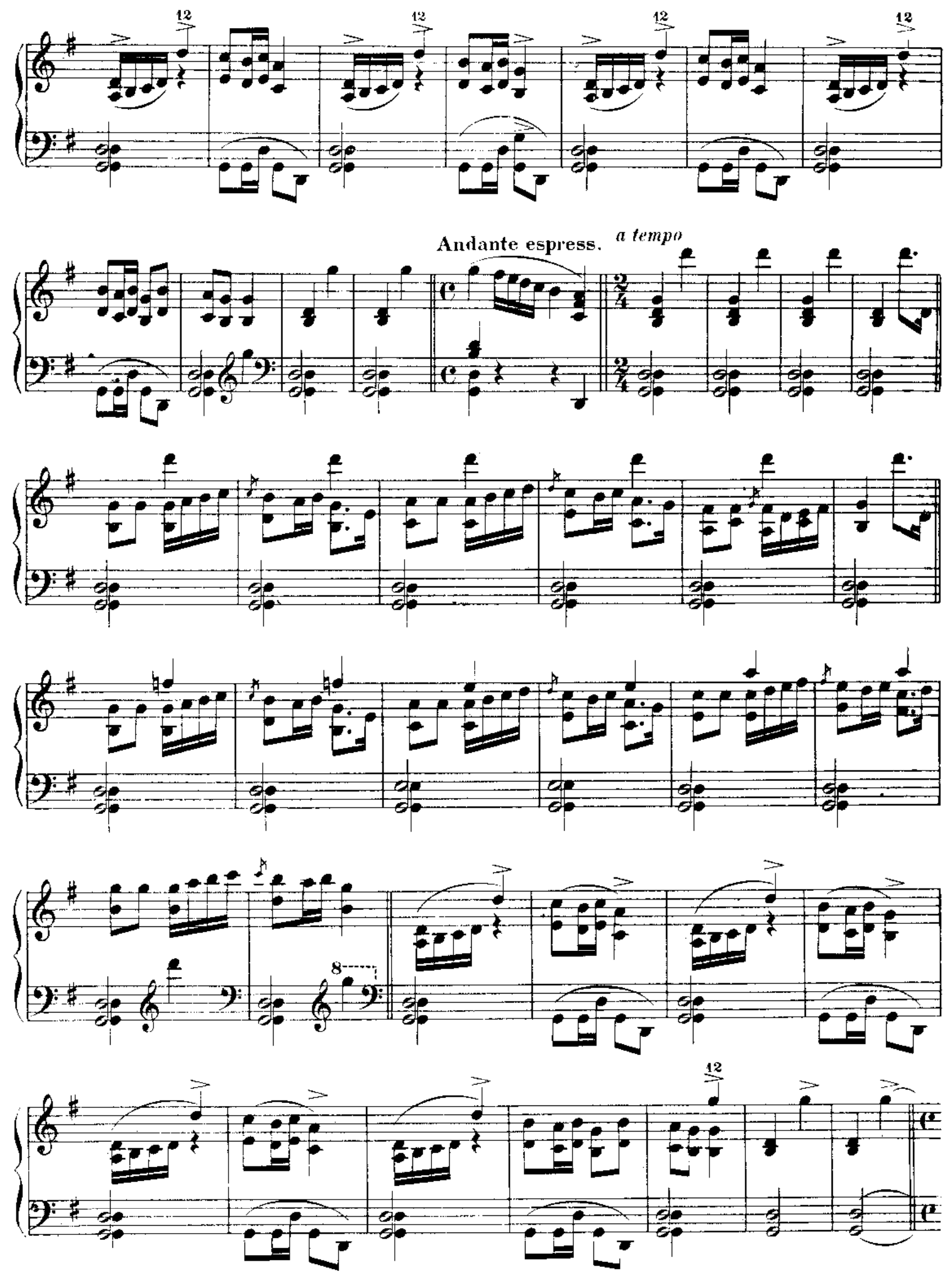


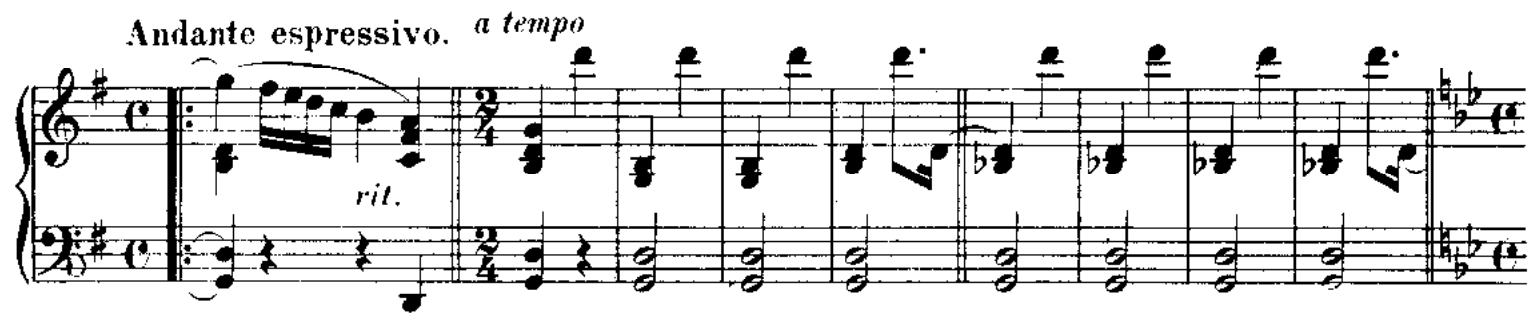

Cancion y estribillo.
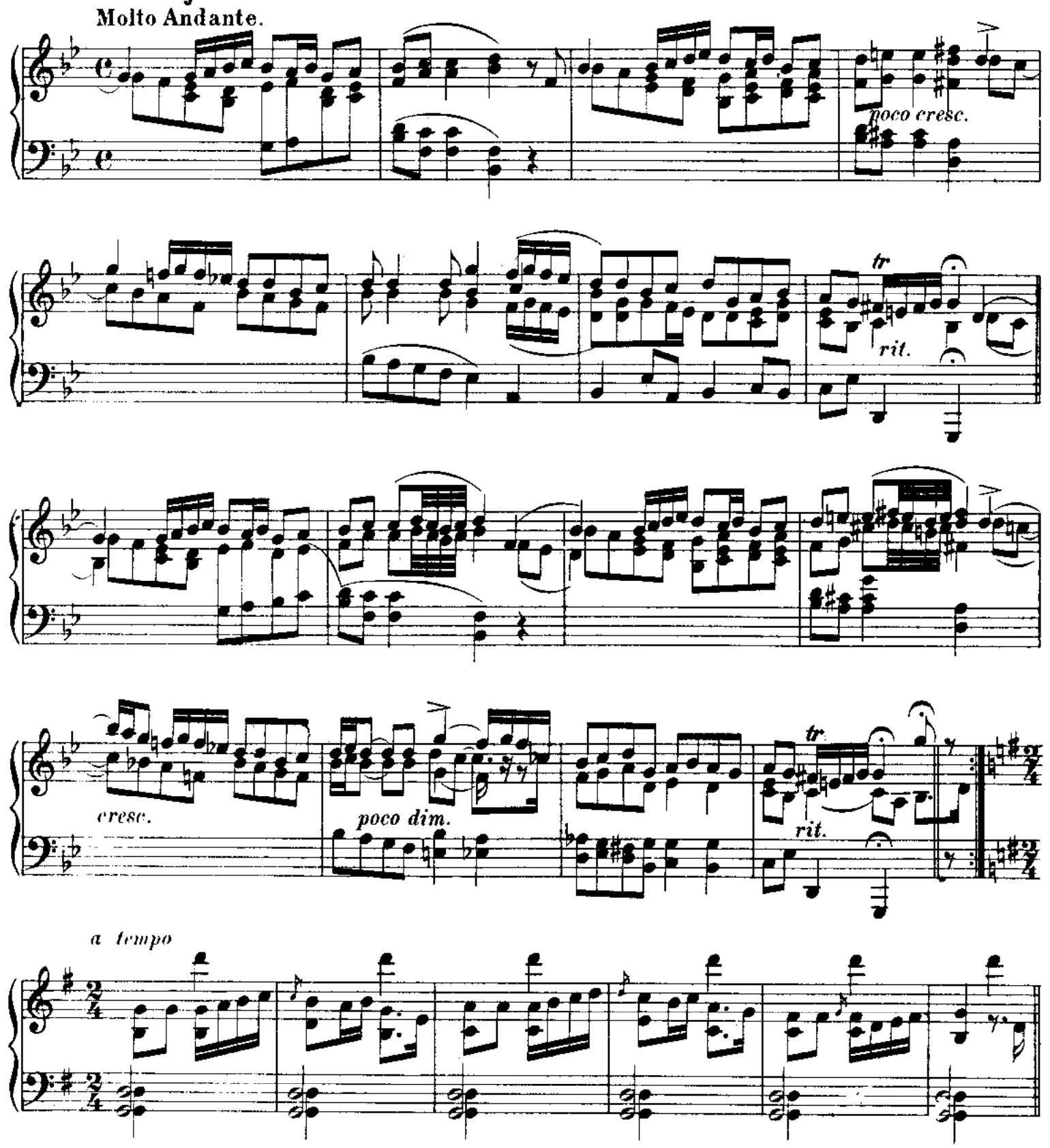

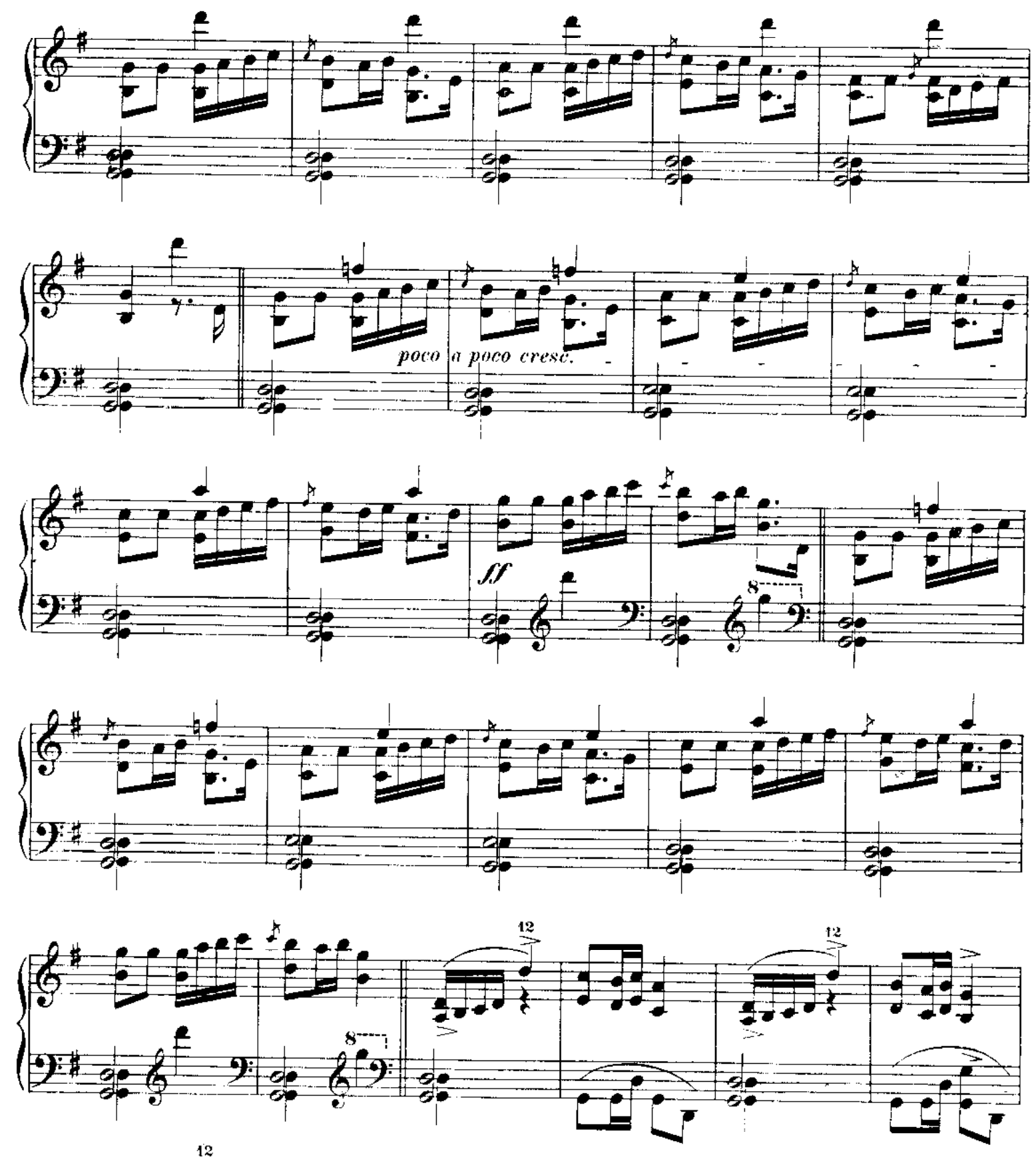

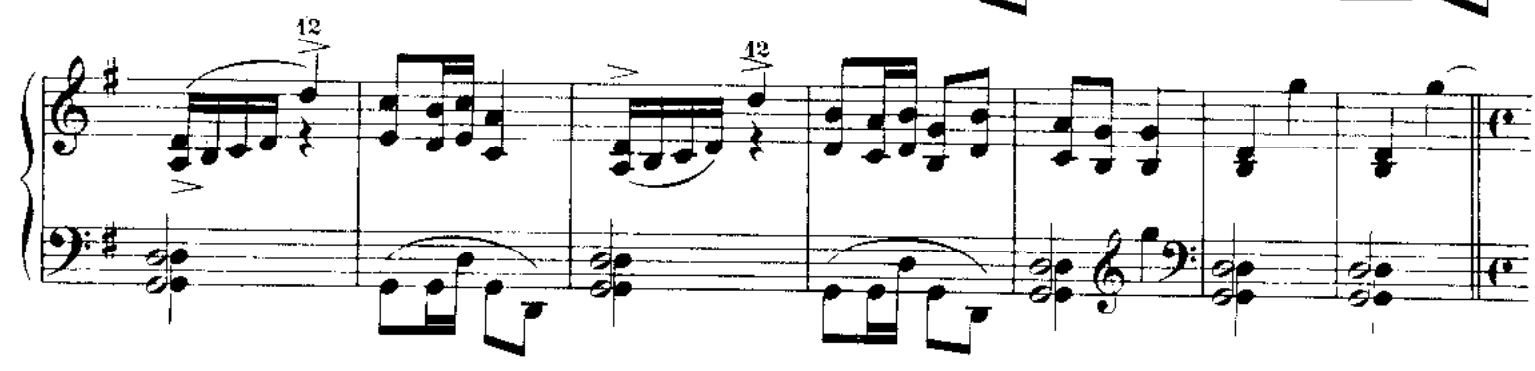



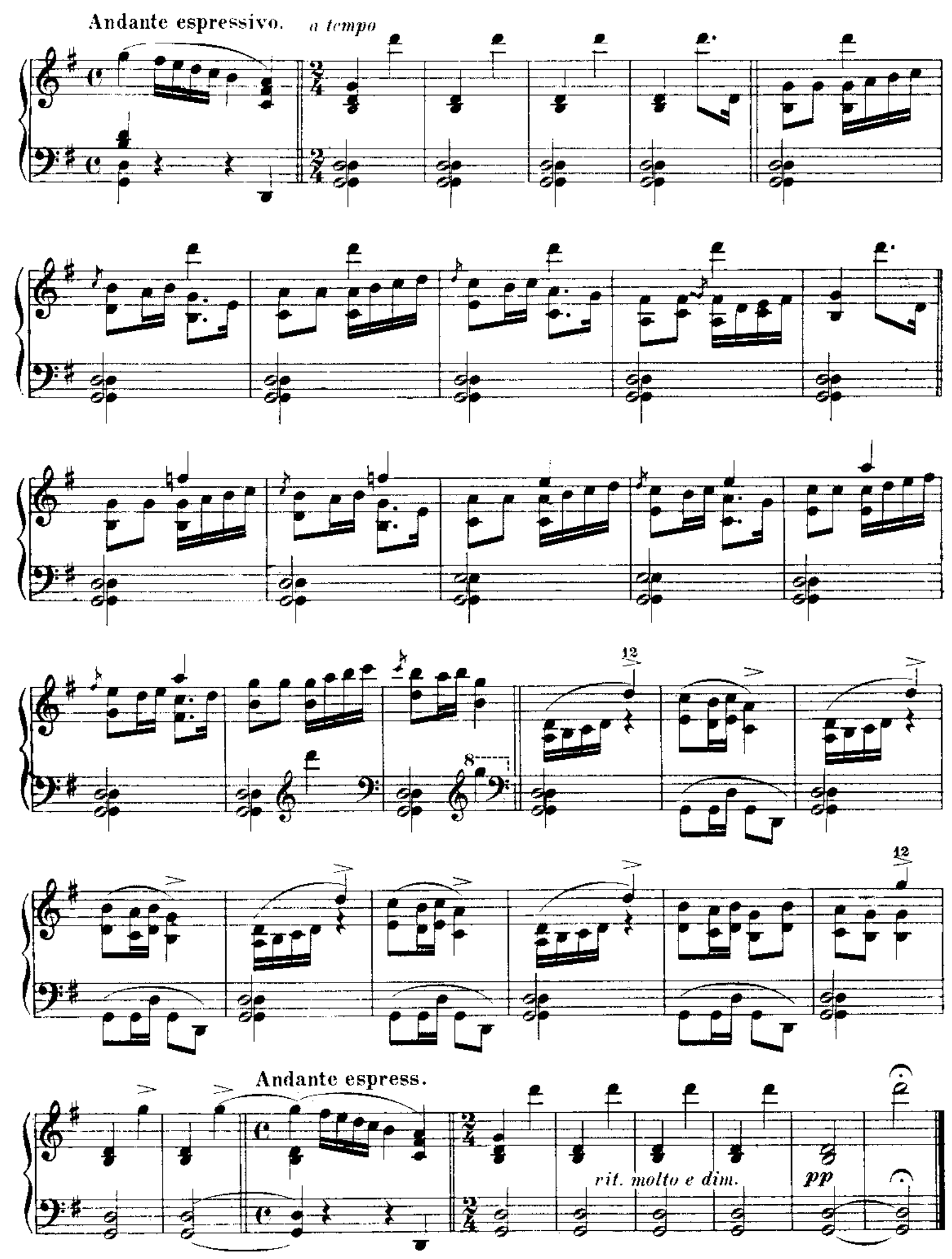


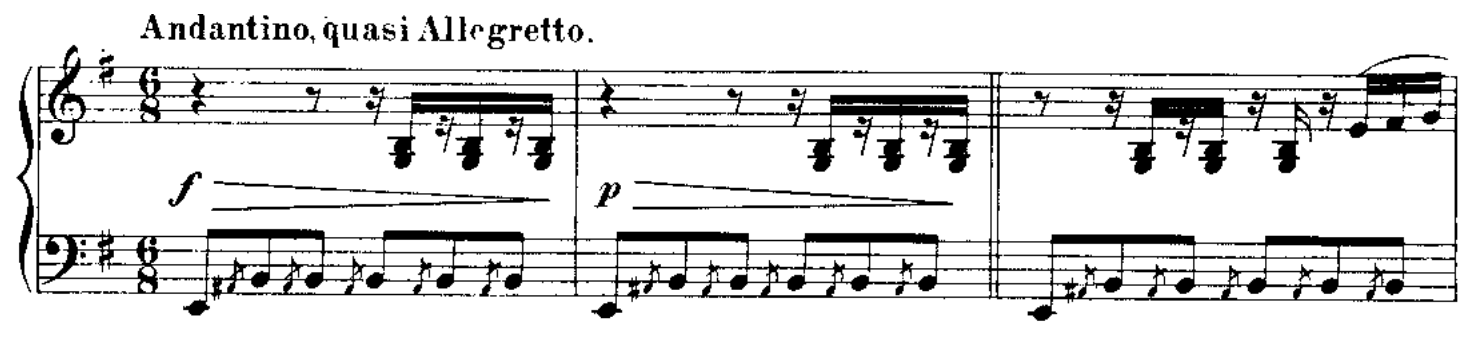

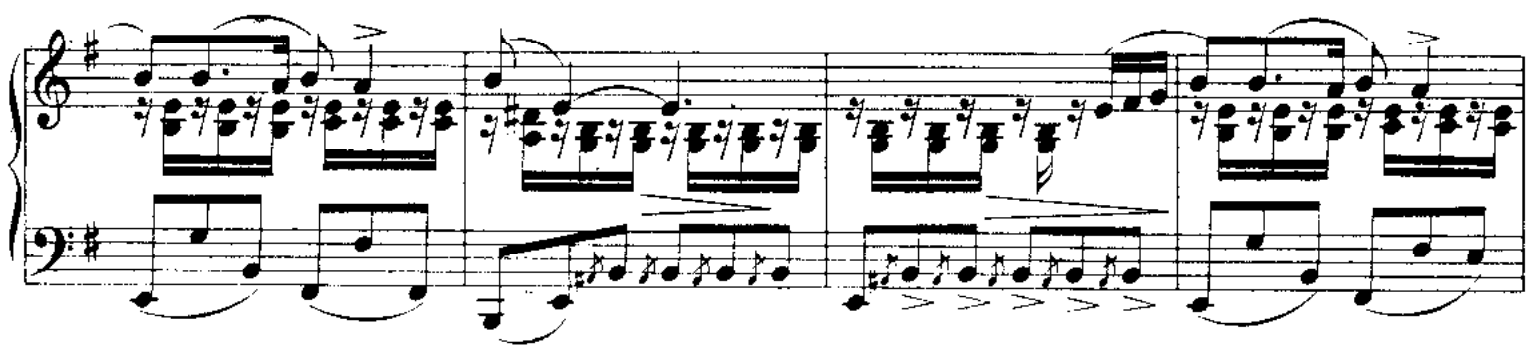

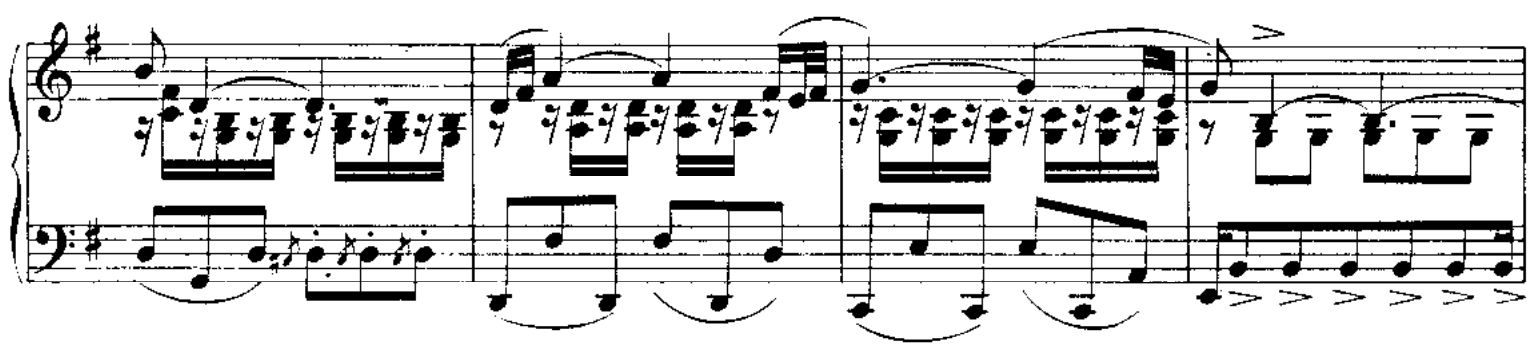

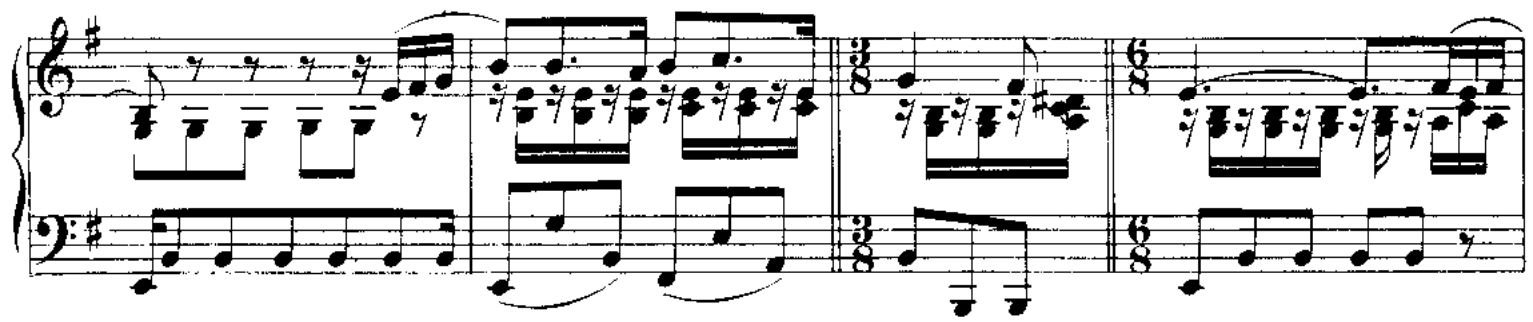

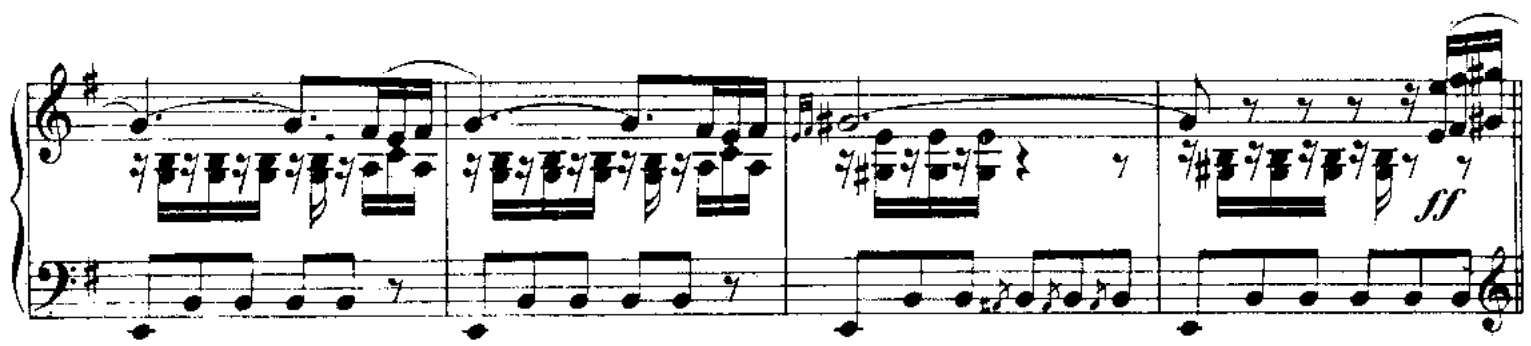



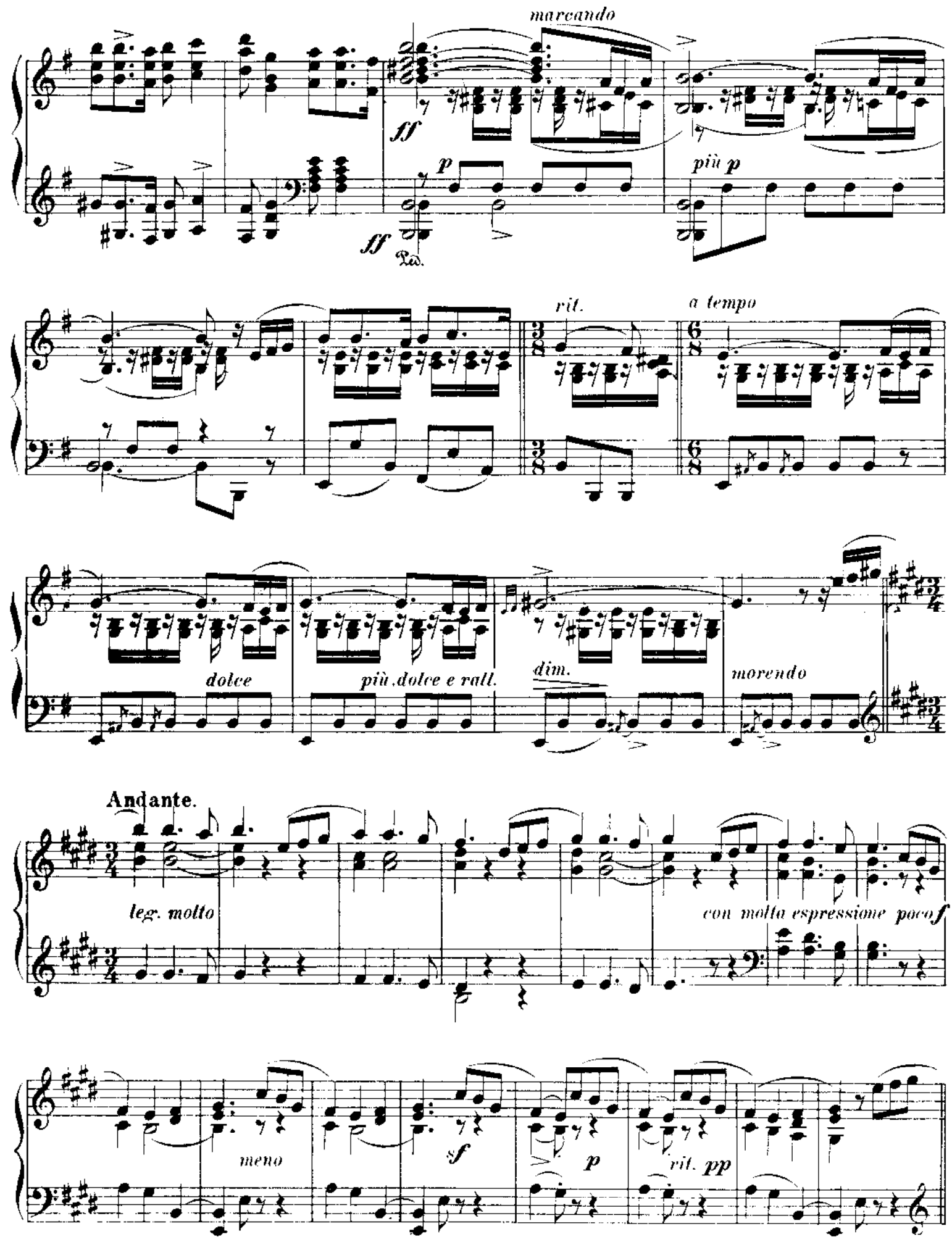

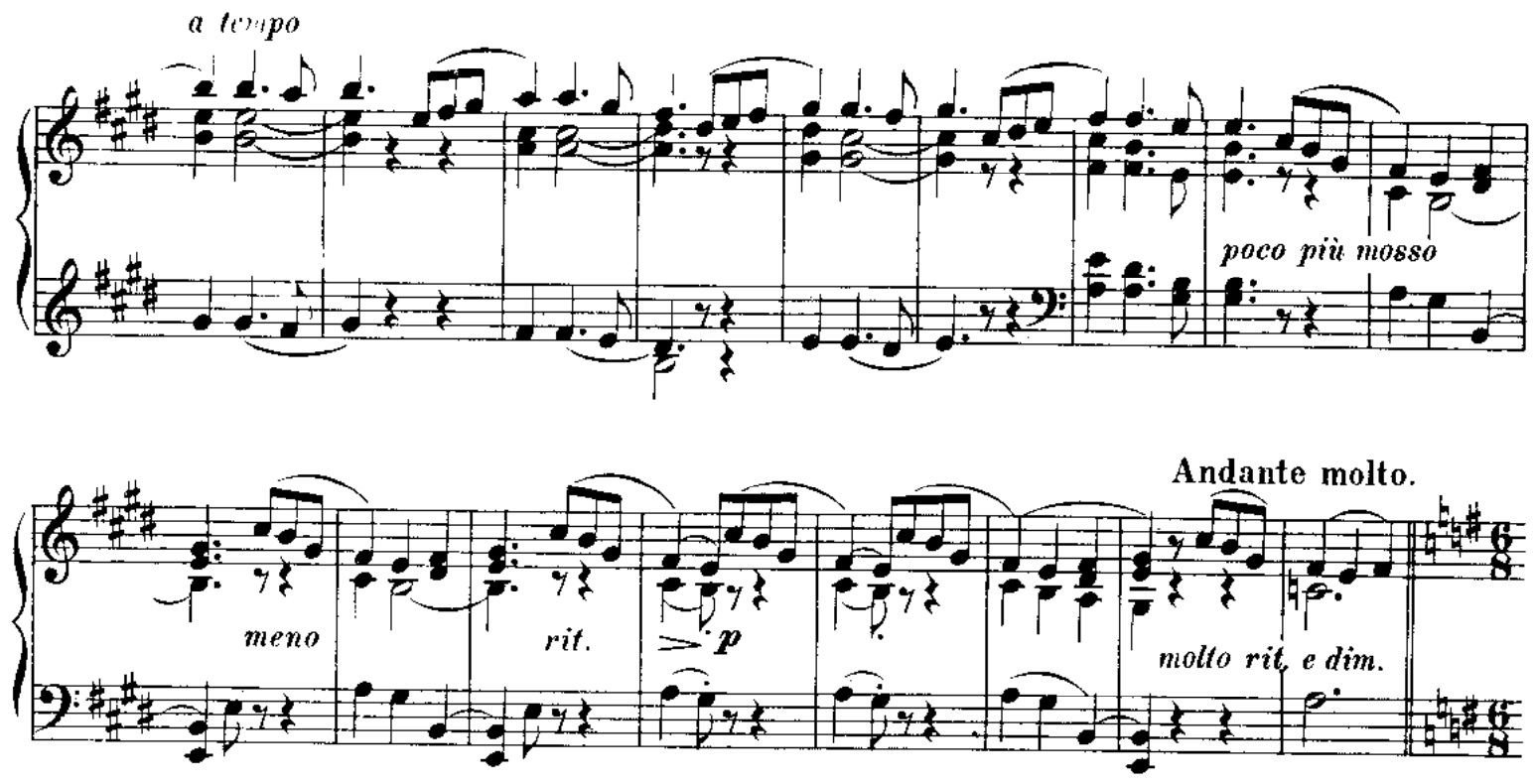

Tempo I.
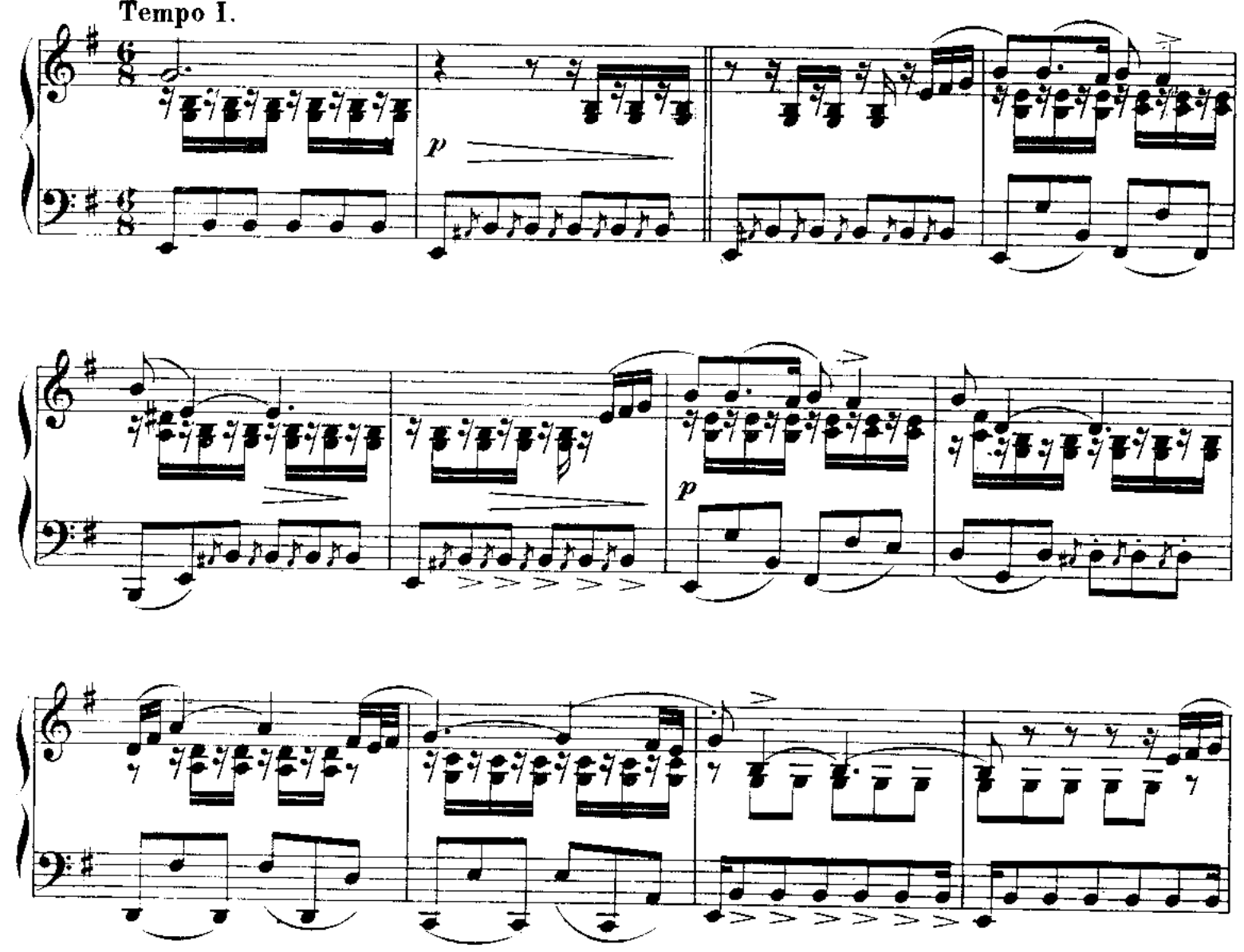

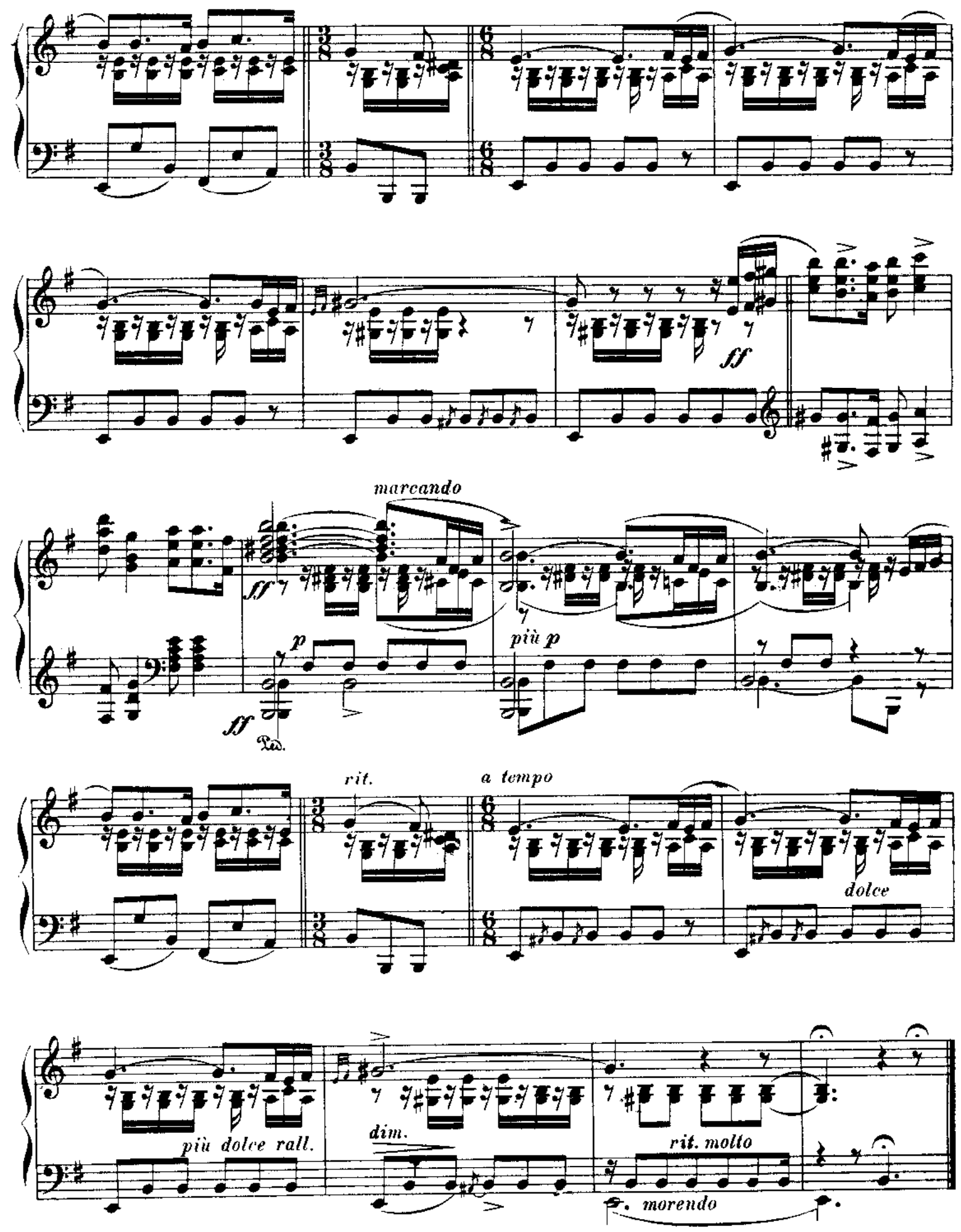
Allegretto,poco a poco accelerando.
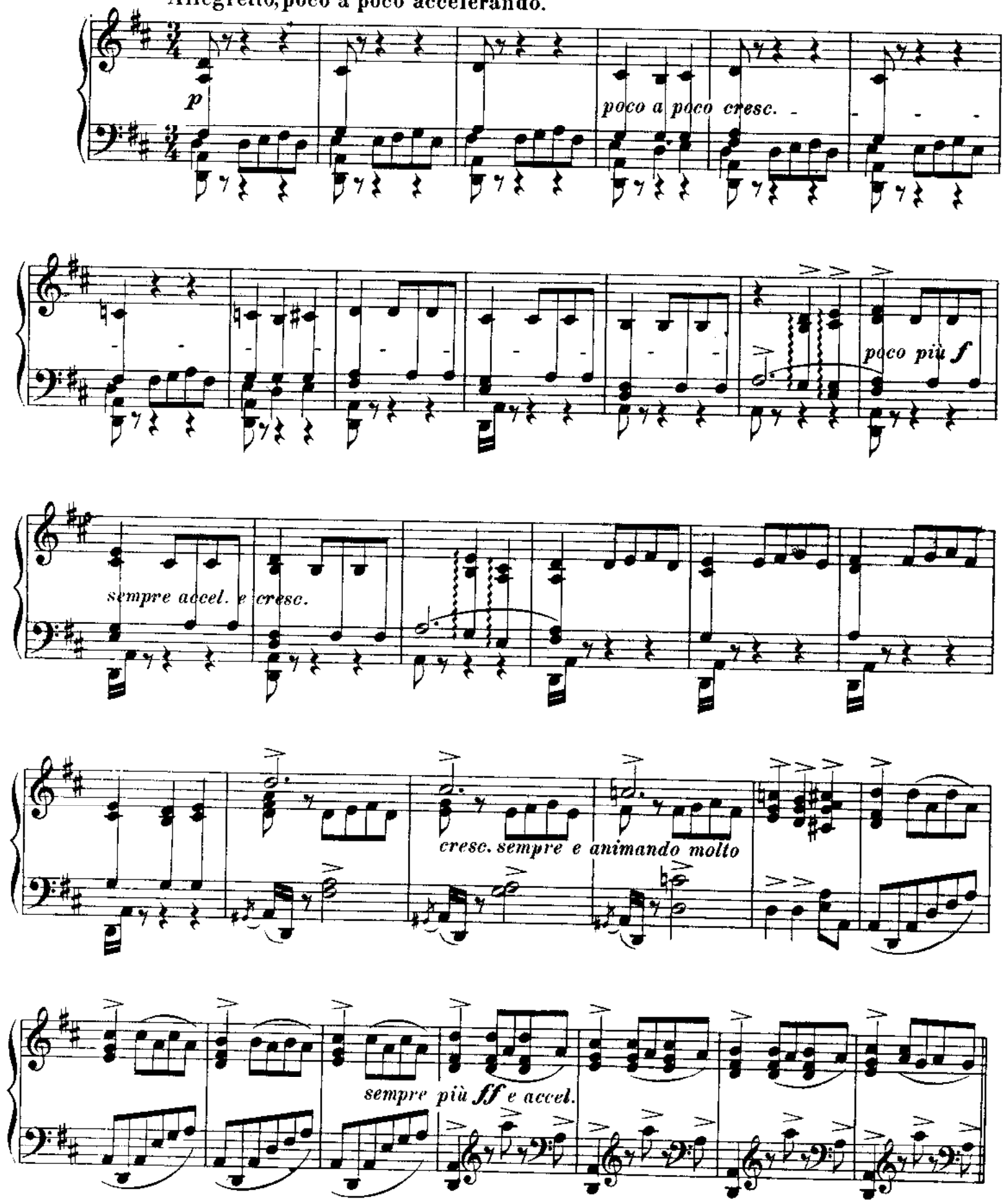

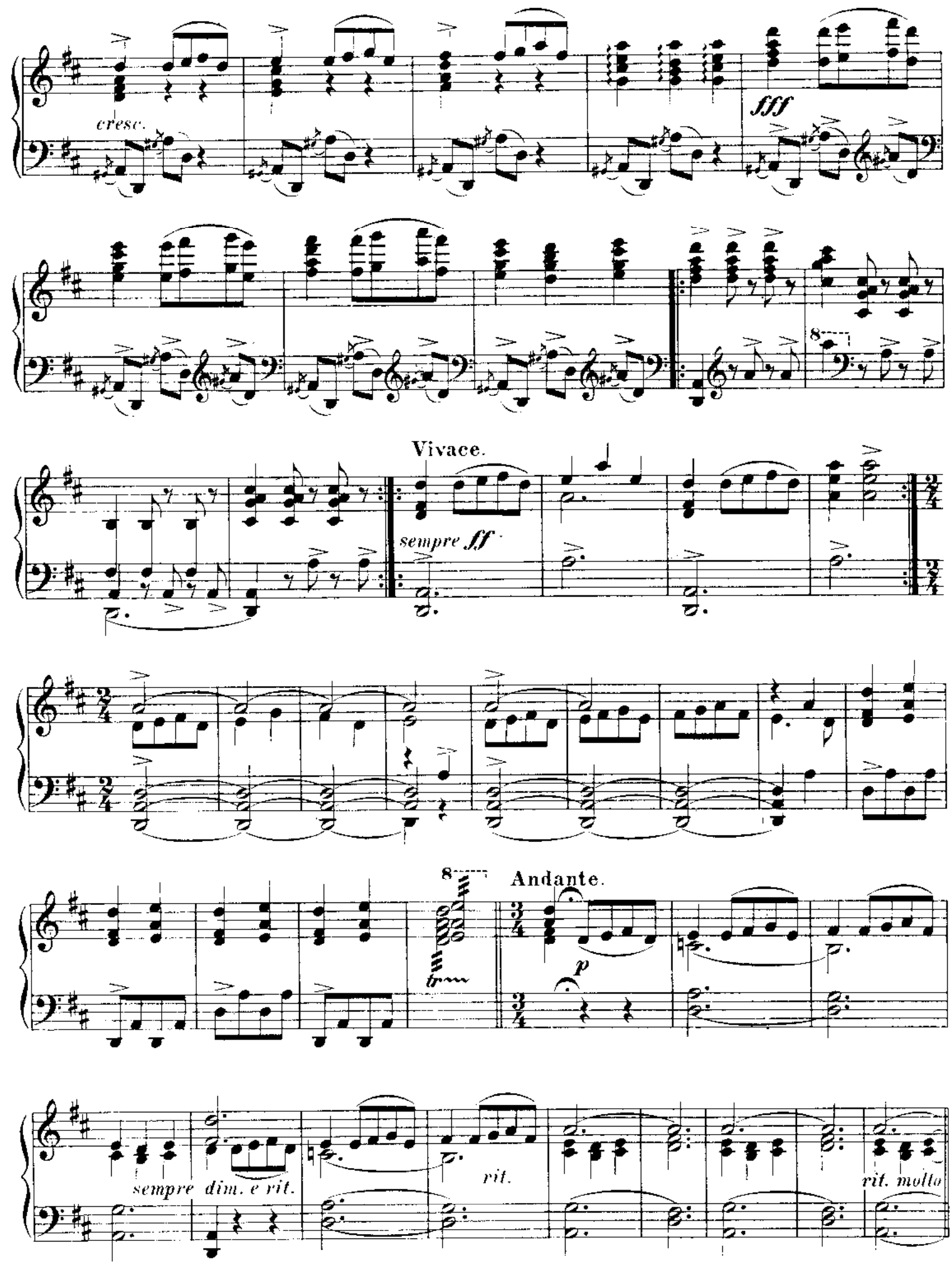

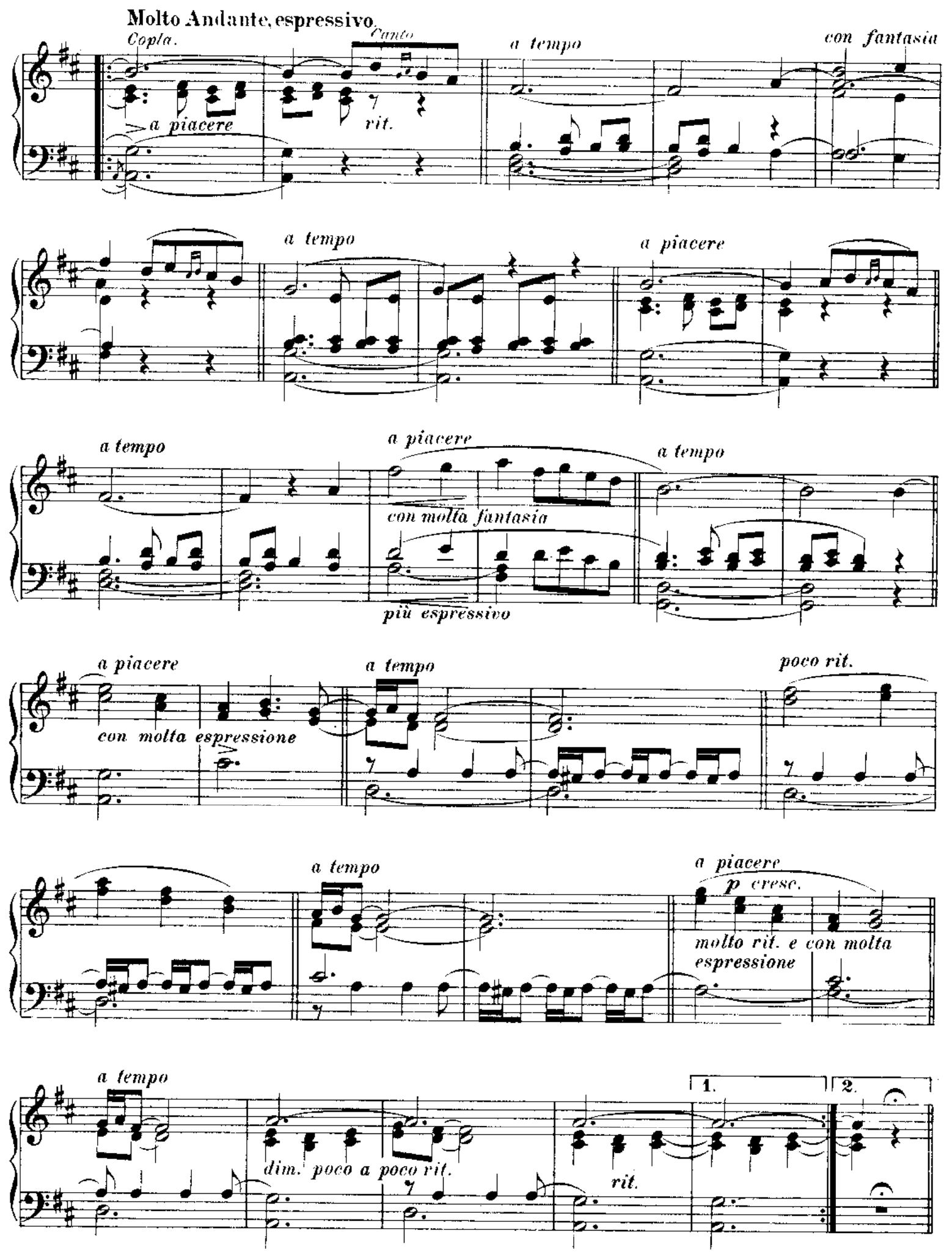
Tempo I.
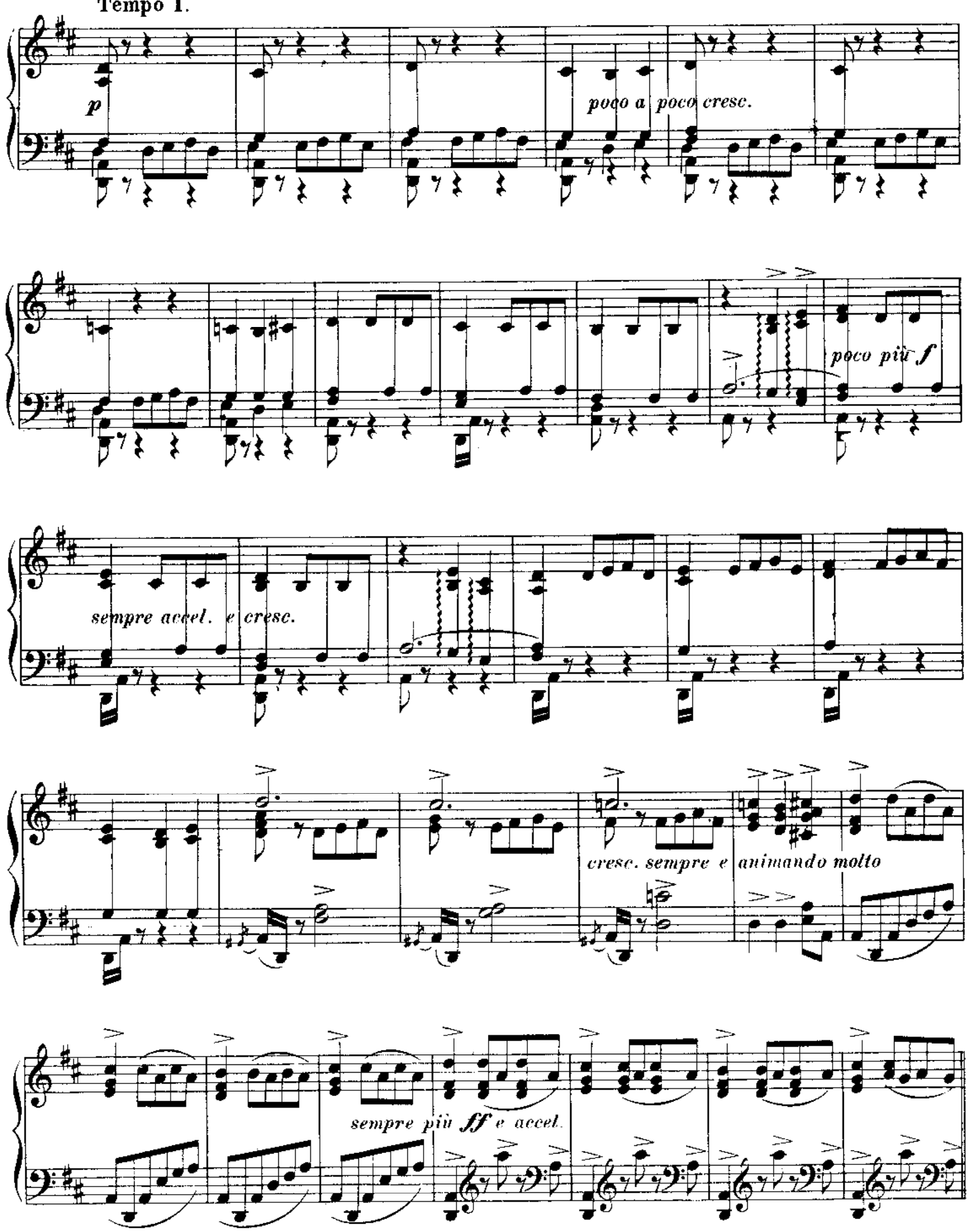

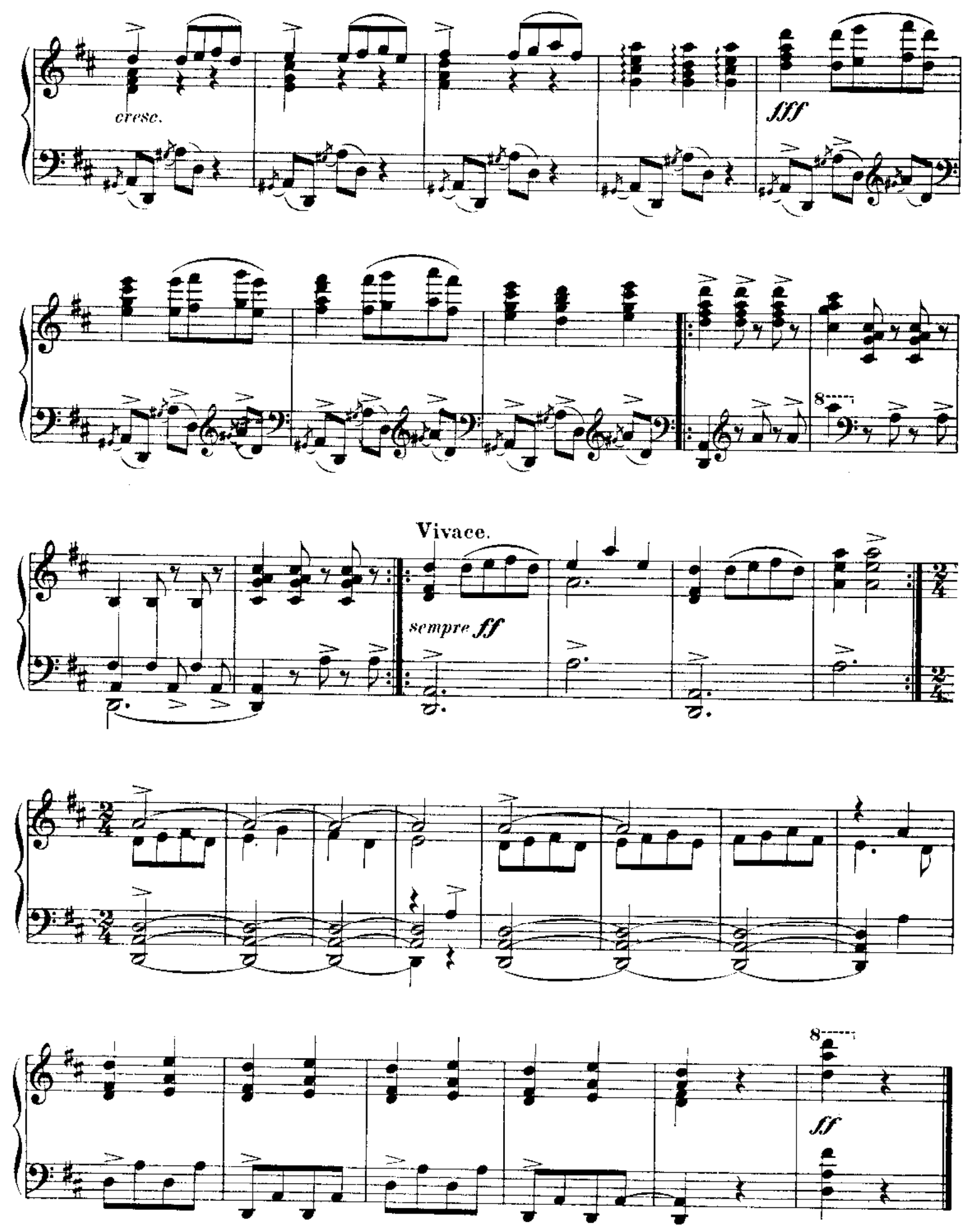


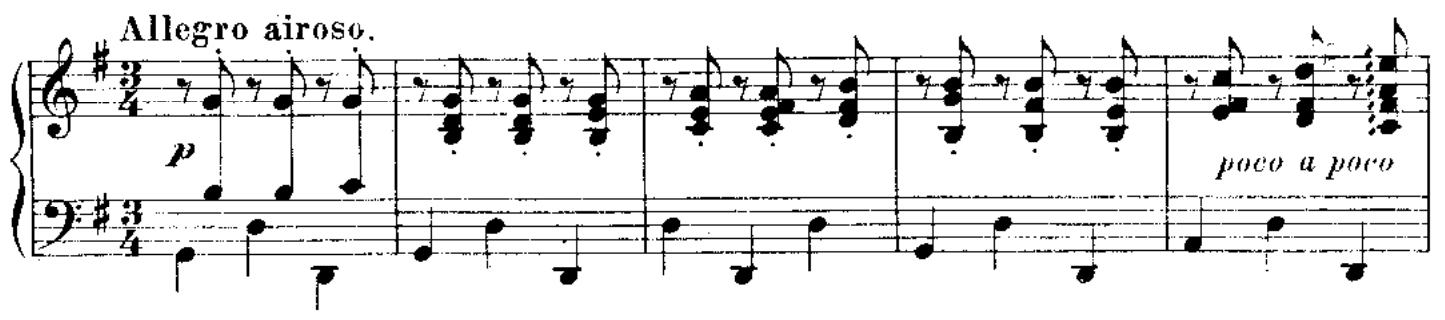

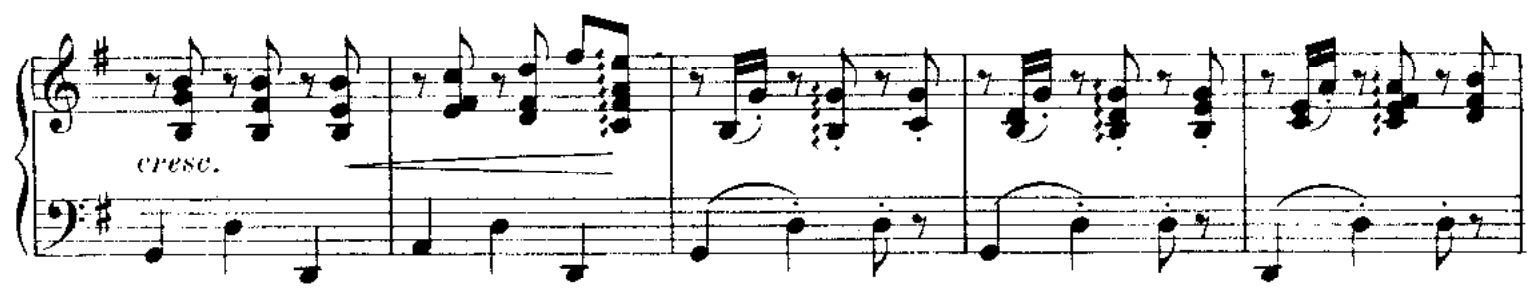
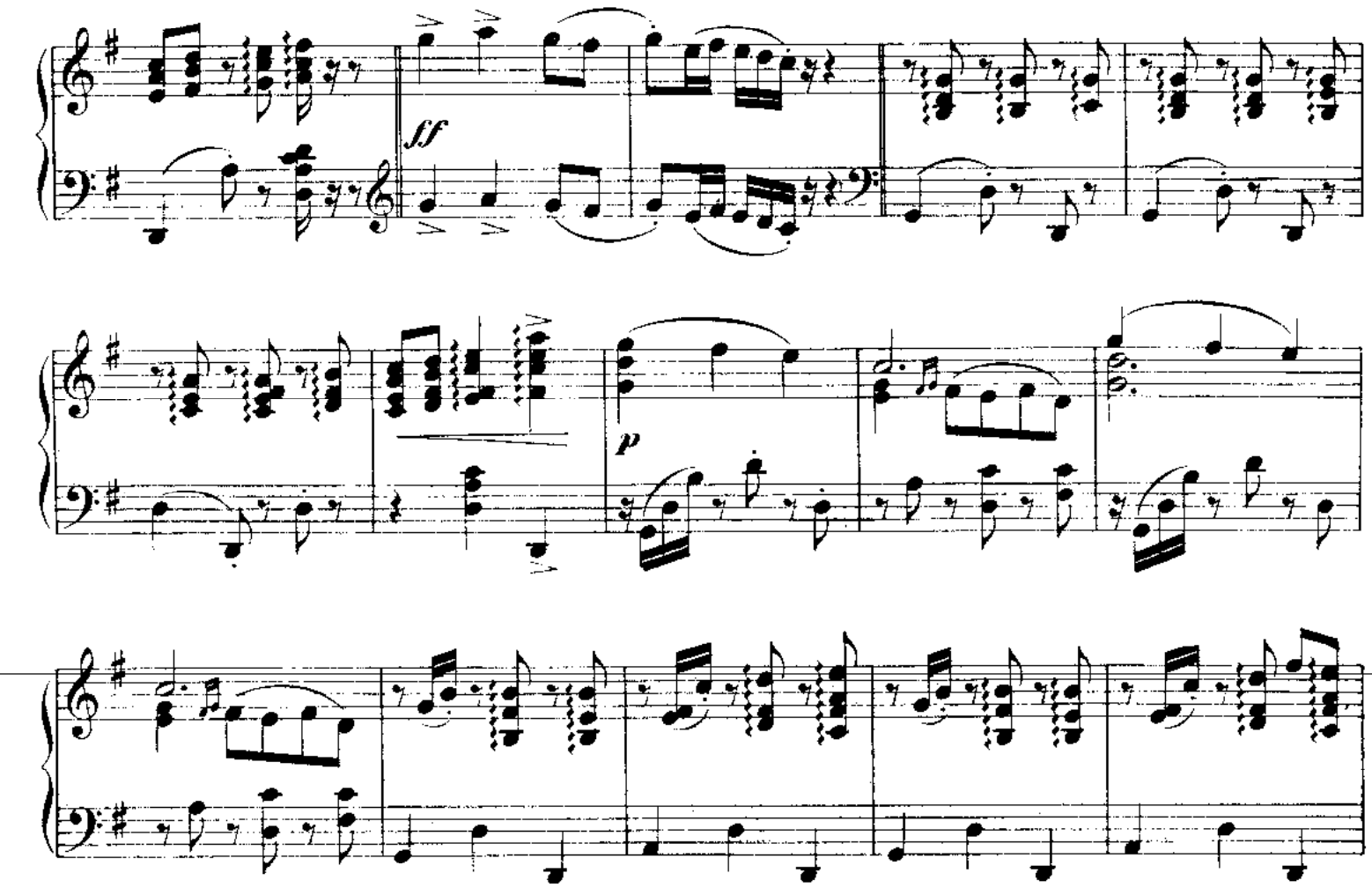

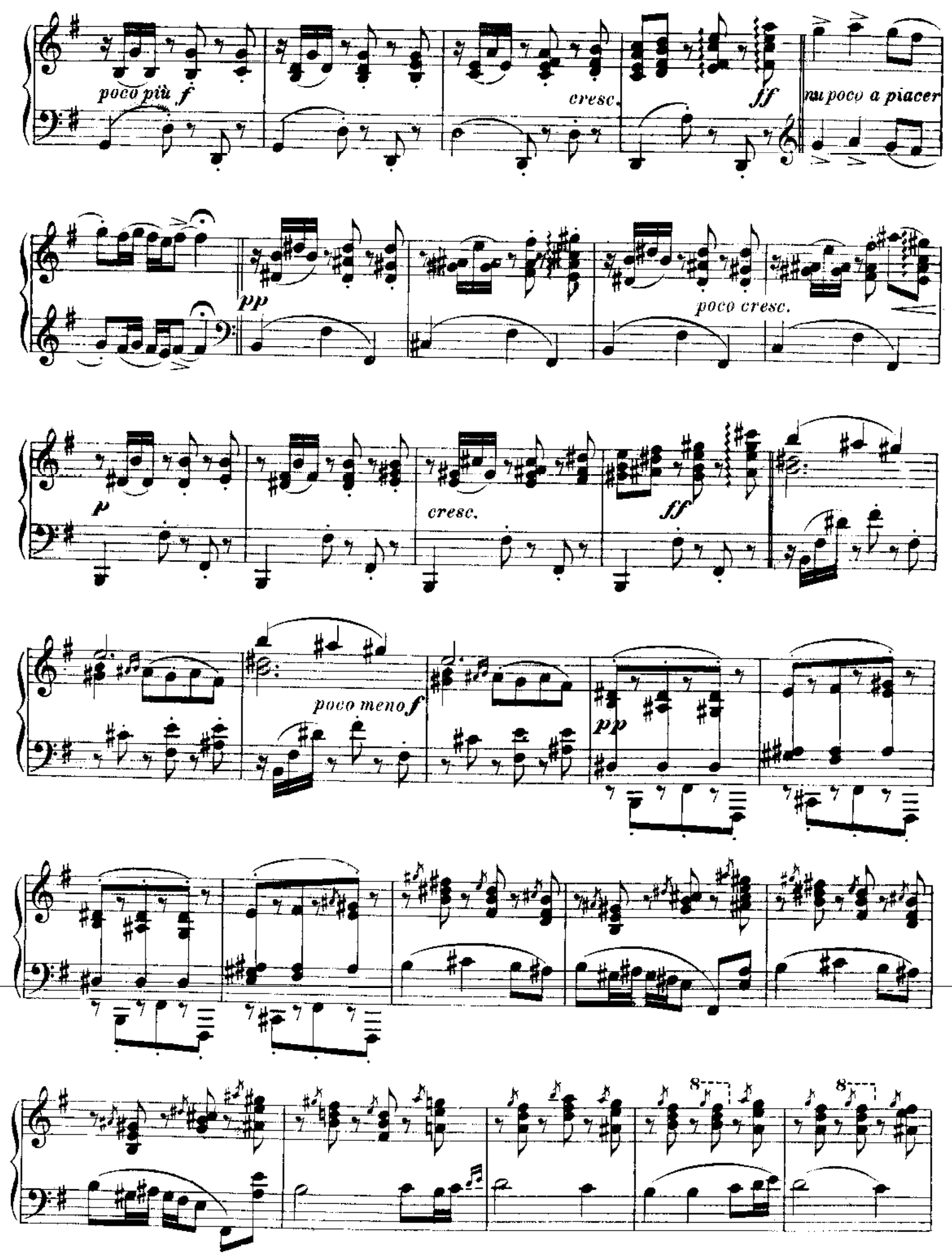

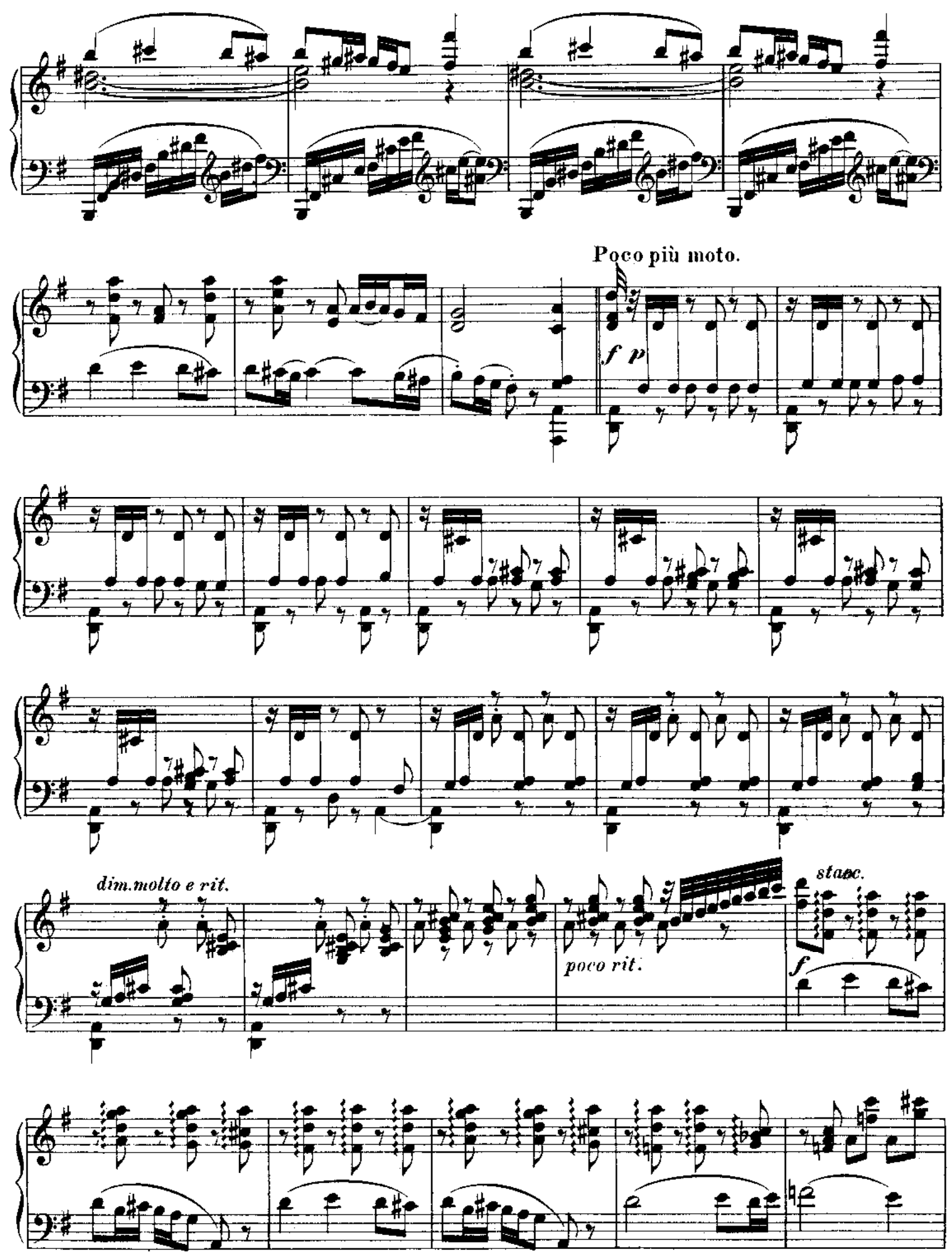


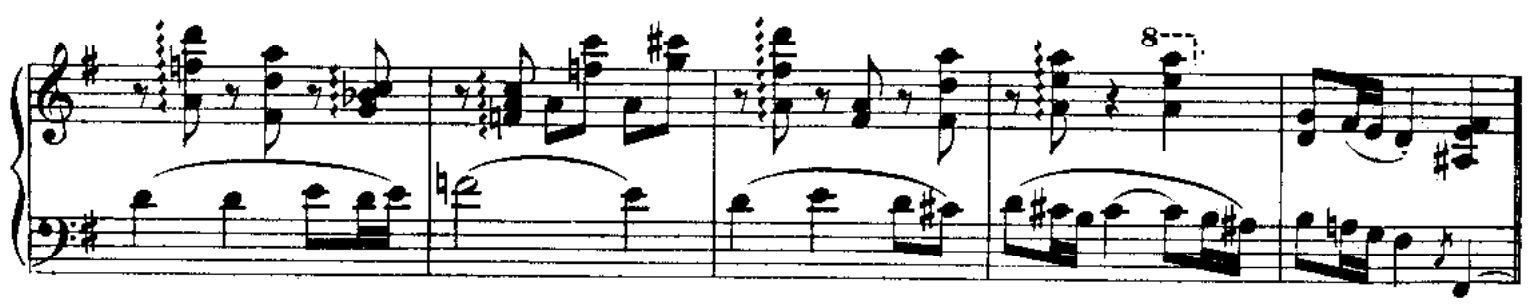

Tempo I.
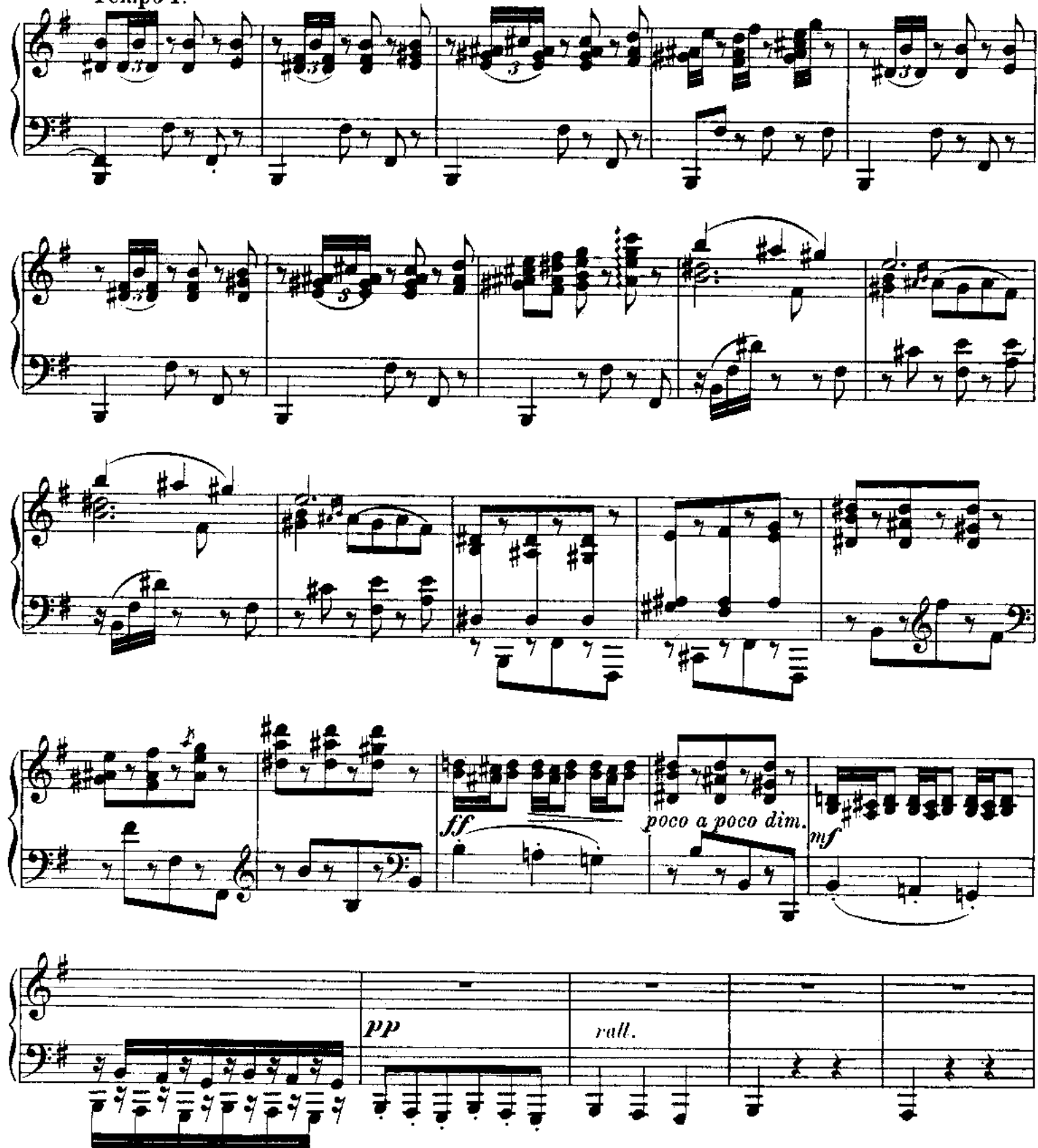

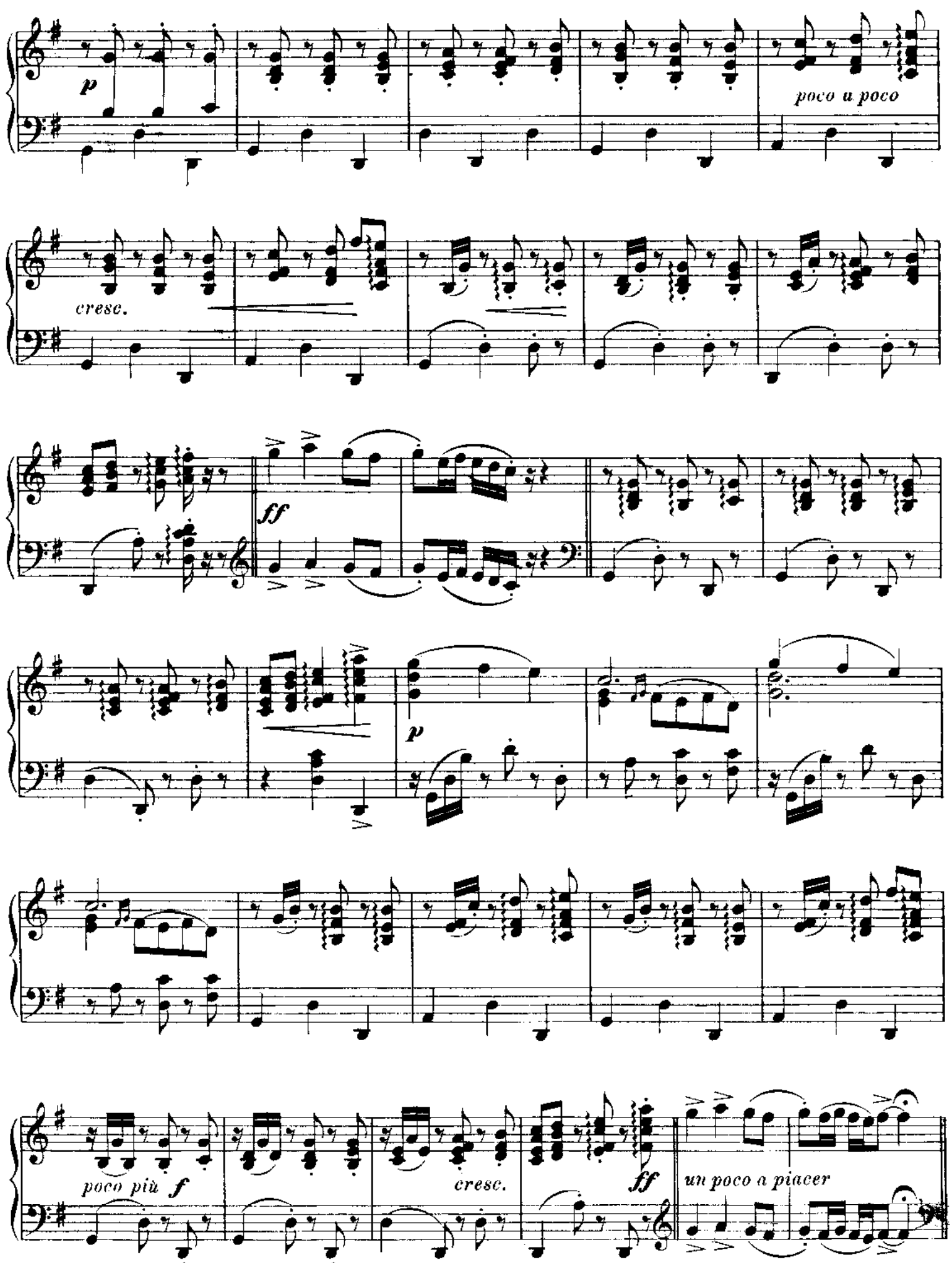

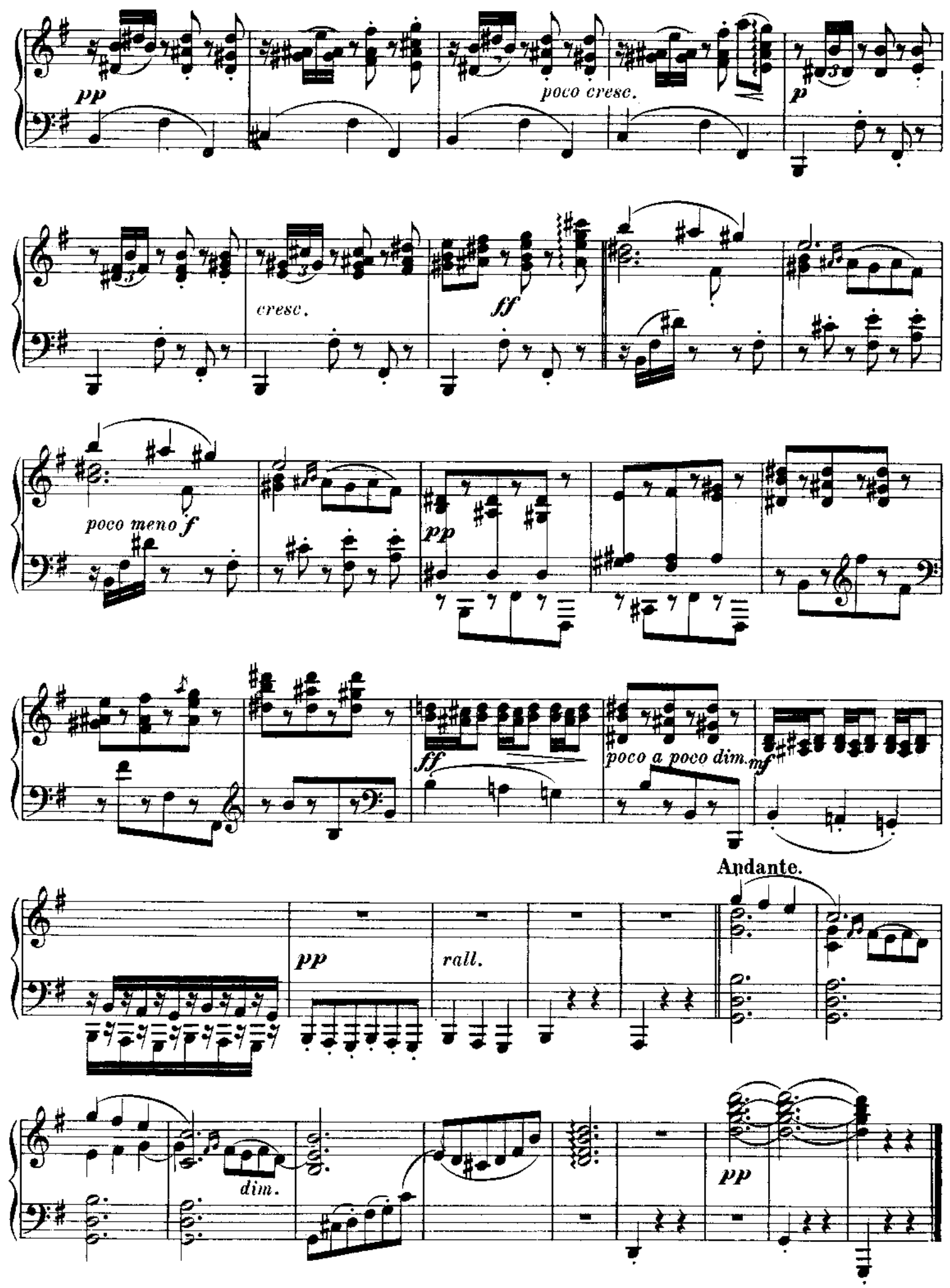
8
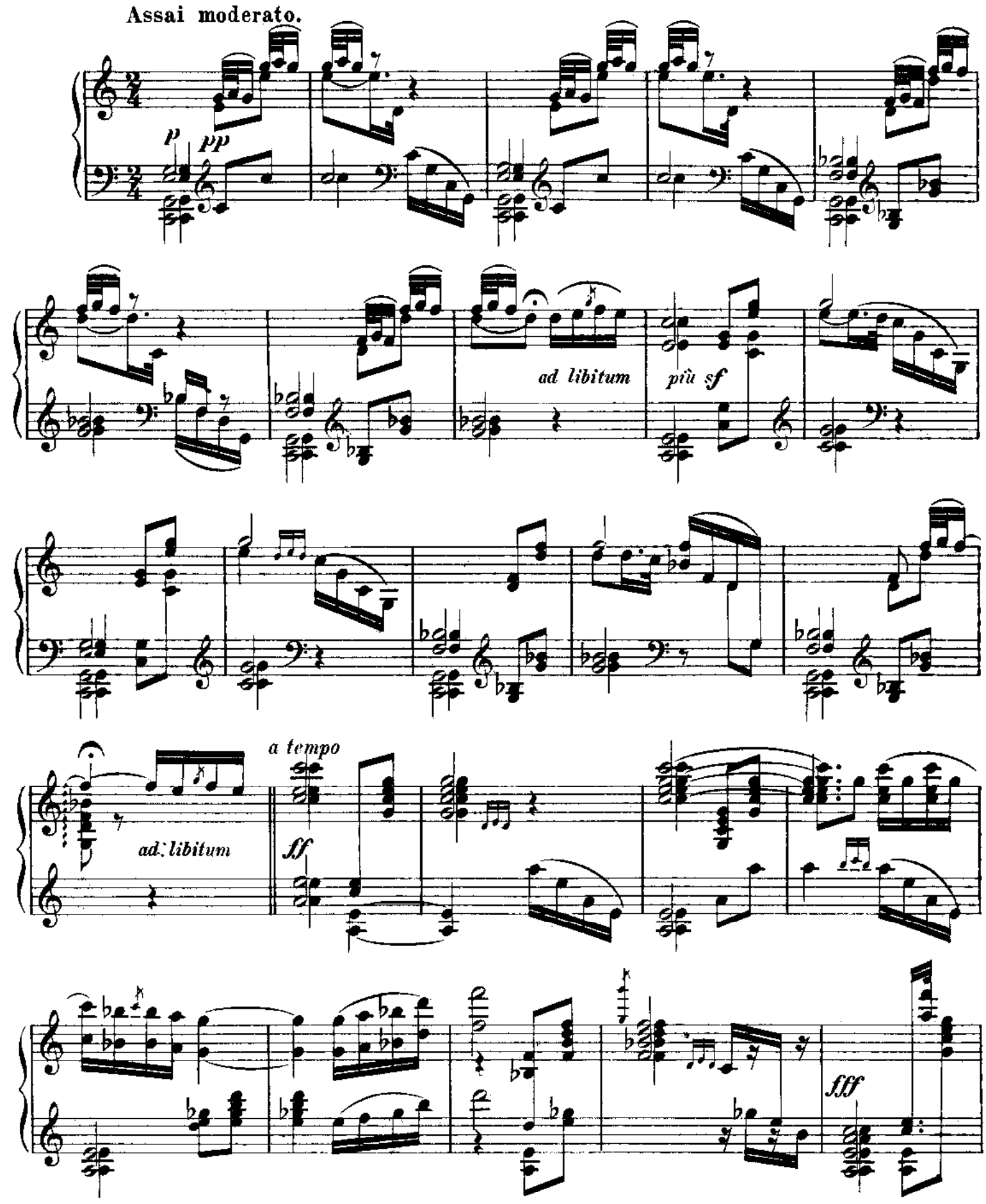

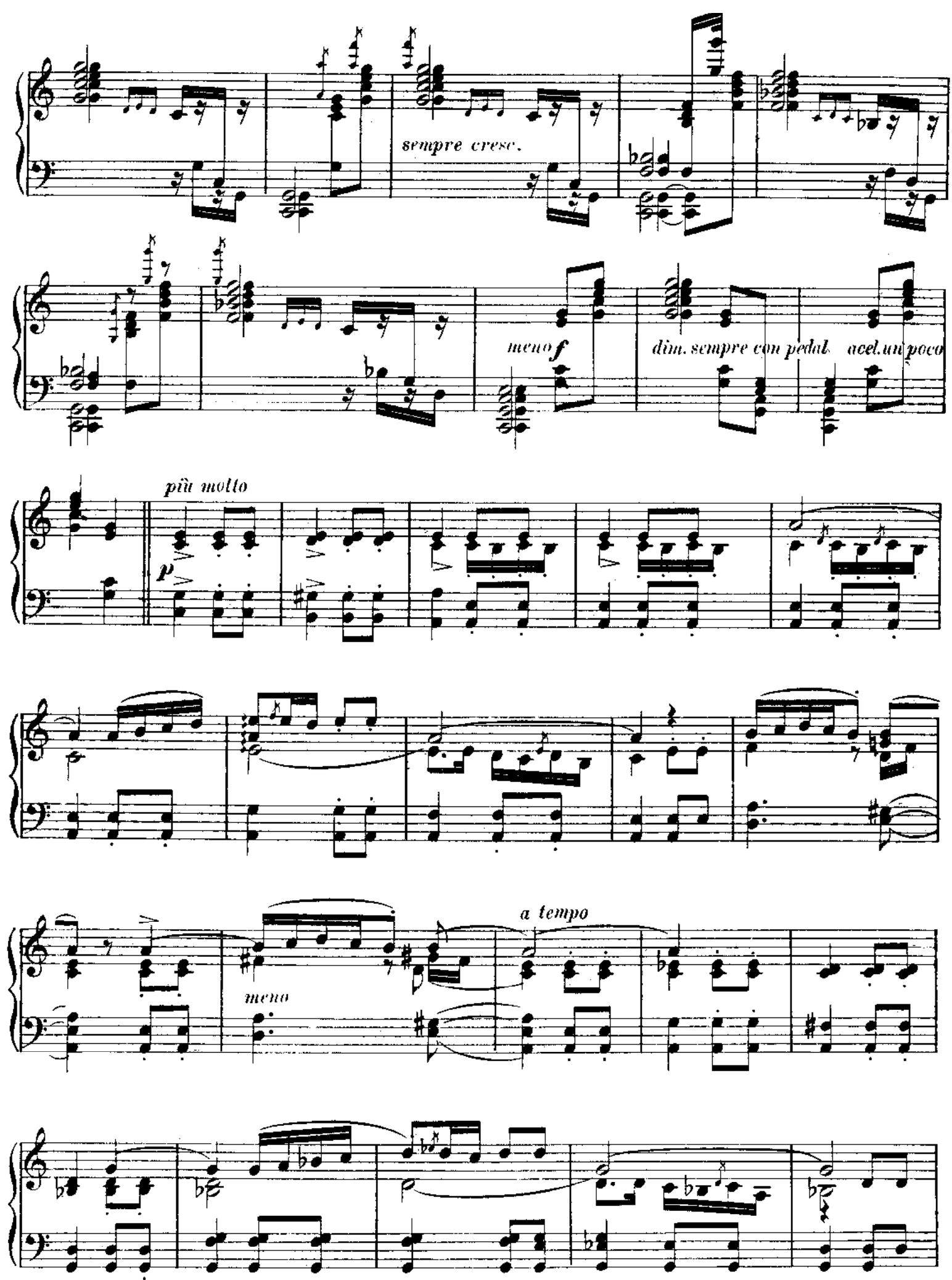

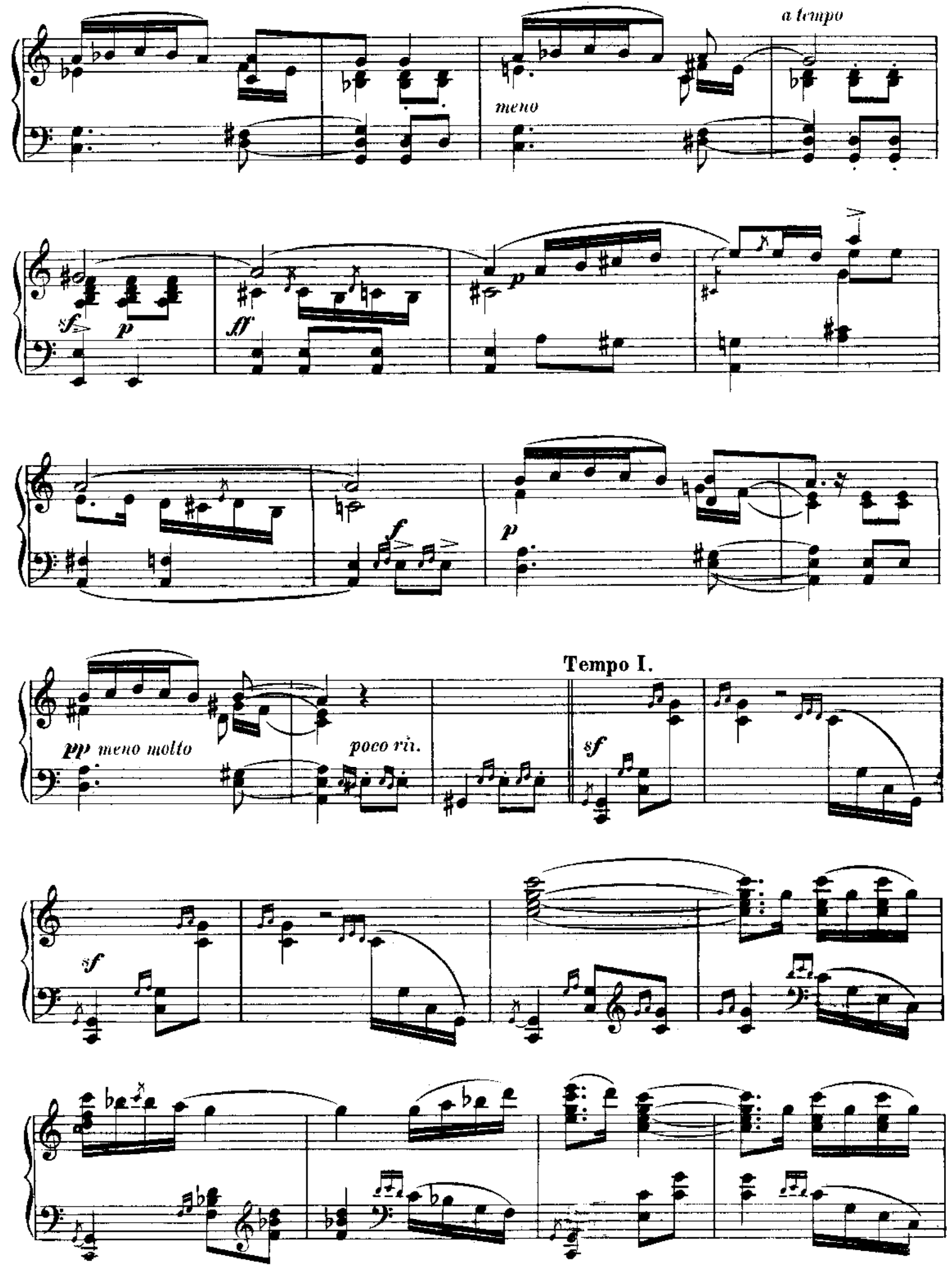

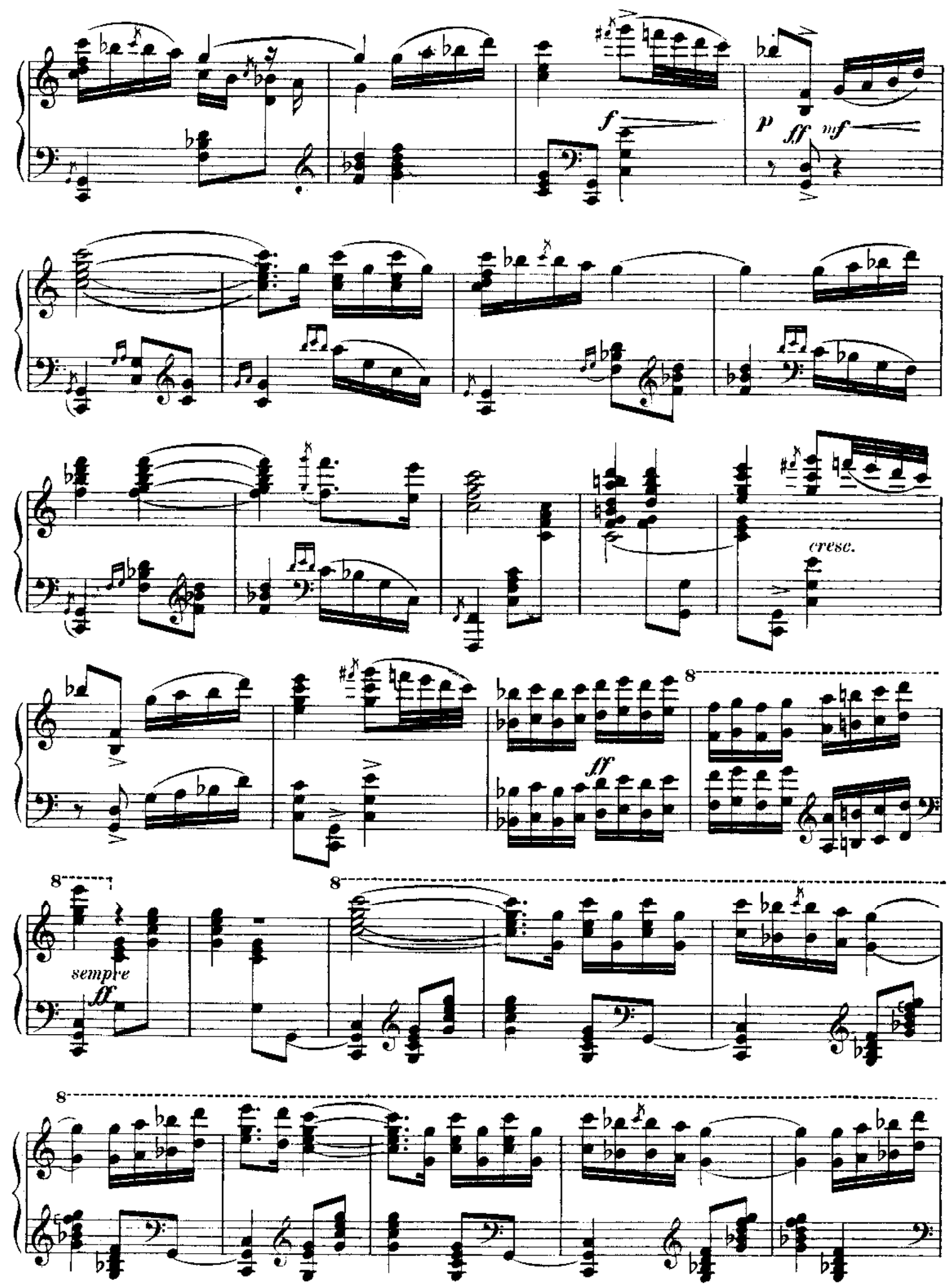

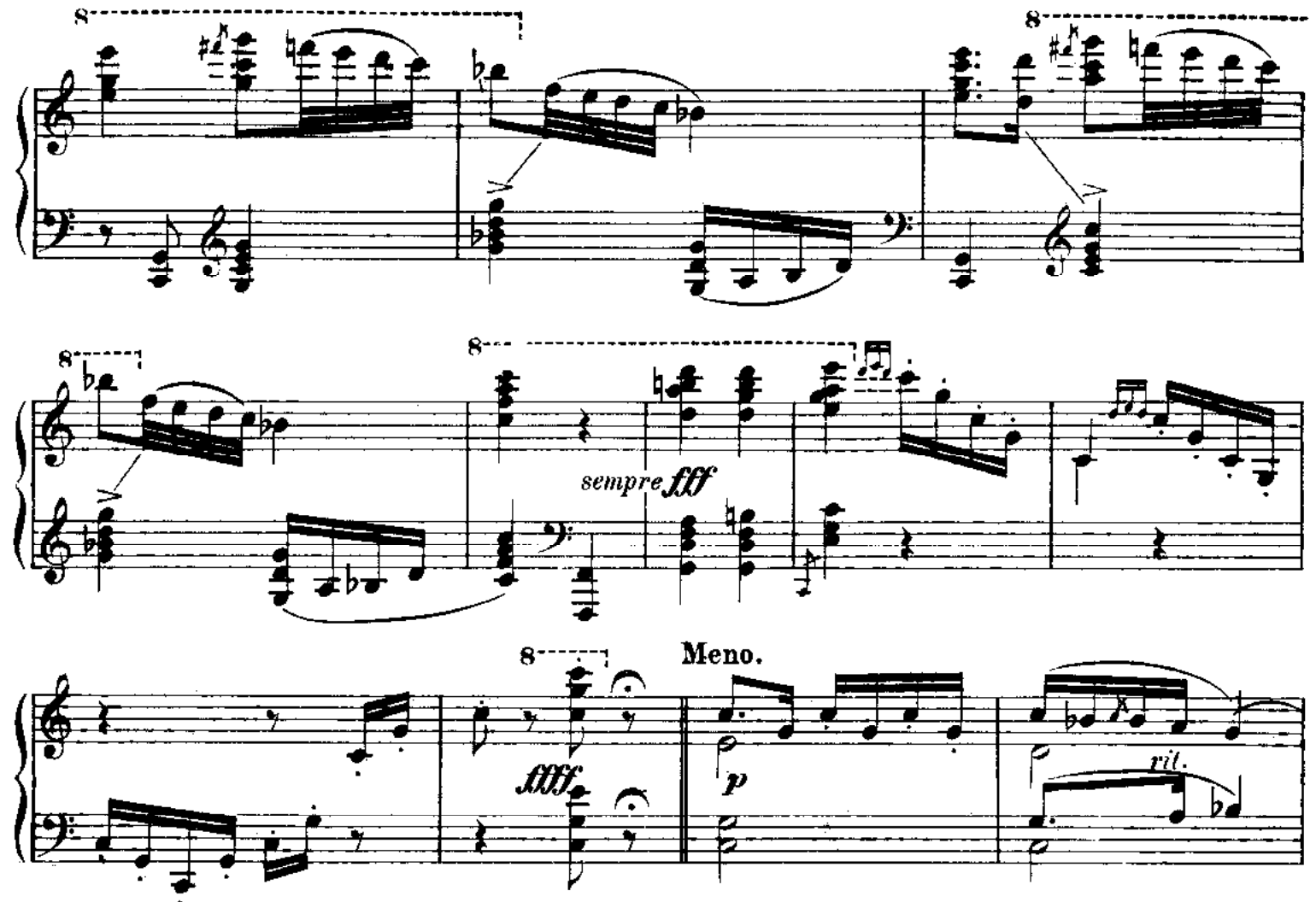

Allegro molto.
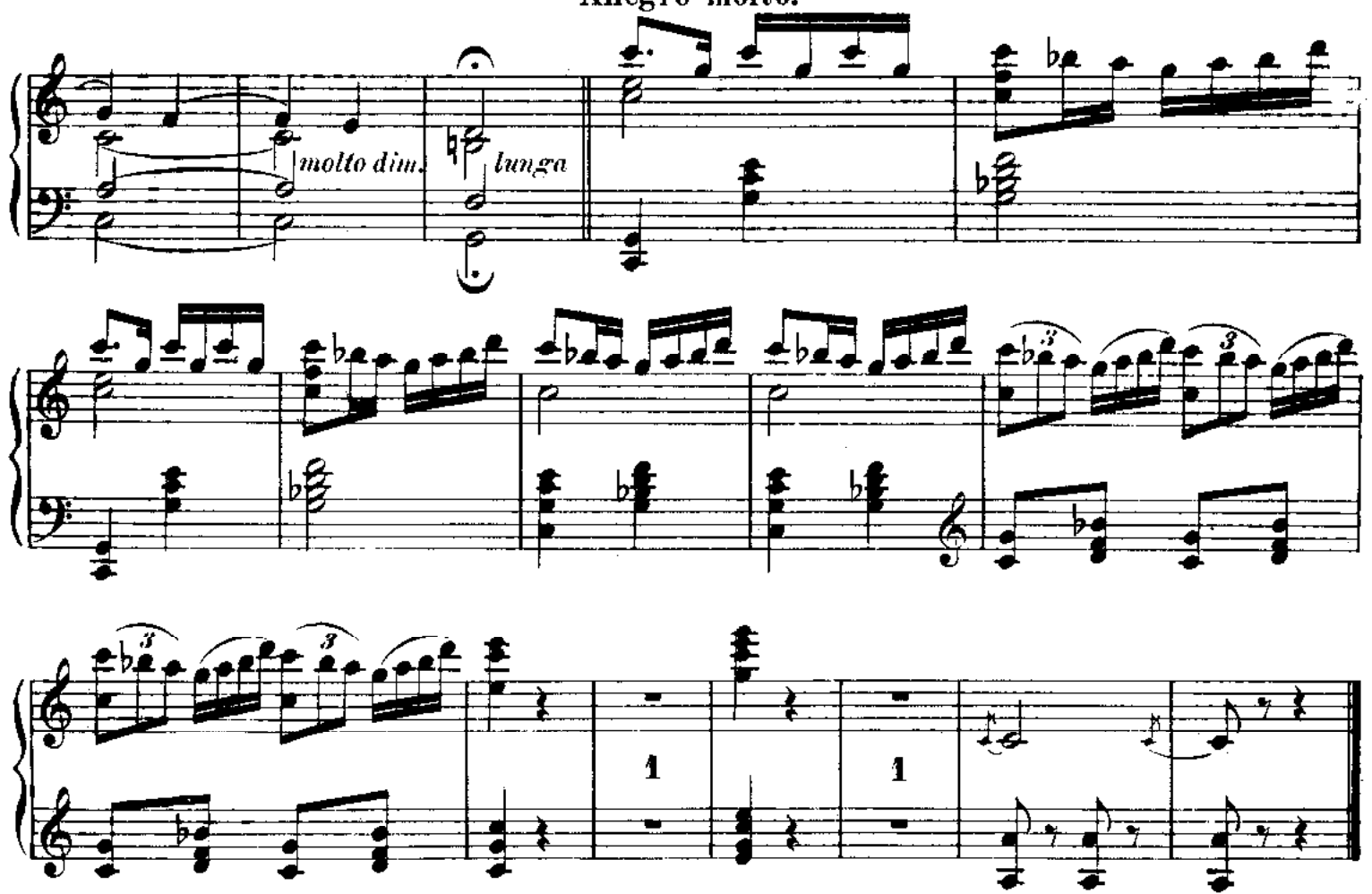

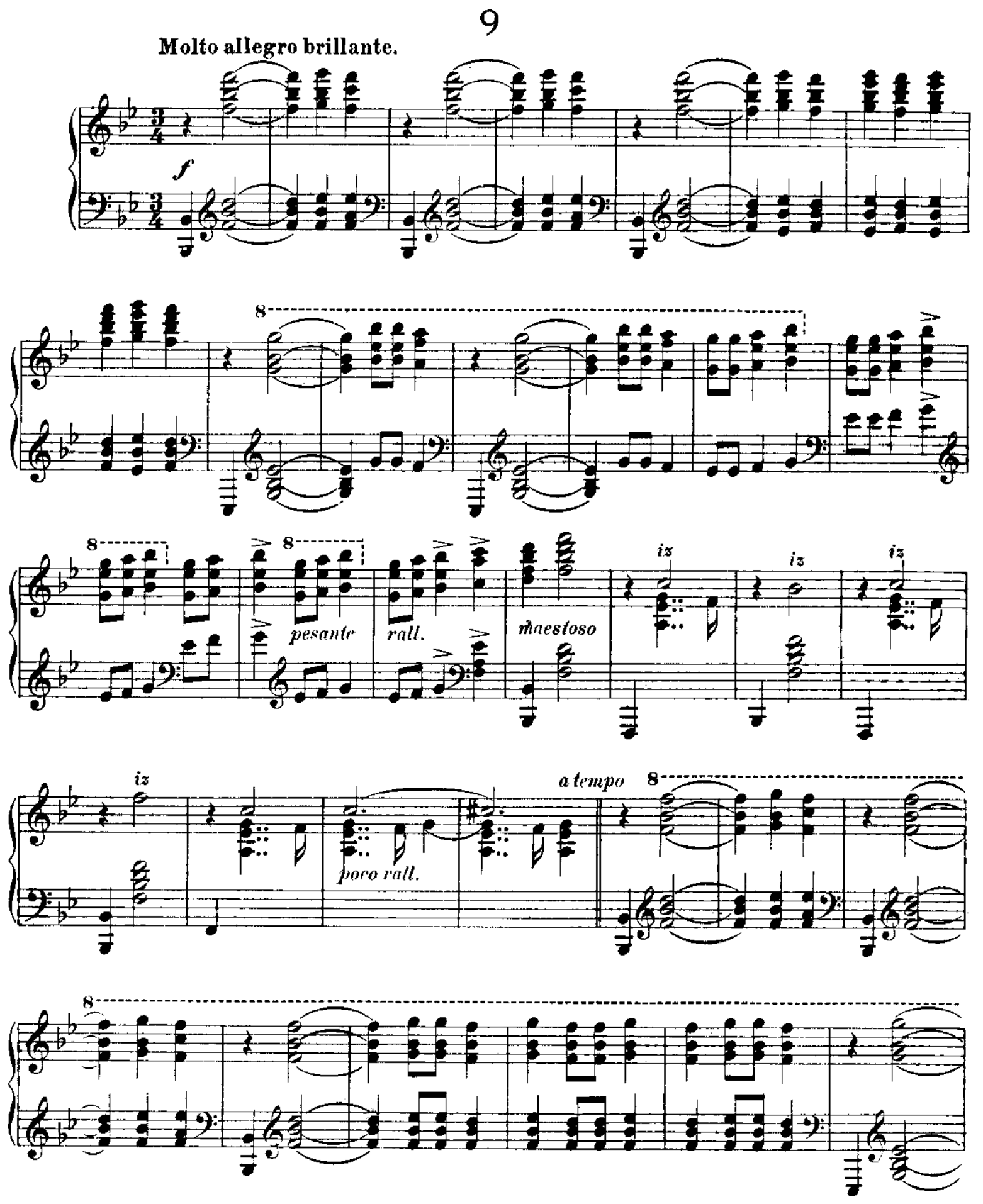


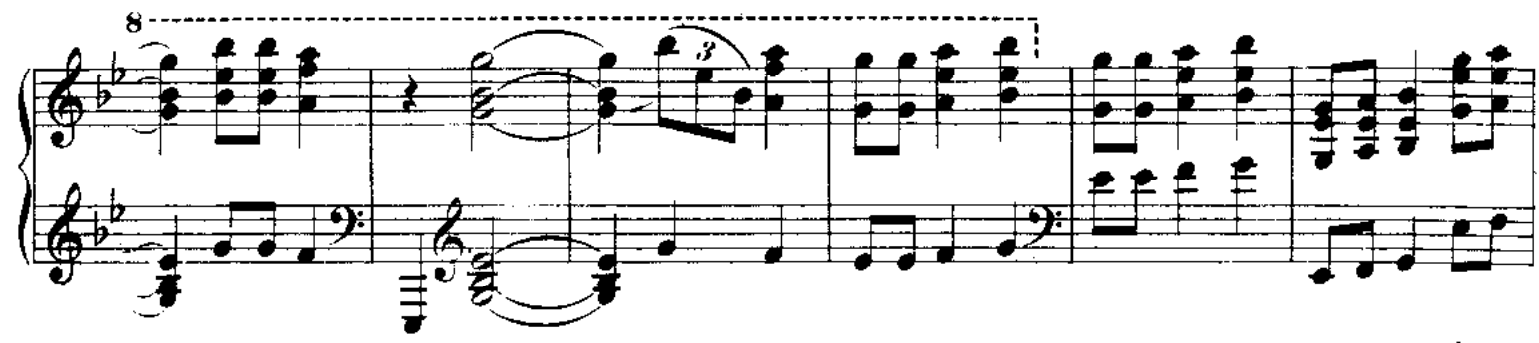

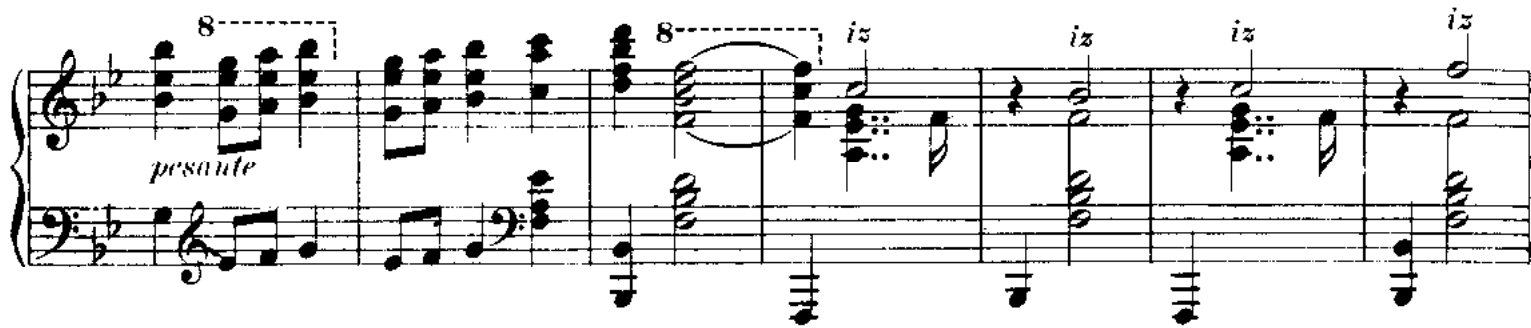

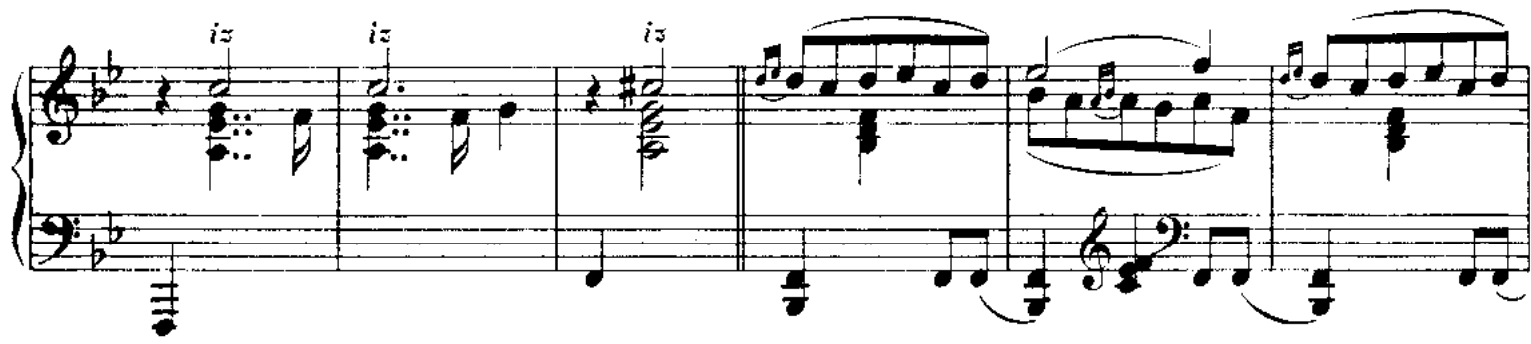

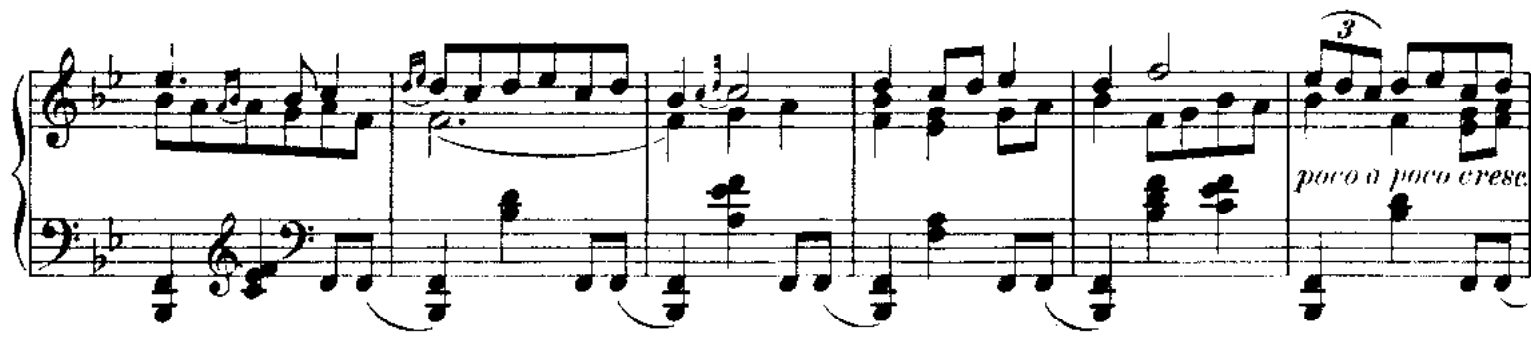
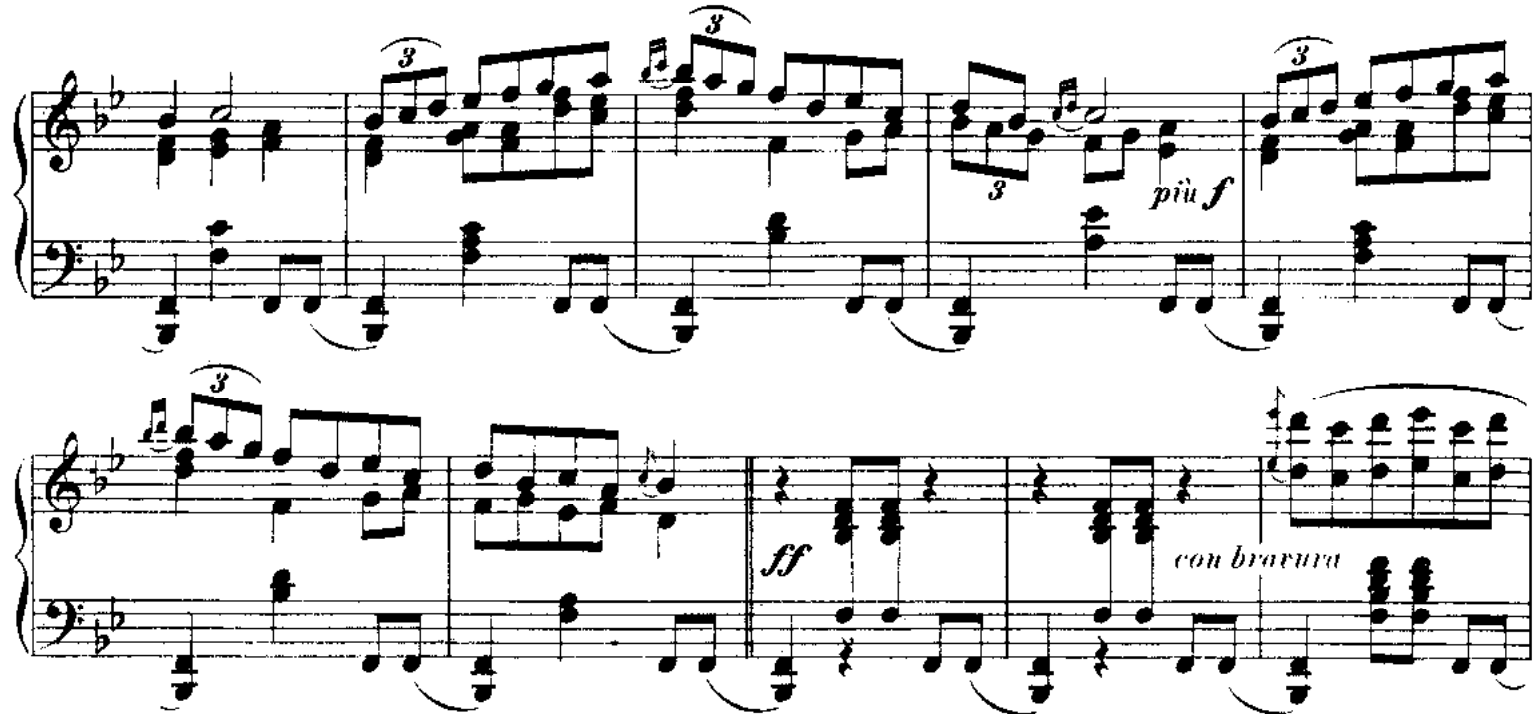

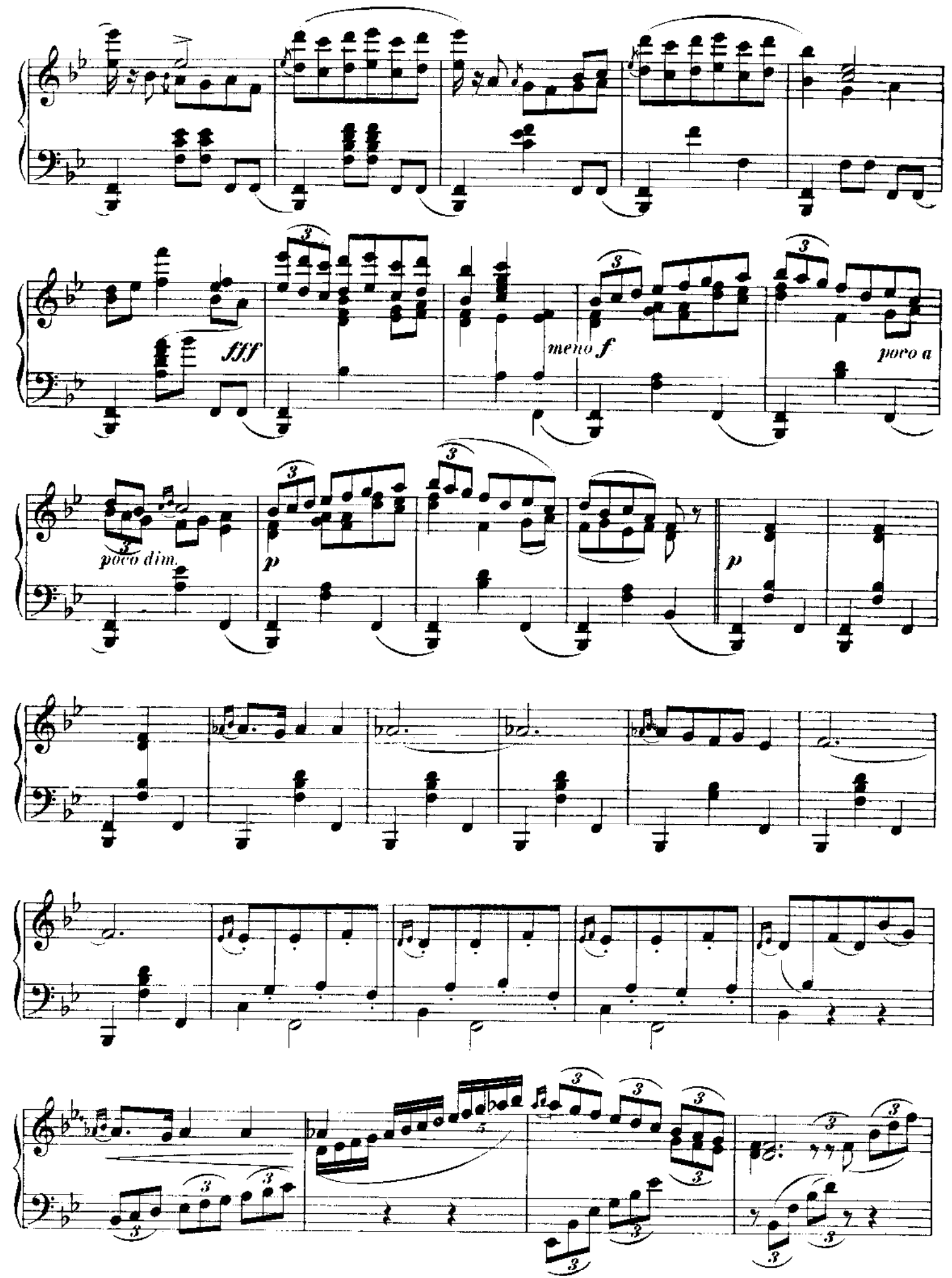

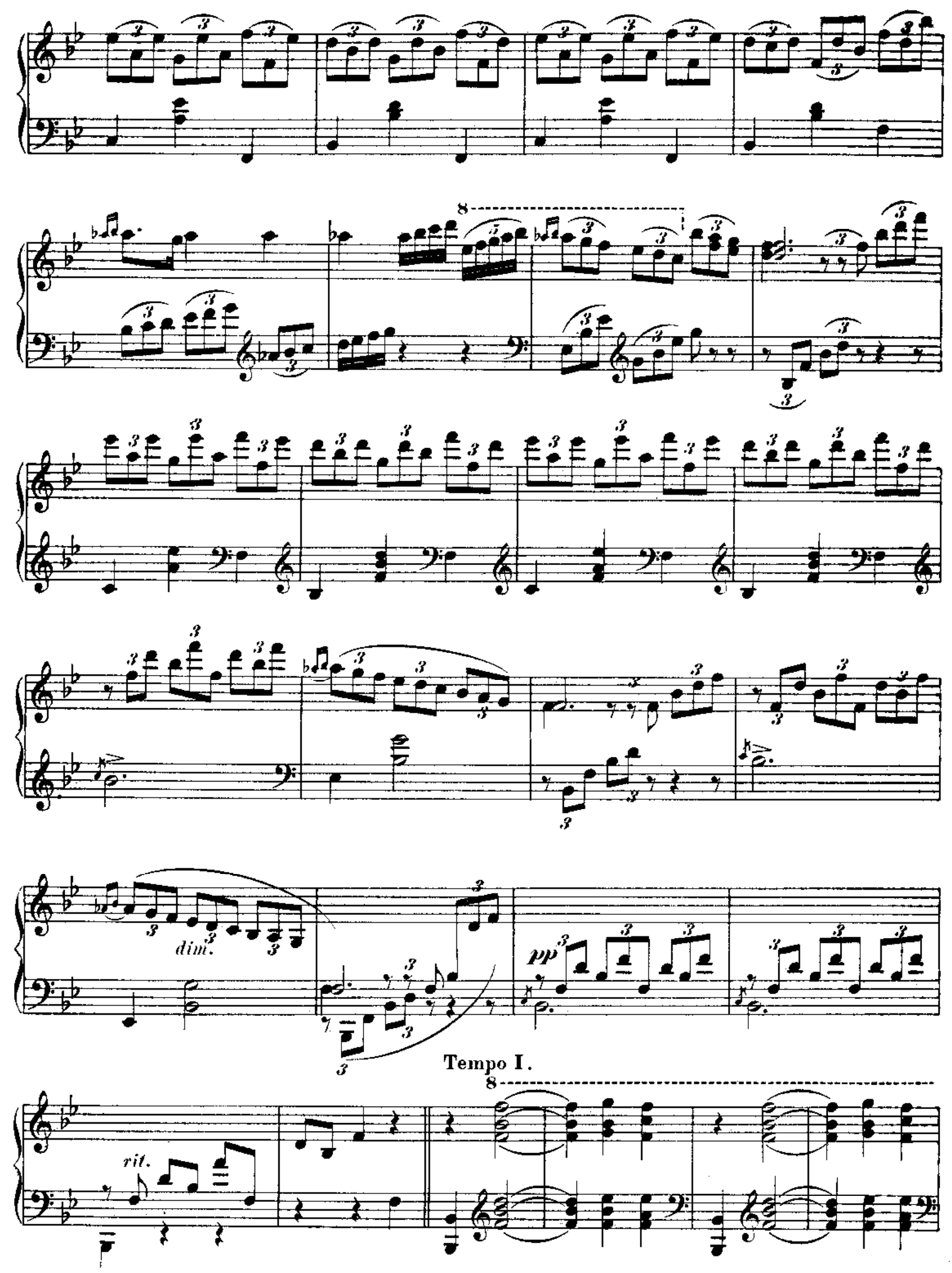


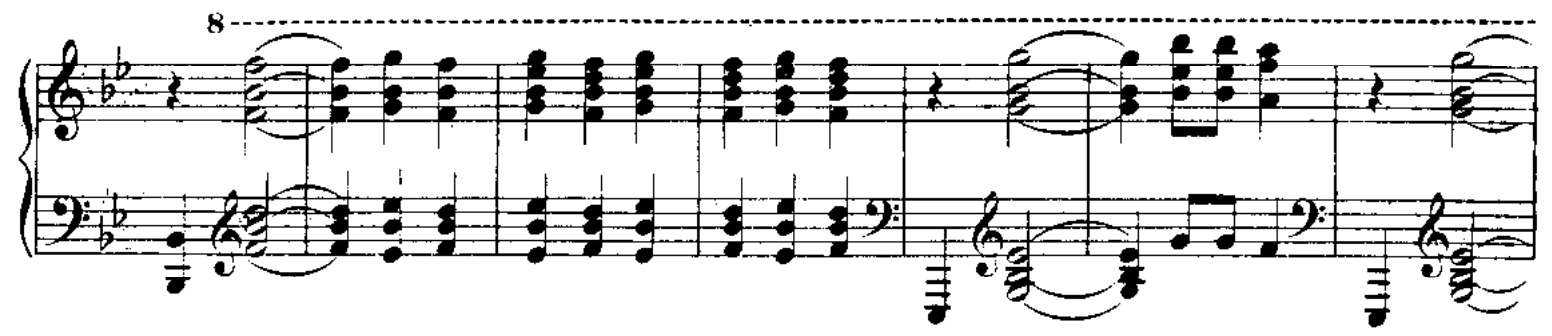

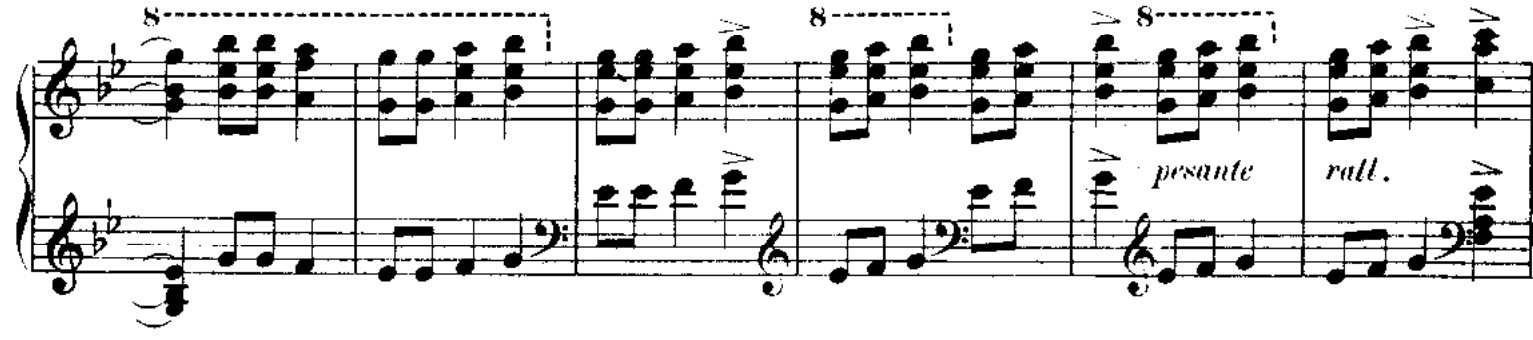
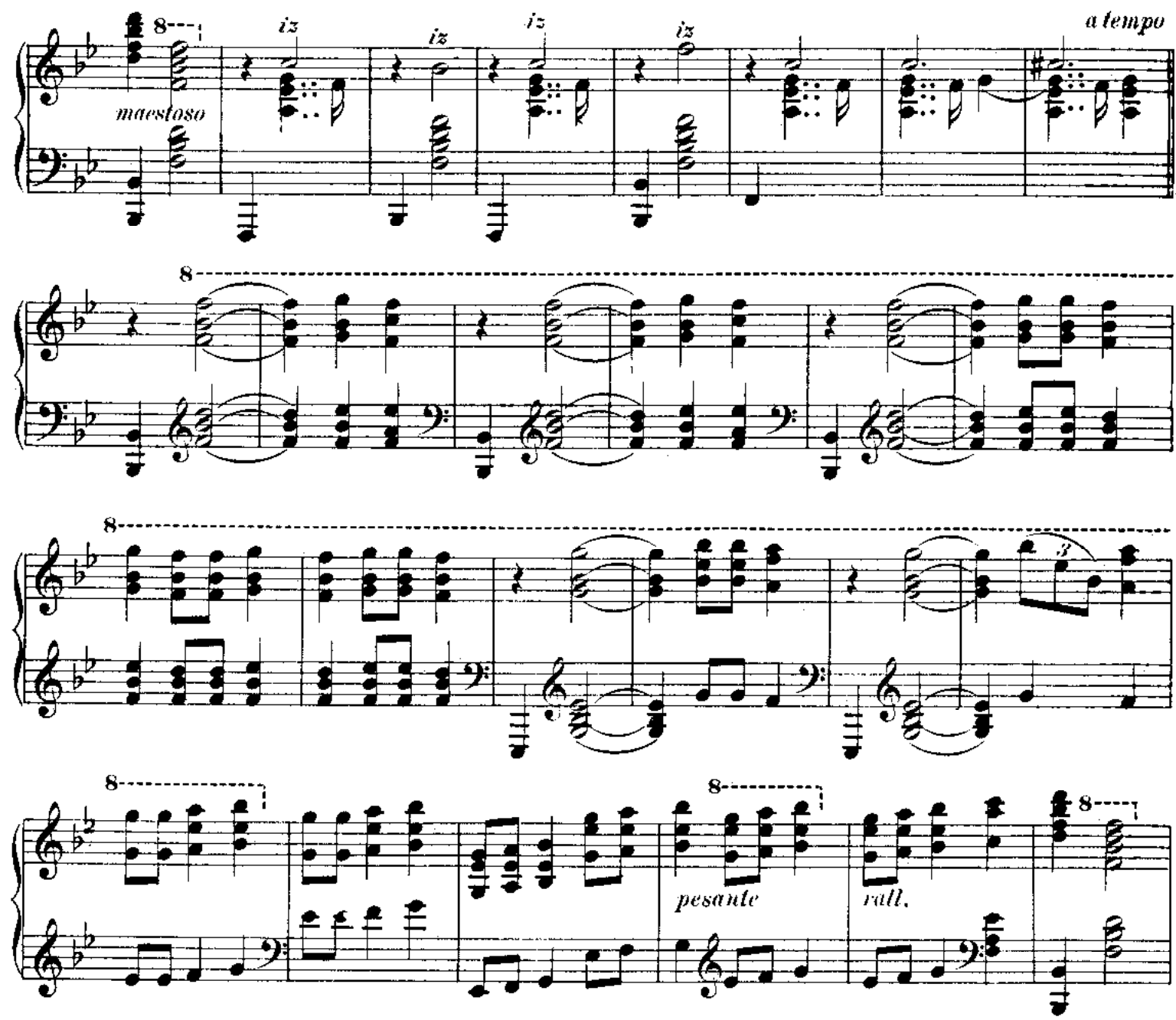

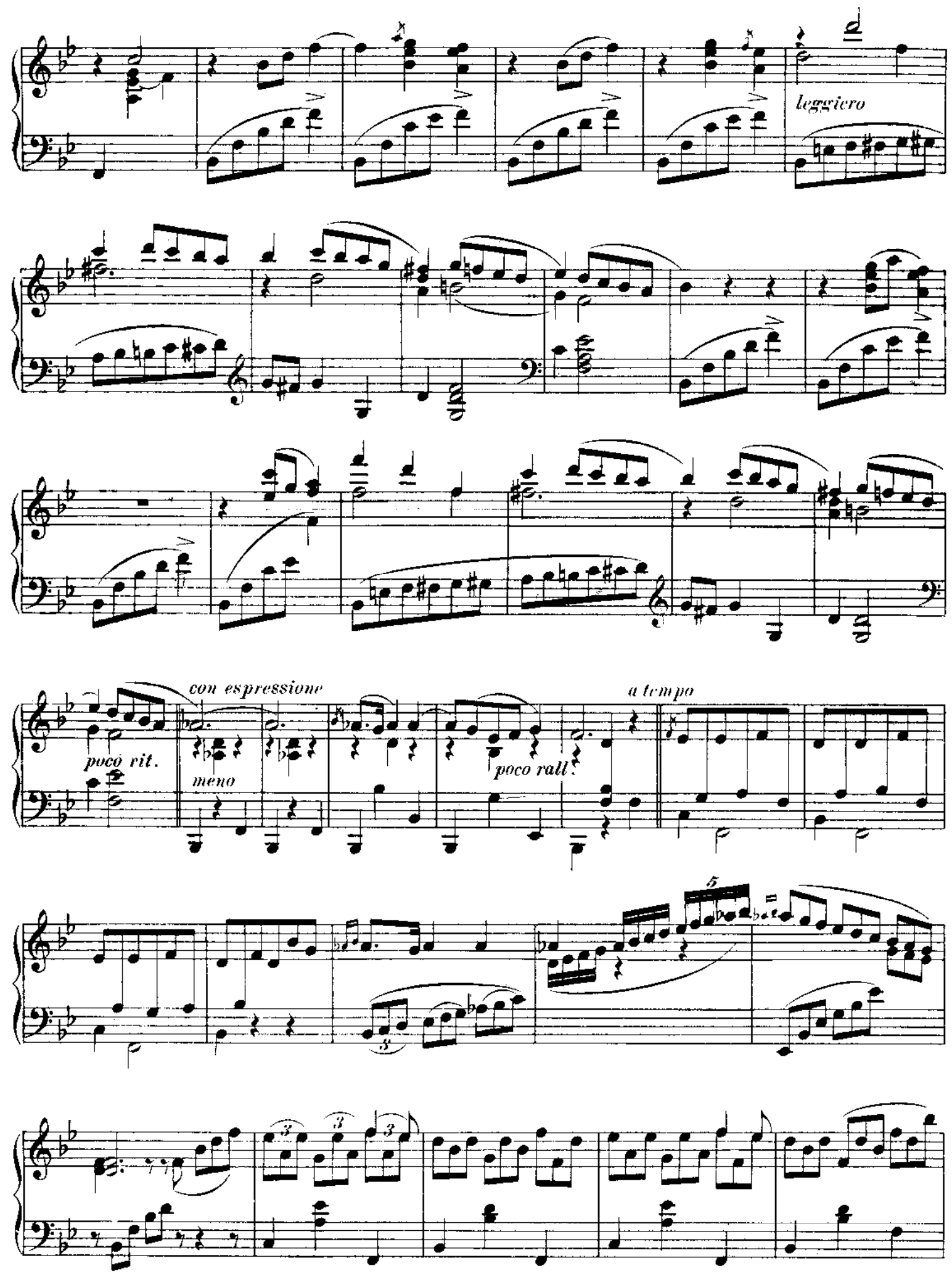

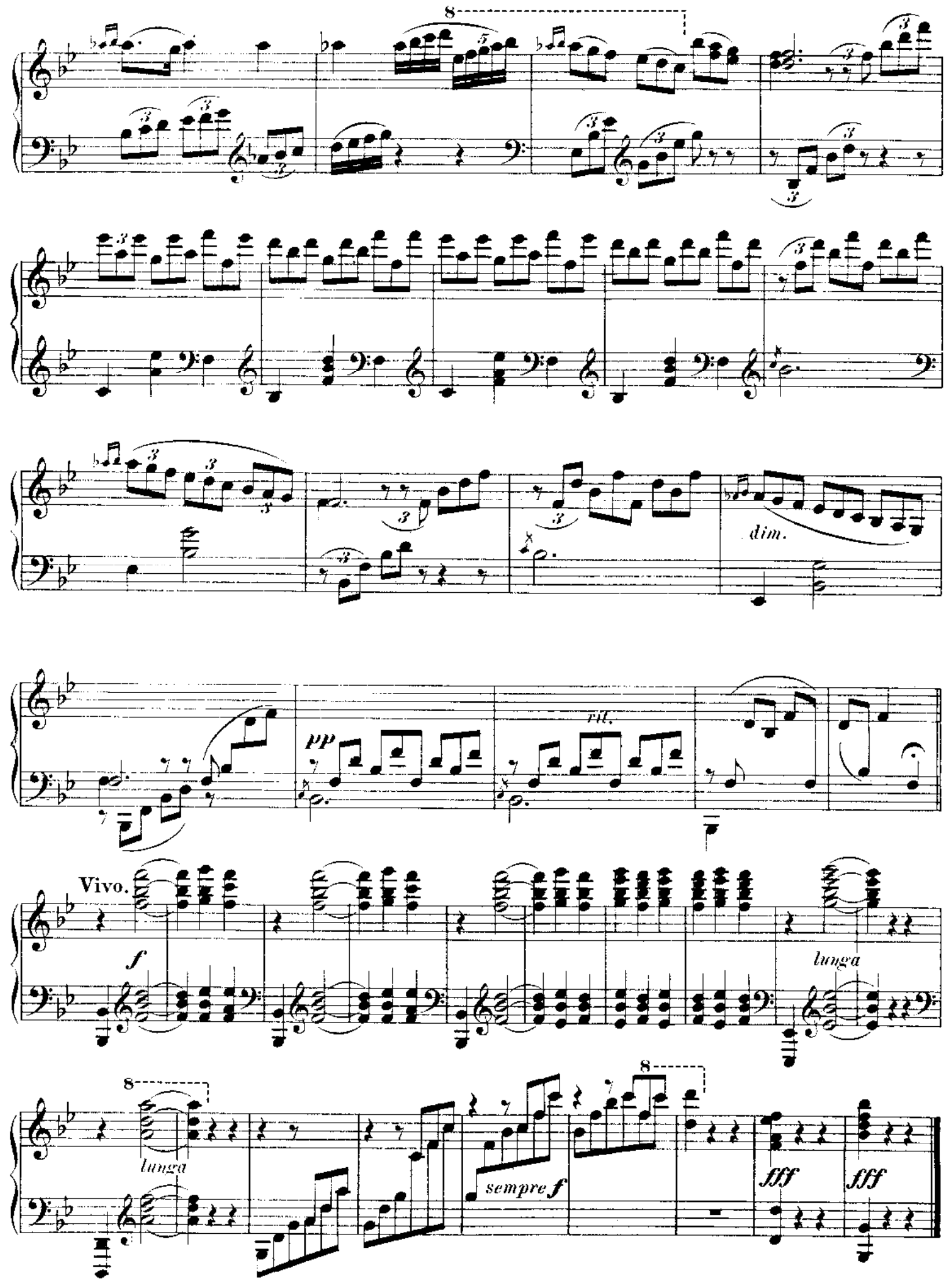


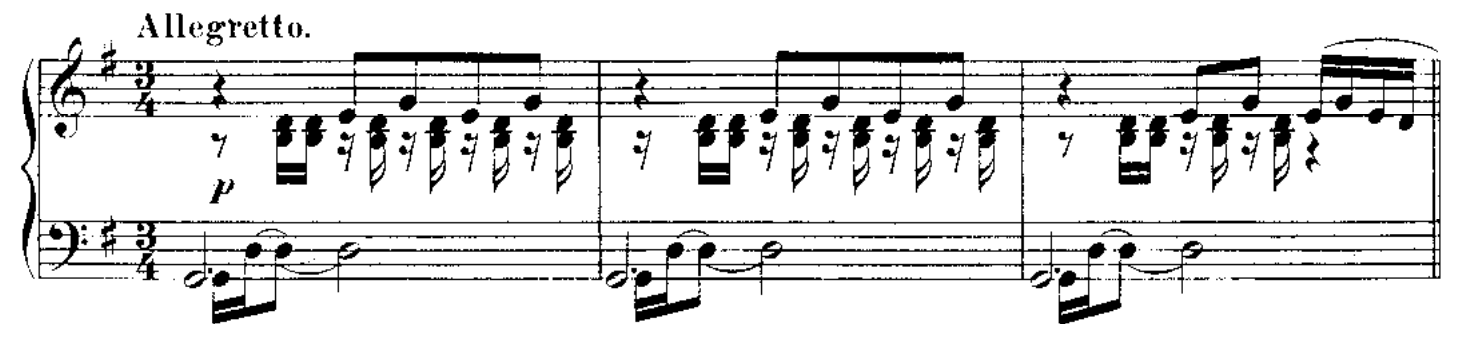
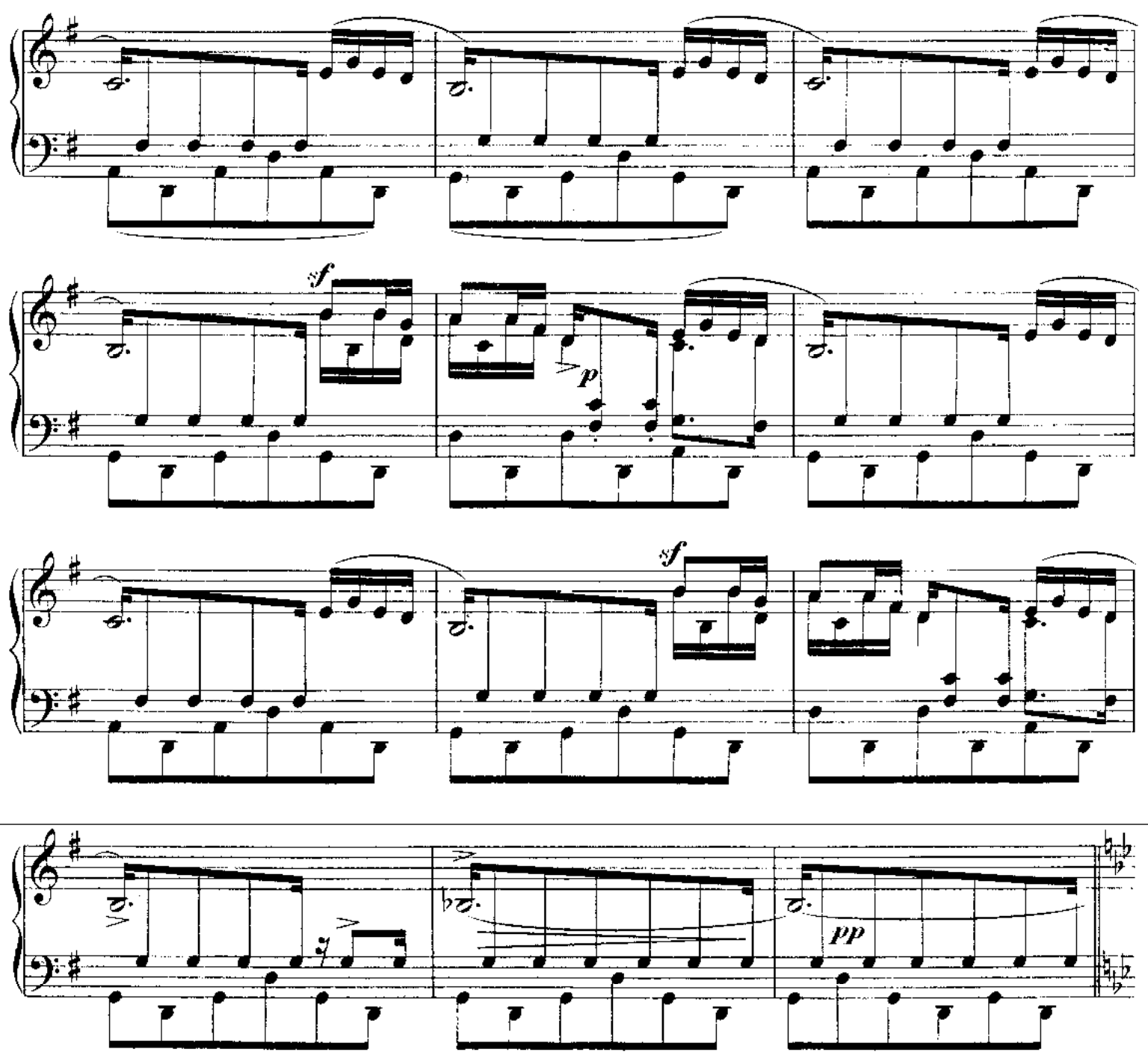

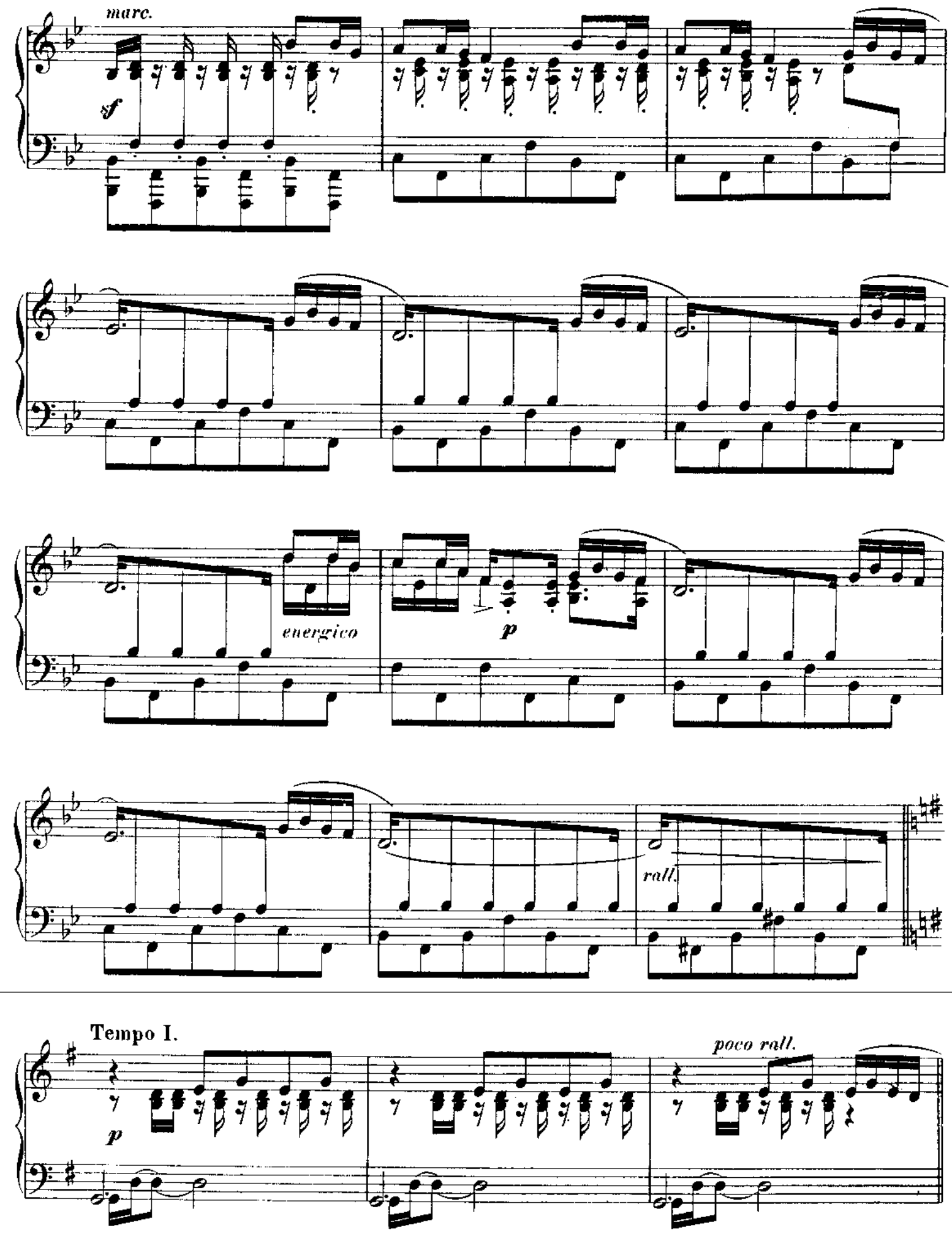

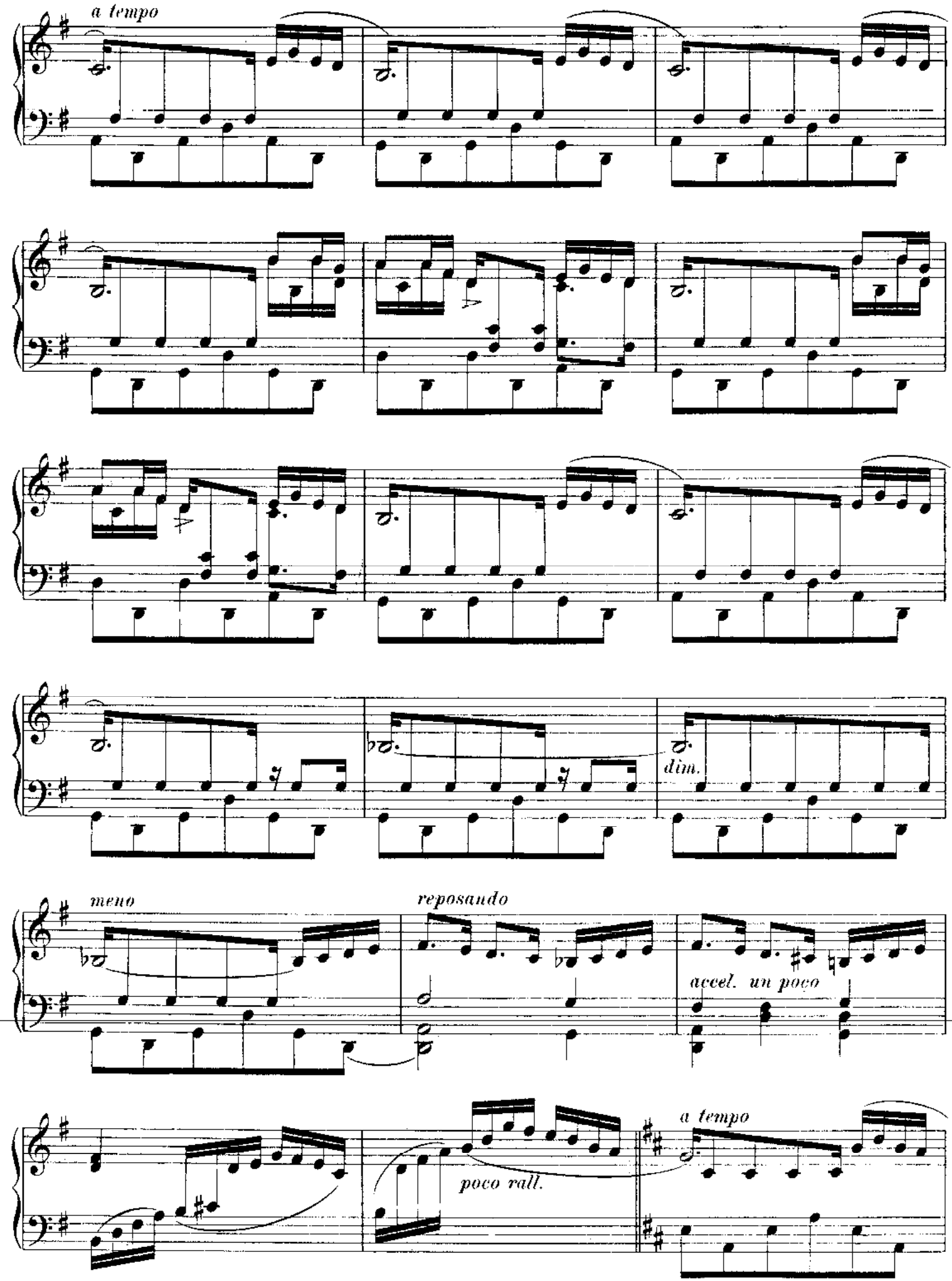

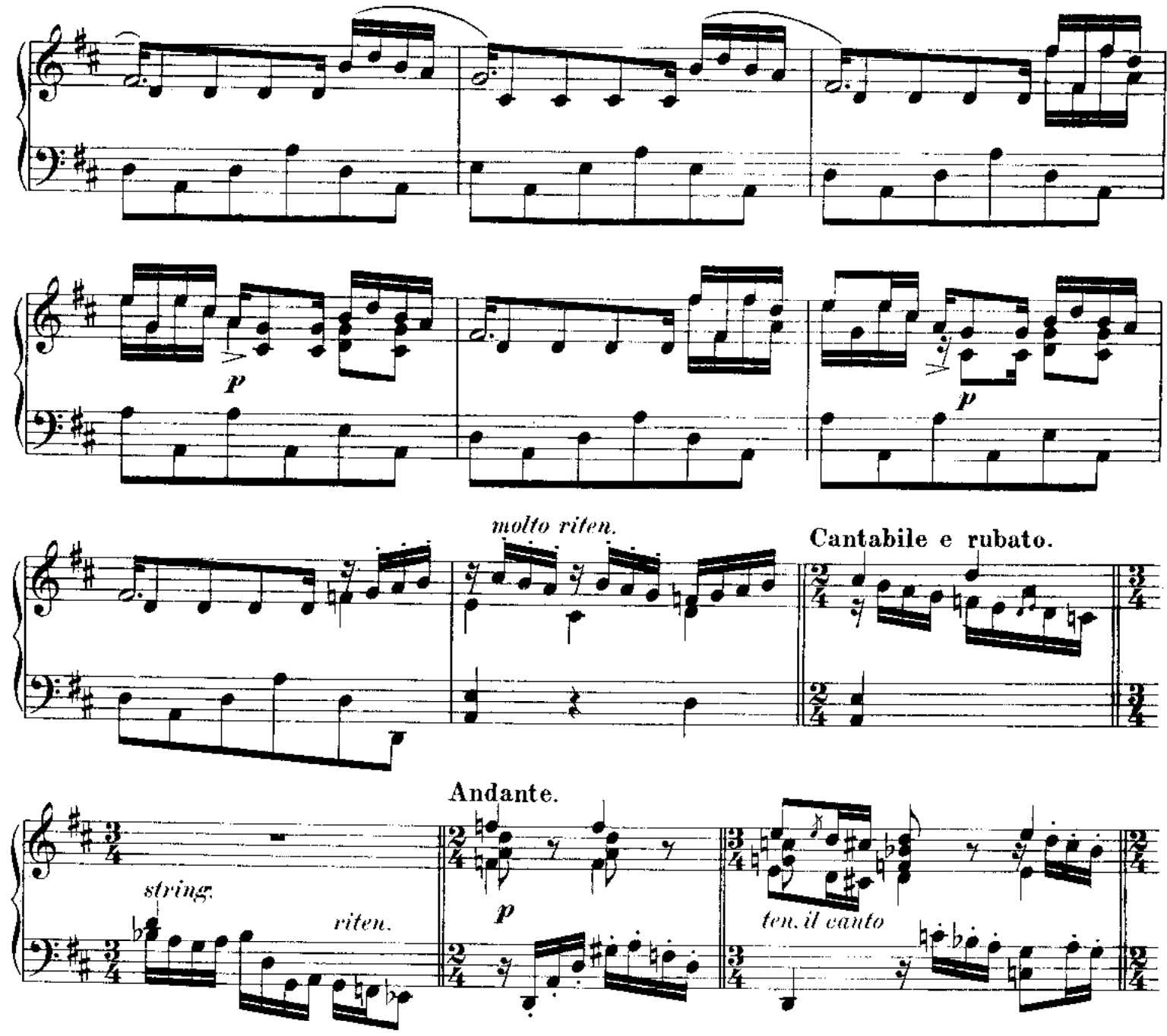

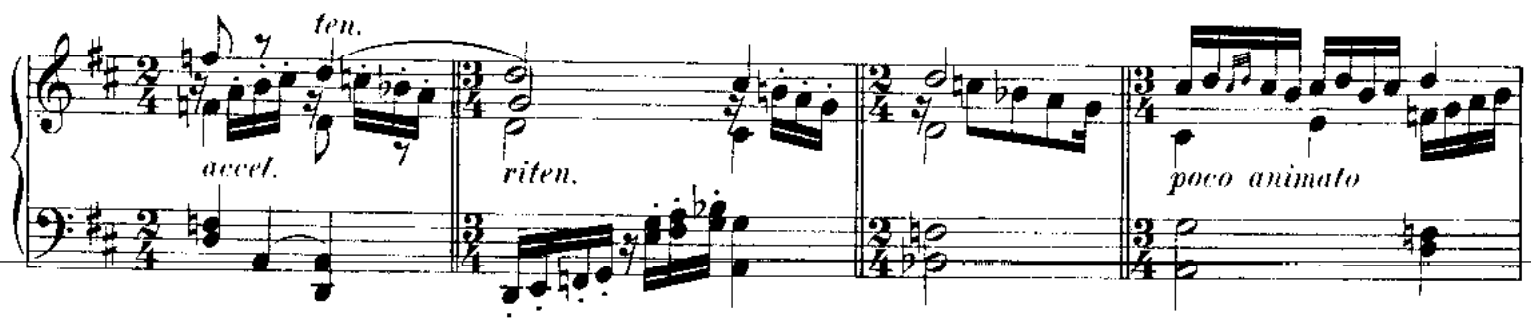

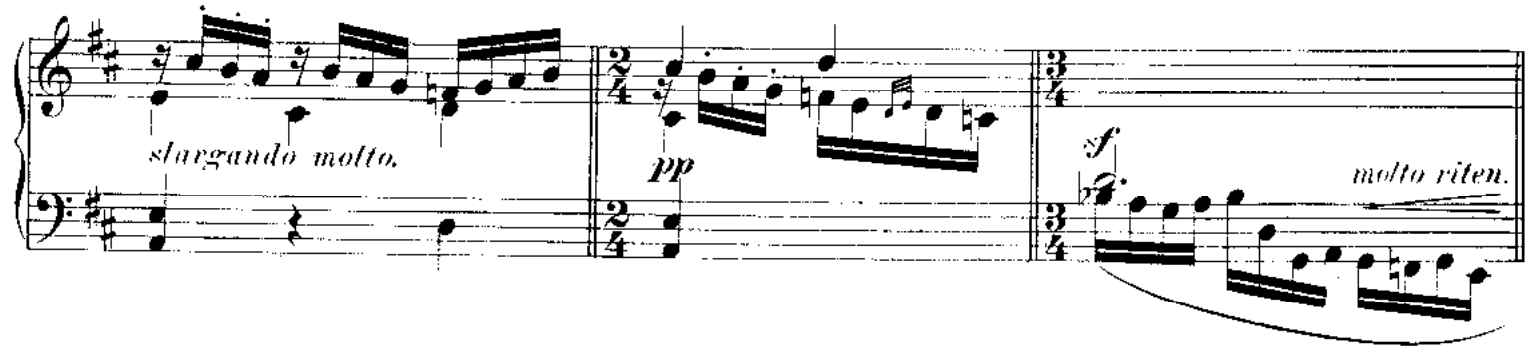




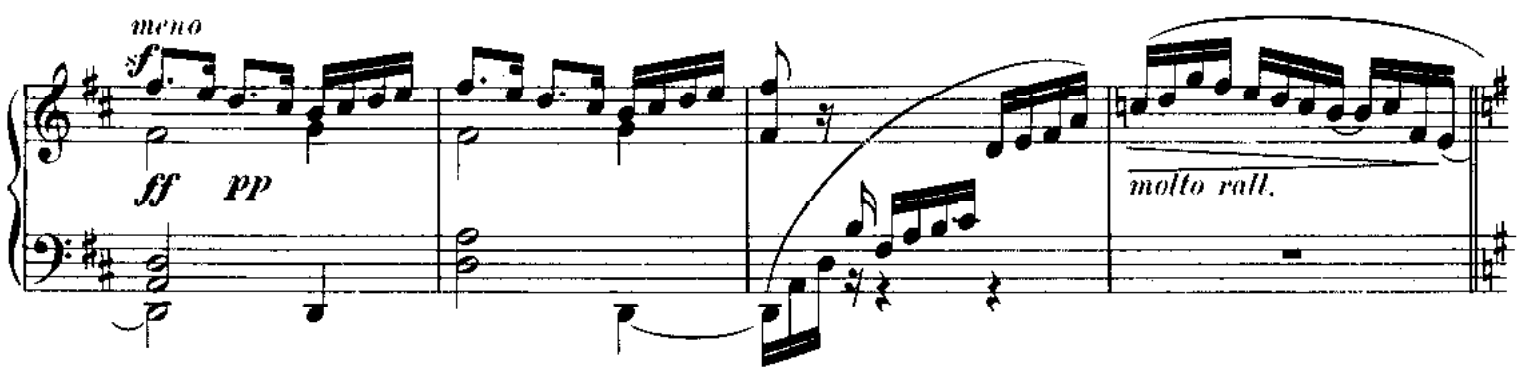

Tempo I.

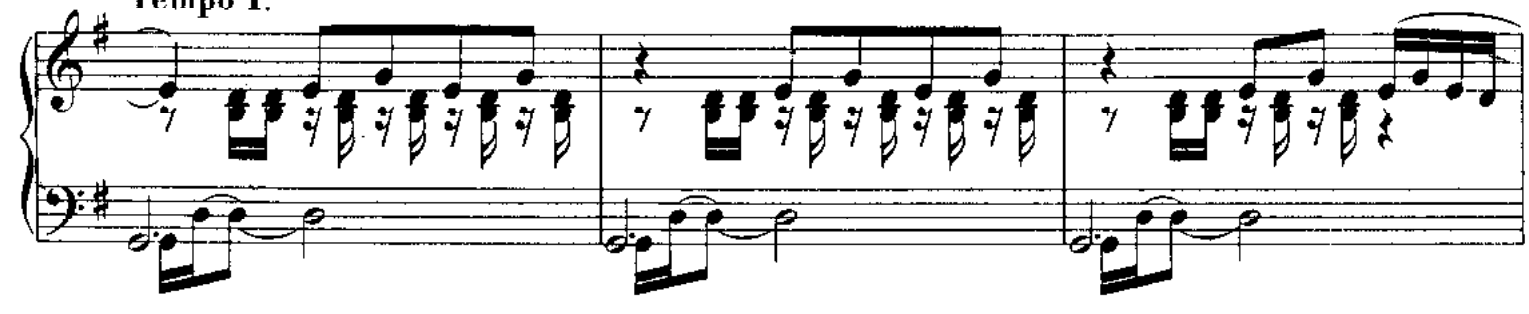
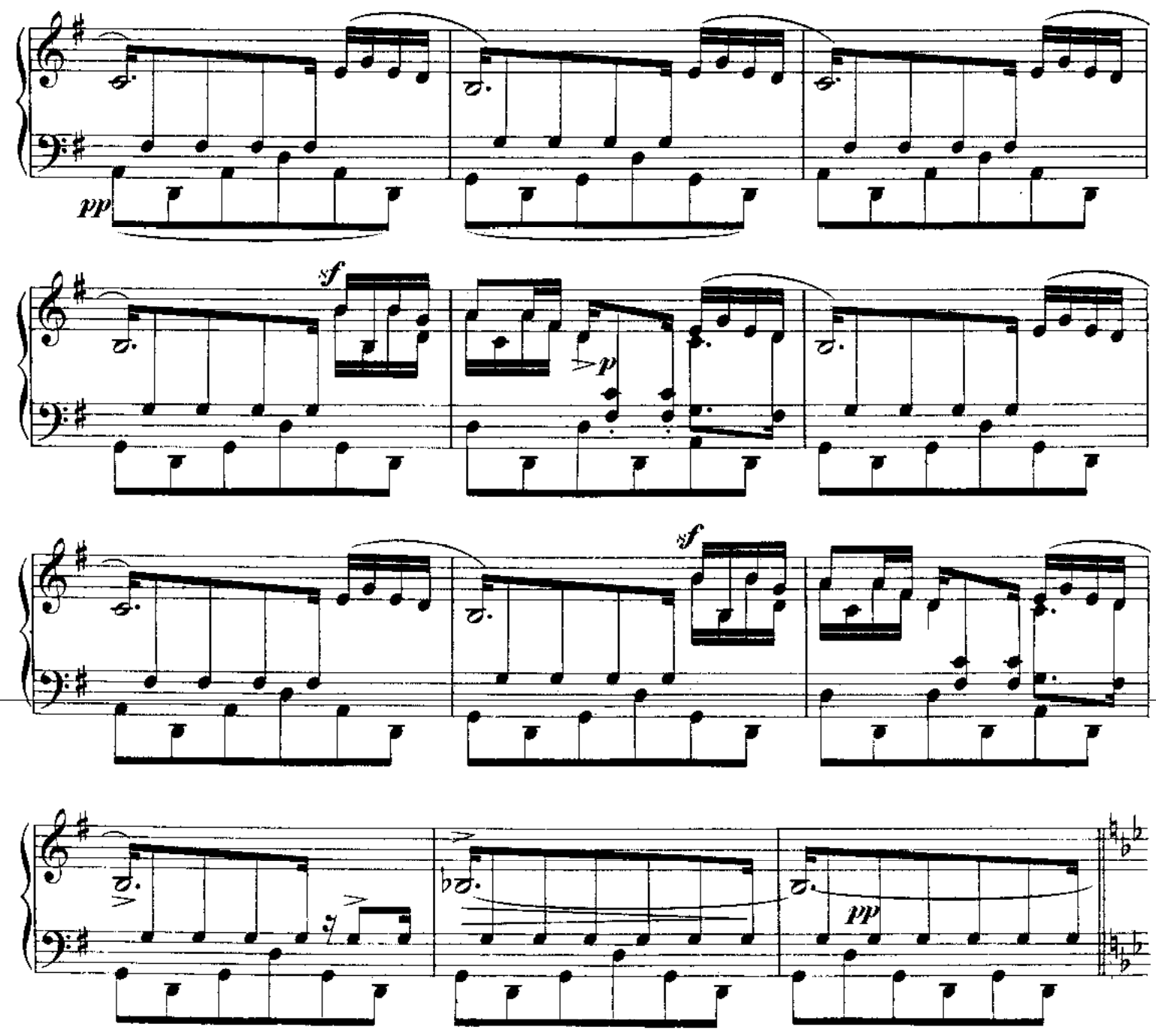

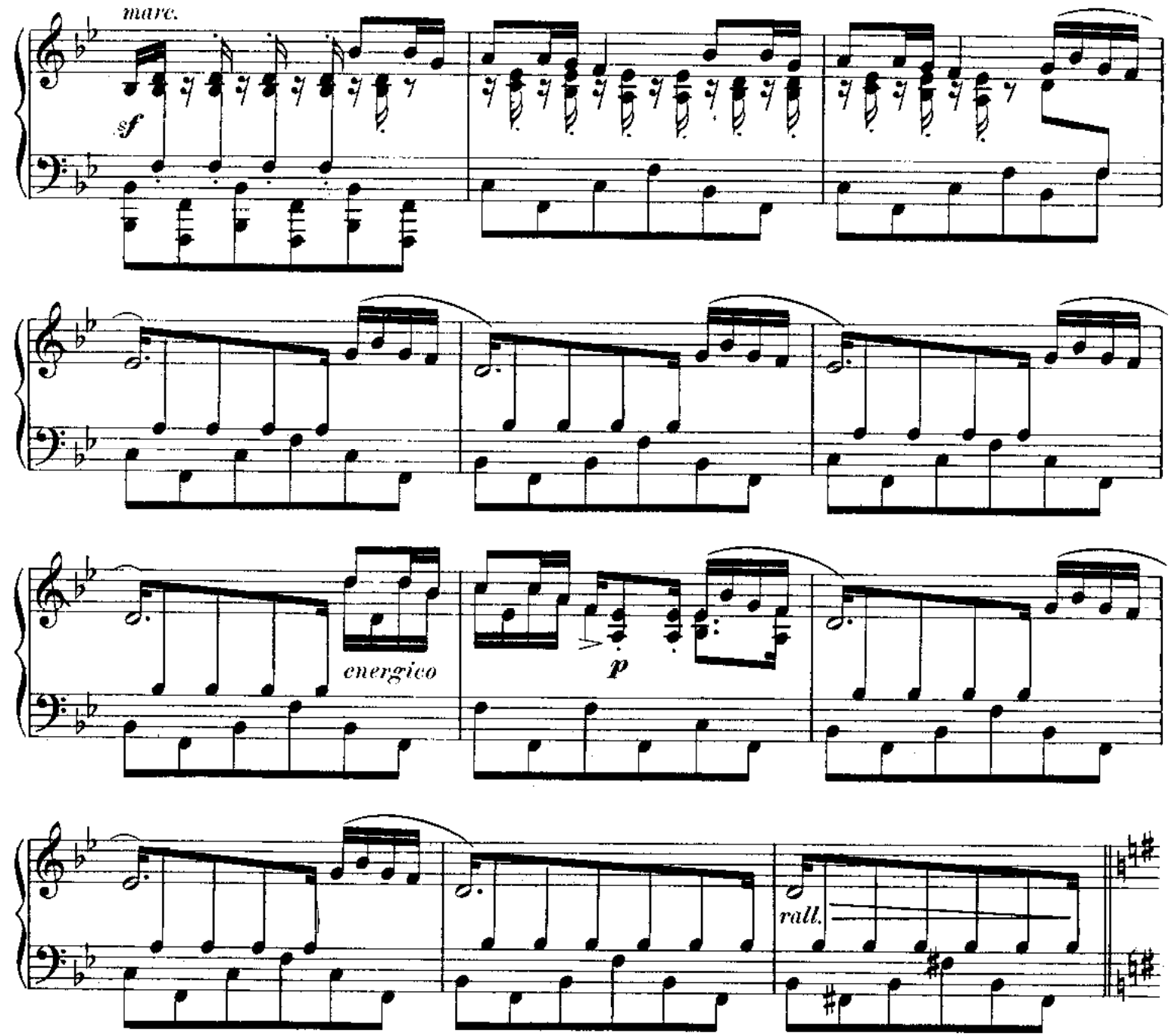

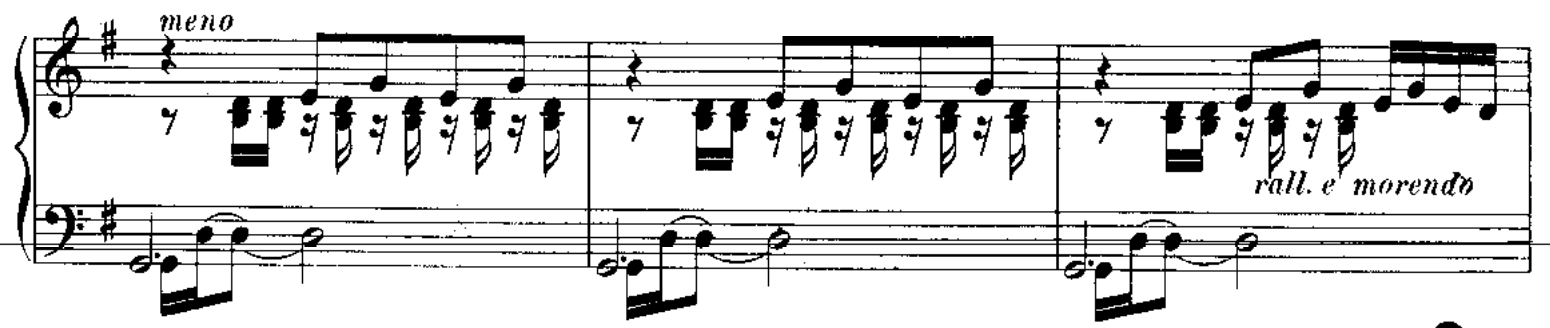

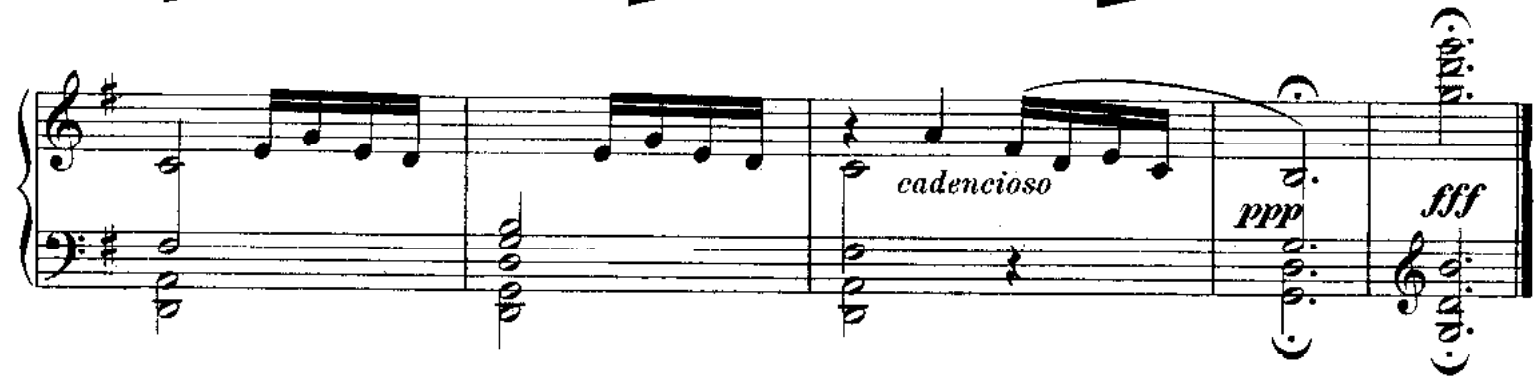


Largo a piacer

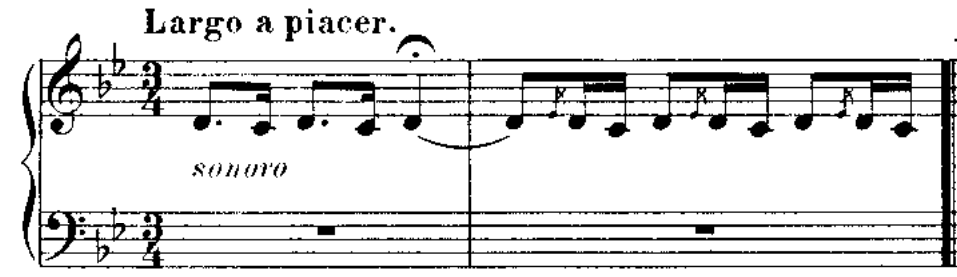

Andante con moto.
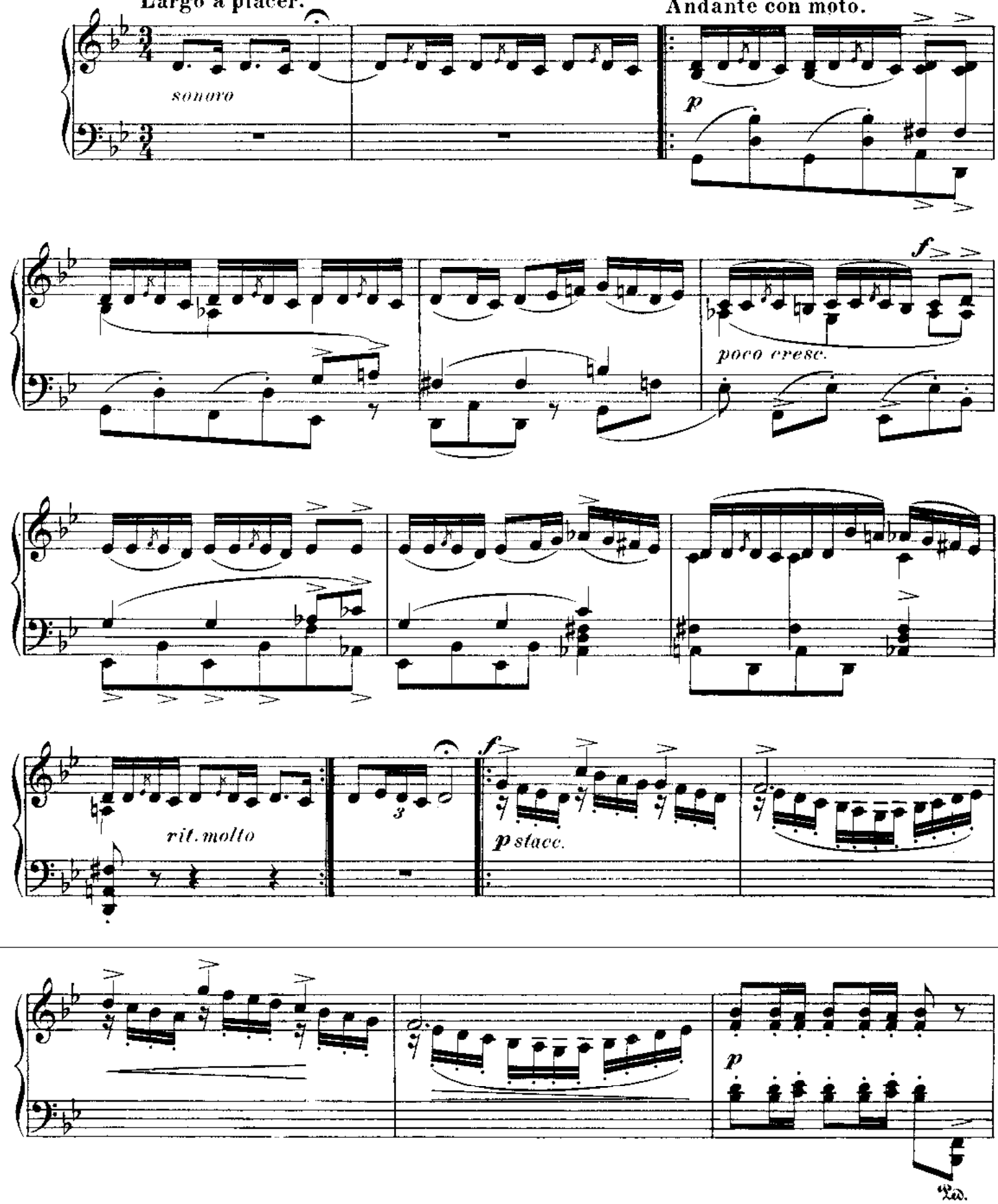

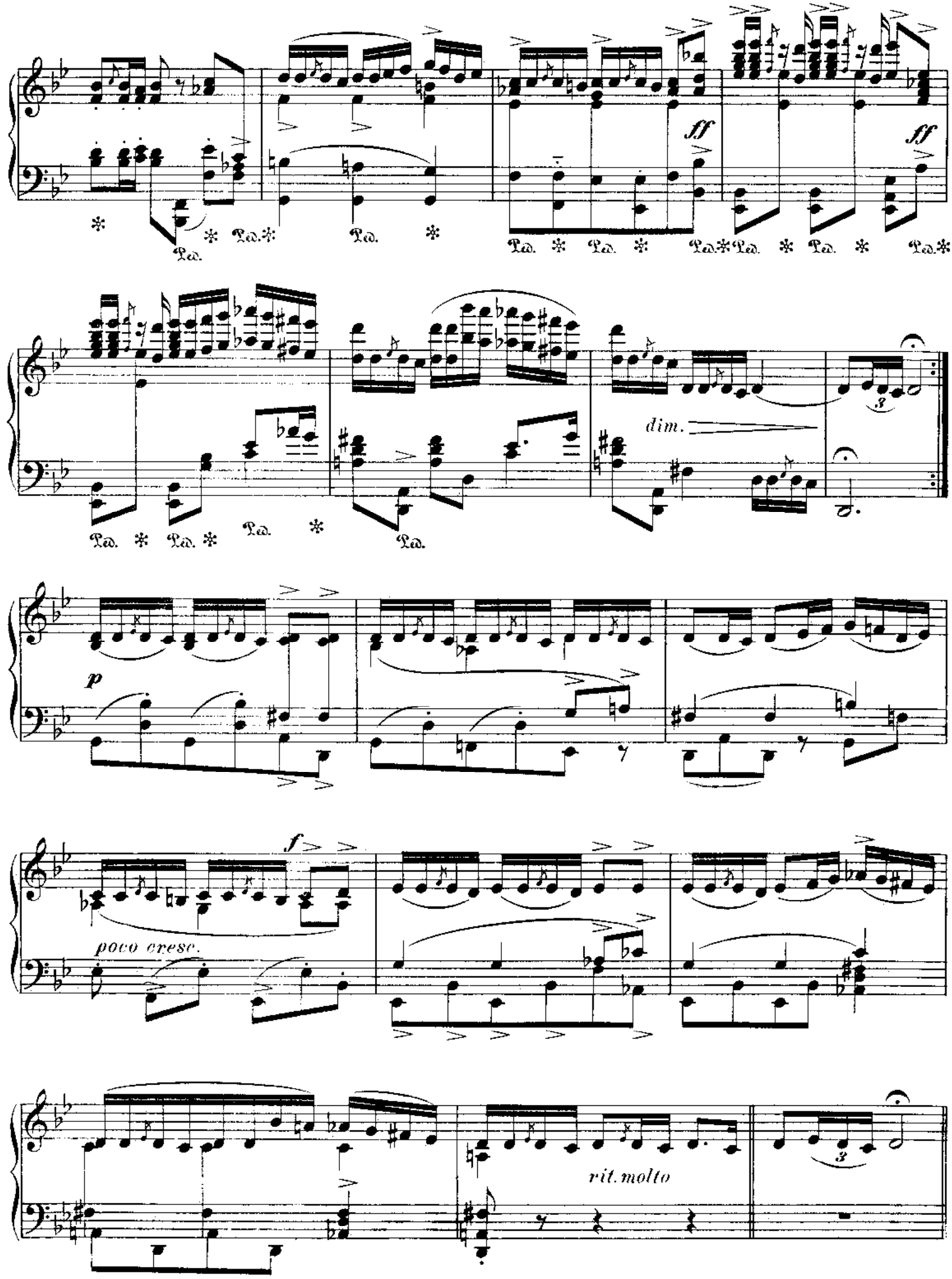

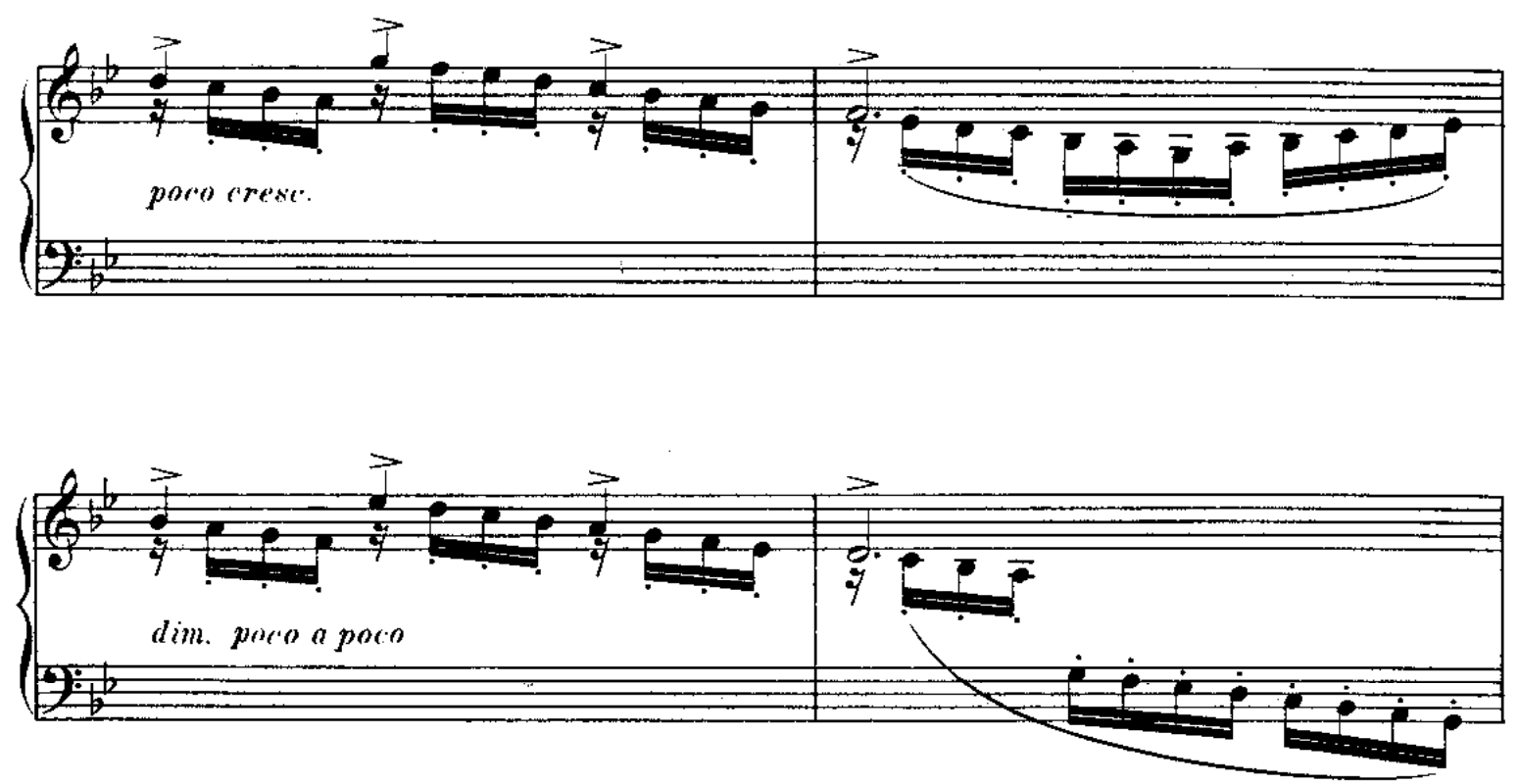

Largamente.
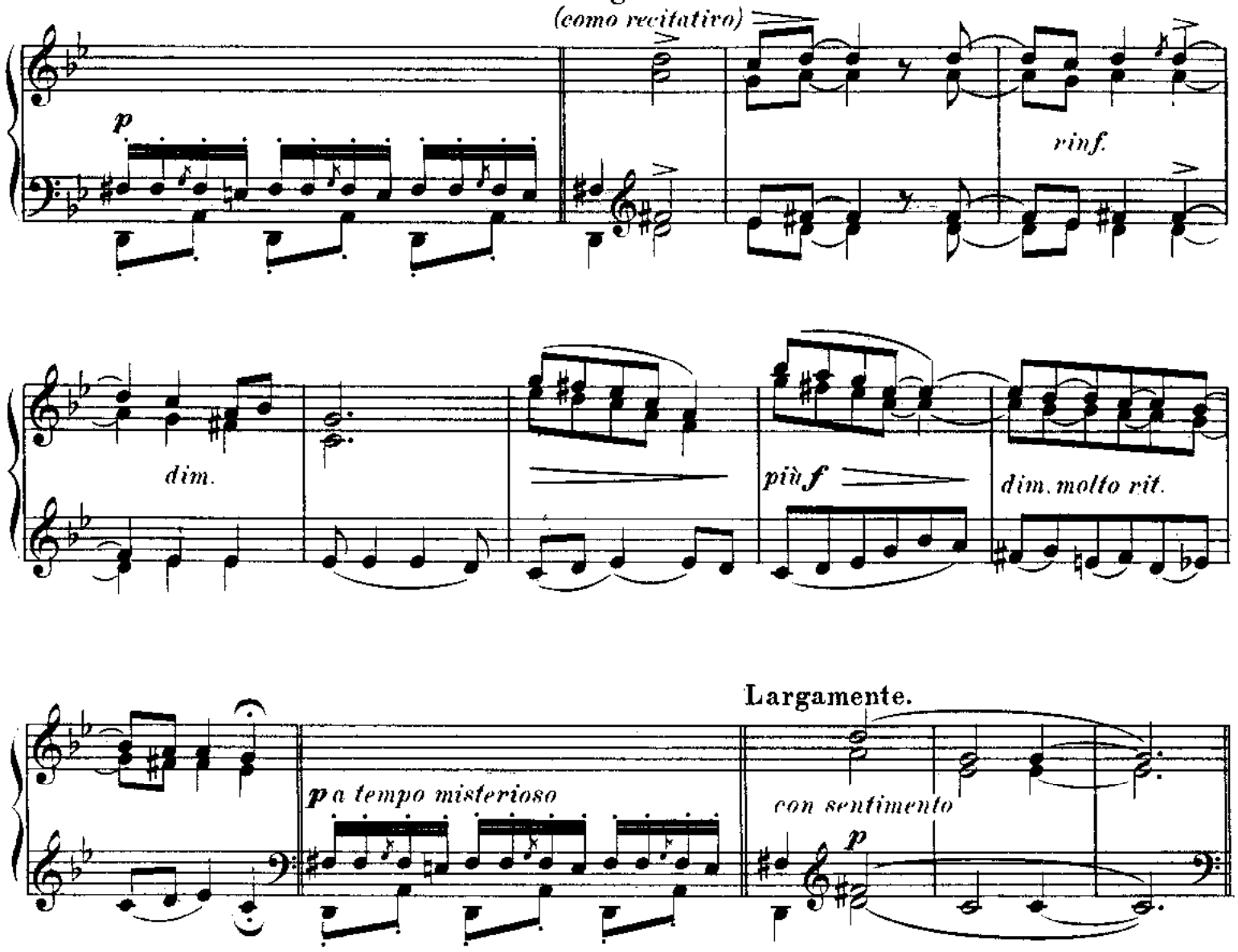
Come primo.
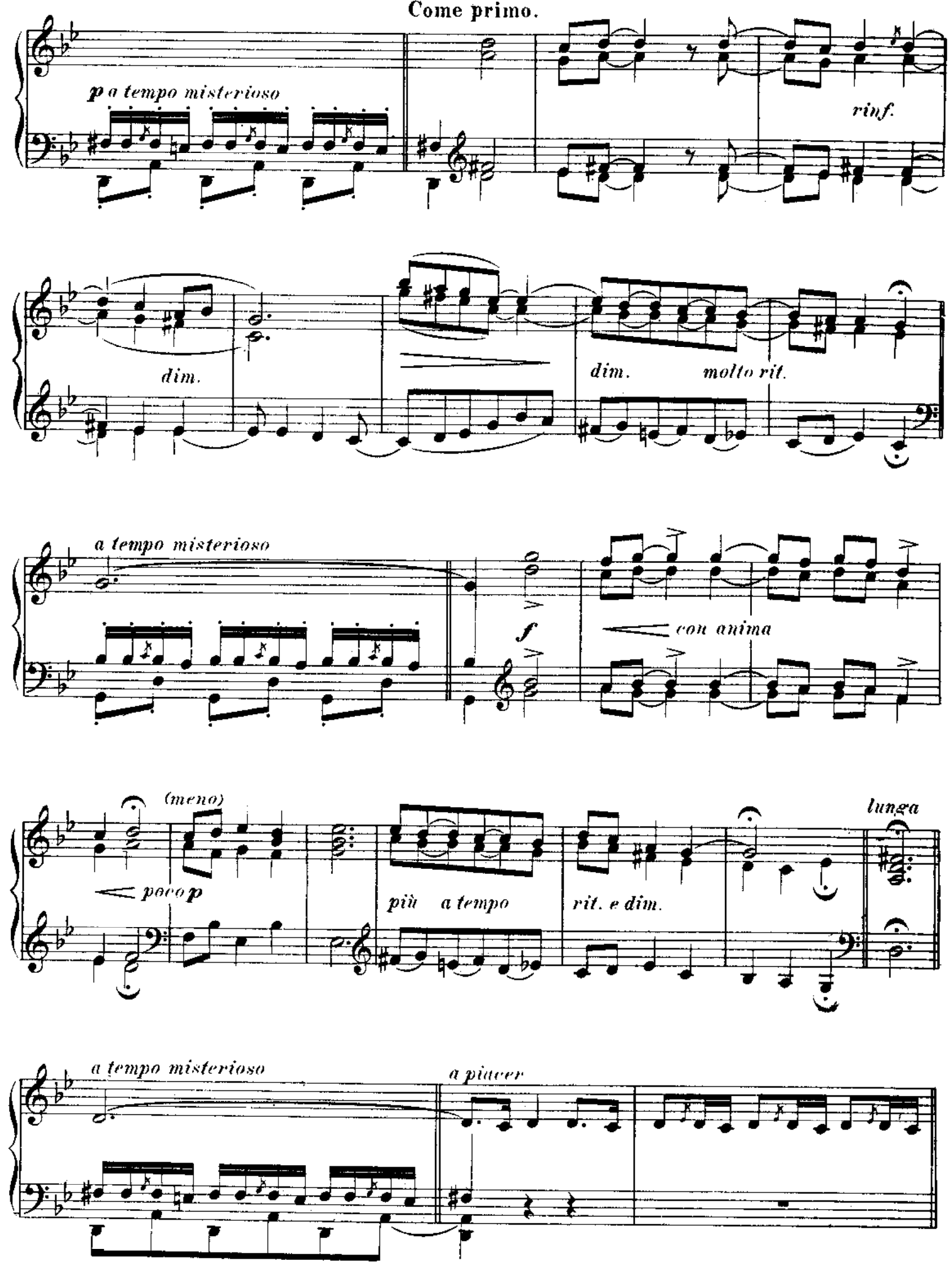

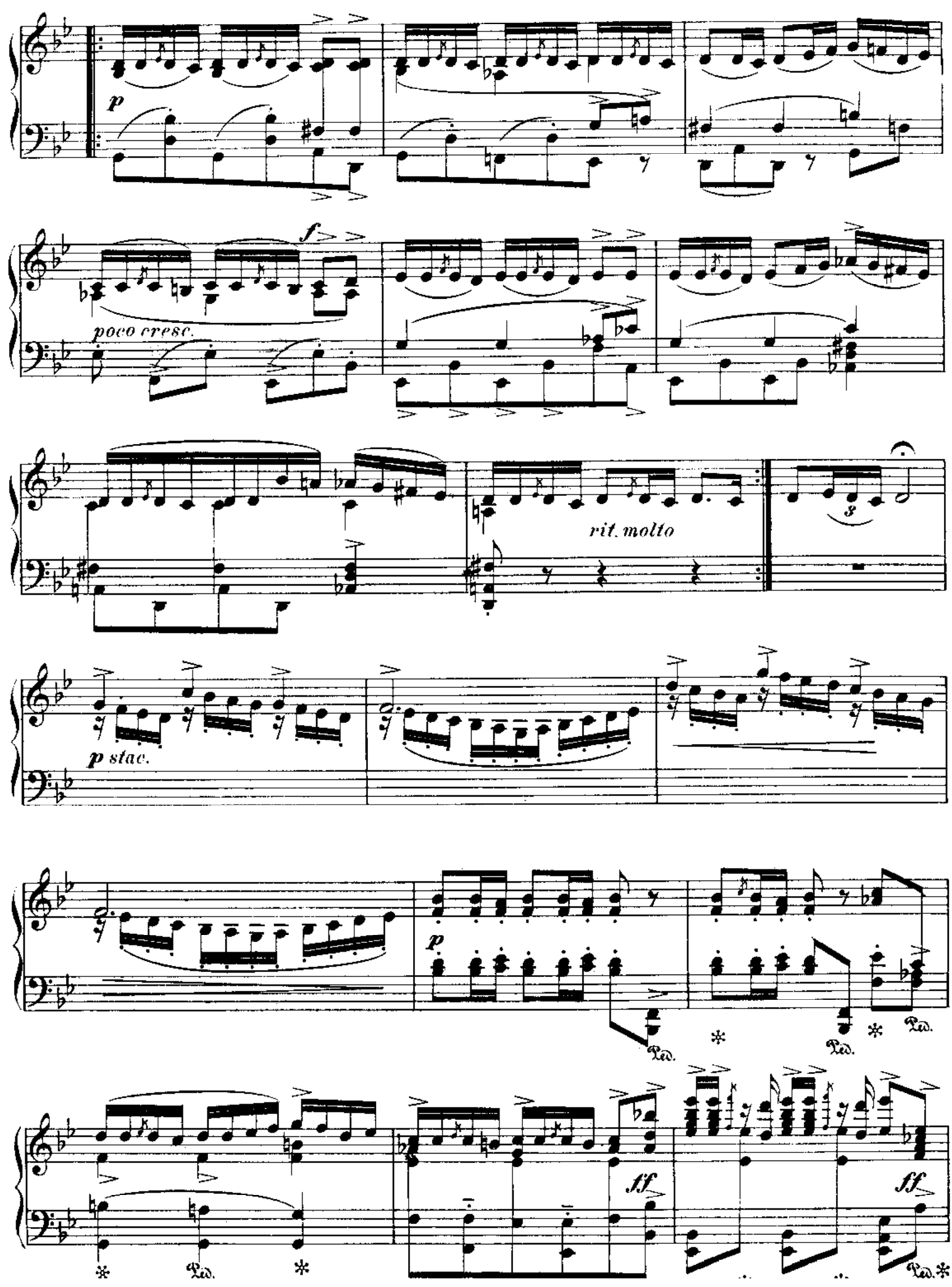

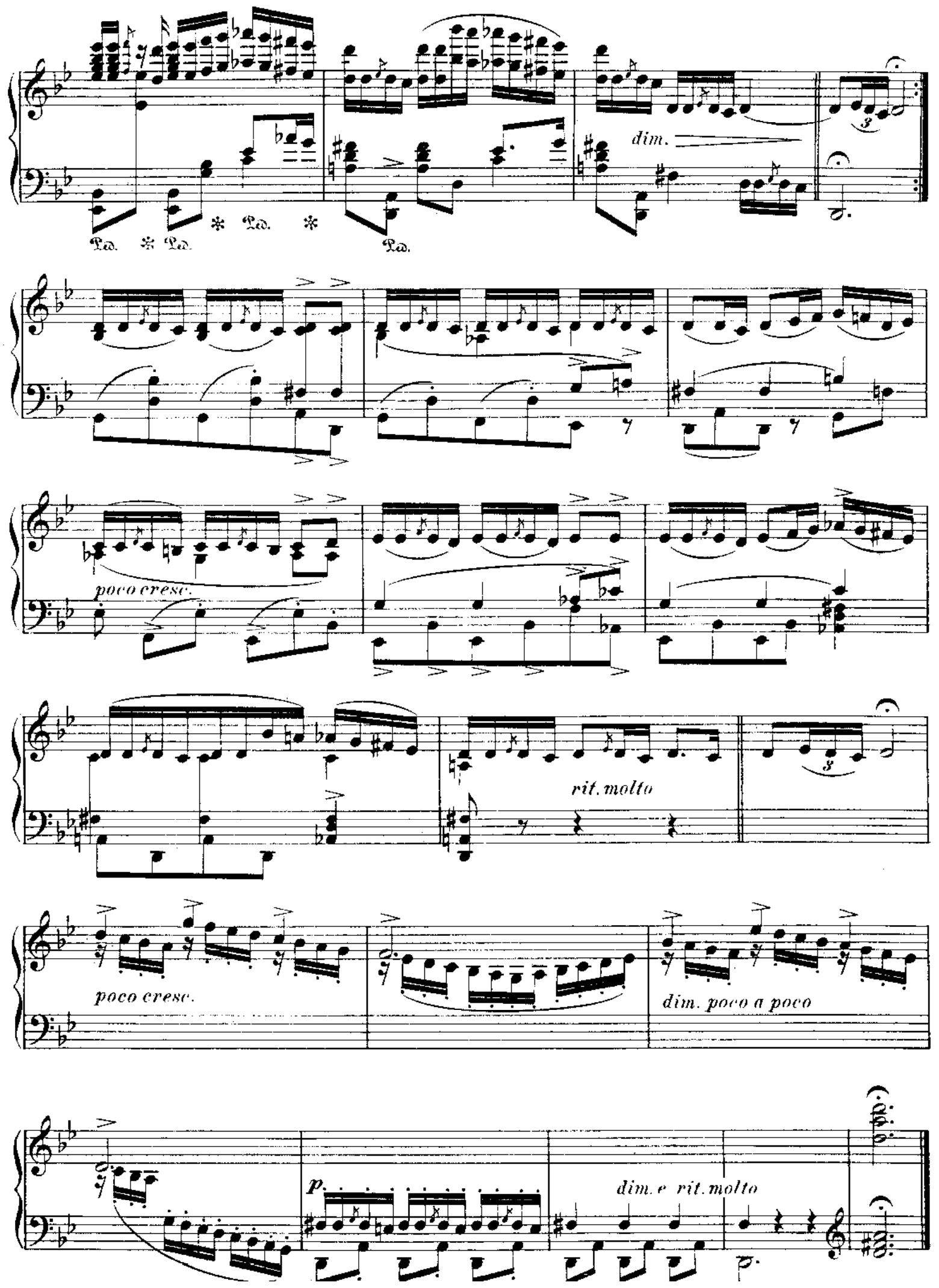

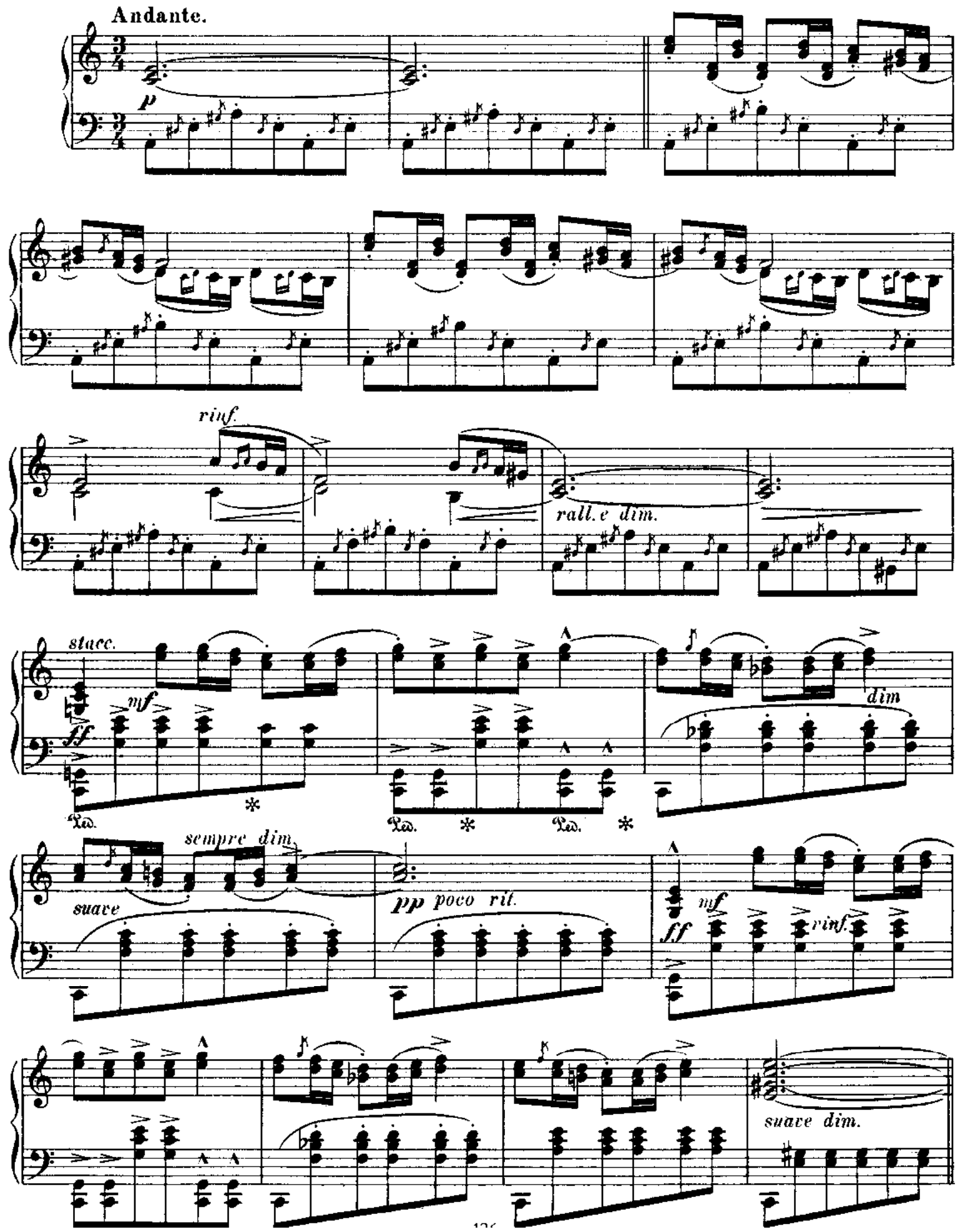

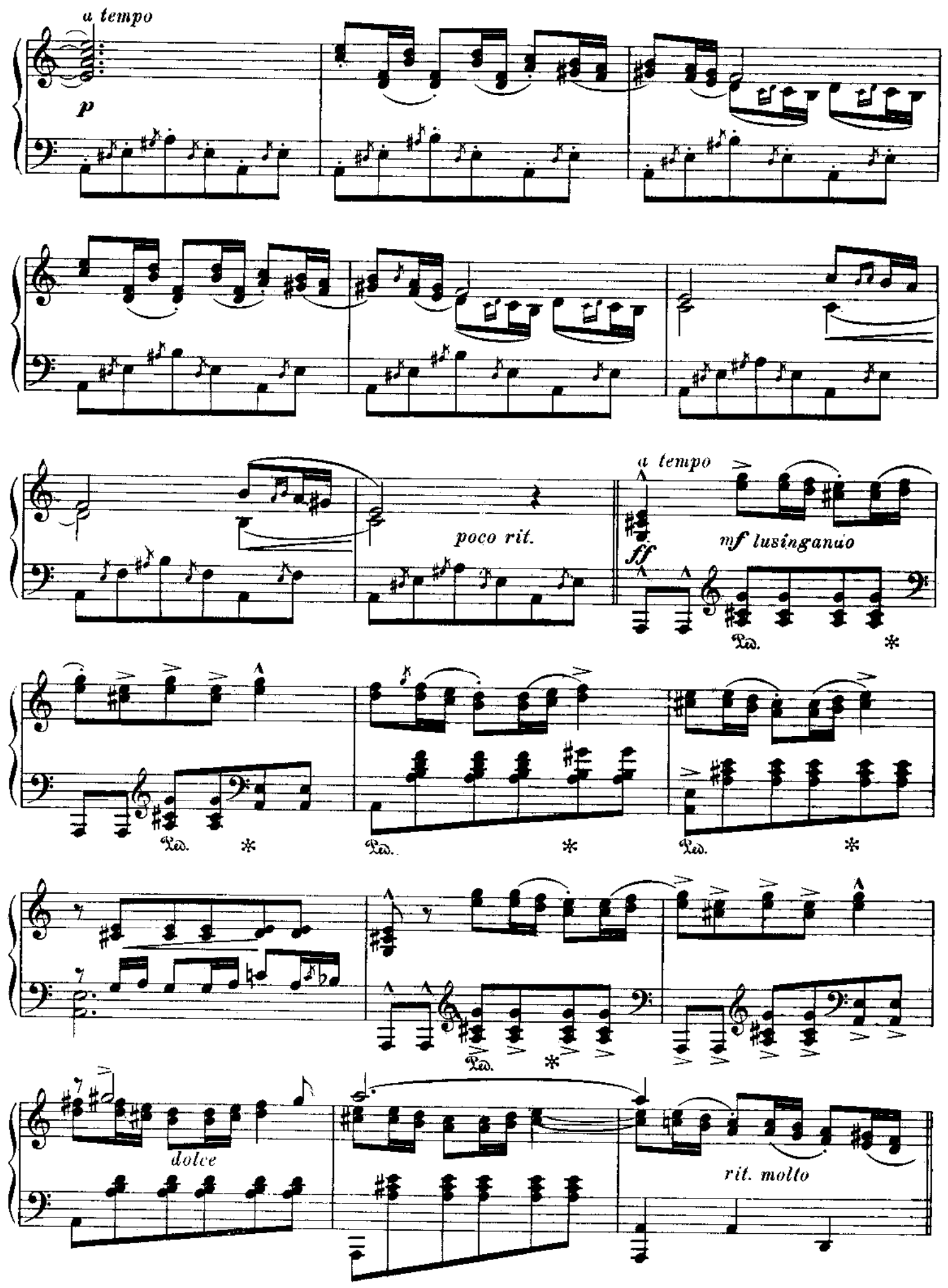

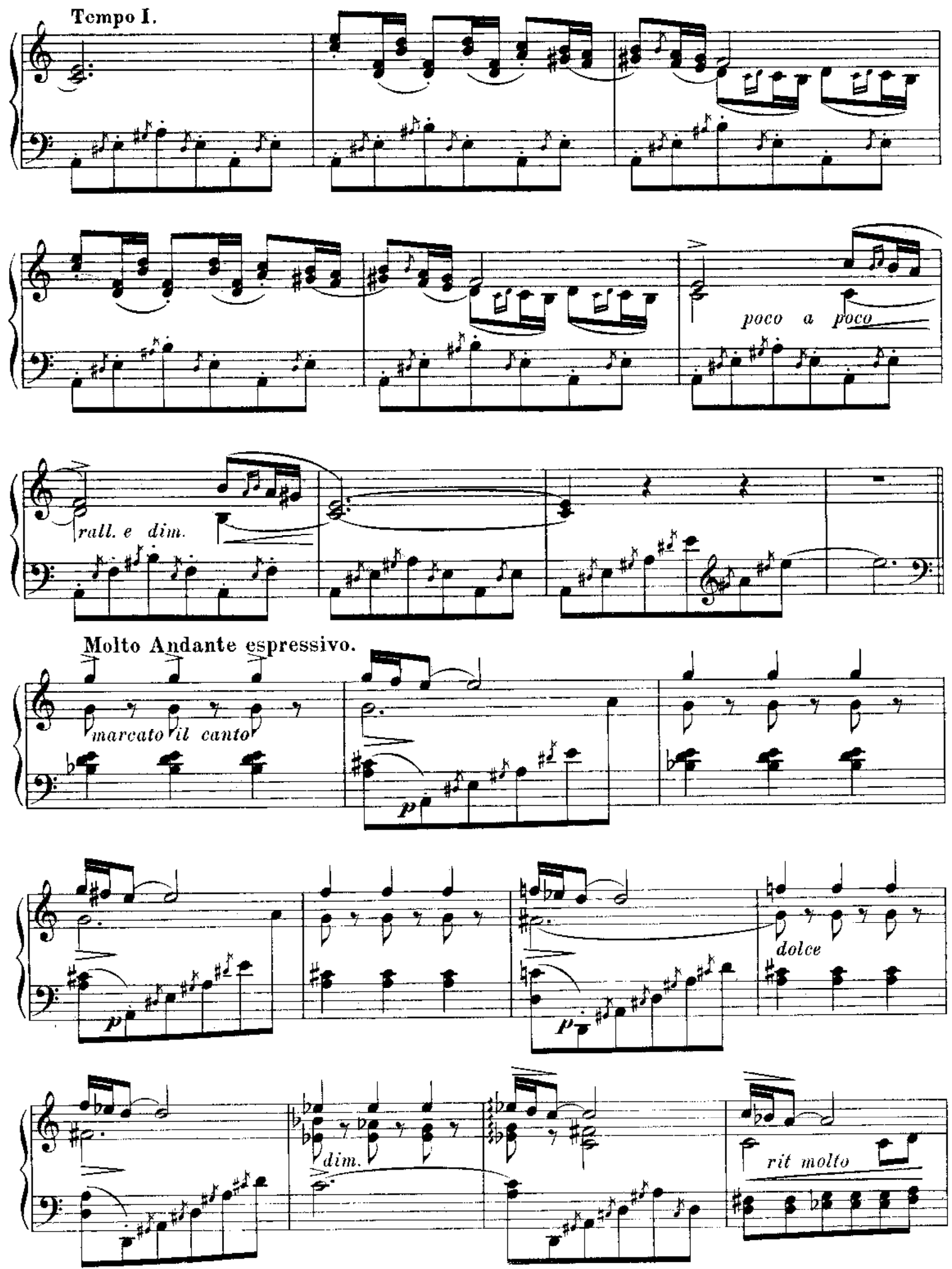

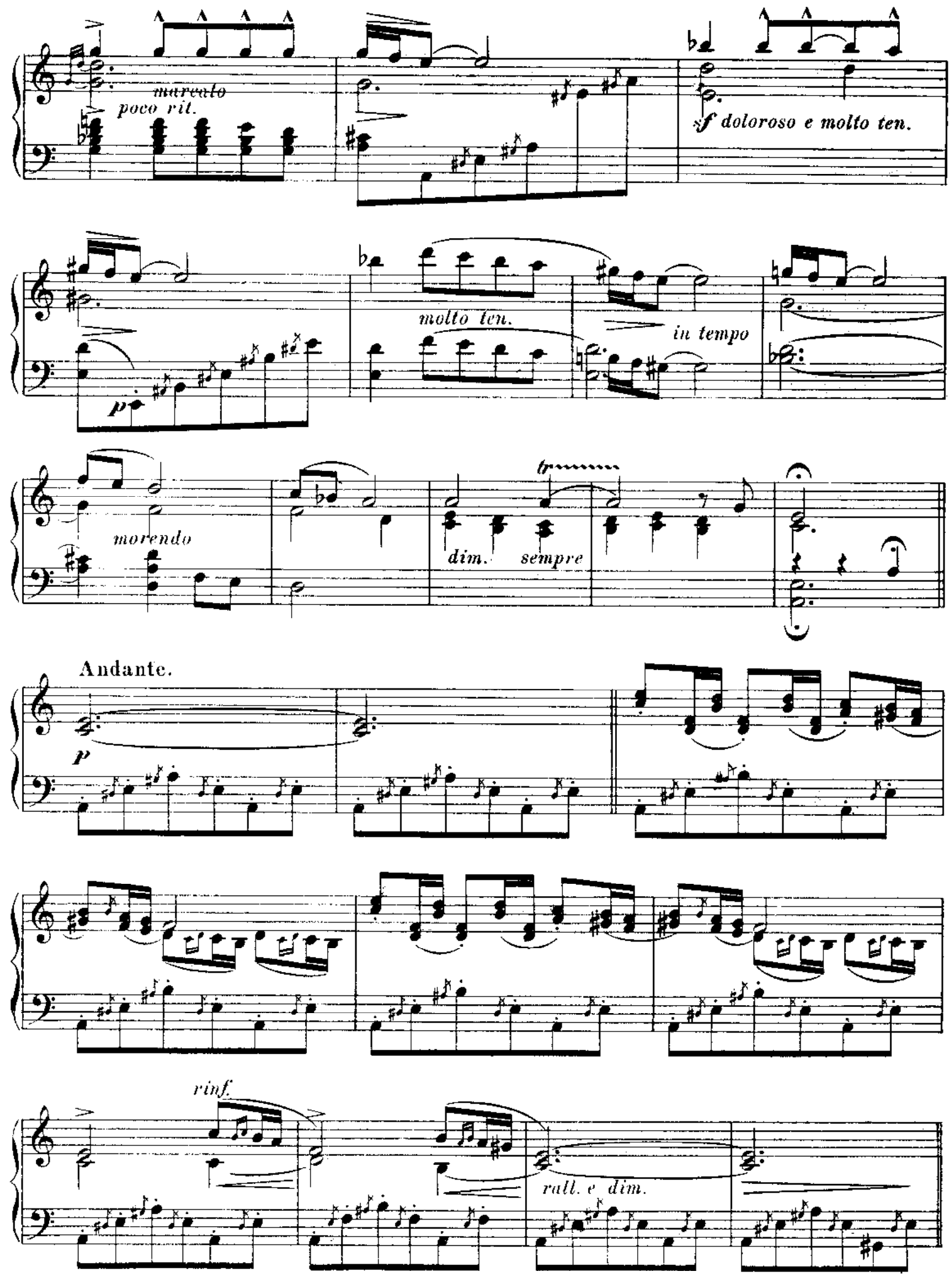

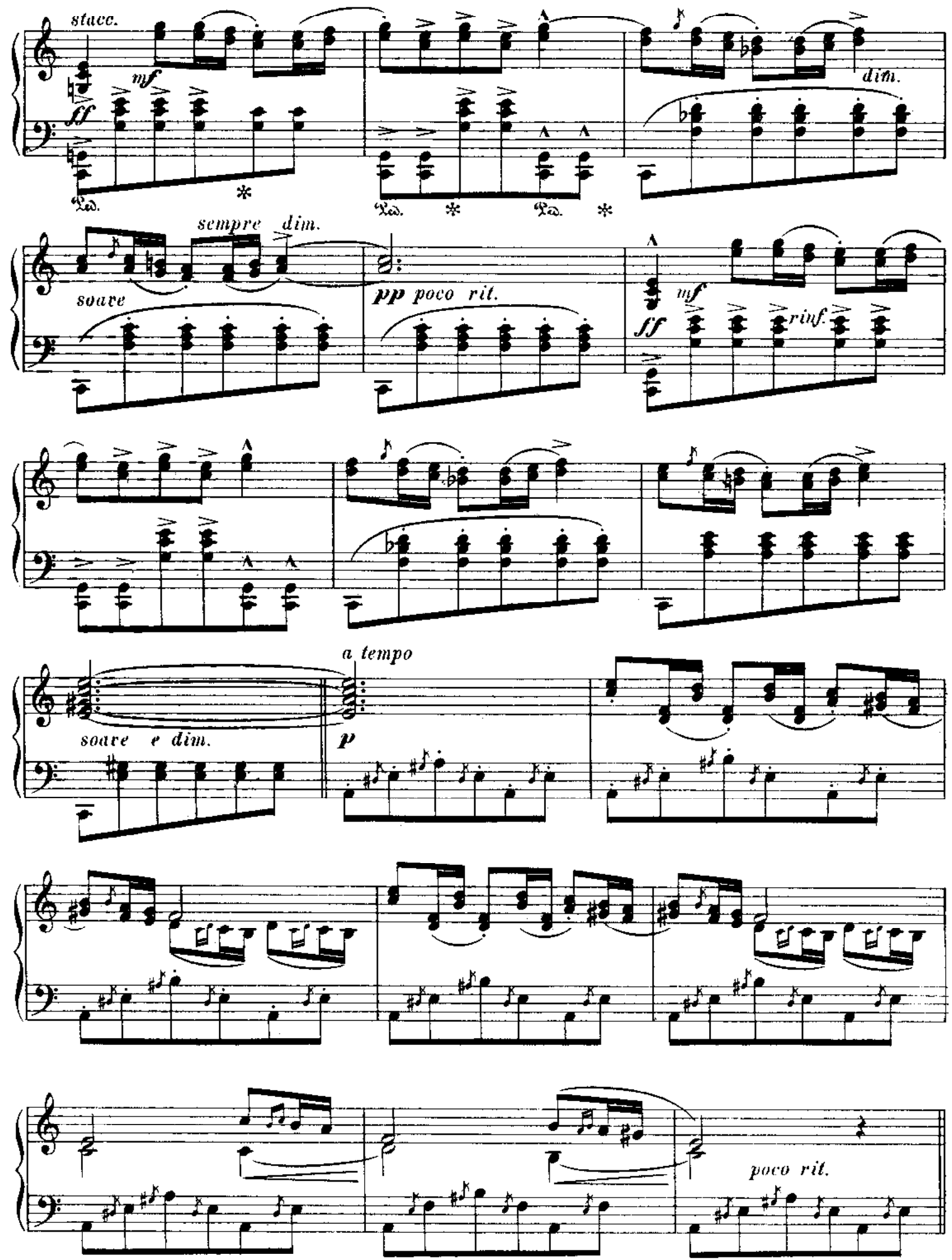


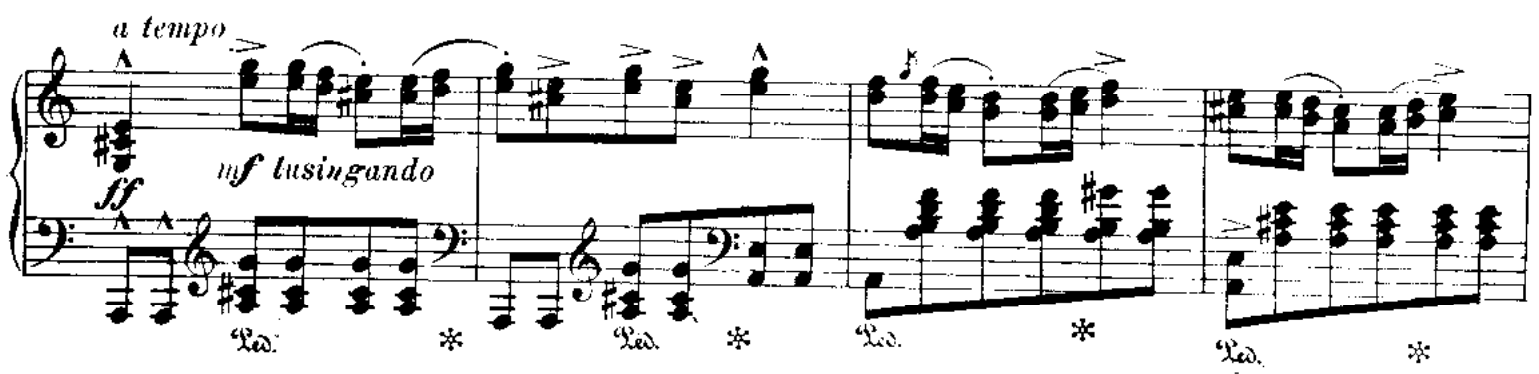

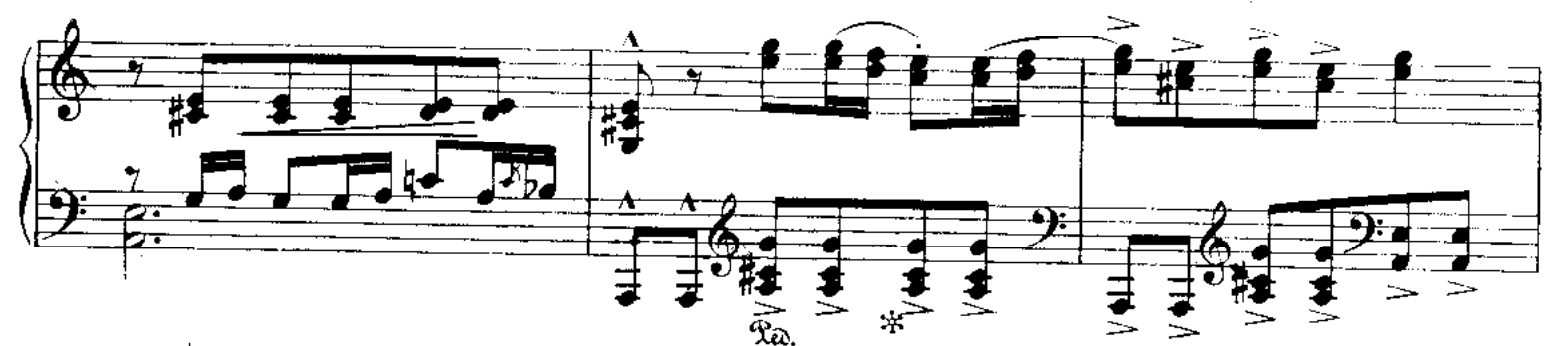

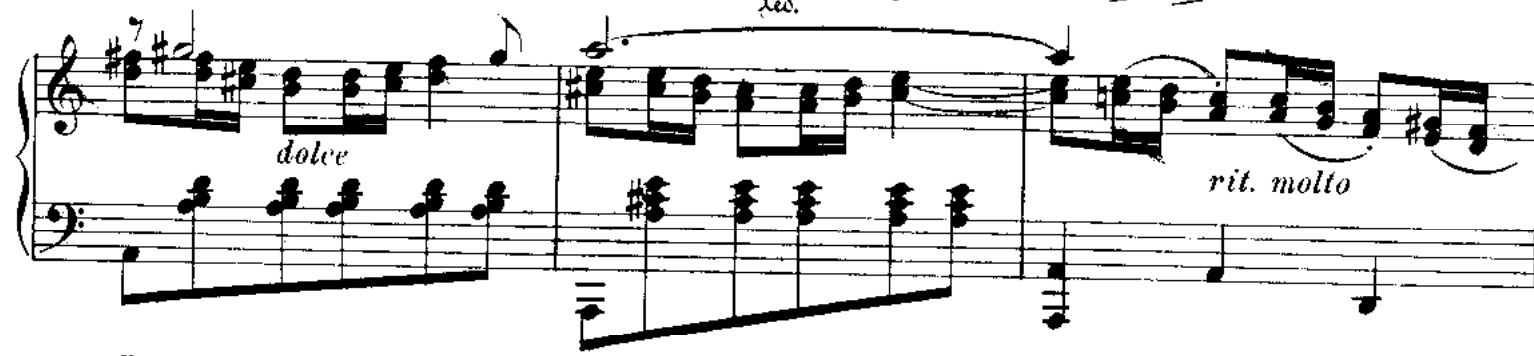

Tempo I.
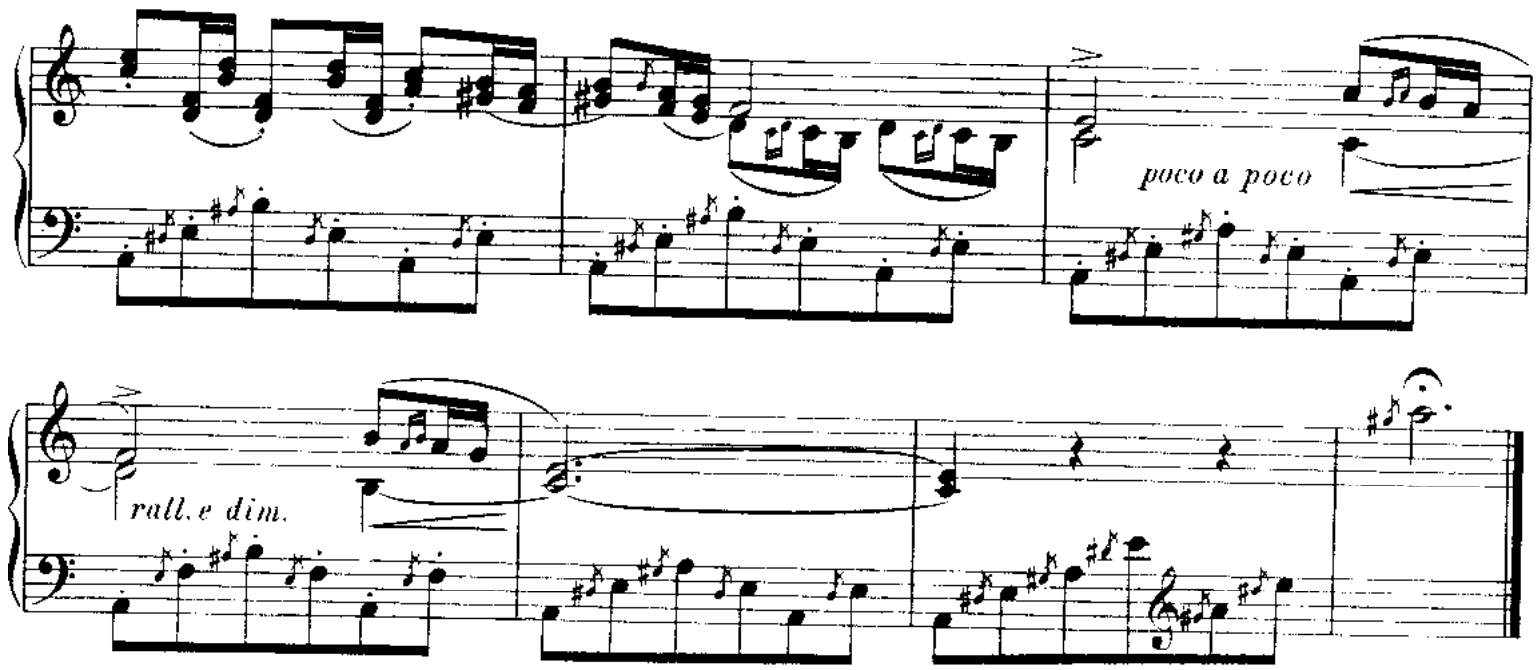